Universidade de São Paulo

Faculdade de Filosofia Letras e Ciências Humanas

Programa de Pós-Graduação em de Sociologia

\title{
O discurso da "racionalidade econômica" e a racionalização na reforma da Previdência Social
}

Rita de Cássia Bessa dos Santos

Orientador: Prof. Dr. Antônio Flávio de Oliveira Pierucci

Tese apresentada ao Programa de Pós-Graduação em Sociologia da Faculdade de Filosofia, Letras e Ciências Humanas da Universidade de São Paulo, como exigência parcial para obtenção do título de Doutor em Sociologia. 
Para Adalton,

Veridiana e Paulo:

Sem vocês, eu nada seria! 


\title{
O discurso da "racionalidade econômica" e a racionalização na reforma da Previdência Social
}

\begin{abstract}
Autora: Rita de Cássia Bessa dos Santos
Orientador: Prof. Dr. Antônio Flávio de Oliveira Pierucci Tese de Doutoramento apresentada ao Programa de PósGraduação em Sociologia, da Faculdade de Filosofia, Letras e Ciências Humanas da Universidade de São Paulo como exigência parcial para obtenção do título de Doutor em Sociologia.
\end{abstract}

\section{Resumo:}

Esta tese aborda as disputas em torno do processo de reforma da Previdência Social e identifica que foram orientadas pela formação de um discurso embasado na racionalidade econômica, segundo o qual a situação de escassez e de crise fiscal foi determinante no projeto de reforma. O discurso do déficit na Previdência Social confrontou o modelo de seguridade social instituído pela Constituição Federal de 1988. O principal ponto da disputa foi o Orçamento da Seguridade Social, que, ao integrar a Previdência Social, tornou-a sujeita ao controle público, tanto na fase elaboração do orçamento, quanto na sua execução. Essa foi a dimensão que alimentou o debate e orientou um amplo processo de racionalização da Previdência Social, indo além da reforma nos critérios de acesso aos benefícios, como um resultado não esperado.

Palavras-Chave: Previdência Social; reforma da Previdência; racionalização; racionalidade econômica; seguridade social. 


\begin{abstract}
:
This thesis analyses the disputes about the social insurance reform process and identifies that they are oriented by a discourse based on the economic rationality, that one the scarcity situation and fiscal crisis determine the reform projects. The social insurance deficit discourse confronted the social security model set up by the 1988 Federal Constitution. The main point of the dispute was the social security budget that subjected to the public control the Social Insurance System as in the stage of budget elaboration as its performance. That was the point that maintained the contend and oriented a extensive process of social insurance rationalization. That got ahead of the reform in the entrance criterion of the social benefits as an unexpected effect.
\end{abstract}

Key-words: Social Insurance; Social Insurance reform; rationalization; economic rationality; social security.

e-mail autor: ritabessa@bol.com.br

ritabessa@usp.br

São Paulo

Março/2008 


\section{AGRADECIMENTOS}

Em primeiro lugar, agradeço a oportunidade de ter sido aluna da Faculdade de Filosofia, Letras e Ciências Humanas da Universidade de São Paulo onde iniciei e fecho um ciclo de formação como socióloga e pesquisadora. Nos tempos que correm, esse agradecimento é duplo: pela oportunidade de seguir os estudos pós-graduados, tanto quanto por fazê-lo em universidade pública.

Ao Programa de Pós-Graduação em Sociologia agradeço poder ter integrado o seu corpo discente e ter me beneficiado de todas as atividades programadas, assim como pelo ambiente de respeito ao debate intelectual. Aos funcionários, meus sinceros agradecimentos pela disponibilidade, gentileza e suporte oferecido.

Ao Prof. Dr. Antônio Flávio de Oliveira Pierucci devo agradecer a generosidade da acolhida sob sua orientação e a grande paciência na trajetória nada regular da realização dessa tese. Agradeço ainda a sua paciência diante de minha enorme teimosia.

Agradeço também aos Professores Cibele Saliba Risek e Brasílio Sallum Júnior por terem participado de meu exame de qualificação, contribuindo para dar um rumo novo a esta pesquisa e por apontar a relevância do tema abordado.

Ao Conselho Nacional de Desenvolvimento Científico e Tecnológico (CNPQ) agradeço a concessão de bolsa de estudos que ajudou a financiar essa pesquisa de doutorado, sem a qual ela jamais teria chegado a termo.

Aos colegas e amigos agradeço terem compartilhado comigo parte dessa jornada, sempre na expectativa de que um dia eu conseguiria por um ponto final. Um ponto final que tem um duplo sentido: de fim e de início. Aqueles a quem tenho grande apreço: Beth, Jenny, Maria Lúcia, Maristela, Carlos, Magda, Mitiko, Márcia, Selma, Ângela, para citar alguns. Ouvir e saber esperar foram talvez as qualidades mais valorizadas durante esse ciclo.

“O prazo, o prazo, o prazo...”, cantava Veridiana, minha filha, nos momentos finais de redação e a ela agradeço particularmente por ter suportado todas as privações que a minha dedicação integral lhe causou. Ao pequeno Paulo (gestado, nascido, embalado e 
criado enquanto essa pesquisa era realizada) agradeço por ter suportado a partilha, por toda a sua vida, com um quase irmão-gêmeo. Á minha mãe, Lourdes, agradeço, sobretudo, ter conseguido se superar e realizar o mais difícil caminho de sua vida. Á minha sogra, Izeraide, agradeço a amizade e a confiança que deposita em mim.

A Adalton Franciozo Diniz agradeço especialmente por fazer parte da minha vida como esposo, amigo e companheiro. Sua contribuição para a realização desse trabalho foi sempre inestimável, através de suporte emocional, prático e financeiro. Agradeço especialmente não ao que partilhou comigo durante esse período, mas ao que pode realizar sem mim e ao que pode realizar por mim.

Ao final, porém, essa é uma trajetória que se cumpre solitariamente, através das interrogações que nos fazemos, algumas apenas teóricas, outras com repercussão nas nossas próprias expectativas de vida, e só resta assumir os erros que porventura sejam cometidos. Todas as falhas e erros cometidos somente a mim poderão ser imputados.

R.C.B.S.

Março/2008 


\section{Sumário}

Lista de figuras........................................................................ 9

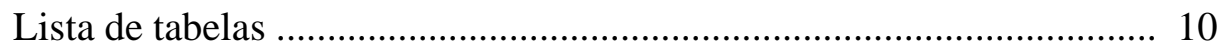

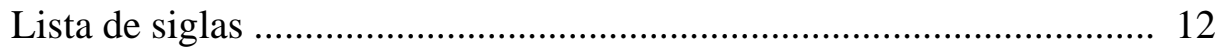

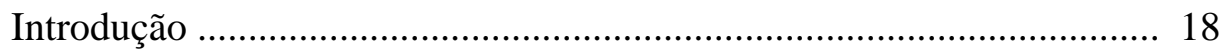

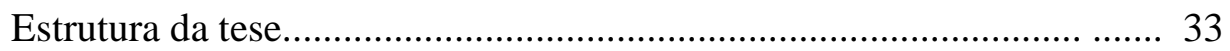

Capítulo I. O custo do direito .......................................................... 37

Financiamento dos gastos sociais ............................................... 37

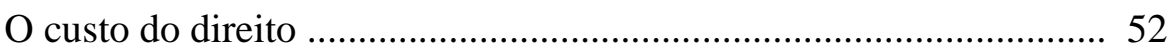

Direitos sociais e o "custo dos direitos" ........................................... 58

Weber e a racionalidade econômica ................................................. 64

Encargos sociais e o custo do trabalho: o “custo do direito” ............. 75

O problema da solidariedade.......................................................... 77

\section{Capítulo II. Política de previdência social: financiamento e}

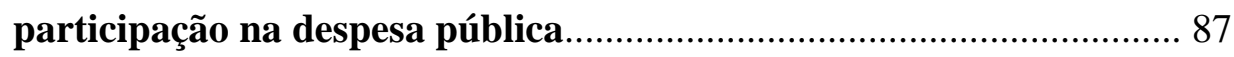

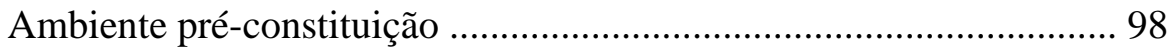

Política social no governo Sarney: a Nova República ...................... 107

A Constituição Federal de 1988 e o problema da seguridade social .. 115

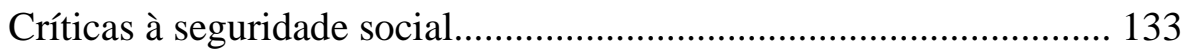

Impactos da transição demográfica sobre a Previdência Social .......... 142

Capítulo III. As “contas” da Previdência Social .................................. 148

Dados comparativos relativos à arrecadação e pagamento de

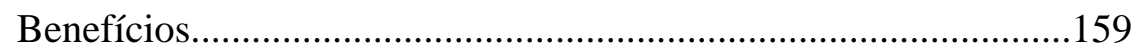

Composição de pagamentos de benefícios do INSS...................... 170

Déficit previdenciário............................................................... 171

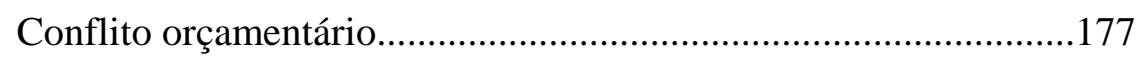

Crescimento do número de benefícios............................................182 
Capítulo IV. Tempo de renovação: a regulamentação dos direitos

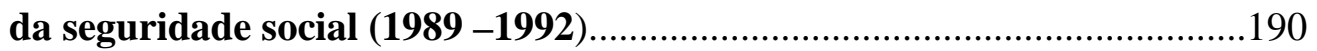

Governança e Governabilidade na reforma do Estado ...............................208

\section{Capítulo V. Tempo da revisão constitucional: a disputa em}

torno do modelo de proteção social...........................................................214

O financiamento da seguridade social na reforma tributária ....................219

Conflito distributivo entre Fazenda e seguridade social ............................231

O Ministério da Previdência Social e a revisão constitucional....................234

A revisão constitucional: o debate ...........................................................241

A revisão constitucional: o processo ......................................................247

Capítulo VI. Tempo de reformas: as reformas previdenciárias de

Fernando Henrique Cardoso e Luiz Inácio Lula da Silva ........................261

A reforma do Governo Fernando Henrique Cardoso...................................261

A reforma de Fernando Henrique e o fator previdenciário ........................287

Lei de Responsabilidade Fiscal, CPMF e DRU.......................................290

Governo Lula e a reforma da racionalidade..............................................292

Financiamento da previdência na reforma.................................................307

Crise gerencial e técnicas de gestão............................................................310

Capítulo VII. As reformas da Previdência...................................................315

Reformas na América Latina....................................................................... 319

Reformas paramétricas no Brasil.............................................................324

Nota sobre a previdência complementar ................................................ 339

Nota sobre racionalização na Previdência Social.......................................341

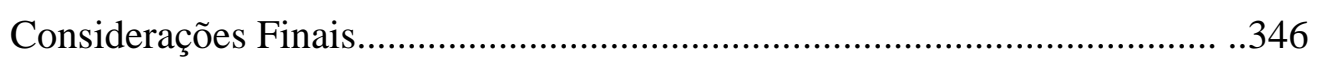

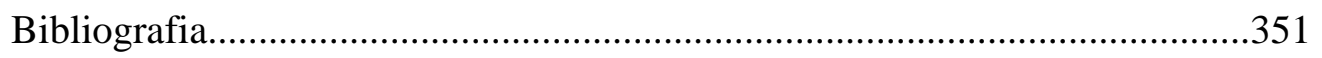

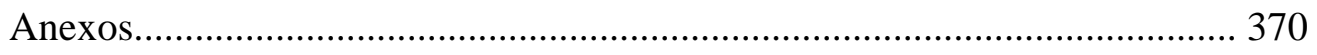

Anexo 1. Nota técnica sobre o fator previdenciário................................... 370

Anexo 2. Propostas de reforma da seguridade social divulgadas

(1991,1992,1993). 


\section{Lista de Figuras}

1. Distribuição dos pagamentos realizados pelo SINPAS/INSS: 1988-1993................162

2. Distribuição dos pagamentos realizados pelo INSS: 1994 - 2005............................170

3. Distribuição dos benefícios pagos pelo INSS por tipo: 2000 - 2005 (\%)..................171

4. Evolução do superávit da seguridade social: 2000-2005

(R\$ bilhões em valores correntes)

5. Evolução dos principais impostos versus contribuições sociais................................181

6. Quantidade de benefícios concedidos: 1980-1991.................................................183

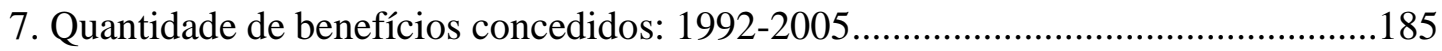

8. Distribuição de aposentadorias concedidas segundo espécies: 1998-2005................187

9. Distribuição dos benefícios por espécie: 1988-2005.................................................188 


\section{Lista de tabelas}

1. Gastos estatais (\%) por área e por governo: 1950-1975 ............................................41

2. Renúncia de contribuição previdenciária em face de tratamento diferenciado:

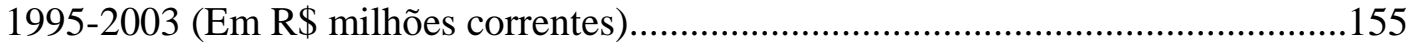

3. Dados consolidados de arrecadação e pagamento de benefícios do SINPAS: 1988-1990 ( $\mathrm{R} \$$ em valores correntes). 160

4. Recebimentos próprios e transferências da União na composição da receita previdenciária: 1988-1993 (\%) 160

5.Transferências relativas ao EPU na composição das transferências da União .161

6. Fluxo de caixa anual do INSS: 1994-1996 (R\$ Mil) ....................................................163

7. Fluxo de caixa anual do INSS: 1997-1999 (R \$ Mil)..................................................164

8. Participação dos recebimentos próprios e das transferências da União na receita da Previdência Social (\%) 166

9. Participação das transferências para financiamento dos EPU nas transferências da União: 1994 - 1999 (\%) 167

10. Distribuição dos recebimentos e pagamentos do INSS: 2000 - 2005 (R\$ Mil em valores correntes) 168

11. Participação dos recebimentos próprios e das transferências da União na receita da Previdência Social: 2000 - 2005 (\%). 169

12. Participação das transferências para financiamento dos EPU nas transferências

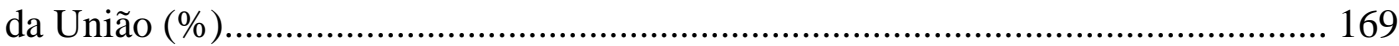

13. Déficit Previdenciário (INSS): 1991-1999 (\% PIB) …………………......................172

14. Evolução do déficit previdenciário: 2000-2005 (R\$ milhões).................................. 173

15. Aplicação das receitas da seguridade social: 1995-2006 ( $\mathrm{R} \$$ milhões em valores correntes) 175

16. Aplicação das receitas da seguridade social - 1995-2006 (\%)..................................176

17. Quantidade de benefícios concedidos: 1980-1991...................................................... 182

18. Quantidade de Benefícios concedidos: 1992-2005 (R\$ milhões em valores correntes). 
19.Taxa de crescimento dos benefícios concedidos: 1986-2005

186

20. Brasil: taxas anuais de retorno por tipo de programa de benefício .............................332

21. Volume de reservas técnicas do setor (R \$ bilhões)....................................................341

22. Estimativa de renuncia previdenciária 2006 (R\$ bilhões)......................................... 343 


\section{LISTA DE SIGLAS}

ADN Aliança Democrática Nacional

ADTC Ato das Disposições Transitórias Constitucionais

AIS

Ações Integradas à Saúde

AMB Associação dos Magistrados Brasileiros

ANC Assembléia Nacional Constituinte

ANFIP Associação Nacional dos Fiscais da Previdência Social

BID Banco Interamericano de Desenvolvimento

BNDES Banco Nacional de Desenvolvimento Sócio-Econômico

BNH Banco Nacional de Habitação

CAP Caixa de Aposentadorias e Pensões

CAT Central Autônoma dos Trabalhadores

CCJR Comissão de Constituição, Justiça e Redação

CEESP Comissão Especial para Estudo do Sistema Previdenciário

CEIC Comissão de Economia, Indústria e Comércio

CEPAL Comissão Econômica para América Latina e Caribe

CERF Comissão Executiva de Reforma Fiscal

CESP Comissão Especial da Previdência

CFFC Comissão de Fiscalização Financeira e Controle

CFT Comissão de Finanças e Tributação

CIESP Centro das Indústrias do Estado de São Paulo

CGT Confederação Geral dos Trabalhadores

CIRS Comissão Interministerial de Reforma Sanitária

CLT Consolidação das Leis Trabalhistas

CND Certidão Negativa de Débito

CNI Confederação Nacional das Indústrias

CNIS Cadastro Nacional de Informações Sociais

CNS Conferência Nacional da Saúde

COFINS Contribuição para o Financiamento da Seguridade Social 
CPI Comissão Parlamentar de Inquérito

CPF Cadastro da Pessoa Física

CPMF Contribuição sobre Movimentação Financeira

CRC Comissão de Revisão Constitucional

CRP Certificado de Regularidade Previdenciária

CSLL Contribuição sobre Lucro Líquido

CSSF Comissão de Seguridade Social e Família

CSTOF Comissão do Sistema Tributário, Orçamento e Finanças

CTASP Comissão de Trabalho, Administração e Serviço Público

CTN Código Tributário Nacional

CTPS Carteira de Trabalho e Previdência Social

CVA Contribuição sobre Valor Adicionado

CUT Central Única dos Trabalhadores

DIAP Departamento Intersindical de Assessoria Parlamentar

DRU Desvinculação de Receita da União

EC Emenda Constitucional

EPU Encargos Previdenciários da União

FAD Fundo de Assistência aos Desempregados

FAT Fundo de Amparo ao Trabalhador

FEF $\quad$ Fundo de Estabilização Fiscal

FENAPREVI Fundação Nacional de Previdência Privada e Vida

FGTS Fundo de Garantia por Tempo de Serviço

FIESP Federação das Indústrias do Estado de São Paulo

FINSOCIAL Fundo de Investimento Social

FIPE Fundação Instituto de Pesquisa Econômica da Universidade de São Paulo

FMI Fundo Monetário Internacional

FPE Fundo de Participação do Estado

FPM Fundo de Participação do Município

FS Força Sindical

FSD Fundo do Seguro Desemprego

FSE $\quad$ Fundo Social de Emergência 
FUNABEM Fundação Nacional para o Bem Estar do Menor

FUNPRESP Fundo de Previdência Complementar do Servidor Público Federal

GTRP Grupo de Trabalho para Reestruturação Previdenciária

IAPAS Instituto de Administração da Previdência e Assistência Social

IAPI Instituto de Aposentadorias e Pensões dos Industriários

IBGE Instituto Brasileiro de Geografia Econômica

INPC Índice Nacional de Preço ao Consumidor

IPEA Instituto de Pesquisa Econômica Aplicada

ICMS Imposto sobre Circulação de Mercadorias

ISS Imposto sobre Serviços

INAMPS Instituto Nacional de Medicina e Previdência Social

INCRA Instituto Nacional de Colonização e Reforma Agrária

INPS Instituto Nacional de Previdência Social

INSS Instituto Nacional do Seguro Social

IOF Imposto sobre Operações Financeiras

IPC Instituto de Pensão do Congressista

IPI Imposto sobre Produtos Industrializados

IRPF Imposto de Renda sobre Pessoa Física

IPMF Imposto sobre Movimentação Financeira

IPTR Imposto sobre Propriedade Territorial Rural

ITF Imposto sobre Transações Financeiras

IVA Imposto sobre Valor Adicionado

LBA Legião Brasileira da Assistência

LDO Lei de Diretrizes Orçamentárias

LOAS Lei Orgânica da Assistência Social

LOPS Lei Orgânica da Previdência Social

LOS Lei Orgânica da Saúde

LRF Lei da Responsabilidade Fiscal

MTPS Ministério do Trabalho e Previdência Social

MPAS Ministério da Previdência e Assistência Social

MPS Ministério da Previdência Social 


\begin{tabular}{|c|c|}
\hline MTAF & Ministério do Trabalho e Administração Federal \\
\hline MPF & Ministério Público Federal \\
\hline MPOG & Ministério do Planejamento, Orçamento e Gestão \\
\hline MEFP & Ministério da Economia, Fazenda e Planejamento \\
\hline OCDE & Organização para Cooperação e Desenvolvimento Econômico \\
\hline OF & Orçamento Fiscal \\
\hline OIT & Organização Internacional do Trabalho \\
\hline OGU & Orçamento Geral da União \\
\hline OS & Ordem de Serviço \\
\hline OSS & Orçamento da Seguridade Social \\
\hline PARSEP & Programa de Apoio às Reformas dos Sistemas Estaduais de Previdência \\
\hline PASEP & Programa para Formação do Patrimônio do Servidor Público \\
\hline PCB & Partido Comunista Brasileiro \\
\hline PCdoB & Partido Comunista do Brasil \\
\hline PDC & Partido Democrata Cristão \\
\hline PDT & Partido Democrata Trabalhista \\
\hline PDS & Partido da Democracia Social \\
\hline PEA & População Economicamente Ativa \\
\hline PEC & Projeto de Emenda Constitucional \\
\hline PGBL & Plano Gerador de Benefício Livre \\
\hline PIB & Produto Interno Bruto \\
\hline PIA & População em Idade Ativa \\
\hline PIS & Programa de Integração Social \\
\hline PL & Projeto de Lei \\
\hline PL & Partido Liberal \\
\hline PMDB & Partido do Movimento Democrático Brasileiro \\
\hline PMN & Partido de Mobilização Nacional \\
\hline PNAD & Pesquisa Nacional de Amostra por Domicílio \\
\hline PNBE & Pensamento Nacional das Bases Empresariais \\
\hline $\mathrm{PP}$ & Partido Popular \\
\hline PPB & Partido Progressista Brasileiro \\
\hline
\end{tabular}




$\begin{array}{ll}\text { PPR } & \text { Partido Progressista Reformador } \\ \text { PPS } & \text { Partido Popular Socialista } \\ \text { PRAS } & \text { Plano de Reorientação de Assistência à Saúde } \\ \text { PRN } & \text { Partido da Reconstrução Nacional } \\ \text { PRORURAL } & \text { Programa Rural } \\ \text { PSDB } & \text { Partido da Social Democracia Brasileira } \\ \text { PSB } & \text { Partido Socialista Brasileiro } \\ \text { PST } & \text { Partido Social Trabalhista } \\ \text { PT } & \text { Partido dos Trabalhadores } \\ \text { PTB } & \text { Partido Trabalhista Brasileiro } \\ \text { PFL } & \text { Partido da Frente Liberal } \\ \text { RG } & \text { Registro Geral } \\ \text { RGPS } & \text { Regime Geral de Previdência Social } \\ \text { RJU } & \text { Regime Jurídico Único } \\ \text { RPC } & \text { Regime de Previdência Complementar } \\ \text { RPPS } & \text { Regime Próprio de Previdência Social } \\ \text { SAT } & \text { Seguro de Acidente de Trabalho } \\ \text { SEBRAE } & \text { Serviço Brasileiro de Apoio às Micro e Pequenas empresas } \\ \text { SENAI } & \text { Serviço Nacional de Aprendizado Industrial } \\ \text { SENAR } & \text { Serviço Nacional de Aprendizagem Rural } \\ \text { SENAT } & \text { Serviço Nacional de Aprendizagem do Transporte } \\ \text { SEPLAN } & \text { Secretaria de Planejamento da Presidência da República } \\ \text { SESC } & \text { Serviço Social do Comércio } \\ \text { SESCOOP } & \text { Serviço Nacional de Aprendizagem do Cooperativismo } \\ \text { SESI } & \text { Serviço Social da Indústria } \\ \text { SEST } & \text { Serviço Social do Transporte } \\ \text { SINPAS } & \text { Sistema Nacional de Previdência Social } \\ \text { SRF } & \text { Secretaria da Receita Federal } \\ \text { SRP } & \text { Secretaria da Receita Previdenciária } \\ \text { Supremo Tribunal Federal } \\ \text { STHal da Justiça }\end{array}$


SUDS Sistema Único e Descentralizado da Saúde

SUS Sistema Único de Saúde

TCU Tribunal de Contas da União

TFT Taxa de Fecundidade Total

URV Unidade de Referência de Valor

USI União Sindical Independente

VGBL Vida Gerador de Benefício Livre 


\title{
INTRODUÇÃO
}

\author{
Quando a maneira como os homens são \\ solidários se modifica, a estrutura das \\ sociedades não pode deixar de mudar. \\ Émile Durkheim
}

O papel que o direito ocupa na sociedade tem sido um objeto privilegiado na análise sociológica. Ele é, ao mesmo tempo, condição para a estabilização social e para o seu movimento e deve manter-se aberto para acompanhar o movimento da sociedade e assim lhe conferir estabilidade (Ewald, 1993; Ost, 2005).

A sociologia nasce e se desenvolve a partir da análise do movimento da sociedade, muito mais do que da análise de suas estruturas ${ }^{1}$. Épocas de transformações intensas põem em movimento o direito, obrigando a repensar as suas categorias, princípios e fundamentos.

Essa concepção está presente em todos os clássicos da sociologia e se torna mais presente quando as categorias do pensamento dão sinais de esgotamento, quando não conseguem acompanhar a dinâmica social. É para as transformações sociais que o direito se volta, tentando captar os sinais de sua "descontinuidade” (Foucault, 1995) ao mesmo tempo em que se nutre delas. A descontinuidade assinala não um momento de revisão do direito, mas uma mudança de paradigma. Assinala dois pontos no tempo, para fazer aparecer entre eles um sistema contínuo e unitário; o ponto de partida de uma nova compreensão, um modo novo de pensar que deslegitima o já estabelecido (Elias, 1998).

Em Habermas (1997: 168) a idéia de movimento está representada como uma tensão contínua entre facticidade e validade, entre positividade e legitimidade do direito. A legitimidade extraída da legalidade parte da premissa de que o direito não é um processo circular que se encerra em si mesmo. Não existe direito abstrato e tampouco normas estáticas, subtraídas ao tempo e resistente às transformações históricas, afirma Habermas. O conflito social está no centro das mudanças no direito ${ }^{2}$.

\footnotetext{
${ }^{1}$ Lembrando muito de perto a representação comteana da estática e da dinâmica, que apanha a sociedade em repouso e em movimento.

${ }^{2}$ Ralf Dahrendorf entende que a questão central do conflito social é a inclusão social, ou, como o poder e as desigualdades geradas por ele, podem ser transformadas em avanços em termos de liberdade, na modificação
} 
A idéia de que o direito lança um olhar retrospectivo sobre a realidade tanto quanto prospectivo sobre o futuro (Lopes, 2006: 274) ajuda a situá-lo na dinâmica das transformações sociais. Quanto ao passado, as normas podem qualificar o fato, avaliar e julgar o que foi feito; quanto ao futuro, permitem fazer planos, imaginar resultados, corrigir e orientar (Ost, 2005).

A Previdência Social e o conjunto de reformas que vêm se processando nas últimas duas décadas assinalam como o direito vem acompanhando a dinâmica das mudanças sociais, econômicas e políticas. Não se pode pensar a sua reforma como um processo único e tampouco acabado, mas como um movimento que acompanha as transformações na própria forma de se conceber o direito e não apenas na forma como é efetivado.

A questão da Previdência Social é uma questão em aberto e representa a dificuldade em se estabilizar uma noção legítima do direito social na sociedade brasileira. Para colocar a questão nos termos de Habermas (1995), mantém-se a tensão entre aquilo que a norma institui e as condições de produção de sua legitimidade ${ }^{3}$. Nesse caso, o que tem sido acentuado é exatamente como, com o fato objetivo da escassez de recursos públicos para financiar o nível de direitos que a norma instituiu, as próprias condições de produção da legitimidade do direito entram em questão. Assim, a Previdência Social é um ponto privilegiado para a análise do direito em movimento.

A legalidade da seguridade social instituída pela Constituição Federal de 1988 pública, universal e igualitária - vem sendo questionada tanto sob a forma de sua inefetividade, quanto de sua idealidade. São duas lógicas argumentativas diversas que se entrecruzam na não instituição da seguridade social: uma que reclama da sua não realização e outra que afirma a impossibilidade de sua realização. Ao final, o que de fato a crítica

das chances de vida (DAHRENDORF, 1992). Como afirma Jacques Rancière é aí que se funda a política, como uma interrupção que obriga a pensar a proporção, que obriga a contar os não contados e a redefinir os limites do justo e do injusto. A política tem uma racionalidade própria que é a racionalidade do desentendimento (RANCIÉRE, 1995).

${ }^{3}$ A legitimidade do direito em Habermas está ancorada naquilo que denomina modelo procedimental de política deliberativa, que tem por pressuposto que o consenso se apóia no fato de que os cidadãos partilham da mesma cultura. Sua visão é diferente da concepção liberal de legitimidade (fundada no compromisso de interesses) ou da concepção republicana (fundada na formação da vontade comum). Para Habermas é o procedimento democrático que estabelece a conexão interna entre compromissos, justiça, vontade comum etc. e que pode ser localizado tanto nas instituições parlamentares quanto na rede de comunicação dos espaços públicos.A instância geradora de poder legítimo é a esfera pública, a dimensão da sociedade onde se estabelece a troca discursiva, embora apenas o poder administrativo seja capaz de traduzir em ações efetivas (HABERMAS, 1995). 
instituiu foi um discurso sobre a não efetividade da seguridade social no Brasil (Ivo, 2004; Marques; Mendes, 2004; Silva, 2004; Soares, 2001; Vianna, 2000; Marques, 1995; Mota, 1995).

No posfácio de Direito e Democracia, Habermas (1997: 308) afirma que uma norma jurídica passa a ser válida apenas quando o Estado consegue garantir a sua obediência e a criação de pressupostos institucionais para o seu exercício legítimo e para que, então, possa ser seguida em respeito à lei. A sua questão é a do estabelecimento da medida comum, a mesma da Arendt (1981). É saber em que condições uma legalidade em uma determinada conjuntura pode funcionar como uma medida comum (Ewald, 1993: 224).

Percebe-se um certo tratamento indistinto entre lei, direito e norma nas discussões sobre o direito social e sua crise no Brasil. A confusão existente entre direito e legalidade, de origem platônica, leva a crer que a existência da lei é o sinal da existência do direito. No Brasil, temos visto que freqüentemente há legalidade sem que exista direito. A legalidade responde à questão do "que deveis fazer" e o direito a "como sereis julgado". A normatividade é a operação do direito sobre si mesmo (Arendt, 1981).

A Previdência Social tem sido colocada no centro de uma disputa entre a legalidade e a legitimidade do direito, entre a sua positividade e as condições que o torna socialmente válido. Ela evidencia a tensão entre duas unidades discursivas, a que promove o seu papel de ser integrante de uma noção mais ampla de seguridade social ${ }^{4}$ e aquela que reduz o seu papel à condição de seguro social ${ }^{5}$. A primeira potencializa o seu papel no sistema de proteção social, enquanto a segunda o reduz num sentido bem estrito de amparo em situação de risco social.

O ponto paradoxal desta discussão é a expectativa frustrada de que a norma constitucional pudesse estabilizar uma noção de seguridade social amparada nos critérios de justiça social e fixada em parâmetros redistributivos. Expectativa que adquire sentido na análise histórica e no desrespeito à legalidade pelo Estado (especialmente quando em estado de exceção), evidenciando uma relação de desconfiança entre sociedade e o Estado, como se este agisse contra a sociedade.

\footnotetext{
4 "A seguridade social pode ser definida como o conjunto de políticas e ações articuladas com o objetivo de amparar o indivíduo elou seu grupo familiar ante os eventos decorrentes de morte, doença, invalidez, idade, desemprego e incapacidade econômica em geral" (OLIVEIRA, 1992a: 3).

5 "O seguro social, também conhecido como previdência social, constituído por programa de pagamentos em dinheiro e/ou serviços feitos/prestados ao individuo ou a seus dependentes, como compensação parcial/total da perda da capacidade laborativa, geralmente mediante um vinculo contributivo" (Idem: 3).
} 
A reforma da previdência evidencia uma discussão sobre a norma constitucional, fazendo-a preceder a uma discussão sobre o direito social. Como afirma Habermas (1997: 166), toda norma constitucional é um projeto cuja durabilidade depende de uma interpretação continuada em todos os níveis de positivação do direito. O campo da seguridade social que a Constituição Federal abriu teve uma curta duração, não chegando a ser regulamentada, nem implementada, embora tivesse permanecido no imaginário político e social como um sonho possível.

As disputas que se travaram ao longo da década de 1990 podem ser interpretadas como disputas relativas à legitimidade do direito. Em outros termos, o momento de regulamentação do texto constitucional foi o momento de questionamento da validade do direito instituído, assim como uma disputa em torno de sua efetividade, para usar os termos de Habermas (1997). A configuração de um esquema de seguridade social não saiu do papel, foi mais uma lei "que não pegou”. Contudo, demarcou um campo de conflito no qual se questionou a produção da própria Assembléia Nacional Constituinte (ANC) como o processo de construção da legitimidade do direito. Em meio às disputas em torno da revisão constitucional (1993-1994), atribuía-se ao lobby e à pressão realizada por vários segmentos sociais o fato de haver sido inscrito no texto constitucional direitos inexeqüíveis em razão do alto custo. A ANC não foi um local neutro, mas palco onde os conflitos sociais foram negociados em meio à conjugação de duas dinâmicas: democracia e cidadania.

Pretendia-se com a produção da norma constitucional a estabilização democrática e a fixação dos direitos civis, políticos e sociais, todavia, ela não fez mais que acentuar a mobilidade dos direitos. De qualquer forma, ela reabriu a experiência do direito e deve ser vista como o ato simbólico de fixação da democracia, como o reconhecimento recíproco, como ruptura com o passado autoritário e o compromisso com a construção democrática.

Uma Constituição é o ato fundador que faz surgir o Estado e o direito, é ela quem produz uma ordem jurídica e que pode garantir ao mesmo tempo a segurança e a liberdade (Ost, 2005: 224). A justiça social que funda é o resultado do balanceamento entre os dois valores máximos: solidariedade e liberdade (Greco, 2005a: 169).

Foi sob o argumento do "resgate da dívida social” que se buscou, em primeiro lugar, uma nova configuração para os direitos sociais no processo de transição democrática. Ofertado como dádiva, foi requisitado como direito; momento em que a sociedade desafiou 
o Estado (burocrático, autoritário e conservador) a construir o espaço da democracia, articulando às promessas liberalizantes, conteúdos que ultrapassavam os limites estreitos nas quais a própria Constituição era produzida (Paoli, 1993; Sader, 1988). O direito social que emergia da sociedade em transformação exigia o seu próprio reconhecimento e a fixação de novos parâmetros que redefinissem a questão da justiça social. Retirava a sua legitimidade do próprio processo democrático em que era formulado, naquela dupla dimensão em que Habermas (1997) trabalha: tanto na discussão pública que o motivava, quanto na construção e respeito às regras do jogo.

A ANC tentou responder a esse duplo movimento, de ser social e ser democrática, de construir as regras do jogo e se pautar por essas mesmas regras para renovar o arcabouço daquilo que deveria ser reconhecido como direito. É essa dupla dimensão que se materializou na idéia de Estado de Direito Social, inscrita no texto constitucional. A ANC foi, ela mesma, a experiência da discussão pública da fixação do justo e do injusto, na qual a pressão popular provocou a alteração das margens estreitas em que os direitos sociais eram fixados. A experiência da ANC de 1988 moldou o seu formato, sendo o produto final não limitado por questões técnicas ou de poder, mas potencializado pelas críticas das quais o direito social se alimentava. Toda a disputa em torno dos direitos sociais é uma disputa por fixar os limites e os critérios a partir dos quais torna-se legítima a própria idéia de justiça social (Ewald, 1993; Lefort, 1991). Porque é na dinâmica social que se produz a idéia do justo e do injusto, do legítimo e do ilegítimo, do direito e do privilégio, e que não podem ser configuradas como universais e nem como imutáveis (Ost, 2005).

A principal crítica que hoje se formula em torno da não configuração da seguridade social como direito está amparada na tese da violação constitucional (Soares, 2001; Vianna, 2000; Marques, 2004; Silva, 2004), isto é, o Estado descumpre a Constituição duplamente: ao não garantir a organização da seguridade social e não assegurar que o seu orçamento não seja usado em outras finalidades. Mas ao ser assim formulada, a crítica perde a sua força porque desvincula os direitos sociais das práticas sociais e o identifica com a legalidade. O direito que a Constituição produziu é visto como estático, subtraído à dinâmica do conflito social, enquanto são questões políticas que fazem com que os conteúdos e as práticas sociais sejam, ou não, legislados, sem, no entanto, atingir a idéia do que seja a experiência do direito (Ewald, 1993). 
A produção do direito é sempre a combinação de forças que clamam pela padronização numa forma de organização social e de forças que, espontânea ou organizadamente, emergem e geram um efeito de desorganização social a partir do qual se abre a experiência do direito. Desse ponto de vista, são as próprias contradições sociais que dão ao direito o seu caráter permanentemente dinâmico e que permite que o direito seja continuamente renovado.

É no caminho do reconhecimento da legitimidade da produção normativa democrática que se abrem novas perspectivas para o direito (Habermas, 1997). O "direito do direito” de Ewald (1993), como o exercício de sua reflexividade, é a forma de produção que permite que o direito seja renovado a partir de usos alternativos do próprio direito e que o direito seja reconhecido como tal a despeito das normas tornadas positivas.

A dupla referência à qual encontra-se submetida a Constituição de 1988 como “moderna” e "avançada”, de um lado, e expressão de um "anacronismo” de outro ${ }^{6}$, não faz mais que representar o confronto entre forças de renovação e forças de conservação. Mas, de qualquer forma, a seguridade social é uma experiência de direito que já nasce em crise, sob uma forte contestação, a qual perdura ao longo dos próximos 20 anos.

Para Campilongo (1994: 16), o problema central é que a Constituição foi pensada como se a transição democrática já estivesse consolidada, o que levou o Estado a um impasse: ter que compatibilizar entre uma estrutura formalmente democrática e a incapacidade de implementar decisões com impacto econômico. Como o próprio Estado caminha à margem da legalidade que criou, o seu problema é como conferir institucionalização e respeito ao processo democrático.

O direito à seguridade social perdeu sua força integradora (entre as áreas da saúde, previdência e assistência) menos pela inobservância da lei do que pela sua deslegitimação enquanto direito. Os discursos que se produziram ao longo das últimas duas décadas trataram não de uma contestação pública da legitimidade das suas áreas integrantes - saúde, assistência social e previdência social - como direito. A contestação dirigiu-se à definição

\footnotetext{
${ }^{6}$ A idéia de anacronismo sugere a superposição de tempos históricos, como um tempo descontextualizado. Ao ser tratada como "anacronismo" a Constituição foi criticada por reafirmar um programa social que estava sendo questionado nos países avançados, como expressão da crise do Estado de Bem-Estar Social. Nicole Loraux propõe, porém, uma outra interpretação para o problema do anacronismo na história, sugerindo que ele nos convida a escutar o nosso tempo de incertezas e nos ensina a não negar o tempo na história (LORAUX, 1992).
} 
legal do quantum de benefícios o Estado deveria prover e à realização dos critérios de universalidade e igualdade, por isso boa parte das reformas está centrada no processo de desconstitucionalização dos direitos. Em outras palavras, a legalidade ${ }^{7}$ que a Constituição produziu em 1988 perdeu a sua validade sob o argumento do déficit público, argumento que submeteu a legitimidade ${ }^{8}$ do direito a uma perspectiva identificada com a racionalidade econômica.

A crise econômica motivada pelo aumento da taxa de juros da dívida externa e pelo déficit público tornaram evidente a incapacidade do Estado em garantir o mesmo nível de direitos para todos os cidadãos, bem como a necessidade de se estabelecer tetos para a concessão de prestações pecuniárias. Se, a Constituição fixara o nível mínimo de direitos, o debate que seguiu tratou de fixar o nível máximo para os mesmos direitos.

A questão do “custo do direito” aparece por inteiro na forma de apresentação do déficit da Previdência, na incapacidade de financiamento do gasto social pelo Estado, na forma de regulação do trabalho e na discussão dos riscos sociais. Os conflitos por recursos, armados tanto entre as áreas integrantes da seguridade social e destas em relação a outras áreas do governo $^{9}$, expressa a necessidade de priorização, mesmo entre direitos. A crise fiscal do Estado não é apenas objeto de retórica, mas a expressão concreta de uma crise no padrão de financiamento dos serviços públicos e da dificuldade em se obter créditos externos.

No Brasil, a década de 1990 foi a expressão de um paradoxo nas expectativas de ação do Estado: a consolidação de direitos sociais e a consolidação de uma política macroeconômica dirigida à contenção do déficit público. Uma força que puxava para a ampliação dos gastos sociais e outra, que puxava para o esforço de formação de superávit

\footnotetext{
${ }^{7}$ Legalidade faz parte da concepção secular das leis positivas consideradas da ordem imanente, ou seja, é criação artificial do homem. A lei como parte de um sistema normativo com força de obrigação. Ver à respeito, o verbete Lei (OUTHWAITE \& BoTTOMORE, 1996: 414-418).

${ }^{8}$ Em Weber, a legitimidade está amparada na idéia de pretensão de apoio a uma ordem social ou política no lugar de mera aquiescência. Weber estava preocupado com as condições de produção na ordem social de uma autoridade legítima e concebeu três tipos ideais: baseado na tradição, no carisma e na aceitação da legalidade de uma ordem instituída. Numa ordem legal, a legitimidade provém da aceitação das regras do jogo. Habermas vai além e concebe que a legitimidade é extraída do próprio processo de construção das regras, e não da mera aceitação. É o procedimento democrático em discussão pública que fornece os instrumentos de legitimação (WEBER, 1979a; HABERMAS,1995).

${ }_{9}^{9}$ Incluem tanto a disputa entre as áreas sociais e as econômicas (financiamento de obra de infra-estrutura, de programas de crescimento econômico, de financiamento para empresas, cumprimento de metas fiscais) e entre outras áreas sociais, como transporte, educação etc.
} 
primário e pagamento dos serviços da dívida externa em respeito aos compromissos assumidos com as agências de financiamento. Ao final do processo da Assembléia Nacional Constituinte, os principais problemas não haviam sido resolvidos e a Constituição de 1988 apenas apontava a direção das reformas, sem consolidá-las, uma vez que muitos aspectos ficariam dependentes da legislação complementar e ordinária (Rezende \& Afonso, 1987).

A definição foi adiada, talvez por força da pressão exercida pelos lobbies, sendo que o principal aspecto seria justamente a compatibilização entre a reforma tributária e a seguridade social, que demandava uma análise mais acurada de como as mudanças se refletiriam sobre as contas do setor público e qual a margem de manobra que a União disporia para acomodar a descentralização de recursos, a consolidação do orçamento da seguridade social, o pagamento dos serviços da dívida externa e a realização de suas atribuições governamentais. Essa análise já apontava para o conflito distributivo que se armava com a instituição do Fundo de Participação de Estados e Municípios e a criação de um Orçamento da Seguridade Social, à parte do Orçamento Fiscal e de caráter vinculado. Em 1975 o orçamento da Previdência Social já era, isoladamente, o segundo orçamento do país $^{10}$ (Malloy, 1976: 94), mesmo sem o aporte de novas contribuições sociais. O Congresso Nacional ao tornar a arrecadação e a despesa previdenciária peças orçamentárias, permitiu o exercício do controle público sobre as suas contas e lhe conferiu centralidade e relevância no debate.

O início da década de 1990 foi marcado pelas disputas em torno da regulamentação dos dispositivos constitucionais e pela expectativa de consolidação da seguridade social como o princípio norteador da execução das políticas sociais. No entanto, as áreas constituintes - saúde, assistência e previdência social - receberam tratamento em separado. O maior peso coube à previdência social, sob o argumento central de que a realização do dispositivo constitucional que estabelecia o salário mínimo como o valor mínimo dos benefícios previdenciários, incluindo o mesmo critério para os trabalhadores rurais,

\footnotetext{
${ }^{10}$ Em 1975, o orçamento da Previdência Social, considerando apenas as contribuições previdenciárias de empregados e empregadores sobre a folha de pagamento de salários, somava, em valores da época, Cr\$ 43 bilhões de cruzeiros, enquanto que o orçamento fiscal somava Cr\$ 133 bilhões de cruzeiros. Como o Orçamento da Seguridade Social integrava ainda outras contribuições sociais (lucro, faturamento, loterias) o montante era ainda mais significativo em relação ao Orçamento Fiscal (MALLOY, 1976a).
} 
provocara um aumento de $100 \%$ nas despesas com este grupo populacional e elevara as despesas gerais da Previdência, provocando déficits em suas contas.

A idéia de "crise financeira da Previdência social” ganhou corpo, alimentada também pelo decréscimo das contribuições sobre a folha de pagamentos decorrente do crescimento do trabalho informal e do desemprego, embora essa dimensão tenha ficado de fora dos argumentos pró-reforma. Os discursos empresariais sobre o custo da mão de obra no Brasil e a composição da carga tributária, como uma das mais elevadas do mundo, reforçavam a tese de que o mercado de trabalho não poderia ser recomposto no mesmo nível dos anos 1980. Os projetos de flexibilização do mercado de trabalho, com impacto sobre os direitos trabalhistas e previdenciários foram correntes durante a década de 1990, e pleiteavam subsídios fiscais e eliminação de encargos sociais que deveriam resultar em redução do custo do trabalho, incluindo a redução das contribuições sociais para a seguridade social (Santos, 2001; Noronha, 1998).

Se, de um lado o governo produziu o discurso do déficit da Previdência Social provocado pela elevação dos gastos com benefícios definidos na Constituição, de outro os empresários produziram o discurso da pesada carga tributária que compromete o crescimento econômico, a competição desigual e o emprego formal, com ameaça de "dumping social”" . No discurso empresarial os direitos dos trabalhadores provocavam custos, fossem eles trabalhistas ou previdenciários, e reclamava-se a flexibilização dos direitos decorrentes do trabalho, para ajustá-lo às condições de produção e distribuição.

As condições em que estes discursos foram produzidos foram de crise econômica, inflação, desemprego, crescimento do mercado informal de trabalho, deterioração das condições de vida e pobreza generalizada. Sob o comando do Presidente Collor, as propostas de privatização, de reforma administrativa, de retração no tamanho do Estado ganhavam fôlego e animavam os discursos desfavoráveis à implantação da seguridade social.

O conteúdo político de reconhecimento dos direitos e de "resgate da dívida social” dos anos 80 foi superado pelo argumento de que a adoção da equivalência nos direitos de seguridade social provocaria uma crise de "governabilidade" associada ao seu conteúdo

\footnotetext{
${ }^{11}$ Forma de competição desleal provocada pela contratação de trabalhadores fora das normas legais, com redução de salários, sem respeito à legislação trabalhista e previdenciária.
} 
econômico (Melo, 1995; Ugá, 2003). A crise da Previdência Social adquiriu relevância neste contexto em que não se podia negar que o item principal da disputa era a constitucionalização do valor dos benefícios, não apenas por provocar elevação das despesas, mas por inserir uma dimensão de controle público nas suas contas. Desse modo, o dispositivo constitucional buscava não apenas introduzir garantias contra a deterioração no valor dos benefícios, mas, principalmente, impedir a manipulação técnica que forçava a adequação entre receitas e despesas através do recurso sistemático da redução no valor dos benefícios, assim como a prática de inserir outras despesas públicas nas contas da Previdência.

Ao final da década de 1980, os benefícios previdenciários estavam aquém não apenas do salário mínimo ${ }^{12}$, mas de prover aos mais pobres de um mínimo de condições de vida. Com a constitucionalização do valor mínimo e dos critérios de reajuste dos benefícios, os técnicos perdiam a possibilidade de manipular o orçamento da Previdência Social, uma vez que dependeriam de leis públicas como a fixação do salário mínimo nacional. Doravante toda a discussão sobre o salário mínimo implicou uma discussão sobre a Previdência Social e a sua elevação ficou condicionada à existência de recursos para honrar os compromissos previdenciários.

Entretanto, a fixação de um mínimo no valor dos benefícios no texto constitucional produziu uma nova discussão sobre os critérios de justiça que envolve ativos e inativos no modelo de repartição simples. Devem ser portadores dos mesmos direitos? Devem ter reajustes paritários? A discussão encaminhou-se, desse ponto de vista, para uma questão mais conceitual acerca do seguro social e introduziu ao debate a questão do risco social, que havia sido abandonada em nome da universalidade no acesso aos direitos sociais. Uma discussão bastante influenciada pelos mandamentos de Milton Friedman, para quem a Previdência Social deveria se tornar um seguro social, privado, individualmente contratado e em sistema de capitalização (Draibe, 1993: 90).

Em meados da década de 1990, a expectativa da instalação de um programa de seguridade social já havia sido superada e começou a se delinear um projeto de seguro social mais estritamente falando, no qual a noção de risco adquiriu centralidade enquanto

\footnotetext{
${ }^{12}$ Em 1975, a Lei 6.205, de 29/04/75, estabeleceu a descaracterização do salário mínimo como fator de correção monetária das prestações previdenciárias (BRASIL, 2006).
} 
critério de elegibilidade - doença, invalidez e idade avançada. Foram questionados benefícios como o direito à aposentadoria por tempo de serviço e licença-maternidade, auxílio-reclusão e salário-família.

Ante a impossibilidade de se configurar um esquema de proteção social amparado na idéia de seguridade social, a previdência social adquiriu centralidade no debate, reportada às despesas, ao modelo de financiamento e aos critérios de elegibilidade. A Previdência Social concentrou a maior parte das disputas em torno do direito social porque ela é uma política de transferência de riscos, entre grupos com perfis de renda distintos (transferência horizontal) e entre gerações (transferências verticais) (Baldwin, 1990). Decorre dessa condição que as decisões a respeito de mudanças não podem representar uma ruptura com a segurança jurídica e a segurança política. As mudanças devem ser processadas em respeito à dupla condicionalidade do direito - a retrospectiva e a prospectiva - isto é, devem considerar não apenas os critérios que envolvem elegibilidades presentes, mas também o direito adquirido (passado), bem como a expectativa de direito (futuro). Essa é uma exigência do seu caráter intertemporal, intergeracional.

Como uma dimensão importante do conflito, a previdência social não permitia o ajuste técnico de suas contas, como ocorreu com a saúde e a assistência social. Sujeita como era ao controle público, o governo precisava construir a validade do discurso que daria legitimidade à reforma. Nesse ponto de vista, a reforma não diz respeito tão somente aos direitos, mas à forma de financiamento, às disputas orçamentárias e ao conflito distributivo.

A questão adquiriu ainda relevância por ter sido alçada à dimensão de um debate constitucional, o que contribuiu para ampliar o universo de problemas co-relacionados, em especial, a questão da reforma tributária, financiamento e o “custo do direito” social. Se, uma Constituição é feita para durar, o ambiente de revisão constitucional demanda tempo para a reconstrução do sentido e para a formação de novos consensos sociais, como o tempo da construção da sua própria legitimidade (Ost, 2005; Habermas, 1997). Um tempo que executa o trabalho de “desligar o passado" e "ligar o futuro”, de moldar o equilíbrio entre a estabilidade e a mudança, entre a continuidade e a ruptura (Ost, 2005). Eis porque na reforma da Previdência o tempo demandado é tão relevante quanto o seu conteúdo. 
A “reforma da Previdência” não foi um episódio único, mas um movimento de reorientação da política previdenciária que se estendeu ao longo de 20 anos e cujo resultado não se pode dizer que é fechado. Em resposta a uma crise contínua e permanente na história da Previdência Social, a reforma também tem sido uma resposta contínua e permanente, eis porquê a história da Previdência Social deve ser interpretada como uma questão em aberto.

Até o momento, o resultado alcançado foi o reforço do vínculo contributivo e a auto-sustentação financeira baseada nas contribuições de empregados e empregadores sobre a folha de pagamento de salários, o que reforça o seu papel de seguro social. O vínculo contributivo obrigatório seria a chave de um novo modelo de solidariedade social, com corte horizontal (entre gerações) e vertical (numa hierarquia de renda e benefícios). Um modelo que valoriza a solidariedade ancorada na capacidade contributiva de cada um.

A solução para a crise se dá com a contração do Estado, diferente do percurso até o momento, quando o privado cedia cada vez mais espaço ao público e o Estado assumia mais tarefas e serviços e o direito público avançava sobre o direito privado (Souza Filho, 1999). A privatização e a focalização desfazem o percurso da universalização e retira do campo dos direitos benefícios e serviços sociais, remetendo-os ou para o mercado, ou para a assistência aos mais pobres, com a política social pensada de modo residual e cindida em dois campos opostos.

A mudança de paradigma em relação à provisão de direitos sociais promove uma mudança na própria concepção de justiça, com o pressuposto de que os gastos sociais devam ser dirigidos prioritariamente aos segmentos mais pobres (subsídios à alimentação, nutrição, geração de renda, renda mínima etc.). É uma mudança que propõe uma revisão dos critérios sociais utilizados na definição de direitos e, portanto, nas classificações sociais. Neste plano discursivo, o conteúdo dos direitos sociais foi redefinido a partir de um ponto de vista técnico amparado em critérios de eficiência, que tratava de medir o efeito dos remédios sobre os males, ou seja, o resultado dos gastos públicos sobre a redução da desigualdade social e da pobreza (resultado); e de eficácia, que tratava de avaliar o melhor remédio para cada mal (meios empregados). 
Em um termo bastante pejorativo, mas elucidativo, o movimento de reforma foi chamado de "desobstruinte”"13, o que assinala a ilegitimidade do direito constitucionalmente garantido e reafirma o principal ponto da disputa que são os altos custos para torná-los efetivos. É o tema da sociedade contra o social de Renato Janine Ribeiro (2000: 24): os direitos tornaram-se um obstáculo à realização do econômico. Com a desobstruinte, remove-se as obstruções interpostas pelo direito social ao crescimento econômico, promove-se a cisão entre o social e a sociedade, com o crescimento da subordinação da vida social à economia.

Uma nova racionalidade tomou conta do direito à Previdência Social: a racionalidade econômica. Houve uma inversão no modo como o direito havia sido enfocado até o momento. De um déficit de direito, passou-se a um déficit de caixa (contabilidade). A insuficiência financeira tornou-se a chave para a avaliação do quantum de direito que deveria estar disponível ou o quanto de direito o Estado seria capaz de proporcionar. A associação entre direito e dinheiro subverte toda a lógica pela qual a expansão dos direitos havia sido pensada. A racionalidade política (Reis, 2000) e a racionalidade jurídica (Lopes, 2006) são confrontadas pela racionalidade econômica como o modo de justificar e dar razão às reformas. A análise econômica torna-se parte integrante do processo decisório e dos fundamentos da decisão (Lopes, 2006: 279) e influenciam não apenas as decisões do governo, mas também as decisões legislativas. A implicação econômica das decisões legislativas passou a ser levada em consideração e, em certa medida, condicionou também o julgamento de constitucionalidade das propostas apresentadas no Supremo Tribunal Federal (STF) (Rocha, 2004). Nenhuma medida foi aprovada sem ter por referência as “contas da Previdência”, o que nos aproxima da proposta de Rose-Ackerman (2004) sobre a "consistência financeira” das decisões legislativas.

O discurso da oposição, por sua vez, centrou-se no discurso da racionalização burocrática, com propostas de aumento de eficiência da máquina pública na arrecadação,

\footnotetext{
${ }^{13}$ Em novembro de 2006 o Presidente Luiz Inácio Lula da Silva afirmou estar preocupado (agora) em desobstruir o crescimento e o desenvolvimento, o que serviu de mote para Paulo Rabello de Castro escrever um artigo na imprensa que dizia que, já que não se lançava uma Constituinte revisora e modernizadora dos capítulos da tributação, repartição de receitas e da seguridade social, deveria partir para uma "desobstruinte" que encarasse a simplificação tributária (tributos e contribuições sociais). CASTRo, Paulo Rabello. "Desobstruinte", Folha de São Paulo, 22/11/2006.
} 
controle e gastos. A oposição defendia que, eliminando-se os desperdícios (tanto do lado da arrecadação quanto do lado da despesa), seria possível prover os cidadãos com os benefícios que a Constituição determinava. Uma das medidas mais importantes seria, no entanto, uma ampla racionalização dos critérios de concessão de aposentadorias e pensões aos funcionários públicos, como parte de uma racionalização da própria administração pública, especialmente sobre a folha de salários $^{14}$. No entanto, a própria oposição não se furtou à criação de fundos de pensão quando essa se revelou uma possibilidade prática ${ }^{15} \mathrm{e}$ passou a defender reformas como medidas de preservação da previdência social pública e básica.

Ao final, podemos dizer que, além da introdução de uma reforma embasada na racionalidade econômica, que modifica critérios de igualdade, justiça social, solidariedade, a máquina pública também foi tomada de um amplo processo de racionalização, com fortalecimento das estruturas burocráticas centralizadas e criação de modelos/agências de regulação tomados de empréstimo da economia ${ }^{16}$.

Sob o governo de Luiz Inácio Lula da Silva a reforma da Previdência não apenas teve continuidade como perseguiu os mesmos objetivos de seu antecessor, Fernando Henrique, com ênfase tanto no processo de racionalização, quanto no discurso amparado na racionalidade econômica. Ademais, a reforma foi mais profunda para o segmento dos funcionários públicos que viram todos os diferenciais em relação aos trabalhadores da iniciativa privada serem removidos. A remoção da estabilidade no emprego público só não ocorreu por demandar reforma administrativa, a qual não caminhou apesar de constar da agenda pública.

\footnotetext{
${ }^{14}$ Lembremos que a folha de pagamento de salários da administração pública era responsável pelo pagamento de ativos e inativos, uma vez que a aposentadoria não possuía caráter previdenciário e não tinha vínculo contributivo, diferentemente do que ocorria com o pagamento de pensões. O funcionário público passava à inatividade sem perder o seu status de funcionário, mantendo todos os direitos e prerrogativas do cargo. $\mathrm{O}$ programa de aposentadoria dos funcionários públicos havia se constituído como um sistema meritocrático, cuja concessão dependia do julgamento dos serviços prestados sem qualquer outro critério que não fosse o tempo de trabalho. Do mesmo modo, um funcionário podia passar a inatividade como punição, a exemplo do que ocorreu durante a ditadura militar com as aposentadorias compulsórias.

${ }^{15}$ Ver a respeito a criação de fundo de pensão do sindicato dos bancários, por exemplo, o qual era vinculado à CUT, que fazia oposição ao projeto de reforma de Fernando Henrique, como ilustra SILVA (2007).

${ }^{16}$ Uma particularidade desse processo de racionalização burocrática é o foco nas questões relativas à arrecadação e aos gastos, bem como a gestão dos recursos da Previdência Social. É uma racionalização que envolve aspectos econômico-financeiros visando à contenção do déficit público.
} 
A ênfase na reforma da previdência do funcionalismo público assumiu a forma de um corporativismo às avessas (como uma vingança contra o corporativismo histórico) em que os funcionários públicos foram alçados à condição de vilão pelas mazelas da economia pública. Ocorreu uma desmontagem da clivagem entre trabalhadores da iniciativa privada e da administração pública, que reforçou uma imagem negativa dos funcionários públicos perante a sociedade. Sob o argumento da remoção dos privilégios na concessão de aposentadorias aos funcionários públicos, procedeu-se a uma ampla reformulação do próprio Estado, em relação a tamanho, despesas e implementação de políticas ${ }^{17}$. Foi a necessidade de reforma do Estado e a necessidade de estabilizar as contas públicas que conduziu à remoção das condições que sempre possibilitaram dividir os custos dos inativos públicos com a Previdência Social, como ocorria com a maioria das políticas sociais.

A tese que sustento é que o tema da reforma da Previdência encontrou uma nova racionalidade discursiva para o tratamento da questão do direito social que desloca as antigas demandas de proteção social amparadas na busca da universalidade, da igualdade e de mecanismos redistributivos. A racionalidade econômica (Weber, 2004) é a nova chave discursiva através da qual se busca construir ou desconstruir os parâmetros de legitimidade do direito social. De outro modo, a reforma é a vitória da racionalização sobre a produção institucional de bens públicos. Nesse caso, os seus resultados se voltam também para a administração pública, fazendo com que se paute pelos princípios da racionalidade econômica. É um duplo efeito das reformas processadas nas últimas duas décadas e as quais se pode observar no novo desenho da Previdência Social.

A reforma da Previdência foi construída a partir de uma outra unidade discursiva diferente daquela que presidiu o discurso político e social da década de 1980. As “contas” da Previdência - apresentadas e reapresentadas, contestadas e defendidas, contadas e recontadas - foram a justificativa dessa unidade discursiva. A escassez de recursos, num ambiente de déficit público, foi o argumento central das propostas embasadas em critérios de racionalidade econômica.

\footnotetext{
${ }^{17}$ Desmond King analisa como as estruturas do bem-estar social nos países avançados foram modificadas pelo crescimento tanto do emprego público, quanto dos beneficiários dos programas de bem-estar. Essa dupla dimensão ajuda a compreender como a necessidade de ajuste nas contas públicas provoca controle e minimização da provisão pública que, no caso, incide tanto sobre os funcionários ativos quanto sobre os inativos. A tentativa de maximizar o orçamento, reduzir as despesas fixas (como a folha de pagamento de salários) leva a uma redistribuição dos custos. Em outros termos, a reforma afeta não apenas a Previdência Social, mas a própria estrutura do emprego público (KING, 1988).
} 
O discurso da racionalidade econômica conduziu, como resultado inesperado, a um amplo processo de racionalização que fez com que as mudanças fossem sentidas não apenas nas regras do direito, mas também, nos processos institucionais. O processo de racionalização avançou sobre suas estruturas de arrecadação, pagamento de benefícios, contencioso jurídico, informação e informatização, processos judiciais, relação entre os entes da Federação, etc. Ao final da reforma da Previdência essa se projetou sobre si própria e em nome do combate a fraudes, desperdícios, sonegação, roubos e aproveitamento bancário, produziu um amplo processo de racionalização que modificou suas estruturas institucionais. Racionalização que levou ao uso de novos instrumentos técnicos de controle, de gestão e de avaliação. Racionalização que também se projetou sobre o Estado, considerando os três níveis de governo, para exigir-lhes o cumprimento das mesmas regras do setor privado. Racionalização que também se projetou sobre o sistema bancário invertendo a lógica da concessão do serviço bancário pela compra de carteira de clientes à qual se oferece o serviço bancário.

A racionalização foi o resultado não pretendido da reforma da Previdência. O discurso da racionalidade econômica, amparado na eficiência, eficácia, redução de custos e racionamento da cesta básica de direitos, iluminou os desperdícios históricos da Previdência Social que evidenciam não apenas as falhas das técnicas de gestão, mas o uso irregular e ilegal dos recursos previdenciários pelo Estado. O discurso da racionalidade econômica produziu efeitos que se fazem sentir em duas direções: na mudança do direito e na sua forma institucional. Resta saber, se o movimento de racionalização irá conferir transparência à instituição, contribuindo, assim, para torná-la, de fato, pública.

Ao final das reformas, a Previdência Social foi confirmada como direito público, obrigatório, de vínculo contributivo e amparado na idéia de risco social e tornou-se um modelo de Previdência unificado, uniformizado e universal, como se buscou ao longo da história. Contudo, o resultado foi um regime bastante diferente daquele de Beveridge, e acabou por reforçar a idéia de seguro social a la Bismarck. O sistema de proteção social no Brasil caminhou de um modelo meritocrático ${ }^{18}$ para um modelo cindido em dois, com reforço tanto da idéia de seguro social, quanto de assistência social. A seguridade social foi

\footnotetext{
${ }^{18}$ Com referência ao modelo proposto por TITMUss (1958).
} 
apenas uma promessa não cumprida (Arendt, 1981; Ost, 2005; Habermas, 1997; Koselleck, 2006; Sennet, 2001). Promessa que deve ser compreendida como a capacidade de comprometer duradouramente a sua palavra, em fazer-se acreditar, como diria Hannah Arendt (1981).

\section{Estrutura da tese}

Esta tese apresenta-se dividida em duas partes. A primeira concentra-se no debate sobre a produção da crise da previdência social, a partir do conceito constitucional de seguridade social e do padrão de financiamento que introduziu. A segunda parte, busca reconstituir o debate no tempo, concentrando-se nas propostas de reforma discutidas no Congresso Nacional, bem como os seus resultados efetivos. A partir desses dois movimentos é que se evidenciam as disputas em torno das medidas que tornaram de controle público a instituição, bem como o amplo processo de racionalização que a envolveu.

O capítulo I apresenta uma discussão sobre o deslocamento de questões sociológicas relevantes a partir da perspectiva do “custo do direito” proposto por Holmes e Sunstein (1999). Buscamos apresentar como, ao longo dos últimos vinte anos, houve um deslocamento do enfoque sobre os gastos sociais predominante nas abordagens sobre políticas de proteção social para a questão dos “custos do direito”. É como mais diretamente podemos perceber a construção de uma unidade discursiva em torno da racionalidade econômica. As conseqüências que esse deslocamento produzem afetam tanto a percepção sobre o direito, quanto sobre a solidariedade social, que é reconstruída como uma solidariedade contributiva. O modo como a questão é apresentada nos leva diretamente às proposições de Comte sobre o fato de que não há direitos, senão deveres na sociedade.

O capítulo II reconstrói as duas unidades discursivas a partir dos eventos que lhe deram notoriedade para interpretá-las como dotadas de racionalidades próprias e distintas. Como método de abordagem, recuamos no tempo para resgatar as abordagens sobre a crise da previdência social na década de 1980 e demonstrar como as questões econômicas já eram dadas, mas não foram suficientes para barrar a inserção de um novo conceito de proteção social no texto constitucional de 1988. O recuo no tempo foi fundamental para percebermos que o discurso atual sobre a crise da Previdência atualiza o debate da década 
de 1980 e faz com que a seguridade social instituída pela Constituição seja interpretada como a vitória da irracionalidade.

O capítulo III objetiva apresentar de modo crítico o conflito distributivo armado em torno das “contas da Previdência” e a polêmica sobre se é deficitária ou superavitária. A redação desse capítulo se beneficia do tempo histórico, uma vez que parte da polêmica já se encontra resolvida em função das decisões do Tribunal de Contas da União que denunciou que os resultados obtidos são frutos das metodologias adotadas e refletem o conflito distributivo no interior do orçamento público. As disputas em torno das contas da Previdência evidenciam como esta se tornou objeto de controle público, o que permitiu a denúncia das manipulações técnicas em torno de seus resultados, constituindo-se, talvez, na medida mais importante consagrada no texto constitucional de 1988.

A segunda parte desta tese concentra tanto o debate sobre a reforma da previdência e o seu conteúdo, quanto o reconstitui no tempo, o que ajuda a lhe conferir densidade e a reconhecer a sua relação com outros temas relevantes na agenda pública. Ela é constituída por quatro capítulos, que perpassam os debates em torno da regulamentação dos direitos, da revisão constitucional, das reformas e de seus principais resultados.

O capítulo IV, “o tempo da regulamentação”, reconstitui o debate em torno da expectativa de construção do modelo de seguridade social a partir da carta constitucional de 1988 e se estende até 1993, abrangendo o fim do Governo Sarney e o Governo Collor, até o impeachment. A promulgação da Constituição Federal confrontou duas expectativas: a da regulamentação dos direitos sociais e a do controle do déficit público. O período que vai de 1988 a 1993 expressa o confronto entre duas agendas: a social e a econômica. Do confronto, tem início uma mudança de perspectiva na compreensão do direito social que passa a ser limitado pelas questões econômicas. O ano de 1992 é um marco, porque representa o fim do Governo Collor com sua agenda de privatização e o início do Governo Itamar, comprometido com as reformas econômicas. As discussões decisivamente mudam de patamar, com a definição de uma agenda de reformas da qual a previdência passa a fazer parte.

O capítulo V, “tempo da revisão constitucional” apresenta o deslocamento do centro do debate sobre a construção do programa de seguridade social para um debate centrado nas contas públicas e na tributação. É o momento em que a racionalidade econômica 
assume preponderância nos debates sobre a Previdência Social e no qual o foco será deslocado para as suas contas. As questões sobre a reforma da Previdência são atravessadas pelas questões da reforma tributária. A revisão constitucional, embora curta no tempo (1993-1994) trouxe de volta o debate em torno da instituição da seguridade social, conceitos e financiamento, que, no entanto, foi sufocado pela agenda econômica do Executivo. De qualquer forma, nesse período, evidenciou-se que a reforma da previdência tinha conseqüências além de si própria, uma vez que exigia também uma reforma constitucional, que pressupunha um novo processo de negociação e de formação de compromissos.

O capítulo VI, “tempo da reforma da Previdência”, faz o recorte a partir de 1995 e é um tempo em aberto, dado que a agenda de reformas não se esgotou. Esse tempo é apresentado como aquele em que o debate econômico, financeiro e atuarial se sobrepõe à discussão conceitual ou de defesa dos direitos sociais. O longo período da reforma de Fernando Henrique expressa o tempo da legitimação de um novo discurso sobre a previdência, sobre o direito social e sobre as contas públicas. Essa interface pode ser compreendida pelos temas da responsabilização e do custo do direito. A reforma do Governo Lula tem uma outra direção e pode ser identificada como a imposição de um processo de racionalização sobre a Previdência Social nos dois regimes.

O capítulo VII sistematiza as principais mudanças ocorridas com as reformas e aborda o seu significado, a especificidade do caso brasileiro perante os demais países da América Latina e os temas que permanecem em aberto.

As Considerações Finais realizam a síntese desta tese ao apresentar as questões mais relevantes na compreensão tanto do processo de racionalização na reforma da previdência, quanto do discurso da racionalidade econômica que o orienta. Compreender como as contas da Previdência se tornaram objeto de controle público ajuda a entender o próprio encaminhamento das medidas de racionalização e de reforma. 


\section{CAPÍtulo I}

\section{O CUSTO DO DIREITO}

\section{Financiamento do gasto social}

As pesquisas sobre o financiamento dos gastos com política social no Brasil foram fortemente influenciadas por The Fiscal Crisis of State, de James O’Connor (1973), que forneceu um instrumento para analisar o papel do Estado no desenvolvimento capitalista a partir das suas funções fundamentais (acumulação e legitimação) e da distribuição de recursos no orçamento ${ }^{19}$. Sob essa perspectiva foi possível analisar o papel do Estado na articulação dos processos econômicos, políticos e sociais no que denominou a "crise fiscal do Estado”. O’Connor defende a tese de que a provisão pública de bem estar teria institucionalizado o conflito de classes, deslocando-o das questões relativas à produção para questões de caráter distributivo.

Para esta vertente “neomarxista” (Esping-Andersen, 1998; Faria, 1998), as políticas sociais são úteis e funcionais ao capitalismo, posto que suavizam o processo de acumulação e asseguram a redução dos conflitos sociais, enquanto reduzem os custos de reprodução da força de trabalho e aumentam a produtividade do trabalho. Por outro lado, a transferência direta de renda permite a manutenção do consumo e a realização do ciclo econômico. É uma análise que foca mais na institucionalização do conflito distributivo dos recursos públicos do que propriamente no seu efeito sobre a redução das desigualdades sociais ou no provimento de "segurança social”20.

\footnotetext{
${ }^{19}$ Pierson relata que um primeiro ciclo de crise fiscal ocorreu como conseqüência da crise de 1929, que provocou corte nas despesas sociais, que demonstravam ser incapaz de sustentar atuarialmente um seguro social sob profunda recessão econômica; que a demanda por gastos sociais está inversamente relacionada com a capacidade econômica em atendê-la; a resposta a este problema através do corte dos gastos sociais poderia ser intensifica, ao invés de aliviar os problemas econômicos. O problema do corte nos gastos sociais em épocas de recessão já estava demonstrado bem antes do aprofundamento das estruturas de bem estar social. (PIERSON, 1991: 118).

${ }^{20}$ Dado que a expressão "seguridade social” representa um neologismo em português utilizo-me da tradução portuguesa, "segurança social", que permite compreender o tipo de efeito pretendido sobre os problemas sociais. Flora e Heidenheimer expressam ainda que o objetivo das políticas sociais era produzir "segurança
} 
O’Connor interpreta o orçamento estatal como o resultado de uma disputa de recursos entre desenvolvimento econômico e despesas sociais. O total de gastos do Estado seria a soma de duas grandes contas: capital social e despesas sociais de produção. Ao primeiro estão relacionadas despesas requeridas pela acumulação de capital, como investimentos sociais destinados a aumentar a produtividade do trabalho e a taxa de lucro; o consumo social, projetos e serviços que reduzem a reprodução do trabalho e aumentam a taxa de lucro. Nas despesas sociais de produção estariam embutidos os projetos e serviços destinados a manter a harmonia social e satisfazer a função legitimadora do Estado, o que para Gough (1979) e Therborn (1987) é a essência da natureza contraditória do Estado de Bem Estar Social, que pretende conciliar dois interesses divergentes. É a "unidade contraditória” de que fala Offe (1984), que traz pontos negativos e positivos para ambos, capital e trabalho, na disputa por recursos públicos.

Boaventura Souza Santos (1989: 327) aponta que a renúncia - de lucros por parte do capital e de reivindicações por parte dos trabalhadores - é o componente central do compromisso keynesiano, que é gerido pelo Estado de Bem-Estar Social nos países centrais, reforçando a tese da institucionalização do conflito social. Esping-Andersen (1998) partilha da mesma tese, nomeando a renúncia efetuada por meio desse compromisso como um efeito de des-capitalização muito mais que um efeito de socialização dos custos. O capital social é a transformação dos recursos obtidos com a tributação em investimento social (tudo que aumente a produtividade do trabalho) e em consumo social (tudo que reduza o custo do trabalho). Ao gerir o capital social, o Estado pode criar condições gerais de acumulação, aumentar o nível de consumo e realizar a harmonia social, através dos mecanismos de redistribuição. A análise de Boaventura Souza Santos sobre a ampliação generalizada das despesas sociais está assente no mesmo pressuposto de O’Connor de compatibilidade entre acumulação e legitimação, crescimento econômico e políticas sociais, capitalismo e democracia.

Esping-Andersen explora o argumento de Heimann ${ }^{21}$ sobre a formação de um equilíbrio sui generis patrocinado pelos direitos sociais cujo efeito central é, justamente,

sócio-econômica, uma vez que deveriam suprir a carência de renda em momentos em que houvesse incapacidade para o trabalho (FLORA \& HEIDENHEIMER, 1987b).

${ }^{21}$ HeImANN, E. (1929). Sociale Theorie der Kapitalismus. Frankfurt: Suhrkamp apud EsPING-ANDERSEN, 1998: 45. 
fazer avançar sobre as fronteiras do poder capitalista (1998: 95). A mesma idéia está presente em Ewald (1993: 187), quando afirma que o que distingue o Estado Liberal do Estado Social é o modo específico com que se estabelece a partilha, como se traça o limite entre o que pode e o que não pode ser direito.

A posição do Estado entre acumulação e legitimação produz uma disputa pelos fundos públicos (Oliveira, 1988), que financiam tanto a reprodução da força de trabalho por meio de gastos sociais, quanto a expansão econômica, a qual vai estar no centro da crise fiscal do Estado. Seguindo a mesma linha de interpretação de Esping-Andersen, o conceito de fundo público de Francisco de Oliveira expressa não a contraditoriedade entre as duas funções a que se destina o financiamento público, mas a composição de um mix na mesma unidade (Oliveira: 53) que permite o deslocamento da luta de classes da esfera das relações privadas para uma esfera pública, ou seja, das relações de trabalho, para o orçamento público. É a idéia de “balanço de interesses” de Therborn (1987), a partilha entre capital e trabalho organizado.

Wilenski (1975) também fez do gasto social um instrumento privilegiado para compreender a expansão do Estado de Bem-Estar Social numa pesquisa empírica comparativa entre os países. Para ele, a principal função do gasto social seria garantir a participação do indivíduo na riqueza coletiva, influenciado tanto pela estrutura demográfica quanto pelo tempo de existência da instituição responsável pela execução, ou seja, o grau de maturidade do sistema. Ao Estado competiria garantir determinados padrões mínimos de vida, que poderiam ser definidos, analisados e comparados, segundo a estrutura do gasto social, que se torna a medida do grau de desenvolvimento do Estado de Bem-Estar Social.

Utilizando o método desenvolvido por O’Connor, Afonso e Souza (1977: 17) foram pioneiros na análise da crise fiscal brasileira através da relação entre receita agregada e despesa agregada do Estado no período de 1950 a 1975 e identificaram que a tendência histórica foi a despesa ser maior que a receita no período. Os autores sugerem que a crise do Estado brasileiro não é restrita à área fiscal, mas sim, uma crise do modelo de desenvolvimento e supõem que a ausência de mecanismos democráticos de fiscalização permitia desvios, fraudes e corrupção na execução orçamentária. Os dois argumentos em relação ao déficit público já se encontravam delineados naquele momento: crescimento das despesas maior que as receitas e falta de racionalização no uso dos recursos públicos. A 
receita agregada do Estado, por sua vez, era composta pela soma de impostos sobre o capital, impostos sobre o trabalho e outras fontes internas da receita estatal.

No aspecto metodológico, Afonso e Souza apontam que apesar de adotarem a classificação de O’Connor, a sua adequação ao estudo das estatísticas nacionais era difícil, pois elas, além das deficiências e constantes mudanças de critérios de classificação e agrupamento de dados ${ }^{22}$, não permitiam um reconhecimento fácil da dicotomia entre capital e trabalho. A sua análise do orçamento indica o volume de capital aplicado pelo Estado e expressa um aspecto da intervenção crescente do Estado no processo econômico e social. Divididos por períodos, os dados indicam a importância atribuída pelo Estado e governos a cada uma das atividades segundo o agrupamento proposto por O’Connor.

$\mathrm{O}$ que os autores pretendiam demonstrar era o baixo gasto com o bem-estar social no período analisado, vis a vis com os investimentos em capital social e infra-estrutura. No período foram crescentes os gastos com administração e governo, refletindo o crescimento da estrutura burocrática sob o regime militar, assim como os gastos com capital social, especialmente com a criação e a sustentação de empresas estatais. Os autores destacavam também a regressividade existente na carga tributária e o grande peso de taxas diretas e indiretas sobre os preços na arrecadação, o que acabava por fazer com que uma carga tributária maior recaísse sobre o consumidor final, penalizando os mais pobres.

Toda a literatura que analisa a política social produzida a partir da segunda metade da década de 1970 passou a conter análises dos gastos sociais do governo como uma dimensão importante de sua definição. O nível de gastos sociais também serviu como indicador de avaliação da configuração de um Estado de Bem-Estar Social, especialmente nas comparações com os países do primeiro mundo.

\footnotetext{
${ }^{22}$ Os autores apontam a baixa confiabilidade dos dados oficiais, devido a erros, manipulações e limitações da fonte. Consideram também que seja difícil assegurar que as despesas por item tenham sido de fato realizadas de acordo com o programa orçamentário oficial. O estudo do orçamento estatal precisa sempre ser complementado com uma análise de outras variáveis sociais e econômicas (AFONSo \& SouZA, 1977: 15-20).
} 
Tabela 1. Gastos estatais (\%) por área e por governo: 1950-1975

\begin{tabular}{|c|c|c|c|c|c|c|c|}
\hline \multirow[t]{2}{*}{ Áreas ** } & Vargas* & $\mathrm{JK}^{*}$ & Jango* & Castelo* & Costa e Silva* & Médici* & Geisel* \\
\hline & $1950-1954$ & $1956-1960$ & 1961-1964 & 1964-1966 & 1967-1969 & $1970-1973$ & 1974-1975 \\
\hline $\begin{array}{l}\text { Governo e } \\
\text { administração }\end{array}$ & 24,7 & 32,6 & 39 & 35,2 & 31 & 40,9 & 58 \\
\hline Serviço & 18,7 & 22,1 & 22,4 & 24 & 23,7 & 18,4 & 18 \\
\hline Infra-estrutura & & & & & & & \\
\hline $\begin{array}{l}\text { Bem estar } \\
\text { social }\end{array}$ & 7 & 5,3 & 6,5 & 4,8 & 4 & 2 & 4 \\
\hline $\begin{array}{l}\text { Defesa } \quad \text { e } \\
\text { segurança }\end{array}$ & 29 & 25,4 & 14,7 & 18 & 24,2 & 22,8 & 13 \\
\hline Capital social & 54 & 64,6 & 71 & 69,4 & 66 & 66,7 & 83 \\
\hline
\end{tabular}

Fonte: Afonso e Souza (1976). Tabela elaborada a partir das informações dos autores.

* média do período do governo, respectivamente: Getúlio Vargas, Juscelino Kubtscheck, João Goulart, Castelo Branco, Costa e Silva, Garrastazu Médici, Ernesto Geisel;

** Governo e Administração: incluem a Presidência da República, Ministério da Fazenda, Ministério do Interior, Ministério das Relações Exteriores, Encargos Gerais da União, Transferências a Estados, Reserva de Contingência;

** Serviços e Infra-Estrutura: incluem Ministério das Comunicações, Ministério das Minas e Energia e Ministério dos Transportes;

** Bem Estar Social: incluem Ministério da Previdência e Assistência Social, Ministério da Saúde e Ministério do Trabalho;

** Defesa e Segurança: incluem Aeronáutica, Exercito, Marinho e Ministério da Justiça. ${ }^{23}$

Não há muitas divergências quanto a esse diagnóstico na literatura que se produziu a partir de então, o qual demarca uma das principais características dos gastos sociais no Brasil: o seu percentual baixo em comparação com outros gastos públicos e a regressividade da carga tributária. Mesmo quando se registrou a ampliação dos gastos públicos em programas sociais não houve garantia de que os beneficiários pertencessem aos

${ }^{23} \mathrm{O}$ agrupamento por Ministério talvez indique a destinação real das despesas por órgãos federais e atendendo objetivos específicos, enquanto o agrupamento por programa pode comportar uma margem de manobra maior em relação ao destino e os reais beneficiários das despesas, conforme apontam os autores. 
grupos menos favorecidos da população, o que fortalece a tese de que os impactos redistributivos eram nulos (Rezende, 1987: 7; Dain, 1989).

Pires (1995), ao analisar os gastos sociais, também parte da metodologia criada por O’Connor, porém criticando-o quanto à inclusão dos gastos com educação na rubrica "capital social”, o que definiria um interesse e um investimento exclusivo do capital e não como uma política de "bem-estar social” (1995:119-120). Critica também o trabalho de Afonso e Souza por restringirem a sua análise ao âmbito federal e por ministério ${ }^{24}$. Desse modo, considera que o seu próprio estudo preenche uma lacuna importante, ao pretender conciliar a análise dos gastos sociais com bem-estar social (educação, saúde, previdência e assistência social) com a política implementada no período populista.

A agregação dos itens orçamentários sob a rubrica da política social é sempre objeto de uma controvérsia e, conforme assinala Wanderley Guilherme dos Santos, "na literatura preocupada com o problema da eqüidade, os componentes do agregado 'política social' restringem-se aos itens do que convencionalmente se compreende por política previdenciária, acrescidos das clássicas rubricas 'gastos em saúde' e 'gastos em educação'. Eventualmente, um ou outro analista decide incluir itens como nutrição, ou habitação, sem, entretanto, apresentar justificativas teóricas convincentes” (1987: 38). Adverte, assim, que o problema da definição do que deve compor a rubrica "política social" passa por uma análise de corte teórico e político do componente da "eqüidade” ou da “justiça social”. Comumente se considera legítima a intervenção governamental nas áreas da previdência ou proteção social, saúde e educação, para as quais não há divergências na literatura. O desempenho dos gastos sociais do governo sem o quadro material das carências é pouco revelador do impacto que produz na atenuação das injustiças sociais, o que torna análises comparativas como as efetuadas por Wilenski (1975), sempre problemáticas.

O mesmo defende Esping-Andersen, que avalia que toda uma primeira geração de estudos (Wilenski, 1975; Cutright, 1965) pressupôs que o nível das despesas sociais poderia espelhar adequadamente a existência de um Estado de Bem-Estar Social e partiu para testar seus modelos teóricos, acreditando que o nível econômico, o padrão demográfico e perfil

\footnotetext{
${ }^{24}$ Embora reconheça os fatores que limitavam a realização de uma pesquisa mais ampla, como o fato de terem escrito no exílio e a indisponibilidade de dados (PIRES, 1995:120).
} 
burocrático poderiam explicar a variação entre os diversos países. Esping-Andersen avalia que os gastos sociais não contam igualmente, posto que podem incluir benefícios fiscais e privilégios de uns grupos sobre outros. Como exemplo, cita o fato de que na Grã-Bretanha de Tatcher, os gastos sociais se elevaram em razão de uma taxa elevada de desemprego e não de alocação de mais recursos em bem-estar. Somente quando os gastos sociais destinam-se à cobertura de toda a população, num modelo universalista, os benefícios sociais podem vir a cumprir a sua função de bem-estar social. Esse é um outro critério, não apenas quantitativo, mas qualitativo, de avaliação de políticas sociais (Esping-Andersen, 1998).

Pierson (1991) analisa que o desenvolvimento econômico e industrial foi condição necessária ao crescimento do Estado de Bem-Estar a partir das necessidades sociais que geraram. Identifica que embora houvesse forte correlação entre as necessidades sociais e o crescimento de gastos sociais na Europa, não havia correlação entre a disponibilidade de recursos e o crescimento de gastos até a década de 1980, ou seja, os gastos cresceram independentemente de haver disponibilidade de recursos. O crescimento nos gastos, no entanto, deveria remeter ao questionamento de suas causas: contingência, fortalecimento dos mecanismos de proteção; maturidade do processo em decorrência da mudança demográfica ou na estrutura de salários; mudança na política e esforço para modificar a regulação legal; provisões legislativas mais generosas? Quais desses fatores, isolados ou combinados estariam exercendo essa influência? (Alber, 1987: 177).

O crescimento das demandas por segurança sócio-econômica, no contexto da modernização e da diferenciação social, atuou em duas direções: como mecanismo compensatório para quem tem menos e como critério meritocrático destinado a aumentar ou manter o status das categorias melhor situadas no mercado de trabalho. Segurança e liberdade são, para Flora e Alber (1987: 31), os dois valores básicos perseguidos pelo Estado de Bem-Estar Social, o que nos ajuda a compreender a posição das duas dimensões da seguridade social - assistência e previdência - no debate nacional.

Pires (1995) aponta uma cisão existente na literatura que analisa a política social no Brasil, com um corte analítico entre os processos políticos e os fenômenos econômicos e propõe-se a um estudo que combine as duas vertentes analíticas. Nesse caso, a política social deve ser compreendida como uma forma de intervenção governamental na economia para aumentar o nível de bem-estar social, que pode ser medido através da taxa de 
mortalidade bruta, proporcional e infantil; expectativa de vida ao nascer; incidência de doenças preveníveis; condições de acesso e qualidade dos benefícios de previdência social; acesso à educação formal; taxa de alfabetização; taxa de evasão escolar etc. Identifica que os progressos são perceptíveis quando essas variáveis são analisadas.

No entanto, uma economia em crise afeta duplamente as bases de sustentação financeira da política social, porque influi negativamente no valor arrecadado enquanto faz crescer as despesas, o que leva ao acirramento do conflito distributivo e torna os consensos mais difíceis de serem alcançados. Em "tempos de crise" ${ }^{25}$, tem-se um embate de forças para fixar a repartição da renda entre os agentes sociais (Pires, 2000: 42) ou, nos termos de Oliveira (1988), acirra-se a disputa pelo fundo público. Esse é o problema do direito: definir onde colocar o ponto de corte (Ewald, 1993), até que ponto a partilha de recursos pode ir. Ou, nos termos de Rosanvallon: qual o grau de socialização tolerável de um certo número de bens e serviços (1997: 15). Nesse caso, o problema central seria o da repartição do financiamento, ou seja, de fazer retroceder a taxa de impostos e cotizações sociais a um nível socialmente aceitável ${ }^{26}$.

De novo, portanto, retornamos à ressalva de Wanderley Guilherme dos Santos (1987: 40), de que os gastos devem ser analisados de acordo com o PIB e com o quadro das carências materiais, senão, eles nada representam.

A abordagem sobre financiamento e gastos sociais se incorporou à discussão sobre o desenvolvimento e a crise do Estado de Bem-Estar, pretendendo traçar quadros comparativos capazes de explicar o dinamismo de cada Estado em particular (OIT, 1983; Break, 1977). De outro modo, deu um novo alento às análises das políticas sociais a partir da estrutura de financiamento dos gastos públicos, que repercutiu sobre as análises específicas traçadas sobre a política de Previdência Social.

As discussões sobre a dívida pública, a crise fiscal, o déficit orçamentário, a capacidade de financiamento público e políticas sociais conduzem a decisões distributivas e redistributivas subjacentes ao desenho de uma estratégia de política social (Dain, 1989). Os problemas de natureza econômica rebatem no nível dos gastos públicos, pressionando para

\footnotetext{
${ }^{25}$ Para parodiar o documento produzido por: MPAS/CEPAL (1989). A política social em tempo de crise: articulação institucional e descentralização, op. cit.

${ }^{26}$ Rosanvallon cita que, na França, os descontos obrigatórios evoluíram de 35\% do PIB (produto interno bruto) em 1970, para 45\% em 1990, ultrapassando aquilo que era dado como tolerável no financiamento das despesas públicas (RosANVALLON, 1997: 13).
} 
baixo os gastos com políticas sociais. O crescimento dos gastos sociais é um problema não apenas pelo seu volume, mas também pelo ritmo de seu crescimento (Rosanvallon, 1997). Em épocas de crise reduz-se a legitimidade dos gastos em políticas sociais, justamente quando a demanda é maior em razão do desemprego, de trabalho precário, retração dos salários e empobrecimento geral da população. Entretanto, a pressão que a redução de recursos exerce sobre a Previdência Social é diferente, posto que os gastos com aposentadorias e pensões não podem deixar de ser realizados (Pierson, 1991: 138), o que leva a contínuos arranjos técnicos para ajustar receita e despesas. No Brasil, esse ajuste sempre foi realizado com aumento de alíquotas de contribuição e redução do valor dos benefícios.

A análise dos gastos sociais em políticas de previdência social constituiu aquilo que tem sido denominado uma “economia política da previdência social” (Dain, 1993; James, 2001), ancorada nas análises do orçamento público, da estrutura de financiamento (contribuições sociais) e de gastos sociais. Esses três pontos serão centrais na disputa por recursos públicos não apenas entre as áreas sociais, mas principalmente entre essas e outras áreas do governo, como economia e fazendária.

O que essa abordagem demonstra é a aproximação entre política fiscal e política social, como uma tomada de decisão sobre a arrecadação e alocação de recursos públicos. No caso específico da previdência social enquanto política social, a existência de um orçamento próprio $^{27}$, composto por contribuições sociais exclusivamente destinadas a este fim, faz com que as análises apareçam auto-centradas, distante do conflito distributivo no qual está imersa. Na base do conflito distributivo está implícita a idéia de que a previdência social deva ser auto-sustentada, ou seja, financiada exclusivamente com os recursos provenientes de contribuições sociais de empregados e empregadores sobre a folha de

\footnotetext{
${ }^{27}$ O orçamento da Previdência Social distingue-se do orçamento comum pela origem de seus recursos, que provêm de contribuições de natureza estritamente previdenciária e que não podem ser alocados em outros fins. Por outro lado, destina-se a realizar um compromisso de cobertura, que independe da disponibilidade imediata de recursos. A alocação não pode ser definida a partir da disponibilidade de receita, o que leva a requerer uma base de financiamento estável. Na Constituição Federal de 1988 a base de financiamento previdenciário foi alargada para integrar um “Orçamento da Seguridade Social” que incluiu também as contribuições sobre o lucro (CSLL), sobre o faturamento das empresas (Cofins) e rendas de concursos e prognósticos. Esse orçamento é partilhado entre previdência, saúde e assistência social. O "Orçamento Fiscal”, composto pelos impostos deveria cobrir todas as demais despesas públicas, incluindo a participação de Estados e Municípios, gastos administrativos e o financiamento de todas as demais políticas governamentais (DAIN; SoARES \& CASTILHO, 1993).
} 
salários da empresa ou com contribuições sociais decorrentes da condição de trabalhador doméstico, autônomo ou facultativo.

A redução no ritmo de crescimento dos gastos ${ }^{28}$, a introdução progressiva ou incremento de mecanismos de seletividade, a definição de público-alvo prioritário e restrições na demanda, promovem um tipo de privatização por default, com expulsão para a iniciativa privada dos setores populacionais com perfil de renda mais elevada, como ocorre na saúde e na educação (Draibe, 1997; Soares, 2001) e delineia um processo não declarado de “americanização da seguridade social” (Vianna, 2000). A “desaceleração do esforço social” implica em sucateamento dos equipamentos públicos, falta de funcionários qualificados e afrouxamento na produção de bens e serviços, que abrem amplo espaço para uma composição entre serviços públicos e privados, com avanço do privado sobre o público (Dumont: 1988).

Apesar de amplamente divulgada como a causa da deterioração dos serviços públicos, a privatização não é um fenômeno nem unívoco, nem isolado. Draibe (1997: 215) distingue três tipos diferentes de privatização que se combinam a outros fenômenos como descentralização e focalização e que devem ser observados na análise das políticas sociais.

Além de ser uma política deliberada, a privatização pode ser identificada como uma ampliação do espaço da filantropia, através do repasse de atividades sociais para organizações não governamentais, que continuam a ser executadas com recursos públicos; e decorrente da deterioração da qualidade dos serviços públicos. No Brasil observa-se, especialmente, a privatização por default nas áreas da saúde e da educação, com migração para serviços privados provocada pela deterioração dos serviços públicos (Draibe, 1997; Dumont, 1988; Vianna, 2000; Soares, 2001). O que nos faz lembrar que no começo da década de 2000 escolas em bairros de classe média de São Paulo foram fechadas por falta de alunos inscritos.

Para Olsson, são estratégias que visam reorganizar a política social de modo a recompor o equilíbrio de proteção social patrocinada pelo tripé: Estado, mercado e sociedade. Essas estratégias visam retirar do Estado o lugar central de promoção do bem-

\footnotetext{
${ }^{28}$ Soares realiza uma análise detalhada dos níveis de gasto público nas três áreas da seguridade social entre meados da década de 1980 até 1993 e conclui que os níveis têm sido decrescente, sem conseguir recuperar os índices alcançados em 1982. Em 1992 o índice de gasto foi o menor, especialmente para a área da saúde, que se viu em competição por recursos com a Previdência Social (SOARES, 2001).
} 
estar social, promovendo um revival da ética do trabalho e de valores tradicionais (Olsson, 1990: 251). Privatização e descentralização aparecem como capazes de romper com a crescente burocratização da vida (Offe, 1987). São medidas que objetivam conferir maior racionalidade na alocação de recursos públicos através da aproximação entre problemas e gestão (descentralização); gastos sociais e pobreza (focalização e seletividade) e entre contribuição social e benefícios sociais (privatização).

A maior parte das explicações para o recrudescimento das políticas sociais tem sido a crise econômica, visto que, em "tempos de crise”, a capacidade de autofinanciamento da seguridade social é duplamente abalada, seja pela incapacidade de ampliar o contingente de contribuintes ativos $^{29}$, seja pelo aumento dos níveis de pobreza. A receita decresce enquanto a demanda se eleva. Dada a característica dos compromissos assumidos, o déficit interno da Previdência precisa ser coberto por recursos da seguridade social e do Tesouro, dando origem a uma disputa de natureza distributiva.

Embora possa haver divergências em relação à definição do escopo das políticas sociais entre os países, os gastos públicos com aposentadorias e pensões têm sido o denominador comum, o chamado "núcleo duro do sistema de proteção social” (Dain: 1989; Werneck Vianna: 2000), aqueles que mais têm sofrido a influência de processos reformistas. Na falta de garantia de poder honrar o compromisso histórico, o governo pode não apenas ter a confiança abalada, mas ser fator de grande instabilidade social. Como afirma Leite (1993), aposentadorias e pensões são benefícios que não podem deixar de ser pagos, haja orçamento ou não, haja déficit ou não.

$\mathrm{O}$ argumento de que a crise financeira do Estado decorre do aumento das despesas sociais e de sua incapacidade em continuar sustentado alguns direitos sociais se tornou dominante nos anos 90 (Giambiagi; Além, 2000) e suscitou linhas de análises sobre os padrões alocativos dos gastos públicos. Esse argumento era coerente com as críticas ao modelo tradicional de intervenção estatal na economia. Rosanvallon (1997: 14) atribui o problema do impasse financeiro ao fato do ritmo de crescimento das despesas sociais ser maior que o da produção nacional, o que gera um distanciamento entre crescimento econômico e social.

\footnotetext{
${ }^{29}$ As contribuições previdenciárias são dependentes da folha de pagamento de salários do trabalhador urbano, sofrendo alterações de acordo com o comportamento do mercado de trabalho, não apenas no que ser refere ao nível de emprego, mas também o nível salarial (DAIN, 1989).
} 
No entanto, dados do Banco Mundial apontam que não houve redução dos gastos públicos como percentual do PIB, com crescimento tanto entre os países desenvolvidos (18\% em 1960; 45\% em 1980 e 48\% em 1995), quanto entre os países "em desenvolvimento" (15\% em 1960; 28\% em 1980 e 28\% em 1995).

Flávio C. Rezende (2002), partindo dos dados do Banco Mundial, comparou 64 países em razão de renda e participação dos gastos públicos no PIB e observou que houve crescimento da presença do governo em todos os grupos. Tomando como indicador o percentual dos gastos sociais no total de gastos públicos, observou que quase todos os países tinham presença marcante em funções sociais no ano de 1998: 53\% apresentava gasto social superior a 50\% dos gastos públicos; 44\%, entre $25 \%$ e 50\%; e, apenas 3\%, inferior a 25\%. O padrão de intervenção governamental demonstrou alguma diferença quando analisado em função da renda do país: os países com renda elevada gastaram mais de $55 \%$ com função social, enquanto que os de renda baixa gastaram menos de $40 \%$. A mudança no padrão alocativo nos países de renda média poderia ser explicada pela reorientação de suas preocupações com ajustes ficais e pagamento dos juros das dívidas, como é o caso do Brasil. Nesse caso, o nível de renda do país foi determinante para a redução do gasto social.

O gasto social em previdência social deve ser definido tomando por base três componentes: tamanho da população (variável demográfica que considera a expectativa de vida e de sobrevida), proporção da população beneficiada (critérios de elegibilidade) e o valor do beneficio real (nível médio dos serviços) (Dain, 1989). As mesmas três dimensões que foram consideradas na introdução do "fator previdenciário”, com a reforma ocorrida após $1998^{30}$.

Ao se questionar "quando e porquê mudam as políticas sociais, admitidos os parâmetros de acumulação e eqüidade?”, Wanderley Guilherme dos Santos (1987) analisa as hipóteses da mudança na composição das elites ${ }^{31}$, da estrutura de escassez ${ }^{32}$, do processo

\footnotetext{
${ }^{30}$ Ver Nota Técnica sobre o fator previdenciário, Anexo 1.

31 A plausibilidade dessa hipótese é descartada, por considerar que a renovação das elites produz instabilidade e que, em situações de crise, a elite no poder tende a rever o seu próprio comportamento, constituindo-se em fonte de mudança, a despeito da baixa taxa de renovação (SANTOS, 1987: 54-55).

${ }^{32} \mathrm{O}$ autor propõe que o conceito de escassez não seja analisado somente do ponto de vista da magnitude dos recursos orçamentários disponíveis, mas que sejam consideradas as situações de um ponto de vista mais estrutural e relacional Idem: 57.
} 
de diferenciação social ${ }^{33}$ que compõem um mix de causas. A estruturação do sistema previdenciário no Brasil seria assim explicada pela convergência entre acumulação, diferenciação na estrutura produtiva e regulamentação social, que permitiram administrar os problemas de acumulação e de eqüidade no contexto de uma escassez aguda e, depois, crônica, de recursos. À convergência desses dois movimentos, denominou cidadania regulada, que definia, pela regulamentação profissional e por um sistema estratificado de profissões quem era e quem não era cidadão. E, aos cidadãos, fornecia benefícios também estratificados segundo nível de renda, que definia numa escala graduada quem era mais cidadão.

A ruptura de tal padrão de regulação social teve início com a uniformização e unificação da Previdência Social ocorrida na década de 1960 e com o extravasamento dos conflitos sociais nas décadas de 1970 e 1980, sob a forma de movimentos sociais organizados (Sader, 1988). Nos dois momentos, foi colocada em questão a necessidade de se reformular as instituições em que se processavam a acumulação e a distribuição compensatória, alterando o seu próprio conteúdo e extensão. É nesse quadro que deve ser inscrita a formulação do novo texto constitucional.

Foi a tipologia de Titmuss (1958) que exerceu grande influência nas pesquisas que enfocaram critérios qualitativos, além daqueles referentes ao gasto social: universalidade, condições de elegibilidade, tipo de benefícios e serviços, nível de emprego etc. Titmuss cindiu a análise em dois tipos-ideais: o estado de bem-estar social residual e o estado de bem-estar institucional. Ao primeiro caso corresponderia o atendimento a grupos definidos segundo o critério da necessidade (grupos marginais) e de mérito (grupos privilegiados), enquanto que no segundo, o atendimento seria universal, garantido a toda a população, personificando um compromisso social institucionalizado e focado na produção do bem estar-social. Nessa tipologia, o Brasil claramente se situa no primeiro caso, com medidas de bem-estar apenas residuais ${ }^{34}$.

\footnotetext{
${ }^{33} \mathrm{O}$ autor considera, sob este aspecto, a formação de organizações e grupos de pressão que geram novas demandas, atentando para o fato de que existem, tanto na estrutura da escassez quanto na complexificação social, fenômenos não controláveis, como crescimento populacional, urbanização etc. Ibidem: 58-60

${ }^{34}$ Aureliano e Draibe analisam que o sistema brasileiro de proteção social é frágil, ancorado na manutenção do status adquirido pelo trabalho contra riscos de declínio social e está fundamentado na capacidade produtiva do trabalhador, sem qualquer papel reprodutivo. Define-se por ser meritocrático-particularista (Titmuss) e corporativista-clientelista, com características de um sistema assistencial e denso paralelo (AURELIANO; DRAIBE, 1989: 145).
} 
A proposta de Esping-Andersen (1997: 101) para avaliar o padrão de bem-estar é a combinação entre uma abordagem de direitos e garantias, e o modo como são entrelaçados os papéis do Estado, da família e do mercado em termos de provisão social. Ou seja, propõe que a provisão social seja analisada sob a perspectiva do quanto contribui para livrar o indivíduo da dependência do mercado.

Pensando numa linha contínua imaginária, seria possível traçar o ponto eqüidistante dos indivíduos entre benefícios sociais e o seu efeito “des-mercadorizante" (decommodification). Nessa linha imaginária, a assistência social estaria mais próxima do mercado, porque é residual, atada à condição de pobreza e objetiva fortalecer o mercado e porque atua pressupondo a sua eficiência (Esping-Andersen, 1997: 103).

O autor se propõe a analisar os arranjos entre Estado, mercado e família e o efeito “des-mercadorizante” que produz através da seguinte tipologia: o tipo liberal, baseado em modestas transferências de renda tem por objetivo reforçar o mercado; o tipo corporatistaestatal, no qual predomina a diferenciação de status (decorrente da posição no mercado de trabalho) e o Estado ocupa lugar central; o tipo universalista em que a de-commodification de direitos sociais estendido à classe média, com promoção da igualdade e inclusão de todos em serviços sociais de alto nível. No terceiro tipo há uma fusão entre políticas sociais de bem-estar e trabalho.

O problema de Esping-Andersen é diferente da proposta de Wanderley Guilherme dos Santos, para quem a análise dos gastos sociais deve ser comparada ao quadro de carências materiais, porque se situa além da simples redução da pobreza. Em certa medida, pode haver correspondência com a visão de Flora e Heidenheimer (1987: 31) de que o Estado de Bem-Estar permite a externalização dos custos, que são retirados da unidade familiar e reintroduzidos como custo social assumido pela economia e partilhado socialmente.

A externalização dos custos teve sua primeira experiência com as leis de Otto von Bismarck que organizou toda uma comunidade de risco baseada no princípio da solidariedade forçada, que permitia distribuir os riscos entre o conjunto de segurados e fez desenvolver uma mentalidade de pertencimento social entre os trabalhadores. A genialidade de Bismarck (Flickinger, 2000b: 51-55) estava, porém, em manejar os riscos sociais dentro da 
própria sociedade e sem a participação financeira do Estado ${ }^{35}$. Ao mesmo tempo em que promovia o direito social, mantinha livre o seu orçamento fiscal. Foi a Primeira Guerra Mundial que modificou essa solução apontando para uma maior participação do Estado na resolução dos problemas sociais.

A previdência social de base contributiva também é inteiramente dependente do trabalho, emprego e renda e as regras que fazem com se aproxime ou se afaste do mercado são tão importantes quanto o próprio direito que promovem. A análise do gasto público, portanto, deve ser relativa ao efeito que produz sobre a participação dos indivíduos no mercado de trabalho e o seu conseqüente resultado.

Os gastos com o emprego público encontram nessa questão um lugar de destaque, posto que se elevou em decorrência do crescimento da provisão de serviços sociais prestados pelo Estado e produziu impacto direto sobre o crescimento dos gastos públicos. Como lembra King (1987: 72), a crise produz como alternativa a necessidade de reduzir o tamanho agregado do setor público, restringir gastos sociais, reduzir tributação e elevar gastos com a lei e a ordem. Questão que pode ser remetida à disputa entre direitos por recursos escassos.

Há um paradoxo na idéia de crise financeira do Estado de Bem-Estar Social: o sentimento contrário ao gasto social torna-se maior quando ele é reduzido. King (1987) questiona: porquê? A origem da crise seria uma ruptura na base de sustentação do sistema de lealdades ao Estado, especialmente em relação às classes médias, que poderiam buscar outras alternativas no mercado (King, 1987; Esping-Andersen, 1998; Rosanvallon, 1997). O que o tema da reforma da Previdência propõe é a recomposição da produção de bens e serviços públicos entre Estado, mercado e família.

\footnotetext{
${ }^{35} \mathrm{O}$ artigo de Flickinger é uma ótima referência para o estudo de caso alemão, ajudando a compreender a trajetória histórica do seguro social (FLICKINGER, 2000b).
} 


\section{$O$ custo do direito}

Quando se pergunta “quanto custa o direito?” (Holmes \& Sunstein, 1999) e são apresentadas propostas de imposição de adequação do Legislativo à "consistência financeira” entre as leis aprovadas e os recursos orçamentários disponíveis (Rose-Ackerman, 2004), estamos diante de um fato novo no direito.

A novidade consiste precisamente na introdução de uma nova racionalidade no campo legislativo e no campo jurídico. Uma racionalidade que promove uma inversão na pauta dos direitos, que sempre responderam às demandas de regulação social sem se basear em critérios financeiros ou econômicos.

Em parte, essa nova racionalidade é promovida pelo que Rose-Ackerman (2004: 243) denominou "análise econômica reformista do direito"36, a qual parte do pressuposto de que uma combinação entre direito administrativo e análise econômica poderia ser proveitosa na busca da eficiência e no alcance de objetivos distributivos na formulação de políticas públicas ${ }^{37}$. A análise parte do pressuposto de que o Legislativo deve se tornar mais responsável perante os cidadãos, o que implica na possibilidade de exame judicial da “consistência orçamentária”, de modo a exigir que o Congresso reconheça as limitações impostas por objetivos conflitantes com o nível de recursos disponíveis. A conseqüência última seria a invalidação judicial de direitos que não tivessem “consistência orçamentária”.

\footnotetext{
${ }^{36}$ Rose-Ackerman parte da discussão sobre como o comportamento social, em relação ao respeito ou violação das obrigações legais, é moldado por um tipo de racionalidade econômica, promovida pela "Análise Econômica do Direito" (AED) para problematizar a questão em relação ao processo legislativo, na aprovação de leis. Os indivíduos se comportam como maximizadores racionais de seu bem-estar quando tomam decisões não realizadas ao mercado, como casar-se, divorciar-se, cometer ou abster-se de cometer delitos, entrar com um processo etc. (Kornhauser, 2002; PosNer, 2002a). De outro modo, também tem sido assinalado um movimento de decadência do direito como disciplina autônoma, que se torna cada vez mais influenciado por avanços no campo da ciência e tecnologia, filosofia e economia, que promove uma renovação na idéia de direito, que se torna um campo interdisciplinar. As implicações mais importantes seriam: 1. economistas, estatísticos e cientistas sociais passam a ter um papel mais proeminente nos esforços de reforma legal, como na lei dos impostos; 2. literatura mais honesta sobre os méritos políticos das doutrinas legais; 3 . compromisso mais honesto com as premissas realistas da decisão; 4. reforma do ensino legal, com criação de departamentos de direito sobre teoria legal (PosNER, 2002b).

${ }^{37}$ A autora propõe uma análise do direito administrativo, baseada na teoria das finanças públicas, na análise de políticas públicas e na teoria da public choice, que busca procedimentos que resolvam problemas distributivos de maneira mais justa. Critica o fato de que o direito administrativo norte-americano permanece focado nos tribunais, no controle das agências sem se dedicar ao processo legislativo. Embora trate especificamente do caso americano e lamente o fato de que o direito não assegure os princípios da eficiência econômica, o simples fato de teorizar sobre o assunto já é indicativo de uma nova proposição para a análise do direito (ROSE-ACKERMAN, 2004).
} 
Um dos principais objetos de disputa no direito público americano tem sido justamente a inconsistência entre recursos orçamentários e benefícios relativos ao bem-estar social. É uma questão também presente no debate brasileiro sobre a reforma da previdência ou sobre a implantação da política de seguridade social, num sentido mais amplo. Uma das principais acusações tem sido o fato de que a ampliação dos direitos sociais teria provocado déficit no sistema previdenciário e afetado as contas públicas, situação agravada frente à meta econômica de formação de superávit primário para o pagamento dos serviços da dívida externa.

De um modo geral, o argumento aparece como o ponto central da idéia de "crise do Estado de Bem-Estar Social” em diversos países. Numa vertente economicista de explicação, a crise seria tanto o resultado do aumento das demandas postas ao Estado, quanto da sua incapacidade fiscal em continuar sustentado-as, sob os critérios de universalidade, igualdade e qualidade dos serviços (Rosanvallon, 1992; 1995; Pierson, 1991; 1996).

O aumento de impostos que acompanhou tanto a valorização da propriedade quanto a expansão de direitos, produziu uma redução do apoio do público ao contínuo crescimento da administração pública e dos programas sociais. No contexto econômico, a dependência de importação do petróleo e o aumento dos preços na década de 1970 provocaram aumento nas taxas de juros, com repercussão sobre as contas públicas e retração na arrecadação de impostos $^{38}$. A partir de então, o governo americano passou por uma ampla reformulação da administração pública com base na contraposição entre o “orçamento positivo” dos anos 50-60 e um novo período de "orçamento negativo" nos anos 70-80, que impôs a necessidade de políticas de racionamento (cobrança de cotas de participação no uso do serviço público) e seletividade, como uma nova estratégia administrativa na aplicação de recursos públicos ${ }^{39}$ (Shafritz; Hyde, 1999: 615-9).

Na cruzada para reduzir os gastos públicos, os direitos positivos dos americanos, aqueles que demandam uma ação efetiva do Estado, têm sido atacados, enquanto se

\footnotetext{
${ }^{38} \mathrm{O}$ mesmo fenômeno foi percebido no Brasil, como produtor de uma penúria fiscal que levou ao recurso do uso constante de crédito e falta de recursos para o financiamento tanto de políticas sociais quanto de ações estatais (DAIN,1989a).

${ }^{39}$ As mudanças na administração pública americana se amparavam tanto na crise fiscal, quanto nos protestos dos contribuintes e levou a uma revisão de seus pressupostos, originando movimentos de descentralização, privatização, novas distinções entre público e privado, reforma do serviço público, criação da lei de responsabilidade fiscal, que tanto influenciariam o debate nacional nos anos 90 . Ver a respeito revisão bibliográfica de SHAFRITZ \& HYDE ,1999.
} 
defende a proteção dos direitos negativos de propriedade e de contrato. Direitos negativos tipicamente protegem a liberdade, enquanto direitos positivos promovem a igualdade. Há, da parte dos contribuintes, um claro interesse em reduzir o montante pago em impostos, o que de certo modo reforça o argumento liberal de que os direitos sociais tornam as pessoas dependentes do governo e acaba com a liberdade.

O livro de Holmes e Sunstein é uma provocação ao afirmar que “direito custa dinheiro" (rights cost money) e que não pode ser protegido ou obrigado sem recursos ou suportes econômicos, o que é verdade para velhos ou novos direitos (1999: 15), para o direito público ou privado, social ou individual. A necessidade de impor legalmente o direito torna-o sempre um direito positivo, o que implica em imposto e em gasto público. Todo direito implica numa resposta governamental ${ }^{40}$ : depende de uma burocracia que supervisiona, monitora e protege o direito; de um tribunal que julga e obriga, como determina a observância ao princípio do “devido processo legal”.

O direito à propriedade também é sustentado por recursos públicos, que em 1992 totalizaram US\$ 73 bilhões gastos com proteção policial e correção criminal (Holmes \& Sunstein, 1999: 63). É desse modo que a propriedade deixa de ser uma coisa para ser convertida em uma relação social legalmente construída ${ }^{41}$, cujo acesso e exclusão são juridicamente dados. O direito de propriedade só existe porque a sua posse e o seu uso são criados e regulados por lei, o que desfaz a tese de que os direitos negativos não têm custo para o Estado.

A conclusão dos autores é que o debate se localiza num terreno movediço, posto que as fronteiras entre o que é público e o que é privado não podem ser demarcadas sem a presença do Estado. O mercado simplesmente não cria prosperidade fora do perímetro da lei; ele é dependente da assistência legislativa, judiciária e regulatória do Estado e o funcionamento do Estado depende de impostos e de gastos públicos. Num ambiente de competição por recursos escassos, os direitos competem entre si e alguns indivíduos podem sofrer com a falta de garantia de seus direitos. Normalmente, a ausência de garantia dos

\footnotetext{
${ }^{40}$ A tese dos autores recupera a tese de Hume de que é absurda a idéia de um direito sem remédio. Para Hume a obediência civil está amparada em uma "promessa” do Estado em assegurar justiça e proteção, as quais não podem ser realizadas sem ações efetivas, que demandam recursos públicos, que podem ser obtidos através de contração de débitos ou de impostos (HUME, 1963).

${ }^{41}$ Novamente percebemos a influência de Hume sobre o texto, ao afirmar que a propriedade não é um objeto, mas uma relação moral, fundada na justiça: "A nossa propriedade nada mais é do que os bens cuja posse constante as leis da sociedade estabelecem - isto é, as leis da justiça” (Idem: 33).
} 
direitos sociais se faz acompanhar da não observância dos direitos de primeira geração também, como a proteção aos direitos humanos ${ }^{42}$. Se os direitos custam dinheiro, eles nunca poderão ser completamente protegidos, sejam eles positivos ou negativos.

Os direitos são bens públicos e sempre positivos, afirmam Holmes e Sunstein. Os impostos e a administração pública promovem não apenas o bem-estar coletivo, mas também o individual. O reconhecimento de que os direitos têm custos promove uma reviravolta na idéia de direito: nos força a considerar as finanças públicas nas decisões sobre o direito. E não apenas do ponto de vista já clássico do gasto social, mas também da arrecadação. Os direitos se põem no centro do conflito distributivo, numa disputa por recursos escassos.

Sob essa nova perspectiva, direito e economia deverão se digladiar em busca da realização do justo, uma vez que a eficiência não oferece por si só uma “conexão de sentido” (Weber, 2004) à questão jurídica. O direito permite dizer o que é proibido, permitido, obrigatório, segundo uma regra jurídica (Lopes, 2006: 270-1), mas a sua submissão a um preceito da racionalidade econômica, como a disponibilidade de recursos, a consistência orçamentária ou a relação custo-benefício torna-o apenas uma variável na decisão sobre a alocação de recursos públicos, que nada tem a ver com a legalidade. As regras às quais obedecem direito e economia são conflitantes e o que não pode ocorrer é que a economia colonize as demais formas de construção do sentido da razão ao desqualificar outros motivos para a ação (Sen, 1992).

As disputas em torno da questão "devem ser os direitos sociais constitucionalizados?”, não é apenas de natureza filosófica, mas de natureza prática. A maior parte dos direitos de proteção social é determinada politicamente e não judicialmente e a escassez é uma razão legítima que pode justificar a falha do Estado em proteger absolutamente os direitos (Lopes, 2006: 131). Se tudo depende de recursos públicos, sua

\footnotetext{
${ }^{42} \mathrm{O}$ mesmo problema também foi identificado por Álvaro de Vita, ao afirmar que todos os direitos, incluindo os de primeira geração, impõem o cumprimento de deveres negativos e positivos, o que anula o argumento de que a natureza negativa dos direitos exija menos recursos públicos. Expressa, dessa forma sua rejeição do corolário de que os direitos negativos deveriam ter uma precedência sobre a efetivação de direitos mais onerosos. A efetivação de direitos civis exige do Estado muito mais que abstenção de determinadas ações e condutas, requer uma complexa rede de instituições em funcionamento, que também requer recursos públicos. O problema de Vita é o da escolha, saber qual curso de ação provocará menos injustiça (VITA, 2000: 235238).
} 
aplicação sempre será seletiva, o que de pronto nos remete a um conflito distributivo não apenas entre áreas do governo, mas também entre direitos.

Os direitos respondem a um problema concreto e mudam porque as necessidades humanas também mudam sejam quais forem as razões: tecnológicas, econômicas, políticas, demográficas, culturais, organizacionais, institucionais etc. O direito se move naquela direção do “direito do direito” de Ewald (1993), quando reinterpreta-se a si mesmo ao buscar no silêncio das leis as condições para a sua própria transformação. Os direitos são móveis: são criados e suspensos, redesenhados e renomeados. O que precisa ser investigado são as condições históricas da mudança e o sentido em que muda o direito.

O problema que a adoção de uma racionalidade econômica coloca é saber se a escassez de recursos pode ser um argumento válido na definição de direitos, que continua a ser um problema da política. Este é um problema que não vem sendo suficientemente explorado pelos analistas. Lopes ressalta que o problema também é válido para o Judiciário, que, permeado pelos princípios da racionalidade econômica, modifica o seu posicionamento no julgamento de matérias que impliquem em gastos de recursos públicos. É um tema que conduz ao coração dos problemas da justiça distributiva (igualdade) e da justiça comutativa (liberdade). É um problema que afeta tanto o jurídico, na realização da justiça comutativa, quanto o político, na realização da justiça distributiva (Lopes, 2006: 282).

Entre o crescimento dos gastos públicos e o decréscimo da arrecadação de impostos novos arranjos vêm sendo tentados, com primazia, sobretudo, de parâmetros calcados nos princípios da racionalidade econômica, que enfatizam a relação entre custo e benefício. $\mathrm{O}$ que Holmes \& Sunstein (1999) propõem é que haja uma deliberação pública em torno de questões como: “quanto devemos gastar com cada direito?” "Qual é o melhor "pacote” de direitos, dado a competição entre direitos por recursos escassos?” "Qual é o máximo de direito que pode ser protegido ao menor custo?" "Pode-se justificar o movimento redistributivo que se pretende realizar?" "O que é melhor para cada sociedade?" Submetido a uma deliberação pública, o problema é reenviado à dimensão da política em que os parâmetros alocativos devem ser definidos e cuja resolução dependerá sempre de um julgamento de valor. Como assinala Lopes, a defesa intransigente de direitos pode se chocar com políticas de reforma da justiça social. Nesse novo contexto, o que pode ou não 
ser direito deve ser colocado em discussão pública (Lopes, 2006: 291). O ônus da mudança deve ser repartido entre todos os beneficiários, para que haja justiça distributiva ao final.

No caso da reforma da previdência, em que se trata de examinar os custos, redistribuir os direitos e reconstruir o seu nexo de sentido a partir de critérios econômicos, a contabilidade tem antecedido a análise do direito. A qualificação dos fatos tem sido, em primeiro lugar, contábil. É o caixa da Previdência que tem servido como parâmetro para definir o escopo dos direitos capazes de serem suportados pela sociedade, dado a sua natureza contributiva. Tem sido em nome das futuras gerações que os direitos têm sido reformulados, mas deve-se questionar se os direitos presentes podem ser sacrificados em nome de direitos futuros. Lopes (2006: 291) provoca com a questão: é possível redistribuir os direitos?

As análises sobre a crise da previdência social têm contornado o problema central do direito que é o tipo de racionalidade que o tem posto em movimento. Em outros termos, é o problema da construção de um novo discurso sobre o direito social, preocupado mais com as contas da Previdência, propriamente falando, e com a desestabilização do conceito de seguridade social. O gasto social com previdência perde o seu poder de avaliação do nível de bem-estar social e assume uma conotação negativa, a causa do déficit público.

A construção da crise da previdência como um fato externo e objetivo, retira a discussão do campo da política, "da legitimidade de um debate sobre o legítimo e o ilegítimo" (Lefort, 1991: 57) e nos reenvia ao campo da disputa por recursos escassos, no qual o discurso da racionalidade econômica não apenas adquire sentido, como sustenta os argumentos pró-reforma.

É nessa chave de interpretação que a “crise” ganha um sentido mais universal, em que as diversas histórias dos países podem se encontrar numa nova formação discursiva em torno do problema da definição dos direitos sociais. Sob o argumento da "crise" ou do impasse financeiro, é o direito por inteiro que se põe em movimento, tema clássico da sociologia. 


\section{Direitos sociais e o "custo dos direitos"}

A idéia de "custo do direito" põe um freio não apenas às demandas sociais, mas à própria noção de expansão dos direitos sociais, na seqüência histórica (e evolucionista) dos direitos civis, políticos, sociais, culturais e difusos (Marshall, 1967; Bobbio, 1992). Trata-se de um freio interposto em nome da responsabilidade e do equilíbrio financeiro, que acentua não a dimensão da igualdade, mas a da liberdade (não a idéia de distribuir, mas a idéia de justiça) e que provoca uma reviravolta na idéia da realização da justiça social.

A noção de direito está ligada à teoria da justiça formulada em cada época histórica. Assim, ao direito clássico correspondia uma teoria clássica da justiça; ao direito moderno, uma teoria moderna do direito, assim como ao direito contemporâneo corresponde a teoria da justiça social (Farias, 1998: 42).

A justiça é, para Hume (1963), um sentimento moral, produto de uma convenção que tenta moderar qualidades humanas, tais como o egoísmo e a generosidade ilimitada, frente a situações de troca e em ambiente de escassez. A justiça é uma convenção que tem por objetivo moderar, regular e restringir a paixão humana em face dos objetos ${ }^{43}$. É um artifício que permite atribuir estabilidade à posse de bens externos e que se baseia não em uma promessa, mas na expectativa de reciprocidade. Direito, propriedade e obrigação são, portanto, decorrentes da definição de justiça.

A justiça social não representa somente um aumento na qualidade da liberdade (justiça comutativa) e da igualdade (justiça distributiva), mas uma mudança no modo de pensar as relações entre indivíduo e sociedade, entre indivíduo e Estado. A justiça social está no centro da concepção de um sistema baseado na trama de um processo de associação, coordenação, reciprocidade, mutualidade, afinado com o processo de irrupção do social (Durkheim, 1995 ; Arendt, 1981; Castel, 1998).

É Proudhom, com sua tese sobre a capacidade dos interesses em comum dos homens em sociedade de converter uma multidão em associação, de modo que a coletividade tenha a sua dignidade aumentada, quem fornece o referencial para a construção de uma nova forma de pensar a justiça como um equilíbrio movente entre os princípios da justiça comutativa e da justiça distributiva (Farias: 60). A idéia de Proudhom é a

\footnotetext{
${ }^{43}$ Ver a respeito o discurso “Da origem da Justiça e da propriedade” (HUME, 1963).
} 
de que ao aumentar a dignidade, a seguridade e a felicidade do homem em sociedade, a justiça deveria ter força para produzir e assegurar a ordem social.

A justiça social é a essência da sociedade, a forma de reconhecimento de que a sociedade deve ser vista como um meio de felicidade a serviço do indivíduo. É uma concepção que tenta resolver o problema da conciliação entre a liberdade individual e o bem-estar social, entre o individual e o coletivo. É a construção de uma justiça una, válida tanto para os indivíduos, quanto para a coletividade, uma forma de integração entre a justiça e a moral, entre o privado e o público.

Como assinala Arendt (1981), a justiça é remetida para o social, como o espaço intermediário entre o público e o privado, um lugar complexo, conflituoso e relacional (Durkheim, 1995). A justiça é social porque é chamada a conciliar, a equilibrar os conflitos reais entre os valores individuais e os coletivos, reconhecidos como equivalentes (Durkheim, 1995; Arendt, 1981; Ewald, 1986). O seu ponto de partida é o reconhecimento da desigualdade entres os homens para buscar criar um fator igualador sob certos aspectos e por motivos específicos. O fator igualador é externo, como o dinheiro, não é inerente à condição de humanidade ou de um direito natural do homem (Arendt, 1981). No âmbito social, todo conflito tem sido pela obtenção de segurança econômica, prestígio social e poder político (Arendt, 1981: 228).

O direito, ao ser problematizado em razão de seu custo, desfaz a lógica da busca do equilíbrio entre valores individuais e coletivos e questiona também o ideal de justiça social. De um modo inteiramente novo, o direito coloca-se no centro de uma disputa que não é apenas política no sentido demarcatório, mas política como a luta pela distribuição da riqueza social, relembrando os termos em que a questão da justiça é apresentada por Hume (1963).

A disputa em torno da fixação de novos parâmetros para os direitos sociais é uma disputa não apenas pela aplicação de recursos escassos, mas a expressão do conflito distributivo que atravessa o Estado, nas dimensões da arrecadação e dos gastos públicos. É o ponto que permite a compreensão da proximidade entre as propostas de reforma do direito, de reforma tributária, de reforma do Estado. Não apenas o direito entra em discussão pública, mas todo o Estado - sua sustentação e a regulação social. 
Como conflito distributivo, as reformas se realizam num duplo movimento de racionalização e de formação de uma nova razão explicativa, que é a racionalidade econômica. Há um discurso que antecede, orienta e organiza o movimento de racionalização que se processa. A reforma da previdência é um ponto privilegiado de observação desse duplo movimento, discursivo e orientador, que permite apanhar o direito em movimento.

O movimento de mudança no direito que mais tem sido acentuado pela literatura tem sido o da privatização, da focalização e da seletividade (Draibe, 1997). Aspectos que têm sido considerados como de restrição incidentes, respectivamente, na ação do Estado, nos direitos contemplados e no contingente populacional a ser coberto. Essa mudança tem sido observada na discussão sobre a reformulação do direito e na doutrina jurídica, que tem cada vez mais defendido o "mínimo existencial” em face da limitação de recursos. O critério da dignidade da pessoa humana, que remete ao campo dos direitos humanos fundamentais, tem sido cada vez mais utilizado na busca de eficácia dos direitos prestacionais (direitos sociais) (Rocha, 2004).

O tema da escassez e do "custo dos direitos” repercute sobre toda a ordem jurídiconormativa e não apenas sobre os direitos sociais, revelando a necessidade de se fixar prioridades e realizar escolhas, que cada vez mais são pautadas por critérios financeiros no domínio de um tipo de racionalidade que é econômica.

O discurso da racionalidade econômica tem sido o discurso sobre a escassez, que permite: limitar o âmbito das pessoas atendidas (demandas focalizadas $\mathrm{x}$ demandas universais) e tornar o atendimento baseado na adoção do critério da necessidade (teste de meios). O caminho da seletividade e da focalização se expressa na idéia de que, se, a proteção social não pode ser integral, deve ser priorizada no enfrentamento dos riscos sociais mais relevantes, o que implica em escolhas e renúncias baseada na realização da relação entre custo e benefício. O caminho da racionalização é o caminho da priorização das carências e da eliminação dos privilégios, dos desperdícios e das distorções.

Sob o discurso da escassez, a racionalização é um movimento que apanha a sociedade por inteiro, implicando em tornar os indivíduos mais responsáveis no exercício de seus direitos; em obrigar os tribunais e as instituições públicas a fundamentarem suas decisões com base em critérios de efetividade dos direitos e a examinar a competição por 
recursos escassos que afeta outros direitos básicos e outros valores sociais. O discurso da escassez introduz uma nova lógica na forma como se opera a dimensão do direito em sociedade e muda os critérios de realização da justiça social.

Confrontado com a dimensão do custo, o direito sofre modificações não apenas no quantum de benefício proporciona à população, conduz também a uma modificação na forma como os princípios da reciprocidade, da igualdade, da universalidade e da solidariedade se põem em movimento no direito. Os conceitos vão se modificando na definição dos critérios de realização da justiça social.

A seletividade passa a operar como o critério que permite tornar iguais os menos iguais, como uma compensação ao déficit de igualdade. O ponto de partida do direito passa a ser a diferença, a desigualdade social como origem. $\mathrm{O}$ argumento central tem sido o de que os direitos sociais não partem da mesma ficção dos direitos da primeira geração, pois pretendem favorecer a organização da sociedade e o protagonismo das pessoas com base nas diferenças econômicas, sociais ou culturais. Os direitos distributivos têm na desigualdade o seu ponto de partida: a igualdade como critério de diferenciação e a universalidade como ponto de chegada. Por isso, os direitos sociais são restritivos, intervenientes e compensatórios operando como uma seletividade inclusiva (Rocha, 2004).

A solidariedade que o discurso da racionalidade econômica proclama é de natureza contributiva e promove um deslocamento das questões essencialmente distributivas para aquelas de natureza fiscal. O discurso da solidariedade contributiva constrói um novo critério de classificação que divide a sociedade segundo a capacidade contributiva de cada um (justiça comutativa). Ele está na raiz das propostas de privatização das políticas sociais ou do sistema multi-pilar defendido pelo Banco Mundial, a de que os direitos são relativos aos deveres sociais; os benefícios, proporcionais à contribuição social. Não é mais o critério do risco que passa a ser o critério da igualdade como observara Ewald (1986) e Baldwin (1990) no século XIX e que permitiu a construção dos planos de seguro social.

Como Baldwin formulou (1990), a despeito das inúmeras diferenças que atravessam a sociedade, a insegurança havia se tornado um critério de igualdade. Enquanto sujeitos ao risco, todos puderam ser considerados iguais. O risco foi o critério que permitiu o desenvolvimento de medidas de proteção social que tinham por efeito moderar os infortúnios. O risco tornou-se um critério com pretensão de validade universal e que 
permitiu a construção de todo um referencial de eqüidade e a partilha de seu custo entre todos os membros da sociedade (Ewald, 1986).

A construção dos direitos sociais foi realizada como um movimento de integração social e de formação da coesão social, sob a forma de sacrifícios mútuos que visavam ligar indivíduos de modo duradouro. A categoria do risco permitia o reconhecimento de todos como iguais e a construção de uma forma de solidariedade no amparo ao infortúnio (Baldwin, 1990). Um dos aspectos bastante difundidos em relação à crise do Estado de BemEstar Social é o confronto entre demandas sociais crescentes e a incapacidade do Estado em continuar sustentando-as. O pilar mais enfatizado tem sido o da expansão dos direitos, das demandas postas ao Estado, do quanto de benefícios se pode retirar desse Estado, que reforça o vínculo mais imediato entre indivíduo e Estado. Há aqueles que advogam a redução do papel do Estado como epicentro da realização da justiça social, assim, as formas de privatização (abertura ao mercado ou crescimento das ações filantrópicas e de organizações sociais) se constituem numa revalorização da sociedade como produtora de solidariedade social, em sua dimensão pública.

O critério da igualdade dado pela capacidade contributiva passa a ser aquele que definirá quanto de benefício cada um retirará da sociedade (a cada um segundo a sua contribuição), mas de um modo inovador em relação a toda a história dos direitos sociais no país. Toda a lógica de inclusão e de pertencimento aparece aqui invertida. Esse novo critério é o fundamento da inovação mais radical que as reformas da previdência efetivaram $^{44}$ : a instituição do fator previdenciário. Uma nova lógica de calcular o valor do benefício que estabelece o cruzamento de critérios de elegibilidade e que pretende aproximar o benefício do total de contribuição. O fator previdenciário foi uma alternativa criada que, sem modificar a estrutura do direito previdenciário, permitiu individualizar o benefício, aproximando-o da idéia de uma conta individual de poupança pública e compulsória.

\footnotetext{
${ }^{44}$ A segunda parte dessa tese trabalha com o movimento de reforma da Previdência em curso a partir dos anos 1990. Ao adotar o termo no plural, buscamos enfatizar que a Previdência não foi objeto de uma única reforma e nem mesmo de um único projeto de reforma. A reforma tem sido um processo contínuo que atualiza o fato de que a questão permanece em aberto, a partir de um ponto inicial, arbitrariamente fixado, como a Constituição Federal de 1988, que introduziu a noção de Seguridade Social, o novo esquema de financiamento e fixou novos direitos.
} 
Uma das principais críticas interpostas ao modelo de proteção social brasileiro foi a de que proporcionava uma distribuição de forma horizontal e reproduzia a estrutura de desigualdade com base na renda oriunda do trabalho. O modelo de proteção reproduzia o modelo de estratificação de renda, excluindo os segmentos mais necessitados (com menor renda, sem formalização das relações de trabalho e desorganizados politicamente).

O discurso da solidariedade contributiva reorganiza o lugar das demandas sociais e tal qual afirmava Comte, enfatiza que o indivíduo sempre retira da sociedade mais do que dá e que não se deve propriamente falar em direitos, mas tão somente em deveres (Comte, 1978; Moraes Filho, 1978; Benoit, 1999). Deveres de todos para com todos, a “dívida social” seria a categoria a melhor explicar a vida em sociedade.

Os direitos previdenciários possuem essa característica peculiar de representar o gozo individual de um direito social. A dimensão mais explorada pela literatura sempre foi a da lógica da solidariedade e do efeito redistributivo que deveria proporcionar, dentro da lógica da integração social e da partilha dos custos entre todos os membros da sociedade. Um dos problemas centrais na longa disputa sobre a sua conformação é o da medida: qual é a medida da justiça social que proporciona? Como se fundam os critérios de acesso e de elegibilidade do direito?

É exatamente a questão da medida que é problematizada na disputa em torno da reforma da previdência, medida que se pauta pela capacidade contributiva. É ela que permite cindir os direitos sociais prestacionais em duas vertentes: os que não possuem capacidade contributiva deverão ser atendidos por benefícios de natureza assistencial; os que possuem alguma, deverão ter essa dimensão reforçada, com estreitamento do vínculo entre benefícios e contribuição previdenciária, não apenas em termos de valores, mas também de tempo de contribuição. O novo discurso da racionalidade econômica vai enfatizar mais o dever de contribuir do que o direito ao benefício.

O direito é deslocado pelo dever de contribuir, o que provoca uma reviravolta também na idéia de solidariedade. O que nos faz lembrar da advertência de Comte, muito mais preocupado com a relação entre indivíduo e Estado do que com os laços que unem homens entre si na sociedade: "Nós nascemos carregados de obrigações de todo gênero para com os nossos predecessores, os nossos sucessores e os nossos contemporâneos. Eles não fazem depois senão desenvolver-se ou acumular-se antes que possamos prestar 
qualquer serviço. Sobre que fundamento humano poderia, pois, assentar a idéia de direito, que razoavelmente suporia uma eficácia prévia? Por maiores que possam ser nossos esforços, a mais longa vida bem empregada não nos permitirá jamais restituir senão uma parte imperceptível do que houvermos recebido. Entretanto, só depois de uma restituição completa é que ficaríamos dignamente autorizados a reclamar a reciprocidade nos novos serviços. Todo direito humano é, portanto, tão absurdo quanto moral” (Comte, 1978: 278-280).

O positivismo de Comte não reconhece a ninguém outro direito senão o de cumprir sempre com o seu dever (de proteger e de se submeter), como um esforço sobre si mesmo em favor dos outros, como a subordinação da personalidade à sociabilidade, como o resultado de uma ação geral e combinada.

\section{Weber e a racionalidade econômica}

Os argumentos favoráveis à reforma da Previdência Social enfatizaram a necessidade de promover um expurgo, o da irracionalidade. A ampla reforma promovida pela Constituição de 1988 que modificou critérios de acesso ao direito social, a universalização da atenção à saúde, o controle público sobre o valor dos benefícios e a fixação de uma referência mínima para os benefícios sociais, ocorreu de forma irracional e até irresponsável. A irracionalidade consiste em não ter levado em conta as considerações econômico-financeiras do Estado em franca crise fiscal e necessitando conter as despesas públicas. A penúria fiscal e a carência de recursos públicos para o seu financiamento não deveriam ter permitido o avanço dos direitos sociais com elevação de despesas públicas.

Mas, no ambiente político da Nova República e da Assembléia Nacional Constituinte, a reforma era plenamente justificada e visava compensar o déficit de cidadania, promovendo a condição de igualdade e de justiça social.

Os debates em torno da reforma assumem, assim, uma dupla conformação que têm nas contas da Previdência o seu ponto de encontro: a defesa dos direitos instituídos com base na racionalidade política e a valorização dos princípios da democracia e da cidadania; e a crítica a esses direitos em razão do aumento dos gastos públicos, que conduziu a uma situação de ingovernabilidade financeira, amparado numa racionalidade econômica. A discriminação entre o racional e o irracional se faz em nome de certos valores que 
prejudicam outros, nos lembraria Freund (1987:106). A irracionalidade é construída a partir de um ponto de vista racional que desautoriza o outro. A verdadeira irracionalidade está em ter que se fazer escolhas (arbitrárias e limitadas) promovendo o estranhamento dos valores e das esferas da vida entre si (Nobre, 2000).

É necessário retornar a Weber para compreendermos o debate sem incorrer em juízos de valores ou tentar apurar quem está certo ou errado. São duas lógicas diferentes de racionalização que se confrontam no tema da reforma da previdência ${ }^{45}$. Talvez esse seja de fato o núcleo e o cerne da disputa.

Ao se questionar sobre a singularidade da civilização ocidental, Weber (Weber, 1979b) acreditou encontrar a resposta num tipo de racionalização dos modos de vida amparado num conjunto de técnicas, especializações, divisão do trabalho, conhecimento científico, disciplinas, sem precedente. A racionalização expressa uma intelectualização progressiva da vida que torna as formas de organização social cada vez mais abstratas. Expressa um movimento de diferenciação, autonomização e sistematização das esferas da vida.

O processo de racionalização e intelectualização adquire a inflexão de um processo de desencantamento do mundo, que deve ser entendido em duas chaves: como desencantamento pela religião e como desencantamento pela ciência (Pierucci, 2003). O intelectualismo repele as práticas mágicas e busca re-encaixá-la num outro sentido, reconstruído. Para o próprio Weber, a singularidade histórica da modernidade está na busca da "dominação racional do mundo" perseguida pelos puritanos, da qual o homem era um instrumento (Weber, 1979b: 158). O processo de racionalização está ligado ao ato de calcular, sistematizar, controlar e conferir sentido. É o desencantamento do mundo que abre passagem para o crescimento das modalidades de ação racional e o despojamento de todas as práticas mágicas. Ao penetrar o conjunto da vida, a racionalização torna o mundo artificial, produto da criação humana.

\footnotetext{
${ }^{45}$ Weber pontua que não existe representação objetiva da realidade, mas é possível ordená-la pelo pensamento e que os conceitos são construídos intelectualmente para tornar compreensíveis determinadas relações, através da construção de tipos ideais. Representa o modo pelo qual procuramos dominar a realidade, pela reflexão. "Obtém-se um tipo ideal mediante a acentuação unilateral de um ou vários pontos de vista, e mediante o encadeamento de grande quantidade de fenômenos isoladamente dados, difusos e discretos, que se podem dar em maior ou menor número ou mesmo faltar por completo, e que se ordenam segundo os pontos de vista unilateralmente acentuados, a fim de se formar um quadro homogêneo de pensamento. Torna-se impossível encontrar empiricamente na realidade esse quadro, na sua pureza conceitual, pois trata-se de uma utopia" (WEBER, 1979c:106). Grifos do autor.
} 
A racionalização é o traço específico da modernidade e as ações sociais se tornam racionalmente orientadas As análises de Weber seguem em duas direções: uma que se refere a uma racionalização instrumental (técnicas e meios) e outra que se refere à ação social.

Weber (Weber, 2004: 16) distingue a ação social em quatro tipos-ideais dos quais nos interessa particularmente aquelas racionalmente orientadas: ação racional orientada por fins (racionalidade formal do cálculo entre meio e fins) e a ação racional orientada por valores (racionalidade voltada para a efetivação de um valor). O que distingue a ação racional com relação a valores da ação afetiva é a consciência dos atos e a orientação conseqüente e planejada, a medida da conseqüência dos atos. Quem age a serviço de suas convicções, em nome da dignidade, da ética, da religião e do sentimento de justiça. Age racionalmente com relação a fins quem orienta sua ação pelos fins, meios e conseqüências secundárias, que analisa e pondera sobre os diferentes fins possíveis entre si.

Weber (Weber, 1979b: 159) enfatiza ainda que do ponto de vista da racionalidade referente a fins, a racionalidade referente a valores será sempre irracional, porque não reflete as conseqüências dessa ação. O que permite entender e distinguir duas lógicas discursivas: as que se orientam pelo cálculo econômico e que produzem um tipo específico de racionalidade, a racionalidade econômica; e aquelas que se orientam pelo sentimento de justiça, e, que produzem uma racionalidade política (solidariedade). A racionalização confere sentido à separação irremediável entre as duas ordens (Cohn, 1995: 18).

Eisen (1978), ao estudar o conceito de racionalidade em Weber, distinguiu que há seis elementos que reaparecem freqüentemente relacionados à ação social: realização de um propósito (a ação consciente de um ato ao perseguir determinado fim); calculabilidade e busca da maior eficácia; controle (ação racionalmente controlada); lógica (relação entre meios e fins); universalidade (racionalidade como o significado construído); organização metódica sistemática.

Para Weber (Weber, 2004) o que define a qualidade de “econômico” a um fenômeno é o nosso interesse no seu significado para a luta material pela existência. Uma ação será “economicamente orientada” na medida em que seu sentido visado seja o de satisfazer o desejo de obter certas utilidades. Weber denomina “ação economicamente orientada” toda ação que não apenas leva em consideração a necessidade de provisão econômica, mas que 
se orienta por ela. "Se economia significa algo, então na prática ela é a escolha previdente entre fins precisamente, ainda que se oriente pela escassez dos meios que parecem disponíveis e acessíveis para estes vários fins” (Weber, 2004: 38) ${ }^{46}$. Na prática, economia é a escolha previdente entre fins precisos, ela não é apenas meio. A técnica racional, por sua vez, implica na aplicação de meios - consciente e planejadamente, orientada pela experiência e pela reflexão - em seu máximo de racionalidade, pela ciência e intelectualização. Técnica não é atributo econômico, mas está presente em todo e qualquer tipo de ação e é sempre suscetível e amparada por diversos graus de racionalidade. O critério da racionalidade técnica é o melhor resultado possível em comparação com os meios disponíveis. Quando se leva em conta a raridade ou a escassez, a orientação da ação já não é puramente técnica, mas também econômica (Weber, 2004: 39). A escassez é o que permite a aproximação entre técnica e economia e a produção de um tipo específico de racionalidade: a racionalidade econômica. "Do ponto de vista da 'gestão econômica', problemas 'técnicos' significam o exame dos 'custos”' (Weber, 2004: 39) problema da economia, mas que também compartilha a preocupação com a satisfação de outras necessidades. A questão do custo, de natureza técnica, está relacionada à aplicação de meios para diversos fins. É a relação entre custo e benefício que torna a aplicação da técnica um problema de caráter econômico. Enquanto a economia se orienta pelo fim aplicado, a técnica se orienta pelos meios a serem aplicados. A orientação econômica do desenvolvimento tecnológico pela possibilidade de lucro é um fato fundamental na história da técnica, mas certamente não o único fator explicativo.

É da perspectiva sociológica, no entanto, que se pode aproximar as duas racionalidades, técnica e econômica, ou a avaliação entre os fins e o custo, organizar essa relação pelo pensamento e dotar-lhe de sentido. A análise sociológica opera com base no fato de que existem certas regularidades na ação social, processos que se repetem ao longo do tempo, se tornam rotina e se incorporam ao cotidiano dos múltiplos agentes. A racionalidade é um tema de interesse tanto da teoria econômica quanto da sociologia, ambas produzem sistematizações e seguem um método racional.

A “dominação racional do mundo” foi potencializada pelo emprego do conhecimento técnico especializado, pelo uso de método científico de conhecimento, pelo

\footnotetext{
${ }^{46}$ Grifos do autor.
} 
emprego de métodos racionais de controle da natureza e pela ação instrumental. A força da ação racional é a faculdade de classificação, inferência, dedução, o funcionamento abstrato do pensamento, como diria Horkheimer (1976: 11), sem qualquer explicitação de conteúdo. O autor aponta, ainda, uma cisão entre a razão subjetiva e a razão objetiva que não é de mera oposição, mas o resultado de um processo histórico em que o pensamento deixou de ser uma objetividade absoluta e foi renegada como ilusão. Isto ocorre porque a racionalização é um processo de sistematização, de diferenciação, uma característica das ações em processo e não o seu fim (Cohn, 1995).

A racionalidade formal econômica representa a extensão do cálculo econômico, a contabilidade, a tecnicamente possível, enquanto que a racionalidade substantiva representa o grau no qual a provisão é tomada sob alguns critérios de valor. A distinção realizada por Weber mostra a relatividade da racionalidade, entre o tecnicamente possível e o realmente aplicável. As decisões são influenciadas por normas diferentes da generalização lógica da interpretação do significado abstrato.

A racionalização enfatiza a adequação de procedimentos a propósitos tidos como certos e auto-explicativos, como uma razão subjetiva, voltada para fins. O esvaziamento de seu conteúdo expressa uma "crise da razão”, como afirmaria Horkheimer (1976), como o desligamento da razão de um conteúdo objetivo, que passa a enfatizar apenas o seu aspecto instrumental, de valor operacional. Um modo de procedimento sem conteúdo e sem valor normativo, a serviço da técnica.

Uma ação será economicamente orientada na medida em que esteja referida a cuidados para satisfazer o desejo de obter certas utilidades. Gestão econômica racional é o exercício pacífico do poder de disposição que primariamente é orientado economicamente, (com relação a fins e de acordo com um plano). Processos e objetos econômicos adquirem este caráter pelo sentido que neles põe a ação humana e que parte da idéia de que as utilidades são desejadas. Toda política pode pôr-se a fins econômicos, mas o inverso não é verdadeiro.

As medidas típicas de gestão econômica racional são: distribuição planejada entre o presente e o futuro das utilidades com disponibilidade que podem contar os agentes econômicos (poupança); distribuição planejada das utilidades disponíveis, segundo uma ordem de importância e a utilidade marginal; abastecimento planejado (produção e 
obtenção); aquisição planejada de um poder garantido de disposição ou participação naquela utilidade (administração, racionamento, critérios de acesso, troca etc.). Utilidades podem ser bens, trabalho ou outros. Uma preocupação com o presente e outra com o futuro, como uma administração racional dos recursos escassos.

Weber distingue racionalidade formal de gestão econômica da racionalidade material (2004: 52). A racionalidade formal é o grau de cálculo tecnicamente possível e que ela realmente aplica. A racionalidade material é o grau em que o abastecimento de bens de determinados grupos de pessoas, mediante uma ação social economicamente orientada, ocorre conforme determinados postulados valorativos, que é o ponto de referência para o seu julgamento. O segundo é mais vago, abstrato e genérico. A consideração que faz não se satisfaz com o fato puramente formal e relativamente inequívoco de que se calcula de modo racional com vistas a um fim e com os meios técnicos disponíveis. Para padrões artísticos, éticos, estéticos, ascéticos, a função meramente formal do cálculo em dinheiro pode parecer uma coisa adversa aos seus postulados (Weber, 2004: 52-53). A racionalidade formal conflita com a racionalidade substantiva porque leva em conta não apenas a previsibilidade dos cálculos econômicos, mas também dos juízes, organismos, autoridades governamentais etc.

Do ponto de vista puramente técnico, o dinheiro é o meio de cálculo econômico mais perfeito, isto é, o meio formalmente mais racional de orientação da ação econômica. $O$ cálculo em dinheiro, no caso de maior racionalidade, significa: 1 . analisar a situação de mercado; 2. relação custo-benefício; 3. comparação periódica; 4. fluxo de caixa; 5. uso do dinheiro disponível par a satisfação das necessidades ou utilidades desejadas, segundo a utilidade marginal (Weber, 2004: 53). Todo cálculo racional em dinheiro está orientado pelas oportunidades de preços provindas de luta (de preços e concorrência) e de compromisso entre interesses diversos que ocorrem no mercado (Weber, 2004: 57). O dinheiro é abstrato e impessoal, o símbolo máximo da racionalização na economia, o meio de cálculo mais perfeito e o mais racionalmente orientador da ação econômica. O dinheiro permite estimar a utilidade segundo uma situação de mercado, estabelecer a relação custo-benefício, comparar um conjunto de bens e possibilidades, ser instrumento contábil e se dispõe a um emprego racional.

Talvez seja a sua tipologia da ação social e a definição da ação social racional com relação a fins um dos aspectos da sociologia de Weber que adquirem maior centralidade na 
discussão sobre o papel da racionalidade econômica. Apresenta uma certa combinação entre interesses e comportamento social. A teoria econômica só leva em conta o comportamento racional, enquanto que a sociologia considera exclusivamente a ação social (ação voltada para o comportamento dos outros). Sociologia e economia têm em comum o estudo da ação racional com relação a objetivos econômicos.

Weber chama ordem econômica "a distribuição do efetivo poder de disposição sobre bens e serviços econômicos, que resulta consensualmente do modo de equilíbrio de interesses e da maneira como ambos, de acordo com o sentido visado, de fato são empregados, em virtude daquele poder de disposição efetivo baseado no consenso" (Weber, 2004: 209).

A ordem jurídica se encontra no plano ideal de vigência pretendida, e a ordem econômica, no plano dos acontecimentos reais. Porque essa interpretação é da ordem do direito, do normativo, do dever ser. Quando as ações humanas são motivadas pelo ordenamento normativo, o sentido da ordem jurídica modifica-se, torna-se do campo empírico, sociológico (2004: 210). Com Weber, aprendemos que nem todo direito é direito garantido.

Weber (2004: 210) ao tratar da relação entre economia e direito irá enfatizar que o direito não garante apenas os interesses econômicos, ele é fundamental por garantir a natureza do contrato. É o reconhecimento do papel que o contrato desempenha na economia que confere centralidade ao direito no Estado moderno e a sua garantia, por meio da coerção legal administrada pelo Estado (Swedberg, 2005: 155). A lei é também um sistema coerente de regras abstratas, estabelecidas intencionalmente, racionalmente, e levada a cabo por profissionais especializados e imparciais.

Uma ordem jurídica pode permanecer inalterada mesmo quando mudem radicalmente as relações econômicas e as categorias do pensamento jurídico podem ser diversas das categorias econômicas sem que isso a atinja de modo decisivo, desde que o efeito prático para ambos seja o mesmo. O poder dos interesses privados podem ser opor à aplicação do direito e a garantia estatal dos direitos não é indispensável para fenômeno econômico fundamental algum, como a proteção da propriedade ou o pagamento de dívidas. (Weber, 2004: 225-226). O funcionamento de uma ordem econômica do tipo moderno não é possível sem uma ordem jurídica de caráter muito especial, que só pode ser uma 
ordem estatal. A economia moderna baseia-se em oportunidades adquiridas por contratos, a velocidade das transações exige um direito que funcione de modo rápido e seguro, exige um direito calculável segundo regras racionais e que se adapte ao mercado (Weber, 2004: 227).

A racionalização econômica tem centralidade nos primeiros escritos de Weber. Weber (2004) entende por econômica a relação humana que tem por base uma necessidade ou um complexo de necessidades que exigem satisfação, enquanto os meios e os atos capazes de proporcionar essa satisfação são limitados (raros ou carência de recursos). O comportamento assim orientado é chamado de "econômico".

Weber também se preocupou com a questão do financiamento do Estado, do qual a cobrança de tributos representa o seu elemento mais racional e que se torna permanente no desenvolvimento do capitalismo ocidental. Para Weber, o financiamento estabelece uma conexão direta entre economia e organizações políticas dirigentes, que se diferencia conforme o tipo de dominação (poder de mando e obediência). Para Swedberg (2005: 115124), a análise do papel dos tributos no financiamento da burocracia e dos serviços prestados pelo Estado configura-se numa sociologia fiscal weberiana, numa demonstração de que a cada tipo de legitimação (legal, carismático e tradicional) corresponde uma forma de organização do corpo funcional e um modo de tributação. Num quadro comparativo, estabelece que apenas na dominação legal baseada numa administração burocrática o funcionário teria direito a um salário e provavelmente, uma aposentadoria, o que introduz um elemento de previsibilidade fundamental ao capitalismo.

O discurso da racionalidade econômica visa a promover o encontro da modernidade com os fundamentos da sociedade de mercado. A questão da racionalidade econômica é a questão epistemológica da economia política como ciência (Godelier, s/d: 18). A gênese da racionalidade se confunde com a da produção do mercado capitalista (Godelier, s/d: 29).

O discurso da racionalidade econômica visa explicar o comportamento humano a partir da maximização de ganhos dos agentes econômicos e do modo como se organizam para fazer um uso ótimo de recursos escassos, retirando dele o máximo de satisfações. (Godelier, s/d: 29). O conceito de "racionalidade econômica” exerce atração sobre outros termos que aparecem como pertencentes ao mesmo campo semântico: eficácia, eficiência, rentabilidade, rendimento, produtividade, relação custo-benefício, lucro, satisfação máxima, decisão ótima, escolha, cálculo, previsão, gestão e organização. Há como que um 
encadeamento natural entre eles. O conceito de "racionalidade econômica" permite operar uma naturalização entre produtividade e bem-estar social, entre maximização de oportunidades e maximização de ganhos (Godelier, s/d: 17).

A racionalidade econômica não é uma propriedade universal da atividade econômica dos homens, porque não há racionalidade em si ou racionalidade absoluta. Ela é sempre um produto histórico de uma fase do desenvolvimento econômico do capitalismo. É um tipo de racionalidade específica que se difunde como um princípio geral do comportamento humano, através do qual o homem busca fins coerentes consigo mesmo e emprega meios apropriados para alcançar fins desejados.

Weber (2004). compreende o desenvolvimento do espírito do capitalismo como parte de um movimento de modernização como um todo, como um tipo de atitude que julga o mundo conscientemente em termos de interesses a partir dos indivíduos e que leva os outros em consideração.

Godelier (s/d) propõe uma renovação da noção de racionalidade econômica ao rever que esta noção se organiza em torno de dois pólos de significados - eficácia e justiça. Uma economia eficaz é aquela referente à estrutura técnica de produção e ao domínio do homem sobre a natureza, enquanto que a economia justa se refere às relações dos homens entre si no acesso aos recursos e ao produto social. Entre ambos os pólos há assimetria, uma vez que o primeiro é ajustado por cálculos e o segundo, é sempre objeto de contestações irredutíveis, como parte do conflito social em torno da definição do direito.

Não há como dissociar economia e política, que se colocam com o crescimento da riqueza e a produção de excedentes e com o controle de recursos e produtos nas operações de repartição social. Na teoria econômica, a racionalidade é reduzida à busca do próprio interesse, supondo que todo o resto seja irracional. Ela é definida como coerência interna de escolhas e maximização do interesse individual. Se, a primeira definição consiste na possibilidade de explicação racional sobre o que se quer e o que se faz para obtê-lo (ação instrumental), a segunda se baseia na correspondência externa entre escolhas e seus próprios interesses (Sen, 1992: 115).

A afirmação da superioridade da racionalidade econômica opera uma inversão de valores, que provoca a perda do humano (Sen, 1992). A racionalidade econômica é tornada 
autônoma e já não se comporta como razão humana. A técnica, a capacidade cientifica e a tecnologia se distanciam do homem, se naturalizando em relação a ele.

A confusão entre racionalidade econômica e racionalidade técnica fez com que o sentido de ambas se tornassem um único e mesmo movimento, que recusa tanto os limites ao progresso cientifico, quanto ao capital. Sen (1992) propõe que, para inverter esse sentido, é essencial compreender que as estratégias de racionalização econômica não se reportam apenas à questão da produção, do desenvolvimento e do crescimento econômico, mas, sobretudo, à questão da repartição dos excedentes sociais, de encontrar um lugar para o homem na realização do econômico, de admitir outra racionalidade que não a econômica, um lugar para a ética e para a moral, sem tomá-las como irracionais.

Nessa dimensão, ganha sentido a tese de Rosanvallon (1992), de que a crise de financiamento do Estado não pode ser vista apenas como crescente desequilíbrio entre arrecadação e despesa do Estado, mas deve ser analisado em benefício de quem esta despesa é realizada. A crise é um problema referente ao grau de socialização tolerável de um certo número de bens e serviços e implica na reivindicação da mudança da equação redução das prestações sociais em favor de maior capacidade de financiamento do capital e como recomposição das cotizações sociais entre empregadores, empregados e Estado (Rosanvallon, 1992: 15). A economia transforma-se em economia política ao acrescentar o problema da escolha e do julgamento (Meek, 1971: 268). Também é a questão de Godelier (s/d: 18) quando pergunta: "em benefício de quem a eficácia deve ser buscada?”

A reforma da Previdência é um recorte a partir do qual é possível apanhar esse processo de racionalização amparado num discurso embasado na racionalidade econômica que reporta tanto ao movimento do próprio direito, quanto às mudanças institucionais. São essas as duas dimensões da reforma da previdência social que têm que ser observadas em separado: a reforma institucional e a reforma no direito.

Racionalização na reforma representa o movimento em que a instituição se modifica em seu papel, organização e dinâmica estatal para promover ela própria uma mudança na forma com que Estado e sociedade se relacionam em seus múltiplos aspectos. A reforma que visualizamos é a reforma em sentido amplo que permitiu o aperfeiçoamento da gestão econômica e o uso de técnicas que favoreceram a sistematização, a diferenciação, a organização e o controle da máquina pública. 
Mas, de outro lado, o que permitiu o amplo movimento de racionalização foi o discurso amparado na racionalidade econômica e que conferiu a essa esfera papel preponderante nas razões para a reforma. Na análise dos argumentos pró-reforma da Previdência, é possível capturar como o discurso econômico foi investido de uma racionalidade condutora das reformas. A ação social que aqui se estabeleceu foi acompanhada de uma racionalidade com relação a fins econômicos. A contabilidade, os custos, a escassez de recursos, o planejamento, a reorientação da ação foram tematizados ao longo de todo o período como os sustentáculos de um objetivo reformista que visou a relação entre meios e fins. O discurso da racionalidade econômica promoveu o encontro entre a economia e a técnica não apenas na definição do direito, mas também da gestão econômica dos direitos.

Para realizá-lo, os argumentos embasados na racionalidade econômica promoveram o expurgo da irracionalidade que havia adentrado à Previdência Social pelas vias da política e do direito. Como não se pode propriamente chamar de irracional a reforma amparada na realização dos valores da democracia e da cidadania, identificamo-la com um discurso embasado na racionalidade política ou na realização dos valores da igualdade e da justiça social.

Os argumentos pró-reforma, dessa forma, se orientam tanto pela retratação dos debates econômicos pré-constituinte que demonstravam a penúria fiscal do Estado, quanto pela demonstração da ingovernabilidade fiscal conduzida pela Constituição de 1988. É nesse duplo debate que emerge a irracionalidade dos direitos instituídos diante da incapacidade financeira do Estado para sustentá-los. Eles são irracionais do ponto de vista da racionalidade econômica, a qual relaciona meios a fins em ambiente de escassez econômica.

\section{Encargos sociais e o custo do trabalho: o custo do direito}

A abertura de um debate público sobre o "custo do direito" também adentrou ao pensamento político brasileiro, sobretudo pela ênfase na crise fiscal e na política de contenção do déficit público e formação de superávit primário. Esse debate não tem ocupado somente o campo da retórica, mas da prática econômica, da formulação de 
políticas cuja base é a própria competição por recursos escassos, dentro da lógica da racionalidade econômica.

O cerne desse argumento está no "custo do direito" sobre o desenvolvimento econômico ${ }^{47}$. Nesse caso, duplamente pensado, enquanto carga tributária e enquanto encargo, fardo que o setor econômico é obrigado a sustentar. Ele concorda com a reivindicação empresarial de redução dos custos do fator trabalho, negociação coletiva e flexibilização das relações de trabalho, como modo de ajustar o preço do produto no mercado internacional.

A contabilidade dos custos dos encargos sociais constituiu-se em uma polêmica nos anos 1990 e teve em José Pastore um de seus principais articuladores, que acusava a exorbitância do custo do trabalho no Brasil, em torno de 102\% da folha de pagamento de salários de uma empresa. Essa polêmica foi alimentada por preços, metodologia e justificativas diferenciadas ${ }^{48}$, que lhe conferiu um caráter técnico científico e contribuiu para a defesa da adoção de medidas de flexibilização do contrato de trabalho e do direito do trabalho (Santos, 2001; Noronha, 1998).

Para Pastore, um dos principais problemas era que, definidos por lei, os encargos sociais representavam custos, diretos ou indiretos, que, por serem compulsórios, não podiam ser negociados e trocados por qualidade, produtividade ou lealdade. Para os empresários, o principal problema era a “cunha fiscal”, propriamente dita, incidente sobre a folha de pagamentos.

A regulação do trabalho foi posta em discussão como fator de custo alheio aos mecanismos de mercado. No discurso empresarial assumiu a forma de combate ao

\footnotetext{
47 Segundo o discurso empresarial, deve-se computar como encargos sociais: 1. obrigações sociais como contribuição para a Previdência Social e FGTS, salário educação, acidentes de trabalho, "Sistema S” (Senai, Sesi, Sebrae, Sesc, Incra); 2. tempo não trabalhado ( repouso semanal remunerado, férias, feriados, abono de faltas, aviso prévio, auxílio-doença, 13\% salário, despesa de rescisão contratual, incidência de FGTS no $13^{\circ}$. salário) (SANTOS, 2001).

${ }^{48}$ Na década de 1990, houve intenso debate publicado na imprensa. José Pastore, Edward Amadeo, Jorge Mattoso e Demian Fiocca foram alguns que publicaram artigos na imprensa, ajudando a sustentar a polêmica em torno dos custos do trabalho. Ver: MATTOso, Jorge EL. "Encargos sociais e o desemprego", Folha de São Paulo, 01/06/1994; AMAdEo, Edward, "O Consenso sobre os encargos sociais, Folha de São Paulo, 04/06/1994; “O real peso dos encargos sociais sobre salários”, FSP, 04/01/1994; "uma agenda para o trabalho”, Folha de São Paulo , 17/07/1994; PASTORE, José. “a batalha dos encargos sociais”, Folha de São Paulo, 28/02/96; "Encargos Sociais”, Folha de São Paulo, 05/07/1994; “A Copa e o Custo do ócio”, Jornal da Tarde, 15/07/1998; "Corpo Mole no Trabalho", Jornal da Tarde, 03/06/1998; "Como simplificar os encargos sociais?”, Folha de São Paulo, 27/07/1994; FIOCCA, Demian,“o salário mínimo não custa R\$ 202 para a empresa I”, Folha de São Paulo, 01/03/96; “o salário mínimo não custa R\$ 202 para a empresa II”, Folha de São Paulo, 29/03/96; “a batalha dos encargos sociais”, Folha de São Paulo, 28/02/96.
} 
“dumping social” e de garantia da isonomia competitiva, duas formas de concorrência desleal. Esse ataque dirigia-se também às empresas nacionais, que não declaravam seus trabalhadores, não recolhiam tributos sobre a movimentação do mercado de trabalho, alimentando o mercado informal de trabalho, no qual o não cumprimento das obrigações trabalhistas implicava em redução do custo do trabalho. Além de desleal, a não observância da formalidade nas relações de emprego cindia a sociedade brasileira em duas, protegidos e não protegidos pelos direitos ${ }^{49}$. O questionamento do custo do trabalho é o questionamento da composição da carga tributária e do percentual gasto para sustentar os direitos relacionados ao trabalho, incluindo os direitos previdenciários. No discurso empresarial há uma tripla relação entre custo do trabalho, direitos e carga tributária. De um modo ou de outro, prevalece a idéia de que os direitos sociais são onerosos demais para serem suportados: para os empresários, o custo do trabalho reflete-se em impostos e contribuições sociais que oneram a produtividade e comprometem a concorrência; para o Estado, os direitos sociais implicam em custos que provocam o déficit público, em especial, o da Previdência Social.

Harris e Milkis (1996) apontam a emergência de uma nova política regulatória nos EUA, assentadas na busca de eficácia e legitimidade que traduzem a aspiração de uma renovação das relações entre Estado, negócios, sociedade e instituições que os representam. A reforma do Estado tem por incumbência resolver as suas três crises: fiscal, do modelo de intervenção na economia e do modelo burocrático de administração pública (Andrews; Kouzmin, 1998: 100). É uma reforma que se estende por todos os ramos do Estado e alcança a questão tributária, a política, a justiça, o aparato administrativo, as agências regulatórias, a previdência social e toda a estrutura do direito público.

Na reforma administrativa, tem sido buscada a construção de vínculos entre eficiência pública e competência, autoridade e responsabilidade gerencial, com adoção de práticas como o planejamento estratégico, atendimento ao consumidor, garantia de qualidade, administração de riscos e resultados. A reforma assume como pressuposto uma

\footnotetext{
49 “A reorganização administrativa e a previdenciária, que não objetivam suprimir direitos, mas eliminar privilégios, o equacionamento das contas públicas, a reforma do sistema fiscal e tributário, a revisão das relações de trabalho, a reforma judiciária e todas as medidas que concorram para a redução do Custo Brasil justificam-se e são urgentes” (FERREIRA, 1997: 20).
} 
racionalização econômica, baseada na gerência como instrumento técnico (Andrews e Kouzmin, 1998).

Para Boaventura Souza Santos, o trabalho desloca-se como o sustentáculo da cidadania (2000), movimento que tem sido denominado desfiliação (Castel, 1998), quando a segurança proporcionada pelo assalariamento torna-se ultrapassada e dá origem a uma crescente vulnerabilidade. Sem o ideal da promessa do futuro (Koselleck, 2006; Sennet, 1999; Ost, 2005), os homens são condenados a "viver a cada dia” (Castel, 1998). Há na literatura mais concordância do que questionamento sobre as premissas nas quais esse tipo de argumento se ancora.

\section{O problema da solidariedade}

A mudança na forma como o direito vem sendo pensado remete também à mudança na interpretação das formas de solidariedade ${ }^{50}$. A solidariedade é, como afirma Farias (1998: 194), uma espécie de mito da nossa contemporaneidade, uma idéia força, um fenômeno que faz parte do nosso imaginário político e social, que ajuda a compreender o nosso passado. Mas, uma idéia que está se desvanecendo, que vai perdendo a sua força de integração social e se tornando um fantasma na memória coletiva.

Talvez, de uma forma não tão pessimista quanto a de Farias, seja possível observar uma mudança no próprio conceito de solidariedade, ancorado muito mais no esforço de contribuição individual para com a sustentação do Estado do que no exercício do pluralismo democrático que o fenômeno da irrupção do social apresentava. A categoria solidariedade é o tema que permite organizar um conjunto de áreas de interpretação do lugar do direito na dinâmica social. As análises atuais sobre o direito social têm sido tangenciadas por três grupos de problemas: déficit público, nível do gasto social e seu efeito redistributivo.

Já se encontra superado o debate sobre se, no Brasil, se constituiu um verdadeiro Estado de Bem-Estar Social (Faria, 1998; Aureliano \&Draibe, 1989). As análises mais atuais têm focado na extensão das políticas de proteção social, que parte de um outro referencial teórico, menos centrado em análises comparativas. Como já destacava Malloy (1979: 11), a

\footnotetext{
${ }^{50}$ Bachelard assinala que é no momento em que um conceito muda de significado, que ele adquire mais sentido (BACHELARD, 1978).
} 
adoção de programas sociais destinados a "proteger”, no mínimo, uma parte dos seus cidadãos, das vicissitudes da vida moderna, causadas por perturbações sociais próprias do desenvolvimento econômico e da modernização, foi um fenômeno decisivo do século XX e deu forma à construção de um Estado de Solidariedade (Farias, 1998). Ele introduz uma ruptura na história do Estado de Direito, que passa a buscar a sua fonte na sociedade, na conciliação dos interesses e na resolução dos conflitos sociais. É um direito que é chamado a ser a medida da regulação social capaz de se colocar como critério objetivo e flexível na determinação da aceitação das obrigações jurídico-políticas. O direito de solidariedade é um direito que busca a conciliação do coletivo com o individual, como um modo de ajustar a liberdade do homem à autoridade dos grupos sociais a que pertence o indivíduo.

O tema da solidariedade emerge em meio aos conflitos sociais que tomam a Europa da segunda metade do século XIX com a industrialização, o pauperismo, o movimento operário, o socialismo e que suscitam tentativas de compreensão e intervenção. A solidariedade é um tema que se circunscreve não apenas no meio laico, mas também no religioso. É, para Durkheim (1995: 430), o tema do equilíbrio dos interesses em conflito em permanente renovação. É uma tarefa diária edificar essa sociedade em que cada indivíduo terá o lugar que merece como uma recompensa e na qual todos concorrerão espontaneamente para o bem de todos e de cada um. A solidariedade, longe de servir para emancipar o indivíduo, tem a função essencial de torná-lo parte integrante da sociedade, de tirar-lhe a liberdade de movimento. O problema que Durkheim (1995) enfrenta é o da coesão social; é saber se a solidariedade que a divisão do trabalho produz contribui para a integração geral da sociedade, se serve para unir os indivíduos. No entanto, como a solidariedade social é um fenômeno moral impossível de ser estudado, localiza no direito o fato externo e objetivo, passível de observação.

Para Durkheim (1995), o direito reproduz os tipos essenciais de solidariedade social, os quais classifica segundo o tipo de sanção que produz - repressivas ou restitutivas. A sanção repressiva existente no direito penal produz um vínculo de solidariedade mecânica, como produto de similitudes sociais. Os atos reprovados podem ser definidos por expressar um sentimento comum à média da sociedade, por estar no consciente coletivo e não pode propriamente ser chamada de solidariedade. A sanção restitutiva, por sua vez, está distribuída pelos ramos especializados do direito (civil, administrativo, constitucional etc.) 
e depende de órgãos especiais que o operacionalize, tais como tribunais, funcionários especializados e burocracia. As suas regras são estranhas à consciência comum e determinam relações que não atinge igualmente a todos, não ofende à consciência comum, mas, liga as pessoas entre si.

A solidariedade orgânica que a função restitutiva produz deriva do fato de que cada indivíduo se consagra a uma função especial na divisão do trabalho e se encontra, pela força das coisas, solidário aos outros. A sociedade não precisa intervir para que a solidariedade se produza, ela é o acordo espontâneo dos interesses individuais. O direito que obriga os indivíduos a agir visando fins que não lhe são próprios, a fazer concessões, a aceitar compromissos, constrói vínculos que vão além do momento de troca. Forma um sistema solidário do qual derivam deveres permanentes numa rede de obrigações das quais não se pode emancipar. Os homens não podem viver juntos sem fazer sacrifícios mútuos, sem se ligarem uns aos outros de modo duradouro (Durkheim, 1995: 192). Essa é a essência da solidariedade social: renúncia e abnegação em troca de continuidade. Mas Durkheim também irá afirmar que a reparação deve ser sempre proporcional à despesa que provoca, como o difícil equilíbrio do dispêndio de energia no orçamento do organismo vivo (Durkheim, 1995: 271). Assim sendo, a divisão do trabalho produz solidariedade porque supõe os indivíduos diferentes uns dos outros, porque reconhece em cada um uma personalidade diferente e porque a sociedade é capaz de se mover no seu conjunto quando cada um dos elementos se movimenta.

A classificação adotada por Durkheim permite superar a dicotomia então predominante entre o direito privado e o direito público, pois concebe que todo o direito é público porque é uma função social e todos os indivíduos são funcionários da sociedade. Todo o direito é publico porque todo direito é social (1995: 101). Esse é um tema presente no momento em que o social se constitui enquanto categoria, enquanto uma nova forma de organização que se põe de forma intermediária entre o indivíduo e o Estado (Arendt, 1981; Farias, 1998).

Farias (1999), ao fazer a genealogia do Estado de Solidariedade, demonstra como esse se encontra fundado em critérios jurídico, político e sociológico; como a construção do Estado de Solidariedade implicou a desconstrução de noções e categorias do pensamento 
político $^{51}$ que informavam o Estado Liberal, para construir novas categorias que dessem conta dos problemas fundamentais da época que eram a industrialização, a divisão do trabalho e os novos conflitos sociais. Em Rosanvallon (1997: 21) essa transição é descrita como a passagem de um Estado protetor (policial) para um Estado Providência, assentado na busca da promoção da segurança social.

Uma nova estrutura discursiva que se opunha ao direito no Estado Liberal, produzia uma nova articulação entre tradição e modernidade (Farias, 1999: 39), modificando os conceitos tradicionais de liberdade e segurança, os quais se tornariam as duas dimensões essenciais do Estado de Bem-Estar Social. Na base dessa transformação está a compreensão de que o Estado deve responder não a requisitos de igualdade sócio-econômica, mas de segurança sócio-econômica (Flora; Heidenheimer, 1987). Tanto liberdade quanto segurança devem reafirmar a base meritocrática (posições sociais) e a preservação das diferenças sociais (trabalho). Ewald (1986), através do percurso da lei dos acidentes do trabalho, também dá conta dessa transformação operada no discurso e na prática jurídica que se irradia para uma compreensão nova da dinâmica do trabalho e do dever de proteção social nascente.

O problema da integração de uma nova classe social e da admissão do conflito se colocava por inteiro na construção do Estado de Solidariedade. Por causa dele as noções de soberania nacional, nação e poder público se renovavam para provocar uma fissura capaz de criar um novo espaço social que absorveria a dinâmica das práticas coletivas que emergiam na sociedade. Esse novo espaço era onde a solidariedade podia se manifestar, porque era distinta tanto do Estado quanto dos interesses individuais, era a própria constituição do social.

É a idéia de soberania do direito sobre o Estado que promove a reviravolta na forma de se pensar o direito e faz surgir o conceito de Estado de Direito (Farias, 1999: 42) contra o poder arbitrário do Estado (Estado de Polícia). O Estado de Direito não é apenas uma forma de Estado na qual os seus órgãos estão submetidos ao direito para assegurar proteção a todos os indivíduos, ele supõe o predomínio da ordem do direito de solidariedade sobre a

\footnotetext{
${ }^{51}$ Como o deslocamento da fonte de soberania do rei para a soberania do povo, por exemplo, tematizado por Leon Duguit. Ver: Duguit. Leon (1908). Le droit social, le droit individuel et la transformation de l'État. Paris. Félix Alocan Editeur, apud FARIAS, 1999).
} 
do individualismo jurídico (Farias, 1999: 55). Corresponde, assim, a um imaginário políticojurídico que é o imaginário segurador (Ewald, 1993).

As noções de "serviço público" e de "instituição" são complementares e centrais na compreensão da modificação do Estado, que se torna promotor da solidariedade social. A noção de "serviço público" permitiu construir a intermediação do espaço social e ultrapassar a clivagem entre público e privado; conciliar as obrigações negativas e positivas do Estado. A noção de “instituição”, por sua vez, é o ponto de equilíbrio de elementos múltiplos. A idéia de equilíbrio (social, político, econômico e jurídico) pretende reconstruir a unidade na pluralidade, que deve ser buscada nas duas fontes de solidariedade social: o estatismo e o comunitarismo, num reconhecimento de que o Estado não pode ser a única fonte de socialização, porque ela passa também pela participação da sociedade civil (Farias, 1999). A genealogia que Farias realiza é a da formação de um novo discurso no direito, o discurso solidarista, como a criação de um espaço intermediário que rompe com as dicotomias tradicionais entre o público e o privado, o Estado e a sociedade civil, o Estado e o mercado, o político e o econômico. A admissão do social permitiu a renovação do Estado que passava a preencher a função de instituidor simbólico da identidade e da coesão social.

O “nascimento do social” é tematizado por vários autores (Castel, 1998; Ewald, 1993; Donzelot, 1984; Arendt, 1981; Farias, 1998; 1999), que demonstram como o social foi apanhado pelo discurso jurídico, e, ao fazê-lo, modificou o próprio Estado. Hannah Arendt (1981: 56) atesta a promoção do social (quando o trabalho deixa o domínio do privado), como a admissão de que a dependência mútua em prol da subsistência fosse expressa em praça pública.

Entretanto, o ponto principal da formação do Estado solidarista está, não propriamente na intervenção estatal, mas no reconhecimento do pluralismo jurídico, no reconhecimento da sociedade civil como produtora de direitos autônomos em relação ao Estado. O reconhecimento de que o direito resulta dos conflitos e das disputas sociais é o que forma um novo discurso jurídico - o solidarismo jurídico (Farias, 1999: 223). Nesse sentido é que Farias vê (1999: 58) na crise do Estado de Solidariedade o retorno às disputas sobre a relação entre indivíduos, grupos e classes sociais e a obrigação de se repensar formas não estatais de socialização fundamentadas no pluralismo da vida social. Sua crítica concentra-se no peso que o Estado concentra na formação da solidariedade social. 
Em Gurvitch (1931) $)^{52}$, a idéia de direito social torna-se produto dos tempos modernos, como o reconhecimento de que não pode ser reduzido a uma política do Estado, porque não deriva do Estado, mas das práticas sociais. Não pode ser compreendido como o direito de proteção (decorrente da legislação social) aos mais fracos. O direito social não se reduz à regulamentação da ajuda social do Estado, ele pressupõe a autonomização da sociedade e um novo tipo de regulação social. Ele bebe na fonte do pluralismo jurídico e nele se reconhece como um direito de produzir direitos, dos atores sociais se autogovernarem e defenderem seus direitos. O direito social é um direito de integração, que não exclui a pluralidade das partes nem se reduz a elas.

O sistema de seguros sociais que se desenvolveu na Alemanha é o corolário dessa visão orgânica da sociedade implicada no conceito de solidariedade tal como desenvolvido ao final do século XIX. O que o seguro social criou foi o dever jurídico de solidariedade que perpassará toda a lógica do direito do trabalho criado a partir de então. A noção de solidariedade é uma base positiva que ajuda a definir a atividade do Estado, conferindo-lhe uma nova legitimidade, amparada na localização de sua missão social (Farias, 1998: 193). A solidariedade é uma noção que permite a organização de formas de gestão do social.

A divisão do trabalho (Durkheim, 1995) por si só não assegura a solidariedade social, são necessários outros mecanismos para realizar a socialização, tais como o serviço público, a instituição e novas formas de regulação do social. O Estado de solidariedade é a regulação social da nova dinâmica social, que não busca negar o conflito, mas utilizá-lo como parte constitutiva do imaginário social que permite renovar continuamente as formas de gestão do social. O discurso do direito de solidariedade projeta a noção de serviço público no centro de um espaço social intermediário, no qual não há separação rígida entre Estado e sociedade (Farias, 1999: 243). Rosanvallon (1997) assinala que a crise do Estado é uma crise na solidariedade, que provém de uma decomposição do tecido social, fazendo com que tudo se passe como se não houvesse mais o "social” entre o indivíduo e o Estado.

Este longo percurso tem por objetivo demonstrar como tem havido uma inversão no modo como a solidariedade social é concebida. As disputas em torno do impasse financeiro apontam para uma mudança de acento com o valor arrecadação tornando-se maior que o

\footnotetext{
${ }^{52}$ GURVITCH, George (1931). L'idée du droit social. Notion et système du droit social. Paris: Librairie du Recueil Sirey apud FARIAs, 1998.
} 
valor da solidariedade social. O tema da capacidade contributiva tem sido objeto de preocupação de várias áreas das ciências sociais tanto quanto da execução das políticas fiscais.

A tributação não pode contrariar os preceitos do valor da solidariedade e deve prover o Estado dos meios de exercer o seu papel. Entra em pauta o dever de pagar tributos, o que torna coerente falar em "Estado fiscal” (Greco, 2005a: 182). A capacidade contributiva surge como um conceito que justifica um certo tipo de critério de rateio dos custos do funcionamento do Estado. O vínculo entre arrecadação e gastos vai perdendo a sua força, especialmente quando existem desperdícios, improbidades, fraudes e subvenções, de tal modo que a arrecadação de impostos passa a ser identificada como subtração e custo.

A Constituição definiu uma seguridade social financiada por toda a sociedade, o que vem sendo contestado a partir de argumentos que enfatizam o alto custo dos impostos e os danos sociais e econômicos que promovem, realizando o seu oposto. Para Grego (2005a) todo o debate sobre as reformas tributária e previdenciária provoca uma inversão no modo como o tema da solidariedade social foi inscrito no texto constitucional, para fazer prevalecer a capacidade contributiva de cada um, nas perspectivas horizontal e vertical, ou seja, entre os diferentes níveis de renda e entre as gerações.

Sachetto (2005: 15) afirma que o fundamento da tributação é sempre político e não econômico, embora produza um dever de solidariedade econômico. É o dever solidário contribuir para os objetivos comuns e a obrigação fiscal que onera a todos indistintamente. Assim, o dever de pagar impostos integra a solidariedade social na Constituição Italiana, fazendo prevalecer a idéia de compartilhamento de compromissos e responsabilidades assumidos como interesse comum.

O corolário da tese da solidariedade fiscal é o do dever de concorrer para a própria subsistência do Estado e não como uma prestação comutativa diante da distribuição de vantagens específicas para o obrigado (2005: 21). O que de novo nos faz retornar à idéia de Comte de que não se tem senão deveres para com a sociedade. Ou seja, não se pode chamar de solidariedade apenas o ato de receber benefício das despesas públicas, mas, principalmente, o dever de contribuir para a sustentação do Estado.

Um dos efeitos mais relevantes na discussão do princípio da solidariedade fiscal está em repartir o custo das políticas públicas com base no princípio da capacidade 
contributiva e não na contraprestação, que seria o benefício. A capacidade contributiva é medida por meio de indicadores indiretos como renda, patrimônio, comércio, consumo, etc., que exprimem a aptidão para concorrer para as despesas públicas. O princípio da progressividade representa o "custo da solidariedade", como uma forma de garantir a igualdade de sacrifícios entre os cidadãos (Sachetto, 2005: 27). A capacidade contributiva pode ser entendida como a repartição racional dos encargos públicos e diz respeito a todos os indivíduos em sua relação com o Estado.

Na inversão dos argumentos da solidariedade, o tributo, na forma de imposto, tornase o instrumento para realizar a justiça, operada por meio de uma redistribuição dos rendimentos, ou seja, na forma do imposto progressivo (Sachetto: 26). O vínculo entre os princípios da solidariedade e o da progressividade viveram seu maior desenvolvimento até os anos 70, quando a tributação passou a pautar-se por critérios de proporcionalidade. Sem respeitar o princípio da progressividade o sistema tributário não pode ser redistributivo. Esse é um dos limites do financiamento da previdência social no Brasil, que tem se mostrado altamente regressivo, ou seja, os custos acabam sendo repassados para os preços dos serviços e mercadorias e sobrecarregando os mais pobres.

A decisão sobre a capacidade contributiva de cada um é tomada não somente através da tributação, mas também pela decisão de subsidiar, de incentivar, de definir alíquotas diferenciadas. A solidariedade não coincide com a igualdade, ela pressupõe a desigualdade e age como limite a seus efeitos. A solidariedade que os direitos sociais expressam não pode se separar da dimensão da vida em sociedade, fundada no reconhecimento recíproco entre as pessoas.

Na Constituição Federal de 1988, por força do princípio de solidariedade cabe a cada cidadão brasileiro dar a sua contribuição a fim de financiar o Estado, assim como determina que a "seguridade será financiada por toda a sociedade "(... mediante recursos provenientes ...) das seguintes contribuições sociais" "53. O determinado é que sejam sujeitos à tributação todos os que detém capacidade contributiva medida através da renda, do patrimônio ou do consumo.

Há, com a dimensão da capacidade contributiva, a idéia de que os contribuintes devem suportar a totalidades dos serviços públicos de que se beneficiam todos os cidadãos,

\footnotetext{
${ }^{53}$ Constituição Federal, 1988.
} 
contribuintes e não contribuintes. Daí que seja subjacente a idéia de justiça distributiva traduzida na redistribuição dos rendimentos dos contribuintes para os não contribuintes (Nabais: 2005: 129).

A idéia de solidariedade encontrou no Estado fiscal a sua verdadeira concretização (como um objetivo a ser realizado pela via direta de impostos), o que nos conduz a uma visão unitária das receitas e despesas sociais, e não a uma consideração isolada das receitas fiscais originadas do pagamento dos impostos (Nabais, 2005: 130). Isto não é não se realiza no Brasil com o seu quadro sui generis de contribuições sociais. Um regime unitário deve considerar não apenas os impostos que arrecada, mas também os impostos negativos oriundos de subsídios e isenções fiscais. Os impostos são o que pagamos por uma sociedade civilizada, e podem tanto ser positivos, quanto negativos. Este é um dos aspectos presentes nos debates sobre o déficit da previdência social, como analisado no capítulo III.

A cidadania está vinculada pelo direito fiscal. Cada contribuinte tem o dever de pagar impostos, de contribuir e de exigir o mesmo a todos os membros da sociedade. Essa vinculação permite compreender o porquê da proximidade dos temas da reforma da previdência social e da reforma tributária. Como assinala com precisão Nabais (2005: 137) a crise do Estado social está associada à crise do direito dos impostos, ou, à defasagem crescente entre aqueles que são cidadãos e os que são contribuintes, o que torna problemática a realização da solidariedade social.

Diante do déficit apresentado nas contas da Previdência Social, uma das saídas tem sido reforçar o vínculo contributivo dos benefícios, tanto quanto favorecer projetos de inclusão previdenciária para aqueles que têm baixa capacidade contributiva. É um outro percurso diferente da trajetória em que sempre se valorizou retirar do Estado benefícios, não necessariamente vinculados a uma contribuição pretérita.

Os temas desse capítulo - financiamento dos gastos sociais, o custo do direito, o peso dos encargos sociais, a racionalização, o problema da solidariedade social e da capacidade contributiva - nos ajudam a compreender o debate sobre a reforma da previdência no contexto de uma outra formação discursiva que confere um significado diametralmente oposto à forma como os direitos sociais vinham sendo compreendidos. Ajudam também a reconhecer nas reformas processadas a ênfase nos deveres mais do que nos direitos, a partir da definição do vínculo contributivo dos direitos previdenciários e do 
fortalecimento da solidariedade social que ela emana. Essa subversão no modo de compreensão permite promover uma emancipação entre benefício e trabalho. Ao mesmo tempo em que a previdência se fortalece como seguro social ela perde a sua referência em relação ao mundo do trabalho. O "tempo de serviço" deixa de ser a chave de acesso aos direitos, que doravante serão reafirmados em função do vínculo contributivo. Lida dessa forma, a redefinição dos critérios de elegibilidade e acesso aos benefícios é muito próxima do projeto de inclusão previdenciária para a população de baixa renda, posto que visam fortalecer o vínculo contributivo. Se os direitos provocam custos, eles devem ser repartidos por toda a sociedade, como expressão de uma solidariedade social embasada na capacidade contributiva de cada um. 


\section{Capítulo II}

\section{PolíticA DA PREVIDÊNCIA SOCIAL: FINANCIAMENTO E PARTICIPAÇÃO NA DESPESA PÚBLICA}

O sistema previdenciário brasileiro ${ }^{54}$ foi formado com base no mecanismo compulsório de financiamento que contribuiu para gerar vinculação entre contribuição e o direito de acesso aos benefícios patrocinados pelo Estado, configurando a já conhecida situação em que direitos sociais básicos deixaram de ser decorrência natural da cidadania (Santos, 1979; Malloy, 1986; Rezende, 1987). O direito à previdência social sempre foi atado à participação no mercado de trabalho formal e dependente da estratificação profissional e do nível salarial ${ }^{55}$. Inicialmente assentado na idéia de uma composição tripartite, o financiamento da previdência social era de responsabilidade do trabalhador, do empregador e do Estado, tendo por base a folha de pagamento de salários, para os dois primeiros, e a quota da Previdência, para o Estado (Malloy, 1979; Cohn, 1980; Oliveira; Teixeira, 1986; Faleiros, 1985; Gomes, 1992).

A literatura demonstrou como a contribuição estatal sempre foi irregular e irrisória, o que gerou uma situação em que a Previdência deveria se auto-sustentar com base nas contribuições sociais de trabalhadores e empregadores (Cohn, 1980; Malloy, 1986; Oliveira \& Teixeira, 1986). Ocorria, porém, de algumas empresas reterem os valores correspondentes às contribuições dos empregados, além de não efetuarem as suas próprias.

Com base nos argumentos de Amélia Cohn (1980), a história da Previdência poderia ser cindida em duas fases, uma primeira em que cumpriu o papel de formação de poupança compulsória para sustentar o projeto de desenvolvimento (até a década de 1950) e, uma

\footnotetext{
${ }^{54}$ Não é nosso objetivo refazer a trajetória histórica da Previdência Social no Brasil, o que já está bastante documentado pela literatura. Resgataremos apenas alguns elementos chaves à compreensão da crise da Previdência, especialmente no que se refere ao padrão de financiamento, estrutura organizacional e definição de direitos. Compreendê-los é, porém, essencial para a acompanhar o debate sobre a crise da Previdência e as propostas de reforma, visto que algumas questões são estruturais.

${ }^{55}$ Issuani afirma haver correlação positiva entre cobertura previdenciária, capacitação profissional e status, o inverso ocorrendo com trabalhadores informais. Ver: (IssUANI, 1984).
} 
segunda, em que cumpriu o papel de controle sobre a classe trabalhadora. A história da previdência se confunde com a constituição do primeiro fundo de provisão ${ }^{56}$ criado pelos trabalhadores urbanos e tornado público nas teias da história da política brasileira (Andrade, 2003: 69).

No Brasil, ao contrário do que ocorre na maior parte dos países desenvolvidos e subdesenvolvidos, os recursos para o financiamento dos programas sociais não provêm da arrecadação tributária. Historicamente sempre foi grande a importância dos recursos do sistema de previdência social, bem como outras contribuições compulsórias no financiamento de programas sociais (Coutinho \& Salm, 1986; Oliveira \& Teixeira, 1986; Rezende, 1987; Faleiros, 1980). Esse modelo de financiamento tem implicações sobre a estrutura tributária e conduz a um conflito fiscal acirrado com a promulgação da Constituição Federal de 1988.

As contribuições previdenciárias sobre a folha de pagamento de salários têm o seu valor repassado aos preços de mercadorias e serviços, o que faz com que o ônus do financiamento seja repartido de forma regressiva por toda a sociedade, o que não justificaria a discriminação no acesso (Rezende \& Mahar, 1974; Rezende \& Silva, 1985; Aureliano \& Draibe, 1989; Dain, 1989). Ineficiência, fraudes, sonegação e desperdício eram fatores que marcavam tanto a arrecadação de recursos, quanto a realização das políticas sociais.

Ao longo do tempo, a estrutura da Previdência Social foi sobrecarregada com a execução de políticas sociais cuja finalidade eram estranhas à idéia de cobertura dos riscos sociais, tais como nutrição, saúde, assistência social, habitação etc (Oliveira \& Teixeira, 1986; Malloy, 1986). Sem correspondência entre contribuição e benefício (considerando valor e tempo das contribuições), tampouco a previdência social poderia ser caracterizada como um seguro social strictu sensu. Apesar da contribuição dos trabalhadores, o tratamento político era diferenciado segundo o posicionamento no mercado de trabalho formal.

Na década de 1980 a Previdência Social se caracterizava por abranger três áreas bem definidas de atuação: programas previdenciários (aposentadorias, pensões); assistência médica ambulatorial e hospitalar e assistência social à população carente (idosos e menores). O desemprego, contudo, não contava com proteção previdenciária até $1986^{57}$.

\footnotetext{
${ }^{56}$ Para uma análise do processo de implantação da legislação social, ver: (GoMES, 1979; LACERDA, 1980; ZANIRATO, 2003; LUCA, 1980).

${ }^{57}$ Apesar de constar das Constituições de 1946, 1967 e da EC 1/69 e do artigo 167 da Lei 3.807/60, que instituiu a LOPS (Lei Orgânica da Previdência Social), o seguro-desemprego só foi instituído efetivamente
} 
O sistema de proteção social brasileiro tinha um enfoque dualista, dividido entre uma política para trabalhadores do mercado formal e outra, para os pobres (Issuani, 1984). O atendimento de urgência na rede médica da previdência social pode ser incluído como uma modalidade de atendimento assistencial, mais ampla para segurados e atendimento de urgência para os não segurados (Possas, 1981; Teixeira, 1984) ${ }^{58}$. A expansão da previdência social seguiu nessas duas trajetórias, promovendo uma integração vertical (com benefícios mais amplos e melhores para os segurados com nível de renda maior) e uma integração horizontal (extensão para população não coberta anteriormente, como domésticos, trabalhadores rurais, autônomos e população em geral).

Em meados da década de 1980, o sistema via-se confrontado entre duas perspectivas: manter o sistema dualista ou promover a sua universalização, com garantia de um mínimo de proteção social independente de contribuição (Issuani, 1984). A necessidade de alcançar o equilíbrio orçamentário e definir o escopo das prestações previdenciárias apontava como alternativa uma reforma institucional que estabelecesse uma rígida separação entre as funções assistenciais e previdenciárias e as devidas dotações orçamentárias, fontes de custeio e órgãos executores (Teixeira, 1984). O critério de separação seria o vínculo contributivo, o qual reforçava, do lado previdenciário, o seu caráter de seguro social. De outra parte, buscava-se também criar mecanismos de controle social sobre os recursos da Previdência.

pelo Decreto-Lei 2.284, de 10/03/1986 com base no Plano Cruzado (Lei 2.283, de 28/02/1986). Apenas com a Constituição de 1988 o seguro-desemprego passou a ser assegurado em caso de desemprego involuntário e com financiamento a ser realizado com recursos do PIS/PASEP e através da contribuição adicional ao sistema das empresas que superassem o índice médio de rotatividade no setor. A partir de 1990, os recursos do seguro-desemprego passaram a integrar o FAT (Fundo de Amparo ao Trabalhador) sob gestão do Ministério do Trabalho. Apesar de ser considerada uma prestação previdenciária, é administrado e financiado por sistemas paralelos, não integrando a relação de benefícios previdenciários (MARTINS, 1999).

${ }^{58}$ As duas tendências sempre foram objeto de disputa entre as correntes que enfatizavam que a previdência social deveria exercer a sua função prioritária de seguro social e aqueles que defendiam que deveria ter essa função alargada para se caracterizar mais como um modelo de seguridade social. Entre os defensores do primeiro grupo se encontram, principalmente, os técnicos do IAPI (Instituto de Aposentadorias e Pensões dos Industriários), que ao longo da década de 1960 passaram a reunir poder suficiente (político e econômico) para se instalar nas estruturas da Previdência Social e do MPAS. Os técnicos do IAPI constituíram-se em um grupo coeso e baseado na competência técnica que buscava imunizar a burocracia de pressões políticas (necessidade de reduzir as expectativas e controlar as demandas) com a reivindicação da primazia da técnica sobre a política. Os “cardeais da Previdência”, como ficaram conhecidos foram os artífices da unificação previdenciária na década de 1960 e passaram a integrar o quadro dirigente de outros órgãos públicos. Sob um modelo administrativo-tecnocrático, ocorreu a criação de novos programas, benefícios e serviços previdenciários (OliVEIRA \&TEIXEIRA, 1986; MALloy,1976; HochMAN, 1992) 
Os diagnósticos realizados indicavam que o alargamento do espectro de benefícios ocorridos nas décadas de 1970 e 1980, sem a correspondente cobertura financeira e sem o amparo em contribuições pretéritas, conduziu a uma situação de déficit crônico nas finanças previdenciárias, corrigidas tecnicamente com o rebaixamento do valor dos benefícios (Coutinho \& Salm, 1986; Dain, 1989; Aureliano \& Draibe, 1989). Sem a contrapartida de contribuição, os benefícios se convertiam em benefícios assistenciais. A existência de um caráter assistencial nos benefícios previdenciários dificultava que fosse identificada como um seguro social stricto senso. De outra parte, a contribuição previdenciária criava a ilusão de correspondência entre contribuição pretérita e valor dos benefícios.

Naquele que foi considerado o primeiro estudo econômico da Previdência Social (Rezende \& Mahar, 1974) já se apontava a necessidade de promover uma separação entre as áreas da previdência, assistência e saúde, como forma de conter o déficit crescente ${ }^{59}$. A proposta era a criação de três fundos distintos para custeá-los de forma independente, o que provavelmente não produziria ganhos econômico-financeiros, mas daria maior visibilidade aos problemas de financiamento de cada área individualmente (Rezende \& Silva, 1985). A medida era uma alternativa que visava a proteger os recursos previdenciários e prover as demais políticas com novas fontes de financiamento. Havia um consenso quanto ao fato de que o crescimento com os gastos com a saúde eram os responsáveis pela crise financeira da Previdência Social (Oliveira \&Teixeira, 1984; McGreevey, Piola \& Vianna, 1986), sobretudo, pela prática de compra de serviços médicos e das inovações tecnológicas em diagnósticos e tratamento. Os estudiosos da saúde apontavam que não haveria outra saída senão universalizar o atendimento e descentralizar as responsabilidades, de modo a incorporar toda a população como beneficiária.

O sistema de arrecadação previdenciária era considerado ineficiente e a falta de controle fazia com que as empresas acumulassem débitos com a União, cujo montante era utilizado para financiar a produção e para rebaixar o valor das contribuições, num contexto de alta inflação (Rezende \& Mahar, 1974; Possas, 1981; Malloy, 1986). Por outro lado, a renúncia

\footnotetext{
${ }^{59}$ Posição que foi reiterada em novo estudo de Fernando Rezende de 1984, chamando a atenção para a complexidade do problema, visto que toda a população contribui indiretamente para o sistema previdenciário e que a assistência foi dependente da previdência para constituir-se em política social. No entanto, advogava a separação institucional, gerencial e financeira entre as três políticas sociais, bem como maior controle da população sobre o uso dos recursos públicos (REZENDE, 1984).
} 
fiscal obtida através de um amplo programa de subsídios e isenções fiscais limitava a base tributária e o investimento em políticas sociais.

O Finsocial ${ }^{60}$ criado para financiar as políticas sociais acabou por ser utilizado no financiamento de outras áreas do governo, bem como para reduzir o aporte de recursos tributários ${ }^{61}$. Dain (1989b: 65) aponta que o Finsocial além de não ter sido capaz de neutralizar a tendência à queda na arrecadação tributária, teve seus recursos alocados nos orçamentos dos Ministérios a partir de 1985, passando a financiar gastos do Governo Federal e transferências negociadas a Estados e Municípios. A queda na receita do Finsocial repassada ao BNDES despencou de 79\% em 1984 para 12\% em 1985 e 4\% em 1986, alcançando 6\% em 1987. A partir de 1985, o Programa de Prioridade Social do Governo foi basicamente financiado com recursos do Finsocial, o que nos dá uma idéia da perda do potencial de gasto social e de seu significado para as populações mais carentes. É nesse contexto de queda na arrecadação tributária e falta de recursos para financiar as políticas sociais que a crise financeira da Previdência Social emerge e se torna um problema político e econômico.

A falta de mecanismos de financiamento em consonância com a amplitude da natureza da política social efetuada era uma falha do nosso sistema de "seguridade social”,62 (Coutinho \& Salm, 1986: 218). A folha de pagamento de salários era considerada insuficiente para cobrir um amplo leque de serviços sociais prestados e, nesse caso, a crise

\footnotetext{
${ }^{60}$ Criado pelo Decreto-Lei 1.940, de maio/1982, tinha por objetivo custear os investimentos de caráter assistencial em alimentação, habitação, saúde, educação e amparo ao pequeno agricultor. Sua receita era formada pela contribuição social de $0,5 \%$ sobre a receita bruta das empresas públicas e privadas que vendem de produtos, das instituições financeiras e das sociedades seguradoras; 5\% (sobre Imposto de Renda) de empresas que realizam venda de serviços e podia ser acrescido de recursos orçamentários da União e de empréstimos. Ela não incidia sobre produtos exportados. Os recursos do Finsocial somaram US\$ 1 bilhão em 1984, geridos pelo BNDS e alocados por decisão presidencial a partir de programas e projetos prioritários. No entanto, a sua participação no custeio de ações de saúde foi de 1,5\% orçamento federal, em 1982, e 6,8\%, em 1983.

${ }^{61}$ O Finsocial era visto como um retrocesso do ponto de vista das modernas técnicas de tributação, embora representasse um avanço político a tentativa de garantir recursos para o financiamento de programas sociais e o grau de liberdade no uso dos recursos por não apresentarem vinculações. Foi considerado um mérito o fato de, pela primeira vez, recuperar a noção de que os gastos sociais deveriam ser financiados por recursos de natureza fiscal (REZENDE \& SILVA,1985).

${ }^{62}$ A inclusão de serviços de natureza assistencial na Previdência Social e o uso de seus recursos para financiar outras políticas sociais promoveram uma confusão conceitual entre os pesquisadores, que ora se referem à Previdência Social como uma política particular que tem por objetivo o pagamento de aposentadorias e pensões e que também presta serviços assistenciais ou a sua configuração como seguridade social. Esse debate perpassou os debates constituintes e foi inserido no texto constitucional, que buscou conformar as duas situações, tratar a previdência social como uma política particular, mas integrada às áreas da saúde e da assistência social, na seguridade social.
} 
previdenciária não podia ser identificada como de natureza conjuntural, mas estrutural, como uma crise de concepção.

A Previdência Social sempre se debateu entre duas características negativas: falta de equilíbrio financeiro e baixa qualidade dos serviços prestados (Oliveira \& Teixeira, 1986; Coutinho \& Salm, 1986). A assimetria entre critérios de financiamento e escopo do sistema previdenciário comprometia a sua estabilidade. A carência de recursos para o financiamento da política social conduzia a um conflito distributivo no interior das políticas sociais e entre essas e a política econômica.

A situação paradoxal é que os recursos financeiros da Previdência Social eram diretamente afetados pelo desemprego e pelo arrocho salarial, que comprometia a capacidade do Estado reagir à crise econômica com ampliação do gasto social (Coutinho \& Salm, 1986; Rezende, 1987: 9). A conseqüência era uma elevada sensibilidade às flutuações cíclicas da atividade econômica: a expansão econômica, o crescimento do emprego e dos salários assegurava o crescimento das bases financeiras, enquanto que os ciclos recessivos provocavam um efeito contrário. O efeito da recessão era duplamente perverso, posto que quando as demandas sociais eram exacerbadas, reduzia-se a capacidade do Estado em atendê-las (Dain, 1989b; Aureliano \& Draibe, 1989).

A desproporção entre os recursos fiscais destinados à saúde e os aplicados pela instituição previdenciária era apontada como uma das causas da ênfase na assistência médica curativa em detrimento de políticas de saúde pública e preventiva (Possas, 1981; Oliveira \& Teixeira, 1986; McGreevey; Piola \& Vianna, 1986) e foi o principal objeto do movimento de defesa da reforma sanitária ${ }^{63}$, ao mesmo tempo em que era apontada como a principal razão da crise financeira.

A crise financeira da Previdência na década de 1980 foi enfrentada com o aumento da alíquota de contribuição de empregados e empregadores, mantendo-se intacto o mecanismo básico de financiamento (Coutinho \& Salm, 1986: 232), ao mesmo tempo em que o padrão de alocação dos serviços prestados foi revisto. O pagamento de aposentadorias e pensões não podia ser cortado, visto que era obrigatório em decorrência do regime de

\footnotetext{
${ }^{63}$ Reforma sanitária designa diferentes experiências de reforma normativas e institucionais na área da saúde. No Brasil, a noção se encontra associada à idéia de movimento e teve início em meados dos anos 1970, ela foi motivada tanto pela crise da Previdenciária e redução dos gastos com assistência médica, quanto pela vontade de fortalecer propostas de um setor público de saúde. O movimento da reforma sanitária marca uma trajetória que vai da assistência médica curativa à saúde pública e coletiva (CoHN, 1989).
} 
repartição simples ${ }^{64}$ adotado na Previdência Social e, portanto, independia do volume de recursos disponíveis.. O atendimento médico era, por sua vez, fortemente dependente da disponibilidade de recursos e foi o setor que mais sofreu com a crise. A assistência social também dependida da disponibilidade de recursos, mas não exercia grande influência na elevação dos gastos sociais.

Nesse contexto, o MPAS passou a adotar algumas medidas restritivas na assistência médica, como o fim do pagamento de tratamento médico no exterior, controle de despesa de atendimento médico, ruptura de convênios com prestadores de serviços, definição de cotas de internação aos hospitais conveniados, que repercutiram no rebaixamento do padrão de atendimento (Malloy, 1986).

No âmbito da previdência, a saúde era de efeito assistencial e um direito do contribuinte. Os trabalhadores sem vínculo formal de trabalho tinham acesso a algum serviço, em caráter emergencial. Os recursos da Previdência Social eram socialmente partilhados, incluindo outras áreas da política social. O acesso diferenciado à política previdenciária levou à visão dos trabalhadores do mercado formal de trabalho como privilegiados, a qual foi fortemente influenciada por uma interpretação baseada na concepção universalista de direitos sociais, cujo critério de acesso era a cidadania (Marshall, 1967). Há nesse ponto, uma cisão na literatura, especialmente entre as abordagens que consideram o seu aspecto político-social e as abordagens que consideram o aspecto econômico-financeiro.

O problema clássico da literatura foi tomar a previdência social não como um seguro social, mas como idêntica à seguridade social, esperando dela a realização dos direitos de cidadania, sem o caráter meritocrático e estratificado do mercado de trabalho. No entanto, ela sempre foi profundamente cindida pelo mercado de trabalho. Para Teixeira (1989: 45) o problema estava na realização das três modalidades de proteção social (seguro social, assistência social e seguridade social ${ }^{65}$ na mesma base institucional, que fazia com

\footnotetext{
${ }^{64}$ Em um regime de repartição simples, os recursos arrecadados a título de contribuições são utilizados para o pagamento dos benefícios durante este mesmo exercício, podendo ocorrer ou não a formação de "reservas de contingência” com a finalidade de amortecer eventuais flutuações sazonais no comportamento da receita e da despesa do sistema a ser financiado (OLIVEIRA, 1992a).

65 Rimlimger diferenciou as três políticas da seguinte forma: assistência social é o reconhecimento, a compensação e, muitas vezes, a punição por uma necessidade social; seguro social reflete uma relação jurídica do tipo contratual, com benefícios proporcionais à contribuição; seguridade social rompe com ambas as concepções de proteção social e institui que o Estado é obrigado a fornecer um mínimo vital a todos. Em
} 
que em momentos de crise financeira, se defendesse o caráter contratual e restritivo dos benefícios previdenciários e se considerasse os demais programas como "hóspedes”. É preciso diferenciar o que é a instituição Previdência Social do que é a política de previdência social, não necessariamente idênticas, como demonstra o desenrolar dos conflitos em tornos dos direitos.

Na década de 1980 mudanças importantes ocorreram na estrutura dos gastos com a saúde, representada por dois movimentos: redução de recursos previdenciários destinados à assistência médica (de 88,4\% para 82\%) e crescimento real dos recursos alocados em programas de saúde pública (alimentação, nutrição, prevenção de doenças transmissíveis) de 7,3\% para 13,5\% entre 1980-1983 (McGreevey; Piola \& Vianna, 1986). O Finsocial foi o responsável pelo aumento do aporte de recursos tributários no financiamento da saúde a partir de 1982.

Anteriormente, a área da saúde era cindida em duas: a saúde pública era da competência do Ministério da Saúde e financiada com recursos fiscais e a assistência médica previdenciária, de competência do MPAS.

A terceira atribuição da Previdência, a assistência social, permanecia à margem da discussão pública e era integrada não apenas pelos programas de amparo e proteção a menores carentes e idosos, desenvolvidos pela LBA e pela FUNABEM, como também pelos benefícios de renda mensal vitalícia ${ }^{66}$ para idosos carentes. Se os programas da LBA e da FUNABEM absorviam apenas $2 \%$ da receita de contribuição previdenciária, a renda mensal vitalícia representava cerca de $6 \%$ do orçamento, num contingente de $15 \%$ dos beneficiários da Previdência em 1982.

Os dados tornam a linha demarcatória entre previdência e assistência social bastante tênue, visto que não se pode associar tempo de contribuição a benefícios. Grande parte dos benefícios previdenciários apresentava um componente assistencial, uma vez que não estavam amparados em contribuição passada e nem era exigido tempo mínimo de carência

sua tipologia, a seguridade social redefine as relações sociais em direção à redistribuição de renda, eqüidade e justiça social. Apenas a seguridade social é capaz de conferir a cidadania plena aos cidadãos, enquanto que a assistência social promove uma cidadania invertida, negativa, que promove a figura do não-cidadão (RIMLIMGER, 1971)

66 A Renda Mensal Vitalícia foi criada pela Lei 6.179/74 e era denominado “amparo previdenciário”. Correspondia em valor a meio salário mínimo. Com a Constituição de 1988 passou a ser devida idosos com mais de 70 anos e portadores de deficiência sem meios de vida, tendo o seu valor alterado para um salário mínimo. A denominação também foi alterada para beneficio de prestação continuada, reconhecida como uma prestação de assistência social, regulamentado pelo Decreto 1.744, de 8/12/95 (MARTINS, 1999). 
para o acesso (renda mensal vitalícia, salário-família, salário-maternidade e aposentadoria por idade).

Teixeira (1989) identificou que o recorte institucional, a natureza jurídica, o critério contábil e o tipo de benefício eram utilizados nas disputas políticas para tentar promover a separação entre assistência e previdência, o que demonstra uma grande preocupação com a natureza da instituição previdenciária, tanto quanto com as políticas de previdência e assistência. Essa preocupação caminha para uma discussão de caráter conceitual, de formulação de políticas sociais e de financiamento. No fundo trata-se de distinguir "quem financia o quê para quem”.

No contexto da expansão das políticas sociais, a previdência social brasileira combinou expansão da cobertura e serviços com baixo valor dos benefícios, que atesta a insuficiência de amparo do sistema e a inviabiliza como sustentáculo de uma política de proteção social (ou de segurança social). A previdência social não conseguiu se constituir num mecanismo efetivo de concessão de condições de sobrevivência aos inativos, nem de correção das situações de pobreza, o que denuncia a sua ineficiência enquanto política de proteção social (Coutinho \& Salm, 1986: 240). Era uma instituição insuficiente na sua condição de seguro social, tanto quanto na de seguridade social ${ }^{67}$, com inconsistência entre políticas e recursos para a sua execução.

Os argumentos centrais sobre a crise financeira da previdência social e os indicativos de reforma com o fim da aposentadoria por tempo de serviço e mudança no esquema de financiamento já estavam dados antes da promulgação da Constituição de 1988. Esses argumentos apontavam para a redução da arrecadação previdenciária em decorrência da queda da massa salarial (desemprego e rebaixamento do nível salarial), do atendimento a compromissos financeiros do Banco Central (encargos da dívida, subsídios etc) e a necessidade do uso de recursos fiscais para a cobertura das políticas sociais.

O peso das “contribuições sociais” na receita tributária da União foi estimado em 80\% no ano de 1985, recursos extraídos de forma compulsória da sociedade sob a justificativa de estarem vinculados a aplicações de interesse social (Rezende \& Silva, 1985: 1). O volume de recursos arrecadado ajudava a questionar a tese da escassez de recursos para o atendimento de demandas sociais. Uma das propostas vigentes no período pré-constituinte

\footnotetext{
${ }^{67}$ Para uma discussão conceitual mais elaborada ver: FLORA \& HEIDENHEIMER, 1987b.
} 
era justamente a revisão do padrão do financiamento a partir da ampliação do percentual da receita tributária destinada ao financiamento da política social.

As mudanças no padrão de financiamento do setor público estão relacionadas ao ciclo de desenvolvimento econômico: durante o ciclo de crescimento (1967/1973) aumentou a capacidade do Estado extrair recursos da sociedade para financiar seu projeto de modernização, seja através da tributação, seja através da criação de novas contribuições sociais $^{68}$, acontecendo o inverso em época de estagnação econômica (Aureliano \& Draibe, 1989; Dain, 1989; Rezende \& Silva, 1985).

O crescimento das contribuições extra-fiscais levou ao seu questionamento e à reivindicação de uma reforma tributária. A baixa carga tributária (22,5\% do PIB em 1985) e a política de transferência de recursos para cobertura dos encargos financeiros do governo resultaram na redução dos recursos disponíveis para investimentos sociais. Ao longo da década de 1980 a recessão econômica e a aceleração inflacionária provocaram redução na carga tributária total (impostos, taxas, contribuições sociais, empréstimos compulsórios sobre o PIB e renúncia à arrecadação) ${ }^{69}$.

A perda da capacidade de financiamento fiscal do setor público implicou não somente na redução dos gastos orçamentários, mas também obrigou a uma recomposição entre orçamento fiscal, orçamento das estatais e orçamento monetário (Dain, 1989b: 57). O orçamento fiscal acolheu ainda pressões de desequilíbrio do setor público, obrigado a renunciar a seus gastos próprios para gerar recursos fiscais para o saneamento das empresas estatais e pagamento dos encargos da dívida mobiliária.

A reforma tributária era, naquele momento, aspecto importante na concretização de políticas de descentralização, especialmente as de municipalização, que implicariam na redefinição política de atribuições e responsabilidades governamentais e na repartição das competências fiscais e de recursos. Também era vista como condição essencial para a

\footnotetext{
${ }^{68}$ Em 1986, as contribuições sociais estavam classificadas em três categorias: patrimônio do trabalhador administrado pelo Estado (FGTS, PIS/PASEP); previdência social contributiva; contribuições sociais vinculadas a gastos sociais (Finsocial e salário-educação). As contribuições sociais possuíam importância crescente no financiamento do gasto público, especialmente aquelas de natureza social. Ver estudo sobre as contribuições sociais integrante do Estudo para Reforma Tributária de (REZENDE \& SILVA,1987).

${ }^{69}$ Dain aponta que a limitação da receita tributária própria e de recursos disponíveis para as esferas estadual e municipal, aliado à crescente drenagem para cobertura de encargos financeiros levou a crise fiscal a transformar-se em crise financeira, o que está na raiz do clamor pela reforma tributária. Para uma visão ampla da penúria fiscal no Brasil nos anos 80, provocada pelo declínio na arrecadação tributária, consultar a análise de (DAIN,1989b).
} 
realização de transferências compensatórias para comunidades em que a insuficiência da base econômica não dava condições de arrecadar recursos suficientes para atender às necessidades de gasto. O seu objetivo era corrigir o padrão de financiamento das políticas sociais, de modo que fosse possível atender aos mais pobres, através de políticas focalizadas, o que demandaria recursos que tornasse viável essa alternativa, mas ela não ocorreu.

No âmbito dos estudos para a reforma tributária, várias propostas eram relativas às contribuições sociais: fusão do FGTS e do PIS/PASEP a ser usado no financiamento do programa de seguro-desemprego; diversificação das fontes de financiamento da Previdência Social; extinção das contribuições do Finsocial e do salário-educação; criação de um adicional do Imposto de Valor Adicionado (IVA) e da cota-federal do salárioeducação para garantir recursos para a descentralização de encargos sociais (Rezende \& Silva, 1987).

O clima de "austeridade fiscal" reforçou posições conservadoras de busca de saneamento econômico e financeiro do Estado através de corte de gasto público e redução da intervenção do Estado na economia. O momento não era, portanto, propício à reestruturação da política social na direção recomendada pelos estudos (MPAS, 1986). Nos dois caminhos possíveis para a Previdência, venceu aquela visão política de ampliação dos direitos e universalização da cobertura, que só pode ser compreendido no quadro das negociações políticas em torno da transição democrática. Rezende (1987: 26) defendia a integração da política social à política econômica como passo decisivo em sua reestruturação, com o objetivo de promover o desenvolvimento sustentado, através de políticas de emprego e renda.

Havia uma incompatibilidade entre a dinâmica democratizante, com o alargamento dos canais de participação e diversificação das demandas, em contraposição a uma agenda minimalista, com prioridade para a estabilização econômica, redução dos gastos públicos e realização dos compromissos financeiros (Diniz, 1997b). O resultado foi o acirramento do conflito distributivo em torno de recursos escassos, que iria se estender durante os trabalhos da Assembléia Nacional Constituinte. 


\section{Ambiente pré-constituição}

Os diagnósticos produzidos pela literatura sobre o padrão da política social brasileira no período pré-consituinte eram contundentes: atendimento garantido com base na contribuição social que excluía parcela significativa da população brasileira. A vinculação entre benefícios sociais e participação no mercado de trabalho produzia privilégios, estratificação social e desigualdades (Santos, 1987; Rezende, 1987; Teixeira \& Oliveira, 1986; Cohn, 1980; Malloy, 1986).

As questões que envolviam a avaliação do sistema de proteção social ${ }^{70}$ diziam respeito à sua cobertura (critérios de universalidade), ao seu financiamento (quem paga) e aos critérios distributivos e redistributivos (quem se beneficia). No Brasil, a política social refletia, entre outras coisas, o seu efeito reduzido, o baixo grau de eficácia e de efetividade no combate aos problemas sociais. No plano institucional e administrativo a sua realização era marcada por fragmentação, superposição, ausência de transparência, opacidade do gasto social e multiplicidade de contribuições e fundos sociais, que contribuíam para conferir baixa densidade ao conceito de proteção social (Aureliano \& Draibe, 1989: 87). As demandas, apresentadas por categoria profissional, também não conferiam dimensão simbólica ao caráter universal. As políticas sociais vinham sendo pautadas por um conteúdo compensatório, uma postura assistencialista e um caráter excludente (Rezende, 1987: 12) ${ }^{71}$.

A década de 80 trouxe uma nova fase de dificuldades econômicas, com choques externos (petróleo e outros insumos) que provocaram a elevação de preços de matériasprimas importadas, queda na cotação internacional de produtos exportados e explosão dos juros da dívida externa. Datam deste período os primeiros programas de ajuste na balança de pagamentos sob patrocínio do FMI (Rezende, 1987). Com o esforço de contenção do déficit público, os gastos sociais, especialmente com educação e saúde, foram reduzidos drasticamente.

\footnotetext{
${ }^{70}$ Utilizo o conceito no sentido abrangente de integração de diversas técnicas de proteção diante de situações de riscos sociais. Assistência social, previdência social, seguro-desemprego e seguridade social são abrangidos pelo conceito enquanto técnicas de proteção social.

${ }^{71}$ No conjunto, as características negativas que predominavam nas análises levaram Rios Nogueira a concluir que além da crise financeira perpassava a Previdência Social uma "crise moral” (NoGUEIRA, 1985).
} 
Em 1985, o clima era de extremo pessimismo e temia-se que o desequilíbrio fiscal pudesse conduzir à insolvência do governo, com absorção de toda a poupança nacional no pagamento dos serviços da dívida externa (juros e encargos). Como proporção do PIB, a dívida alcançara 12,7\% em 1984, 18,9\% em 1985 e chegaria a 24,6\% em 1986, conforme as projeções realizadas (Rezende, 1987).

Apesar da adoção de medidas clássicas de correção dos desequilíbrios fiscais (elevação de impostos e contenção dos gastos), os programas sociais foram afetados pela elevação dos encargos financeiros que sangrou os recursos orçamentários. A sua fragmentação por várias instituições tornava o quadro ainda mais precário. O cenário de recessão contribuiu para o debate sobre o efeito perverso das estratégias de desenvolvimento às custas dos programas sociais e da deterioração das condições de vida, emprego e renda.

Havia concordância de que a centralização e a burocratização contribuíam igualmente para a alocação ineficiente de recursos públicos. Descentralização e participação eram as ações indispensáveis à eficiência e ao controle do gasto público. Fortalecer mecanismos adequados de participação da comunidade na definição das prioridades de investimentos nacionais, descentralizar as decisões e as ações para Estados e Municípios e alocar os recursos de modo mais eficiente eram propostas que circulavam durante a segunda metade da década de 1980.

Durante a Nova República, foram construídos dois parâmetros de avaliação das políticas sociais: financiamento das políticas sociais e a organização institucional (centralização, burocratização, fragmentação institucional e superposição de órgãos). O discurso oficial passou a incorporar os princípios reclamados pelos movimentos sociais: descentralização, integração entre serviços e equipamentos sociais, participação popular nos processos de decisão, implantação e controle das políticas sociais, concepção alternativa na organização e distribuição de bens e serviços sociais. O debate incorporou também a idéia que as políticas de assistência social devessem estar integradas a um sistema de proteção social como direito de cidadania (Aureliano \& Draibe, 1989: 159). As condições para a sua implementação tornavam necessárias, tanto o redesenho institucional e administrativo, quanto a criação de mecanismos que assegurassem o suporte financeiro 
adequado. Um dos pilares básicos seria justamente a compatibilização entre as políticas sociais e as demais políticas do governo e em particular, com a política econômica.

Durante a Constituinte tiveram relevância os debates sobre a repartição da renda pública nas seguintes direções: reforçar o sistema federativo, propiciar garantias contra o arbítrio do Estado, proporcionar maiores recursos para o custeio das políticas públicas e maior transparência e controle do poder Legislativo sobre os orçamentos públicos (Rezende \& Afonso, 1987). Essas questões não apenas tangenciaram os debates, mas ajudaram a formatar o texto final da Constituição Federal de 1988 e se tornaram centrais no conflito distributivo a partir de então.

De algum modo, as questões do presente já estavam dadas como preocupações no ambiente de negociações políticas, atravessadas não apenas por questões partidárias ou ideológicas, mas também por questões regionais. Temia-se que a descentralização de recursos financeiros da União para Estados e Municípios sem a garantia de descentralização de encargos públicos e a ampliação das atribuições do Estado na área de bem-estar social pudessem produzir impactos negativos sobre a crise fiscal que já estava plenamente configurada.

Durante a década de 1980, a falta de transparência no orçamento público era objeto de críticas. O orçamento do governo federal estava dividido em três (fiscal, monetário e das estatais) e o grande problema identificado era a criação de despesas sem o empenho de verbas e sem autorização do Congresso Nacional. Além da aprovação do orçamento, estava em debate a falta de controle parlamentar sobre as finanças públicas. Essa reivindicação pesava também sobre a Previdência Social, posto que operava com receitas públicas (oriundas de contribuições sociais) e deveria ter o seu orçamento aprovado e controlado pelos organismos de representação da sociedade, o que não ocorria. A partir de 1985, houve uma revalorização do orçamento fiscal como o principal instrumento de programação e controle das finanças públicas.

O debate sobre a descentralização fiscal previa inicialmente dotar Estados e Municípios de maior autonomia fiscal (poder de cobrar e administrar impostos). No

\footnotetext{
${ }^{73}$ As contribuições sociais não são consideradas tributos, mas receitas públicas que se constituem em um sistema para-fiscal e uma de suas principais características é não estar sujeita às mesmas regras da fixação dos impostos, como anualidade e vinculação. São contribuições que o Estado se obriga a cobrar para atender a objetivos econômicos ou sociais (GIACOMONI, 2005).
} 
entanto, entre a responsabilidade de administrar o tributo com maior autonomia e o conforto de usufruir de recursos provenientes de transferências da União, prevaleceu a segunda solução. A descentralização fiscal tomou um formato conservador na tributação e reforçou a dependência em relação ao Governo Federal (Rezende \& Afonso, 1987: 8-12).

A competência tributária da União ficou restrita ao IRPF, IPI, IOF, IPTR, impostos sobre importação e exportação e impostos sobre grandes fortunas. Os Estados tiveram sua competência tributária aumentada com a integração aos seus orçamentos de impostos sobre combustíveis, lubrificantes, energia elétrica, mineração e prestação de serviços de transporte e comunicações, circulação de mercadorias, impostos sobre heranças e doações. Os Municípios tiveram sua participação no ICMS aumentada e adquiriram competência para tributar sobre a transmissão inter-vivos de bens imóveis e criar impostos sobre vendas a varejo de combustíveis e para construção em solo urbano. No entanto, o mais sério impacto produzido foi o acréscimo nos percentuais dos impostos federais que deveriam ser transferidos para Estados e Municípios.

O formato da descentralização fiscal foi definido ainda nos inícios do debate da ANC, da qual o governo não participou. As bancadas do Norte e Nordeste, bem representadas na Comissão do Sistema Tributário, Orçamento e Finanças (CSTOF) buscaram assegurar compensações tributárias ao baixo desenvolvimento regional, barrando propostas que não provocassem acréscimo significativo na receita. $\mathrm{Na}$ época, estimativas do Ministério da Fazenda apontavam que a participação da União na receita tributária nacional cairia para $36 \%$ (contra os $45 \%$ vigente antes da promulgação do texto constitucional), enquanto que a receita dos Estados se elevariam de 37\% para $41 \%$ e a dos Municípios, de 18\% para 23\%.

O debate foi conduzido mais em termos de vícios e virtudes da descentralização do que propriamente a partir de um planejamento que previsse a descentralização de tributos e de encargos e as suas conseqüências. Aliás, a transferência progressiva de responsabilidades foi um tema contornado durante a ANC, até porque não havia soluções consensuais e as negociações políticas eram muito frágeis. Acreditava-se que o problema seria resolvido "naturalmente”, no entanto, a própria diferença no desenvolvimento entre Estados e Municípios minava a possibilidade de uma solução “natural”. 
A possibilidade de que o governo pudesse contrabalançar a perda de receitas propiciada pelo federalismo fiscal com o alargamento da base de incidência de contribuições sociais $^{73}$ também era remota, num contexto em que se previa a vinculação das contribuições sociais à seguridade social.

Durante a ANC tentou-se reverter a tendência ao rebaixamento do nível dos gastos públicos com a área social através da vinculação entre receita e programa. De um modo geral, educação, saúde, judiciário, transportes, ciência e tecnologia e cultura tentavam assegurar a sua parte através da inserção no texto constitucional de uma porcentagem mínima pré-estabelecida do orçamento para o seu financiamento (Rezende \& Afonso, 1987: 21).

Houve, entre as áreas sociais, uma verdadeira disputa por recursos, especialmente entre saúde, educação e previdência social. A educação já dispunha de um percentual de 18\% de recursos da União e 25\% de recursos dos Municípios vinculados, após a aprovação da Lei Calmon de Sá. O peso e a influência dos profissionais da saúde contribuíram para a construção da seguridade social e para a garantia de que as receitas oriundas das contribuições sociais estivessem a ela vinculadas. A saúde reivindicava a vinculação de $30 \%$ do orçamento para o seu financiamento.

O conceito de seguridade social adotado no texto constitucional pretendia alargar as concepções estreitas de associação entre direitos e contribuição com base no contrato formal de trabalho. Criava e designava um campo de mecanismos e reintegração direta e indireta de renda, formado por políticas de previdência social, assistência social e saúde (Aureliano \& Draibe, 1989).

Com a criação do OSS e a sua definição, começava a ser redesenhada a previdência social, com a separação das ações em campos especializados e ampliação da base de financiamento. A saúde, a previdência e a assistência social começavam a ser definidas como campos autônomos de política social, embora com ações integradas. Era uma resposta concreta a um dos principais problemas identificados na previdência social: o conflito entre os objetivos mais restritos de um seguro social (benefícios vinculados a contribuições) e objetivos mais amplos de política social, em que a concessão de benefícios deveria basear-se em critérios de necessidade (saúde e assistência social) (Rezende, 1974).

Acreditava-se que o conceito de "seguridade social" resolveria o problema institucional da Previdência Social, enquanto que a vinculação das contribuições sociais 
ampliaria a base de financiamento e lhe daria estabilidade, permitindo a realização de critérios de eficácia, eqüidade e distribuição de renda. Esperava-se que a criação de um OSS pudesse livrar a seguridade social da disputa por recursos no OGU, dotando-a de maior estabilidade e conferindo-lhe uma dimensão pública. O controle público lhe daria maior transparência, de modo que o controle e o uso político da instituição fosse menos possível (Cohn, 1980; Malloy, 1976).

A saúde se encontrava entre duas alternativas: insistir no paradigma americano que concebia a assistência médica como intrínseca ao seguro social; ou prosseguir para uma cobertura universal, ainda que baixa, como fez a Inglaterra (McGreevey; Piola \& Vianna, 1986). A ampla mobilização social e a crítica ao formato de assistência médica previdenciária acenavam para a sua construção como uma política dissociada da previdência e dotada de recursos próprios, o que deveria reforçar o caminho que já vinha sendo adotado de universalização, descentralização, expansão da cobertura ${ }^{74}$ e fortalecimento das ações de saúde pública e de saúde do trabalhador.

A hipótese de Braga (1986) é que o casamento entre previdência e assistência médica respondia a uma limitação na estrutura tributária e nos recursos públicos e permitia o atendimento aos trabalhadores com recursos da previdência, que era auto-sustentável. No entanto, o crescimento da demanda por atendimento médico e saúde pública reivindicava outra forma de financiamento, tanto quanto outra lógica institucional. Em 1980, 64\% dos gastos públicos em saúde ainda eram realizados pelo INAMPS.

Acreditava-se que a definição do OSS garantiria a ampliação de recursos para os programas sociais e teria uso restrito, vinculado às ações da saúde, previdência e assistência social. O Finsocial que financiava os programas sociais e que não foi incluído no

\footnotetext{
${ }^{74}$ Do lado da Previdência Social, o Plano de Reorientação da Assistência à Saúde (1982) tinha como pontos principais a eliminação da capacidade ociosa do setor público, prioridade à atenção primária e cuidados ambulatoriais, integração das diferentes agências de saúde em um sistema único, fixação de limites orçamentários para atenção médica e racionalização na prestação de serviços e sistemas de pagamentos de serviços prestados. A estratégia denominada "Ações Integradas de Saúde" tornou-se um mecanismo de coordenação das instituições públicas no setor de saúde, incluindo os MPAS e os Ministérios da Saúde e da Educação para repensar todo o modelo de assistência à saúde no país. Tornou-se um instrumento de descentralização, envolvendo Secretarias Estaduais e Municipais de Saúde, e de eqüidade, estendendo o atendimento médico de urgência para trabalhadores rurais e não-segurados da Previdência Social. Com as AIS foi possível a transferência de recursos federais para estados e municípios; um passo adiante no acesso e universalização aos serviços de saúde, que estimulou a produtividade em nível local (parâmetros de produtividade) e a unificação do sistema numa rede integrada de serviços (MCGreEveY; Piola \& VianNa, 1986).
} 
Orçamento Fiscal deveria ser integrado ao OSS ou extinto, tornando-se, de qualquer forma, indisponível. Com isso, a União deveria financiar os demais programas sociais com recursos fiscais, o que restringiria ainda mais as suas disponibilidades financeiras já solapadas com a descentralização tributária. Apenas o seguro-desemprego teve como base de financiamento recursos oriundos do PIS/PASEP, que foi transformado em Fundo de Seguro Desemprego (FSD) e ao FGTS coube o papel de proteger o patrimônio do trabalhador.

Esperava-se que a folha de pagamento de salário se tornasse base exclusiva de financiamento da seguridade social, deixando de ser partilhada com o financiamento do salário-educação e do financiamento de instituições patronais ${ }^{75}$. Com a ampliação da base das contribuições sociais, estimava-se um crescimento expressivo dos recursos para a previdência (40\%) e para a saúde (56\%).

O interesse em garantir maiores recursos para os programas sociais conduziu a uma cisão no Orçamento Geral da União, entre Orçamento Fiscal e Orçamento da Seguridade Social, a partir da origem dos fundos: impostos e contribuições sociais. Um terceiro componente do orçamento público passou a ser o Orçamento das Empresas Estatais.

Já se tinha conhecimento de que as restrições orçamentárias impostas à União com transferências a Estados e Municípios, financiamento de programas sociais, manutenção de incentivos à produção através de renúncia fiscal e a vinculação das contribuições sociais ao financiamento da seguridade social, poderiam vir a agravar o desequilíbrio nas contas públicas, com crescimento das despesas e redução de receitas. As contas públicas poderiam vir a ser afetadas pela inserção de novas atribuições e ampliação de direitos para trabalhadores, aposentados e pensionistas, públicos e privados e o aumento nas despesas administrativas.

O projeto da Constituição não apresentava um todo harmônico. Era marcado por contradições entre as atribuições e os recursos orçamentários disponíveis para sustentá-las, tais como a ampliação de direitos para funcionários públicos (pagamento de hora extra, 1/3 de férias, pagamento de indenização no ato da demissão, creche para filhos de funcionários,

\footnotetext{
${ }^{75}$ O que não foi aprovado no texto final da Constituição Federal de 1988. O “Sistema S” é integrado por contribuições de terceiros incidentes sobre a folha de pagamento de salários e repassada às instituições empresariais correspondentes: SESI, SENAI, SENAC, SESC, SEBRAE, SEST, SENAT, SENAR, SESCOOP e Incra.
} 
efetivação de funcionários públicos com mais de cinco anos de serviços etc) que representavam um incremento nas despesas públicas e a fixação de tetos para gastos com despesas de pessoal (que englobava ativos e inativos).

De certo modo, a responsabilidade pela definição formal dos programas e novos direitos ficaria para depois, dependente da regulamentação e da legislação ordinária. Isso também já era conhecido, até porque havia muitos problemas a serem resolvidos fora do contexto da ANC. O problema central da ANC era acomodar forças sociais conservadoras e reformadoras para que pudesse estabilizar e construir condições para a realização da transição democrática.

Um terceiro ponto, não menos importante, que já era esperado era a perda do poder decisório do Executivo Federal, submetido ao controle público parlamentar, do TCU, do MPE e dos Conselhos Sociais. Matérias referentes à tributação e à definição do orçamento anual passariam a ser objeto de decisões do Congresso Nacional, como requeria uma ordem democrática e a busca do equilíbrio entre os Poderes. Esse é um ponto central nas disputas pós-1988.

A área da seguridade social representou um incremento considerável nas responsabilidades governamentais e já era esperado que provocasse aumento na magnitude das despesas públicas, especialmente na previdência social. O diagnóstico de Rezende e Afonso era de que "a ampliação de benefícios previdenciários coloca em sério risco a disponibilidade de recursos para as demais atividades compreendidas no sistema de seguro social" (1987: 41), o que representaria o acirramento do conflito distributivo entre as áreas da seguridade social. A tentativa de impor a vinculação de 30\% do OSS para a área da saúde refletia o temor de ser espremida contra o crescimento das despesas com aposentadorias e pensões.

A ANC procurou dar respostas a velhos problemas do Estado brasileiro, algumas das quais contraditórias, inconsistentes e difíceis de serem realizadas ao longo prazo (Aureliano \& Draibe, 1989). Ela redefiniu o escopo das políticas sociais, o desenho do sistema tributário, princípios e tendências, porém, deixou um campo aberto para ser discutido posteriormente, permitindo que o clima fosse revivido durante as fases de regulamentação e de revisão constitucional. 
Sem dúvida, no ambiente de discussão da ANC foi aberta uma nova via de discussão que era o fato de que "nenhuma despesa deverá ser criada sem uma receita correspondente $^{\text {"76 }}$. Esse princípio remete a uma associação que não pode ser rompida e torna a realização das políticas sociais dependente de um esquema de financiamento. Uma discussão séria sobre a política e o direito social deve se pautar por critérios de alocação de recursos públicos, o que encontra consistência no tema da "responsabilização" (Scott, 2006: 87; Rose-Ackerman, 2004).

Como podemos observar, havia naquele momento uma associação entre os temas da crise financeira do Estado e da crise da política social de um modo mais amplo, ou da previdência social, de modo mais restrito. A política social situa-se no centro de uma de uma disputa distributiva em torno da apropriação de recursos escassos, cujo limite é dado pela ação política e pelos constrangimentos econômicos. Eis porque o debate da reforma previdenciária é indissociável do debate sobre a reforma tributária, porque os conflitos distributivos e redistributivos são sempre antecedidos pela questão da arrecadação, ou, pela partilha de seus custos pela sociedade. Nos termos de Ewald (1993), é a questão mesma de definir os limites da partilha. A Constituição Federal, ao ampliar esse limite, levou ao acirramento do conflito distributivo. Como afirma Dain (1989b: 22), as discussões sobre a crise fiscal, déficit orçamentário, capacidade de financiamento público e políticas sociais conduzem a decisões distributivas e redistributivas subjacentes ao desenho de uma estratégia de política social, sempre passível de ser renovada.

\section{Política social no Governo Sarney: o resgate da “dívida social” na Nova República}

Sob o discurso do resgate da “dívida social” o governo Sarney deu início às reformas que implicavam o redesenho das políticas de previdência social, assistência social e saúde e que acabaria por influir na definição de seguridade social assumida pela Constituição Federal de $1988^{77}$. O resgate da dívida social significou uma "metamorfose na

\footnotetext{
${ }^{76}$ Art. 195, Item III, § 5 , Constituição da República Federativa do Brasil, 1988.

${ }^{77}$ Para uma abordagem da política social no governo Sarney ver: (Silva, 1992).
} 
agenda pública” (Diniz, 1997b: 113) assentada na crítica ao modelo de desenvolvimento e no comprometimento com a temática da justiça social.

Há autores que afirmam ter ocorrido uma ruptura na concepção de política social a partir de 1985, com o compromisso assumido de constituir um padrão mais eqüitativo de proteção social e na elaboração de outra estratégia de intervenção, com a priorização do social (Soares, 2001; Vianna, 2000; Silva, 1992). Havia um certo otimismo em relação à retórica reformista que visava a ampliação de gastos sociais, a racionalização de programas, a integração das políticas sociais, a democratização na execução e controle de programas sociais, a universalização dos mecanismos de seguridade social e maior comprometimento das fontes fiscais no financiamento das políticas sociais.

A retórica do governo estava afinada com o projeto de redemocratização, de mudanças institucionais e de construção de parâmetros de eqüidade e justiça social. Para Fagnani (1997), haviam sido alteraradas as relações entre política econômica e política social, que, para Aureliano e Draibe (1989) resultado mais da retomada do crescimento econômico do que propriamente da mudança de orientação governamental.

A aceitação política dos diagnósticos produzidos - social, técnico e acadêmico levou o governo a formar três grandes comissões técnicas (saúde, assistência social e previdência social) com o objetivo de "proceder a um diagnóstico, em profundidade, do estado atual da Previdência Social brasileira, com vistas a informar as decisões políticas para a sua reestruturação e atualização" (MPAS, 1986) ${ }^{78}$.

Na Exposição de Motivos 28, de 13/05/1986, o Ministro Raphael de Almeida Magalhães (MPAS) apresentava o resgate da dívida social como um "compromisso moral” da Nova República afinado com a preocupação em garantir padrões mínimos de justiça social. O ministro reconhecia que a previdência social estava longe de garantir o alcance de tais objetivos, visto que o plano de benefícios reproduzia a mesma iniqüidade e

\footnotetext{
${ }^{78} \mathrm{O}$ documento é parte integrante do relatório final do Grupo de Trabalho para reestruturação da Previdência Social criado pelo Presidente Sarney através do Decreto 92.654, de 15/05/1986 e que teve duração de cinco meses. O grupo de trabalho deveria funcionar como “um núcleo de reflexão e formulação” para que não fosse preciso "improvisar um novo curso de ação, de maneira apressada e irresponsável...” (e ) “...encontrar maneiras de aumentar os recursos da Previdência". O Presidente José Sarney afirmava que "o resgate da dívida social passa pela reestruturação da Previdência". SARNEY, José. "Discurso do Presidente na cerimônia de assinatura da Mensagem ao Congresso Nacional abolindo o desconto previdenciário dos aposentados e do Decreto criando a Comissão destinada a estudar a reforma da Previdência Social”. In: MPAS, 1986:33-34.
} 
regressividade da renda nacional ${ }^{79}$. No documento, o ministro expressava sua preocupação com o fato do desemprego afetar o fluxo das receitas diretas, o que revelava a contradição entre a base econômica e a função social da previdência no Brasil. O tempo de escassez aumentava a demanda por benefícios sociais quando havia retração nas receitas. Para superar as insuficiências e iniqüidades do sistema era imprescindível rever o plano de benefícios e as bases de financiamento, que sintetizam as duas metas do Grupo de Trabalho de Reestruturação Previdenciária (GTRP). Esse diagnóstico é similar ao produzido após a promulgação da Constituição Federal de 1988 e que serviu de justificativa para as reformas das décadas de 1990 e 2000.

O GTRP deveria abordar os seguintes temas: bases de financiamento (estrutural atual da receita e plano de custeio da previdência social urbana e rural); revisão do plano de benefícios (urbanos, rurais, segurança e medicina do trabalho); sistema de informação e fiscalização de benefícios (cadastramento de usuários, controle e acesso do beneficiário às informações e mecanismos de fiscalização externos) ${ }^{80}$.

A presidência do GTRP foi entregue a Wanderley Guilherme dos Santos e a secretaria executiva a Sulamis Dain (MPAS) e contava ainda com a participação de representantes de vários segmentos sociais: Hélio Jaguaribe, Florisa Verucci, Luciano Martins e José Gomes de Pinho Neves (especialistas em questões sociais e previdenciárias); Anníbal Fernandes, Rodolpho Rebollo Júnior, José Francisco da Silva, Marlise Maria Fernandes (representantes dos empregados urbanos e rurais); Luis Eulálio de Bueno Vidigal Filho, Abram Abe Szajamn e José Maria Teixeira da Cunha (representantes dos empregadores); Obed Dorneles Vargas, Luiz Viegas da Motta Lima (representantes de aposentados e pensionistas); Dorothea Fonseca Furquim Werneck (Ministério do Trabalho); Eleutério Rodrigues Neto (Gabinete Civil da Presidência da República); Maria Emília R. M. de Azevedo (Secretaria de Planejamento da Presidência da República); João Manoel Cardoso de Mello (Ministério da Fazenda).

Colaboraram ainda com o Grupo de Trabalho: Celso Barroso Leite (representante de José Maria Sobrinho), Cristina de Albuquerque Possas (Fiocruz), Fernando Rezende

\footnotetext{
79 Discutia-se a aposentadoria por tempo de serviço, a aposentadoria especial e a falta de cobertura ao desemprego; apontava-se que a Previdência Social não se apoiava em bases atuariais e, ao ser financiada com base nas contribuições sobre a folha de pagamento de salários, era dependente dos ciclos econômicos. Exposição de Motivos 28, de 13/05/1986.

${ }^{80}$ Ver Decreto 92.654, de 15/05/1986.
} 
(IPEA), Hélio Portocarrera (MPAS), José Almino (MPAS), José Gomes Temporão (INAMPS), Pedro Luís Barros Silva (INAMPS), Antônio José de Arruda Rebouças (DIESAT), Elisa Maria Pereira dos Reis (IUPERJ), Francisco Eduardo Barreto de Oliveira (IPEA), Maria Helena Castro Santos (FINEP), Paulo Machado (MPAS), Sérgio Cutolo dos Santos (representando de Dorothea Werneck), dentre outros ${ }^{81}$. Um aspecto bastante enfatizado, porém, foi a baixa participação dos empregadores nos trabalhos da Comissão ${ }^{82}$. A principal conclusão do relatório apontava que o país necessitava superar a fase em que o sistema de seguridade se apoiava estritamente sobre uma concepção contratualista para iniciar a implantação de um amplo sistema de bem-estar social. Reconhecia-se que o sistema previdenciário já vinha se transformando, “lenta e aleatoriamente” num sistema cujas responsabilidades ultrapassavam uma concepção previdenciária, sem uma correspondente redefinição das fontes de financiamento. As premissas de um sistema de bem-estar social deveriam ser fixadas sobre dois enunciados: 1) todo cidadão é titular de um conjunto mínimo de direitos sociais independentemente de sua capacidade contributiva; 2. é da responsabilidade da sociedade prover os recursos para assegurar o cumprimento do primeiro enunciado. As duas premissas foram incorporadas pelo texto constitucional de 1988. A questão básica que o GTRP buscava responder era como promover a compatibilização entre a justiça social, os constrangimentos financeiros da previdência social e o estágio econômico do país. No relatório está expresso que os resultados não tiveram como objetivo construir um pacto social, mas pensar um estilo de formulação de política pública negociada e com representação plural (MPAS, 1986: 5).

O diagnóstico realizado pela Comissão apontava que o tipo de contrato entre previdência social e a população brasileira era de cobertura dos riscos sociais mais graves e urgentes, na atividade e inatividade, e tinha como contrapartida contribuições sociais diretas dos trabalhadores e indiretas, da sociedade. A estrutura de benefícios correspondia

\footnotetext{
${ }^{81}$ Seria exaustivo reproduzir a lista integral de todos os participantes. Os nomes relacionados visam a demonstrar o peso e a importância do trabalho do GTRP, através dos convidados e das instituições envolvidas. Muitos dos convidados, especialistas em previdência social ou política social, integram a bibliografia sobre o tema e alguns tiveram relevância pública ao se tornarem ministros ou ocuparam outras posições estratégicas no governo. A lista completa de todos os participantes encontra-se em: (MPAS, 1986: 35 - Tomo I).

${ }^{82} \mathrm{O}$ que também se refletiu posteriormente durante os trabalhos da ANC, que contou com baixa participação dos empresários em matérias relativas aos direitos sociais e direito do trabalho, enquanto apresentaram participação significativa nas questões econômicas, tais como a reordenação das relações entre o público e o privado, livre empresa, ordem econômica, propriedade privada etc (DINIZ \& BosCHI, 1987; DinIZ, 1986).
} 
às condições gerais dos contratos e processos de trabalho, da distribuição de renda e de salários, reproduzindo-as na inatividade. Em face das enormes carências sociais e da ausência de capacidade contributiva por parte expressiva da população, o aporte financeiro decorrente de contribuições sociais era baixo, e, no rateio, produzia benefícios em valor insuficiente para cobrir gastos indispensáveis à sobrevivência. Além disso, convergiam para a Previdência Social as pressões populares por atendimento nas áreas de assistência médica e social, que rompiam, na prática, as barreiras entre os direitos dos contribuintes e os da população em geral.

O GTRP captou a polaridade entre direito à cidadania e direito do contribuinte que se expressava na instituição previdenciária. A solução pensada foi reordenar o padrão de financiamento e reformular a Previdência Social, corrigindo sua estrutura e o plano de benefícios segundo uma concepção de "seguridade social”, cujo pressuposto era exprimir a cidadania universal e estar amparada nas contribuições diretas ou indiretas de toda a sociedade. Denunciava o uso do rebaixamento do valor do benefício como forma de conter o déficit da Previdência gerado pela recessão, pelo desemprego e por uma política social adversa, além dos desvios de recursos e do patrimônio dos contribuintes (MPAS, 1986: 8).

Em relação ao plano de benefícios foi observado: falta de unificação nos planos de trabalhadores urbanos e rurais; valores insuficientes de cobertura dos riscos sociais básicos (velhice, doença, invalidez, morte e desempenho); falta de isonomia no tratamento de diversas categorias de segurados e seus dependentes.

As propostas para correção podem ser divididas em cinco grupos: 1. universalização da assistência médica e da assistência social; 2. unificação da previdência em um plano básico contributivo para trabalhadores urbanos, rurais, domésticos, contribuintes individuais e donas de casa; 3. revisão dos critérios de concessão, forma de cálculo, pisos e tetos para todos os benefícios e estabelecimento de relação direta entre valor do benefício e salário de contribuição; 4. introdução do princípio da seletividade em função da renda na concessão de benefícios como salário-família, auxílio-natalidade e auxílio-funeral; 5. manutenção do PRORURAL para os trabalhadores rurais sem condições de ingresso no plano contributivo e concessão de amparo pecuniário nos riscos de velhice e invalidez, independente de contribuição individual, a todos os cidadãos sem capacidade contributiva (custeados com recursos da União). 
Evidenciou-se uma dificuldade na formulação de um amparo previdenciário destinado a idosos e inválidos no valor de meio salário mínimo. Durante o debate, a medida foi apontada como sendo de origem assistencial, a ser financiada por recursos fiscais, não caracterizando-se como uma ação típica do seguro social. Para eliminar as diferenças entre contribuições e benefícios sugeriu-se que todos os cálculos da previdência fossem expressos em salário mínimo, com uso do princípio de correção integral das contribuições para cálculo de benefício, a partir do índice de custo de vida (MPAS, 1986: 10). Recomendouse a eliminação da carência na cobertura de riscos como morte, doença e invalidez, coadunada com o princípio de que estes têm prioridades sobre benefícios programáveis e, como contrapartida, ampliação da carência para benefícios programáveis como aposentadoria por tempo de serviço e velhice. Recomendou-se, ainda, a elevação dos valores mínimos de aposentadorias, pensões e auxílio doença para 100\% do salário mínimo.

Aspectos polêmicos no GTRP foram a aposentadoria por tempo de serviço, a aposentadoria especial (aeronautas, jornalista e professor), aposentadorias especiais de trabalhadores em situações perigosas ou insalubres. Embora os representantes do MPAS e da SEPLAN tenham se mantidos firmes na posição contrária à aposentadoria por tempo de serviço, prevaleceu a resistência dos representantes sindicais e dos aposentados. Chegou-se a levantar a hipótese de fixar a idade mínima para aposentadoria aos 55 anos de idade, numa tentativa de associar aposentadoria à incapacidade para o trabalho.

Para resolver o problema do financiamento da previdência social foi pensada uma proposta de ampliação de recursos de modo a se promover uma política de proteção social mais justa, que levasse em consideração: a necessidade de recompor o valor dos benefícios; a instituição de novas regras de cálculo para aproximar valor do benefício e contribuição; a elevação do valor mínimo dos benefícios de prestação continuada; a mudança na composição etária da população; a não participação da União no financiamento da previdência social. A proposta mais viável seria a diversificação da base de financiamento, com a manutenção da folha de pagamento de salários como a principal fonte de arrecadação e alteração nas alíquotas para conferir maior progressividade ao sistema; criação de novas contribuições sociais (lucro e faturamento das empresas) e restauração da contribuição da União (através do custeio das despesas de pessoal e de administração geral do sistema, bem como a cobertura de eventuais insuficiências financeira). Como a Previdência Social vinha 
desenvolvendo ações de equalização social, essa ação extensiva deveria ser custeada com recursos da União, bem como aquelas de caráter administrativo.

O GTRP identificava duas saídas para a questão do déficit previdenciário: ou a Previdência se atinha às limitações orçamentárias restringindo suas ações no campo dos serviços médicos e da assistência social, ou prosseguia na realização das atividades de assistência médica e social, sabendo que as insuficiências financeiras seriam cobertas por recursos da União. Qualquer decisão adotada, com certeza, traria conseqüências políticas e éticas.

No Grupo de Trabalho sobre a atenção à saúde, os resultados também apontaram para um quadro distorcido com concentração urbana e regional na alocação dos recursos previdenciários, sucateamento da rede própria do INAMPS e expansão da rede contratada. As despesas de saúde por habitante haviam decrescido 30\% entre 1980 e 1983 (MPAS, 1986: 18). As propostas apresentadas adotaram como pressuposto básico que a saúde era conquista e direito do trabalhador e dever do Estado, para o quê o acesso deveria ser universal e sem qualquer diferença entre as áreas urbana e rural, descentralizado no atendimento e na provisão de medicamentos essenciais, exames complementares e serviços de pronto-socorro. As orientações eram de aprofundamento da construção das AIS (1984) e maior integração da assistência médica previdenciária, envolvendo o controle de todas as modalidades assistenciais e coordenação junto aos serviços públicos de saúde. Descentralização e eliminação da capacidade ociosa do setor público também eram metas de racionalização administrativa a serem cumpridas, assim como a revisão no financiamento das ações. Em decorrência da implantação da AIS houve um aumento na ordem de 153\% nos recursos da saúde. No entanto, para o fortalecimento das ações de caráter universal, continuava sendo necessário o aporte de recursos do Tesouro Nacional, bem como dos orçamentos dos Estados e Municípios.

A realização da VIII Conferência Nacional de Saúde, considerada um marco na história da política de saúde brasileira, apontou como questão estratégica a construção de um sistema único de saúde, universal, descentralizado, participativo, apoiado em novas bases financeiras e conduzido por apenas um ministério setorial. Essa estratégia, na verdade, redesenhava toda a política de saúde, retirando-a da sua função subsidiária à política previdenciária. Embora não houvesse apoio absoluto à tese da universalidade do 
direito à saúde e dever do Estado quanto à sua promoção, proteção e recuperação, ficou patente a insuficiência de recursos oriundos das contribuições sociais para financiar de modo adequado a assistência médica ao conjunto da população brasileira, com suas múltiplas particularidades (MPAS, 1986: 21). Os três princípios organizativos - integração, descentralização e participação - foram aceitos integralmente e transformados em recomendação do Grupo de Trabalho a serem discutidas na Comissão Interministerial da Reforma Sanitária (MPAS, 1986: 22).

Na assistência social, o Grupo de Trabalho apontou, também, para a necessidade de total reversão do modelo adotado, superando a precária situação institucional, financeira e o tratamento residual recebido no orçamento fiscal. Foram apontados como aspectos negativos a fragmentação de recursos por diversos órgãos; a multiplicação de serviços que competiam entre si por recursos; a centralização e a falta de uma base única de financiamento. As propostas definidas tinham por objetivo superar as desigualdades sociais e tornar a assistência social instrumento de sua conquista. Para tanto, deveria ser promovida a integração das funções assistenciais do MPAS e a priorização do atendimento ao núcleo familiar, às crianças carentes, idosos e deficientes físicos. Para a sua realização, o Grupo propunham a criação de um fundo permanente de financiamento dos programas assistenciais, com objetivo de assegurar-lhe recursos estáveis.

A necessidade de promover a distinção entre seguro social e assistência social surgiu no decorrer dos trabalhos do GT em decorrência do financiamento de caráter não contributivo que requeria. O problema não era de inadequação da sua inserção no SINPAS, ou da amplitude que conferia ao sistema de proteção social, mas, essencialmente de falta de recursos para o seu financiamento (MPAS, 1986: 23-24).

Ao final, previdência social (ou seguro social) foi definida como "programa de proteção social (ou seguridade social) de cujo custeio o trabalhador participa mediante contribuições individuais, em correspondência a riscos sociais definidos, ou é custeado por outras fontes”. E, assistência social (ou serviços sociais) foi definida como "programa de proteção social (ou seguridade social) de várias modalidades, não correspondentes a um risco definido, no conceito do seguro social, e de prestação descontínua” (MPAS, 1986: 24).

Os conceitos cunhados nos Grupos de Trabalho promoveram uma confusão entre os conceitos de seguridade social e proteção social, tornadas idênticas; assistência social 
tornou-se termo equivalente à prestação de serviços sociais de caráter descontínuo e a previdência social foi identificada com o seguro social de natureza contributiva.

O diagnóstico realizado pelo GTRP e as recomendações influíram no debate da ANC e no redesenho do sistema de proteção social, que passou a ser concebido a partir da idéia de seguridade social, com integração entre as áreas da saúde, previdência e assistência social concebidas como técnicas diferentes de proteção social. Do mesmo modo, percebe-se a sua influência na reorganização da base de financiamento e inclusão de novas fontes de receitas e a fixação dos princípios de universalidade, uniformidade, seletividade, distributividade, eqüidade, diversidade da base de financiamento, participação social, irredutibilidade do valor dos benefícios e descentralização.

A agenda inicial do governo Sarney buscou conciliar sob a Aliança Democrática Nacional o enfrentamento da crise econômica, a instauração da ordem democrática e o compromisso com a justiça social. Em 1987 o fim da Aliança expressava a impossibilidade de conciliar interesses e objetivos contraditórios (Diniz, 1997b: 114-115). Questões como a dívida externa, o déficit público, o controle dos gastos e as taxas de juros geravam divergências na equipe econômica. Dentro do próprio governo expressava-se a disputa entre Fazenda e Planejamento ${ }^{83}$, entre honrar os compromissos financeiros e a incapacidade em continuar a consumir entre 4 e $5 \%$ do PIB com os pagamentos.

No plano das realizações, o governo pouco produziu. Fatores técnicos e políticos contribuíram para a não realização da reforma da previdência social, cuja mudança requeria alterações profundas na dinâmica estatal e nas suas relações com a sociedade (Silva, 1992).

Na saúde, teve início um movimento que buscou alterar as regras do jogo e a distribuição de recursos e alianças de modo significativo, com a descentralização das decisões e ações da esfera federal para as esferas estadual e municipal (Aureliano \& Draibe, 1989). A descentralização envolveu uma verdadeira disputa em torno da distribuição de recursos orçamentários, políticos (distribuição de postos e comandos, nomeações) e administrativos (convênios e contratos).

O movimento sanitário veio impulsionar um novo arranjo institucional ao pleitear a descentralização das ações, investimento em saúde pública, criação de um "sistema único da saúde” que integrasse o conjunto dos cidadãos, maior controle social e participação

\footnotetext{
${ }^{83}$ Representadas pelas disputas entre Francisco Dornelles e João Sayad em torno da política fiscal.
} 
social na gestão. Enfim, não apenas introduziu um discurso democrático, como propunha redesenhar o formato institucional. Por outro lado, a crise financeira da previdência social dos anos 80 conduziu a uma política de racionalização/racionamento da assistência médica gerida pelo INAMPS, com redução da compra de serviços e maior aproveitamento da rede pública instalada. As ações de saúde passaram a ser integradas e resultaram na sistematização de repasse de recursos previdenciários para a área estadual e municipal, que remodelou todo o sistema.

A Previdência também manifestava o desejo de alterar as regras do jogo e de repassar a administração de hospitais e da assistência médica para o Ministério da Saúde. Em 1987 teve início uma série de medidas práticas que deu início à descentralização para Estados e Municípios, segundo o nível de complexidade da atenção à saúde. Uma ampla reforma administrativa do INAMPS procurou fundir superintendências regionais com as secretarias de saúde estaduais, através da cessão de imóveis, equipamentos, pessoal, eliminando o duplo comando na área da saúde (previdência e saúde). A descentralização administrativa e de recursos faria uma redistribuição geográfica dos problemas e foi uma idéia que repercutiu por todo o texto dos direitos sociais.

\section{A Constituição Federal de 1988 e o problema da seguridade social}

A Constituição Federal de 1988 realizou um movimento de reorganização das políticas sociais de previdência social, assistência social e saúde sob novas bases e princípios. A sua realização pode ser sintetizada como um movimento de institucionalização de um novo conceito, ampliação da base de financiamento e criação de novos direitos.

Sem dúvida, o novo texto legal foi o produto possível dos debates dentro e fora da ANC e que envolveu não apenas partidos políticos, mas movimentos sociais, pesquisadores e técnicos da burocracia. ${ }^{84}$. O debate público contribuiu para modificar não apenas 0 direito, mas para tornar a Constituinte um espaço democrático (Paoli, 1993).

\footnotetext{
${ }^{84}$ A introdução de um conceito "vigoroso e peculiar à proteção social como o da seguridade social a um texto constitucional respondeu, à época, às expectativas da sociedade organizada de ampliação do estoque
} 
De certa forma, a Constituição resolvia a “crise política” da previdência social, cuja figura central era o déficit de cidadania, o caráter meritocrático e a desigualdade nos critérios de acesso ao direito social e a vinculação da condição de cidadania social ao trabalho formal. Redesenhava não apenas o conteúdo dos direitos sociais, mas a forma de integração social, promovendo a igualdade na condição de trabalhador a despeito das desigualdades que marcavam o mercado de trabalho, dividido entre formais e informais, rurais e urbanos, públicos e privados. A nova Constituição promovia à condição de cidadania toda a população brasileira, independente da condição de trabalhador.

Marshall (1967) é, sem dúvida, uma referência obrigatória para a compreensão do modo como foram realizadas as análises sobre a previdência social no Brasil. É possível identificar na leitura de Política Social (1967) uma ampla referência ao debate europeu e americano sobre a condução da problemática do direito social e, o quanto oscilava entre dois pólos extremos - assistência social e seguro social.

Flora \& Heidenheimer (1987) destacam que há três mecanismos básicos através dos quais um sistema de bem-estar social persegue seus objetivos: transferência direta de renda, provisão de serviços sociais e redução de impostos e política de créditos (indiretos). Dentre os primeiros, destacam-se situações de incapacidade para o trabalho (doença e invalidez), fases improdutivas (maternidade, velhice, infância) e desemprego, financiados seja com base em contribuição social, seja com mecanismos de transferência de renda para os mais necessitados. No segundo grupo, trata-se de provisão pública de serviços em espécie, em conexão com a intervenção estatal no mercado privado (educação, medicina e serviço social). No terceiro grupo, quase nunca reconhecido como parte da política social, encontram-se as deduções dos impostos de renda, como por exemplo, com gastos em educação e saúde ou os créditos educativos. Para os autores, uma caracterização de um sistema de proteção social depende da combinação desses elementos e está sempre envolvida em dois tipos de disputas: definição do mínimo social (em transferências diretas) e definição do nível de serviços sociais. Asa Brigs (1961) ${ }^{85}$ define o Estado de Bem-Estar

de direitos sociais associados à cidadania, traduzindo a sensibilidade do legislador diante da situação preexistente” (VIANNA, 2005: 90).

85 “A 'Welfare State' is a state in which organised power is deliberately used (through politics and administration) in an effort to modify the play of market forces in at least three directions - first, by guaranteeing individuals and families a minimum income irrespective of the market value of their property; second by narrowing the extend of insecurity by enabling individuals and families to meet certain 'social 
Social pelo esforço que faz para modificar o papel do Estado em três direções: garantia de renda mínima; promoção da segurança econômica diante de certas contingências sociais e garantia do mesmo status a todos os cidadãos.

As discussões que marcaram a produção acadêmica brasileira nas décadas de 1970 e 1980 estavam fortemente influenciadas pelo padrão de proteção social implementado nos países europeus, sobretudo na França e na Inglaterra. O Plano Beveridge (s/d) foi o modelo perseguido, com seu padrão universalista de proteção social, que pretendia ultrapassar, ao mesmo tempo, o modelo assistencial inglês (aos pobres) e o modelo de seguro social alemão (aos trabalhadores). Houve quem comemorasse, porque, enfim, com quarenta anos de atraso, havíamos conquistado a nossa "seguridade social”86 (Vianna, 1998). Mas, há uma série de ponderações a serem realizadas, que situam essa comemoração no plano mais do desejo do que da realidade.

O que Beveridge propôs foi criar um sistema que propiciasse "segurança social” ao cidadão inglês, baseada em políticas de emprego e renda, para o quê duas condições seriam necessárias: o pleno emprego e a redução do número de dependentes de políticas de assistência social. Desse modo, a sua contribuição fundamental está em integrar à rede de solidariedade pública um amplo contingente de trabalhadores, na condição de contribuinte (Beveridge, s/d).

Ao realizar um balanço e um resumo compreensivo do campo dos Seguros Sociais e Serviços Idênticos ingleses, Beveridge concluiu que haviam dois campos definidos de benefícios: seguros sociais públicos (contra doença, desemprego, velhice, viuvez) servidos por um sistema obrigatório de socorros mútuos organizado pelo Estado e subsidiado pelos operários e patrões; e os serviços sociais ou assistência pública, que concediam pensões gratuitas de velhice após os 70 anos de idade; pensões suplementares aos necessitados não

contingencies' ... which lead otherwise to individual and family crises; and third by ensuring that all citizens without distinction of status or class are offered the best standards available in relation to a certain agreed range of social services" (BRIGGS, 1961 apud FLORA; HEIDENHEIMER, 1987b: 29).

${ }^{86}$ Amélia Cohn apresenta com riqueza de detalhes a tentativa de construir o Instituto de Serviços Sociais do Brasil (ISSB) no formato do modelo beveridgiano e que teve uma curta existência. O projeto aprovado em 1945 (Decreto-Lei 7.526, de 7/5/1945) não foi regulamentado e ruiu junto com o Governo Vargas. Malloy destaca como o projeto do ISSB pretendia lhe conferir uma legitimidade internacional, ao perseguir os ideais da universalização no atendimento; padronização na cobertura e unificação administrativa. Pretendia-se organizar as três funções da Previdência Social (aposentadorias e pensões, serviços médicos e serviços sociais), em respeito aos princípios de eqüidade (a cada um segundo seus meios) e igualdade (a cada um segundo sua necessidade) (COHN, 1980; MALLOY, 1986). 
cobertos por outras pensões; subsídios aos desempregados e auxílio aos indigentes. Os benefícios do segundo grupo eram financiados pelo Estado mediante teste de meios. Outros serviços sociais de saúde e educação, socorro a cegos e doentes mentais estavam a cargo do Ministério da Saúde Pública e do Conselho de Educação. A proposta de Beveridge era de revisão, unificação, estatização e ampliação dos seguros sociais para cobrir pessoas e eventos excluídos e promover aumento de taxas e pensões pagas.

O Comitê presidido por Beveridge formulou três princípios para as suas recomendações: descentralização das ações; estabelecimento de um rendimento mínimo de segurança (como um ataque à miséria) e cooperação entre Estado e indivíduo. A idéia de um mínimo nacional estava ligada à manutenção de um padrão de vida mínimo, incluindo, portanto, despesas como alimentação, gás, combustível, luz, transporte. O seu projeto de segurança social envolvia um rendimento de segurança (Beveridge, s/d: 244), uma alternativa contra a miséria quando da perda de rendimentos provenientes do trabalho. O relatório previa que os seguros sociais deveriam ser dependentes de cálculos atuariais e que o sistema deveria realizar reservas matemáticas para cobrir riscos futuros.

O Plano Beveridge realizou uma consolidação de várias medidas assistenciais já existentes, através da padronização de benefícios e inclusão de novos benefícios. Propôs seis novos benefícios, incluindo o seguro de acidentes de trabalho, salário-família, segurodesemprego, aposentadoria, auxílio-funeral, auxílio-maternidade, abono nupcial, benefícios para esposas abandonadas, assistência às donas de casa enfermas e auxílio-treinamento para os que trabalhavam por conta própria (Marshall, 1967: 98-99; Beveridge, s/d: 7-9; Guedes, s/d). Dos seis benefícios pretendidos, foram acatados apenas o auxílio-maternidade e o auxíliofuneral.

A família estava na condição central de beneficiária, o que justificava a instituição do salário-família para todo casal a partir do segundo filho, financiado por imposto. Era uma medida de conversão do salário individual em salário familiar, ajustando-o ao número de pessoas que dele dependia para a subsistência. De responsabilidade do empregador, era baseado na contribuição para um fundo comum de compensação e um de seus objetivos era reverter a tendência à queda na taxa de natalidade.

O Plano Beveridge formava um seguro contributivo, compulsório e universal, três princípios interdependentes e a cobertura universal foi considerada a sua inovação mais 
arrojada. No entanto, a ênfase no modelo contributivo focava a idéia de que cada cidadão contribuiria de acordo com seus meios (realizaria a eqüidade) e receberia de acordo com suas necessidades (realizaria a igualdade), o que fundava um modelo de solidariedade social novo, diferente tanto da lógica da assistência social (não contributiva), quanto da lógica do seguro social (vinculação entre contribuição e benefícios), ao promover uma fusão entre os dois modelos. Um dos pontos fundamentais era justamente a dissociação entre vínculo contributivo e benefícios, ou seja, o benefício não precisaria fundamentar-se em cálculos atuariais. No entanto, só poderia ser realizado com a integração de um amplo contingente populacional na condição de contribuinte.

O conceito de "segurança social” era o ponto de encontro entre o seguro social que perdia a sua base atuarial e a assistência social que se libertava do estigma da culpa pela pobreza. A proteção social a que o indivíduo teria direito estava relacionada ao reconhecimento de reivindicações feitas com base no trabalho de uma vida inteira. Formulava, assim, uma nova lógica em que a solidariedade social é que era a fiadora de um modelo de proteção social (Marshall, 1967b: 197).

Flora e Heidenheimer (1987) promovem uma inversão na compreensão da discussão sobre a "seguridade social" ao afirmar que o quê o Estado de Bem-Estar Social procurava responder não era exatamente à demanda por igualdade sócio-econômica, mas a de segurança sócio-econômica. O esforço que realizava era por integrar a classe trabalhadora na instituição e distribuição da propriedade privada. Reconhecer e institucionalizar as relações de trabalho e o conflito social era uma forma de estabilizar o mercado e, portanto, não era exatamente ao problema de Durkheim da anomia que respondia, mas à insegurança econômica. Igualdade e segurança são as duas dimensões do Estado de Bem-Estar Social dirigidas a objetivos opostos e contraditórios: promover a igualdade (através da garantia da renda mínima e dos esforços redistributivos) e legitimar a desigualdade (através da manutenção da igualdade de oportunidade e da diferenciação social com base na renda e no status). O fato de denominar segurança social e não segurança econômica traz, para os autores, uma dificuldade adicional à sua compreensão. 
Esse novo modelo de "segurança social” proposto por Beveridge não sujeitava qualquer beneficiário à prova de teste de meios ${ }^{87}$ e os benefícios deveriam ser concedidos "como de direito", mas reconhecendo que quem concede os “direitos" é a própria sociedade. É a sociedade que se organiza para assumir coletivamente os riscos sociais através de sua ampla participação no seu financiamento. Como lembra Marshall, “o elemento comum presente em todas as medidas era a idéia de que a Política Social consistia em serviços prestados pela sociedade como um todo à sociedade como um todo" (1967b: 113). E deveria embasar-se num modelo tripartite de contribuição: empregadores, empregados e contribuintes (impostos). Na contribuição também estava implícita a idéia da participação da sociedade como um todo.

O Plano trazia a idéia de um equilíbrio na política entre seguro social para necessidades básicas; assistência para casos especiais e seguro voluntário para adições à previdência básica (Beveridge, s/d: 302). O terceiro ponto foi abandonado na sua implantação. A ruptura com o modelo assistencial da Lei dos Pobres trazia duas inovações: transferência do financiamento das taxas para os impostos (de caráter nacional) e a separação entre benefícios pecuniários e serviços sociais (abrigos aos desamparados, por exemplo).

O Plano Beveridge convertia políticas assistenciais em políticas de previdência social (Marshall: 84). A política de "segurança social” tornava a assistência social residual, no escopo de uma política social mais abrangente fundada no pleno emprego. Uma "segurança contra a necessidade”, contra a miséria, era o seu objetivo. A idéia de "mínimo nacional” de Beveridge era consistente com o princípio liberal de que o benefício não deveria assegurar mais do que o necessário para a subsistência, o que poderia interferir nas responsabilidades individuais. De caráter contributivo, considerava que havia um "ponto de tolerância” para que os pobres pudessem suportar as contribuições.

França, Alemanha, Estados Unidos experimentaram a criação de outra categoria de assistência social pública, funcionando como um serviço de finalidades múltiplas destinadas a atender categorias muito pobres. Nos Estados Unidos, desenvolveu-se a prática da "assistência preferencial” às classes de pessoas selecionadas, como mães de crianças

\footnotetext{
${ }^{87}$ Dever de apresentar prova de necessidades para obtenção do benefício social. Mais do que medir a necessidade, o teste de meios busca revelar a má-fé do indivíduo que pleiteia o benefício e expressa sempre uma avaliação de caráter moral.
} 
pequenas, velhos, cegos e inválidos. Embora em expansão, a assistência pública manteve serviços de caráter não contributivo e sujeita a teste de meios.

Marshall afirma que as três vigas mestras da política do Estado de Bem-Estar Social inglês foram a Lei Nacional de Educação (1942), a Lei de Seguro Nacional (1948) e a Lei de Serviço Nacional de Saúde ${ }^{88}$ (1946) (Marshall, 1967a: 106-112), como a fundação de um sistema eclético, para a qual convergiram um conservador (Butler), um liberal (Beveridge) e um progressista (Bevan). Enquanto Beveridge pregava a idéia de um mínimo social, Bevan pregava um ótimo; enquanto Beveridge assentava seu plano na previdência e na iniciativa individuais, Bevan buscava o alívio de toda a responsabilidade individual, entregue ao Estado. A idéia de um mínimo de subsistência, contribuições e benefícios de valor fixo contrastavam com os planos universais e gratuitos de Bevan (Marshall, 1967a: 112). A proposta provocava um deslocamento entre as esferas de segurança social da família para o Estado, através da provisão do mínimo social.

Na França, um movimento de integração à sociedade salarial (Castel, 1998) também fez verificar-se com a (lenta) passagem de políticas meramente assistenciais para um modelo misto que integra políticas de saúde, previdência e assistência social (um conjunto de 07 prestações financeiras de apoio familiar), numa base contributiva e com benefícios proporcionais à contribuição (Dumont, 1995). Para Castel, é a integração à sociedade salarial que promove o nascimento do trabalho como pertencente à categoria do direito público, que é a base solidarista do acesso à coisa pública. É o pertencimento que transforma o seguro em propriedade social e um dos principais mecanismos de promoção da igualdade e da cidadania.

No Brasil, as discussões que vinham sendo produzidas desde a década de 1940, pleiteavam a unificação, a universalização e a unidade da Previdência Social, o núcleo central da política de "segurança social”, com forte influência do Plano Beveridge (Cohn, 1980). O modelo de previdência adotado por aqui estava mais próximo do modelo de seguro social de Bismarck: fragmentado em categorias profissionais, estratificado, meritocrático,

\footnotetext{
${ }^{88}$ A reformulação foi produto de dois relatórios publicados entre as guerras. O primeiro deles, era o Relatório Dawson, de caráter mais prático, que defendia a criação de Centros de Saúde que poderiam reunir clínico geral, especialistas e os modernos recursos para diagnóstico e tratamento, dirigidos pelas autoridades sanitárias locais. A Lei do Governo Trabalhista pretendeu reabilitar a clínica geral transformando-a na espinha dorsal do modelo assistencial. Aneurin Bevan reviu todo o plano e nacionalizou os hospitais privados criando um autêntico serviço médico gratuito e universal, desligado do aparato do seguro social (MARSHALL, 1967a: 109-110).
} 
de base contributiva, dependente do reconhecimento estatal. Era um modelo corporativista, como eram as relações de trabalho, que produziam estratificação social entre categorias profissionais e entre estas e aqueles que se encontravam excluídos de seu acesso.

A promulgação da LOPS em 1960 conferiu uniformidade aos seis planos de previdência existentes, com extensão para empregadores e autônomos. Em 1966, foi criado o INPS que passou a funcionar operacionalmente em 1967. A unificação somente foi possível com a passagem do regime de capitalização para o regime de repartição simples, numa lógica da "racionalidade possível” (Cohn, 1995: 56). No entanto, apenas em 1974 seria criado o MPAS, que promoveu a separação entre questões trabalhistas e previdenciárias. O MPAS deveria responder pela implantação de uma política previdenciária, assistencial e de saúde.

Entre 1968 e 1975, a previdência passou a incorporar contingentes de trabalhadores antes não contemplados, como rurais (1971) e domésticos (1972). O Seguro de Acidentes de Trabalho também foi incorporado à Previdência Social, tornando-se um seguro público, custeado pelos empregadores. Em 1977, foi criado o SINPAS (Sistema Nacional de Previdência Social) integrado por quatro instituições: INPS (benefícios previdenciários e assistenciais); IAPAS (administração); INAMPS (assistência médica) e LBA (assistência social).

O crescimento econômico e a criação de novos empregos favoreceram a adoção de medidas de racionalização no sistema previdenciário na década de 1960, com unificação, uniformização e incorporação de novos contribuintes, embora se mantivesse a exclusão dos trabalhadores rurais, dos mais pobres e marginalizados e o acesso via contribuição salarial.

Durante o regime militar, a exclusão dos canais de participação política foi compensada com ampliação dos gastos sociais e inclusão dos mais pobres ao sistema previdenciário (Cohn, 1995). Do mesmo modo, foram criados vários fundos sociais (FGTS, PIS/PASEP, BNH) que financiaram o setor privado na produção de serviços, vis a vis o aumento da renúncia fiscal.

A inclusão de novos benefícios sem a devida carência e sem contrapartida contributiva já apontava para um sistema de proteção social com traços de seguridade social, mas, no entanto, introduzia um problema estrutural, com a ambivalência entre 
direitos contributivos (previdenciários) e não contributivos (assistenciais) na mesma instituição.

Em 1988, como desdobramento da nova Constituição Federal, deu-se uma ampla reformulação das instituições vinculadas à Previdência Social: a LBA passou a integrar a pasta do Ministério da Habitação e Bem-Estar Social; e deu-se a fusão entre INPS e IAPAS fazendo surgir o INSS (Instituto Nacional do Seguro Social); o INAMPS foi absorvido pelo Ministério da Saúde e em 1993, cessaram definitivamente os repasses da Previdência para a Saúde.

A previdência social é entendida como um sistema de solidariedade horizontal (entre trabalhadores ativos) e vertical (entre as gerações). Desde a unificação previdenciária, o sistema tem sido de repartição simples, com aposentadoria de inativos financiada pelos ativos contemporâneos. A opção pelo modelo de repartição simples foi reativa, como fruto da dilapidação das reservas capitalizadas das antigas CAPS (Cohn, 1980; Teixeira \& Oliveira, 1986; Malloy, 1986; Giambiagi, 2000) e pela tradição paternalista brasileira que pensa caber ao Estado fornecer aos indivíduos meios de subsistência (Giambiagi, 2000).

O regime de repartição simples cria uma ilusão de que há correspondência entre o valor das contribuições dos empregados e os benefícios futuros, como funcionaria numa poupança individual ou um título de capitalização. A solidariedade intergeracional anula essa possibilidade e os benefícios dos que atualmente contribuem para o sistema são dependentes das contribuições futuras. Por outro lado, as contribuições dos empregadores têm o seu custo repassado ao preço e ao consumidor final, fazendo com que toda a sociedade participe de seu financiamento. O vínculo entre salário de contribuição e salário de benefício é uma ilusão vendida pelo sistema de seguridade social e se constitui em um de seus mitos.

A ANC foi o momento em que "o Brasil fez a sua reforma à inglesa, eliminando os fundamentos bismarckianos segmentares do alemão” (Vianna, 1998: 130). Os debates constituintes estavam amparados por esse referencial, o que contribuiu para a integração entre as áreas da saúde, assistência e da previdência social. A seguridade social introduzia um novo conceito de proteção social informado pelos princípios da universalidade, da uniformidade e equivalência; da seletividade e distributividade; da irredutibilidade do valor dos benefícios; da diversidade da base de financiamento e do caráter democrático e 
descentralizado de financiamento, que exigiriam um novo formato institucional. O novo conceito, ao mesmo tempo em que alargava o campo da previdência social, o modificava por inteiro, abrindo espaço para a configuração de outras políticas sociais, como um movimento de libertação da saúde e da assistência social da influência e decisão previdenciária. Para Oliveira e Beltrão (1989: 1) o conceito de seguridade social promovia um duplo critério: benefícios concedidos conforme a necessidade e custeio segundo a capacidade de cada um. Esses princípios eram uma resposta ao padrão histórico de realização da previdência social. Pode-se dizer que esses princípios respondiam mais ao plano ideológico de busca de realização de um valor, do que propriamente à possibilidade concreta de implantação. As novas recomendações eram incompatíveis com o diagnóstico de penúria fiscal, de miséria, de desemprego, de queda na arrecadação, de revolta contra a cobrança crescente de impostos, de renúncias fiscais e de sonegação. Mesmo assim, prevaleceram as recomendações políticas contra as econômicas ${ }^{89}$.

Em termos weberianos, a instituição da seguridade social pode ser entendida como a realização do valor universalidade, o que ajuda a situar as reformas num plano racional, mas sem a conotação econômica das reformas da década de 1990 e 2000 . A racionalidade que informou a instituição do direito à seguridade social foi a redução do déficit de cidadania, com a promoção dos valores de igualdade, universalidade, solidariedade social, eqüidade e justiça social. A preocupação com os fatores econômicos foi demonstrada a partir da tentativa de ampliar a base de financiamento da seguridade social por meio da criação de novas contribuições sociais e da vinculação de recursos à seguridade social.

A adoção do conceito de seguridade social indicava a promessa ${ }^{90}$ de conferir um sentido público, universal e igualitário ao direito social, da qual deveria participar toda a

\footnotetext{
${ }^{89}$ As razões políticas aparecem em contraposição às razões econômicas e tomadas como tipos ideais aparecem em disputa e configurando duas racionalidades distintas que aparecem como em oposição nessa tese. Diante do grave déficit financeiro as razões políticas são tomadas como irracionalidade para aqueles que enfatizam aspectos econômicos e vice-versa. É a irracionalidade identificada no discurso do outro que permite identificar duas racionalidades distintas e em oposição.

${ }^{90}$ Promessa é aqui usado no sentido cunhado por H. Arendt, como a capacidade da sociedade em "creditar o futuro" comprometer-se com ele, através de antecipações normativas. Promessa, como uma figura de mediação que mobiliza e regenera as estruturas sociais pré-existentes de cooperação e que permite começar de novo (ARENDT, 1981). Ost trabalha com as categorias subjetivas de memória, perdão, promessa e questionamento para pensar o direito, que se renova num sempre tenso equilíbrio entre tradição e modernidade. Em sua proposição, o direito nunca é um dado novo, mas o que faz o duplo jogo de ligardesligar o tempo histórico. A instituição da promessa é duplamente moderna, porque supõe uma consciência de futuro e que o direito não se declina às tradições do passado. A confiança na promessa (o respeito à lei) é o
} 
sociedade, na condição de contribuinte e de beneficiário. Ao adotar essa nova definição, o Brasil deveria construir políticas sociais universais de assistência social e saúde e tornar a previdência social mais abrangente e homogênea entre os trabalhadores, ou seja, deveria não apenas atuar na melhoria da qualidade dos benefícios já existentes, como incorporar outras categorias, como os domésticos e os trabalhadores rurais. Ao mesmo tempo, buscava-se fortalecer a previdência social e fazer com que deixasse de ser a viga mestra da proteção social. Um dos principais pontos de crítica era exatamente o seu escopo corporativista e elitista, ao incorporar apenas o contingente de trabalhadores inseridos no mercado de trabalho formal e urbano ${ }^{91}$ e reproduzir as desigualdades de renda existentes no mercado de trabalho.

Acreditava-se que o conceito de seguridade social era suficientemente forte para promover uma reviravolta no modelo de proteção social, tornando-a independente do mercado de trabalho e fazendo da cidadania a condição de acesso aos direitos. Embora reconhecendo uma relação de dependência entre as áreas da saúde, da previdência e da assistência social, elas não deveriam ser tomadas como parte uma da outra. Saúde e assistência social deveriam ser direitos de todos os trabalhadores e não apenas daqueles que possuíam a “carteira assinada”. O texto constitucional visava, dessa forma, fortalecer as diretrizes que já vinham sendo adotadas, tais como a extensão do atendimento médico de urgência a toda a população, independente de contribuições, atendimento descentralizado e a criação de um fundo de amparo ao trabalhador rural. Mas pretendia também garantir que

que confere estabilidade às sociedades. Assim, dirá ele, “toda arte do legislador consiste em acompanhar o tempo em sua prova de triagem: será preciso conservar o que resistiu, rejeitar o resto e de vez em quando preencher as lacunas que o presente fez surgir" (OsT, 2005: 282). Koselleck propõe o uso das categorias históricas “espaço da experiência” e "horizonte de expectativas” para expressar a polaridade tensa na qual a história é possível, como uma vinculação entre o passado e o futuro. A experiência permite a elaboração racional na qual se mesclam esperança e medo, desejo e vontade, inquietude e a curiosidade. No conceito "horizonte de expectativas" se projeta tanto a elaboração crítica do passado, quanto a liberação para o futuro. O conceito de Constituição concretiza a separação consciente entre o espaço da experiência e o horizonte de expectativa, e confere à ação política a realização da conciliação dessa diferença (KOSELLECK, 2006).

${ }^{91}$ Ver a respeito a análise de Wanderley Guilherme dos Santos, decisiva sobre a política social no Brasil que constrói o conceito de "cidadania regulada" para explicar como a cidadania está embutida na profissão e os direitos restritos ao lugar ocupado no processo produtivo. Como os direitos decorrem das profissões e as profissões só existem via regulamentação estatal, a carteira de trabalho torna-se o instrumento jurídico comprovante do contrato entre Estado e trabalhadores, uma “certidão de nascimento cívico”, que promove a distinção entre os que têm e os que não têm acesso aos direitos (SANTOS, 1987: 68-71). 
o seu financiamento fosse partilhado por toda a sociedade, com base no princípio da solidariedade $^{92}$ e na busca da realização do bem-estar e da justiça social ${ }^{93}$.

Saudada como a “Constituição Cidadã”, a Constituição de 1988 representa o ato histórico de construção democrática num momento em que se buscava resgatar a dívida social e transformar o conteúdo da proteção social, promovendo uma mudança conceitual de seguro social para seguridade social. A autonomia que a seguridade social adquiriu em relação ao trabalho, ao deixar de ser a chave de acesso aos direitos ali inscritos, foi reforçada ao longo da década e adquiriu maior consistência durante o ciclo de reformas.

Há, ao menos cinco aspectos que devem ser enfatizados em relação ao que dispôs a Constituição. Em primeiro lugar, o reconhecimento de que a previdência social é uma modalidade de seguro social e não deve ser confundida com saúde e assistência social indica que o conceito de seguridade social possibilitaria a emancipação das áreas da saúde e da assistência social do seguro social e que fossem repensados os modelos de financiamento, gestão, administração e de cobertura. A principal conseqüência era a

\footnotetext{
92 “Art. $3^{\circ}$. Constituem objetivos fundamentais da República Federativa do Brasil: I. construir uma sociedade livre, justa e solidária”. Constituição da República Federativa do Brasil, 1988.

93 "Art. 193. A ordem social tem como base o primado do trabalho, e como objetivo o bem-estar e a justiça sociais”. Constituição Federal da República do Brasil, 1988.

${ }^{96}$ O seguro-desemprego já havia sido previsto no inciso XV do artigo 157 da Constituição de 1946, regulamentado somente pela Lei 4.923, de 23/12/1965. O Decreto 58.155, de 05/04/1966 constituiu o Fundo de Assistência aos Desempregados (FAD) e regulamentou a sua aplicação; o Decreto 58.684, de 21/06/1966, instituiu o plano de assistência e disciplinou o custeio. Na Constituição de 1967, foi novamente incluído entre as prestações da Previdência Social, repetindo a orientação na EC 1 1/1969. Contudo, o sistema somente foi efetivamente instituído como parte integrante do Plano Cruzado (Decreto-Lei 2.283, de 2802/1986, regulamentado pelo Decreto 92.608/86. As previsões anteriores foram modificadas pelo texto da Constituição de 1988, para ser assegurado tanto aos trabalhadores urbanos e rurais, apenas no caso de desemprego involuntário, o que impõe que se o desemprego for motivado pelo trabalhador, o benefício é indevido. Embora tenha sido considerada uma prestação previdenciária, o seguro-desemprego teve seu financiamento vinculado ao PIS-PASEP e deverá receber uma contribuição adicional da empresa cujo índice de rotatividade da força de trabalho superar o índice médio do setor de atividade econômica no qual se insere (MARTINS, 1999: 441-449).
} 
possibilidade de reforçar a construção do SUS e da assistência social, de acesso universal, vinculado à cidadania e não ao trabalho no mercado formal. A previdência social continuaria a ser o seguro social relacionado à proteção decorrente do trabalho. O seguro social seria, portanto, parte integrante da seguridade social no novo modelo de proteção social.

Em segundo lugar, encontram-se os "novos direitos” inscritos na Constituição, dos quais novos mesmo são apenas a equiparação de direitos dos trabalhadores rurais em relação aos trabalhadores urbanos e os Benefícios de Prestação Continuada pagos para famílias de idosos e deficientes de baixa renda, no valor de um salário mínimo. Todos os outros direitos já existiam, apenas foram reformulados e/ou transcritos para o texto constitucional: seguro-desemprego ${ }^{96}$, salário-família ${ }^{97}$, salário-maternidade ${ }^{98}$, auxílioreclusão ${ }^{99}$, pensão por morte de segurado ${ }^{100}$, aposentadoria por idade ${ }^{101}$ com redução de 5

${ }^{97}$ O salário-família foi instituído pela Lei 4.266, de 03/10/1963 e regulamentado pelo Decreto 53.153, de 10/12/1963 e era devido a todo empregado regido pela CLT, qualquer que fosse sua forma de remuneração, na razão de $5 \%$ do salário mínimo por número de filhos com idade inferior a 14 anos. A Lei 5.559, de 11/12/1968 estendeu o salário família aos filhos inválidos de qualquer idade e a EC 1/69, assegurou o direito aos dependentes do trabalhador. A Constituição Federal de 1988 estendeu o benefício ao trabalhador rural e seus dependentes e retirou a sua vinculação ao salário mínimo. Somente com a promulgação da Lei 8.213/91, passou a ter um valor fixo, atualizado periodicamente. Não têm direito ao salário-família o empregado doméstico, o autônomo, o empresário e o segurado facultativo (Idem: 389-394).

98 A assistência à gestação e à maternidade já era prevista desde 1932, com o Decreto 21.417-A, de 17/05/1932 e visava assegurar o descanso antes e depois do parto. A partir da Constituição de 1934, o benefício passou a ser previsto sem prejuízo do salário e, com a Constituição de 1946, sem prejuízo do emprego também. As prestações passaram a ser de responsabilidade do seguro social a partir de 1962, com a promulgação da Convenção 3 da OIT (Decreto 51.627, de 18/12/62) e endossada pela Convenção 103 da OIT (Decreto 58.820, de 14/06/1966). O dever de proteção à maternidade foi mantido nos textos constitucionais de 1967, da EC 1/69 e da Constituição de 1988. A Lei 6.136, de 07/11/74 tornou o salário-maternidade uma prestação previdenciária, com custeio de $0,3 \%$ sobre a folha de pagamento e que eximia o empregador do pagamento do salário da empregada durante o período. Em 1989, essa contribuição foi extinta e ficou englobada no percentual de $20 \%$ da contribuição da empresa e mantida na Lei 8.212/91. A Constituição de 1988, porém, ampliou o período de licença-maternidade de 84 para 120 dias, sem prejuízo do emprego e do salário. O direito à licença é atribuído à empregada urbana, rural, doméstica e à segurada especial, sem exigência do período de carência. O salário-maternidade é uma renda mensal igual à remuneração da segurada empregada, pago pela empresa, cujo valor será compensado quando do recolhimento das contribuições previdenciárias sobre a folha de salário. O salário-maternidade é devido apenas enquanto existe a relação de emprego, em caso de demissão, a empresa deverá arcar com o pagamento do salário-maternidade (Ibidem: 385-389).

${ }^{99}$ O benefício já era previsto, desde 1960 (Lei 3.807), para os detentos que tivessem realizado no mínimo 12 contribuições mensais e que não recebessem nenhuma remuneração. O pagamento do benefício era mantido enquanto durasse a prisão do segurado, com a necessidade de comprovação da condição pela autoridade competente. A primeira Constituição a tratar do tema foi a de 1988 (art. 201, I),i disciplinada pela Lei 8213/91 (Ibidem: 394-396).

${ }^{100}$ A pensão por morte é um benefício previdenciário pago aos dependentes em decorrência do falecimento do segurado e, com a Constituição de 1988, passou a ser devido, independente do sexo do dependente. O dever de previdência contra as conseqüências da morte foi previsto na Constituição de 1946. A Lei 3.807/60 
anos para mulher, aposentadoria por tempo de trabalho ${ }^{102}$ com redução de 5 anos para mulher, aposentadoria especial ${ }^{103}$, aposentadoria com redução de 5 anos de trabalho para ambos os sexos.

O terceiro aspecto e que adquirirá grande repercussão e relevância na discussão pública nos anos seguintes é a determinação de que o menor valor de benefício pago deveria ser de um salário mínimo, a constitucionalização do cálculo do valor do benefício e a obrigação da manutenção do valor real do benefício expresso em salário mínimos. Essas

determinou que era devida aos dependentes do segurado, aposentado ou não, que falecesse após haver realizado 12 contribuições mensais. Foi mantido nas Constituições de 1967 e na EC 1/69 com a redação “previdência social nos casos de morte”. A Constituição de 1988 difere da anterior ao estabelecer que os planos de previdência social atenderão à cobertura dos eventos de morte, mediante contribuição, tanto para o segurado homem ou mulher, cônjuge ou companheiro e dependentes e determina que nenhum benefício deverá ser inferior a um salário mínimo. O Decreto 89.312 (Consolidação das Leis da Previdência Social) estabelecia um período de carência de 12 meses para o pagamento da pensão por morte, que foi suprimida pela Lei 8.213/91, para a qual o pagamento da pensão por morte independe de período de carência. O direito à pensão é devido também quando o segurado já é aposentado (Ibidem: 378-381)

${ }^{101}$ A instituição de "previdência em favor da velhice” foi prevista no texto constitucional de 1934 e recebeu melhor redação em 1937, que passou a especificar “a instituição de seguros de velhice”. A Previdência Social nos casos de velhice foi mantida nos textos constitucionais posteriores. No âmbito da OIT, o tema foi tratado nas Convenções 102 (1952), 128 (1967) e nas Recomendações 67 (1944) e 162, nenhuma delas ratificadas pelo Brasil. A Constituição de 1988 atualiza a denominação "velhice”, de conotação subjetiva, para aposentadoria por idade, conferindo um critério mais objetivo de acesso, a idade especificada em lei. A nova regra determinou a idade de 65 anos para homem e 60 anos para a mulher. Embora sem antecedentes nos textos legais do Brasil, a redução de cinco anos na idade de aposentadoria das mulheres em relação à dos homens é prática corrente na Inglaterra, na Itália, Austrália, Áustria, Bélgica, Grécia, Cuba, Indonésia, Taiwan e Luxemburgo. Diferença inferior a 5 anos foram registrados na Alemanha, Argentina, Dinamarca e Suíça. Não apresentam diferença de idade para homens e mulheres: Espanha, EUA, Finlândia, França, Holanda, Irlanda, Israel, Colômbia, Costa Rica, Cingapura, Japão, Malásia, Noruega, Nova Zelândia, Portugal, Suécia, e Uruguai (Ibidem: 358-368).

${ }^{102}$ A aposentadoria por tempo de serviço, que já foi denominada “aposentadoria ordinária”, existe no Brasil desde 1923. Em razão do elevado custo que representa no sistema foi suspensa em 1940 e restabelecida em 1948 e mantida pela Lei 3.807/60 (Lei Orgânica da Previdência Social), quando passou a ser denominada "aposentadoria por tempo de serviço", mas com limite de idade de 55 anos. O limite de idade foi suprimido em 1962, através da Lei 4.130, de 28/08/1962. O diferencial de tempo de serviço para a mulher foi instituído em 1967, pelo texto constitucional, que determinava a aposentadoria para a mulher aos 30 anos de trabalho, com salário integral. As duas prerrogativas foram mantidas com a EC 1/1969 e pelo texto constitucional de 1988. Esse é um dos pontos mais polêmicos na discussão previdenciária, posto que não há risco a ser coberto, o que não justifica a proteção da previdência social embasada na idéia de risco social. Sistema similar existe apenas no Egito, Equador, Iraque, Líbano e Kuwait (Ibidem: 336-357).

${ }^{103}$ A aposentadoria especial é um benefício de natureza extraordinária que tem por objetivo compensar o trabalho do segurado que presta serviços em condições adversas à sua saúde ou que desempenha atividade com riscos superiores aos normais. Foi instituída pela Lei 3.807/60 (art. 31) e tinha como requisito que o segurado tivesse, no mínimo, 50 anos de idade e 15 anos de contribuição e exercesse atividades penosas, perigosas ou insalubres. A Lei 5.440-A suprimiu o requisito idade para a sua concessão, o que foi mantido pela Lei 5.890/73. O tempo mínimo de trabalho requerido poderia ser de 15, 20 ou 25 anos em condições prejudiciais à saúde ou à integridade física do trabalhador. Faziam jus à aposentadoria especial os trabalhadores em contato com agentes químicos, físicos ou biológicos (NR 15, da Portaria 3.214/78), que implique contato permanente com inflamáveis, explosivos e em condições de risco acentuado (NR 16, Portaria 3.214/78) e o trabalho dos eletricistas (Lei 7.369/85 e seu regulamento, Decreto 93.412/86) (Ibidem: 368-378) 
medidas de caráter econômico além de produzirem um impacto direto ${ }^{104}$ nas contas da Previdência, impedia o governo de manipular o valor dos benefícios. Se, por um lado, a intenção manifestada era de manter o valor do benefício impedindo que aposentados e pensionistas vissem deteriorados seus meios de vida, também introduzia uma medida de controle público sobre a concessão e reajustes dos benefícios, além de definir um mínimo social.

O quarto aspecto foi a definição de que a seguridade social deverá ser custeada por toda a sociedade e a criação do orçamento próprio, que nasceu vinculando às receitas das contribuições sociais (CSLL, Finsocial, folha de pagamento de salários, concursos e prognósticos). De outro modo, a Constituição determinava que eventuais insuficiências financeira da Previdência Social deveriam ser cobertas com recursos do Tesouro. Se, a seguridade social deve ser custeada por toda a sociedade, se ela tem um orçamento próprio e se o Tesouro deve cobrir as eventuais insuficiências financeiras, então, a discussão sobre o déficit da Previdência aparece deslocada em face do texto legal.

Um outro aspecto, não menos importante, foi o estabelecimento de mecanismos públicos de controle sobre a seguridade social, sob a forma dos Conselhos tripartites de gerenciamento em todos os níveis da administração pública e a própria inclusão do Orçamento da Seguridade Social no Orçamento Geral da União, que o tornou sujeito ao controle parlamentar e o constituiu num mecanismo de gestão ${ }^{105}$. Uma das principais reivindicações populares do momento era exatamente o controle público sobre a administração, gestão e execução das políticas sociais, de forma que fossem evitados desvios de recursos, redução do gasto social e interrupção no fornecimento de serviços sociais.

O Orçamento Geral da União foi dividido em três: fiscal, seguridade social e investimento das empresas estatais. Cada um contemplava despesas e receitas previstas para o exercício fiscal. A previsão da receita obedecia às normas dos entes encarregados da

\footnotetext{
${ }^{104}$ A partir da Promulgação da Constituição Federal, 05/10/1988, todos os benefícios pagos com valor inferior a um salário mínimo deveriam ser equiparados ao salário mínimo, o que representou um grande volume de gastos nas contas da Previdência. Todos os pagamentos de benefícios de renda mensal vitalícia que eram de $1 / 2$ salário mínimo, tiveram aumento de $100 \%$.

${ }^{105}$ Delgado considera que, da estrutura transversal da seguridade social, emergiram duas instituições chaves para executá-la: os Conselhos de política Social (Saúde, Previdência e Assistência Social) e o Orçamento da Seguridade Social, das quais, a segunda é a mais importante (Delgado, 2002).
} 
administração da arrecadação - Secretaria da Receita Federal (tributos de natureza fiscal) e INSS (para a maioria das contribuições sociais).

A criação do OSS teve como objetivo proteger a área social da disputa por recursos no âmbito do Tesouro Nacional e acabou por ratificar a prática de vinculação entre receitas e despesas, contrariando os princípios tributários. As contribuições sociais de empregados e empregadores se tornaram parte do OSS, que, por sua vez, integrou o OGU. Dessa forma, as contas previdenciárias tornaram-se objeto de controle público, seja no momento de discussão e aprovação anual do Orçamento no Congresso Nacional (incluindo deputados e senadores), seja pelo controle externo exercido pelo Tribunal de Contas da União. A existência de um único orçamento permite conhecer a priori todas as receitas e despesas do governo e, desse modo, impedir o Executivo de realizar qualquer operação (de receita ou despesa) sem prévia autorização parlamentar, bem como permite conhecer o exato volume das despesas projetadas pelo governo e autorizar a cobrança dos tributos necessários para atendê-las.

Antes da promulgação da Constituição de 1988, o orçamento previdenciário era aprovado no âmbito exclusivo do Poder Executivo. Sustentada pela tese da auto-suficiência financeira do setor, a Previdência não integrava o orçamento do governo federal, o que quer dizer que não havia publicidade ou transparência nas contas da Previdência Social, que tampouco estava sujeita a qualquer forma de controle. Não se conhecia o total arrecadado, nem as despesas efetuadas e, tampouco, com o que gastava a Previdência Social. Como não estavam sujeitos à aprovação do Congresso Nacional, os recursos poderiam ser manipulados pelo Executivo: para alocação em finalidades estranhas à previdência social; rebaixamento do valor dos benefícios de modo a ajustar a contabilidade (receitas e despesas); aumento de alíquotas de contribuição etc. A história da previdência social no Brasil é bastante farta em exemplos (Teixeira \& Oliveira, 1986; Malloy, 1986).

A definição do salário mínimo como o piso mínimo previdenciário, corroborado pelo princípio da irredutibilidade do valor do benefício, também teve por objetivo estabelecer uma medida de controle público sobre as contas da Previdência. Nesse caso, expressava uma tentativa de proteger o benefício previdenciário do constante rebaixamento dos seus valores além do mínimo para a sobrevivência. Adotou-se para os inativos os mesmos parâmetros para os trabalhadores ativos. 
Juntas, essas duas medidas conferiram uma dimensão pública à questão da Previdência Social, que passou a ser discutida a partir das suas “contas” e, em nome de sua preservação financeira, é que as reformas foram efetuadas. A Constituição Federal de 1988 reenviou a previdência social para o campo da política, mas de uma forma inovadora em relação à sua trajetória histórica de uso para controle dos trabalhadores ou de inclusão controlada (Malloy, 1986). O que as novas proposições provocaram foi o surgimento da Previdência Social como uma instituição pública, alimentada pelos novos processos democráticos de participação e controle público. E, sem dúvida, representou uma ruptura com o padrão de gestão técnico-administrativo adotado no regime autoritário. A partir de 1988 qualquer questão relativa à previdência social tomou a dimensão de uma questão pública, retirada a possibilidade de ajustes técnicos no interior da própria instituição.

Universalidade, uniformidade, equivalência, seletividade, distributividade, eqüidade, diversidade, democracia e descentralização são os princípios em torno dos quais se buscou construir a seguridade social e que não foram postos em questão durante todo o debate pela regulamentação do capítulo dos direitos sociais. Apesar de seu reconhecimento como objetivos fundantes da ordem social, conceitualmente sofreram modificações relacionadas à construção de um novo modo de se pensar o social.

A Constituição Federal de 1988 é em si mesma emblemática, porque no campo dos direitos sociais ela faz a transição entre o passado e o futuro. Ao mesmo tempo em que sedimenta as aspirações e discussões de uma década, se projeta como o problema da outra. Fundado no ideal de busca de justiça social e da eqüidade, o conceito de seguridade social tornou-se o foco das disputas que fortaleceram os princípios do seguro social, inclusive com admissão de critérios atuariais de inscrição, vínculo e concessão de benefícios.

Os direitos sociais foram colocados em foco em função dos recursos necessários ao seu financiamento, com ênfase tanto na carga tributária necessária para sustenta-lo, quanto nos gastos púbicos para efetiva-los. Nessa discussão procedeu-se a uma ampla revisão do papel do Estado como fornecedor de serviços sociais, que fez prevalecer o objetivo da focalização, com prioridade no atendimento dos serviços sociais básicos e dirigidos à população de baixa renda. Sob essa lógica foi questionado o caráter universal das políticas de saúde e educação, o que inclui a proposta do fim da gratuidade nas universidades públicas. 
Ao final da década de 1990, o ideal da seguridade social já havia sido suplantado, assim como, a necessidade de reformas no sistema de previdência social alcançava amplo consenso. Entre as três áreas, a previdência social foi a que alcançou maior dimensão pública, pelo seu alto grau de conflituosidade e por seu efeito sobre várias.

Dotada de regras rígidas e constitucionalizadas, a política de previdência social foi o centro do debate na construção de um novo modelo de proteção social, no qual prevaleceu a oposição entre direitos e privilégios, servidores públicos e trabalhadores da iniciativa privada. Regras de acesso e critérios de cálculo mais generosos para alguns segmentos de trabalhadores, fizeram com que os direitos fossem vistos como privilégios e corrigidos. Os funcionários públicos foram, sem dúvida, a categoria mais atingida pelas reformas processadas no período entre 1990 e 2005. E, dentro desse segmento, os magistrados, os professores universitários e os parlamentares.

Com as reformas, garantiu-se maior uniformidade nos critérios de concessão de aposentadorias e na definição de seus valores, focalização no pagamento de alguns benefícios (salário-família, auxílio-reclusão), melhor distributividade nos recursos públicos disponíveis, equivalência entre servidores públicos e trabalhadores da iniciativa privada e manteve-se a diversidade da base de financiamento e eqüidade na participação do custeio. Enfim, os objetivos definidos no texto constitucional foram mantidos, embora com conteúdos profundamente modificados. O conceito de universalidade foi aquele que mais sofreu modificações internas para fortalecer a noção de que a previdência social é, por princípio, seletiva, ou seja, direcionada àqueles que dela participam através de vínculo contributivo. A sua universalidade está em que qualquer cidadão possa a ela ser integrada, mediante o pagamento de contribuições. Esse último aspecto foi reforçado, por exemplo, no governo Lula com o projeto de "inclusão previdenciária” que buscou construir regras de filiação à Previdência Social separadas da inserção no mercado formal de trabalho.

A singularidade do debate sobre a construção da seguridade social no Brasil consiste em que os direitos conquistados pelas categorias de trabalhadores melhores situadas no mercado formal de trabalho passaram a ser vistas como privilégios: de se aposentar com menos idade e com valores mais altos; acumular aposentadorias ou superpor aposentadoria a rendimentos do trabalho. A discussão sobre a seguridade social conduziu ao questionamento dos direitos corporativos e a uma focalização nos segmentos menos 
favorecidos da população. A conversão da “cidadania regulada” em cidadania universal fortaleceu a construção de benefícios de assistência pública, como a garantia de renda a idosos e deficientes e, de certa forma, esteve na base do lançamento de políticas de renda mínima.

A discussão pública sobre os novos direitos não se encontra, porém, isolada de outros fenômenos incidentes sobre o mercado de trabalho, como o desemprego e o crescimento do mercado informal de trabalho, que tornou os vínculos mais precários e desprotegidos.

\section{Críticas à seguridade social}

É consenso na literatura que a "seguridade social” institucionalizada formalmente na Constituição não foi implementada (Cohn, 1995; Vianna, 2000; 2005 ; Draibe, 1994 ; Boschetti, 2003 Marques, 2003; Silva, 2004; Mota, 1995; Batik, 2004), assim como não houve efetiva integração entre as áreas da saúde, previdência e assistência social. Essas se mantiveram como políticas autônomas, com regras próprias de acesso e em disputa acentuada pelos recursos que integram o OSS.

No Brasil, as reformas na previdência social têm tido um caráter defensivo e têm respondido à preocupação com o equilíbrio nas contas previdenciárias, com aumento da contribuição e redução de benefícios, controle mais rígido na concessão de benefícios, focalização e seletividade, relação atuarial entre contribuição e valor de benefícios. Tem sido forte a tentativa de dissociar trabalho e benefício numa tentativa de eliminar a idéia de prêmio vinculado à vida laboral, o que desfaz toda a lógica de integração social a partir do mercado de trabalho. Promove, dessa maneira uma mudança substancial na solidariedade social, entre as classes e entre as gerações (Tapia \& Henrique, 1995: 71).

Ao definir que a "seguridade social será financiada direta ou indiretamente por toda a sociedade»106, a Constituição reafirmou o sistema de repartição simples e a sua complementação com recursos do orçamento fiscal em caso de déficit. No começo dos debates sobre a reforma, propunha-se o retorno à forma do regime de capitalização, com aumento da poupança privada e a possibilidade de uso desses recursos para investimentos

${ }^{106}$ Art. 195, Constituição da República Federativa do Brasil, 1988. 
que permitissem viabilizar o desenvolvimento econômico sustentado. É o seu retorno à condição de captação de poupança individual e da previdência como instrumento de política econômica $^{107}$.

A Constituição tem sido problematizada como o ponto de origem da crise da previdência social devido ao alargamento da demandas sem correspondência de recursos capazes de financiá-los. No entanto, o direito é um sistema de normas e valores, que não se preocupa com o ônus financeiro a ser suportado pela sociedade (Rocha, 2004).

A Constituição está no centro de um conflito como o ponto de separação entre dois modos de fazer política, de pensar o direito, entre duas racionalidades, a racionalidade política (input) e o problema da realização de um programa (output) (Reis, 2000: 97) baseado na racionalidade econômica. São duas racionalidades diferentes que circunscrevem a separação dos dois momentos: a política e a econômica. Utilizando os tipos ideais de Weber de ação social, poderíamos identificar a racionalidade política como mais próxima da realização de um valor, a universalização dos direitos de cidadania e a afirmação da impossibilidade de manutenção do sistema tal como concebido como a busca da eficiência na alocação de recursos públicos.

A Constituição foi um ponto de inflexão na história da Previdência Social com avanço (formal) na construção do sistema de proteção social através da: ampliação da cobertura para segmentos sociais antes desprotegidos, eliminação na diferença de tratamento entre urbanos e rurais, direitos básicos universais de cidadania e o uso da cidadania como critério de acesso. A Constituição definiu princípios e valores pelos quais deveriam se pautar a cidadania social, completando a realização da cidadania civil e política. A principal critica em relação à Constituição Federal resume-se ao fato de ter focado mais as despesas do que as receitas (Giambiagi, 2000), mais a ampliação de direitos do que na sustentação financeira, mais no alargamento do espectro de serviços do que no de contribuintes.

A universalização dos direitos sociais pretendida com a Constituição de 1988 foi um tiro que saiu pela culatra, com o reforço do elemento assistencial da Previdência Social. É precisamente neste ponto que o projeto foi o inverso da reforma realizada na Inglaterra a

\footnotetext{
${ }^{107} \mathrm{O}$ uso da poupança individual como instrumento de política econômica foi percebido, por Amélia Cohn, na primeira fase de implantação da política previdenciária. O uso efetivo em políticas de desenvolvimento econômico foi demonstrado por (COHN, 1980; OLIVEIRA \& TEIXEIRA, 1986).
} 
partir das recomendações de Beveridge. Sem o contraponto do pleno emprego, e, portanto, de uma política de incorporação de fato dos trabalhadores, a incorporação apenas formal provocou um aumento da demanda por benefícios sociais sem base contributiva, que desfez o sonho de universalização. Ou, melhor, a universalização deu-se por baixo, sob a forma de políticas focalizadas nos seguimentos mais pobres da população e uma privatização por default, tornando o sistema "americanizado" (Vianna, 2000).

Tão logo foi promulgada, a Constituição sofreu uma série de críticas que afirmava o quanto era anacrônica, numa clara referência à idéia de crise financeira do Estado de BemEstar Social entre os países centrais, assim como, as políticas de privatização chilenas. A crítica contra a Constituição tem sido embasada em três argumentos centrais:

1. a Constituição produziu uma elevação nos gastos com benefícios sociais;

2. a elevação dos gastos com benefícios sociais aumentou o déficit previdenciário e

3. o Brasil está passando por uma transição demográfica, com envelhecimento da população, o que aumentará a demanda por benefícios sociais e provocará desequilíbrio entre beneficiários e contribuintes.

A combinação entre envelhecimento da população e mudança nas relações de trabalho reduz a cobertura previdenciária e altera a relação entre contribuintes e beneficiários $^{108}$, sem contar que os não contribuintes deverão pressionar o sistema pela concessão de benefícios assistenciais (Pinheiro, 2004).

Os três argumentos citados vêm sendo amplamente apresentados e sustentados, principalmente, por técnicos do IPEA. Os argumentos são condizentes com uma visão de que há poucas chances do déficit ser revertido sem a adoção de reformas da previdência que colaborem para conter a expansão dos custos previdenciários. Esses argumentos sustentam tratar-se de uma crise estrutural, decorrente do desequilíbrio entre receitas e despesas e que somente poderá ser revertida com reformas que torne menos pródiga a concessão de benefícios. As reformas têm valorizado mais a questão do déficit contábil numa redenção à lógica securitária (Faro, 1993).

\footnotetext{
${ }^{108}$ Dados do Ministério da Previdência Social indicam queda na relação entre ativos/inativos: na década de 1950 a relação era de 8/1; na década de 1970 passou de 4,2/1; na década de 1990 caiu para 2,3/1 e estimativas apontam que em 2020 estará em 1/1, tornando o sistema inviável. A relação entre ativos e inativos é essencial no regime de repartição em que os trabalhadores atuais sustentam os inativos atuais, e, que, portanto, não se refere a uma poupança para aposentadoria futura (BRASIL, 2002).
} 
Giambiagi (2000) aponta que a Previdência Social que já era atuarialmente deficiente, mas superavitária (arrecadava mais que pagava) tornou-se, com a ampliação de direitos, deficitária. Situação agravada pelo fato de ter deixado de financiar a saúde, o que demandou dotação maior de recursos tributários para a área, inclusive com a criação de novos tributos, como a CPMF (Giambiagi, 2000: 279). Para o autor, os três fatores que levaram ao crescimento do déficit foram: envelhecimento da população, generosidade da lei e ampliação do contingente de beneficiários, como proporção dos contribuintes (Giambiagi, 2000). Nenhuma menção é feita em relação ao mercado de trabalho, à a retração do número de contribuintes e à queda no valor arrecadado a título de contribuição, conseqüência direta do desemprego, da informalização nas relações de trabalho, e da queda na massa salarial.

Em todos os casos, a solução encontrada foi procurar conter o crescimento na demanda por benefícios através da alteração nos critérios de elegibilidade e na reformulação do cálculo no valor dos benefícios. Essas são as duas questões implícitas na reforma da Previdência.

A literatura está dividida em dois campos que têm em comum a crítica à política de previdência social: de um lado, por sua insuficiência na promoção da igualdade e dos efeitos redistributivos; de outro, pela insuficiência financeira e seus efeitos nas contas públicas. No primeiro grupo situam-se aqueles que vêm na não realização do conceito de seguridade social o problema central, tanto no aspecto institucional de integração entre as três áreas ${ }^{109}$, quanto no financiamento que deveria ser coberto pelo OSS (Boschetti, 2003; Marques, 2003; Silva, 2004; Andrade, 2003). No segundo grupo, situam-se principalmente economistas e técnicos do IPEA e do MPS que sustentam no déficit previdenciário o principal argumento para a reforma. Esses vêm o déficit como estrutural, decorrente, sobretudo, do envelhecimento da população que alterou a estrutura demográfica e o coeficiente demográfico da Previdência (percentual entre ativos/inativos). Regras menos rígidas de acesso e generosidade nos benefícios elevaram tanto o número de beneficiários quanto o valor dos benefícios, causa principal do déficit previdenciário (Giambiagi, 2000; Beltrão, 1995).

A queda da arrecadação tem sido menos explorada do que o crescimento das despesas previdenciárias. Em seu favor, contribuem desemprego, informalização das

\footnotetext{
${ }^{109}$ Para uma síntese do debate ver (MARQUES, 2003).
} 
relações de trabalho, redução da massa salarial, não partilha de recursos do OSS no seu custeio, renúncia fiscal, sonegação etc.

Boa parte da polêmica concentra-se em saber se há déficit ou superávit nas contas da Previdência. Como a questão não é simplesmente uma questão atuarial, ela remete diretamente à questão de Ewald (1993), como o fundamento da política ou o quanto de recurso público está disponível para a partilha social. Implica não somente no quanto de benefícios se paga, mas em definir o nível aceitável dos gastos sociais. Como percebeu Rosanvallon, o problema está em saber qual é o grau de socialização tolerável da riqueza social (1997). A contabilidade dependerá sempre do que seja considerado receita da, tanto quanto do que seja considerado despesa da Previdência. É uma questão política, embora se tente torná-la apenas de nível técnico, uma questão de contabilidade.

Pouca atenção foi dada às alterações no mercado de trabalho, que modificou as proporções entre ativos e inativos e provocou queda na arrecadação previdenciária (Marques, 1995; Marques; Batich \& Mendes, 2003; Batich, 2004; Melo, 1995). As reformas no Brasil tocam no problema do assalariamento e suas transformações contemporâneas (Marques, 1995). Um dos importantes significados da reforma promovida pela Constituição de 1988 foi a ruptura com o vínculo entre o direito social e a inserção no mercado de trabalho, como assinala Melo (1995), o que lhe conferiu um valor positivo. A desvinculação poderia demonstrar não uma postura anacrônica, mas antecipatória, acompanhando as discussões na Europa sobre o fim do trabalho de longa duração e suas conseqüências sobre a vida das pessoas (Sennet, 1999). É o fim do paradigma "produtivista" das políticas sociais e a radicalização dos direitos de cidadania com base na defesa da renda mínima (citizens income) (Melo, 1995).

Historicamente a expansão dos direitos sociais foi acompanhada de uma cisão entre trabalho e direitos, que se expressa na idéia de cobertura de famílias com prole numerosa, mães solteiras e aposentadoria como prêmio à vida laboral. Ao mesmo tempo em que as aposentadorias se desvinculam da idéia de incapacidade e idade avançada, desassocia-se da idéia de mínimo universal, para aproximar-se dos salários da vida ativa e tem correlação com a incorporação das classes médias (Esping-Andersen, 1998). A intervenção social do Estado foi orientada por três movimentos: inclusão (que vai dos servidores públicos aos trabalhadores das indústrias, camponeses e autônomos); ampliação das categorias de riscos e necessidades; elevação do nível de benefícios no sistema. O padrão internacional aponta, 
portanto, para a expansão da população de segurados e ampliação de benefícios, sem guardar relação direta com o atendimento a necessidades sociais.

A crise do Estado de Bem-Estar Social é, ao mesmo tempo, a crise da sociedade salarial, isto é, do assalariamento como expressão de uma forma específica de integração social (Castel, 1998). Os riscos individuais/sociais perdem este caráter e assumem uma forma mais permanente, relacionada com o desemprego de longa duração (Rosanvallon, 1994) e com mudanças no paradigma fordista de produção (Harvey, 2003). É o tema de Castel da desfiliação, desincorporação do mercado de trabalho com ruptura nos padrões de proteção social.

A aposentadoria por tempo de serviço, fórmula estranha à condição de risco social, como vem sendo apontado tanto na literatura ${ }^{110}$ quanto no debate político, expressa essa modificação na lógica do direito social como decorrente da participação no mercado de trabalho e produtor de um status diferenciado. Foi, ao longo de todo o período estudado, o benefício mais contestado e objeto da primeira e mais importante reforma previdenciária ocorrida em 1998, quando o tempo de serviço cedeu lugar ao tempo de contribuição, indicando a condição prévia de contribuição como o critério que garante o acesso. Essa medida não apenas modifica o critério de acesso, mas rompe com a idéia de prêmio, embora não chegue a estabelecer a condição de um seguro, fica a meio termo entre dois objetivos.

No Brasil a associação entre trabalho e acesso à previdência foi implantada sob a forma de um prêmio garantido "ao fim da áspera caminhada",111, como uma recompensa não apenas pelos 50 anos de trabalho, mas pela boa conduta, pela prestação de relevantes serviços, pelo trabalho ininterrupto (sem férias, licença ou ausências do serviço em 45 anos) e após julgamento de mérito realizado pelos diretores da empresa. A fórmula

\footnotetext{
110 “Esse privilégio corporativo, elitista e socialmente injustificado é deletério para a gestão racional da Previdência, alimenta a dependência improdutiva ao Estado de gente produtiva, e é iníquo”, como sintetizou (ABrANCHES, 1992: 77). Ver ainda: (BRASIL, 1998; OllVEIRA; BELTRÃo \& MANIERO, 1993).

111 No discurso de apresentação do Projeto de Lei à Câmara dos Deputados, o deputado Eloy Chaves argumentou que o mesmo era uma aspiração dos empregados das estradas de ferro que não tinham nenhuma garantia para a velhice e em suas palavras: "o homem não vive só para si e para a hora fugaz que é o momento de sua passagem pelo mundo. Ele projeta sua personalidade para o futuro, sobrevive a si próprio em seus filhos. Seus esforços e aspirações devem também visar no fim da áspera caminhada, o repouso, a tranqüilidade. Os espinhos, as angústias, só são suportados com a esperança no prêmio final, seja este embora incerto e quase sempre inatingível (...)”. Deputado Eloy Chaves, Anais da Câmara, 1921: 203, apud ZANIRATO, 2003: 128. Grifos meus.
} 
“aposentadoria por tempo de serviço” sempre esteve presente no direito previdenciário como um prêmio conquistado ao final de uma carreira exercida sob a mais estrita disciplina. O acesso inicial era obtido mediante súplica e a concessão feita como um privilégio. Ela não foi criada nem como direito nem como expressão de um risco social (Zanirato, 2003: 148).

Os projetos de reforma debatidos e aprovados realizaram uma aproximação entre prestações previdenciárias e a condição de risco social, dotando-a de características de seguro social ao promover a associação entre contribuição e benefício, com componentes atuariais.

Há duas questões no centro do conflito armado em torno da reforma da Previdência Social e elas não se remetem ao mesmo tipo de problema. Para sintetizar de uma forma bastante simplificadora o tipo de argumentação e justificativa em que se amparam, poderíamos dizer que a primeira refere-se à definição de novos critérios políticos, enquanto a segunda refere-se a questões econômicas, como déficit público, gasto social, financiamento etc. Política e economia se confrontam no debate sobre a questão da definição do nível dos direitos sociais e este é um tema que cada vez mais vem sendo incorporado pela discussão da regulação econômica, o que promove uma reviravolta na idéia de direito, com a obrigação de se pensar o seu custo.

A primeira questão está armada em torno da tese da violação constitucional, ou seja, a não realização da promessa feita através da promulgação da Constituição Federal de 1988 de implantar a seguridade social (Vianna, 2000; Soares, 2001; Silva, 2004; Boschetti; 2003). Os defensores dessa tese tomam como ponto de partida o nível de direitos obtidos em 1988 como a realização de um ótimo social que deve ser formalmente preservado e institucionalmente implantado, tanto no que se refere a assegurar os direitos instituídos, quanto em garantir o seu financiamento. Essas duas dimensões implicam a realização tanto da Seguridade Social, concebida como uma nova técnica de proteção social superior (qualitativa e quantitativamente) em relação à previdência social, quanto a realização do OSS em sua finalidade de garantir recursos ao seu financiamento.

Nesse núcleo de argumentação, as reformas da previdência deveriam ocorrer para assegurar a realização daquilo que foi definido formalmente na Constituição, ou seja, a construção da universalidade como critério de acesso aos direitos sociais e realização da 
justiça social. No entanto, ao partir da acusação de violação constitucional constrói-se uma argumentação paradoxal para o direito social, imobilizando-o e perdendo de vista o fato de que ele representa o conflito distributivo por excelência. A definição do que pode ou não ser direito representa o quanto de recursos públicos está disponível para a partilha social. Se, a inscrição dos direitos sociais na Constituição Federal de 1988 representou uma tentativa de garantir a ampliação do estoque de benefícios e do contingente contemplado, ela revelou-se uma condição insuficiente e que só podemos compreender na chave de Ewald (1993), de que este é um problema da política e não do direito. O direito não é idêntico à legalidade, ele diz respeito à linha de corte, ao limite da partilha dos recursos públicos, sempre escassos.

A segunda questão está armada em torno das contas da Previdência Social, em saber se há déficit ou superávit entre arrecadação e despesas com benefícios (Dain, 2003; Soares, 2001; Anfip, 2002; Giambiagi et al, 2004; Gentil, 2007 ).

Há, entre as duas questões, razões diferentes para a realização de reformas. Se, ambas coincidem em sua interpretação negativa em relação à previdência, os argumentos são diametralmente opostos, porquê referido, de um lado, ao déficit de cidadania e de direitos e, de outro, ao déficit financeiro. A tentativa de diálogo entre esses dois núcleos argumentativos tem produzido a contestação da idéia de déficit financeiro, denunciando que a contabilidade não é uma técnica neutra, mas expressão de uma definição política das prioridades sociais.

Sem dúvida, houve ampla reformulação e reorganização dos direitos sociais, mas não no sentido intencionado com o texto constitucional. A primeira e mais importante foi a definição de uma política de assistência social de forma organizada e integrada, com garantia de renda para idosos e deficientes pobres e a equalização nas condições de acesso a benefícios previdenciários para trabalhadores rurais. A segunda foi a universalização do direito de acesso à saúde ao conjunto da população. No plano previdenciário, os direitos incorporados não provocaram uma mudança significativa que modificasse a sua lógica, o conjunto de beneficiários ou os critérios de elegibilidade.

As mudanças mais importantes que a previdência social iria sentir seria o lento processo de afirmação da saúde e da assistência social como políticas autônomas, fora da condição de integrantes do direito previdenciário. Nesse ponto, a Constituição representou 
mais significativamente a construção do direito de acesso à saúde universal e ao direito de renda para as populações mais pobres do que propriamente a criação de uma rede de seguridade social. Quando afirmo que foi um lento processo, estou me referindo a uma discussão não apenas conceitual, mas, sobretudo, de formalização de propostas concretas de separação, na base da produção material do direito e da sua base de sustentação financeira. Ao final desse lento processo algumas conseqüências não previstas inicialmente foram produzidas:

1. a afirmação da previdência social como uma política de seguro social, de base contributiva e vinculação obrigatória;

2. a afirmação da assistência social como uma política focalizada nas populações mais pobres;

3. um direito universal à saúde, como direito de cidadania;

4. a não efetivação do direito à seguridade social e

5. a disputa por recursos tributários.

As disputas em torno da previdência social são o centro de um conflito distributivo. O nascimento da saúde e da assistência social como direitos universais trouxe à tona a questão da necessidade de ampliação da base de financiamento. Tornava-se necessário captar recursos para financiá-los, uma vez que se tornavam independentes. Os conflitos em torno das contas da Previdência evidenciam a dificuldade do governo em partilhar recursos tributários para a realização de políticas sociais.

Embora a questão mais presente no debate público tenha sido o tema das reformas, a privatização e a retração de direitos sociais, o certo é que a previdência social reforçou o seu caráter de seguro social público, obrigatório e de vínculo contributivo. Se, por um lado, o escopo dos direitos foi redefinido e puxado para baixo, com critérios mais rígidos de elegibilidade e acesso, benefícios menores e sem diferenciais por categorias econômicas, por outro, foi assegurado que os recursos oriundos das contribuições sociais para a Previdência Social serão utilizados apenas e tão somente com essa finalidade.

Esse foi um lento processo em que, no debate público, tratou-se de definir qual é o objeto da Previdência Social, quem são os seus beneficiários, quem a sustenta e quais são seus objetivos. Desse escopo deixou de fazer parte tanto a saúde, quanto a assistência 
social. Ao final, a seguridade social fixou-se entre dois pólos: assistência social e seguro social. A discussão sobre o déficit da Previdência Social foi o fator que possibilitou a emergência de como os recursos oriundos de contribuições sociais diretas sobre a folha de pagamentos eram utilizados para fins estranhos à política de previdência social.

\section{Impactos da transição demográfica sobre a Previdência Social}

A bibliografia tem apontado que a análise dos critérios demográficos jamais foi levada em consideração para os ajustes necessários ao equilíbrio financeiro da Previdência Social (Beltrão, 1995) e que a situação tornou-se dramática na década de 90, tendo em vista a razão de dependência demográfica ${ }^{112}$ declinante: $9 / 10$ na década de 60; projeção de 6/10 em 2020. A taxa específica para a razão de dependência demográfica de jovens por idoso foi de 8/1 na década e deverá chegar a 2/1 em 2020, produzindo um grande impacto sobre as políticas públicas: saúde, educação, habitação, assistência, previdência etc. (Beltrão, 1995: $63)$.

Segundo a literatura, o Brasil passa por uma transição demográfica, que consiste num ciclo entre estabilidade, queda dos níveis de mortalidade, seguido de um intervalo, queda nos níveis de fecundidade, e um outro período de estabilidade. A especificidade do Brasil e dos países latino-americanos foi a velocidade em que a transição ocorreu, aproximadamente de 30 anos, enquanto levou dois séculos na Europa. A redução da taxa de mortalidade infantil e da mortalidade ${ }^{113}$ em geral, aliada ao declínio da taxa de fecundidade ${ }^{114}$ provocou uma queda na taxa de crescimento populacional de $3 \%$ ao ano entre os anos 50 e 60, para 1,9\% na década de 1980 e com projeção de que não atinja 1\%

\footnotetext{
112 Dependência demográfica é o quociente entre a população dependente (jovens de 0 a 14 anos e idosos com mais de 60 anos) e a População em Idade Ativa (15-59 anos).

113 "A população brasileira experimentou uma queda na mortalidade antes da redução na fecuniddade, conforme indica o aumento da esperança de vida ao nascer, que passou de 43,6 anos, na década de 40, para 53,7,na de 60. A mortalidade continuou sua tendência de declínio nos anos 70, com a esperança de vida passando para 59,9 anos - um ganho de 6,2 anos apenas nesta década” (RIOs-NeTO, 2005: 375).

114 “A Taxa de Fecundidade Total (TFT), definida como o número de filhos que uma mulher teria ao final do período reprodutivo, passou de 6,3 filhos por mulher, em 1960, para 2,9 em 1991 e diminuiu para 2,3 em 2000. Os resultados do PNAD de 2003 apontam uma taxa de fecundidade total de 2,1 filhos por mulher, o que representa o chamado nível de reposição. Isto quer dizer que, se esta taxa perdurar por um período de cerca de 25 anos, o crescimento populacional brasileiro convergirá para zero" (RIOs-NETO, 2005: 372). A situação torna-se ainda mais grave ao se considerar que a maior taxa de fecundidade tem ocorrido entre mulheres pobres mais jovens, com idade entre15 e 19 anos, o que poderia ser corrigido com políticas universais de combate à pobreza e de saúde reprodutiva da mulher, fazendo declinar ainda mais a TFT.
} 
em 2020 (Beltrão, 1995: 61). A conseqüência direta tem sido um rápido envelhecimento da população que altera a demanda por políticas sociais, quantitativa e qualitativamente, especialmente na saúde, previdência e assistência social.

O impacto sobre a previdência social deve levar em consideração, além da transição demográfica, aquela que incide na dinâmica do mercado de trabalho ${ }^{115}$ (Beltrão, 1995;Marques, 1995; Carvalho \& Bernardes, 1996). Nesse caso, devemos considerar que tanto a razão de dependência demográfica, quanto a razão de dependência entre beneficiários/contribuintes tem se alterado.

Historicamente, a previdência privilegiou o ajuste de curto prazo com base no aumento de alíquotas de contribuições para trabalhadores e empresas e criação de novas fontes de contribuições, como o lucro e o faturamento, subindexação na correção monetária do valor do benefício e encurtamento de prazos para recolhimento das contribuições. Ou seja, os ajustes processados foram internos à contabilidade da Previdência, com aumento das contribuições ou redução das despesas, possível porque as regras de cálculo do valor dos benefícios e reajuste eram procedimentos normativos intrínsecos à instituição. A alteração das regras de cálculo do benefício conduziu a uma reconfiguração da problemática.

A análise demográfica, ao ser considerada nos ajustes processados na previdência social, poderia levar a uma maior estabilidade e à preservação do equilíbrio econômicofinanceiro e, ao mesmo tempo, atender aos critérios de eqüidade. O que consiste em razão suficiente para defender o fim da aposentadoria por tempo de serviço e dos critérios diferencias de elegibilidade, como aqueles de tempo e idade para mulheres ${ }^{116}$, trabalhadoras trabalhadoras rurais e condições especiais de trabalho (Beltrão, 1995).

\footnotetext{
${ }^{115} \mathrm{Na}$ indústria paulista, em 1995, houve uma perda líquida de cerca de 180 mil postos de trabalho. A retração do emprego na indústria vem adquirindo um caráter estrutural, com perda de dinamismo na geração de novos postos de trabalho. Um outro fator relevante nesta análise é a introdução de novas tecnologias substitutivas de mão de obra e o crescimento do emprego no setor de serviços, em condições mais precárias e, muitas vezes, à margem do sistema de proteção social (CARVALHo \& BERNARDES, 1996: 55). Na Grande São Paulo apurouse um aumento na taxa de desemprego de um patamar médio de 9,9\% da PEA, no período de 1985-1989, para um nível médio de 13,2\%, nos anos 1990-1995, com uma mudança significativa no perfil do contingente de desempregados, que passou a incluir categorias antes não ameaçadas (MoNTAGNER \& BRANDÃo, 1996: 44). 116 "A esperança de vida das mulheres, em 1980, era de 66 anos, contra 59,6 anos dos homens, ou seja, 6,4 anos a mais para mulheres. Em 2001, a esperança de vida feminina já era 7,8 anos superior à dos homens 72,9 anos e 65,1 anos, respectivamente” (RIOS-NETO, 2005: 375). Uma das principais explicações para o diferencial na expectativa de vida por sexo seria as mortes por causas externas (acidentes, homicídios, suicídios, quedas acidentais, afogamentos, trânsito, etc), com maior incidência entre os homens.
} 
As análises demográficas têm apontado diferenças na expectativa de vida entre homens e mulheres, com taxa de sobrevida maior entre estas, o que não justificaria o tempo e a idade reduzida em cinco anos para aposentadoria, em comparação com os homens. Do mesmo modo, Beltrão (1995) identifica que há uma expectativa de vida ao nascer maior entre trabalhadores rurais do que entre trabalhadores urbanos, sendo que o que reduz a expectativa é a condição de pobreza do estado de origem, o que demandaria uma análise mais aprofundada de condições regionais na definição de critérios de elegibilidade, que poderiam não ser universais. Essas análises influenciaram as discussões sobre as reformas da Previdência de 1998 (Ornélas; Vieira, 1999) e foram decisivas na formulação do projeto sobre o fator previdenciário, que traz como critério de elegibilidade para aposentadoria uma combinação entre tempo de contribuição, idade e expectativa de sobrevida ${ }^{117}$. As teorias que tratam da transição demográfica tornaram-se de domínio público, principalmente aquelas patrocinadas pelo IPEA, que tem por atribuição fornecer suporte técnico e institucional às ações do governo ${ }^{118}$.

A ênfase na teoria da transição demográfica avançou durante o debate ANC e intensificou-se após a promulgação da Constituição, contribuindo para consolidar a idéia da necessidade de reformas na previdência social. O Censo de 1980 havia revelado uma queda na taxa de fecundidade, declínio moderado na taxa de mortalidade, a configuração de uma nova dinâmica demográfica e uma mudança na estrutura etária do país, especialmente nos grupos dependentes - menores de 15 anos e maiores de 65 anos (Henriques \& Beltrão, 1986). Começava a ser delineada uma preocupação com o equilíbrio entre contribuintes e beneficiários na Previdência Social, com vistas a garantir o seu próprio equilíbrio econômico-financeiro, mas havia também uma preocupação com a migração interna, especialmente de áreas rurais para áreas urbanas e a adoção de regras diferenciadas de acesso à aposentadoria, que poderia afetar o desempenho das contas da Previdência Social $^{119}$.

\footnotetext{
${ }^{117} \mathrm{O}$ diferencial de tempo de vida entre a idade de vida e a expectativa de vida, sendo que quanto maior for o diferencial, menor será o valor do benefício (Lei 9.876/99). A fórmula de cálculo está transcrita no Anexo 1.

${ }^{118}$ São exemplos das análises efetuadas pelo IPEA: PinHeIro \& Sugahara, 2001; BELTrão \& PinHeIRo, 2002a; Beltrão\&Pinheiro, 2002b; Beltrão; Sugahara; Peyneau \& Mendonça, 2003; Beltrão, 2000; VARSANO, 998; ELLENY JR., 1998.

${ }^{119}$ Uma ênfase histórica na abordagem do perfil demográfico sobre a Previdência Social pode ser encontrada em (ANDRADE, 1997).
} 
Em 1994, durante os debates da revisão constitucional, Rios-Neto (1994) e Alves (1994) afirmavam que, no entanto, a transição demográfica era mais uma teoria do que um fato consumado e que o cenário era ideal para a realização de reformas, dado que o aumento da expectativa de vida não havia alterado a estrutura etária da população, ou seja, o percentual de idosos sobre o conjunto da população não havia se alterado. Indicava, no entanto, ser necessário observar outros fenômenos relacionados ao mercado de trabalho como o ingresso tardio e a aposentadoria precoce, mesmo com redução no seu valor; o maior tempo de permanência da mulher no mercado de trabalho e aumento da participação na condição de autônomo na população acima de 40 anos, estes sim, com repercussão sobre o aumento dos gastos previdenciários.

Uma outra dimensão que, embora incipiente, já vem sendo abordada na análise demográfica é a questão da incapacidade, que sobrepõe à análise da esperança de vida, aquela de “esperança de vida ativa” (Baptista, 2003). Neste caso, importa refinar a análise para conhecer quantos anos de vida ativa, sem incapacidade (de enxergar, ouvir, se locomover) ou deficiência (física ou mental) uma pessoa terá ${ }^{120}$. Comparativamente, as mulheres, embora possuam esperança de vida superior à dos homens, passam uma maior proporção de seu tempo de vida em estado de incapacidade, e também em incapacidade severa (em média 50\% maior que a dos homens). Essa descoberta demonstra que a questão não é simples e tem conseqüências sobre a previdência social, aumentando a necessidade de investimento em políticas de saúde e assistência aos idosos. De outro modo, uma análise mais refinada da relação de incapacidade entre homens e mulheres demonstra a falácia do argumento de remoção da clivagem de gênero na concessão de benefícios previdenciários centrado apenas na expectativa de vida. O que essa clivagem parece estar indicando é a necessidade de cautela nas análises que consideram apenas o tempo de vida, sem considerar a condição para o trabalho. Fazer declinar o número de aposentadorias por idade ou tempo de contribuição pode fazer aumentar a incidência de aposentadorias por incapacidade para o trabalho.

\footnotetext{
${ }^{120}$ Calcula-se que a esperança de vida ativa de um homem corresponda a 80,4\% de sua esperança de vida, enquanto que a das mulheres corresponderia a $77 \%$ de sua esperança de vida em São Paulo. Comparativamente, as mulheres passam uma maior proporção de seu tempo de vida em estado de incapacidade, e também em incapacidade severa, 50\% maior que ao dos homens (BAPTISTA, 2003).
} 
Análises mais recentes têm, ainda, indicado a influência de outros fatores sobre a dinâmica populacional, como a migração internacional e seus desdobramentos futuros sobre a dinâmica do mercado de trabalho, arrecadação e gastos previdenciários ${ }^{121}$.

Fugindo às análises convencionais, Rios-Neto (2005) enfatiza que a mudança do perfil demográfico pode ser benéfica para o investimento em capital humano, através do incentivo à educação, o que provocaria dupla mudança nas transferências intergeracionais ${ }^{122}$, como uma “troca de recursos no tempo". Toda a sua análise está centrada na hipótese de que a universalização da educação, através de investimento público, poderia fortalecer o papel da família na distribuição social, reduzindo a participação do Estado em assegurar a velhice como conseqüência de uma revisão no papel da solidariedade entre gerações.

Rios-Neto retoma a tese dos três mecanismos básicos de troca de recursos no tempo, pilares da geração do bem-estar social (Esping-Andersen, 1998): Estado, família e mercado. No Brasil, o papel do mercado é restrito devido à baixa renda, restrições ao crédito e imperfeições na posse de ativos. A transmissão de herança, a educação (em relação aos filhos) e os cuidados com idosos representam trocas de recursos no tempo, realizadas pela família. Ou seja, a família está no centro dos dois extremos da pirâmide etária - crianças e idosos. A limitação orçamentária e as restrições ao crédito de famílias pobres impedem as transferências de herança e investimentos em educação, levando à maior dependência do Estado (Rios-Neto, 2005: 395-396). O seu principal limite é a desigualdade social, que tende a se reproduzir com impacto negativo sobre a previdência social. Portanto, a saída que vislumbra é o investimento em educação pública, gratuita e de qualidade, que possa fazer parte do pacto de transferência intergeracional, assim como a seguridade social (Rios-Neto: 396). O investimento estatal universal em educação representaria a hipótese da eficiência: reduziria o investimento ineficiente das famílias pobres (no presente), permitiria elevação de renda (no futuro) e melhoraria a provisão de segurança na velhice (futuro).

\footnotetext{
${ }^{121}$ Dados do Ministério das Relações Exteriores de 2002 indicavam um total de 188.895 brasileiros emigrantes, apud Rios-NETo, 2005: 378. É oportuno ressaltar que, mesmo sem contribuírem para a Previdência Social poderão requerer benefícios assistenciais quando em idade avançada.

${ }^{122}$ A Previdência Social estruturada a partir do modelo de repartição simples, no qual os trabalhadores da ativa financiam a aposentadoria de inativos, realiza um programa de transferência de renda intergeracional.
} 


\section{Capítulo III}

\section{AS CONTAS DA PREVIDÊNCIA SOCIAL}

O conflito que as “contas da Previdência Social” encerra é de natureza distributiva e contém uma dupla dimensão: a de quem paga e a de quem recebe. Este é o tema deste capítulo: quem é o sujeito deste direito e quem deve financiá-lo. O conflito não é intrínseco à Previdência Social, mas social, no sentido de que perpassa os novos arranjos institucionais e a forma como são financiados os diversos programas sociais. Os argumentos empresariais sobre o “custo Brasil”. Do lado da arrecadação projeta-se uma crítica à afirmação constitucional de que "a seguridade social será financiada por toda a sociedade" e a tendência tem sido a do fortalecimento da previdência como um seguro social, de vínculo contributivo obrigatório para todos que tenham capacidade contributiva.

As “contas da Previdência” têm sido objeto de uma longa controvérsia entre estudiosos e tem sido pautada principalmente pela idéia de racionalidade econômica, segundo a qual, se deve buscar o máximo de eficiência e de eficácia na alocação de recursos escassos. Por atender aos trabalhadores melhores situados no mercado de trabalho - que possuem capacidade contributiva e que podem comprovar tempo de contribuição - a previdência social deveria ser financiada única e exclusivamente pelos seus futuros beneficiários. Esse argumento seria suficiente para retirar toda e qualquer participação do Estado em seu financiamento, assim como a participação dos empregadores, o que implica não apenas na não partilha das contribuições sociais que compõem o OSS, como o não repasse de recursos fiscais para o seu financiamento ou mesmo cobertura de eventuais insuficiências financeira. O contra-argumento é que esse recurso deve se destinar ao financiamento de políticas sociais focalizadas nas populações mais pobres. O resultado é o fortalecimento da tese de que a previdência social deva ser auto-sustentada.

Ao longo do processo de reforma da previdência e da polêmica que o tem acompanhado, pudemos verificar a oscilação do debate entre dois pólos opostos: como a construção de uma referência que torna os números indiscutíveis e sustenta o argumento da 
reforma e como alvo de denúncias que objetiva desconstruir aqueles argumentos. É Desrosière (1993) quem ajuda na compreensão de como os resultados estatísticos são objeto de sínteses e de debates públicos sempre apoiados em comparações e como os resultados e as descrições dependem de métodos, de formalismoe de modos de argumentação. Ou seja, os dados estatísticos podem representar a tensão entre como a informação entra como referência ao debate e como pode sempre ser questionada. Para Desrosière (1993), a construção de um sistema estatístico é inseparável da construção de espaços de equivalência que garantam a consistência e a persistência de objetos que fornecem a referência ao debate, como uma construção de “fatos indiscutíveis”.

Nos debates sobre a reforma da previdência dois argumentos centrais foram armados em torno dos direitos instituídos pela Constituição de 1988, a sua base de financiamento e o impacto nas contas públicas. As “contas da Previdência Social” são centrais na formação de propostas de reforma e na defesa dos direitos sociais, mas o debate que gera perpassa outros objetos como o orçamento público e a partilha de recursos públicos, expressando um conflito distributivo pela partilha do fundo público. Como argumenta Ewald (1993) é a disputa essencial da partilha, do que pode ou não ser direito.

Saber se a Previdência Social era deficitária ou superavitária mobilizou um amplo grupo de pesquisadores que demonstraram que os resultados dependiam principalmente das metodologias utilizadas e de como o déficit era apurado. Vários pesquisadores vêm demonstrando como a metodologia de cálculo do governo baseia-se tão somente na razão entre arrecadação própria (contribuição de empregados e empregadores sobre a folha de pagamentos) e os gastos com benefícios sociais (Gentil, 2007; Soares, 2001; ANFIP, 2002; 2005; Dain, 2003; Marques, 1995). O uso de dois artifícios foi denunciado ao longo do tempo: de um lado, a desconsideração da participação das contribuições sociais na formação da receita e, por outro, a inclusão entre as despesas de benefícios não contributivos. Isto é, para a formação da receita trata-se a previdência como um seguro social de vínculo contributivo e sob regime de repartição em que as contribuições atuais financiam as aposentadorias atuais, enquanto que para a formação das despesas inclui benefícios assistenciais, encargos previdenciários da União, aposentadoria dos trabalhadores rurais e aposentadorias especiais, tratando-a como expressão da seguridade social. 
O longo debate em torno das contas da Previdência assumiu a forma de um conflito público que conduziu a um amplo processo de racionalização que incidiu sobre a sua contabilidade, aprofundando a reforma iniciada com a Constituição de 1988. As contas da Previdência Social foram submetidas a um amplo controle público que exigiu maior transparência e explicitou o conflito distributivo. Muito longe de decidir a disputa em torno do déficit ou do superávit nas contas, o controle permitiu sistematizar a análise das receitas e das despesas e reafirmar a previdência social como um regime público, de vínculo contributivo obrigatório, cuja contribuição deve estar referida a um sistema atuarial de contrapartida em benefícios.

O controle público sobre as contas da Previdência foi um segundo caminho de um amplo processo de reforma que permitiu que não apenas fossem modificados os critérios de acesso e elegibilidade dos benefícios, mas também fosse modificado o modo como os dados são apresentados à sociedade.

O documento "Trabalhos relevantes sobre a Previdência Social: uma contribuição do TCU ao debate da Reforma da Previdência Social”"123 contribui com um olhar externo das contas da Previdência que permite romper com a perspectiva de uma análise apenas do fluxo de caixa. Este documento é uma síntese dos processos que tratam das contas do Governo Federal. A função do Tribunal de Contas é exercer o controle externo sobre a gestão pública, dentro de suas atribuições constitucionais.

Um dos principais pontos abordados no processo sobre as contas do Governo Federal no exercício de $2002^{124}$ foi a Previdência Social. O crescimento do pagamento de benefícios previdenciários foi da ordem de 17\%, com acréscimo líquido de 1.092 .654 novos benefícios. O cálculo da diferença entre a arrecadação líquida das contribuições dos trabalhadores e empregadores para a Previdência Social e os valores pagos a título de benefícios previdenciários pelo INSS apontava um diferencial negativo de R\$ 17 bilhões no exercício, confirmando o déficit previdenciário.

No entanto, o TCU desagregou o déficit apontando problemas tanto no lado das despesas quanto das receitas. A síntese dos processos que analisam as contas da

\footnotetext{
${ }^{123}$ Tribunal de Contas da União, Brasília: TCU, 4 ${ }^{\text {a }}$ Secex, 2003. O documento assim como outros relatórios do TCU podem ser acessados na home-page do TCU na internet: www.tcu.gov.br.

${ }^{124}$ TC n. 006.113/2003-2.
} 
Previdência assinala que do déficit apurado apenas $\mathrm{R}$ \$ 2,2 bilhões podiam ser atribuídos aos trabalhadores urbanos, um universo de 14.255.920 beneficiários do RGPS.

A análise do TCU apontou que os maiores desequilíbrios eram verificados no pagamento de benefícios previdenciários aos trabalhadores rurais, cujo diferencial era de R\$ 14,8 bilhões, relativos a 6.869 .592 benefícios; no pagamento das aposentadorias ou pensões concedidas aos trabalhadores por idade, que representavam mais de $30 \%$ dos benefícios concedidos e no pagamento de pensões aos portadores de necessidades especiais sem meios próprios de sobrevivência e que integravam a despesa do Sistema Previdenciário.

A inserção de benefícios de natureza assistencial na contabilidade do RGPS contribui para o desequilíbrio financeiro e atuarial e fere o princípio de que as contribuições sociais, patronais e dos trabalhadores, somente podem ser utilizadas para o pagamento de benefícios do RGPS. A assistência social deve ser financiada exclusivamente por receitas orçamentárias não vinculadas e distintas daquelas. ${ }^{125}$ De outro modo, salienta que a baixa contribuição patronal do setor rural é uma das principais razões do desequilíbrio financeiro do RGPS.

Do lado das receitas, o TCU apontou que o impacto das renúncias de receitas ${ }^{126}$ sobre a Previdência Social correspondeu a R \$ 9,2 bilhões em 2002 e já havia alcançado R\$ 7,59 bilhões em 1998. “Isso implica em que alguns segmentos, a exemplo das entidades filantrópicas, já estão se beneficiando ou se beneficiarão sem nunca terem contribuído para o Sistema, o que tende a prejudicar ainda mais a situação existente, não obstante, no caso dessas entidades, estarem amparadas pela Constituição Federal” 127. A baixa eficiência na arrecadação nos créditos previdenciários em cobrança é também apontada pelo documento: do volume de R 169 bilhões em 2002, correspondente a R\$ 93,4 bilhões em dívida ativa e R\$ 75,6 bilhões em cobrança administrativa, foram arrecadados respectivamente 4,17\% e 1,45\% ${ }^{128}$. Em março de 2007 a dívida com o INSS alcançava R\$

\footnotetext{
125 “Contas do Governo Federal”, in: (TCU, 2002: 12).

126 São contabilizados como montante da renúncia fiscal a imunidade a entidades filantrópicas, clubes de futebol profissional, produtores rurais, empresas de pequeno porte (recolhimento de tributos simplificados por meio do SIMPLES) e contribuições substitutivas.

127 “Contas do Governo Federal”, in: (TCU,2002: 11).

${ }^{128}$ No exercício de 2002 foram arrecadados R\$ 3,9 bilhões da dívida no âmbito administrativo e R\$ 1,1 bilhões no âmbito judicial. Idem: TC n. 006.113/2003-2. A análise do TCU detectou indícios de falhas no sistema de arrecadação de receitas previdenciárias, com falta de controle no repasse de documentos e valores
} 
129,894 bilhões ${ }^{129}$. A previsão de renúncia fiscal para o ano de 2008, fixada no PL das Diretrizes Orçamentárias enviado pelo governo ao Congresso projetava a renúncia de R\$ 14,767 bilhões em receitas da Previdência Social, por conta de renúncias concedidas a micro e pequenas empresas, entidades filantrópicas e exportadores agrícolas e representa aumento de $16,7 \%$ em relação à previsão para $2007^{130}$.

Com a crescente evolução das renúncias das contribuições previdenciárias, o Ministério da Previdência Social iniciou uma forte campanha para retirar esses benefícios fiscais das suas contas, o que aliviaria o déficit previdenciário. Em 2006, o total de contribuições que deixaram de ser arrecadadas era da ordem de R \$ 18 milhões de reais.

O ponto central da análise, contudo, repousa no alto índice de informalidade da economia que acabará por exaurir a fonte de financiamento principal da Previdência Social, a folha de pagamentos do mercado urbano e formal de trabalho, caso persistam as distorções apontadas no documento. Mesmo que se consiga reduzir drasticamente os benefícios daqueles que contribuem e se aumente significativamente o limite de idade, o Sistema de Seguridade Social será inviabilizado por falta absoluta de recursos. Isso porque o sistema deverá absorver com pagamento de aposentadorias ou pensões um percentual considerável da população economicamente ativa que hoje não contribui para o sistema, estimado pelo IBGE em 41 milhões de pessoas (54\% da PEA) ${ }^{131}$.

Ao acompanhar o OSS no período de 1997 a 2000, o TCU ${ }^{132}$ constatou dificuldades para identificar o resultado da seguridade social porque inexiste balanço específico para essa esfera orçamentária. Na análise, o TCU constatou que não existe uma separação de fato entre o OF e o OSS, o que impede observar com clareza as receitas que compõem a sua base de financiamento e a real destinação das receitas legalmente vinculadas ao OSS. Para

referentes à arrecadação bancária que concentra a maior parte da receita previdenciária. Na denúncia apurouse que o INSS não realiza fiscalizações para verificar a segurança e a confiabilidade dos relatórios emitidos pelos bancos arrecadadores. TC 015.984/2001-4, DOU de 11/04/2003.

${ }^{129}$ A lei 8.212/91, determinou a publicação trimestral da relação dos devedores das contribuições e um relatório circunstanciado das medidas administrativas e judiciais adotadas para a cobrança e execução da dívida e, que de fato só passou a ser cumprida em maio de 2003. Na relação do INSS ficavam de fora empresas que contestavam os débitos administrativa ou judicialmente. A publicação deixou de ser realizada com a criação da Secretaria da Receita Federal.

130 “Renúncia previdenciária aumentará 17\% em 2008”. Folha de São Paulo, 28/04/2007, B6.

${ }^{131}$ A PEA de 2001 foi calculada em 75 milhões de pessoas. IBGE, 2001.

132 TC n. 928.231/1998-4, Decisão n. 1511/2002 - Plenário. Relatório, voto e decisão publicados no DOU de 8/7/2002 e na Ata TCU-Plenário nº. 21/2002. Síntese do processo integra o documento "Trabalhos Relevantes sobre a Previdência Social: Uma contribuição do TCU ao Debate da Reforma da Previdência Social” (TCU, 2003). 
efetuar a análise, o TCU ajustou a despesa da seguridade social através da exclusão de despesas consideradas como não pertencentes ao referido orçamento, que foi da ordem de 2,3\% em média, no período.

Ao analisar as receitas e despesas da seguridade social referente ao exercício de 2002, o TCU novamente observou a inexistência de um orçamento específico para a seguridade social em descumprimento à norma constitucional. Em particular, as classificações orçamentárias da receita, por natureza ou fonte orçamentária, não conduzem à identificação das receitas vinculadas à seguridade social. Foram apuradas receitas vinculadas à seguridade social no total de R\$165,8 bilhões, deduzidas as receitas desvinculadas pela DRU (R \$19,5 bilhões) restaram R\$ 146,28 bilhões para aplicação na esfera orçamentária da seguridade social. Com a DRU, o resultado da seguridade social foi deficitário no período de 1997 a 2002. Sem a DRU, o resultado apresentaria situação superavitária nos exercícios de 2000 a 2002.

Em relação às despesas por unidades orçamentárias vinculadas ao MPAS e ao Ministério da Saúde, somaram R\$ 175,4 bilhões, dos quais 56,75\% corresponderam ao MPAS e 16,12\% ao Ministério da Saúde. A função “previdência” acumulou despesa de R\$ 123,2 bilhões, cabendo R \$92,3 ao MPAS e o restante, corresponde ao pagamento da previdência de inativos e pensionistas da União.

O TCU foi responsável pela exigência de uma modificação não apenas na forma de apresentação das “contas da Previdência Social”, como na sistematização do uso dos recursos a ela destinados, consolidando o controle público.

Em 2002, o Livro Branco da Previdência Social já admitia que “a folha de salários deve ser fonte de financiamento da Previdência Social. Mas as outras ações da Seguridade Social devem ser financiadas por fontes outras que não a folha salarial, dentre elas as contribuições incidentes sobre faturamento, lucro, concursos e prognósticos $e$ movimentação financeira. Esta última tem a virtude de incluir na base de tributação até mesmo a parcela informal da economia. Dessas fontes deveriam provir também os recursos para financiar os benefícios previdenciários subsidiados, de caráter assistencial, e as renúncias de contribuições previdenciárias” (MPAS, 2002: 62).

Expressava também a necessidade de se distinguir entre benefícios previdenciários e assistenciais e fonte de custeio específico; entre benefícios para trabalhadores urbanos e 
rurais; entre segurados normais e especiais; entre trabalhadores da iniciativa privada e servidores públicos. O documento também expressava o reconhecimento de que os benefícios rurais não perderão o seu caráter assistencial, pois, embora sejam formalmente previdenciários, são, efetivamente assistenciais, em face da insignificância da contribuição em relação ao dispêndio com o pagamento dos respectivos benefícios. A arrecadação na área rural tem representado menos de $10 \%$ do valor total da despesa e, se for considerada a despesa com segurados especiais, essa relação cai a menos de $2 \%$.

O documento explicitava o reconhecimento da necessidade de promover uma rígida separação nas contas previdenciárias entre os benefícios contributivos e os não contributivos e também de se tornar públicos os critérios de financiamento, custeio e pagamento de benefícios. Mas, o documento foi além e denunciou como a promoção de regras diferenciadas de financiamento também produz impacto negativo nas contas previdenciárias, contribuindo para agravar o déficit previdenciário. O MPAS passou a investir contra as renúncias de arrecadação previdenciária, a formação de contratos especiais e a introdução de categorias especiais de beneficiários e a exigir a sua reformulação. Identifico este como um movimento de racionalização da instituição previdenciária que foi um produto de todo o debate em torno das contas previdenciárias e das reformas da previdência social. Um movimento plenamente identificado com a modernização das técnicas de gestão e com o discurso da racionalidade econômica.

O tratamento diferenciado a segmentos especiais da sociedade em relação à contribuição previdenciária reduz o valor das receitas previdenciárias e influenciam no desequilíbrio entre receita e despesa. Recebem tratamento diferenciado: as políticas de garantia de renda ao trabalhador rural idoso; a geração de emprego e renda para micro e pequenas empresas; a formalização do emprego doméstico; o estímulo às ações de saúde, educação e assistência social e o parcelamento em condições especiais como o Programa de Recuperação Fiscal (REFIS). As entidades beneficentes de assistência social gozam de imunidade constitucional, não recolhendo a contribuição patronal ao RGPS. Os empregadores rurais (pessoa física e jurídica), os clubes de futebol e as empresas optantes pelo SIMPLES também se beneficiam de contribuição substitutiva com encargos inferiores às contribuições sobre a folha de pagamento de salários. A cota patronal do empregador doméstico também é reduzida, como política de incentivo à formalização do emprego 
doméstico. O segurado especial também tem acesso aos benefícios previdenciários com a contrapartida de uma contribuição decorrente da receita obtida com a comercialização de sua produção. A estimativa de perda de receita no ano de 2001 foi de R \$ 7,4 bilhões, o que afeta o nível do déficit do INSS.

A perda de receita foi definida na LRF como renúncia, anistia, remissão, subsídio, crédito presumido, concessão de isenção em caráter não geral, alteração de alíquota ou modificação da base de cálculo que implique em redução discriminada de tributos ou tratamento diferenciado tanto em relação à contribuição, quanto em relação ao benefício. Em 2003, a renúncia previdenciária totalizou R \$ 4,8 milhões, considerando apenas micro e pequenas empresas, entidades filantrópicas, empregadores rurais (pessoa física e jurídica) e clube de futebol, como demonstra a tabela 2.

Tabela 2. Renúncia de contribuição previdenciária em face de tratamento diferenciado 1995-2003 (Em R\$ milhões correntes)

\begin{tabular}{|c|c|c|c|c|c|c|c|c|c|}
\hline Segmento & 1995 & 1996 * & $1997^{*}$ & 1998 & 1999 & 2000 & 2001 & 2002 & 2003 \\
\hline SIMPLES (1) & -- & - & 969,1 & 1044,9 & 1723,4 & 1937,4 & 1400 & 1552,7 & 1703,2 \\
\hline Ent. Filantrópicas & 921,3 & 1156,6 & 1264,6 & 1336 & 1501,4 & 1684,9 & 1790 & 1985,2 & 2177,7 \\
\hline Empregador Rural & 394,3 & 495 & 541,2 & 571,8 & 608,7 & 683 & 766,1 & 849,7 & 932,1 \\
\hline Clube de Futebol & 46,7 & 58,7 & 64,2 & 45,2 & 48,1 & 54 & 60,5 & 67,1 & 73,6 \\
\hline Total & 1362,4 & 1710,3 & 2839,1 & 2997,9 & 3881,6 & 4359,3 & 4016,6 & 4454,7 & 4886.6 \\
\hline
\end{tabular}

As discussões em torno da renúncia previdenciária e as propostas de revisão são reveladoras do conflito interno ao governo, entre as áreas previdenciária e fazendária, e buscam redefinir quem deve pagar a conta dos incentivos fiscais. Não se trata de pôr em discussão a sua finalidade ou os benefícios sociais que geram, mas que não compete à Previdência Social arcar com o ônus que representa a perda da receita previdenciária. É sob esse prisma que as contribuições à Previdência são reafirmadas como "o prêmio do seguro social pago por empregados e trabalhadores para garantia de renda na falta temporária ou permanente de forças de trabalho. O custo desse seguro é similar para todos, devendo, portanto, haver igualdade de contribuições” (MPAS, 2002: 85). O Ministério reafirma, assim, que os eventuais incentivos e subsídios que o Estado der a estes setores devem limitar-se a tributos outros que não as contribuições à Previdência Social. 
Em relação às entidades beneficentes de assistência social, o MInistério defende que a imunidade constitucional deva ser dirigida às entidades que auxiliam ou substituam o Estado nas ações previstas de assistência social definidas na Constituição (proteção à família, à maternidade, à infância, à adolescência e à velhice; amparo às crianças e adolescentes carentes; a promoção da integração ao mercado de trabalho; a habilitação e reabilitação de pessoas portadoras de deficiência e a promoção de sua integração à vida comunitária). A Previdência Social passou a defender que a isenção das contribuições previdenciárias a entidades filantrópicas carece de sustentação técnica e/ou doutrinária e que não se funda em qualquer princípio previdenciário e que a solução mais adequada seria a vedação constitucional de isenção de contribuições previdenciária e que qualquer subsídio deveria ser decorrente de outros tributos.

Embora sejam reconhecidos os ganhos que a arrecadação simplificada de tributos e contribuições sociais trouxe à sociedade com a formalização dos empregos, a redução da sonegação fiscal e a simplificação de procedimentos arrecadatórios, o Ministério lançou uma ofensiva contra a renúncia previdenciária. Pelo SIMPLES, a totalidade de recursos arrecadados é repartida conforme uma cota-parte fixada em lei que leva à redução da contribuição previdenciária. Com base nos pareceres do TCU, o Ministério passou a defender que a cota patronal (de $20 \%$ sobre a folha de salários) fosse integralmente repassada à Previdência Social posto que, embora o aumento do nível de formalização de emprego compense a perda presente de arrecadação, no futuro poderá provocar importante impacto financeiro negativo.

A situação dos clubes de futebol é ainda mais complicada, posto que não têm patrimônio próprio, possuem diretoria temporária e são grandes inadimplentes. A contribuição patronal sobre a folha de pagamento de salários foi substituída em 1993 pela contribuição de 5\% da renda dos espetáculos desportivos e, em 1996, foi ampliada para 5\% da receita bruta decorrente dos espetáculos desportivos de que participem em território nacional, considerando também o patrocínio, licenciamento do uso de marcas e símbolos, publicidade, propaganda e transmissão de espetáculos. Mesmo assim, a arrecadação revelase sistematicamente inferior à da aplicação da regra universal. Por isso, o Ministério defende o retorno da contribuição sobre a folha de salários e alternativas que alcancem a contribuição sobre a negociação de jogadores, empresas intermediadoras etc. 
A contribuição do empregador rural foi substituída por um percentual da receita bruta decorrente da comercialização dos produtos, de 2,1\% para empregador pessoa física e 2,6\% para empregador pessoa jurídica. A substituição da forma de contribuição foi uma decisão política para atender às peculiaridades do setor e incentivar a formalização do trabalho rural. No entanto, o Ministério estima como baixa (menos de 30\%) a formalização no segmento agrário e a arrecadação, de fato, tornou-se menor que a decorrente da folha de salários. Por isso, passou a defender o retorno da arrecadação sobre a folha de salários, com adoção da mesma regra aplicada às demais empresas. Os empregadores rurais são, também, beneficiados pela isenção do recolhimento da contribuição previdenciária sobre a produção exportada, o que gera uma perda de receita da ordem de R \$1,07 bilhão.

Os pequenos produtores rurais (segurados especiais) também recebem tratamento previdenciário diferenciado, com contribuição de 2,1\% incidente sobre a receita bruta decorrente da comercialização dos produtos rurais, tendo como condição apenas a comprovação da atividade rural. A proposta do MPAS é que a Constituição seja alterada para exigir que os segurados especiais sejam identificados e inscritos na Previdência Social, o que além de facilitar o recolhimento das contribuições, permitirá o reconhecimento automático do direito, eliminando os processos burocráticos de comprovação da atividade rural. Propõe, ainda, a individualização da contribuição previdenciária para cada um dos membros do grupo familiar com alíquota de $2,1 \%$ sobre a receita bruta da comercialização da produção no ano per capita.

Os empregados domésticos não são considerados contribuintes individuais, embora a soma de suas contribuições com as de seu empregador correspondam à contribuição daqueles. O empregador doméstico recebe tratamento diferenciado em relação aos demais, contribuindo com apenas $12 \%$ do salário de contribuição do empregado doméstico a seu serviço. A alíquota reduzida tem por finalidade incentivar a formalização da contratação e ampliar a cobertura previdenciária. Nesse caso, a Previdência sugere apenas ajuste de rotina para que se tome conhecimento da filiação e controle sobre as contribuições.

Os debates em torno do déficit da Previdência Social serviram para explicitar o conflito distributivo entre áreas do governo e entre políticas sociais e tem obrigado a repensar a base de financiamento, não apenas dos direitos previdenciários, mas de toda a política social. Sem dúvida, a Constituição Federal de 1988 deu o primeiro passo no sentido 
de tornar as contas da Previdência um objeto de controle público, pela sua inscrição no OSS, pela constitucionalização das regras de cálculo do valor dos benefícios e pela adoção do salário mínimo como parâmetro do valor mínimo de benefícios assistenciais e previdenciários. A partir daí, a discussão se pautou pela mudança nos critérios de acesso que teriam por efeito reduzir a quantidade de novos benefícios, assim como o seu valor. $\mathrm{O}$ ponto mais enfatizado foi o fim das aposentadorias por tempo de serviço, convertidas em tempo de contribuição e a tentativa em torná-las também sujeita a regras que definiriam a idade mínima de acesso ao benefício.

Mas, a contrapartida foi uma ampla discussão a respeito da metodologia utilizada no cálculo do déficit previdenciário, que tornou discutível aquilo que era apresentado como indiscutível e a própria Previdência Social se envolveu no processo de racionalização e sistematização em torno dos dados apresentados. O resultado, sem dúvida, não aponta para o fim do déficit ou para uma situação de conforto nas contas previdenciárias, mas traz o benefício de maior transparência, permitindo identificar como são compostas a receita e a despesa previdenciária e como são afetadas por decisões outras, alheias ao seu caráter de seguro social.

O MPAS não atuou apenas na defesa da reforma da Previdência como medida inevitável para conter o déficit explosivo, mas também, na defesa da arrecadação previdenciária, ao reivindicar que não exista renúncia previdenciária e quando a concessão de subsídios for essencial para a formalização das relações de emprego, para a geração de emprego ou para manutenção de serviços sociais em substituição ao Estado, que assim o seja com base nos recursos fiscais. O princípio de defesa do Ministério é o da necessidade de se garantir o vínculo contributivo para garantir o benefício futuro. O mesmo se pode dizer sobre a definição de que as despesas previdenciárias devam ser compostas, apenas e exclusivamente, pelos benefícios contributivos, programáveis ou não, fortalecendo o papel de seguro social da Previdência Social.

Os dados relativos à arrecadação e às despesas previdenciárias permitem acompanhar ao longo do tempo como a sistematização em relação as contas da Previdência Social foram ocorrendo. Ela não é fruto apenas de decisões do MPAS ou do governo, mas do debate que se formou e que ajudou a conferir transparência aos dados debatidos. O TCU exerceu papel importante no controle público sobre os dados apresentados, contestando a 
metodologia e exigindo a diferenciação entre os benefícios pagos pela Previdência, bem como a partilha no financiamento.

Esse movimento explicita um dos principais problemas apontados pela literatura sobre a história da Previdência Social no Brasil: o uso de seus recursos para o financiamento de finalidades estranhas ao conceito. O controle público sobre as contas da Previdência ajudou a denunciar o baixo aporte de recursos fiscais para o financiamento do conjunto das políticas sociais que integram a área da seguridade social, assim como a manipulação das suas contas.

\section{Dados comparativos relativos a arrecadação e pagamento de benefícios}

A série sobre arrecadação e pagamentos ${ }^{133}$ do INSS tem início em 1988 com valores convertidos para o Real. A partir de 1991, com a criação do INSS, o SINPAS deixou de existir, motivo pelo qual realizamos um primeiro corte em 1990.

Dentre os recebimentos próprios da Previdência Social destacam-se a arrecadação bancária, rendimento de aplicações financeiras, resgate de títulos e bonificações, prêmio do DPVAT e outros. Dentre as transferências da União encontram-se relacionas as cotas da Previdência, EPU, renda de loterias/outras e Pronav/LBA.

Dentre os pagamentos do SINPAS, destacam-se benefícios, pessoal, assistência médica e outros. As transferências a terceiros referem-se a arrecadação da contribuição das empresas para o "sistema S", recolhida sobre a folha de pagamento de salários e transferida ao sistema para financiamento de atividades empresariais.

No período em tela, as principais mudanças ocorridas foram relativas ao financiamento do Sistema em 1989 com a criação da CSLL e a inclusão do Finsocial como transferências do governo, dando a forma do Orçamento da Seguridade Social determinada pela Constituição.

O saldo final entre recebimentos e pagamentos apresentou resultado negativo apenas nos anos de 1990 e 1992. Em 1993 o saldo final foi de R\$ 4 milhões de Reais.

\footnotetext{
${ }^{133}$ Os dados aqui utilizados são os apresentados em: (BRASIL, 2006).
} 
Tabela 3: Dados consolidados de arrecadação e pagamento de benefícios do SINPAS: 1988-1990 (R\$ em valores correntes)

\begin{tabular}{|l|r|r|r|r|r|r|}
\hline \multicolumn{1}{|c|}{ RUBRICAS } & \multicolumn{1}{c|}{1988} & \multicolumn{1}{c|}{1989} & \multicolumn{1}{c|}{1990} & \multicolumn{1}{c|}{1991} & \multicolumn{1}{c|}{1992} & \multicolumn{1}{c|}{1993} \\
\hline Saldo inicial & 34,951 & 34,960 & $-57,910$ & 30220.73 & -9066.14 & 4199763.44 \\
\hline Recebimentos & 1577,014 & 24854,650 & 770232,590 & 3465044 & 40884489 & 961501869 \\
\hline Próprios & 1522,981 & 21037,530 & 687930,540 & 3076161 & 39114268 & 865357744 \\
\hline Transferências da União & 54,033 & 3817,120 & 82302,050 & 388883 & 1770221 & 96144125 \\
\hline Pagamentos & 1577,008 & 24947,520 & 739953,950 & 3504331 & 36675659 & 833567087 \\
\hline SINPAS/INAMPS/INSS & 1491,737 & 23829,280 & 699281,860 & 3327708 & 34648534 & 779315922 \\
\hline Transferências a terceiros & 85,270 & 1118,240 & 40672,080 & 176623 & 2027124 & 54251165 \\
\hline Saldo final & 34,957 & $-57,910$ & 30220,730 & -9066.14 & 4199763.44 & 132134546. \\
\hline
\end{tabular}

Fonte: BRASIL. MPS/INSS/DATAPREV (2005). Elaboração própria

No ano de 1988, o balanço entre arrecadação e despesas previdenciárias ficou praticamente zerado, enquanto em 1989 apurou-se saldo final negativo, que foi corrigido no ano de 1990. A partir de 1991, as contribuições sociais que integram o OSS passaram a compor as transferências da União. O período expressa a transição entre as formas de financiamento antigas e as consolidadas após a regulamentação do Plano de Custeio da Seguridade Social (1991). O mesmo ocorre em relação aos pagamentos do INSS, com as transferências para o custeio da assistência médica (INAMPS).

Entre 1991 e 1993 não ocorreu alteração no modo de financiamento, com maior peso sobre a arrecadação própria, porém os dados sobre as transferências da União passaram a ser desagregados por tipo de contribuição.

Tabela 4: Recebimentos próprios e transferências da União na composição da receita previdenciária: 1988-1993 (\%)

\begin{tabular}{|l|r|r|r|r|r|r|}
\hline Rubricas & \multicolumn{1}{|c|}{$\mathbf{1 9 8 8}$} & \multicolumn{1}{c|}{1989} & \multicolumn{1}{|c|}{$\mathbf{1 9 9 0}$} & \multicolumn{1}{|c|}{$\mathbf{1 9 9 1}$} & \multicolumn{1}{|c|}{1992} & 1993 \\
\hline Recebimentos & 100,00 & 100,00 & 100,00 & 100,00 & 100,00 & 100,00 \\
\hline Próprios & 96,60 & 84,60 & 89,30 & 88,79 & 95,67 & 90,00 \\
\hline Transf. União & 3,40 & 15,40 & 10,70 & 11,24 & 4,33 & 10,00 \\
\hline
\end{tabular}

Fonte: BRASIL. MPS/INSS/DATAPREV (2005). Elaboração própria

A rubrica "Transferências da União" demonstra o repasse das contribuições sociais para a Previdência Social, assim como o repasse do montante para custeio dos EPU e o aporte de recursos fiscais para cobertura de déficit operacional. Os dados relativos ao período de 1988 a 1993 permitem identificar que a participação das Transferências da 
União para custeio da Previdência Social é baixa ao longo de todo o período. Em 1992, ela foi inferior a 5\%, retomando o patamar de 1988. Apenas em 1989 as transferências ultrapassaram o percentual de $12 \%$.

Ao desagregarmos os percentuais relativos às "Transferências da União" verificamos que a maior parte foi realizada a título de cobertura dos EPU, revelando o baixo aporte de recursos das contribuições sociais para o financiamento de benefícios previdenciários no período. Em 1988, o custeio dos EPU mobilizou 77,7\% do total das Transferências da União, havendo, porem, nos anos seguintes uma forte queda nessa participação, para atingir apenar 0,38\% do total em 1993. Cabe ressaltar que os encargos previdenciários da União não são despesas previdenciárias.

Tabela 5: Transferências relativas ao EPU na composição das transferências da União

\begin{tabular}{|l|r|r|r|r|r|r|}
\hline Rubrica & $\mathbf{1 9 8 8}$ & $\mathbf{1 9 8 9}$ & $\mathbf{1 9 9 0}$ & $\mathbf{1 9 9 1}$ & \multicolumn{1}{|c|}{1992} & \multicolumn{1}{|c|}{1993} \\
\hline Transf. União & 100,00 & 100,00 & 100,00 & 100,00 & 100,00 & 100,00 \\
\hline EPU & 77,70 & 14,30 & 14,70 & 14,72 & 19,42 & 0,38 \\
\hline Outros & 22,30 & 85,70 & 85,60 & 88,28 & 80,60 & 99,62 \\
\hline
\end{tabular}

Fonte: BRASIL. MPS/INSS/DATAPREV (2005). Elaboração própria

Os dados apontam o crescimento contínuo da participação das despesas com benefícios no SINPAS, que passou de 52\% em 1988 para 91\% em 1993. De outro modo, demonstra o crescimento das despesas com assistência médica até alcançar 28\% das despesas e uma queda a partir de 1992 com a recusa do Ministro da Previdência Social em continuar a realizar repasses de contribuições à previdência social para a saúde. É o momento em que começa a especialização das fontes de financiamento para as três áreas integrantes da seguridade social e que são demonstradas nos dados estatísticos.

O recorte que o gráfico 1 faz em relação às despesas previdenciárias visa a demonstrar os gastos com assistência médica no período, sendo que, a partir de 1994, deixa de estar inserida nos pagamentos realizados pela Previdência Social. De outro modo, podese perceber a sua participação decrescente a partir de 1991, como expressão do conflito distributivo entre as áreas. 
Gráfico 1. Distribuição dos pagamentos realizados pelo SINPAS/INSS: 1988 - 1993.

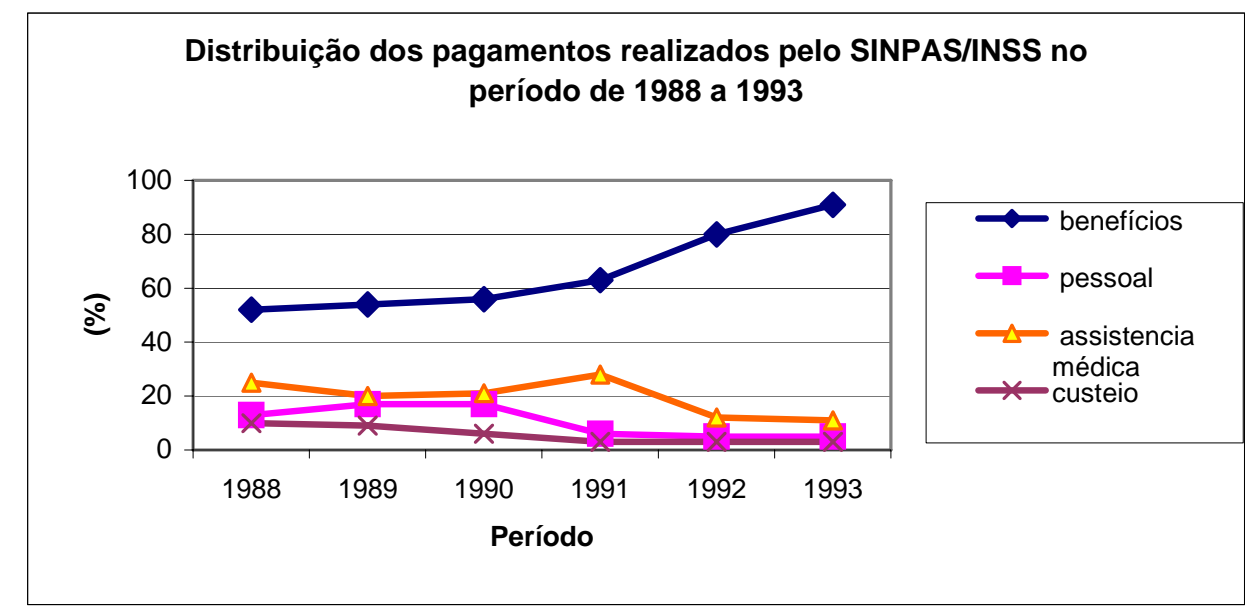

Fonte: BRASIL. MPS/INSS/DATAPREV (2005). Elaboração própria

O ano de 1991 representou uma exceção na verificação de queda na participação da assistência médica nas despesas previdenciárias ao longo do período que vai de 1988 a 1993. Movimento inverso ao que ocorreu com as despesas previdenciárias que tiveram um aumento significativo, passando de 52\% em 1988 para 91\% em 1993, demonstrando a relação entre regulamentação dos direitos sociais inscritos na Constituição e aumento nas despesas com benefícios. As despesas com benefícios reduziram a participação de outros gastos na formação das despesas previdenciárias.

O crescimento dos gastos com benefícios após a regulamentação dos direitos constitucionais, o aumento no número de benefícios concedidos e o baixo repasse de recursos das contribuições sociais para o financiamento da Previdência Social deram o formato a um conflito distributivo entre as áreas do governo. A partir de 1994 deixam de ser realizados repasses da Previdência Social para a saúde, que passou a ser financiada com outros recursos provenientes do OSS. Esse talvez tenha sido o primeiro movimento defensivo em relação às contas da Previdência Social e que levou a uma ampla sistematização, com a definição precisa da sua base de financiamento, tanto quanto dos benefícios de caráter exclusivamente previdenciário. As despesas com pessoal e com o custeio da Previdência também foram decrescentes.

O conflito em torno das “contas da Previdência Social” segue sempre em duas direções: arrecadação e despesas. A ampla sistematização leva à conclusão de que nem tudo que é pago pela Previdência Social define-se como benefício previdenciário e, portanto, os 
recursos que lhe sustentam não devem vir exclusivamente das contribuições sociais de empregados e empregadores sobre a folha de pagamento de salários.

A tabela 6 reflete a composição das transferências de recursos realizadas pela União para a contabilidade da Previdência Social e permite verificar o não repasse realizado em 1996 da CSLL e em 1994 de contribuições decorrentes dos concursos e prognósticos. Permite, também, verificar a inserção de repasses a título do Fundo Social de Emergência após a sua instituição em 1994.

Como é possível observar, nesse período o COFINS foi utilizado como fonte de financiamento dos EPU e financiamento da Previdência Social. A Lei 8.212/91 que aprovou o Plano de Custeio da Previdência Social havia determinado prazo para que essa rubrica deixasse de utilizar os recursos do OSS para o seu financiamento.

Tabela 6. Fluxo de caixa anual do INSS: 1994-1996 (R\$ Mil)

\begin{tabular}{|l|r|r||c|}
\hline \multicolumn{1}{|c|}{ Rubricas } & \multicolumn{1}{c|}{1994} & \multicolumn{1}{c|}{1995} & 1996 \\
\hline Recebimentos & 22282881 & 39802947 & 50705775 \\
\hline Próprios & 20751982 & 36671266 & 47663255 \\
\hline Transferências da União & 1530899 & 3131681 & 3042520 \\
\hline Fundo Social de Emergência* & 4141 & 751602 & 890583 \\
\hline COFINS/EPU & 438967 & 574679 & 612465 \\
\hline Contribuição sobre Lucro & 600793 & 346190 & -- \\
\hline COFINS & 459985 & 992737 & 1289059 \\
\hline Recursos Ordinários & 27013 & 77386 & 1062 \\
\hline Concursos e Prognósticos-- & & 5481 & 15785 \\
\hline Outros & -- & 383606 & 233566 \\
\hline Pagamentos INSS & 20613624 & 39999627 & 51976948 \\
\hline INSS & 19150285 & 36726569 & 48669595 \\
\hline Transf. Fundo Social Emerg. & -- & 300000 & -- \\
\hline Terceiros & 1463340 & 2973058 & 3307353 \\
\hline
\end{tabular}

Fonte: BRASIL. MPS/INSS/DATAPREV (2005). Elaboração própria

* A partir de 1996 passou a denominar-se Fundo de Estabilização Fiscal através da EC 10/96, substituindo a rubrica anterior.

As principais alterações ocorridas e que são relativas ao financiamento da Previdência Social foram a criação do Fundo Social de Emergência (FSE) que deveria contribuir para o financiamento da Seguridade Social. Os repasses começaram a ser realizados a partir de março/1994. Em junho de 1995, foi incluída nos pagamentos 
realizados pela Previdência Social a transferência única do Fundo Social de Emergência à Saúde, no valor de $\mathrm{R} \$ 300.000 .000$ e que, portanto, deve ser descontado do montante transferido para a Previdência Social.

Apesar do repasse de contribuições sociais para o financiamento da Previdência Social é necessário explicitar que os recebimentos próprios ainda constituem o montante mais significativo na cobertura dos benefícios pagos pela Previdência Social. Por outro lado, a Previdência Social é responsável pelo pagamento de benefícios não contributivos como o amparo assistencial, os benefícios previdenciários dos trabalhadores rurais e cobertura dos EPU que contemplam não apenas os gastos com inativos, mas os beneficiários de sistemas especiais de pensões, como anistiados, vítimas da talidomina, do césio, benefício do seringueiro etc.

Tabela 7. Fluxo de caixa anual do INSS: 1997-1999 (R\$ Mil)

\begin{tabular}{|l|r|r|r|}
\hline \multicolumn{1}{|c|}{ Rubricas } & \multicolumn{1}{c|}{1997} & \multicolumn{1}{c|}{1998} & \multicolumn{1}{c|}{1999} \\
\hline Recebimentos & 58416054 & 60985461 & 68734229 \\
\hline Próprios & 53253566 & 49008330 & 51637198 \\
\hline Transferências da União & 5162488 & 11977131 & 17097032 \\
\hline Arrecadação/SIMPLES & 936158 & 1934802 & 1550662 \\
\hline Fundo Estabilização Fiscal & 942242 & 1295996 & 1548022 \\
\hline COFINS/EPU & 757948 & 538036 & 731765 \\
\hline COFINS/LOAS & 380000 & 714270 & 1545901 \\
\hline COFINS & 2053477 & 473666 & 3314551 \\
\hline Recursos Ordinários & 1663 & 1342844 & 3973291 \\
\hline Concursos e Prognósticos & 74240 & 1480370 & -- \\
\hline Outros & 16760 & 134225 & -- \\
\hline CSLL & -- & -- & 999642 \\
\hline CPMF & -- & -- & 3433198 \\
\hline Pagamentos INSS & 56081900 & 63188244 & 68543734 \\
\hline INSS & 52259505 & 59688087 & 65247199 \\
\hline Terceiros & 3822395 & 3500157 & 3296535 \\
\hline Fonte: BRASIL. MPS/INSS/DATAPREV (2005). Elaboração própria \\
\hline
\end{tabular}

O SIMPLES (sistema integrado de pagamento de impostos e contribuições das microempresas e das empresas de pequeno porte) foi instituído pela Lei 9.317, de 05/12/96, através do qual a arrecadação previdenciária passou a ser realizada pela Receita Federal. Não se trata propriamente de transferência ou aporte de novos recursos, mas de arrecadação 
própria da Previdência Social, embora conste da rubrica "Transferências da União”. A partir do ano de 2000, a informação passou a constar da arrecadação própria da Previdência. O SIMPLES, ao promover a simplificação da arrecadação tributária suscitou uma grande discussão por levar também à renúncia da arrecadação previdenciária. Por se tratar de um incentivo fiscal de natureza fazendária, a renúncia da arrecadação previdenciária tornou-se um ponto de conflito, tendo em vista que a Previdência Social não participara das decisões e sequer fora consultada à respeito. Um dos argumentos do Ministério foi a exigência de que as renúncias de arrecadação passassem a ser debitadas das contas do Tesouro e não da Previdência Social. A questão é um exemplo bastante contundente do tipo de conflito distributivo armado entre os Ministérios e como a questão do déficit não pode ser analisada tão somente em razão do fluxo de caixa previdenciária. Decisões fiscais têm implicações diretas sobre o volume de recursos disponíveis para o cumprimento das obrigações previdenciárias.

Aqui, reproduzimos a informação tal qual ela aparece no Anuário Estatístico da Previdência Social, como “Transferência da União”. Outras transferências referem-se à soma da Cota de Previdência, Contribuição ao Plano de Seguridade Social e CSLL (que deixou de constar em rubrica própria em 1997 e 1998).

Durante esse período, o COFINS (Contribuição sobre o faturamento da empresa) foi utilizado para financiar os EPU, os benefícios assistenciais e a Previdência Social, com dotações em separado. Novamente, um ponto de conflito, uma vez que pelo sistema de desoneração do OSS, a União não poderia utilizar recursos desse orçamento para o financiamento de despesas com servidores inativos da União.

A EC 21, de 18/03/1999 definiu que o aumento da arrecadação decorrente da alteração da alíquota da CPMF nos exercícios de 1999, 2000 e 2001 deveria ser destinado ao custeio da Previdência, o que contribuiu para elevar a participação das transferências da União no financiamento da Previdência Social em 1999, quando atingiu o maior percentual (25\%) de todo o período (1988 a 1999), como demonstrado na tabela 6. Pela exposição, podemos observar também as irregularidades nos repasses realizados pela União. 
Tabela 8. Participação dos recebimentos próprios e das transferências da União na receita da Previdência Social (\%)

\begin{tabular}{|l|r|r|r|r|r|r|}
\multicolumn{1}{|c|}{ Rubricas } & \multicolumn{1}{|c|}{1994} & \multicolumn{1}{|c|}{1995} & \multicolumn{1}{c|}{1996} & \multicolumn{1}{|c|}{1997} & \multicolumn{1}{|c|}{1998} & \multicolumn{1}{c|}{1999} \\
\hline Recebimentos & 100,00 & 100,00 & 100,00 & 100,00 & 100,00 & 100,00 \\
\hline Próprios & 93,12 & 92,89 & 94,00 & 91,10 & 80,40 & 75,10 \\
\hline Transferências da União & $6,88 *$ & 7,11 & 6,00 & 9,90 & 20,00 & 24,90 \\
\hline
\end{tabular}

Fonte: BRASIL. MPS/INSS/DATAPREV (2005). Elaboração própria

*Com desconto do valor repassado à Saúde através da Transferência do Fundo Social de Emergência

Em 1994, houve um crescimento considerável das transferências a título de cobertura dos EPU, muito embora se mantivesse financiado pelos recursos do OSS. No entanto, houve oscilação nos percentuais de repasse até 1997 (tabela 10). Em 1998, o repasse chegou a 4,5\% e em 1999, a 4,2\%.

Em 1999 os EPU foram financiados com recursos da CSLL e COFINS com recursos desvinculados pelo Fundo de Estabilização Fiscal. Os amparos previdenciários (LOAS) foram financiados pela CSSL e pelo COFINS.

O uso de contribuições sociais para o financiamento dos EPU foi objeto de intenso conflito que denunciava a sua ilegitimidade, por ser alheia ao conceito de seguridade social tal como definido na Constituição de 1988, uma vez que todo o capítulo referente ao RPPS integra o direito administrativo e não se constitui em matéria previdenciária. O Tribunal de Contas da União definia em 2002 que "o regime previdenciário dos servidores civis e militares não é de natureza previdenciária, sendo mais bem conceituado como unilateral e administrativo" (TCU, 2002: 12).

A determinação constitucional de que os funcionários públicos civis fossem incluídos em um Regime Jurídico Único fez com que 650 mil funcionários do regime de trabalho "celetista”"134 fossem transformados em estatutários, passando a integrar o corpo do funcionalismo público, que, na época, somava apenas 150 mil servidores. Essa medida trouxe algumas implicações contábeis como uma redução da ordem de $28 \%$ no pagamento de encargos sociais da União sobre a folha de pagamentos tais recursos, relativos às contribuições sociais da União para a Previdência Social e FGTS, não passaram a integrar

\footnotetext{
${ }^{134}$ Trabalhadores regidos pelo Regime da CLT (Consolidação das Leis do Trabalho) e com registro em carteira de trabalho.
} 
um fundo contábil para amparar o custeio da inatividade destes funcionários. Como assinala o TCU, nenhuma compensação foi realizada entre a União e o INSS referente às contribuições anteriores desses serviços ${ }^{135}$. Além do acerto pela transformação do vínculo empregatício, a União deve repassar à Previdência Social os valores referentes à contribuição patronal e dos servidores ${ }^{136}$.

A divulgação dos dados referentes aos RPPSs é resultado imediato da Lei Geral de Previdência Pública que exigiu maior rigor técnico e planejamento das ações. A experiência americana de implantação de procedimentos de padronização na apresentação de dados com o Governamental Accounting Standards Board (GASB), de 1992, trouxe um referencial importante não apenas para as contas públicas em todos os entes da federação, o que permitiu conhecer e comparar o déficit nos sistemas próprios (MPAS, 2002: 39).

Tabela 9. Participação das transferências para financiamento dos EPU nas Transferências da União: 1994 -1999 (\%)

\begin{tabular}{|c|r|r|r|r|r|r|}
\hline Rubricas & \multicolumn{1}{|c|}{1994} & \multicolumn{1}{c|}{1995} & \multicolumn{1}{|c|}{1996} & \multicolumn{1}{|c|}{1997} & \multicolumn{1}{|c|}{1998} & \multicolumn{1}{c|}{1999} \\
\hline Transferências da União & 100,00 & 100,00 & 100,00 & 100,00 & 100,00 & 100,00 \\
\hline COFINS/EPU & 28,67 & 18,35 & 20,13 & 14,68 & 4,50 & 4,20 \\
\hline Outros & 71,32 & 81,65 & 79,87 & 85,32 & 95,50 & 95,80 \\
\hline
\end{tabular}

Fonte: BRASIL. MPS/INSS/DATAPREV (2005). Elaboração própria

No período seguinte, o pagamento de benefícios previdenciários correspondeu, na média, a 90\% do total de pagamentos realizados. A partir de 1994, nenhum gasto com assistência médica foi computado entre suas despesas, demonstrando a separação entre as duas áreas e a base de financiamento, o que consolida uma das principais propostas desenvolvidas no período pré-constituinte de distinção das bases de financiamento. No entanto, contestando a tese então sustentada de que a assistência médica era a principal crise da insuficiência financeira da Previdência Social, as discussões persistiram em torno do pagamento de benefícios.

No período entre 1999 a 2001, o custeio da Previdência Social passou a receber o aporte de recursos da CPMF, conforme determinou a EC 21, 18/03/1999. O período se

\footnotetext{
${ }^{135}$ O repasse deveria ser realizado como determinava o art. 247 da Lei no. 8.112/90.

136 A contribuição patronal para o Plano de Seguridade Social do Servidor Público é de 2:1, ou seja, a contribuição da União equivale a duas vezes a contribuição do servidor. O TCU entende, ainda, que em sentido estrito, o regime dos servidores civis e militares não é de natureza previdenciária e seria melhor conceituado como um regime unilateral e administrativo (TCU, 2002: 12)
} 
caracteriza por uma nova sistematização na apresentação das contas, que passou a ter participação específica de cada contribuição mensurada. A partir de 2003, como resultado da reforma constitucional de 2002 passaram a participar das transferências da União os recursos oriundos da Contribuição do Plano de Seguridade Social do Servidor, que significou um grande incremento no financiamento dos EPU.

Tabela 10. Distribuição dos recebimentos e pagamentos do INSS: 2000 - 2005 (R\$ Mil em valores correntes).

\begin{tabular}{|c|c|c|c|c|c|c|}
\hline \multicolumn{1}{|c|}{ Rubricas } & $\mathbf{2 0 0 0}$ & $\mathbf{2 0 0 1}$ & $\mathbf{2 0 0 2}$ & $\mathbf{2 0 0 3}$ & $\mathbf{2 0 0 4}$ & $\mathbf{2 0 0 5}$ \\
\hline Recebimentos & $\mathbf{7 7 1 8 5 8 3 5}$ & $\mathbf{8 8 1 5 6 5 8 5}$ & $\mathbf{1 0 5 0 3 5 1 8 0}$ & $\mathbf{1 2 2 2 2 9 2 2 7}$ & 152684048 & 172719638 \\
\hline Próprios & 59605661 & 66998152 & 76082251 & 86587225 & 101125841 & 115955568 \\
\hline Transferências da União & 15283224 & 20541869 & 25653199 & 38275673 & 48348546 & 45552497 \\
\hline Cont.o Seguridade Social & -- & 159019 & -- & 19752315 & 28483643 & 25193727 \\
\hline Fundo Estabilização Fiscal & -- & 82134 & -- & -- & -- & -- \\
\hline COFINS/EPU & 542945 & 713848 & 622154 & 615043 & 686300 & 798695 \\
\hline COFINS/LOAS & 2012919 & 2712248 & 3438782 & 4450752 & 7593889 & 9361487 \\
\hline COFINS & 547879 & 11132576 & 13035593 & -- & -- & -- \\
\hline Recursos Ordinários & 586379 & 1578342 & 4823922 & 4692126 & 993776 & 112822 \\
\hline Outros & 163728 & 11209 & 1049 & 1816 & 3034071 & 4091892 \\
\hline CSLL & 1557026 & 264865 & 1428742 & 3758011 & 1963218 & 139965 \\
\hline Concursos e Prognósticos & -- & -- & -- & 6015 & 103438 & 32299 \\
\hline CPMF & 4941427 & 3550000 & 2303928 & 4999596 & 5490211 & 5821610 \\
\hline $\begin{array}{c}\text { Saldo Exercícios } \\
\text { anteriores }\end{array}$ & -- & 337628 & -772 & -- & & -- \\
\hline Outros recebimentos ${ }^{\star *}$ & -- & 616563 & 3581416 & -2365328 & 3209660 & 11211573 \\
\hline Pagamentos INSS & 76474268 & 88035343 & 102066204 & 123361223 & 150654269 & 171798592 \\
\hline INSS & 72583742 & 83529081 & 97011634 & 117504148 & 143293811 & 164277121 \\
\hline Terceiros & 3890526 & 4506262 & 5054571 & 5857075 & 7360458 & 7521471 \\
\hline
\end{tabular}

Fonte: BRASIL. MPS/INSS/DATAPREV (2005). Elaboração própria

* A partir de 2003 aparece a rubrica "COFINS e Contribuição do Plano de Seguridade Social Servidor"

A composição dos recebimentos permite identificar uma queda contínua na participação dos recebimentos próprios no custeio dos benefícios previdenciário, muito embora, em todo o período tenha sido superior a 65\%. A redução da participação pode, também, ser explicada pela inclusão da contribuição ao Plano de Seguridade Social do Servidor Público a partir de 2003, na proporção de 2/1 (empregador/servidor), aumentando o aporte de outros recursos no seu financiamento. 
Tabela 11. Participação dos recebimentos próprios e das transferências da União na receita da Previdência Social: 2000 -2005 (\%)

\begin{tabular}{|c|c|c|c|c|c|c|}
\hline rubricas & 2000 & 2001 & 2002 & 2003* & 2004 & 2005 \\
\hline Recebimentos & 100 & 100,00 & 100,00 & 100,00 & 100,00 & 100,00 \\
\hline Outros recebimentos & & 0,60 & 3,20 & & 2,11 & 6,50 \\
\hline Próprios & 77,22 & 76,00 & 72,40 & 70,00 & 66,23 & 67,13 \\
\hline Transferências da União & 19,80 & 23,40 & 24,40 & 30,00 & 31,66 & 26,37 \\
\hline
\end{tabular}

A tabela 12 apresenta um salto significativo da participação da União no custeio das aposentadorias e pensões dos servidores públicos: de 2,4\% para 53,20\% entre 2002 e 2003, em razão da contribuição instituída pela EC 21.

Tabela 12. Participação das transferências para financiamento dos EPU nas Transferências da União: 2000 - 20005 (\%)

\begin{tabular}{|c|r|r|r|r|r|r|}
\hline Rubricas & \multicolumn{1}{c|}{$\mathbf{2 0 0 0}$} & \multicolumn{1}{c|}{2001} & \multicolumn{1}{c|}{2002} & $\mathbf{2 0 0 3}^{*}$ & \multicolumn{1}{c|}{$\mathbf{2 0 0 4}$} & \multicolumn{1}{c|}{$\mathbf{2 0 0 5}$} \\
\hline Transferências da União & 100,00 & 100,00 & 100,00 & 100,00 & 100,00 & 100,00 \\
\hline COFINS/EPU & 3,50 & 4,24 & 2,40 & 53,20 & 60,33 & 57,06 \\
\hline Outros & 96,50 & 95,76 & 97,60 & 46.8 & 39,67 & 42,94 \\
\hline
\end{tabular}

Fonte: BRASIL. MPS/INSS/DATAPREV (2005). Elaboração própria

A distribuição percentual dos pagamentos realizados pelo INSS permite verificar que os benefícios foram responsáveis por aproximadamente 90\% das despesas efetuadas, exceto em 1996, quando atingiram 85\% das despesas. De outra parte, despesas com pessoal e custeio responderam por menos de $10 \%$ do total de gastos efetuados ao longo do período. A média de gasto com pessoal foi de $4 \%$ e com custeio 2,8\%, no período analisado. A mesma tendência foi verificada ao longo de todo o período estudado, não tendo sido observados diferenciais significativos nessa distribuição. 
Gráfico 2: Distribuição dos pagamentos realizados pelo INSS: 1994 - 2005

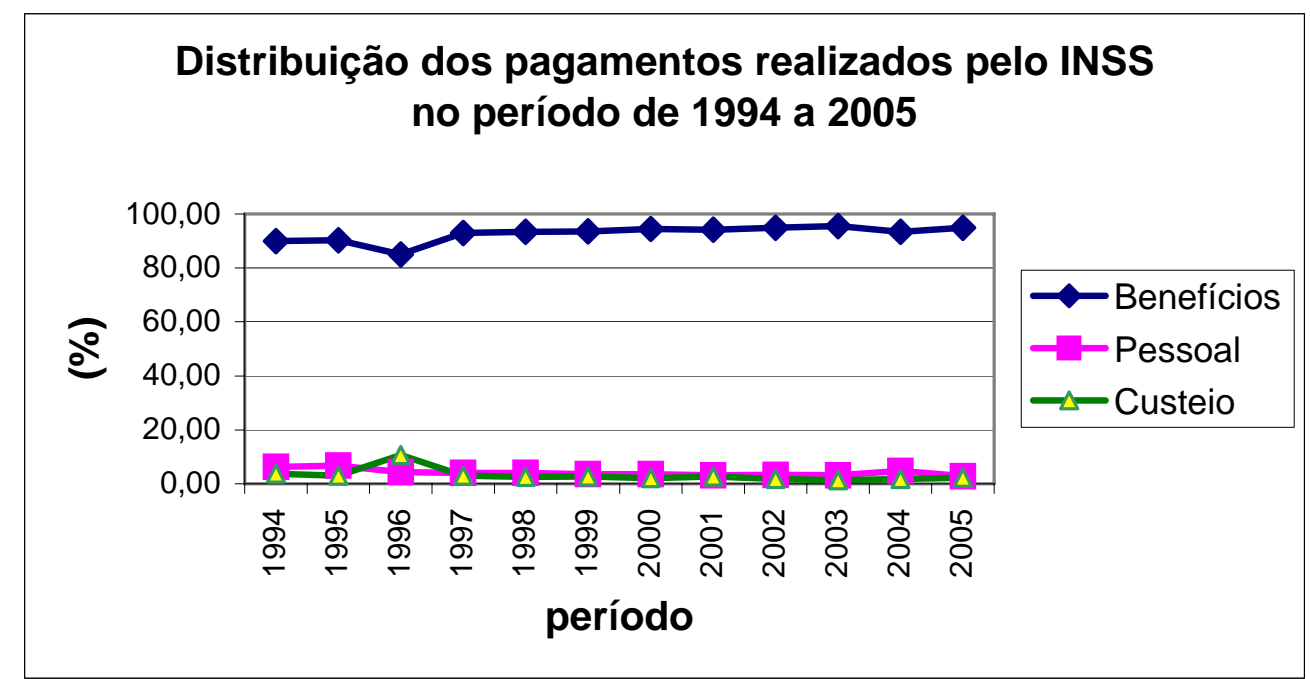

Fonte: BRASIL. MPS/INSS/DATAPREV (2005). Elaboração própria

\section{Composição dos pagamentos de benefícios do INSS}

Até o ano de 1999, os pagamentos de benefícios do SINPAS/INSS eram constituídos basicamente por três rubricas: benefícios, assistência médica, pessoal e custeio. A partir de 1990, a rubrica pessoal foi desmembrada em ativos e inativos e, a partir de 1994, a Previdência deixou de realizar pagamentos relativos à assistência médica. A partir do ano de 2000, os benefícios pagos pela Previdência Social passaram a ter rubrica própria, o que permite comparar a distribuição dos benefícios. Verifica-se que não houve alteração significativa na distribuição dos benefícios por tipo. Em geral, os benefícios de natureza não previdenciária, os EPU e o amparo assistencial mostraram participação inferior a 10\% na composição dos gastos, cujo montante principal foi destinado ao pagamento dos benefícios previdenciários. 
Gráfico 3 . Distribuição dos benefícios pagos pelo INSS por tipo - (2000 - 2005) (\%)

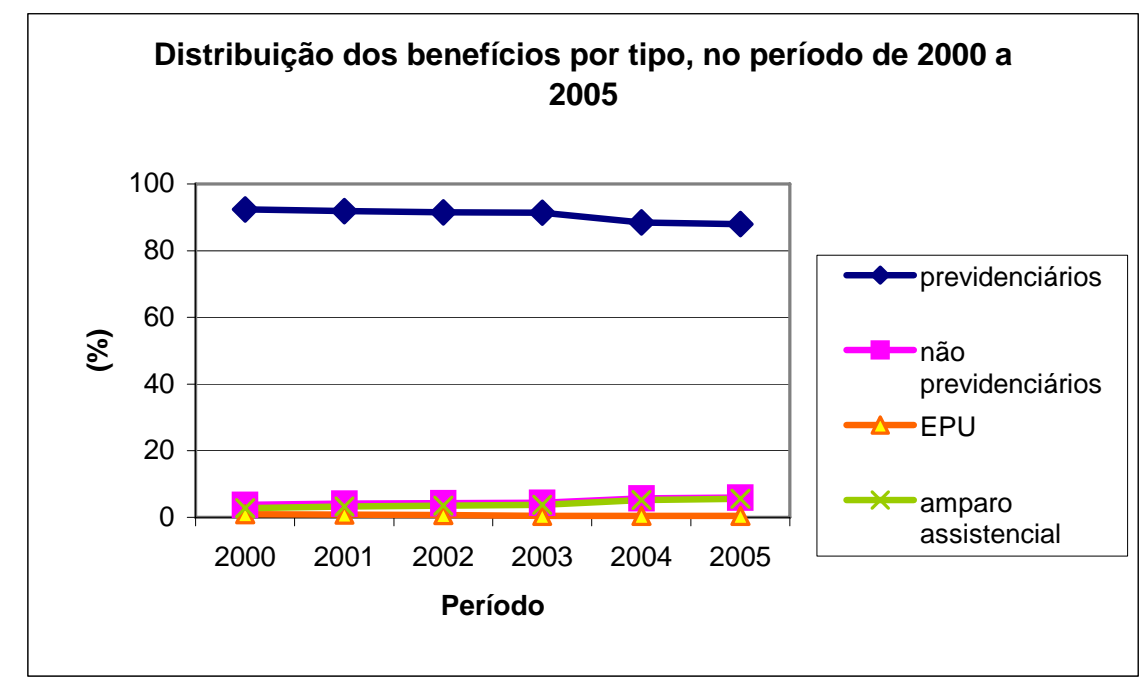

Fonte: BRASIL. MPS/INSS/DATAPREV (2005). Elaboração própria

\section{Déficit previdenciário}

A controvérsia está pautada entre aqueles que defendem a existência de um déficit nas contas da Previdência, alegando-se que os números de benefícios e de beneficiários têm crescido em ritmo superior ao da receita, impondo restrições no financiamento, diagnóstico ainda mais sombrio diante das projeções sobre a maturidade do sistema e sobre a transição demográfica que conduzirão inevitavelmente à insolvência da Previdência, caso não sejam realizados ajustes no plano de benefícios. De outro lado, estão aqueles que defendem que não existe déficit no fluxo de caixa, mas sim um equívoco na “contas da Previdência” tanto no que refere ao que é arrecadado, quanto no que é pago a título previdenciário. De ambos os lados, os números são essenciais para descrever a situação.

O resultado oficial apresentado tem sido o da existência de déficit previdenciário, a partir da análise do resultado do RGPS, que traz a diferença entre o que é arrecadado e pago a título de benefícios previdenciários.

Os dados da tabela 13 apontam o crescimento do déficit previdenciário como proporção do PIB, sobretudo a partir de 1994, após um período anterior em que houve uma 
pequena oscilação entre resultados positivos e negativos, ainda que próximo a zero, demonstrando a inexistência de superávit.

Tabela 13. Déficit Previdenciário (INSS): 1991-1999 (\% PIB)

\begin{tabular}{|r|r|r|r|}
\hline \multicolumn{2}{|c|}{ Ano Receita } & Despesa & Resultado \\
\hline 1991 & 4,59 & 4,46 & 0,13 \\
\hline 1992 & 4,63 & 4,81 & $-0,18$ \\
\hline 1993 & 5,47 & 4,05 & 0,97 \\
\hline 1994 & 5,01 & 5,06 & $-0,05$ \\
\hline 1995 & 5,04 & 5,06 & $-0,24$ \\
\hline 1996 & 5,22 & 5,28 & $-0,3$ \\
\hline 1997 & 5,12 & 5,63 & $-0,51$ \\
\hline 1998 & 5,14 & 6,1 & $-0,96$ \\
\hline 1999 & 4,86 & 5,96 & $-1,1$ \\
\hline
\end{tabular}

Fonte: Secretaria de Política Econômica. Ministério da Fazenda - SPE/MF

Como podemos verificar, os dados apresentados pelo Ministério da Fazenda apenas demonstram o resultado final entre arrecadação e pagamento de benefícios, sem nada dizer sobre a sua espécie, sobre o que é considerada arrecadação previdenciária ou que tipo de benefícios estão sendo considerados. Os dados indicam a existência de déficit em todo o período, exceto nos anos de 1991 e 1993, com pequeno superávit. No ano de 1999 o déficit atingiu a casa de $1,1 \%$ do PIB.

Conforme vimos assinalando, a metodologia utilizada desempenha um papel importante na definição do déficit ou do superávit da Previdência Social como vêm demonstrando os vários estudos já citados. Levando em consideração todas as recomendações do TCU, os dados, certamente seriam modificados.

No centro da controvérsia em torno da existência de déficit estão a maior participação da arrecadação própria da Previdência Social (contribuições sociais de empregados e empregadores sobre a folha de pagamento de salários, depósitos judiciais e quitação de débitos) na composição da receita e a inclusão de benefícios assistenciais, aposentadorias de trabalhadores rurais e de funcionários públicos no lançamento das despesas, além de outros encargos da União. Do lado da arrecadação previdenciária há, ainda, a perda de receitas provocada pela renúncia previdenciária decorrente de subsídios 
fiscais constitucionais ou concedidos pela equipe econômica, sem contar a não realização integral do OSS.

A partir do ano de 2000, o Fluxo de Caixa do INSS passou a apresentar os pagamentos realizados pelo INSS separadamente, nas contas “benefícios previdenciários” e “benefícios não previdenciários” (EPU e amparos assistenciais - LOAS). Essa separação permite analisar em separado a situação da conta previdenciária dos servidores públicos e permite verificar que, apesar de ter havido déficit nas duas contas, ela foi maior no RPPS entre 2000 e 2003, praticamente igualando-se em 2004 com o do RGPS. Mas, no exercício de 2005, novamente, o déficit foi maior no Regime Geral de Previdência Social.

Tabela 14: Evolução do déficit previdenciário: 2000-2005 (R\$ milhões)

\begin{tabular}{|l|r|r|r|r|r|c|}
\hline \multirow{2}{*}{ Discriminação } & \multicolumn{2}{|c|}{ Realizado } \\
\cline { 2 - 7 } & \multicolumn{1}{|c|}{$\mathbf{2 0 0 0}$} & \multicolumn{1}{c|}{$\mathbf{2 0 0 1}$} & \multicolumn{1}{c|}{$\mathbf{2 0 0 2}$} & \multicolumn{1}{c|}{$\mathbf{2 0 0 3}$} & \multicolumn{1}{c|}{$\mathbf{2 0 0 4}$} & \multicolumn{1}{c|}{$\mathbf{2 0 0 5}$} \\
\hline I. Resultado RGPS & $-8.562,3$ & $-11.153,8$ & $-15.255,2$ & $-24.547,9$ & $-31.985,4$ & $-37.576,0$ \\
\hline I.1. Arrecadação INSS & $56.154,3$ & $62.983,5$ & $71.591,6$ & $80.730,1$ & $93.765,4$ & $108.434,1$ \\
\hline I.2. Benefícios Previd. * & $64.716,6$ & $74.137,3$ & $86.846,7$ & $105.278,0$ & $125.750,8$ & $146.010,1$ \\
\hline II. Resultado do RPP & $-22.348,0$ & $-25.835,3$ & $-28.473,5$ & $-30.571,8$ & $-31.685,4$ & $-31.541,6$ \\
\hline II.1. Receita ** & $3.515,7$ & $4.124,6$ & $5.364,2$ & $5.281,0$ & $7.922,5$ & $11.469,0$ \\
\hline II.2. Pagamento de Inativos & $25.863,7$ & $29.960,0$ & $33.837,7$ & $35.852,8$ & $39.608,0$ & $43.010,6$ \\
\hline
\end{tabular}

Fonte: Secretaria de Orçamento Federal. Ministério de Planejamento. SIDOR/SIAF/Fluxo de Caixa do INSS

*Benefícios do RGPS

**Regime Próprio de Previdência dos Servidores Públicos

A análise do balanço entre arrecadação e pagamento de benefícios previdenciários permite verificar não apenas a existência de déficit no RGPS, mas também que ele é crescente, o que corrobora a tese que enfatiza a necessidade de adoção de reformas urgentes como modo de viabilizar economicamente a Previdência Social.

A tabela demonstra ainda que o RPPS vem apresentando resultado ainda pior e que embora os repasses para a Previdência Social tenham aumentado ao longo do período de 2000 a 2005, ela ainda não é suficiente para cobrir as despesas com os inativos. No período analisado, as transferências para cobertura dos EPU representaram respectivamente 13,5\%, 13,7\%, 15,8\%, 14,7\%, 20,0\% e 26,6\% das despesas efetuadas. A instituição da cobrança de contribuição previdenciária de funcionários ativos e inativos possui a finalidade de instituir vínculo contributivo e reduzir o déficit nas contas previdenciárias do RPPS. 
A análise da relação direta entre arrecadação e gasto é uma forma de se apropriar deste debate e de responder ao questionamento sobre a existência do déficit previdenciário. No entanto, de forma alguma ela encerra o debate, porque o ponto central da discussão está fora das “contas da Previdência”. O foco está na disputa pelos recursos orçamentários, cuja origem situa-se em questões que são subjacentes ao desenho institucional do sistema de proteção social no Brasil (Dain, 1989).

Um primeiro ponto de destaque é a dificuldade na assimilação do dispositivo constitucional que define que a seguridade social será financiada por toda a sociedade através de tributos diretos e indiretos ${ }^{137}$. Na regulamentação, as contribuições sociais foram destinadas ao custeio das políticas sociais de seguridade social e os tributos foram destinados às demais despesas do Estado. A cisão entre as atribuições das contribuições sociais e dos impostos foi reafirmada pela separação das receitas em dois orçamentos - o fiscal e o da seguridade social ${ }^{138}$.

No entanto, essa cisão que consta da Lei Orçamentária Anual é de difícil acompanhamento na execução fiscal, como apontou a auditoria do TCU. Gentil (2007) após ter realizado pesquisa minuciosa no Sistema Integrado de Administração Financeira do Governo (SIAFI) observou que o OSS financia também despesas de diferentes órgãos e ministérios, tem parte de seus recurso apropriados como recursos ordinários, de livre emprego no Orçamento Fiscal, é aplicado no financiamento dos EPU (pagamento de aposentadorias e pensões do funcionalismo público) e há uma parte não pode ter sua aplicação identificada, o que dificulta a sustentação da tese do déficit previdenciário.

As conclusões de Gentil (2007) a partir dos dados levantados apontam que não há déficit previdenciário e que a seguridade social não recebe recursos do $O F$, que, ao contrário, tem parte substancial de seus recursos utilizados para financiá-lo.

Gentil (2007) denuncia o uso dos recursos do OSS como ativo financeiro disponível. O desvio desses recursos para o pagamento de aposentadorias e pensões do RPPS é o

\footnotetext{
137 "A seguridade social será financiada por toda a sociedade, de forma direta e indireta, nos termos da lei, mediante recursos provenientes dos orçamentos da União, dos Estados, do Distrito Federal e dos Municípios, e das seguintes contribuições sociais...” Art. 195. Constituição da República Federativa do Brasil, 1988.

138 "As receitas dos Estados, do Distrito Federal e dos Municípios destinadas à seguridade social constarão dos respectivos orçamentos, não integrando o orçamento da União". Art. 195, § $2^{\circ}$. Constituição da República Federativa do Brasil, 1988.
} 
menos legítimo de todos, pois além do desvio, demonstra que a União não faz uso de recurso do OF para fazer a sua contrapartida previdenciária como empregadora (2007: 34).

Tabela 15. Aplicação das receitas da seguridade social: 1995-2006 (R\$ milhões em valores correntes)

\begin{tabular}{|c|c|c|c|c|c|c|c|}
\hline \multirow[b]{2}{*}{ ANO } & \multirow[b]{2}{*}{$\begin{array}{c}\text { RECEITA } \\
\text { ARRECADA } \\
\text { DA }\end{array}$} & \multirow{2}{*}{$\begin{array}{c}\text { RECEITA } \\
\text { APLICADA } \\
\text { SEGURIDAD } \\
\text { E }\end{array}$} & \multicolumn{4}{|c|}{$\begin{array}{c}\text { APLICAÇÃO FORA DA SEGURIDADE } \\
\text { SOCIAL } \\
\end{array}$} & \multirow[b]{2}{*}{ SI IDENTIFICAÇÃO } \\
\hline & & & \begin{tabular}{|c} 
DRU \\
$(20 \%)$ \\
\end{tabular} & RPPS* & $\begin{array}{c}\text { Outros } \\
\substack{\text { Ministérios } \\
* *}\end{array}$ & Subtotal & \\
\hline 1995 & 20284 & 9801 & 4057 & 2964 & 260 & 7281 & 3202 \\
\hline 1996 & 23377 & 12139 & 4342 & 6359 & 0 & 10701 & 537 \\
\hline 1997 & 32449 & 19021 & 2825 & 8763 & 666 & 12254 & 1411 \\
\hline 1998 & 32319 & 27862 & 3655 & 24 & 778 & 4457 & 0 \\
\hline 1999 & 45591 & 18352 & 7699 & 17455 & 657 & 25811 & 1428 \\
\hline 2000 & 61852 & 29681 & 12370 & 18689 & 975 & 32034 & 373 \\
\hline 2001 & 71678 & 32461 & 14335 & 19243 & 628 & 34206 & 5011 \\
\hline 2003 & 97403 & 50022 & 19480 & 21246 & 3256 & 43982 & 3399 \\
\hline 2004 & 123508 & 68397 & 24699 & 21694 & 5991 & 52384 & 2727 \\
\hline 2005 & 143455 & 72167 & 28691 & 24529 & 3604 & 56824 & 14464 \\
\hline 2006 & 152681 & 82397 & 30537 & 28700 & 105 & 59342 & 10942 \\
\hline Total & 804597 & 422300 & 152690 & 169666 & 16920 & 339276 & 43494 \\
\hline
\end{tabular}

Fonte: Siafi. Acompanhamento da Execução Orçamentária da União. Elaboração: Denise Lobato Gentil (2007: 33)

* Pagamento de aposentadorias e pensões de servidores civis e militares

** Presidência da República, Câmara dos Deputados, Ministérios da Educação, da Agricultura, da Justiça, Minas e Energia, da Integração Nacional, do Meio Ambiente, das Cidades e Outros.

*** Receita cuja aplicação não aparece nos demonstrativos de execução orçamentária por fonte de receita do Siafi.

Os relatórios de 2002 foram inacessíveis e não foi realizada a mesma verificação.

Transpondo os mesmos dados para o percentual de distribuição, percebemos que, do total arrecadado a título de contribuições sociais sobre a movimentação financeira, faturamento e lucros das empresas, a receita arrecadada não foi inteiramente aplicada na seguridade social. O ano de 1998 foi aquele em que a receita do OSS teve a maior participação no financiamento de políticas de seguridade social, correspondendo a 86,2\% do total. Os anos de 1995, 1999, 2000 e 2001 tiveram menos de 50\% do total arrecadado aplicado na mesma finalidade. Nos anos em que foi superior a 50\%, não ultrapassou os $60 \%$. Essa simples observação permite identificar que o uso dos recursos da base de financiamento da seguridade social exclusivamente com essa finalidade é baixo. 
O desconto dos 20\% relativos à DRU foi observado nos anos de 1995 e no período de 2000 a 2006. Desvinculações em percentuais menores foram observados em 1996 (18,57\%); 1997 (8,7\%); 1998 (11,3\%) e 1999 (16,88\%). Significativo ainda foi o uso de recursos do OSS para financiamento de atividades sem identificação nos anos de 1995 (15,78\%); 1999 (25,06\%); 2001 (13,98\%) e 2005 (10,08\%).

O uso desses recursos no financiamento do RPPS é, porém, um dos pontos de maior conflito, porque essa finalidade é estranha à seguridade social, muito embora se reporte a aposentadorias e pensões. O seu uso foi insignificante apenas no ano de 1998. Ele sempre foi superior a 15\%, com exceção dos anos de 1998 e de 1995 (14,61\%) e no ano de 1999 chegou a corresponder $38,28 \%$ total do custeio.

Tabela 16. Aplicação das receitas da seguridade social - 1995-2006 (\%)

\begin{tabular}{|c|c|c|c|c|c|c|}
\hline \multirow[b]{2}{*}{ ANO } & \multirow{2}{*}{$\begin{array}{c}\text { RECEITA } \\
\text { ARRECADA } \\
\text { DA }\end{array}$} & \multirow{2}{*}{$\begin{array}{c}\text { SEGURI } \\
\text { DADE } \\
\text { SOCIAL }\end{array}$} & \multicolumn{4}{|c|}{ APLICAÇÃO FORA DA SEGURIDADE SOCIAL } \\
\hline & & & $\begin{array}{l}\text { DRU } \\
(20 \%)\end{array}$ & RPPS* & Outros Ministérios ${ }^{* *}$ & $\begin{array}{c}\text { SI } \\
\text { identificação }\end{array}$ \\
\hline 1995 & 100 & 48,29 & $20 \%$ & 14,61 & 1,28 & 15,78 \\
\hline 1996 & 100 & 51,81 & 18,57 & 27,2 & 0 & 2,29 \\
\hline 1997 & 100 & 58,61 & 8,7 & 27 & 2,05 & 4,34 \\
\hline 1998 & 100 & 86,2 & 11,3 & 0,07 & 2,4 & 0 \\
\hline 1999 & 100 & 40,25 & 16,88 & 38,28 & 1,44 & 25,06 \\
\hline 2000 & 100 & 47,98 & 19,99 & 30,21 & 1,57 & 0,6 \\
\hline 2001 & 100 & 45,28 & 19,99 & 26,84 & 0,87 & 13,98 \\
\hline 2003 & 100 & 51,35 & 19,99 & 21,81 & 3,34 & 3,48 \\
\hline 2004 & 100 & 55,37 & 19,99 & 17,56 & 4,5 & 0,02 \\
\hline 2005 & 100 & 50,3 & 19,99 & 17,09 & 2,5 & 10,08 \\
\hline 2006 & 100 & 53,96 & 20 & 18,79 & 0,06 & 7,16 \\
\hline Total & 100 & 52,48 & 18,97 & 21,08 & 21 & 5,4 \\
\hline
\end{tabular}

Fonte: Siafi. Acompanhamento da Execução Orçamentária da União. Apresentação de Denise Lobato Gentil (2007: 33).

* Pagamento de aposentadorias e pensões de servidores civis e militares

** Presidência da República, Câmara dos Deputados, Ministérios da Educação, da Agricultura, da Justiça, Minas e Energia, da Integração Nacional, do Meio Ambiente, das Cidades e Outros.

*** Receita cuja aplicação não aparece nos demonstrativos de execução orçamentária por fonte de receita do Siafi. Os relatórios de 2002 foram inacessíveis e não foi realizada a mesma verificação.

A ANFIP vem sistematicamente realizando um trabalho de acompanhamento do OSS e computando como receita o conjunto das contribuições sociais, os recursos dos órgãos da seguridade social (Ministério da Previdência, da Saúde e do Desenvolvimento Social), bem como a contrapartida do OF para o custeio dos EPU e despesas decorrentes de 
decisões legais de correção de saldos do FGTS. Com base nessa metodologia, a ANFIP também demonstra que existe superávit nos resultados da seguridade social entre os anos de 2000 e 2005 (gráfico 4).

Gráfico 4. Evolução do superávit da seguridade social: 2000-2005 (R\$ bilhões em valores correntes)

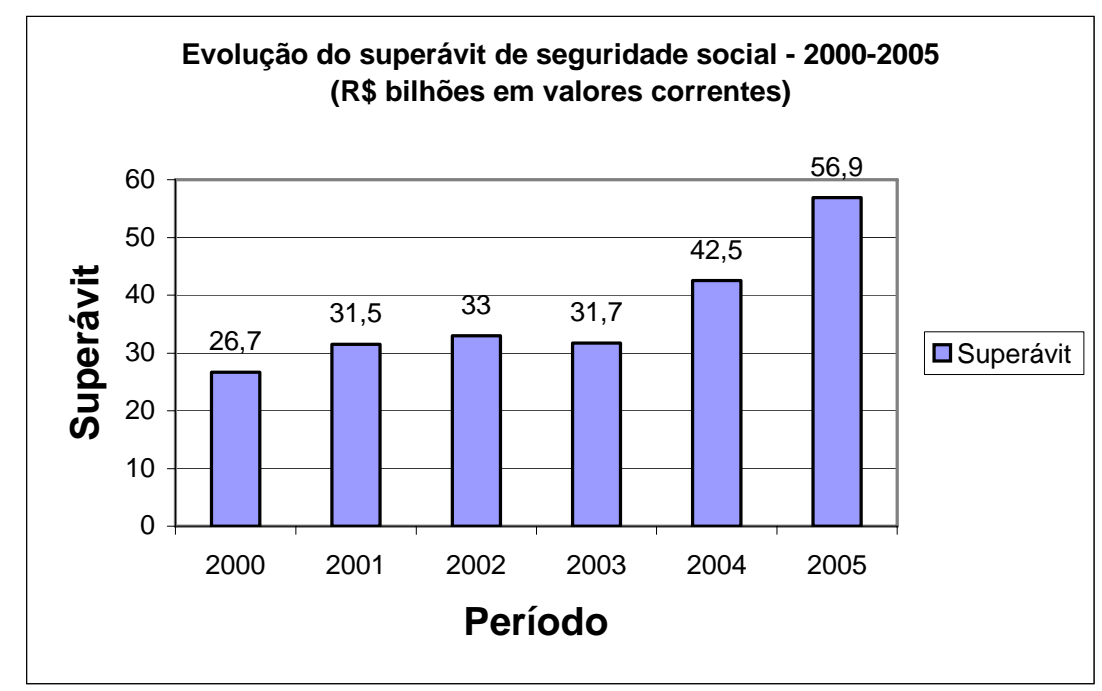

Fonte: MPS. Elaboração: ANFIP - extraído da Análise da Seguridade Social em 2005 (abril 2006).

\section{Conflito orçamentário}

Até a promulgação da Constituição Federal de 1988, o orçamento previdenciário era aprovado no âmbito exclusivo do Poder Executivo e não estava sujeito a qualquer controle público. As “contas da Previdência”139 podiam ser manipuladas tecnicamente através do recurso ao rebaixamento do valor dos benefícios e aumento da alíquota de contribuição. Ao ser inserida como peça orçamentária e ter o menor valor de benefício equiparado ao salário mínimo, a Previdência Social explicitou a sua posição no conflito distributivo entre a área

\footnotetext{
${ }^{139}$ As “contas da Previdência Social” expressam tanto a arrecadação quanto as despesas previdenciárias. Ela expressa a idéia de que as contas expressam o conflito distributivo entre recursos públicos, tanto no que se considera arrecadação previdenciária quanto o que se considera despesa previdenciária. A sua participação no Orçamento da Seguridade Social permitiu o debate público sobre o que deve e o que não deve ser considerada despesa previdenciária e uma nova correlação entre recursos fiscais e oriundos das contribuições sociais. É uma locução que procura não apenas descrever uma situação contábil, mas remete-la ao centro de uma disputa por recursos públicos entre as áreas do governo.
} 
social e a área fiscal. Conflito que vai perpassar toda a trajetória da reforma da Previdência e que se dará tanto em relação à arrecadação quanto às despesas.

A elaboração do orçamento é essencial na viabilização da política governamental e ela segue o prescrito na norma constitucional. Os três instrumentos orçamentários são o Plano Plurianual (PPA), a Lei de Diretrizes Orçamentárias (LDO) e a Lei Orçamentária Anual (LOA). Os três instrumentos são elaborados pelo Executivo e submetido à apreciação do Legislativo, através da Comissão Mista do Orçamento, onde é escolhido um relator geral que elabora e submete à Comissão um parecer preliminar ${ }^{140}$. Se aprovado, é reenviado ao Executivo para sanção e posterior encaminhamento à Secretaria do Tesouro Nacional para liberação dos recursos para os Ministérios. A aprovação do OGU o submete a um exercício de controle público, planejamento e definição de prioridades.

Se, a distribuição de recursos é objeto de uma ampla negociação na esfera Legislativa, o Executivo, porém, exercerá de fato o controle da execução orçamentária, modificando o projeto original através de estratégias de alocação de créditos adicionais, controle de caixa, cancelamento de dotações orçamentárias e outros expedientes. Dessa forma, a LOA não é a resultante final do jogo (Santos; Machado \& Rocha, 1997). Sem transparência e com forte controle do Executivo, o jogo será finalmente decidido sob o comando do secretário do Tesouro Nacional, o que dificulta enormemente o acompanhamento dos projetos orçados, resultando em um projeto inócuo de planejamento e de participação social.

As várias estratégias utilizadas pelo Tesouro Nacional para modificar o que foi orçado é um dos pontos do conflito distributivo que leva ao não repasse de recursos do OSS para a previdência social ou no financiamento de outras políticas nas despesas da seguridade social.

O controle sobre o orçamento se dá em várias etapas: aprovação do PPA, da LDO e da LOA pelo Congresso Nacional; controle interno dos Três Poderes; controle externo realizado pelo Legislativo, pelo TCU e pelo Conselho Social (para fiscalização do OSS). A Constituição Federal de 1988 ampliou o controle de execução orçamentária para contemplar não apenas a fiscalização financeira e orçamentária, mas também a aplicação de

\footnotetext{
140 Comissão Mista de Planos, Orçamentos Públicos e Fiscalização. Congresso Nacional. Cartilha do Orçamento da Câmara dos Deputados. Sítio: WWW.senado.gov.br e WWW.camara.gov.br/orçamento .
} 
subvenções e a própria política de isenções, estímulos e incentivos fiscais (renúncia fiscal). A criação do OSS desvinculado do OF foi uma reação contra o uso indevido de recursos da Previdência Social e do Finsocial. Ela expressa uma tentativa de proteger os programas sociais na disputa por recursos no âmbito do Tesouro Nacional.

A definição do salário mínimo, a cada ano, fez retornar ao debate a questão do déficit previdenciário $^{141}$ e fez com que um fosse a medida reguladora do outro e chegou-se a aventar a desvinculação do salário mínimo de um piso salarial para o trabalhador da ativa $^{142}$, até a mais recente proposta de inserir no orçamento anual a projeção do aumento do salário mínimo.

O OSS, embora não plenamente realizado, foi a peça fundamental a alimentar os debates sobre a questão do déficit previdenciário e as decisões que forçaram à reconsideração do que é despesa previdenciária, expondo de modo claro as disputas entre os Ministérios da Previdência Social e da Fazenda no uso dos recursos da seguridade social. O OSS ${ }^{143}$ é o segundo maior orçamento do país, vindo atrás somente do $\mathrm{OF}^{144}$. A magnitude de recursos que movimenta e que deveriam ser gasto exclusivamente com políticas de saúde, previdência e assistência social também ajuda a compreender o que alguns autores vêm chamando de "produção social da crise da Previdência" (Melo: 1997).

\footnotetext{
${ }^{141}$ O salário mínimo determina o valor dos benefícios de prestação continuada para idosos e deficientes que recebem benefícios sem ter contribuído e as aposentadorias dos trabalhadores rurais, também sem vínculo contributivo, com reajuste automático a cada aumento do salário mínimo. O impacto do aumento dos salário mínimo se refere, portanto, aos benefícios assistenciais pagos pela Previdência, e não propriamente sobre os benefícios previdenciários.

142 Proposta apresentada pelo Ministro do Trabalho em 1997 que propunha no lugar do salário mínimo unificado nacionalmente dois salários diferentes, um para o setor privado e, outro, para o setor público, Previdência Social e empregadas domésticas. O salário mínimo do setor privado teria ainda valores diferenciados por região, negociados entre trabalhadores, empregadores e governo. O objetivo dessa proposta era separar o efeito fiscal da política do salário mínimo de sua função como balizador do mercado de trabalho e muda a essência da função do salário mínimo até o presente, qual seja, determinar um rendimento ao trabalhador que seja o mínimo necessário à sua sobrevivência física. Camargo, José Márcio. "Salário mínimo, um bom começo”, O Estado de São Paulo, 07/02/1997. Como afirmava Roberto Macedo, “o problema do salário mínimo está mais no seu impacto nas contas públicas”. Macedo, Roberto. “O mínimo de racionalidade”, O Estado de São Paulo, $1^{\circ}$./05/1997.

143 “O orçamento da seguridade social, abrangendo todas as entidades e órgãos a ela vinculados, da administração direta ou indireta, bem como os fundos e fundações instituídos e mantidos pelo Poder Público”. Art. 165, § 5., III, Constituição da república Federativa do Brasil. Op. Cit.

144 "O orçamento fiscal referente aos Poderes da União, seus fundos, órgãos e entidades de administração direta e indireta, inclusive fundações instituídas e mantidas pelo Poder Público”, art 165, § 5., I, Constituição da República Federativa do Brasil. Integram ainda a LOA da União o orçamento de investimento das empresas em que a União detenha a maioria do capital social com direito a voto (item II, do $\S 5^{\circ}$., art. 165.
} 
As demais políticas sociais, como educação, habitação, saneamento básico, transporte, etc, não integram a área da seguridade social e devem ser financiadas com recursos fiscais.

As vinculações de receitas do OF e do OSS e a conseqüente rigidez fiscal estão na base do conflito distributivo, ao lado do crescimento das despesas de execução constitucional ou legalmente obrigatória. As despesas com pessoal, encargos sociais, previdência social, assistência social, educação e saúde cresceram significativamente entre 1995 e 2002 (Brasil, 2003b: 4), enquanto que o grande volume de receitas vinculadas impõe restrições à execução fiscal.

As restrições orçamentárias foram fruto da Constituição de 1988, que criou uma série de destinações específicas para as receitas do Governo Federal: vinculação das contribuições sociais ao OSS; vinculação de no mínimo 18\% das receitas dos impostos para educação e transferências automáticas de recursos aos Estados e Municípios. Após 1988, outras vinculações foram criadas: vinculação da CPMF à saúde, previdência social e Fundo de Erradicação e Combate à Pobreza; vinculação do CIDE ao custeio de programas de infra-estrutura e transporte (Brasil, 2003b: 8).

De outro modo, o crescimento da participação das contribuições sociais no total de recursos arrecadados, seja em decorrência da criação de novas contribuições $\left(\mathrm{CPMF}^{145}\right)$, seja pelo aumento de alíquotas (CSLL ${ }^{146}$, COFINS $^{147}$ e a própria CPMF), torna esses recursos cobiçados na execução orçamentária, levando a outras utilizações diferentes daquelas para as quais foram criadas.

Em relação ao PIB, as receitas de contribuições sociais administradas ${ }^{148}$ pela SRF aumentaram a sua participação de 4,6\% do PIB em 1995 para 7,7\% em 2002, o que

\footnotetext{
${ }^{145}$ A CPMF foi instituída pela EC 12/96, que determinou a alíquota máxima em 0,25\%; em 1999, através da EC 21, a alíquota foi elevada para 0,38\% nos primeiros 12 meses e depois cairia para 0,30\% nos 24 meses subseqüentes; em 2002 foi editada a EC 37 que a prorrogou até o exercício de 2004, com nova alíquota de 0,38\% (2002-2003) e depois, 0,08\% para 2004. Apesar de Provisória a CPMF foi efetivamente cobrada até dezembro de 2006.

${ }^{146}$ A CSLL teve alíquota aumentada de $8 \%$ para $12 \%$, relativa ao período entre maio de 1999 a fevereiro de 2000; e de 8\% para 9\% referente ao período entre fevereiro/2000 a janeiro de 2002 (MP 2037-19, de 28/06/00). A Lei n. 10.637 de 31/12/02 manteve a alíquota de contribuição em 9\%.

${ }^{147}$ O COFINS teve alíquota acrescida de $2 \%$ para $3 \%$ a partir de fevereiro de 1999 , conforme a Lei $n$. 9.718/98.

${ }^{148}$ Exclui as contribuições previdenciárias que são administradas pelo INSS.
} 
equivale a uma elevação de sua carga fiscal em 69\% em termos de participação no PIB. Em 2002, as contribuições sociais corresponderam a aproximadamente $43,6 \%$ das receitas administradas pela SRF e 48,4\% em 2003 (Brasil, 2003b: 9-18). A quase totalidade desses recursos é vinculada à seguridade social.

Gráfico 5. Evolução dos principais impostos versus contribuições sociais

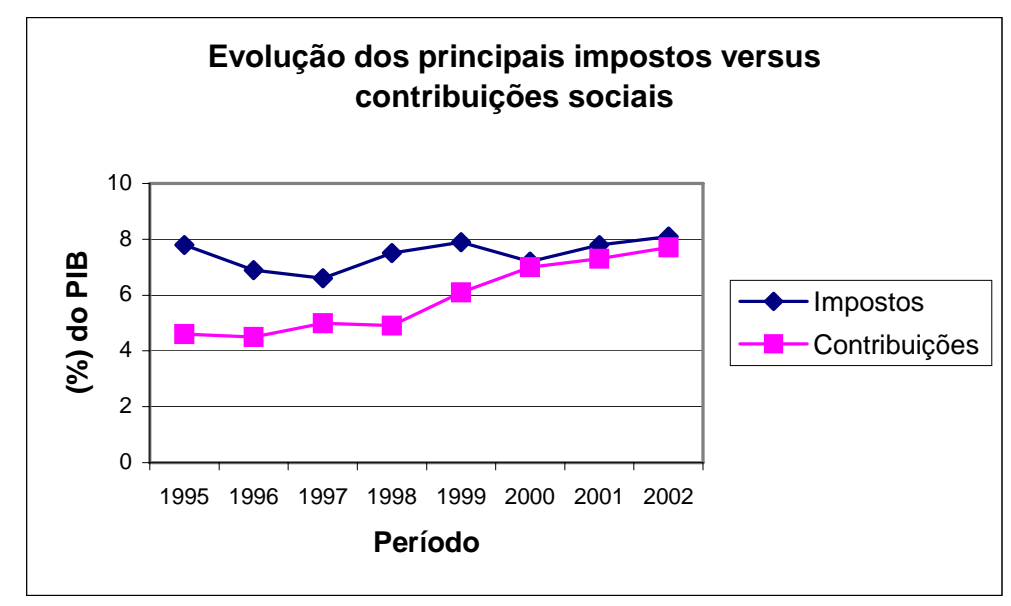

Fonte: Secretaria da Receita Federal.

As vinculações delimitam a possibilidade de uso de recursos fiscais e provocam rigidez fiscal, combatida com a criação do Fundo Social de Emergência, convertido em Fundo de Estabilização Fiscal e posteriormente em DRU, cujo principal objetivo era dotar o regime fiscal de maior flexibilização, ao permitir o uso livre de vinculações de $20 \%$ do orçamento federal. Ficaram de foram dos $20 \%$ da DRU apenas a receita da Previdência Social e a parte da CPMF que financia despesas do Fundo de Combate e Erradicação da Pobreza

A DRU é um mecanismo temporário de flexibilização fiscal enquanto não se aprovam as reformas fiscais. Em documento de 2003, o Ministério de Planejamento, Orçamento e Gestão (MPOG) (Brasil, 2003) estimava que 55\% das receitas desvinculadas eram destinadas ao custeio de despesas de execução obrigatória, dificultando o gerenciamento e a condução de uma política fiscal voltada para o enfrentamento de 
problemas conjunturais. A exigência de manutenção de um determinado nível de superávit primário reduzia ainda mais o nível de despesas discricionárias do Governo Federal.

No entanto, a obrigatoriedade de pagamento de algumas despesas acabava por reverter a criação de recursos livres. Segundo dados do Ministério do Planejamento, do montante de R\$ 20,5 bilhões liberados pela DRU no ano de 2003, apenas R\$ 3,3 bilhões puderam ser livremente utilizados. Um dos principais problemas era o aumento da participação dos gastos com benefícios decorrentes tanto do crescimento vegetativo da massa beneficiaria, quanto dos reajustes do salário mínimo na década de 1990. O amparo assistencial que se propõe a garantir um salário mínimo mensal à pessoa portadora de deficiência e aos com idade avançada e sem meios de prover a própria subsistência, cujo pagamento teve início efetivamente em 1996, aumentou ainda mais as despesas.

\section{Crescimento do número de benefícios}

A constitucionalização dos direitos previdenciários e assistenciais produziu mudanças nos critérios de acesso aos benefícios. Para acompanharmos o efeito produzido apresentamos dois gráficos comparativos para o período pré-regulamentação dos direitos sociais (gráfico 6) e pós-regulamentação (gráfico 7), com dados transcritos, respectivamente nas tabelas 17 e 18. Para tanto, foram realizados dois cortes temporais: de 1980 a 1991, quando foram regulamentados os direitos previdenciários por efeito da promulgação da Lei 8.213/91 e após 1992. Os gráficos demonstram o crescimento total, o crescimento de benefícios previdenciários e o crescimento dos benefícios assistenciais. 
Tabela 17. Quantidade de benefícios concedidos: 1980-1991

\begin{tabular}{|r|r|r|r|}
\hline PERÍODO & BENEFÍCIO RGPS & BENEFíCIO ASSISTENCIAL & TOTAL \\
\hline 1980 & 1450785 & 90897 & 1541682 \\
\hline 1981 & 1614412 & 112319 & 1726731 \\
\hline 1982 & 1585457 & 117319 & 1702776 \\
\hline 1983 & 1701269 & 123242 & 1824511 \\
\hline 1984 & 1554044 & 126285 & 1680329 \\
\hline 1985 & 1564673 & 124005 & 1688678 \\
\hline 1986 & 1480021 & 92053 & 1572074 \\
\hline 1987 & 1406383 & 76053 & 1482585 \\
\hline 1988 & 1347830 & 80150 & 1427980 \\
\hline 1989 & 1469896 & 89664 & 1559560 \\
\hline 1990 & 1305541 & 85152 & 1390693 \\
\hline 1991 & 1288362 & 71536 & 1359898 \\
\hline Fonte: Brasil. MPS/INSS/DATAPREV (2005). Elaboração própria \\
\end{tabular}

O gráfico permite acompanhar a curva de crescimento no período entre 1980 e 1989 e verificar que houve ligeiro aumento no número de benefícios concedidos no ano de 1983 e queda até o ano de 1991. A curva de benefícios previdenciários acompanha a curva do total de benefícios pagos pela Previdência Social, indicando o baixo impacto dos benefícios assistenciais na curva. Apenas entre os anos de 1981 e 1985 o total de benefícios concedidos a título de benefício assistencial superou a casa de cem mil.

Em 1991, foi o ano em que a Previdência Social concedeu o menor número de benefícios, tanto de natureza previdenciária, quanto de natureza acidentária, indicando um estado de expectativa ante a regulamentação da seguridade social, em debate no Congresso Nacional. Há duas explicações para a queda na concessão de benefícios: contenção da demanda pelos usuários que aguardavam a regulamentação ou contenção na concessão pela instituição, pelo mesmo motivo. 
Gráfico 6: Quantidade de benefícios concedidos: 1980-1991

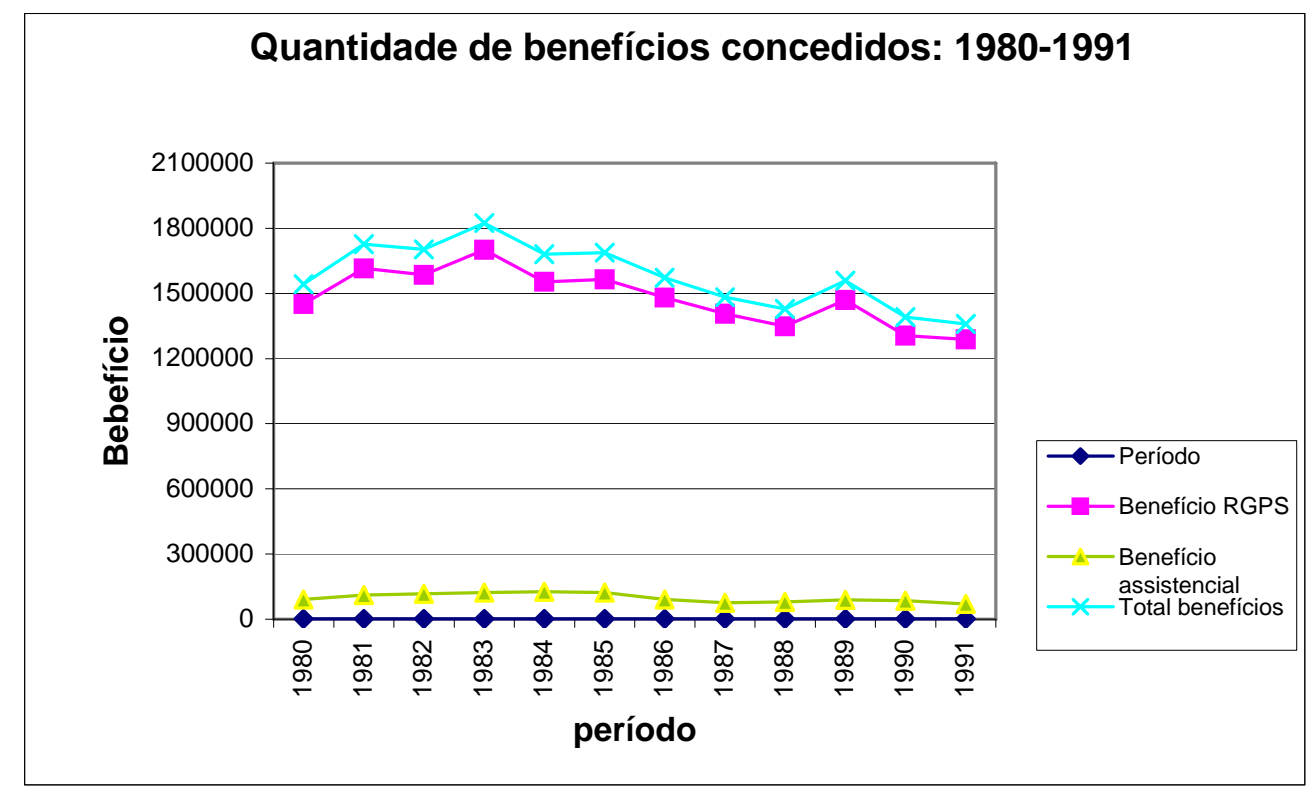

Fonte: BRASIL. MPS/INSS/DATAPREV (2005). Elaboração própria.

No período pós-regulamentação dos direitos previdenciários, o comportamento alterou-se, com crescimento quase que constante no volume dos benefícios concedidos. No entanto, podemos observar que foi a partir de 2000 que o aumento foi maior para os benefícios previdenciários.

Para os benefícios assistenciais, observamos crescimento de concessões a partir de 1996 quando entrou em vigor a LOAS ${ }^{149}$ (Lei Orgânica da Assistência Social). Para efeito de análise foram somados os benefícios concedidos a título de renda mensal vitalícia e os novos amparos assistenciais. Note-se que o número de benefícios assistenciais concedidos saltou de 56 mil em 1995 para 404 mil em 1996. Como assinalou o TCU em auditoria, o pagamento dos benefícios assistenciais foi assumido pela Previdência Social sem que a instituição fosse ressarcida pelos valores dispendidos ou com ampla participação de recursos do Orçamento da Seguridade Social (TCU, 2002: 29).

${ }^{149}$ Lei 8.742/93. 
Tabela 18. Quantidade de Benefícios concedidos: 1992-2005 (R\$ milhões em valores correntes)

\begin{tabular}{|c|c|c|c|c|c|}
\hline ERÍODO & \multicolumn{2}{|c|}{ BENEFÍCIO RGPS } & \multicolumn{2}{|c|}{$\begin{array}{r}\text { BENEFÍCIO } \\
\text { ASSISTENCIA }\end{array}$} & \multirow{2}{*}{$\begin{array}{r}\text { TOTAL } \\
\text { R\$ }\end{array}$} \\
\hline & $\mathrm{R} \$$ & $\%$ & $\mathrm{R} \$$ & $\%$ & \\
\hline 1992 & 1925197 & 97,0 & 61933 & 3,0 & 1987130 \\
\hline 1993 & 2357969 & 96,4 & 87596 & 3,6 & 2445565 \\
\hline 1994 & 2006673 & 96,4 & 74480 & 3,6 & 2081153 \\
\hline 1995 & 1871182 & 97,1 & 55596 & 2,9 & 1926778 \\
\hline 1996 & 1775630 & 81,4 & 404245 & 18,6 & 2179875 \\
\hline 1997 & 2038747 & 86,5 & 318205 & 13,5 & 2356952 \\
\hline 1998 & 2074254 & 88,3 & 272563 & 11,4 & 2346817 \\
\hline 1999 & 2023810 & 86,2 & 226921 & 13,8 & 2250731 \\
\hline 2000 & 2732640 & 92,6 & 216509 & 7,4 & 2949149 \\
\hline 2001 & 2677067 & 93,7 & 179267 & 6,3 & 2856334 \\
\hline 2002 & 3588821 & 92,7 & 284743 & 7,3 & 3867564 \\
\hline 2003 & 3309223 & 93,3 & 236153 & 6,7 & 3545376 \\
\hline 2004 & 3534490 & 88,5 & 459039 & 11,5 & 3993529 \\
\hline 2005 & 3637490 & 91,9 & 318262 & 8,1 & 3955724 \\
\hline
\end{tabular}

Fonte: MPS/INSS/DATAPREV

Anuário Estatístico da Previdência Social. Suplemento Histórico (1980-2005).

Os dados da tabela 18 indicam que houve um crescimento da participação dos benefícios assistenciais no total de gastos previdenciários a partir de 1996, saltando de 2,9\% em 1995, para 18,6\% em 1996, como indicativo do total de crescimento no número de benefícios concedidos. No entanto, nos anos seguintes a quantidade de novos benefícios anuais decresce até alcançar a variação entre 6,5\% e 7,0\% no período entre 2000 e 2003 . A taxa de crescimento no número de benefícios foi de 309\% no período entre 1996 e 2000, estabilizando no período posterior em 2,7\% (Tabela 18). O gráfico 7 permite acompanhar a curva de benefícios concedidos anualmente, no período de 1992 a 1995. 
Gráfico 7. Quantidade de benefícios concedidos: 1992-2005

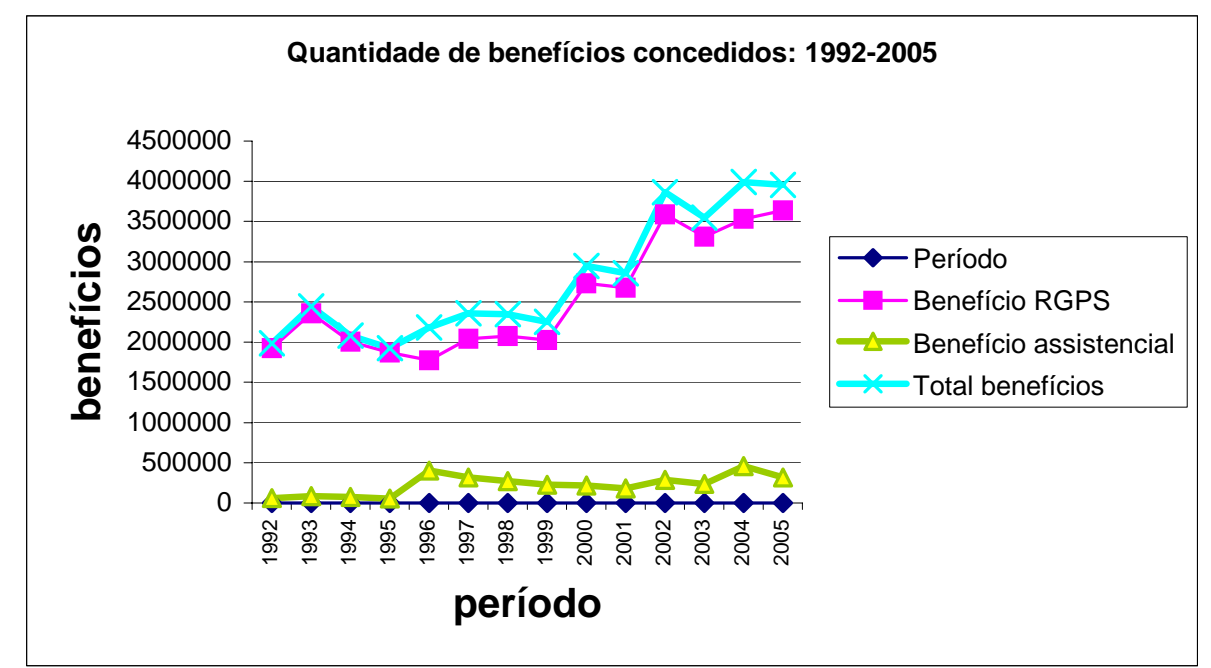

Fonte: BRASIL.MPS/INSS/DATAPREV (2005). Elaboração própria

A curva de concessão de benefício entre os anos de 1992 e 2005 apresentou comportamento diferente em relação ao período anterior, que havia se encerrado contabilizando em torno de 13 milhões de benefícios pagos pela Previdência Social, dos quais apenas 72.000 eram assistenciais. A partir de 1992, como resultado da aprovação do Plano de Benefícios a curva passa a apresentar um crescimento quase que constante, com decréscimo entre os anos de 1994 e 1996. Se, a partir de 1997 inicia-se um novo ciclo de crescimento, ele torna-se expressivo a partir de 2001. É possível estabelecer correlação entre o crescimento no número de benefícios previdenciários e os projetos de reforma em 1991 (com a regulamentação), a partir de 1998 com a EC 20 e a partir de 2001, com a expectativa do terceiro ciclo de reformas no Governo Lula.

No período entre 1980 e 1985, foram concedidos 8.623.025 benefícios pela Previdência Social, dos quais 8.019.855 previdenciários e 603.170 a título de amparo assistencial. As taxas revelam que houve crescimento negativo no período entre 1986 e 1990, período que antecede tanto a promulgação da Constituição quanto a regulamentação do capítulo dos direitos sociais. A taxa de crescimento dos benefícios concedidos permite observar o importante crescimento no número de benefícios assistenciais ocorrido no 
período entre 1996 e 2000, quando teve início a concessão do novo amparo assistencial ${ }^{150}$, que triplicou o número de benefícios concedidos. Crescimento da mesma magnitude não foi observado em relação aos benefícios previdenciários em nenhum período. A maior taxa de concessão de benefícios foi observada entre a promulgação das duas reformas da Previdência Social e não após a regulamentação da Constituição como tem sido divulgado.

Tabela 19: Taxa de crescimento dos benefícios concedidos: 1986-2005

\begin{tabular}{ccrr}
\hline Período & Benef. RGPS & Benef. Assistencial & Total benef. \\
\hline $1986-1990$ & $-12,60$ & $-29,85$ & $-13,80$ \\
$1991-1995$ & 26,84 & $-17,00$ & 31,85 \\
$1996-2000$ & 12,65 & 309,64 & 23,29 \\
$2001-2005$ & 57,32 & 2,71 & 50,77 \\
\hline Fonte: BRASIL PS/INSS/DATAPREV (2005). Elaboração própria
\end{tabular}

Fonte: BRASIL PS/INSS/DATAPREV (2005). Elaboração própria

Os dados relativos à quantidade de aposentadorias concedidas por idade no período de 1998 a 2005 demonstram um aumento explosivo nos anos de 1992 e 1993, quando atingiu mais de 1 milhão de benefícios concedidos, como reflexo da regulamentação do Plano de Benefícios da Previdência Social. O TCU já havia assinalado em 2002 que as aposentadorias por idade representam um grande fator de desequilíbrio no RGPS, visto que não correspondem a contribuições pretéritas em valor/tempo suficiente para a sua cobertura, necessitando de maior subsídio ${ }^{151}$.

As aposentadorias por invalidez não apresentaram mudanças bruscas no seu comportamento. As aposentadorias por tempo de serviço (convertida em tempo de contribuição a partir de 1999) apresentaram um crescimento contínuo até 1998, quando começaram a decair em quantidade numérica, estabilizada na casa de 150.000 benefícios concedidos anualmente.

\footnotetext{
${ }^{150}$ O Decreto n. 1744 de 18/12/95 extinguiu as rendas mensais vitalícias a partir de $1^{\text {o }}$. de janeiro de 1996 quando começou a ser pago o amparo assistencial. Os benefícios pagos a ambos os títulos concomitantemente foram somados para fins analíticos, totalizando os benefícios por idade e para cobertura de deficientes.

${ }^{151}$ Ver a respeito da taxa de retorno, o capítulo VII desta tese, que apresenta a análise de Calsavaro, para quem, por ser contributiva, a aposentadoria por tempo de serviço é a que menos onera a Previdência entre todos os benefícios pagos (CALSAVARO, 2001).
} 
Gráfico 8: Distribuição de aposentadorias concedidas segundo espécies: 1998-2005

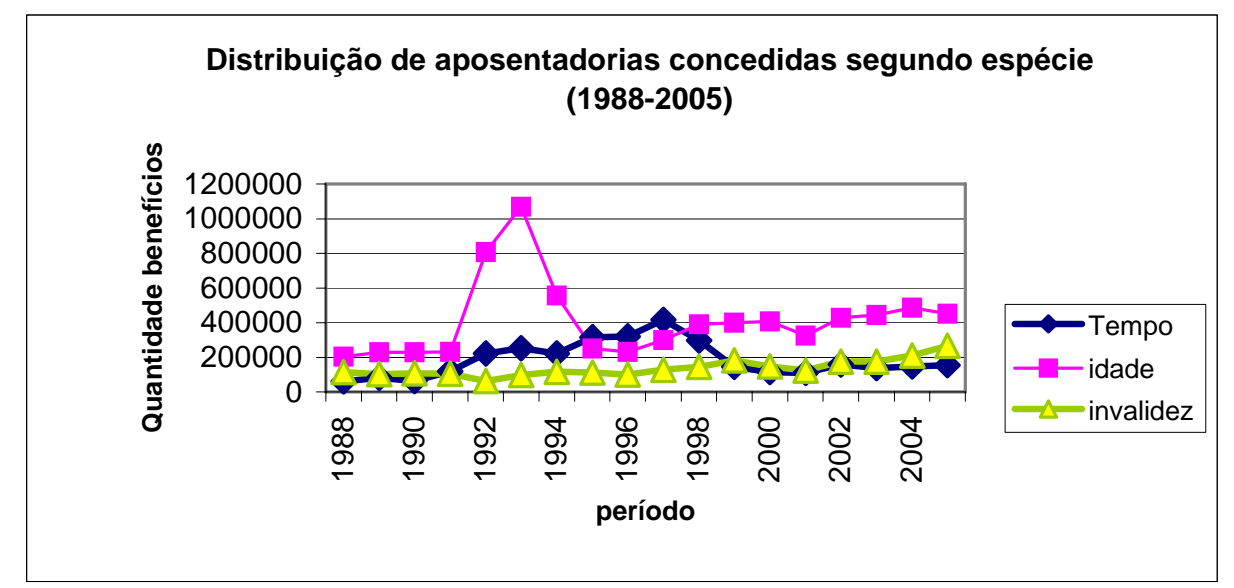

Fonte: BRASIL.MPS/INSS/DATAPREV (2005). Elaboração própria

As aposentadorias são os benefícios concedidos em maior quantidade pela Previdência Social, tendo o ano de 1993 se constituído num ano atípico, quando alcançou a marca de 1.500.000 milhões de benefícios concedidos. Esse comportamento foi decrescente até 1996, quando voltou a crescer, mas não no mesmo patamar. É possível supor que as reformas e a perspectiva de perda de direitos garantidos pela legislação anterior tenham influído no aumento de pedidos de aposentadorias. A pensão por morte e os benefícios acidentários (pensão por morte, aposentadoria acidentária e auxílio-acidente) não apresentaram variação significativa no número anual de concessões.

Os auxílios-doença, por outro lado, têm sido objeto de crescente preocupação da Previdência Social que prepara, em 2008, projetos de mudança na forma de concessão, controle e fiscalização, devido ao crescimento contínuo e acentuado que vem apresentando desde 2001. 
Gráfico 9. Distribuição dos benefícios por espécie: 1988-2005

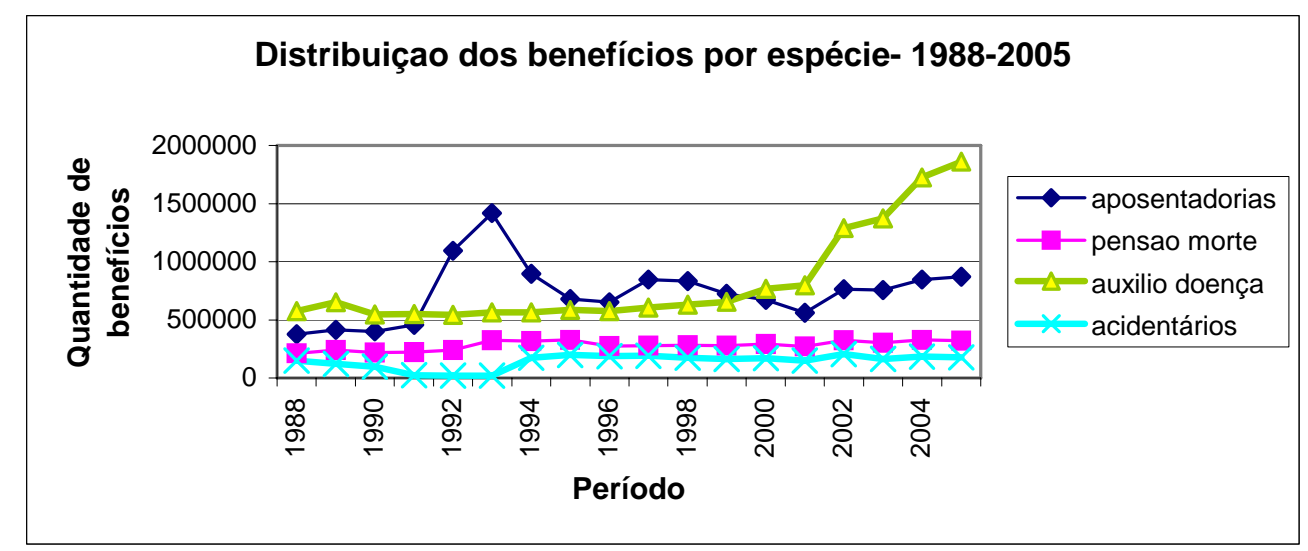

Fonte: BRASIL.MPS/INSS/DATAPREV (2005). Elaboração própria

Apesar das divergências quanto à existência de déficit ou superávit nas contas da Previdência Social, o TCU (2002) é contundente ao afirmar que a grande informalidade no mercado de trabalho e a presença de benefícios assistenciais ou subsidiados (aposentadorias especiais, por idade, renúncia fiscal etc) poderão inviabilizar o sistema, motivo que leva à necessidade de ajustes a serem processados via reforma no plano de benefícios e custeio, mas também através de medidas de racionalização. Nesse sentido, as auditorias perpassaram não apenas as contas da Previdência, mas também a evasão de receitas, fiscalização, mecanismos de cobrança, sistemas de informação, análise de rotinas e procedimentos, sistema de segurança (lógica e física), confiabilidade do sistema etc.

Durante as auditorias, o TCU identificou falhas em três níveis de gestão: estrutural, funcional e operacional, que requeriam medidas urgentes de sistematização. Foram abordados ainda: a gestão de bens imóveis do INSS, o montante de créditos e a análise de contratos e licitações.

O acompanhamento da relação de devedores do INSS (1998-2000) o TCU verificou que a participação de empresas privadas no total da dívida é de cerca de 91\%, mas que órgãos públicos também mantém dívida com INSS que chegam a 8\%. Órgãos públicos federais totalizaram apenas 1\% da dívida. Os grandes devedores em 2000 (com dívidas acima de R\$ 1 milhão) foram 10.324 empregadores responsáveis por 83\% da dívida ativa do INSS. 
Os dados apresentados permitem acompanhar como as informações oficiais relativas a arrecadação e despesas previdenciárias passaram a ser, ao longo do tempo, contestadas em razão não apenas da metodologia utilizada, mas também pela manipulação contida que revelam um conflito distributivo entre as áreas do Governo. O controle público exercido pelo Legislativo, pelo TCU e pela sociedade civil (considerando também as diversas pesquisas realizadas nas contas da Previdência Social) determinou mudanças fundamentais à transparência nas contas públicas.

O objetivo deste capítulo, portanto, foi apresentar como, a partir da contestação do TCU, a receita e a despesa do INSS passaram a ser discriminadas, item por item, permitindo separar e discriminar os gastos em razão de sua natureza previdenciária ou não (incluindo EPU, assistência social, aposentadoria de trabalhadores rurais etc). 


\section{PARTE II}

TEMPO E CONTRATEMPO NA HISTÓRIA DO DIREITO SOCIAL NO BRASIL 


\section{CAPÍTULO IV}

\section{TEMPO DE RENOVAÇÃO:}

\section{A REGULAMENTAÇÃO DOS DIREITOS DA SEGURIDADE SOCIAL (1989-1992)}

O momento de regulamentação dos dispositivos constitucionais e a previsão de uma revisão constitucional para o ano de $1993^{153}$ serviram para alimentar a disputa em torno da definição dos direitos sociais inseridos no novo conceito de seguridade social. Tanto a regulamentação, quanto a revisão pré-agendada, serviram como atenuantes aos direitos consagrados no texto constitucional. O direito à seguridade social na Constituição Federal era afirmado como uma virtualidade que deveria ser reafirmada pela legislação infraconstitucional e, posteriormente, regulamentada. Nesse contexto, o período pósconstituinte foi de intensa disputa em torno dos seguintes itens:

1. seguridade social ou seguro social (conceitual);

2. repartição ou capitalização; público ou privado (modelo);

3. base de financiamento da seguridade social (financeira);

4. salário mínimo como parâmetro para a definição do valor do benefício previdenciário (econômica);

5. aposentadoria por tempo de serviço (critérios de elegibilidade);

6. aposentadoria integral do funcionalismo público (unificação de regimes) e

7. controle social e modelos de participação social.

Inicialmente, a disputa se encerrava muito mais em torno da definição do modelo de proteção social do que sobre o escopo dos direitos e garantias instituídos. A grande divergência estava contida na definição de que "a seguridade social será custeada por toda a sociedade”, porque significava repensar o modelo contributivo de financiamento até

\footnotetext{
${ }^{153}$ A EC 2 previa a realização da revisão constitucional a partir de cinco anos da data de sua promulgação em 1988. Constituição da República Federativa do Brasil, 1988.
} 
então vigente para as áreas da saúde, previdência e assistência social e redistribuir recursos fiscais, especialmente no financiamento das demais políticas sociais ${ }^{154}$.

A construção de um modelo de seguridade social universalista previa tornar o financiamento menos sujeito às variações cíclicas da economia que afetam diretamente o nível de produção, emprego e renda, principais fontes de financiamento das políticas sociais ${ }^{155}$. Os constituintes previram uma base diversificada de financiamento para a saúde, assistência social e previdência social, com base na folha de salário das empresas, no faturamento, no lucro, nas receitas de concursos e prognósticos, além de recursos provenientes do orçamento fiscal para cobertura de eventuais déficits financeiros. Os recursos do PIS/PASEP, sob gestão do FAT deveriam financiar exclusivamente o segurodesemprego e empréstimos a empresas geridos pelo BNDES ${ }^{156}$.

Se, a grande questão dos anos precedentes era como instituir direitos de cidadania universais - igualar as condições de acesso para o conjunto da população, remover os critérios de estratificação social com base em emprego e renda - ela foi invertida e o foco central passou a ser em como garantir o seu financiamento e conferir efetividade aos novos compromissos sociais assumidos.

Um dos problemas centrais enfocados no debate era, justamente, a constitucionalização da definição do parâmetro de equivalência dos benefícios previdenciários e assistenciais ao salário mínimo nacional e a irredutibilidade do valor dos benefícios. A sua aplicação de imediato promoveria um aumento de $100 \%$ nas despesas relativas à renda mensal vitalícia paga pela Previdência Social a título de assistência social.

O foco da disputa foi, desde o início, a previdência social e o seu modelo de financiamento, dado seu peso e relevância no tripé da seguridade social. Em decorrência dessa disputa, a regulamentação da seguridade social, prevista para ocorrer em até 180 dias após a promulgação da Constituição, foi adiada e tornou-se objeto de uma intensa disputa entre políticos e técnicos e entre o Legislativo e o Executivo. O então presidente José Sarney afirmava que a nova Constituição tornaria o país ingovernável e um dos principais

\footnotetext{
154 Educação, habitação, transporte, nutrição, saneamento básico, dentre outras, não integravam o OSS e deveriam ser financiadas com recursos provenientes do OF, tornando ainda mais significativo o aporte de recursos para o financiamento de políticas sociais, elevando o patamar histórico do gasto social.

${ }^{155}$ Até a Constituição Federal de 1988, as políticas sociais eram financiadas com base nas contribuições sobre a folha de pagamento de salários e através dos lucros das empresas (Finsocial).

${ }^{156}$ Entre 1997 e 2007, a CPMF também passou a integrar o OSS, com uso exclusivo para o financiamento da saúde e da previdência social.
} 
problemas apontados era a definição do salário mínimo como parâmetro para o reajuste do valor dos benefícios, não apenas por elevar os gastos sociais, mas também, porque retiraria do gestor previdenciário o controle sobre os critérios de reajuste, e, portanto, o poder de ajustar as despesas às receitas através da redução do valor dos benefícios. O valor dos benefícios deixava de ser uma atribuição técnica e tornava-se um dos principais problemas de política econômica e social, e passou também a ser uma diretiva importante da política de reajuste do salário mínimo.

A rigidez fiscal e orçamentária, a extensão dos direitos sociais e o crescimento dos gastos sociais sem a devida definição da fonte de financiamento entraram na pauta sobre as reformas, conferindo ao tema da governabilidade grande centralidade no debate público, justamente pela sua antítese (Melo: 1997b).

A governabilidade é um daqueles temas que permitem a imbricação entre as dimensões políticas, sociais, econômicas e fiscais da reforma do Estado. Ela é mais que apenas a dimensão institucional do governo. Melo (1995b) resume em cinco os principais argumentos que estruturam a discussão sobre a ingovernabilidade: 1 . saturação da agenda política com a redemocratização e a universalização dos direitos sociais; 2. o excesso de participação política e a baixa institucionalização da Nova República; 3. federalismo fiscal e a descentralização das políticas sociais; 4. a conversão do Judiciário em ator político e fonte de incerteza na gestão econômica; 5. excesso de governo (conteúdos técnicos são politizados de forma invertida).

Ao declarar que com a nova Constituição o país se tornaria ingovernável, o Presidente José Sarney retirou visivelmente o seu apoio ao texto constitucional recém promulgado, embora estivesse constrangido, política e legalmente, a regulamentá-lo. A tentativa de mudança na orientação da política previdenciária tornou-se explícita na troca da direção do MPAS e a conseqüente convocação de antigos quadros para compor a burocracia. A proposta de seguridade social na qual os técnicos do MPAS vinham trabalhando foi deixada de lado ${ }^{157}$ e o Executivo enviou ao Congresso projetos de lei e a

\footnotetext{
${ }^{157}$ O relatório do grupo de trabalho formado em 1986 para a reestruturação da Previdência Social exerceu grande influência no debate constituinte, a partir da proposição da adoção do conceito de seguridade social, com a criação de um sistema abrangente de benefícios universais e a organização de um sistema complementar e facultativo destinado a completar os benefícios dos trabalhadores de maior renda (MPAS, 1986). O capítulo II desta tese traz uma síntese dos debate e das propostas apresentadas no documento.
} 
MP 63/89 que propunham desvincular o valor dos benefícios previdenciários do salário mínimo. ${ }^{158}$

O projeto de regulamentação foi enviado ao Congresso com atraso, através da Mensagem 34, de 30 de junho de 1989, pelo Presidente da República, oito meses após a data da promulgação da Constituição, e foi transformada no PL 2.570/89. O PL foi analisado pela CSSF da Câmara dos Deputados que finalizou seu relatório em dezembro de 1989 e o enviou à CFT para que o órgão técnico compatibilizasse as despesas oriundas desta proposição ao OGU. Em abril de 1990, foi apresentado o relatório geral da Comissão, de autoria do Deputado Fernando Bezerra Coelho, sobre os quatro PLs da área da seguridade social: organização da seguridade social ${ }^{159}$ (PL 3.101-A/89), previdência social $^{160}$ (PL 2.570/89), assistência social ${ }^{161}$ (PL 3.099-B/89) e saúde ${ }^{162}$ (PL 3.110-B/89). Em seguida, os PLs foram novamente remetidos à CFT para compatibilização das despesas com OGU. O relator manifestava a sua preocupação com o prazo de regulamentação e conclamava o Congresso Nacional a concentrar os seus esforços, juntamente com representantes do MTPS $^{163}$, na Comissão de Finanças para que os quatro projetos fossem aprovados simultaneamente e encaminhados ao Senado, uma vez que já havia se encerrado o prazo para o recebimento de emendas ${ }^{164}$.

Os PLs da previdência e da seguridade social haviam sido bem recebidos pelo Congresso como "fruto dos avanços sociais conquistados através da nova ordem

\footnotetext{
${ }^{158}$ Ver a respeito: (SiLVA, 1992; FAgNANI, 1997; CoELHo, 1999).

159 "Dispõe sobre a organização da Seguridade Social, institui o Plano de Custeio e dá outras providências”.

160 “Dispõe sobre os Planos de Benefícios e de Custeio da Previdências Social e dá outras providências”.

161 “Dispõe sobre a Lei Orgânica da Assistência Social, suas definições, princípios e diretrizes, determina competências gerais em cada esfera de governo, benefícios e serviços, fontes de financiamento e dá outras providências".

162 “Dispõe sobre as condições para a promoção, proteção e recuperação da saúde, a organização e o funcionamento dos serviços correspondentes e dá outras providências”.

${ }^{163}$ No Governo Collor ocorreu fusão entre os Ministérios do Trabalho e da Previdência Social, que depois foram novamente desmembrados.

${ }^{164}$ Deputado Fernando Bezerra Coelho (PMDB/PE). Diário da Câmara dos Deputados, 25/04/1990: 33773378. O Deputado Darcy Deitos (PSDB/PR) também considerava a tramitação urgente: “Devemos (...) atentar para o contínuo desgaste que o Legislativo tem sofrido ultimamente pela delonga na votação de questões de extrema importância e que decorrem de disposições constitucionais. Temos que compreender como irrecusável a obrigação de concluirmos o trabalho constitucional, não esgotado com a promulgação da Carta Constitucional, mas que se transferiu ao Congresso em face de sua híbrida função de poder originário, exercido durante os trabalhos da Assembléia Nacional Constituinte e de poder derivado, porquanto os mesmos legisladores prosseguem no exercício do mandato normal”. Diário da Câmara dos Deputados, 25/04/1990: 3378.
} 
constitucional do País...”165, sob o argumento de que combinava os princípios relevantes já consagrados no sistema previdenciário com novos, dentre os quais destacavam-se a cobertura universal no atendimento e no benefício; benefícios aos trabalhadores rurais e urbanos uniformes e equivalentes; prestação de benefícios de forma seletiva; irredutibilidade dos benefícios e eqüidade na participação do custeio ${ }^{166}$. As alterações efetuadas buscavam a correção das imperfeições de modo a tornar o sistema previdenciário consoante os princípios constitucionais. “Consagrou-se o princípio da igualdade de direito de todas as categorias de segurados em relação aos benefícios do sistema, consolidandose, com isso, a identidade de direitos de trabalhadores rurais e urbanos”, conforme declarou o Deputado Floriceno Paixão ${ }^{167}$.

Até esse momento, não havia qualquer indicação de questionamento da organização da seguridade social pelo Congresso, muito embora o PL original tenha seguido a lógica da separação das três áreas (saúde, assistência social e previdência social), mantendo apenas o orçamento integrado.

Sem conseguir alterar a vinculação do piso dos benefícios ao salário mínimo, o mandato do Presidente Sarney expirou sem a regulamentação dos dispositivos constitucionais, pondo fim ao seu compromisso com o "resgate da dívida social”. O presidente Fernando Collor de Mello, empossado em Março de 1990, manteve as críticas de seu antecessor à adoção do salário mínimo como piso dos benefícios previdenciários, apresentando sinais indicativos de que não aprovaria os PLs em discussão no Congresso Nacional.

Em março de 1990, mês da posse do novo Presidente, os deputados federais começaram a reivindicar a aprovação do Plano de Custeio e Beneficio da Previdência e da Seguridade Social ${ }^{168}$ o qual, mesmo após ter sido apreciado no Senado, não seguira para deliberação do Plenário.

\footnotetext{
${ }^{165}$ Deputado Inocêncio Oliveira (PFL/PE). Diário da Câmara dos Deputados, 23/02/1990: 817.

${ }^{166}$ Grifos do autor.

${ }^{167}$ Deputado Floriceno Paixão (PDT-RS). Diário da Câmara dos Deputados, Relatório final do Projeto de Lei $2.570 / 89$.

168 Marcos Queiroz (PMDB-PE), 22/03/1990:1.805-1.806; Paulo Paim (PT-RS). Diário da Câmara dos Deputados, 23/02/1990: 816; Inocêncio Oliveira (PFL-PE). Diário da Câmara dos Deputados, 23/02/1990: 817; Darcy Deitos (PSDB-PR). Diário da Câmara dos Deputados, 25/04/1990: 815; Adhemar de Barros Filho (PRP-SP). Diário da Câmara dos Deputados, 23/02/1990: 814.
} 
O ano de 1990 foi um período de intenso debate no Congresso para apressar a regulamentação dos direitos sociais inseridos na Constituição, tendo em vista as eleições legislativas previstas para o segundo semestre e o temor de que na próxima legislatura não se mantivesse o compromisso original com o texto constitucional, o que revelava, em certa medida, a fragilidade da sua base de sustentação política. O reverso do ambiente político que havia favorecido a universalização dos direitos sociais já era sentido com o novo discurso do Presidente Collor embasado nos termos do Consenso de Washington, com peso considerável em aspectos como a privatização, a contenção do déficit público, fim dos privilégios dos servidores públicos e reforma do Estado ${ }^{169}$. Um discurso que se fundava na oposição tanto ao Governo de José Sarney quanto a Luiz Inácio Lula da Silva, principal líder do partido da esquerda que disputara com ele a Presidência da República.

Em agosto de 1990 ainda não haviam sido aprovadas as leis que disciplinam os dispositivos constitucionais considerados mais importantes, tais como o Código de Defesa do Consumidor, a Lei de Diretrizes e Bases da Educação e as leis orgânicas do Ministério Público, da saúde, da assistência social, da previdência social, da seguridade social.

No Congresso, ao mesmo tempo em que se protelava a regulamentação do Plano de Benefícios, seguia um forte embate sobre a definição do salário mínimo, havendo impasse na aprovação do aprovado na CTASP, com uso de expedientes como o adiamento da votação e a interposição de veto presidencial.

\footnotetext{
${ }^{169}$ A instigante análise de Olga Tavares apresenta os discursos de Fernando Collor como um discurso messiânico que busca consagrar o casamento entre política e religião como um projeto de "salvação nacional”. Para a autora, o enunciado discursivo de Collor tem por objetivo refundar a noção de brasilidade, apresentando-se, ele mesmo, como signo da modernidade: dinamismo, juventude, gosto pela inovação tecnológica, culto ao físico, apreço pela ecologia, pela elegância yuppie, agilidade e cultura. Collor implantou uma espécie de "neopopulismo" ao se proclamar neoliberal e ao prometer uma reforma absoluta na estrutura sócio-econômica do país, que o levaria à modernidade, pregando a favor da privatização das empresas estatais, da abertura do mercado e da caça aos "marajás”, como alusão ao fim dos privilégios e da corrupção. Collor, ao estabelecer um discurso centrado no "nós e eles" criava a ilusão de que junto com o povo (minha gente) tinham o controle da situação e poderiam enfrentar os seus inimigos: José Sarney, Luiz Inácio Lula da Silva e os marajás. Em plena campanha eleitoral, afirmaria "Venho em nome da fé, como mandatário da Verdade e sob a inspiração da Liberdade com Justiça, para promover a prosperidade coletiva, retomar o desenvolvimento, restaurar a dignidade da vida pública, assegurar a soberania nacional, reformar as velhas estruturas e banir de vez os vícios da incompetência, da corrupção e das práticas espúrias que infelicitam o País, degradam a atividade política e envergonham a Nação". Fernando Collor de Mello. Discurso de 12/07/1989 (apud TAVARES, 1998: 31). O “tempo messiânico” apresenta a peculiaridade de estar fora da temporalidade, como uma promessa infinita e indefinida, como um tempo novo, marcado tanto pela vingança quanto pela justiça. Collor o captou bem ao apresentar-se como um cavaleiro andante contra tudo e contra todos, em nome da fé, da verdade, e da liberdade da justiça (OLIVEIRA, 1992b: 48-50).
} 
Em agosto de 1990, o Deputado Hermes Zanetti, registrava em plenário a manobra de Senadores compromissados com o Presidente Collor para adiar a sua votação prevista para 10/08/1990. O Deputado reclamava a independência entre Legislativo e Executivo e afirmava que, se não havia intenção em aprovar o PL, o Presidente deveria fazer uso de seu direito de veto ${ }^{170}$, mas não realizar manobras. O que o deputado de fato pleiteava era o respeito às regras e procedimentos formais democráticos, ainda que o resultado fosse desfavorável.

A resposta do Presidente foi o veto integral ao PL apresentado pelo Congresso que tratava do aumento do salário mínimo e a edição da MP $^{171}$ 199/90 que concedia abono salarial à classe trabalhadora, mas excluía do benefício os aposentados e os pensionistas. Anteriormente, a MP 193/90 já havia proposto a desvinculação entre benefício previdenciário e o salário mínimo.

Em meio às disputas em torno das razões que justificavam tal medida, cujo argumento central era o déficit da Previdência, o próprio Presidente do INSS veio a público afirmar que a Previdência estava em condições de conceder o abono, graças ao superávit de 99 bilhões de cruzeiros obtidos no mês de junho, dos quais o pagamento consumiria apenas 31 bilhões, menos de um terço do superávit anunciado. Mas a equipe econômica mantinhase irredutível na disposição de negociar o abono em troca do veto ao PL salarial aprovado pelo Congresso Nacional. ${ }^{172}$

Os termos da disputa em torno do déficit previdenciário com a equipe econômica estavam armados: o aumento do salário mínimo passou a ser delimitado pelas contas da Previdência Social. O salário mínimo perdia a sua vinculação com o custo da vida e condições mínimas para a sobrevivência e convertia-se em medida do caixa da Previdência

\footnotetext{
${ }^{170}$ Hermes Zanetti (PSDB-RS). Diário da Câmara dos Deputados, 10/08/1990: 9.140.

${ }^{171}$ O artigo 62 da Constituição de 1988 confere ao Presidente da República, em caso de relevância e urgência, o poder de editar Medidas Provisórias, com força de lei, que deve ser submetida ao Congresso Nacional e convertida em lei no prazo de 30 dias, quando perdem a sua eficácia. Collor abusou da edição de MPs como forma de contornar o conflito e as resistências do Congresso ao seu plano de estabilização econômica. Por outro lado, alterações no rumo das relações entre governo, partidos políticos e o Congresso, levaram à redução do número de Medidas Provisórias e o conseqüente aumento de leis ordinárias em tramitação. No entanto, no governo Itamar Franco o seu uso foi retomado, tornando-se especialmente a medida preferida de regulamentação de ações econômicas pelo governo. O uso de MP pelo Executivo é fruto de um cálculo político do Legislativo, da qual se beneficiaria ao não se ver associado a políticas impopulares e incertas, ao mesmo tempo em que não traz o prejuízo de se ver associado à figura de um obstáculo à ação do Executivo (FIGUEIREDO; LIMONGI, 1997: 41).

172 Antônio Câmara (PRN-RN). Diário da Câmara dos Deputados , 22/08/1990: 9.410.
} 
Social, ou seja, no quanto podia sustentar do pagamento dos benefícios. O resultado era sempre referido ás despesas previdenciárias anuais e ao desequilíbrio nas contas públicas $^{173}$.

É necessário apontar que as restrições impostas ao Orçamento da Seguridade não foram obedecidas nem pelo Governo Sarney (1989), nem pelo Governo Collor (1990). Ambos os governos utilizaram recursos do Finsocial no pagamento dos EPUs, que não integram a definição de seguridade social.

A Lei Orgânica da Saúde (Lei 8.080) foi aprovada em 19/09/1990 com o veto presidencial à criação dos Conselhos Municipal e Estadual da Saúde que asseguraria a participação da comunidade ${ }^{174}$ na gestão das áreas integrantes da seguridade social, através de assento nos órgãos colegiados ${ }^{175}$, assim como o repasse automático de verbas para o nível local como pressupunha o federalismo tributário ${ }^{176}$. No entanto, a sua aprovação fez com que a União deixasse de destinar (pelo menos) 30\% do total de recursos da seguridade social para a saúde, como dispunha o artigo 55 do ADTC.

$O$ veto às medidas de controle social e a indefinição quanto às transferências intergovernamentais de recursos financeiros para a área da saúde levaram à apresentação de novo PL para corrigir as distorções da primeira Lei, o qual foi aprovado e transformado numa segunda Lei Orgânica (Lei 8.142, de 28/12/90). Com a sua promulgação, restabeleceu-se a participação da comunidade na gestão do SUS, mediante a criação dos Conselhos de Saúde e das Conferências de Saúde (nos três níveis do governo), bem como disciplinou a transferência dos recursos arrecadados pela União para Estados, Distrito Federal e Municípios.

Tecnicamente, a partilha dos recursos da seguridade social era feita a cada exercício na respectiva LOA e ela apontou para uma certa vinculação entre fontes de financiamento e áreas sociais, com a destinação dos recursos do Finsocial prioritariamente à saúde; da contribuição sobre o lucro para a assistência social e, aqueles originados na folha de pagamentos, para a previdência. No plano de financiamento estava dada a desintegração

\footnotetext{
${ }^{173}$ Atas da CTASP (1990-2002). Diário da Câmara dos Deputados, várias edições.

${ }^{174}$ Item III, art. 198 da Constituição. Constituição da República Federativa do Brasil, 1988.

${ }^{175}$ Item VII, art. 194 da Constituição. Constituição da República Federativa do Brasil, 1988.

${ }^{176}$ A expressão “federalismo tributário” representa a fixação no texto constitucional do Fundo de Participação de Estados e Municípios (FPE e FPM), a partir do princípio da territorialidade na arrecadação dos tributos. O federalismo tributário obrigou a União a partilhar recursos arrecadados por meio de impostos com Estados e Municípios a percentuais fixos.
} 
entre as áreas e a vinculação de recursos a políticas, tudo o que o texto constitucional tentava evitar. A vinculação de recursos conduziu a uma política de competição por recursos entre as áreas da saúde, da previdência social e assistência social, que em nada favorecia a idéia de integração ou de implantação de um sistema de proteção social mais amplo.

O texto constitucional é marcado por uma certa ambigüidade no tratamento da questão da vinculação de receitas a despesas pré-definidas. Ao mesmo tempo em que veda a vinculação de impostos a determinadas despesas, prevê a vinculação de contribuições sociais a políticas como educação, saúde, previdência e assistência social. A vinculação, no caso brasileiro, acaba por ser um importante instrumento para fazer com que as instituições governamentais cumpram com a sua parte no financiamento das políticas sociais. Conforme destaca Sólon Vianna (2005), o seu principal mérito estaria em encerrar a disputa entre as áreas sociais por recursos, ao tornar a partilha automática. No entanto, ela acaba por impedir a função alocativa do Congresso Nacional quando da discussão da LOA.

O Presidente vetou integralmente também o Plano de Benefícios da Previdência Social e a Lei de Custeio da Seguridade Social, sob o argumento de que não havia recursos suficientes para implementá-los tal como fora aprovado e que novos encargos poderiam comprometer a estabilização econômica. Houve, dessa forma, uma desvinculação também no trâmite dos PLs das três áreas integrantes da seguridade social, que levou à sua aprovação em anos diferentes ${ }^{177}$.

O desenho adotado no plano institucional e legal levou efetivamente a uma separação entre as áreas, com vinculação de receitas especificamente para o custeio de suas ações, ou seja, o oposto do pretendido pelos constituintes. O Orçamento da Seguridade preconizado pelo texto constitucional tornou-se uma "peça de ficção" (Soares, 2001: 214; Castro et al., 1997: 83), sem participação social e sem transparência.

O Deputado Jorge Uequed (PSDB-RS) considerou o veto “desumano, cruel, irresponsável e desleal” ${ }^{178}$, porque feria a expectativa de direito, a perspectiva de construir

\footnotetext{
${ }^{177}$ Saúde (1990), previdência social (1991) e assistência social (1993).

178 Jorge Uequed (PSDB-RS). Diário da Câmara dos Deputados, 13/09/1990: 10.037. Pronunciaram-se ainda contra o veto e exigindo a sua derrubada os deputados: Sandra Cavalcanti (PFL/RJ); Luiz Henrique (PMDBSC); João Paulo (PT/MG); Augusto Carvalho (PCB-DF), Inocêncio Oliveira (PFL-PE), Elias Murad (PSDBMG), Renato Vianna (PMDB-SC), Floriceno Paixão (PDT-RS), Arnaldo Martins (PSDB-RO), Maurílio
} 
uma seguridade social moderna e, principalmente, porque o governo teve acesso a todos os dados, participara de todas as discussões e nunca propusera qualquer alteração. O veto era um sinal de desrespeito aos deputados, ao Congresso Nacional, ao processo legislativo e democrático e às negociações que lhe conferiam legitimidade. O PL fora aprovado por unanimidade na CSSF e recebera substitutivo na CFT, que foi acatado, apesar de restringir alguns avanços constitucionais. O veto atacava não apenas o conteúdo do PL, mas invalidava o processo legislativo e feria a democracia.

Os principais pontos do projeto eram: adoção do piso de um salário mínimo para os benefícios da previdência e assistência social; cálculo do valor da aposentadoria baseada na média das últimas trinta e seis contribuições corrigidas monetariamente; criação de um Conselho tripartite formado por empresários, trabalhadores e governo, com atribuição de fiscalização. Um dos objetivos do projeto era impedir o uso de recursos da Previdência Social para finalidades distintas da previdência social.

A votação em plenário do veto presidencial ao PL estava agendada para 26/09/1990. Nesta segunda votação, o Senado manteve o veto ao projeto que havia aprovado meses antes. Sob pressão de mandados de injunção e de uma ação de inconstitucionalidade por omissão encaminhada à Justiça e ao STF pelos partidos de oposição, o Governo enviou ao Congresso um novo PL sobre a matéria em março de 1991.

O governo enviou também uma nova MP ao Congresso Nacional, a qual previa a adoção de um salário mínimo de aposentadoria para os trabalhadores rurais restrita ao titular da unidade familiar a partir de janeiro de 1991 e estipulava uma medida de reajuste para os benefícios previdenciários diferente da vigente para o salário mínimo. O governo pretendia tornar a aposentadoria rural um benefício familiar e não individual, modificando, assim, o texto constitucional.

Pelo novo PL, o salário mínimo seria reajustado com base na evolução nominal de uma cesta básica fixada em Cr\$ 29.600,00, isto é, com acréscimo ao salário da diferença nominal no preço da cesta básica. No entanto, os benefícios seriam reajustados com base na variação percentual, o que significa a adoção de dupla medida, que, na prática, desvinculava os valores dos benefícios previdenciários do salário mínimo.

Ferreira Lima (PMDB-PE), Osvaldo Bender (PDS-RS). Diário da Câmara dos Deputados, 13/09/1990: 10.037-10.095. 
O Deputado Vicente Bogo já havia denunciado no Congresso o uso de Medidas Provisórias para tratar de assunto relativo a PL já vetado pelo Presidente e do seu uso para reduzir os direitos ${ }^{179}$, tratando de temas constitucionais. O problema foi reiterado pelo Deputado José Maria Eymael, que se dizia convencido de que sua a reedição indefinida conduzia ao cerceamento do Congresso Nacional e a um inequívoco desequilíbrio entre os Poderes $^{180}$. O questionamento pontual da edição de Medidas Provisórias se tornaria um ponto importante no conflito entre Legislativo e Executivo durante o governo Collor em sua tentativa de isolar o Congresso (Figueiredo \& Limongi1997: 141).

O Projeto de conversão da $\mathrm{MP}^{181}$, elaborado pelo Deputado Raimundo Bezerra foi aprovado pela Câmara dos Deputados (PL 47/90) e tinha como pontos polêmicos a vinculação dos benefícios da previdência ao salário mínimo e a extensão do benefício aos trabalhadores rurais, conforme garantia o texto constitucional e diferentemente do que dispunha a MP. Segundo o Deputado Osvaldo Bender, a CFT ratificara um percentual de 2\% sobre o faturamento das empresas para o Finsocial, o que deveria ser suficiente para cobrir as despesas decorrentes da implantação do PL de conversão. Um novo veto, no entanto, foi aposto pelo Presidente, e, posteriormente, mantido pelo Senado Federal, o que suscitou a indignação de vários deputados ${ }^{182}$.

Ao mesmo tempo em que protelava a regulamentação dos dispositivos constitucionais, o Presidente Collor tentava conter o valor do salário mínimo, num contexto de alta inflação, deterioração econômica e elevada taxa de desemprego, sob o argumento do aumento do déficit da Previdência Social, como na edição das MPs 294 e 295.

Em março de 1991, Collor apresentou o documento "Brasil, um Projeto de Reconstrução Nacional”183, no qual tratava das reformas estruturais, destinadas a preparar o

\footnotetext{
${ }^{179}$ Vicente Bogo (PSDB-RS). Diário da Câmara dos Deputados, 13/11/1990.

${ }^{180}$ Ver discurso de José Maria Eymael (PDC-SP). Diário da Câmara dos Deputados, 13/03/1991: 1756.

181 Pelo disposto na Constituição as MPs deveriam ser convertidas em PL no prazo de 30 dias, quando perderiam sua validade. Em maio de 1989 foi aprovado no Congresso a resolução 1/89 que distinguia dois momentos distintos na apreciação das MPs pelo Congresso: admissibilidade e conteúdo. Essa regulamentação dificultou a não admissão de uma MP e ao regulamentar a sua tramitação, o Congresso passou a poder também emendar a MP, participando do seu processo legislativo.

${ }^{182}$ Vide, por exemplo, a declaração do deputado Vilson Souza (PSDB/SC): "Não é possível, pois, admitir que assunto de tal importância sofra tantos descaminhos e percalços, em função da má vontade e do pouco caso que lhe devota o Governo...”. Diário da Câmara dos Deputados, 07/12/90: 13766-136767.

${ }^{183}$ A íntegra do documento foi veiculada pela grande imprensa no dia 02/04/1991 e transcrita aos Anais da Câmara dos Deputados. "Temos como objetivo prioritário recolocar o estado e a iniciativa privada em condições favoráveis à retomada do desenvolvimento auto-sustentado (...) viabilizar a necessária elevação
} 
Brasil para o futuro. Os temas abordados eram a reforma do Estado, a reorganização da economia, relações entre capital e trabalho, privatização das empresas estatais e estratégias de reestruturação competitiva da indústria, agricultura, energia, transporte, entre outras. $\mathrm{O}$ documento trazia medidas controversas que enfatizavam propostas como o fim do ensino superior gratuito, o fim do monopólio do petróleo, o fim da estabilidade no emprego para o funcionalismo público e o fim da aposentadoria por tempo de serviço. Através do documento propunha ainda antecipar a revisão da Constituição programada para 1993, com a instalação de um fórum de “entendimento nacional”. A proposição deste fórum visava à reaproximação entre o Governo e o Congresso Nacional e não vinha acompanhada de medidas concretas, como PLs ou novas MPs.

Ao justificar o "projetão"184, o Presidente Collor o identificou como um desdobramento da sua proposta de modernização do país ante a necessidade de aumentar a poupança financeira (privada e pública) e conter os gastos públicos. O Presidente considerava ousadas as medidas que propunha, principalmente aquelas que contrariavam interesses corporativos como o fim da estabilidade do funcionalismo público, ou implicavam sacrifícios, como a adequação dos benefícios previdenciários à disponibilidade de recursos. ${ }^{185} \mathrm{O}$ Projeto de Collor era lançado justamente quando a sua popularidade e a credibilidade no governo começavam a declinar, num quadro social marcado por desemprego, inflação, recessão, crise fiscal e financeira do Estado. Ele tentava, assim, reverter a situação, ao rever a sua relação com o Congresso ${ }^{186}$.

dos investimentos produtivos da economia brasileira. Sabemos que isso só se faz com a ampliação da poupança financeira ... (que) pode vir de três fontes: a poupança privada dos indivíduos e das empresas, a poupança do setor público e a poupança externa, canalizada através de investimentos estrangeiros ... aumentar a poupança do setor público significa diminuir gastos. Ao longo de 1990 muito foi feito nesse sentido. Uma redução ainda maior depende, no entanto, de uma reestruturação ousada ... que acabarão por contrariar fortes interesses corporativos como a estabilidade do funcionalismo, ou implicar sacrifícios como a adequação dos benefícios do sistema previdenciário à disponibilidade de recursos”. Diário da Câmara dos Deputados, 05/04/1991: 3055-3056.

${ }^{184}$ O Projeto de Reconstrução Nacional, de Fernando Collor recebeu o apelido de "Projetão" no Congresso Nacional numa alusão à complexidade e abrangência das proposições contidas. Ver discurso do Deputado José Santana de Vasconcelos. Diário da Câmara dos Deputados, 12/04/1991: 3.681.

185 Fernando Collor DE MELlo. "Projeto de Reconstrução Nacional: opção democrática pelo desenvolvimento”, 02/04/1991. A íntegra do documento foi publicada no Diário da Câmara dos Deputados, 05/04/1991: 3.055- 3.056.

${ }^{186} \mathrm{O}$ poder de legislar do Executivo e a relação conflituosa que estabeleceu com o Legislativo foram objetos de controvérsia ao longo de todo o período e se constitui no pano de fundo do debate em torno da regulamentação dos direitos constitucionais. Para uma análise do poder de legislar do Executivo (PEREIRA; MUELLER, 2000). 
No debate que se seguiu à formulação do "Projetão" começaram a ser difundidas alternativas de privatização do Seguro de Acidente de Trabalho (SAT) e de adoção do critério único de idade para aposentadoria, ao mesmo tempo em que era proposta a suspensão de obrigações trabalhistas, dentre as quais as obrigações previdenciárias, como estímulo à economia. A OAB identificou neste projeto uma tentativa precoce de alteração constitucional ao identificar o seu conteúdo a um obstáculo a ser transposto, o que atentava contra a ordem jurídica, contra a democracia e contra as conquistas do povo brasileiro. ${ }^{187} \mathrm{O}$ deputado Maurílio Ferreira Lima identificava o plano a uma tentativa de atropelar o fórum instituído no Poder Legistativo ${ }^{188}$, ao passo que o deputado Haroldo Sabóia identificava-o como um projeto de marketing político com o qual o presidente tentava reverter os altos índices de desconfiança em relação ao seu governo ${ }^{189}$.

Em março de 1991, vieram a público várias denúncias envolvendo a Previdência Social, tais como a publicação pelo Jornal da Tarde ${ }^{190}$ de uma lista de 315 aposentados que receberiam benefício de valor equivalente a mais de cinqüenta salários mínimos; fraudes; denúncias de manipulação e desvio de recursos públicos através da folha de pagamento de salários de funcionários ${ }^{191}$, que motivaram a instalação de uma CPI para investigar a Previdência Social ${ }^{192}$. A sonegação de encargos previdenciários pelas empresas era então estimada pelo Deputado João de Deus Antunes em dois bilhões de cruzeiros ${ }^{193}$ e o Ministro não sabia informar quem eram os cinco maiores devedores da Previdência.

\footnotetext{
${ }^{187}$ Marcello Lavenere. Presidente da OAB (Ordem dos Advogados do Brasil). “A Constituição Ferida”. Folha de São Paulo, 15/09/1991.

188 (PMDB/PE) Diário da Câmara dos Deputados, 15/03/1991: 1988-1989.

189 Deputado Haroldo Sabóia (PDT/MA). Diário da Câmara dos Deputados, 21/03/1991: 2308.

190 Jornal da Tarde, 22/03/1991.

191 Deputado Mendonça Neto (PDT-AL). Diário da Câmara dos Deputados, 28/03/199: 2.723. Deputado Edson Silva (PDT-CE), Diário da Câmara dos Deputados, 02/04/91: 2.786; Deputado Adylson Mota (PDSRS), Diário da Câmara dos Deputados, 02/04/91: 2.786; Deputado Tony Gel (Bloco-PE), Diário da Câmara dos Deputados 03/03/91: 2.828; Deputado Chico Vigilante (PT-DF), Diário da Câmara dos Deputados, 13/03/1991: 3.737.

${ }^{192}$ O então presidente da CSSF, Deputado Roberto Magalhães (Bloco-PE) manifestava em plenário o seu receio de que a CPI ficasse a reboque da Comissão Especial do Executivo pelos meios materiais que esta dispunha e, como medida preventiva, sugeria a contratação de auditorias privadas e independentes. "Foi oportuna e correspondeu à expectativa da sociedade brasileira a instalação da Comissão Parlamentar de Inquérito". Diário da Câmara dos Deputados, 06/04/1991: 3110.

193 Deputado João de Deus Antunes (PDS-RS), Diário da Câmara dos Deputados, 13/04/1991: 3.728. Em relatório de débitos apresentado pela Diretoria de Arrecadação e Fiscalização do INSS em 01/05/1991 ao Deputado Chico Vigilante (PT-DF), havia 92.596 empresas devedoras, totalizando um débito de Cr\$ 2.562.351.079.808,80 (dois trilhões, quinhentos e sessenta e dois bilhões, trezentos e cinqüenta e um milhões, setenta e nove mil, oitocentos e oito cruzeiros e oitenta centavos). Diário da Câmara dos Deputados, 01/05/91:11.276-11.277.
} 
Duas Audiências Públicas ${ }^{194}$ foram realizadas na CSSF para tratar da estrutura do INSS, das fraudes e irregularidades, da falta de controle na concessão de benefícios, da informatização, da modernização da auditoria, da arrecadação e da concessão de benefícios. Uma das acusações era que o governo não realizara o repasse integral dos recursos da Previdência Social, retendo-o no Tesouro Nacional. Segundo dados da ANFIP, o Ministério da Economia teria repassado somente 21,3\% do total a que teria direito, retendo 407 bilhões de cruzeiros relativos ao custeio de pessoal e administração e mais 425 bilhões de cruzeiros em contribuições arrecadadas. ${ }^{195}$

Em 05/04/91, havia vencido o prazo constitucional ${ }^{196}$ para implantação dos direitos referentes à matéria previdenciária, sem que a matéria tivesse sido regulamentada. $\mathrm{O}$ Deputado Eduardo Jorge, membro da CSSF afirmava a intenção dos aposentados em entrar com mandado de injunção para receber o piso de um salário mínimo, ter direito à adoção da nova fórmula de cálculo da aposentadoria e para que os trabalhadores rurais tivessem acesso a um salário mínimo a partir da data limite definida pela Constituição. ${ }^{197}$

Em 30/04/91 um novo Plano de Benefícios foi enviado ao Congresso pelo Executivo iniciando uma nova tramitação. Esperava-se que, dessa vez, o Governo não se demonstrasse intransigente, para que um entendimento fosse possível ${ }^{198}$. Junto com esse projeto chegavam outros que também abordavam questões polêmicas, tais como o estabelecimento de novas relações entre capital e trabalho, política salarial para funcionalismo civil e militar da União, salário mínimo, isenção e/ou redução de tributos para exportação, que eram considerados prioritários para o Governo.

\footnotetext{
${ }^{194}$ Em 04/04/1991 foram ouvidos o Ministro do Trabalho e da Previdência Social, O Presidente do INSS e o Secretário-Geral da Previdência e em 11/04/1991 foram convocados a prestar esclarecimentos em Audiência Pública: Dr. Pedro Sanchez, ex-Diretor do INSS; Dr. Ulisses Melo, ex-Diretor da Arrecadação e Fiscalização; Dr.Ital Nishi, ex-Auditor de Administração e Finanças. Os convocados tiveram que explicar seu envolvimento nos eventos que vinham sendo denunciados. Diário da Câmara dos Deputados, 13/04/1991: 3796.

${ }^{195}$ Valores em moeda corrente (Cr\$) Deputado Eduardo Jorge (PT-SP). Diário da Câmara dos Deputados, 06/04/1991: 3.103.

${ }^{196}$ Os artigos 58 e 59 do ADTC da Constituição Federal de 1988 estabeleciam que os projetos de lei, relativos à organização da seguridade social e aos planos de custeio e de benefícios, deveriam ser apresentados no prazo de seis meses a partir da data da promulgação da Constituição. O Congresso Nacional teria seis meses para apreciá-lo e, uma vez aprovados, teriam dezoito meses para implantá-los. Estabelecia ainda que todos os benefícios de prestação continuada em manutenção na data da promulgação da Constituição teriam seus valores revistos, para restabelecer o poder aquisitivo, expresso em número de salários mínimos, que tinham na data de sua concessão. Constituição da República Federativa do Brasil, 1988.

${ }^{197}$ Deputado Eduardo Jorge. Diário da Câmara dos Deputados, 06/04/1991: 3.103-3104.

${ }^{198}$ Deputado Germano Rigotto (PMDB-RS). Diário da Câmara dos Deputados , 08/05/1991: 5.504.
} 
A fusão dos Ministérios do Trabalho e da Previdência Social sob o comando do Ministro Antônio Rogério Magri reuniu as duas pautas de maior conflito no período: relações de trabalho e previdência social. O cerne do conflito era o mesmo: os encargos sociais sobre a folha de pagamento de salários que reduzia a competitividade da indústria em ambiente de globalização.

Os acordos para a aprovação do projeto da previdência social giraram em torno da garantia da adoção de um salário mínimo como o menor valor de benefício, porém, com a correção dos benefícios de base nominal, ou seja, sem corresponder aos aumentos conferidos ao salário mínimo e o estabelecimento de um teto de contribuição.

A Lei do Custeio da Seguridade Social (Lei 8.212/91) e a Lei dos Planos de Benefícios da Previdência Social (Lei 8.213/91) foram aprovadas em junho de 1991 pelo Congresso e sancionadas pelo Presidente em julho de 1991, encerrando a primeira fase de disputas em torno da sua aprovação. No entanto, ambas as Leis previam um prazo de 60 dias para a sua regulamentação, que ocorreu somente em dezembro, seis meses depois, através dos Decretos 356/91 e 357/91. No PBPS foi vetado um artigo que instituía o direito ao salário maternidade para as trabalhadoras rurais, e inserido um artigo que obrigava o INSS a tornar pública a lista com os nomes dos maiores devedores da Previdência Social.

A regulamentação dos dispositivos constitucionais sobre a seguridade social foi aprovada tendo como pano de fundo o debate sobre a revisão constitucional agendada para 1993. O governo defendia a sua antecipação de modo a assegurar a governabilidade ao País.

Em 1990 foi aprovada a Lei Orgânica da Saúde (Lei 8.080/90), em 1991 a Lei de Custeio da Seguridade Social (Lei 8.212/91) e a Lei dos Planos de Benefícios da Previdência Social (Lei 8.213/91), porém o terceiro ponto do tripé, a assistência social só teria a sua Lei Orgânica aprovada em 1993 (Lei 8.942/93).

A regulamentação dos dispositivos constitucionais deu-se de modo fragmentado, com a previdência social e o custeio da seguridade social assumindo a maior parte do conflito em torno da sua aprovação. Essa disputa teve como ponto central a questão da paridade dos benefícios em relação ao salário mínimo, bem como a definição das fontes de financiamento para cada uma das áreas integrantes da seguridade social. A Lei do Custeio, aprovada em 1991, optou pela especialização das fontes, reforçando a vinculação entre 
receitas e despesas. Ao mesmo tempo, a questão do déficit da Previdência tornava-se uma questão pública, tal qual o seu financiamento. O esquema de vinculação proposto partia do pressuposto de que deveria ser financiada exclusivamente pelas contribuições de empregados e empregadores sobre a folha de pagamento de salários, sem uso de recursos das demais contribuições sociais. A existência de déficit ou superávit nas contas da Previdência dependerá, portanto, das contribuições sociais que serão computadas no seu financiamento e da metodologia adotada.

A aprovação das Leis não encerrou o conflito em torno da previdência social. Em setembro de 1991, uma nova crise seria aberta em função da proposta de reajuste dos benefícios previdenciários que durou quase um ano ${ }^{199}$. A inserção do princípio constitucional “da manutenção do valor real das prestações previdenciárias” e a vinculação com o salário mínimo como critério excepcional de reajuste visavam a recomposição do valor dos benefícios que se encontravam bastante defasados e com perda real de valor.

Essa nova crise ficou conhecida como a "crise dos 147\%" e resultou da contestação judicial dos aposentados ao reajuste dos benefícios previdenciários $(54,6 \%)$, inferior ao reajuste do salário de contribuição $(147,06 \%)$ e ao estabelecimento de duplo critério, quando ainda não havia sido criada nova regra de reajuste. A crise dos $147 \%$ se estendeu até meados de 1992.

Pelo ADTC, a revisão dos benefícios deveria ser realizada em razão do número de salários mínimos a que correspondia no ato de sua concessão e teria vigência até a implantação do plano de custeio e benefícios. O STJ reconheceu o direito de reajuste dos benefícios em 147,06\% para os associados do sindicato dos metalúrgicos de São Paulo. O Governo argumentou que o pagamento geraria um déficit de 10,9 trilhões de cruzeiros no ano de 1992, o que repercutiria no cumprimento de outras sentenças judiciais e na elevação das alíquotas de contribuição, bem como na instituição de contribuição de aposentados e pensionistas. A Justiça entendeu que o reajuste era devido em função da adoção do salário mínimo como indexador dos benefícios a partir da promulgação das leis, mas o STF

\footnotetext{
199 A “crise dos 147\%” foi deflagrada em setembro de 1991 e encerrada apenas com a revisão da decisão pela administração que editou as medidas necessárias ao pagamento em julho de 1992, com vigência para agosto, incluindo o pagamento da diferença neste período.
} 
suspendeu a sentença de pagamento ${ }^{200}$, por entender que a medida não feria a Constituição, nem reduzia o valor do benefício. Considerou ainda, que os critérios de reajuste eram compatíveis com a regra de preservação do valor real dos benefícios.

Em sua posição, o STF argumentou ainda que a justificativa com base no ADTC não era adequada, uma vez que o texto abordava especificamente os benefícios assistenciais e não situações de caráter previdenciário ${ }^{201}$. Ante uma ampla mobilização dos aposentados e uma forte oposição no Congresso, o governo decidiu rever a sua posição e iniciar os pagamentos devidos a partir de agosto de $1992^{202}$.

Em dezembro de 1991, o Decreto 356 regulamentaria a LCSS e introduzia um parágrafo único no capítulo da contribuição da União, tornando-a responsável pela cobertura de eventuais insuficiências financeira da seguridade social, quando decorrente do pagamento de benefícios assistenciais pela Previdência Social, na forma da LOA, além de detalhar a questão da isenção das contribuições sociais e seu atrelamento ao financiamento da seguridade social. Este é um dos pontos centrais na discussão sobre a natureza da crise previdenciária e na disputa sobre a partilha dos recursos fiscais. Deve a União ser responsável pela cobertura de eventuais insuficiências financeira?

No tripé da seguridade social, a assistência social foi a última a ter sua Lei Orgânica aprovada. Até o prazo constitucional, 05/04/,89 o Executivo não havia encaminhado qualquer PL, embora contasse com subsídios de três Anteprojetos formulados no âmbito Executivo $^{203}$. A iniciativa de legislar sobre a matéria partiu do Legislativo, que após realizar o $1^{0}$ Simpósio Nacional sobre assistência social para colher subsídios, formulou o PL 3.099/89, de autoria do Deputado Raimundo Bezerra, no mês de junho. O Deputado Nelson Seixas, nomeado relator desse PL na Comissão de Saúde, Previdência e Assistência Social (CSPAS) da Câmara dos Deputados apresentou substitutivo, que sofreu emendas e foi aprovado pela Comissão Temática em 28/11/89 e pela CFT em 23/05/1990 e, posteriormente, pelo Senado. Em 17/09/90 o PL sofreria veto integral do Presidente Collor, assim como ocorrera com a Previdência e a Seguridade Social.

\footnotetext{
${ }^{200}$ Deputado Luiz Henrique (PMDB/SC), Diário da Câmara dos Deputados, 12/03/1992: 3641.

Rocha traz a íntegra dos Relatórios de voto dos Ministros Sepúlveda Pertence, e do Ministro Celso de Mello, em relação ao Recurso Extraordinário impetrado no Supremo Tribunal Federal (RocHA, 2004: 169-170 - nota de rodapé $n^{\circ} .528$ e 531).

${ }^{202}$ Através da Portaria MPS (Ministério da Previdência Social), de 20/07/1992, foi reconhecido o direito ao reajuste de 147,06\% sobre aposentadorias e pensões pagas pela Previdência Social.

${ }^{203}$ Ver a respeito: (BARBosA, 1991).
} 
A matéria voltou à pauta em abril de 1991 por iniciativa do Deputado Geraldo Alckimin Filho que reapresentou, com pequenas mudanças, o PL do Deputado Raimundo Bezerra, como PL 626/91, ao mesmo tempo em que o Ministério da Previdência Social vinha trabalhando em um novo PL. Dada a prerrogativa do Executivo em legislar sobre a matéria, todos os PLs em tramitação foram apensados ao Projeto do Ministério da Previdência Social. A aprovação da Lei Orgânica da Assistência Social só ocorreu em 07/12/1993, através da Lei 8.742, regulamentada pelo Decreto 1.097, de 23/03/94, com vigência a partir de 1995.

A condução da aprovação da Lei Orgânica da Assistência Social é emblemática. O fato de ter gerado o menor conflito político, fez com que fosse relegada ao segundo plano e somente aprovada pela insistência no assunto por parte do Congresso Nacional. O Executivo não apresentou qualquer interesse em sua regulamentação. Os benefícios que instituía vinham sendo pagos pela Previdência Social, contribuindo para elevação das despesas da área. Talvez motivada pela idéia de um direito à seguridade social de caráter universal, a disputa pela partilha de recursos entre previdência e assistência social não fosse tão evidente quanto a que se firmava entre previdência e saúde.

Um efeito não esperado da Constituição de 1988 foi exatamente a adoção de um conceito "puro" de previdência social como seguro social, o que seria o tema dos anos 1990. As disputas em torno das contas da Previdência fomentaram também um processo de purificação de suas atribuições, conformadas à idéia de risco social. Os debates em torno da previdência serviriam também para dar maior transparência às políticas de assistência social.

Ao final do processo legislativo de regulamentação dos dispositivos constitucionais referentes aos direitos sociais, verificamos, não apenas o peso político desigual com que as áreas integrantes da seguridade social foram tratadas e os decorrentes conflitos que geraram, mas também a falta de integração entre as mesmas, como preconizava a Constituição de 1988. A Lei que trata do custeio da seguridade social, embora aborde as três áreas programáticas, adota, na prática, a especialização das fontes de financiamento. A constituição de um Ministério da Seguridade Social era esperada por alguns segmentos 
burocráticos e da sociedade civil, mas não se concretizou ${ }^{204}$, fazendo com que o tema retornasse durante o processo de revisão constitucional.

A forma como o processo legislativo foi encaminhado diz muito sobre o resultado alcançado. Na prática, seguiu a fragmentação e a ausência de coordenação institucional e burocrática já verificada, com as ações executivas desmembradas em três ministérios diferentes - Trabalho e Previdência Social, Saúde e Ação Social. No entanto, os recursos para as áreas sociais foram concentrados em um caixa único no Tesouro Nacional, medida que centralizou o controle de recursos e de gestão na área econômica, no Ministério da Economia, Fazenda e Planejamento. Para alguns autores, a dependência de repasses do Tesouro para o caixa da seguridade social e as constantes manipulações tornava o OSS uma “peça de ficção"205. Havia mesmo quem defendesse o crescimento da área de arrecadação do MPS para integrar as demais contribuições sociais e, desse modo, proteger os recursos do OSS dos avanços da área econômica. A história nos conduziu exatamente ao seu oposto, com a centralização da arrecadação na Secretaria da Receita Federal (SRF), pondo fim ao papel de arrecadador do INSS.

A partilha de recursos entre as áreas e a liberdade fiscal é, ainda, ponto central no debate sobre a crise da Previdência Social no Brasil e permeiam a constituição do Fundo Social de Emergência (1994), do Fundo de Estabilização Fiscal (1996) ${ }^{206}$ da Desvinculação das Receitas da União (1998) e a centralização da arrecadação fiscal na Secretaria da Receita Federal (Super-Receita) (2007).

\section{Governança e governabilidade na reforma do Estado}

Os direitos sociais foram capturados pela lógica da racionalidade econômica, que impõe freios aos avanços das conquistas sociais e políticas da década de 1980, num contexto de crise política-institucional. No Brasil, intensa disputa acirrou-se em torno dos recursos públicos a partir da Constituição Federal de 1988 e os direitos sociais nela inscritos, com particular atenção à seguridade social. Quais as necessidades a serem

\footnotetext{
${ }^{204}$ Ver a respeito os debates contidos em: MPS/CEPAL. A previdência social e a revisão constitucional. Debates, op. cit.

${ }^{205}$ Ver a respeito: SOARES, 2001; FIORI, 1992; CASTRO; MACHADO \& RoCHA, 1997.

${ }^{206}$ A EC 10, de 04/03/1996, modificou a denominação do Fundo Social de Emergência para Fundo de Estabilização Fiscal. Art. 1 ${ }^{\circ}$, § 2 ${ }^{\circ}$. Constituição da República Federativa do Brasil, 2007.
} 
satisfeitas com os recursos públicos? Devem orientar políticas de investimento e crescimento econômico ou devem servir para realizar os compromissos sociais assumidos perante a sociedade? Como compatibilizar as necessidades econômicas com necessidades sociais?

A interposição do discurso da racionalidade econômica tem reorientado a realização das políticas sociais subvertendo o princípio adotado na ANC, cujo raciocínio central era como financiar os direitos nela inscritos. Atualmente, o discurso da reforma tem sido o quê financiar com os recursos disponíveis e como aumentar a capacidade de poupança pública. O giro realizado na questão fundante da natureza dos direitos sociais tem obrigado a uma revisão de seus princípios, público alvo, conteúdo e natureza, que tem alterado o sentido do direito social.

As questões que limitam o sentido dos direitos sociais são expostas como sendo predominantemente de natureza econômica e se apresentam de modo inverso àquelas que conduziram à afirmação do direito social na Constituição de 1988. Nesse ponto, a própria Constituição é objeto de um conflito em torno das diretrizes políticas para a questão social.

As duas últimas décadas têm apresentado um imbricamento entre três questões de grande relevância sobre o papel do Estado: a reforma da Constituição, a reforma da Previdência e a reforma tributária. Essas são as três peças chaves da discussão sobre a reforma e modernização do Estado. Elas retratam o descompasso entre Estado e sociedade que está no cerne dos impasses do presente, demonstrando cabalmente a extenuação do Estado como fator de contenção de uma sociedade civil em processo de expansão e dotada de crescente densidade organizacional (Diniz, 1997: 21).

Como enfatiza Diniz, as disputas em torno da agenda de reformas retratam as tensões entre os requerimentos econômicos da estabilização econômica e os requisitos políticos da consolidação democrática e da expansão de direitos. Estão presentes ainda no descompasso entre Executivo e Legislativo, com o primeiro ditando o ritmo e dando condução aos processos de reforma num contexto de crise de credibilidade nas instituições políticas.

A Constituição de 1988 encerrou um primeiro ciclo de reformas, identificado com a agenda da democratização e da eqüidade (Draibe2003: 68) e realizou um corte temporal que marca também o início do segundo ciclo de reformas, identificado com a agenda de ajuste 
fiscal e que tem que se haver tanto com o legado histórico da proteção social quanto com o legado social, institucional, político e cultural deixado pelo primeiro ciclo (Draibe, 2003: 70).

Sem dúvida, tanto o final do Governo Sarney, quanto o breve Governo Collor expressam a construção de um novo discurso e inauguram uma nova disputa em torno dos direitos sociais, com questões referidas ao ambiente pré e pós-Constituição. A tese da ingovernabilidade de Sarney produziu uma nova articulação entre as agendas econômica, política e social com ponto de encontro na questão institucional, ou como responder às diversas demandas interpostas ao governo.

Uma das vertentes para a discussão da crise do Estado tem sido os estudos sobre a governabilidade e o seu potencial desestabilizador relacionado à expansão das franquias e direitos democráticos (Diniz, 1997: 26), que repercute no difícil equilíbrio entre o excesso de demandas sobre o governo e sua capacidade para administrá-las e atendê-las. A conseqüência desse enfoque é um matiz restritivo ao conceito de governabilidade, que confere legitimidade a práticas de impor freios institucionais ou aumentar a autoridade do governo. Dentre as soluções encaminhadas destacam-se: postergar direitos, combater o desequilíbrio fiscal, disciplinar o sistema parlamentar e reduzir o número de partidos. A decorrência natural seria um aumento do poder tecno-burocrático na tomada de decisões, concentração do poder decisório no Executivo e adoção de estratégias coercitivas de implementação.

A discussão sobre os conceitos de governabilidade e governança ressurgiu nos anos 90, liderada particularmente pelos organismos multilaterais de crédito $^{207}$ em meio às políticas de ajuste estrutural e se concentra nas condições sistêmicas e de autoridade que assegurem a um determinado governo condições para a implementação das reformas liberalizantes. Ambos os conceitos são discutidos com vistas a obter consensos sociais que garantam a estabilidade do governo necessária à condução dos negócios públicos e privados (Ugá, 2003: 92). Ela introduz uma ruptura em relação à agenda de democratização e universalização dos direitos sociais e do compromisso do Estado com sua realização. Até então, as prescrições possuíam um caráter mais técnico e restrito a medidas econômicas que focalizavam mais diretamente o re-equilíbrio da balança de pagamentos.

\footnotetext{
${ }^{207}$ Especialmente do Banco Mundial e do Banco Internacional de Desenvolvimento (BID) e os empréstimos gerenciados condicionados ao cumprimento das políticas de ajuste definidas pelo Banco Mundial. O tema tem sido explorado de forma sistemática em documentos do Banco Mundial a partir de 1991.
} 
A partir dos anos 90, muito embora não tenha havido alteração no receituário econômico, as variáveis políticas passaram também a ser consideradas, como a adequação das instituições aos imperativos da reforma e as condições políticas para a sua realização. Por um lado, o ajuste apresentava alto custo social, com achatamento de salários, desemprego, redução de subsídios, redução de gastos com políticas sociais e, por outro, o clima de transição democrática abria espaço para os movimentos sociais expressarem suas demandas, muitas das quais formalizadas em direitos sociais na Constituição redigida em 1988.

No diagnóstico dos organismos multilaterais os países devedores não estavam conseguindo re-equilibrar a balança de pagamentos, ou seja, aumentar a arrecadação tributária e cortar gastos, e tornava-se necessário adotar medidas mais radicais que promovessem a recuperação das finanças públicas através do controle da inflação e da redução do déficit público. A influência do ambiente político na condução e no resultado das políticas de ajuste levou à compreensão de que era necessário apelar à arte da política, de tal modo que o poder do Estado fosse reforçado e que ele fosse capaz de enfrentar as tensões provenientes da reforma, provocando exclusão e conduzindo o processo de reformas. Nesse contexto, conferir governabilidade significava conter as demandas sociais e políticas redistributivas, priorizando o controle da inflação e o manejo do déficit público. Questões centrais no debate sobre a reforma da Previdência.

Uma segunda vertente, que tende a valorizar a democracia, acentua a necessidade de reforçar arenas de negociação que forneçam respaldo às ações do Estado, o que conduziria ao aprofundamento da democracia pela difusão de instrumentos democráticos.

Na condução da agenda de reformas, a consolidação democrática e a eficácia na administração da crise têm sido vistas como objetivos contraditórios, o que acentuou a separação entre Executivo e Legislativo, com predomínio da "visão tecnocrática da gestão econômica” (Diniz, 1997: 44), com primazia da racionalidade técnica, dos especialistas, do chamado “núcleo duro do governo”. A tensão entre as formas de realizar as prioridades da agenda é, em si, parte constitutiva da crise do Estado, não apenas o resultado das reformas o demonstra, mas, principalmente, o modo como elas são realizadas (Diniz, 1997). São reformas orientadas para o mercado, nas quais o Executivo exerce o papel fundamental de condutor (Haggard \& Kaufman, 1993). 
Durante todo o período, o Executivo monitorou a pauta do Legislativo controlando o ritmo de tramitação dos projetos, apresentando propostas, impondo vetos e editando medidas provisórias. O Executivo se impôs como o principal centro de produção legal do País e criou a ilusão de que os problemas podem ser resolvidos com o seu confinamento nas agências de decisão burocrática.

A questão da governabilidade está no centro de uma contradição na qual o governo deve imprimir estabilidade aos processos de rupturas radicais que as políticas de ajuste estrutural requerem. A conseqüência tem sido a exigência de uma concentração de poder pouco provável em condições plenamente democráticas (Ugá: 2003: 95; Pereira \& Mueller: 2000). De outro modo, os ajustes protagonizam medidas de alto custo social que aceleram a geração de demandas num momento em que a economia enfoca a contenção de despesas. Há, não apenas uma despolitização da agenda pública, mas, principalmente, a subordinação da política à economia. Foi a economia quem passou a dizer o quanto de benefício social era possível custear. A democracia enquanto forma política foi duplamente atacada: enquanto forma de organização social foi considerada inferior ao mercado e vista como produtora de irracionalidades e ineficiências.

Os conceitos de governabilidade e governança estão comprometidos com as reformas orientadas para o mercado (Haggard \& Kaufman, 1993), as quais, longe de serem banais, repercutem sobre o sistema jurídico, o sistema político, o sistema tributário, os direitos sociais, o aparelho administrativo do Estado e assim por diante. São alterações que requerem reformas constitucionais, como ocorreu em vários países da América Latina, para criar as condições institucionais desejadas à realização dos objetivos econômicos.

É no contexto do ajuste estrutural que se inserem as propostas de desregulamentação, privatização, redução do tamanho do Estado e focalização nas políticas sociais. Num contexto de flexibilização do processo de produção e da decorrente diferenciação e fragmentação da classe trabalhadora segundo o setor econômico a que pertença, as políticas sociais provedoras de serviços uniformes e coletivos passaram a não fazer mais sentido. As situações de trabalho, de consumo e o sentido de responsabilidade se tornaram cada vez mais individualizadas, desfazendo o sentido coletivo das teses solidaristas e redistributivas das políticas de bem-estar social e cedendo lugar à liberdade de 
escolha e à responsabilidade individual na alocação de recursos pessoais, como prevê a previdência privada.

Os temas do ajuste estrutural, da privatização e da governabilidade se constituem no pano de fundo para as disputas sobre a regulamentação dos direitos sociais que se desenrolaram no Congresso Nacional e nas tentativas do Executivo em determinar a agenda de reformas, usurpando o papel do Legislativo. O “tempo da regulamentação" é o tempo do embate entre duas racionalidades discursivas: da racionalidade política e da racionalidade econômica. É o que permite compreender o projeto de universalização dos direitos sociais não como uma irracionalidade, mas como uma racionalidade distinta, e as disputas em torno das reformas, como o confronto entre interesses e sistemas de valores distintos (Ranciére, 1996). 


\section{CAPÍTULO V}

\section{TEMPO DA REVISÃo CONSTITUCIONAL}

\section{A DISPUTA EM TORNO DO MODELO DE PROTEÇÃO SOCIAL}

Em 16/01/1992, ocorreu na Câmara dos Deputados uma Audiência Pública ${ }^{208}$ conjunta que objetivava colher o depoimento do Ministro da Justiça, Doutor Jarbas Passarinho sobre o PL 2.474/92 do Poder Executivo (Mensagem 17/92), que “dispõe sobre fontes de custeio para a Previdência Social e dá outras providências”. O PL trazia uma proposta de reforma da previdência com objetivo de encontrar uma solução para a crise motivada pelo reajuste de $147 \%$ e o aumento das contribuições para cobrir o déficit do INSS. O Deputado Roberto Jefferson registrou a repulsa de todas as lideranças da Casa ${ }^{209}$ e sugeriu que o Presidente da República opusesse vetos ao referido PL, cuja relatoria fora entregue ao Deputado Antonio Britto. Em 21/01/1992 foram ouvidos em Audiência Pública os Ministros do Trabalho e Previdência Social - Antonio Rogério Magri - e da Economia, Fazenda e Planejamento - Marcílio Marques Moreira. A CTASP rejeitou integralmente o PL em 22/1/92, após sucessivas reuniões com o Colégio de Líderes e a Presidência da Câmara dos Deputados, com relatório do Deputado Amaury Muller ${ }^{210}$.

\footnotetext{
${ }^{208}$ Reunião Conjunta extraordinária das CSSF; CFT; CCJR; CEIC; CTASP. A Audiência Pública foi dividida em três sessões, ocorridas em 16/01/92 (para ouvir o Ministro da Justiça, Jarbas Passarinho), 22/01/92 (MEPF, Marcílio Marques Moreira) e 22/01/92, a reunião deliberativa. O Ministro do Trabalho e da Previdência Social, Antônio Rogério Magri não foi ouvido. Diário da Câmara dos Deputados, 06/05/1992: 8191-8192.

${ }^{209}$ Os trabalhos foram conduzidos pelo Deputado Roberto Jefferson, Presidente da CSSF e compuseram a Mesa os Deputados: Benito Gama, João Natal, Reinhold Stephanes e Amaury Muller (Presidentes das Comissões Reunidas: CFT, CCJR, CEIC e CTASP) e o Deputado Ricardo Fiúza, Líder do Bloco Parlamentar, além dos Deputados Victor Faccioni (Líder do PDS). Como representantes da sociedade, participaram: Dr. Osvaldo Veloso (Presidente da Confederação Brasileira de Aposentados); Dr. Carlos Augusto Amorim (Presidente da Associação Brasileira de Hospitais); Dr. Carlos Eduardo Ferreira (Presidente da Federação Brasileira de Hospitais); Dr José Luiz Spigolon (Superintendente da Confederação das Misericórdias do Brasil); Ubiraci Dantas de Oliveira (Presidente da CGT). Idem.

${ }^{210}$ Em reuniões sucessivas entre Presidência da Câmara dos Deputados e do Colégio de Líderes se acirrou a disposição geral da Casa em rejeitar o projeto de lei. “A decisão desta Casa evidenciará nossa disposição em não aceitar que o povo brasileiro pague, mais uma vez, uma dívida que não é sua”. Deputado Osmânio Pereira (PSDB-MG). Diário da Câmara dos Deputados, 24/01/1992: 1326-1327.
} 
O envio do PL à Câmara suscitou um amplo debate sobre as contas da Previdência, o déficit, a legislação recém aprovada, fraudes, desvios e corrupção, o que, por sua vez, fomentou a apresentação de novas propostas de reforma com conteúdo amplo, abrangendo desde a privatização com base no modelo chileno até uma ampla revisão das formas de gestão, com apelo à racionalização.

Ao final de 1991, o Deputado Antônio Britto ${ }^{211}$ já denunciava a manipulação do OSS pelo governo, ao introduzir despesas como saneamento básico, merenda escolar, assistência médico-odontológica de servidores públicos, encargos com inativos e pensionistas do Ministério da Saúde e até construção de escolas como despesa da área da saúde. Os recursos para as áreas da saúde, previdência e assistência eram minados também com a prática do contingenciamento de despesas para o pagamento de serviços da dívida externa, prática comum aos governos Sarney, Collor, Itamar, Fernando Henrique e Lula (TCU, 2003). O governo também havia inserido os EPUs como despesa da seguridade social, o que foi proibido pela LCSS, além de estabelecer a separação entre o regime geral e o regime próprio de funcionários civis e militares e estabeleceu um cronograma para que a União assumisse a sua responsabilidade como empregadora.

O ponto central das disputas em torno da seguridade social em geral e entre as áreas integrantes, em particular, permaneceu sendo uma questão de financiamento diante da competição por recursos governamentais. Persistia um dos problemas que a Constituição tentara resolver: como garantir um nível satisfatório de recursos para gerir os problemas sociais. No caso, os constituintes tentaram resolver o problema da insuficiência de recursos da Previdência Social para cobrir despesas próprias, como aposentadorias e pensões, além das despesas com saúde e assistência social. A saída encontrada foi ampliar a base de financiamento, de modo que, a direitos universais, correspondesse um modelo de financiamento também universal.

A maior polêmica está centrada na previdência social porque o crescimento dos gastos com aposentadorias e pensões pressiona o OSS, enquanto se verifica que entra como despesa previdenciária o que seria responsabilidade da União e despesas assistenciais, estranhas ao conceito e esquema contributivo da previdência social.

\footnotetext{
211 "Britto reclama do orçamento”. Correio Braziliense, 7/12/1991.
} 
A constante presença do tema na Ordem do Dia do Congresso motivou a instalação na Câmara dos Deputados da Comissão Especial para Estudo do Sistema Previdenciário (CEESP) no primeiro semestre de 1992, sob a presidência do Deputado Roberto Magalhães (PFL/PE) e com relatoria do Deputado Antônio Britto (PMDB/RS), que já vinha demonstrando interesse nas questões da área. O objetivo da Comissão era o de promover “um amplo estudo do sistema previdenciário brasileiro, tanto no tocante à sua estrutura quanto ao seu regime de custeio e de benefícios e propor soluções cabíveis para o seu regular funcionamento e cumprimento de sua destinação social e institucional”212.

O relatório final apresentado pelo Deputado Antonio Britto foi aprovado por unanimidade e alimentou a expectativa de que, com o seu resultado, pudessem ser corrigidas as distorções e os desajustes do sistema previdenciário que o estava tornando inviável, nas palavras do Deputado Inocêncio Oliveira ${ }^{213}$. A versão final do relatório sofreu algumas modificações, principalmente no que se refere às fontes de financiamento. Originalmente, o relatório propunha a extinção do Finsocial e da contribuição sobre os lucros da empresa, a redução da contribuição sobre a folha de salários, e a adoção, em contrapartida, de uma nova contribuição incidente sobre as transações financeiras. A nova versão foi considerada mais cuidadosa e gradual ao recomendar a possibilidade de substituição das fontes de financiamento sem falar em extinção das atuais.

O relatório propunha ainda a fixação de teto de dez salários mínimos para contribuições e benefícios; o fim do acúmulo de benefícios e outras vantagens; a instituição da previdência complementar; a redefinição de aposentadorias especiais; a gestão da Previdência Social por um conselho tripartite, entre outras. Esta seria a pauta para a reforma da previdência, tema que não deixou mais a agenda pública. O ano de 1992 é, portanto, aquele em que se consolida a idéia de reforma da Previdência Social, tornada independente da institucionalização da seguridade social, tal como fora aprovada em 1988.

\footnotetext{
${ }^{212}$ BRITTO, Antônio. "Relatório Final da Comissão Especial para Estudo do Sistema Previdenciário", Brasília, Previdência em Dados, vol. 7, n² 2, abr/jun 1992. Em três meses de trabalho, a partir de 28 de janeiro de 1991, a Comissão ouviu, em Audiência Pública, membros do Executivo (MTPS, MEFP, Presidência do Banco do Brasil, Secretaria de Administração, representantes dos Conselhos Estaduais e Municipais), representantes de diversos segmentos sociais (trabalhadores, empresários, aposentados e pensionistas, estabelecimentos de saúde, seguradoras) e parlamentares e recebeu inúmeras propostas de reforma da seguridade social. Foram incorporados ao relatório estudos realizados pelo IPEA, por entidades empresariais, pelo MTPS na gestão de Antônio Rogério Magri. O relatório legitimava-se pelo próprio processo democrático de sua produção.

${ }^{213}$ Deputado Inocêncio Oliveira (PFL/PE). Diário da Câmara dos Deputados, 28/03/1992: 5343.
} 
O trabalho da CEESP contribuiu para a especialização dos parlamentares em seguridade social, ao mesmo tempo em que permitiu a costura de um consenso reformista em torno de questões que permaneceriam em pauta nos anos seguintes (Costa, 1994) ${ }^{214}$ : o questionamento do conceito de seguridade social, a especialização das fontes de financiamento segundo as áreas integrantes - saúde, previdência social e assistência social; a unificação dos sistemas previdenciários público e privado num sistema básico, público e compulsório; a instituição de um regime de previdência privado e complementar; a extinção das aposentadorias especiais de algumas categorias profissionais; a manutenção do regime de repartição simples para a previdência pública e instituição do regime de capitalização para a previdência privada; o fim da aposentadoria por tempo de serviço; o aumento do tempo de contribuição; o aumento da idade mínima para aposentadoria e a desconstitucionalização dos direitos sociais.

As maiores críticas dirigiam-se contra a generosidade do sistema previdenciário, especialmente no que se refere à aposentadoria especial à aposentadoria por tempo de serviço; aos benefícios assistenciais no valor de um salário mínimo; à falta de correlação entre tempo de contribuição e direito ao benefício; à inserção de direitos trabalhistas na pauta previdenciária, como o auxílio-maternidade de 120 dias; ao salário-família; à clivagem de gênero nas aposentadorias por tempo de serviço e por idade, entre outros ${ }^{215}$.

O relatório Antônio Britto se tornaria a principal referência para os debates sobre a reforma da Previdência nos anos seguintes. Os temas ali introduzidos perduraram no debate e ajudaram a estruturar um projeto de reforma previdenciária propositivo, que contribuiria para atenuar os termos dos dispositivos legais aprovados ao final de 1991. O próprio Deputado Antônio Britto alcançou o seu reconhecimento como especialista na matéria vindo a tornar-se o Ministro da Previdência Social no Governo Itamar Franco, quando adotou medidas de impacto duradouro na instituição e no tratamento da questão do financiamento.

A discussão de propostas de reforma da previdência e do modelo de seguridade social na CEESP coincidia com a tentativa do Governo Collor de antecipar o debate sobre a

\footnotetext{
${ }^{214}$ Costa apresenta uma discussão sobre o diagnóstico reformista da Previdência Social no contexto da revisão constitucional (CosTA, 1994).

${ }^{215}$ Deputado Antonio Britto, Relatório Final da Comissão Especial do Sistema Previdenciário. Março/1992. Diário da Câmara dos Deputados, 28/03/1992: 5343.
} 
revisão constitucional ${ }^{216}$ ao lançar a PEC 51/91, que abordava entre outras matérias o plebiscito sobre as formas de governo, os monopólios do petróleo e das telecomunicações, a aposentadoria do funcionalismo público e o fim da aposentadoria por tempo de serviço. Em pouco tempo, o tema da revisão constitucional tornou-se o assunto de maior repercussão na Câmara dos Deputados, abrindo caminho para a proposição de uma ampla reforma constitucional, enquanto muitos artigos da Constituição, que necessitavam de lei complementar, seguiam sem regulamentação ${ }^{217}$, como era o caso da assistência social e, principalmente, da garantia de um salário mínimo de benefício mensal à pessoa portadora de deficiência e ao idoso sem meios de prover a própria subsistência.

Os comentários sobre uma reforma ministerial com o possível desmembramento do MTSP em dois ministérios ${ }^{218}$ já eram correntes, quando em abril de 1992 ocorreu uma ampla mudança ministerial que correspondeu às expectativas iniciais e que pôs fim à gestão de Magri. O Ministério da Previdência Social foi entregue ao Deputado Reinhold Stephanes, reconhecido especialista na matéria, e o novo Ministério do Trabalho e da Administração Federal, ao Deputado João Mellão Neto, que assumia como um liberal convicto e afirmava que o Estado deveria apenas arbitrar ou intermediar conflitos trabalhistas e deixar o contrato de trabalho ser objeto de livre negociação entre as partes ${ }^{219}$.

Em meio a intenso debate, uma nova Audiência Pública teve lugar em 08/04/1992 para ouvir o parecer do Ministro recém empossado, Deputado Reinhold Stephanes, sobre o relatório do Deputado Antônio Britto da CEESP e sobre o PL apresentado. O Deputado era bastante respeitado como especialista no assunto e influenciara não apenas o trabalho da Comissão, mas todo o debate sobre as reformas.

\footnotetext{
${ }^{216} \mathrm{O}$ art. $3^{\circ}$. do ADTC previa que "a revisão constitucional será realizada após cinco anos, contados da promulgação da Constituição, pelo voto da maioria absoluta dos membros do Congresso Nacional, em sessão unicameral”. Constituição da República Federativa do Brasil, 1988. As regras estabelecidas para a revisão constitucional não seguiam a rotina processual estabelecida pelo regimento interno da Câmara dos Deputados e vedavam iniciativas do Executivo na revisão. Podiam apresentar emendas apenas as Assembléias Legislativas de pelo menos três estados da federação ou um mínimo de três entidades associativas que organizassem proposta de revisão popular subscrita por no mínimo 15 mil eleitores. Uma análise comparativa entre rito da revisão constitucional adotado em 1993 e em 1995 pode ser encontrada em (MELO, 1997a).

${ }^{217}$ Deputado Neuto de Conto (PMDB/SC), Diário da Câmara dos Deputados, 10/04/1992: 6656-6657. Havia uma grande preocupação quanto a forma de governo, parlamentarismo ou presidencialismo, democracia ou monarquia. Deputado Vasco Furlan (PDS/SC). Diário da Câmara dos Deputados, 14/05/1992:8897.

${ }^{218}$ Diário da Câmara dos Deputados 24/01/1992: 1326.

${ }^{219}$ Ver discurso de posse. Diário da Câmara dos Deputados, 15/04/1992:6899-6900.
} 
Entre 1992 e 1994, a agenda do Congresso viu-se confrontada por algumas questões que permaneciam em aberto, incluindo a disputa entre a construção de um modelo de seguridade social e a perspectiva de reforma da previdência, incluindo questões como a privatização. Até o final da revisão constitucional, as disputas estariam centradas na polêmica entre a afirmação da seguridade social, incluindo a formação de um Ministério da Seguridade Social, e a reforma da previdência social, com uma ampla revisão dos direitos tornados constitucionais.

A disputa entre as áreas (saúde, previdência social e assistência social) por recursos do OSS vinha a público e tornava urgente uma nova solução para as questões de financiamento. As questões mais polêmicas estavam, naquele momento, centradas na previdência social, porque representava a despesa mais expressiva da seguridade social, ao mesmo tempo em que os técnicos não podiam controlar o nível das despesas segundo a arrecadação própria, uma vez que se viam constrangidos a manter o valor real dos benefícios e a manter o salário mínimo como o parâmetro para o menor benefício pago pela instituição.

\section{O financiamento da seguridade social na reforma tributária}

A ênfase na questão tributária e no financiamento da seguridade social expôs um conflito distributivo de base fiscal. Num primeiro momento, o debate voltou-se para a tentativa de fazer retroceder o parâmetro de fixação e reajuste do valor dos benefícios assistenciais e previdenciários com base no salário mínimo nacional. A aceitação desse ponto por Collor foi decisiva para que a implementação das leis disciplinadoras fosse completada ao final de 1991, especialmente no que se refere à LCSS e ao PBPS. No entanto, não foi condição suficiente para encerrar o conflito em torno de sua realização.

Medidas de revisão do conteúdo revelaram as frágeis bases da negociação que permitira que a primeira fase das disputas fosse encerrada. Por outro lado, a contestação judicial da cobrança do COFINS (ex Finsocial), que perdurou até fins de 1993, limitava a base de financiamento e deixou a saúde praticamente sem recursos. Na prática, a redução dos recursos para a área da saúde na ordem de 3 bilhões de dólares (entre 1990 e 1992) e a 
centralização administrativa interrompeu o processo de descentralização da saúde e construção do SUS, que só foi retomado em 1993 (Arretche \& Rodriguez, 1998).

O processo da reforma constitucional na área de seguridade social representou a “desconstrução da agenda estruturada” durante a Constituição de 1988 (Melo, 1997b). A regulamentação tardia dos dispositivos constitucionais, o acirramento de um conflito fiscal intragovernamental com uma forte disputa da receita das contribuições sociais e a mobilização pela contra-reforma da Previdência Social iniciada na gestão Collor foram três processos que influenciaram o que chama da "construção social da idéia de crise da Previdência Social” (Melo, 1997b: 298).

O federalismo fiscal $^{220}$ instituído em 1988 e a criação do OSS limitaram o grau de liberdade fiscal do governo. À seguridade social deveriam ser destinados os recursos oriundos das contribuições sociais, o que levava à perda de quase $50 \%$ da receita tributária da União. Num contexto de deterioração das contas públicas e de acertos para pagamento do serviço da dívida externa, tal fato levou a um conflito fiscal intragovernamental entre a área fazendária e de planejamento do governo e a área da seguridade social. O federalismo fiscal conferiu a Estados e Municípios autonomia política e econômica e levou ao desenvolvimento de políticas de atração de novos investimentos com base em incentivos fiscais. Uma das conseqüências foi a guerra fiscal entre Estados com base na renúncia fiscal, para atrair empresas e empregos, numa lógica individual de ação. Apesar dos ganhos individuais dos Estados, coletivamente gerou-se uma situação ruim contribuindo para compressão das receitas públicas.

A reforma do sistema tributário também entrou em pauta no ano de $1992^{221}$, com uma forte presença dos empresários que apelavam para a redução da carga tributária. Os

\footnotetext{
${ }^{220} \mathrm{O}$ federalismo fiscal expressa a partilha de recursos públicos com Estados, Distrito Federal e Municípios. Para uma revisão bibliográfica e sobre a abordagem multidisciplinar, ver: (ALMEIDA, 2001). Para uma abordagem sobre a rigidez fiscal, ver: (VELLOSO, 1993; SILVA, 1997).

${ }^{221}$ O processo oficial de reformulação do Sistema Tributário Nacional teve início com a edição do decreto s/n. do governo, de 01/08/91 que “dispõe sobre a realização dos estudos necessários à elaboração de proposta de reforma fiscal”, estabelecendo como objetivos básicos elevar os níveis de eficiência, equidade e operacionalidade do Sistema Tributário e resgatar a capacidade fiscal do Estado; reformular a estrutura de financiamento do setor público; reestruturar o gasto público e redefinir o papel do Estado. Deputado Luiz Carlos Hauly (PMDB/PR). Diário da Câmara dos Deputados, 20/08/1991: 14303-14304. Suscitou como resposta da Câmara dos Deputados a instalação de duas Subcomissões na CFT para realizar, em conjunto com o Executivo, uma radiografia completa do sistema tributário e fiscal e propor emendas e, acompanhar as licitações realizadas pelo Poder Público. Deputado Germano Rigotto (PMDB/RS). Diário da Câmara dos Deputados,16/08/1991: 14003-14004.
} 
pontos essenciais do argumento reformista coincidiam no diagnóstico de que a carga tributária era pesada, injusta, complexa e custosa para empresas, cidadãos e para o Estado; que a reforma fiscal era necessária e urgente; que as vinculações constitucionais dos tributos dificultavam muito o equacionamento das finanças da União e que a redefinição do papel e do custo do Estado deveria ser prioridade nacional. ${ }^{222}$

No começo do ano, Antônio Ermírio de Moraes escrevera artigo em que propunha que uma nova estrutura de tributos pudesse contemplar a retenção de uma parte das contribuições sociais pelas empresas para investirem diretamente no social através das estruturas já existentes do SESI e do SENAI. O artigo incitava o Estado a ampliar a responsabilidade da sociedade no campo social, o que poderia reduzir o centralismo e a ineficiência estatal ${ }^{223}$, com abertura de espaço para a responsabilidade social. O artigo do empresário paulista era conforme as propostas empresariais de redução das contribuições sociais que estariam sendo destinadas às políticas sociais de nutrição, saúde, educação, formação profissional, tanto quanto de redução do tamanho do Estado, com delegação à iniciativa privada da tarefa concorrente da política social.

A responsabilidade social aparece como uma segunda forma de privatização, através do fortalecimento da participação da sociedade civil (Draibe, 1997) e também como a face mais conservadora, porquanto tenta retirar da arena política e pública os conflitos distributivos, tornando-os objeto da filantropia empresarial, com o benefício da eficiência empresarial (Paoli, 2002).

Dois fenômenos podem ser destacados: a centralidade do tema da reforma tributária e fiscal na agenda pública e a sua correlação com a reforma da previdência. Apesar de serem discussões ocorridas em fóruns paralelos, com tramitação e resultados diferenciados, as duas agendas são superpostas, constituindo-se nas questões mais relevantes da reforma

\footnotetext{
${ }^{222}$ Ver artigo de João Carlos Paes Mendonça, “Do ajuste de emergência para a emergência da reforma”. Jornal do Comércio, 23/10/1992, apud Deputado José Moura (Bloco/PE), Diário da Câmara dos Deputados, 27/10/1992: 23425.

${ }^{223}$ Antônio Ermírio de Moraes. “Iniciativa Privada e Social”. Folha de São Paulo, 10/05/1992. Para se ter uma idéia do montante já movimentado pelo "Sistema S” (SEnAI, SeSi, SENAC, SESC, SENAR, SENAT, SEST, SESCOOP E SEBRAE), no ano de 2006, a arrecadação foi de R 10 bilhões de reais. A Constituição garante às entidades a receita de contribuições compulsórias dos empregadores sobre a folha de salários. São chamadas de contribuições "para-fiscais”, porque os recursos são públicos, mas as entidades beneficiadas, privadas. A renúncia de arrecadação previdenciária em favor do "Sistema S" provocaria importante aumento nessa grandeza sem a certeza de investimento social, uma vez que o TCU já apurou diversas irregularidades, como o uso de recursos públicos para pagamento das despesas das federações de empregadores. "Sistema S registra arrecadação recorde”, Folha de São Paulo, 26/08/2007.
} 
do Estado. Elas se aproximam também pela forte presença de especialistas na condução da discussão, o que lhes confere grande complexidade técnica.

Azevedo e Melo (1997) destacam que duas são as características do debate sobre a reforma tributária: a tecnicalidade das decisões e a invisibilidade. Enquanto as políticas sociais adquirem grande visibilidade na condução dos debates, as decisões relativas às áreas tributárias e fiscais são dotadas de invisibilidade e, porque de difícil compreensão, muitas vezes só são acessíveis a especialistas. Ocorre também o predomínio da participação de atores de natureza burocrática tais como governadores, secretários estaduais, ministros, secretários e técnicos da Fazenda e do Planejamento.

A rigidez fiscal e orçamentária, a expansão dos gastos sociais e a criação de novas fontes de financiamento compõem o quadro da "ingovernabilidade fiscal” tão debatida durante os anos 1990 e que conduziu à formação de uma agenda de reforma tributária. O Tesouro Nacional assumiu frente às perdas representadas pela Constituição de 1988 federalismo fiscal e a criação do OSS - um comportamento defensivo, expresso pela expansão da captação de recursos livres, ou seja, não repartíveis com Estados e Municípios. Esse comportamento levou à expansão da cobrança de contribuições sociais, que representavam ainda o benefício de não responderem ao princípio da anterioridade e poder ser cobrado quase que imediatamente.

As contribuições sociais, que haviam sido destinadas ao custeio da seguridade social, foram disputadas pelo Tesouro através de vários expedientes como boicotes, falta de repasse, desrespeito ao OSS, inclusão de despesas estranhas ao conceito etc.

Há dois movimentos correlacionados ao conflito fiscal e distributivo exacerbado após 1988: 1. o Ministérios da Fazenda e do Planejamento passaram a defender um percentual de 20\% de “receitas livres” incluindo a arrecadação de impostos e contribuições sociais, ou seja, fora da partilha com Estados e Municípios e fora do OSS; 2. a reivindicação de reforma tributária e a apresentação de propostas por vários segmentos. O primeiro teve por resultado a criação do Fundo Social de Emergência (1993), que aumentou o poder das áreas econômicas em administrar e dispor dos recursos arrecadados, fora da lei orçamentária. O segundo suscitou uma ampla discussão com apresentação de diversos projetos e sugestões que tiveram por objetivo reduzir a carga fiscal (Azevedo \& Melo, 1997). 
A criação da Comissão Executiva de Reforma Fiscal (CERF) reuniu propostas de 50 especialistas e o relatório final propunha a criação de um Imposto de Valor Adicionado (IVA) pago no destino; a desoneração plena das exportações; a eliminação de contribuições sociais; a privatização parcial da previdência social; a criação de uma contribuição sobre a transação financeira; a criação de um imposto sobre ativos e a criação de impostos seletivos. O conteúdo do relatório ajudou a pautar a agenda da reforma tributária que tinha por objetivo a redução da carga fiscal global, o fim dos impostos em cascata, a redução do “Custo Brasil” e a desconstitucionalização dos impostos.

Após apresentação do relatório da CERF, havia no Congresso Nacional a expectativa de receber do Executivo as modificações e que estas respeitassem os objetivos de realização da justiça tributária e da simplificação dos impostos. Contudo, em 09/06/1992 o Deputado Carrion Júnior declarava que não havia qualquer PL sobre reforma tributária tramitando na Câmara dos Deputados apesar do prazo exíguo para o exame da matéria ${ }^{224}$, seguindo o princípio da anualidade para a instituição de novos tributos.

A resposta viria na forma de um documento do Executivo, não assinado, declarado como subsídios à discussão da PEC 55/91 (ajuste fiscal) sob análise na CERF da Câmara dos Deputados. O documento tratava não apenas da reforma fiscal e tributária, mas também alterava o financiamento tanto da seguridade social, quanto de outras áreas sociais e tratava de questões mais abrangentes como a aposentadoria aos 65 anos de idade; FGTS; fim da estabilidade dos funcionários públicos; mudança na distribuição dos impostos entre União, Estados e Municípios; taxação da economia informal.

O conjunto de propostas do Presidente Collor, que alterava dispositivos constitucionais, não seguiu o trâmite legislativo regular e obrigatório. O Presidente da CERF ao receber tal documento declarou que aproveitaria as sugestões específicas de caráter fiscal e enviaria as demais à Mesa para que se procedesse ao seu envio às respectivas comissões de mérito, em flagrante desrespeito aos procedimentos formais de trâmite legislativo de Emenda Constitucional. ${ }^{225} \mathrm{Na}$ prática, a proposta do Governo antecipava a revisão constitucional, propondo alteração de 217 dispositivos, os quais

\footnotetext{
${ }^{224}$ Deputado Carrion Júnior (PDT-RS). Diário da Câmara dos Deputados, 09/06/1992, p. 12559; Deputado Osvaldo Bender (PDS/RS), Diário da Câmara dos Deputados, 14/05/1992: 8909.

${ }^{225}$ Deputado Eduardo Jorge (PT/SP). Diário da Câmara dos Deputados, 22/07/1992: 17114-17115; Deputado Pedro Irujo (Bloco/BA). Diário da Câmara dos Deputados, 22/07/1992: 17113.
} 
abordavam temas relativos, principalmente, ao financiamento das áreas sociais: eliminação das contribuições do PIS/PASEP e do salário-educação, extinção progressiva da contribuição sobre o lucro e do Finsocial e a redução gradual da contribuição das empresas sobre a folha de pagamento de salários. No Seminário "O Trabalhador e a Reforma Fiscal” ocorrido na CCTASP, o documento foi repudiado e subscrito por várias entidades civis.

Em agosto de 1992, o Presidente enviou ao Congresso Minuta de MP que visava a alterar a legislação referente ao plano de custeio e benefícios da seguridade social, sob a alegação de que o governo precisava captar recursos para pagar os 147\% de reajuste aos aposentados. A MP, que tinha uma pauta bastante ampla, pregava a redução das contribuições sociais devidas pelos empregadores; a uniformização da contribuição social do empregado através da fixação de uma alíquota única de 10\%; alteração das contribuições sociais devidas pelos segurados rurais; extinção de alguns benefícios previdenciários, tais como o abono de permanência em serviço e os pecúlios; anistia a sonegadores e inadimplentes da Previdência Social; unificação de alíquotas das empresas para o seguro de acidentes de trabalho (SAT) em $1 \%{ }^{226}$; criação do seguro para a cobertura de despesas médico-hospitalares.

O texto sugeria que a cobertura das prestações de auxílio-doença decorrentes do acidente de trabalho fosse feita com base na alíquota do SAT (1\%), o que no parecer elaborado pela Assessoria Legislativa do PT dificultaria o gerenciamento do sistema, além de não cobrir outras prestações decorrentes de acidente de trabalho, como a aposentadoria por invalidez, a pensão por morte, auxílio-acidente e pecúlios por morte e invalidez. Ainda segundo o parecer, a proposição de alíquota única de contribuição dos empregados era inconstitucional por não observar o princípio da eqüidade na forma de participação no custeio, segundo o qual, cada um contribui de acordo com a sua capacidade contributiva ${ }^{227}$.

\footnotetext{
${ }^{226}$ O PBPS havia aprovado pagamento do SAT diferenciado de acordo com o risco, com alíquotas de $1 \%$, $2 \%$ e $3 \%$, para estimular as empresas a reduzirem o grau de risco de sua atividade econômica e investir em medidas de proteção coletiva. A adoção da alíquota única acabaria com o pagamento diferenciado pelo grau de risco, o que também reduziria a arrecadação do Governo nesse item.

${ }^{227}$ Segundo o parecer do PT, a elevação da menor alíquota de 8\% para 10\% representa uma majoração da ordem de $25 \%$ e entre os que contribuem com $9 \%$, a majoração será de $11 \%$. O PT manifesta-se pela rejeição da MP por não gerar recursos adicionais suficientes para o pagamento das despesas com os 147\%, além de ser regressivo e só gerar efeitos 90 dias após a sua aprovação. A proposição de uma contribuição adicional temporária de 5\% (até 31 de dezembro de 1994) para empregados cujo salário excedesse o teto de contribuição, também foi julgada inconstitucional pelo prazo para que uma MP entre em vigor (90 dias), mas também porque deve existir correspondência entre o salário de contribuição e o beneficio previdenciário. O desconto de 30\% nos débitos anteriores a dezembro de 1991de empresas, desde que pagos em 60 dias, foi
} 
O SAT foi objeto de uma disputa à parte relativa não apenas à forma de financiamento, uma vez que passou a ser custeada exclusivamente pelas empresas, mas manteve-se sob o controle e gestão pública através da Previdência Social. Em meio à discussão pública sobre os benefícios sociais e o modelo de financiamento, os empresários reivindicavam a retomada da sua gestão privada, exclusivamente a cargo de entidades patronais.

O impeachment de $\operatorname{Collor}^{228}$ e a assunção de Itamar Franco fortaleceram a expectativa de um amplo debate em torno de medidas para aperfeiçoar a política tributária nacional e rever o sistema de contribuição para a seguridade social. O Deputado Cardoso Alves defendia a tributação indireta como uma forma de impedir a sonegação, a corrupção e a burocracia, três elementos fundamentais que afetavam a economia do país ${ }^{229}$. A tributação indireta serviria ainda para alcançar a economia informal, estimada em $50 \%$ da economia nacional e combater a sonegação fiscal. Para o Deputado, a hora era de modernizar o país, sem aumentar impostos ou ampliar o universo tributário e fazer ingressar os segmentos da economia informal no rol dos contribuintes. Ampliar o universo econômico daqueles que realmente contribuem para os cofres públicos era uma grande preocupação no contexto da reforma tributária. A expectativa geral era de que fosse possível reduzir o número de tributos, enxugar a estrutura administrativo-tributária, eliminar o seu efeito regressivo e a tributação em "cascata” e ressaltar o princípio da "nãocumulatividade” na base da incidência de tributos.

Diversas proposições, Comissões e Grupos de trabalho foram formados no âmbito do Executivo e do Legislativo para modernizar a sistema tributário nacional e para conter a sonegação e a burla ao fisco. Um amplo debate se seguia também nas universidades, entidades empresariais, sindicatos, através de seminários, diagnósticos e propostas de reforma tributária. Azevedo e Melo (1997: 6-7) contabilizaram a participação de trabalhos de

considerado indecoroso. A única medida considerada justa seria a antecipação no recolhimento da contribuição referente ao 13\% salário (para o dia 20 de dezembro), por ajudar a equilibrar o caixa da Previdência e garantir recursos para o pagamento do abono anual aos seus beneficiários. A íntegra do parecer encontra-se publicada em: Diário da Câmara dos Deputados, 14/08/1992: 18448-18450.

${ }^{228}$ Collor sofreu processo de impeachment no decorrer do ano de 1992, motivado por improbidade administrativa e corrupção. O processo foi votado em setembro de 1992 quando assumiu o vice, Itamar Franco.

${ }^{229}$ Deputado Cardoso Alves (PTB/SP). Diário da Câmara dos Deputados, 30/10/1992: 23775. 
50 especialistas na CERF, assim como um movimento de resistência por parte do MPS, do BNDES, governos estaduais e associações empresariais.

A revisão constitucional serviu como pano de fundo para a apresentação de novas propostas e intensificação do debate. Azevedo e Melo (1997: 60) contabilizaram 60 propostas em trâmite no Congresso Nacional, das quais, as de maior repercussão foram as de autoria do Deputado Flavio Rocha (PL), do Deputado Luiz Roberto Ponte, do Deputado Luiz Carlos Hauly, da Comissão Executiva de Reforma Fiscal e do Banco Mundial. Fora da arena parlamentar as propostas da FIESP, do PNBE, da CNI, da CUT, da CGT e da FS também tiveram repercussão. Se, por um lado, havia convergência no entendimento de que a reforma tributária era necessária para superar a crise de financiamento do Estado, havia, por outro, ampla divergência em relação às medidas a serem adotadas.

O Deputado Flávio Rocha (PL/RN) apresentou a PEC 17/91, na qual propunha a fixação de um imposto único a incidir sobre a emissão de cheques e sobre operações financeira e que foi assumida pelos defensores do ITF. O Deputado Benito Gama, relator do projeto de reforma tributária, optara pela implementação da proposta através de grupos de impostos - o ITF (0,3\%) poderia substituir a todos os impostos previdenciários e o IOF, que juntos representam 34\% da arrecadação. Esperava-se que, com a medida, fosse possível alargar a base e reduzir a sobrecarga tributária. $\mathrm{O}$ alargamento da base tributária tinha como principal objetivo desonerar a folha de pagamento de salários e garantir recursos para a previdência social e para a saúde.

A outra proposta de reforma tributária foi apresentada através PEC 48/92 de autoria do deputado Luiz Carlos Hauly (PST/PR) e defendia a redução do elenco de impostos a, no máximo, cinco e apenas uma contribuição previdenciária. O fundamental da PEC era a estruturação tributária entre as três bases conhecidas e que formavam grandes conjuntos: a de renda e proventos de qualquer natureza; a de circulação e de consumo de mercadorias e de propriedades patrimoniais. Segundo o Deputado, o projeto era simplificador porque sugeria um cadastro unificado em todo o país e também um único aparelho fiscoarrecadador $^{230}$. Estava sendo lançada a discussão sobre a centralização da arrecadação de tributos e contribuições sociais em um único órgão, o que se concretizaria em 2007, com a

${ }^{230}$ Diário da Câmara dos Deputados, 11/11/92: 23311-23312. 
criação da SRF. Essa proposta era muito próxima daquela que os empresários filiados à FIESP iriam apresentar ao final do ano de 1992.

A PEC do Deputado Luiz Roberto Ponte obteve a simpatia dos empresários por defender uma proposta de reforma com base no imposto único centralizado em nível federal, que reduziria os custos de arrecadação e fiscalização e eliminaria a burocracia da declaração de diversos impostos. Apesar de não ter sido bem recebida pelo governo, voltou a ser discutida no ano de 1995.

A aguardada proposta do governo de reforma do STN só veio a ser formulada no Governo Itamar Franco: um ambicioso conjunto de propostas que alterava a redação de 22 dispositivos constitucionais, introduzia outros 40, suprimia 9, e procurava adequar a redação de outros 7. No total, propunha 78 alterações, antecipando a revisão constitucional no que se refere aos capítulos tributário e da seguridade social.

O ponto mais importante do projeto era a criação da Contribuição sobre o Valor Adicionado (CVA) em substituição às contribuições sociais (Finsocial, PIS/PASEP e CSLL), com grande impacto sobre o orçamento da seguridade social. A justificativa era que a nova contribuição poria fim às ambigüidades que impediram a cobrança do Finsocial às instituições financeiras e traria um alívio para a atividade produtiva, além do aumento da competitividade econômica. Na proposta, o $\mathrm{FAT}^{231}$ ficaria comprometido, o que tornaria necessário $40 \%$ da receita do CVA para o financiamento das despesas do segurodesemprego. Era proposta ainda a extinção do IPI e sua substituição pelo Imposto Seletivo (sobre automóveis, cigarros, bebidas, combustíveis, energia elétrica, serviços de telecomunicações); a criação do IPMF, com alíquota máxima de 0,3\% e posterior redução para $0,15 \%$ e a criação do Imposto sobre Ativos. A competência para arrecadar o IPTR passaria ao Estado, que partilharia 50\% da receita com os Municípios. Estimava-se que o ganho fiscal com a reforma seria de sete bilhões de dólares anuais.

Apesar da aceitação da idéia de criar um IVA, a proposta foi bastante criticada. Em primeiro lugar, pela sua amplitude que lhe conferia caráter de revisão constitucional, não havendo tempo hábil para a sua aprovação e vigência a partir de $1993^{232}$, além de correr o

\footnotetext{
231 O FAT sustentava o seguro-desemprego, o investimento privado via BNDES (Banco Nacional de Desenvolvimento Sócio-Econômico), pagava o abono aos assalariados de baixa renda e ainda gerava superávit fiscal.

${ }^{232}$ Tendo em vista o respeito ao princípio tributário da anualidade.
} 
risco de ser revista em 1994. Em segundo lugar, porque não resolveria o problema da regressividade dos impostos e produziria impacto negativo nas contas dos Estados e Municípios, ao alterar as transferências federais ${ }^{233}$.

Foi nesse contexto que a FIESP, formulou uma proposta de reforma tributária ${ }^{234}$ que pretendia consolidar o sistema de impostos e contribuições em cinco impostos (quatro deles com finalidade de arrecadação e outro, de regulação): imposto sobre a renda pessoal; imposto sobre a venda de bens e serviços ao consumidor final; impostos sobre a produção e distribuição de fumo e bebidas alcoólicas; imposto sobre imóveis (contribuição de melhoria indireta); imposto sobre comércio exterior. A reforma tributária era enfática quanto à não tributação da renda da pessoa jurídica, do lucro e da folha de pagamento de salários. Os quatro princípios a serem perseguidos eram a transparência, a eficiência no recolhimento, a universalidade na cobrança e o fortalecimento da Federação.

Na proposta da FIESP os encargos sociais, relativos ao financiamento de aposentadorias e pensões, deveriam ficar a cargo exclusivamente dos segurados, dentro de um sistema contributivo. O documento consolidava também uma minuciosa proposta em torno da "rede de proteção social ao cidadão", de natureza básica e de prestação mista, numa composição entre público e privado:

1. previdência social: a) um seguro social básico de natureza contributiva em conta individualizada de todos os trabalhadores, públicos ou privados, urbanos ou rurais, sem isenções; com uma taxa de contribuição de 10\% do salário de contribuição; um sistema auto-sustentado que cobriria aposentadoria por idade ou invalidez, pensões, auxílio-maternidade, auxílio-natalidade e auxílio-funeral; b) uma previdência complementar, privada, mas regulada pelo Estado; c) a transição seria custeada por uma contribuição de solidária compulsória, no montante de $10 \%$ sobre a totalidade dos rendimentos do trabalho, sem isenções e sem contribuição das empresas.

\footnotetext{
${ }^{233}$ O Deputado Paulo Duarte (Bloco) sintetizou em seu discurso os principais argumentos correntes: " $a$ rejeição à proposta é unânime nas manifestações. Muitos a consideram extemporânea. Só seria aceitável no bojo de uma revisão constitucional que viesse a definir o tamanho do Estado, seu custo e a distribuição de encargos entre os Governos Federal, Estaduais e Municipais. Como está sendo apresentada é um disfarce para ajustar contas do fim de ano... Quanto ao mérito da reforma em si, salientam como único aspecto positivo a redução do número de tributos”. Diário da Câmara dos Deputados, 09/12/1992: 26273.

${ }^{234}$ FIESP/CIESP. “Uma Proposta de reforma tributária e de seguridade social”. Brasília, Conjuntura Social, 4, 1:5-20, jan. 1993. O documento foi publicado originalmente na Revista da Indústria, Nova Série, Ano I, n. 4, out/dez, 1992: 7/23, de onde foi transcrito.
} 
2. assistência social: a) seguro-desemprego: renda mínima durante o período máximo de seis meses para desempregado temporário; custeado por um fundo de reserva formado pelo patrimônio do PIS/PASEP, mais uma contribuição obrigatória do segurado em valor voluntariamente estabelecido por ele; b) auxílio- emprego: constituição de frentes de trabalho em instituições públicas para trabalhadores desempregados há mais de seis meses, com objetivo de garantir condições de sobrevivência e qualificação para o trabalho; c) assistência social aos incapacitados através de pagamento de um “cheque” para idosos e deficientes graves cadastrados e não contribuintes da Previdência Social básica; custeado por recursos gerais da União no montante de $0,7 \%$ do PIB e com universo de dois milhões de pessoas a serem assistidas;

3. seguro contra acidente de trabalho: contribuição compulsória do empregador junto a seguradoras privadas e administrado por sindicatos e federações patronais;

4. saúde: pagamento de um “cheque-saúde” no valor médio de 50 dólares/ano, a cada pessoa, para cobertura de qualquer doença mediante compra, exceto aquelas de riscos excepcionais; o valor deveria variar de acordo com a idade;

5. educação: todas as crianças entre 5 e 15 anos deveriam receber um "cheque-salárioeducação” para custear uma escola pública ou privada, o que iria conferir às escolas públicas maior liberdade financeira; o cheque deveria ser de 20 dólares mensais por criança no ensino fundamental; os projetos de pesquisas deveriam ser copatrocinados; custeado com recursos gerais da União, no montante de 2,2\% do PIB; o ensino médico deve ser estimulado mediante bolsas ou crédito educativo aos estudantes.

Preocupados ainda com o controle da rede de proteção social, os empresários da

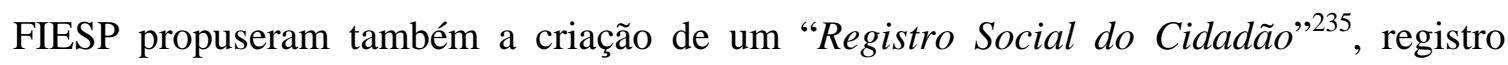
único individualizado que deveria permitir a identificação do cidadão, o controle tributário, o controle ocupacional, o controle do seguro social básico, o controle dos cheques (saúde e educação). As vantagens da proposta seriam: conferir progressividade à carga tributária, através da maior importância do imposto de renda sobre a totalidade dos impostos e a

\footnotetext{
${ }^{235}$ Pela proposta da FIESP, o novo documento pessoal “Registro Social do Cidadão - RSC” deveria substituir os atuais documentos pessoais: RG, CPF, CTPS.
} 
ausência de incentivos fiscais, deduções, imunidades e abatimentos; isenção de impostos sobre máquinas e equipamentos; autonomia fiscal para estados e municípios; redução das despesas de custeio e investimento do governo; aumento dos salários diretos dos trabalhadores; formação de poupança; fortalecimento da cidadania, com a consciência de que todos os cidadãos são contribuintes.

A proposta da FIESP era fortemente marcada pelo fim dos tributos diretamente às empresas, seja sobre o lucro, o faturamento ou sobre a folha de salários, zerando a sua participação no custeio da seguridade social. Apenas a cobertura de acidentes de trabalho seria de sua competência exclusiva, contudo, deveria deixar de ser público, passando a ser gerido pela iniciativa privada e sob gestão direta dos próprios empresários, sem qualquer participação dos trabalhadores. A responsabilidade pelo custeio do seguro social, incluindo seguro-desemprego, passaria a ser integralmente dos trabalhadores e a responsabilidade pelo custeio da assistência social, saúde e educação, deveria ser da União, mas com restrição de gastos definidos a partir de percentuais do PIB. A proposta para uma reforma tributária e de financiamento da seguridade social era conforme as propostas empresariais de redução do custo do trabalho a partir da flexibilização das leis do trabalho.

Ao Deputado Benito Gama, coube a relatoria das propostas de reforma tributária Câmara dos Deputados, cujo substitutivo apresentado também foi bastante criticado. Ele criava o IPMF; introduzia o Imposto Seletivo no lugar do IPI; não extinguia o imposto sobre grandes fortunas; não criava o imposto sobre ativos, e deveria manter os mesmos percentuais dos FPE e FPM (com base no IR, IPI e imposto seletivo), dentre outras medidas. Alguns a consideraram pior que o projeto original e os empresários ameaçavam recorrer à Justiça contra a mudança na matéria constitucional. O substitutivo Ponte, por sua vez, se baseava na simplificação dos tributos e da burocracia correspondente ao recolhimento de tributos, mas não foi acolhido no Congresso.

Com a sensação de que o projeto aprovado somente resolveria o problema do Caixa do governo para o ano seguinte (1993), de forma alguma atendendo aos interesses nacionais, os deputados previam que o tema da reforma no sistema tributário permaneceria na agenda do Congresso Nacional. Seguiam em paralelo na CERF o substitutivo do Deputado Benito Gama ao projeto do governo e um outro projeto que visava instituir o imposto único, de autoria do Deputado Flávio Rocha. 
O ajuste fiscal, a reforma do STN e a organização da peça orçamentária para 1993, foram questões políticas balizadas pela necessidade de gerar superávit primário para o pagamento dos serviços da dívida externa num quadro de grave inflação. O balancete oficial do Tesouro Nacional registrara um superávit de 40 trilhões de cruzeiros na execução orçamentária de 1992, o qual fora depositado no Banco Central para o pagamento dos serviços da dívida externa, em cumprimento aos acordos com o FMI.

O tema da reforma tributária apresentou uma nova via de entrada para a discussão da previdência social que teve como ponto central o aspecto fundamental da base de financiamento que é a contribuição sobre a folha de pagamento de salários. Do mesmo modo, ao longo da votação anual da política salarial, se reacendeu o debate sobre o impacto do aumento do salário mínimo sobre as finanças dos Estados e do Município, com o aumento do déficit público. A cada ano, o reajuste do salário mínimo era discutido e negociado tendo por base as contas da Previdência Social ${ }^{236}$.

\section{Conflito distributivo entre Fazenda e seguridade social}

A LCSS estabelecera um cronograma de desoneração da previdência social que previa que, das contribuições sociais, apenas as incidentes sobre o faturamento e o lucro das empresas poderiam ser destinadas à cobertura dos EPUs dentro de um calendário que previa a sua redução de um patamar de 55\% em 1992 para 10\% em 1995. Do mesmo modo, previa que os recursos da seguridade social, obtidos com as contribuições das empresas e dos trabalhadores sobre a folha de salários, dos trabalhadores domésticos e daquelas incidentes sobre o faturamento e o lucro das empresas poderiam ser utilizados, a partir de 1992, para o pagamento de despesas com pessoal e administração apenas de funcionários públicos das áreas integrantes da seguridade social ${ }^{237}$. Até 1991, quase a totalidade desses encargos era paga com recursos do Finsocial, o que fez crescer bastante os gastos da União com o funcionalismo público e outras despesas, reduzindo ainda mais os recursos fiscais disponíveis. Ao mesmo tempo, a Lei fixava a obrigação da destinação anual de recursos

\footnotetext{
${ }^{236}$ As Atas das reuniões da CTASP de todos os anos demonstram o conflito em torno da aprovação do projeto de lei do salário mínimo. É atribuição da CTASP, enquanto órgão técnico especializado da Câmara dos Deputados propor o PL. Atas da CTASP (1990-2002). Diário da Câmara dos Deputados, várias edições.

${ }^{237}$ Funcionários do INSS, do INAMPS, da LBA e da FUNABEM, conforme art. 18 da Lei 8.212/91.
} 
adicionais do OF para a seguridade social e a cobertura de eventuais insuficiências financeiras da seguridade social quando decorrentes do pagamento de benefícios de prestação continuada da previdência social ${ }^{238}$.

Como a arrecadação das contribuições sociais não incidentes sobre a folha de salários era realizada pela Receita Federal ${ }^{239}$, o controle das transferências de recursos para a seguridade social cabia ao Tesouro Nacional, que as manipulava num claro sinal de boicote à execução do OSS e revelava o conflito distributivo entre as áreas do governo. A disputa envolveu principalmente a forma de financiamento do SUS, o pagamento dos EPU, o custeio do pessoal do Ministério da Fazenda e o pagamento de benefícios assistenciais e de caráter não-contributivo. O controle pela área econômica dos recursos destinados à área social levava à perda de autonomia e deterioração dos serviços sociais essenciais.

No período foram graves a denúncias de retenção de valores a serem destinados principalmente ao SUS. Segundo Soares (2001: 252) o gasto per capita com saúde apresentou declínio a partir de 1990, atingindo em 1992, o menor gasto per capita desde o ano de 1980. Em 1993, ficou estabelecido que 15,5\% da arrecadação da contribuição de empregados e empregadores seriam transferidos para a área da saúde. No entanto, o novo Ministro da Previdência, Antônio Britto, deixou de realizar, a partir do mês de maio, os repasses devidos para a área da saúde, tornando-a dependente dos recursos do caixa do Tesouro Nacional e submetida à política de contenção de gastos do governo federal. Em alguns momentos, foi necessária decretação de “calamidade pública” no setor para que houvesse alguma liberação de verbas.

O motivo do não repasse se sustentava na tese da vinculação entre contribuições sociais sobre a folha de salários e a previdência social, o que contrariava o disposto na LCSS. Para Eduardo Jorge (2005: 23), com essa atitude precipitada, o Ministro especializava,

\footnotetext{
${ }^{238}$ Ver artigo 16 e parágrafo único da Lei 8.212/91.

${ }^{239} \mathrm{Na}$ época, o sistema tributário brasileiro possuía um total de vinte contribuições sociais, de caráter público e privado. As de caráter privado custeiam atividades de instituições patronais, como o SESI e SENAI e, embora sejam recolhidas sobre a folha de pagamentos ao INSS, são repassadas, não fazendo parte do OGU. As contribuições de caráter público se destinam ao financiamento de áreas de saúde, previdência social, assistência social, alimentação, educação e habitação. São arrecadadas e transferidas ao Tesouro Nacional pelo Departamento da Receita Federal ou pelo INSS. O “passeio" dos recursos da seguridade social tem possibilitado a retenção de parte dos recursos pelo Tesouro e acarretado perdas decorrentes da inflação. As contribuições sociais têm representado importante papel no financiamento das políticas sociais no Brasil e vêm crescendo em participação no total da receita tributária, o que conduz a uma disputa intragovernamental por esses recursos (SOARES, 2001).
} 
por conta própria, a fonte de contribuição de empregados e empregadores sobre a folha de pagamento de salários para a previdência social, pondo fim ao uso histórico dessa fonte para financiar a saúde ${ }^{240}$. Tal medida agravou o quadro orçamentário já precário da área da saúde em face da redução das transferências voluntárias do governo. A disputa em torno do financiamento de benefícios assistenciais com os recursos da folha de pagamentos ainda iria perdurar até o início dos anos 2000.

Até abril de 1993, o repasse para a área da saúde foi de 20 trilhões e 900 bilhões de cruzeiros, quando deveria ter sido 41 trilhões de cruzeiros de recursos da seguridade social. Em decorrência da retenção, a área da saúde acumulou dívidas com os hospitais conveniados e filantrópicos e levou todo o sistema à beira do colapso. ${ }^{241}$ Em junho de 1993, o governo liberou 16 trilhões de cruzeiros de recursos do Tesouro Nacional para saldar dívidas do SUS, após reunião conduzida pelo Ministro da Fazenda, Fernando Henrique Cardoso. No mesmo momento em que era aprovado PL enviado pelo governo que extinguia o INAMPS e suas atribuições, equipamentos e recursos humanos eram repassados aos órgãos estaduais e municipais do SUS, finalizando, dessa forma, o processo de descentralização das ações da saúde.

Diferentemente da previdência social, os gastos com saúde podiam ser ajustados às medidas de contenção do déficit público, mediante controle dos repasses governamentais, o que não podia ser feito com a previdência social, pela natureza dos benefícios prestados e pelo controle público que a definição do salário mínimo como parâmetro impunha. A questão da previdência exigia reformas nos próprios dispositivos constitucionais.

A especificidade da construção da agenda da revisão constitucional que implicava na revisão dos próprios direitos sociais de seguridade social, sobretudo, a sua base de financiamento, as vinculações de receitas, a disputa por recursos fiscais, aponta para a confluência das agendas tributária, fiscal e social, fazendo com que parte do debate fosse deslocada para outra arena. A política previdenciária converteu-se em um ponto central de gestão macroeconômica dado a sua dimensão fiscal e a magnitude do orçamento que

\footnotetext{
240 A decisão do Ministro Antônio Britto pôs fim a uma disputa perversa entre aposentadoria ou hospitalização, o quê financiar com os recursos disponíveis. Ver a respeito: VianNA, Solon M. (2005).

${ }^{241}$ Ver a respeito da situação da área da saúde o discurso do Deputado Tuga Angerami (PSDB/SP). Diário da Câmara dos Deputados, 09/06/93: 12093; Deputado Diogo Nomura (PL/SP) e Deputado Daniel Silva (PPR/MA). Diário do Congresso Nacional, 18/06/1993: 12914-12915.
} 
movimenta, sobretudo em contextos de crise fiscal como a vivenciada pelo país e a política de contingenciamento das despesas para gerar superávit primário.

A construção da agenda pública sobre a reforma da previdência segue de perto os debates sobre a modernização das relações de trabalho e as propostas empresariais de redução do “custo Brasil”, ou de redução da carga tributária sobre a folha de pagamento de salários, das quais a contribuição para a previdência social era um item importante. Dentre as propostas apresentadas e de mais forte veiculação estavam aquelas referentes à flexibilização dos direitos do trabalho, a adoção da livre negociação e a redução dos custos do trabalho.

Na previdência, o debate seguia em linha próxima, com propostas mudança na base de financiamento e redução da participação da folha de pagamentos; rigidez nas regras para aposentadoria; redução do número de benefícios; introdução de previdência privada em regime de capitalização e mudança nas formas de tributação. A concentração das duas pastas em único Ministério durante o governo Collor permitiu a confluência entre as duas agendas e sua quase indistinção do tratamento empresarial ${ }^{242}$.

\section{O Ministério da Previdência Social e a revisão constitucional:}

O Ministério da Previdência Social também se preparou para a revisão constitucional e através de um Convênio com a CEPAL ${ }^{243}$ contratou pesquisadores renomados "para a elaboração de cenários e de alternativas para a Previdência Social brasileira"244. Duas alternativas eram consideradas pelo Ministro Antônio Britto: reformas e melhoria na qualidade da gestão previdenciária. Ao mesmo tempo, um ciclo de seminários e debates com especialistas visavam “mostrar a necessidade da reforma",245.

\footnotetext{
242 (CNI, 1994).

${ }^{243}$ O produto do convênio desdobrou-se em duas partes - pesquisas e debates - que se encontra publicado em: (MPAS/CEPAL, 1993). Todo o item foi redigido com base no material publicado pelo convênio e que nos permite mapear os temas debatidos fora do Congresso Nacional, com a participação de especialistas e técnicos da instituição. Com ou sem projeto de reforma para a Previdência, os debates mostram-se ricos como um processo de formação de opinião.

244 (Idem: 10 - Pesquisas, vol. II).

245 (Ibidem, p. 10).
} 
Para o Ministro ${ }^{246}$, cinco anos após a promulgação da Constituição, as “apostas” da ANC frustraram-se: não ocorreu a integração, os direitos não se tornaram universais e os recursos da seguridade social eram insuficientes para sustentar as responsabilidades do Estado. Sem integração, ocorreu paralelismo nas ações da saúde, previdência e assistência social com um ponto de encontro $\operatorname{conflituoso}^{247}$ no OSS. No período que vai até 1992, a soma das despesas superou os recursos disponíveis no OSS, que precisou do aporte de recursos do $\mathrm{FAT}^{248}$. Apenas as contribuições sobre a folha de pagamento de salários apresentaram crescimento contínuo desde 1989.

As diretrizes para a reforma da seguridade social (especialmente saúde e assistência social) deveriam ser a focalização e a descentralização, ou seja, atender aos mais necessitados e repartir com Estados e Municípios a responsabilidade pelo seu financiamento.

A previdência, por sua vez, deveria receber tratamento diferenciado, sem descentralização e com seletividade. O primeiro ponto da reforma previdenciária deveria ser a separação entre os benefícios previdenciários e os benefícios assistenciais ${ }^{249}$. Os primeiros, de natureza contributiva, deveriam se restringir à concessão de pensões e aposentadorias e os benefícios assistenciais deveriam ser incluídos numa política de assistência social a cargo dos Estados e Municípios, segundo o princípio da seletividade.

Nesse momento, a proposta do Ministério caminhava no sentido de um sistema bipartido, entre previdência e assistência social, reconhecendo-as como técnicas diferentes de proteção social. A primeira teria por objetivo proteger os indivíduos na qualidade de assalariados do setor formal do mercado de trabalho e contribuintes de um plano de seguro coletivo; a segunda visaria atender aos mais necessitados na sua condição de cidadão,

\footnotetext{
${ }^{246}$ Utilizamos como referência o texto institucional assinado pelo Ministro Antônio Britto que prefacia os volumes de pesquisas do referido convênio.Ibidem.

247 "Mais do que os números, que dão retrato fiel do que ocorre no OSS, é o fato de que, ano após ano, de 1989 até hoje, viveu-se, no Brasil uma verdadeira “dança entre desesperados”. Os aposentados precisando dos recursos dos doentes que, por sua vez, buscam recursos dos desempregados que, por sua vez, tomam dos carentes que, por sua vez... O que deveria ser o orçamento da solidariedade entre setores envolvidos com políticas sociais, transformou-se no palco de uma feroz luta por recursos”. Ministro Antônio Britto (MPS). Prefácio (Ibidem: 11).

${ }^{248}$ FAT: os recursos transferidos foram respectivamente de 220 milhões de cruzeiros em 1991 e 5 bilhões de cruzeiros em 1992, segundo dados do Ministério da Previdência Social (MPAS/CEPAL, 1993: 10).

${ }^{249}$ Esse também é um ponto que suscita polêmica. Aqueles que se apresentavam como partidários de se aprofundar o modelo da seguridade social da Constituição não identificavam a necessidade de uma separação entre as áreas da previdência e assistência social. Em 1992, já havia sido estabelecida uma separação rígida entre a previdência social e a saúde, através da especialização na fonte de financiamento (DRAIBE, 1993).
} 
independentemente de seu assalariamento e de sua contribuição. Um sistema de proteção social bipartido mescla princípios de eqüidade e de igualdade e dá origem a um modelo de financiamento também misto, integrado tanto por contribuições sociais, quanto por tributos.

Para o Ministro, caso se insistisse, durante a revisão constitucional, no caminho da universalização da seguridade social, sem a devida separação entre benefícios de natureza previdenciária e assistencial, o esquema de financiamento precisaria ser repensado, de modo que a contribuição não continuasse a recair apenas sobre quem trabalha, mas sobre toda a sociedade, com uma contribuição a partir do consumo.

Mesmo com a separação, previa-se que a previdência social precisaria caminhar para um sistema de igualdade entre os cidadãos, com fim de injustiças, tais como o acúmulo de benefícios, aposentadorias precoces, aposentadoria por tempo de serviço, dentre outras. As medidas pensadas se direcionavam para a necessidade de aumento do controle sobre a concessão de benefícios, de modo que fosse impedido o uso de benefícios previdenciários para aumento da renda. Desse modo, um dos principais itens da agenda era tornar incompatível emprego e recebimento de benefícios. Propunha, ainda, a adoção de um sistema previdenciário misto, composto por uma previdência pública, obrigatória e básica destinada a garantir a sobrevivência mínima de todos os brasileiros e uma previdência complementar, opcional, pública ou privada, e de benefício ilimitado, que obedecesse à capacidade contributiva de cada um.

Embora sem ter encontrado acolhida no Congresso Nacional, o professor Celso Barroso Leite (1993) formulou um projeto substitutivo em que propunha um desenho mais focalizado para a seguridade social com base na previdência social obrigatória para trabalhadores ativos, saúde para todos e assistência social gratuita às pessoas necessitadas. De outra parte, o professor Wladimir Novaes Martinez indicava que a seguridade social tal como constava da Constituição nada mais era que uma carta de intenções. O melhor seria denominar o capítulo como "Da Proteção Social”250 e fazer constar desse capítulo também as matérias relativas à previdência do funcionalismo público (direito administrativo), a previdência privada (direito tributário) e direito do trabalho (direito sociais).

\footnotetext{
${ }^{250}$ A principal diferença é que a seguridade social é também vista como uma técnica de proteção social, assim como previdência social, assistência social, direito trabalhista e sindical. A mudança conceitual também permitiria maior flexibilidade ao texto constitucional permitindo a mudança de ênfase numa técnica ou outra conforme as condições sócio-econômicas permitissem. “O financiamento da seguridade social”, palestra proferida em 11/03/1993 (MARTINEZ, 1993).
} 
As pesquisas apontaram para uma rediscussão pontual e minuciosa em relação aos principais temas relativos à previdência social, como acidente de trabalho, aposentadoria por tempo de serviço, previdência complementar, regime de capitalização, etc. No entanto, o que merece destaque é a forte correlação estabelecida entre a reforma tributária e o financiamento da seguridade $\operatorname{social}^{251}$. A questão fiscal tem pautado o debate e condicionado as demais reformas.

No ciclo de seminários e debates com especialistas em previdência social ${ }^{252}$, os mesmos temas foram abordados: financiamento; reforma fiscal; fontes e gastos da seguridade; progressividade do sistema tributário; déficit público e relacionamento com o Tesouro Nacional; gestão de benefícios e prestação de serviços; aspectos específicos do sistema de Previdência Social e suas reformas e aspectos constitucionais e desafios para a reforma. Sob a gestão do Ministro Antônio Britto, a pauta da agenda de reformas para a previdência social não diferiu muito daquela do relatório que produzira em 1992.

A amplitude da publicação não permite recuperar todos os pontos do debate, mas, de certa forma, três temas foram relevantes: a conceituação, o financiamento e as propostas de reforma. O que os expositores, de modo geral, enfatizaram foi o atrelamento do processo de revisão à definição da sociedade e que era necessário definir a técnica da proteção social e desenhar o seu modelo, para somente então iniciar as reformas necessárias (Teixeira, 1993; Martinez; 1993). A questão nos reenvia ao campo da política, no sentido atribuído por Ewald (1993) de fixação dos direitos sociais. Nas palavras de Fernandes (1993): “o problema da revisão é, portanto, um problema político e de equilíbrio entre forças sociais” ${ }^{\text {253 }}$.

Leite apontava que uma das principais críticas à Constituição era o fato de "ter mais cuidado mais da outorga que da cobrança, estabelecendo muito mais direitos que deveres" (1993: 18), ao passo que um dos problemas cruciais está na outorga sem recursos específicos ou condições adequadas, que fazem com que os direitos caiam no vazio. Suas observações auxiliam na compreensão do porquê da previdência social ter sido a área de maior conflito na redefinição dos direitos constitucionais: a rigor, ela não depende de orçamento, porque os benefícios não podem deixar de ser pagos, ainda que não haja ou tenham-se esgotado as

\footnotetext{
${ }^{251}$ Ver especialmente os artigos: (DAIN; SoARES; CASTILHO, 1993; BELTRÃo, 1993).

252 Seminário patrocinado pelo Convênio MPS/CEPAL, sob gestão do Ministro da Previdência Social Antônio Brito, no ano de 1993. Os resultados encontram-se registrados em: (MPS/CEPAL, 1993)

253 “Acidentes de trabalho e a previdência social”, palestra proferida em 23/03/93. FERNANDES, 1993 : 109 Debates, Vol. I).
} 
dotações orçamentárias próprias. Num contexto em que o volume de recursos arrecadados e despesas se tornou de controle público, o conflito distributivo tornou-se explícito.

Uma das questões mais polêmicas durante os debates se concentrava na possibilidade de reforçar a adoção do conceito de seguridade social com toda a abrangência que pressupõe ou, ao contrário, se deveria retornar ao tradicional conceito de seguro social, com seu caráter contributivo e contratual ${ }^{254}$. Era um problema de escolha entre duas de técnicas proteção social diferentes, mas ele foi contornado durante o processo de revisão constitucional, fazendo com que as questões mais relevantes fossem aquelas sobre o financiamento.

Draibe (1993) aponta que o saldo principal da Constituição Federal de 1988 foi o conceito de seguridade social, generoso, denso e democrático, no entanto, mal transposto para o orçamento. Um dos desafios da ANC persistia na revisão constitucional: a destinação de recursos para a seguridade social em quantidade suficiente para a cobertura dos programas definidos, dada a estreiteza e instabilidade da folha de pagamento para o financiamento da política social, em face de sua dependência do mercado de trabalho, do nível salarial e da concentração de renda.

O ciclo de debates permitiu explicitar de temas ignorados pelo público, evidenciando que nem todos os benefícios previdenciários decorrem do vínculo contributivo originado nas relações de trabalho. Desse modo, são financiados pela previdência social ${ }^{255}$ os encargos previdenciários da União decorrentes de outras situações, tais como a aposentadoria especial do anistiado ${ }^{256}$; aposentadoria do ex-combatente ${ }^{257}$;

\footnotetext{
${ }^{254}$ Temos, dentre os partidários de uma posição que pregava o aperfeiçoamento da seguridade social, Wagner Balera, Maria Emília Azevedo e Aloísio Teixeira e os partidários do retrocesso ao modelo de seguro social, Celso Barroso Leite, Wladimir Novaes Martinez e Rios Nogueira (MPAS/CEPAL, 1993)

${ }^{255}$ Na verdade, são benefícios que constam do Plano de Benefícios da Previdência Social.

${ }^{256}$ Têm direito à aposentadoria em regime excepcional, na condição de anistiados (art. $8^{\circ}$. do ADCT/CF, 1988), todos os servidores públicos, da administração direta ou indireta, em qualquer nível da Federação, que, em virtude de motivação política foram atingidos por que foram impedidos de exercer atividades profissionais em virtude de afastamento compulsório de atividade abrangida pela Previdência Social sob pressão ostensiva, no período de 18-09/1946 a 05/10/1988. A esses segurados serão garantidas todas as prerrogativas do cargo ou emprego a que teriam direito se estivessem na ativa, com aposentadoria integral, independente do tempo de contribuição. A natureza jurídica da aposentadoria excepcional do anistiado é de aposentadoria previdenciária, constante do Regulamento de Benefícios da Previdência Social. Em caso de falecimento do segurado, é garantido o direito de pensão por morte a seus dependentes. $\mathrm{O}$ valor da aposentadoria excepcional terá por base o último salário percebido pelo segurado no emprego na época em que foi destituído do cargo, atualizado até 05/10/1988. Ver a respeito: (MARTINS, 1999: 383; Lei 3.212/91 e Constituição Federal da República do Brasil, 2002, ADCT, ART. $8^{\mathrm{O}}$ ).
} 
pensão especial para os portadores da síndrome da talidomida ${ }^{258}$; pensão especial às vítimas da hemodiálise de Caruaru $^{259}$; pensão especial às vítimas do césio em Goiânia; pensão mensal vitalícia aos seringueiros ${ }^{260}$. O que o autor discute não é o mérito desses benefícios, mas a sua inscrição como benefícios de natureza previdenciária, uma vez que não se enquadram nos critérios de risco social, bem como não estão amparados pelo critério de contribuição pretérita. O correto seria financiá-los com recursos do Tesouro, partilhando o seu custeio com toda a sociedade.

A Constituição, ao consagrar a dualidade na concepção da proteção social, obrigou o governo à modernização do sistema previdenciário e a incorporar a base social excluída do mercado formal do trabalho.

A seguridade social foi colocada no centro da disputa orçamentária por receitas, o que a tornou central também ao debate da reforma tributária (Dain, 1993). A União busca o melhor aproveitamento das bases tributárias não sujeitas à partilha com Estados e Municípios. As contribuições sociais, por não respeitar os princípios tributários e por não estar sujeita à partilha com Estados e Municípios, são as que possuem maior potencial de crescimento das receitas públicas. No entanto, são os principais focos de questionamento do sistema jurídico, alimentando inclusive disputas judiciais entre empresários e a União.

As contribuições sociais são o epicentro das críticas ao sistema tributário devido ao número de contribuições, à sua cumulatividade (faturamento), o peso dos encargos sociais sobre a folha de salários (encargos trabalhistas), o elevado grau de evasão fiscal, a sonegação, o impacto sobre os preços dos produtos e a regressividade do sistema.

\footnotetext{
${ }^{257}$ Ao ex-combatente que tenha participado de operações bélicas durante a Segunda Guerra Mundial será assegurada pensão especial correspondente à patente de segundo-tenente das Forças Armadas e poderá ser requerida a qualquer tempo, e seu recebimento é independente de outro benefício previdenciário (Art 53. Constituição Federal da República do Brasil, 2002, ADCT).

${ }^{258}$ Pensão de natureza indenizatória, que não prejudica direitos previdenciários e que não pode ser reduzido em razão de capacidade laborativa. A pensão será mantida e paga pelo INSS, por conta do Tesouro Nacional (MARTins, 1999: 381).

${ }^{259}$ Pensão de um salário mínimo pago ao cônjuge sobrevivente ou dependente até segundo grau das vítimas fatais contaminadas no Instituto de Doenças Renais, na cidade de Caruaru (PE), entre fevereiro e março de 1996. O benefício é pago pelo INSS e deverá ser mantido enquanto não houver sentença condenatória dos proprietários do hospital na Justiça. Lei 9.422, 24/12/1996 (MARTINS, 1999: 382).

${ }^{260} \mathrm{O}$ benefício, no valor de dois salários mínimos, é devido aos seringueiros que contribuíram para o esforço de guerra, trabalhando na produção de borracha na região amazônica durante a Segunda Guerra Mundial. O benefício será pago mediante comprovação material da efetiva prestação de serviços e deve ser deferido pela Defensoria Pública. O benefício deverá ser pago pela Previdência Social (Art. 54 do ADCT, CF, 1988) (MARTins, 1999: 382).
} 
As disputas seguiram em três direções: a União estava interessada em reformas que pudessem significar aumento das receitas não partilhadas com Estados e Municípios; os empresários esperavam a redução dos encargos sociais e o fim dos tributos em cascata; os defensores da seguridade social esperavam maior aporte de recursos tributários no financiamento dos gastos sociais. O debate assumia, assim, um contorno pragmático, com a finalidade de gerar recursos e, se possível, recursos livres da partilha (Munhoz; Werlang, 1993).

Existiam quatro PLs em discussão no período que antecedeu a revisão constitucional: o PL da Comissão Executiva da reforma Fiscal ${ }^{261}$; a proposta "Ponte”; o projeto da Força Sindical e o projeto da FIESP/FIPE ${ }^{262}$. As duas primeiras, previam a eliminação da contribuição sobre a folha de pagamento de salários, sobre o lucro e sobre o faturamento das empresas e, se aprovadas, deveriam resultar em redução das contribuições sociais em 25 bilhões de dólares. Criavam, em seu lugar, um novo imposto sobre transações financeiras (Munhoz \& Werlang, 1993). As duas últimas se aproximavam, ao pretender reduzir o número de impostos e simplificar o sistema. Do projeto dos empresários, destacavam-se as propostas de extinção das contribuições sociais e de toda a carga tributária incidente sobre as empresas. Com as propostas veiculadas, a reforma tributária entrava na agenda da reforma da seguridade social pelas suas duas vias de entrada - reconstruir a base de financiamento e redesenhar o modelo de proteção social.

\section{A revisão constitucional: o debate}

O período pós-impeachment e a confusa agenda política dos anos de 1992 e 1993 marcaram o início da revisão constitucional prevista para o ano de 1993, contribuindo negativamente para o seu fracasso. O governo Itamar Franco, empossado após o impeachment de Collor assumiu características de governo de transição em função do pacto de salvação nacional, com arrefecimento da oposição e o distanciamento de medidas associadas ao governo anterior. A instalação da CPI do Orçamento, após denúncia de

\footnotetext{
${ }^{261}$ Também conhecida como a proposta do relatório do Deputado Benito Gama.

${ }^{262}$ Uma análise comparativa entre os projetos de reforma tributária pode ser encontrada em (DAIN, 1994; MUNHOZ \& WERLANG, 1994).
} 
manipulação ${ }^{263}$, a iminente cassação de parlamentares, os ataques contra o Congresso e o próprio trabalho da CPI geraram falta de comando e desinteresse coletivo na revisão constitucional, além de sobrecarregar a agenda parlamentar.

A reforma da previdência, assim como a reforma tributária, era importante ponto de pauta para a revisão constitucional, e conduziu a um amplo debate nacional sobre o seu novo desenho, assim como questões relativas ao seu financiamento. $\mathrm{O}$ déficit começava a ser um item importante na definição da agenda de reformas. A dimensão fiscal da seguridade social a converteu em ponto central da gestão macroeconômica, seja pelo montante do seu orçamento, seja pelo volume dos seus gastos. Em grande parte, o debate sobre a revisão se converteu no debate sobre a reforma da previdência e sobre a reforma tributária, adquirindo relevância a estrutura de seu financiamento ${ }^{264}$.

Durante todo o ano de 1993 as comissões temáticas da Câmara dos Deputados se prepararam para a revisão constitucional com a organização de seminários, estudos e debates. A CTASP realizou um seminário com a presença de vários especialistas, representantes da sociedade civil, sindicatos dos trabalhadores e dos empregadores. $\mathrm{O}$ debate também reacendeu a expectativa da formação de um Ministério da Seguridade Social com poder o suficiente para conter a força dos Ministérios da Fazenda, da Economia e do Planejamento.

Entre 1992 e 1993, o Executivo havia preparado dois projetos para o processo de revisão constitucional, um da área previdenciária e outro, da área econômica. O projeto da área previdenciária era identificado com o resultado do trabalho da CEESP presidida pelo deputado Antonio Britto. Esse projeto defendia a manutenção do sistema de repartição e a correção de suas distorções, como o fim da aposentadoria especial e o fim da aposentadoria por tempo de serviço. O projeto da área econômica apontava para a realização de reformas estruturais, tais como a instituição de um regime de capitalização, o fim da seguridade social e mudanças nos próprios benefícios como rebaixamento do teto e a sua incorporação

\footnotetext{
${ }^{263}$ Após acusações de manipulação do orçamento a favor de empresas, com proveito pessoal e pagamento de vantagens indevidas, o Congresso teve sua credibilidade abalada, o que motivou a instalação da CPI do Orçamento, com a exigência de que as denúncias contra a Comissão Mista do Orçamento fossem apuradas até o fim, com a cassação dos envolvidos. O escândalo do Orçamento envolveu parlamentares, ministros e exministros e governadores. A Deputada Sandra Starling (PT/MG) demonstra, em discurso proferido na tribuna, a sua preocupação na concomitância entre as agendas: CPI, revisão constitucional e eleições gerais no segundo semestre de 1994. Diário da Câmara dos Deputados, 28/10/1993: 23271-23272. No mesmo sentido, pronunciou-se o Deputado Jair Bolsonaro (PPR/RJ) (Idem: 23272).

${ }^{264}$ Foram apresentadas 218 propostas revisionais relacionadas direta ou indiretamente à matéria.
} 
a um regime de capitalização. A defesa do regime de capitalização encontrava forte vinculação com a formação da poupança pública e com o financiamento do crescimento econômico.

O projeto apresentado pelo MTPS foi elaborado por técnicos preocupados com a estabilidade na política previdenciária. Os técnicos da área econômica estavam preocupados com o equilíbrio fiscal e deram uma guinada em relação à lei aprovada em 1991, defendendo o modelo chileno de previdência, baseado em um sistema privado e complementar. Destacam-se entre os projetos da área econômica, aqueles formulados por técnicos do IPEA e pela CERF, ambos vinculados ao $\mathrm{MEFP}^{265}$. Durante os trabalhos legislativos circularam várias propostas de privatização da Previdência Social, bem como de unificação dos regimes previdenciários dos servidores públicos e do setor privado. Era defendida a existência de um sistema previdenciário complementar acima de determinado teto, facultativo para o setor privado e compulsório para os funcionários públicos, que poderia ser público ou privado. Esse projeto foi assinado por Sérgio Cutolo (MPS), pelo Senador Almir Gabriel e os Deputados Antônio Britto, Geraldo Alckimin e Reinhold Stephanes.

Ao longo do ano de 1993, a questão da sonegação à Previdência continuou em pauta com a divulgação da lista dos principais sonegadores pela imprensa e a exigência de que o Ministério aumentasse o rigor na fiscalização aos sonegadores, garantindo que as dívidas fossem pagas. Ao mesmo tempo, se exigia que o governo honrasse seus compromissos, efetuando os depósitos da sua parte referente aos EPUs que não vinham sendo realizados.

A edição da MP 427, de 11/02/1994, conferia poderes ao Secretário da Receita Federal para efetuar prisão administrativa de contribuintes considerados depositários infiéis, sonegadores de tributos federais, estaduais e municipais, impostos e contribuições sociais, incluídas as contribuições previdenciárias e trabalhistas. O interessante era a inserção dos empregadores que não registravam seus empregados como sonegadores da

\footnotetext{
265 As propostas discutidas pela Comissão estão resumidas em: (AzEREDo; ViANNA; GorgulHo \& GoLDENSTEIN, 1993). Os autores analisam as 18 sugestões para a seguridade social que chegaram às mãos do relator: 7 vindas do próprio Congresso, 1 da Universidade, 3 do Executivo, 4 elaboradas por entidades empresariais, 2 por associações de funcionários públicos e 1 por instituição representativa do mercado de seguridade social. Oficialmente, nenhuma proposta foi entregue pelas Centrais Sindicais. O documento analisa ainda outras sugestões que não foram incorporadas ao relatório final, mas que suscitaram amplas discussões, totalizando 35 propostas. O Anexo 2 apresenta, com base nos autores citados, um resumo das propostas segundo a sua origem, os modelos de seguridade sugeridos.
} 
Previdência, em torno de 53\% da PEA correspondente ao mercado informal de trabalho, cujos empregadores deixaram de contribuir não apenas para a Previdência, mas também para o FGTS, PIS, CONFIS, FAT etc. ${ }^{266}$, impedindo os trabalhadores de ter acesso a direitos previdenciários e trabalhistas.

Para o Deputado Nelson Morro, o raciocínio do Governo simplificava o problema: “faltando recursos ao Tesouro, a solução é colocar a mão no bolso do contribuinte indefeso (...enquanto que...) o cerne da questão não está em decretar a prisão administrativa de inadimplentes, apressadamente classificados como sonegadores. O ponto fundamental da questão está em avaliar as causas que provocam os altos índices de evasão fiscal, que contribuem para o inadimplemento das obrigações tributárias”. E, continua “(...)Não é por acaso que há mais de mil propostas revisionais para o nosso sistema tributário nacional (...)”267. Para o Deputado, a MP, ao determinar a prisão administrativa, transformou em caso de polícia um problema que deveria ser tratado como uma questão econômica, convertendo-se em um atentado contra o ordenamento jurídico e o Estado de Direito $^{268}$. A questão da sonegação encontrava, desse modo, uma forte vinculação com o debate em sobre reforma tributária, como o demonstravam os exaustivos argumentos sobre o custo da mão de obra, os encargos sociais que oneram a produção e encarecem os produtos brasileiros no mercado externo. Os argumentos dos empresários indicavam a forte vinculação entre as duas agendas e, esses, esperavam da revisão constitucional a modernização da política tributária e fiscal do País. Era consenso a necessidade de conversão da aposentadoria por tempo de serviço para aposentadoria por idade; rever a

\footnotetext{
${ }^{266}$ Carta de Jair A. Meneguelli, presidente da CUT enviada ao Senado e transcrita nos Anais da Câmara dos Deputados. Diário da Câmara dos Deputados, 10/07/1993: 14927-14928.

267 Deputado Nelson Morro (Bloco Parlamentar/SC). Diário da Câmara dos Deputados, 16/03/1994: 36513654.

${ }^{268} \mathrm{O}$ Jurista Ives Gandra Martins identificou o ato do Governo Itamar Franco à edição do Decreto 3.415, de 10/07/1941, que instituiu a prisão administrativa por 90 dias, e ao AI5 do Governo Costa e Silva, contra depositários infiéis do IPI. Porém, nas duas vezes, a Justiça Federal de São Paulo, o Tribunal Federal de Recursos e o STF entenderam que não era condizente com as garantias constitucionais. A Constituição Federal de 1988 foi ainda mais clara quanto à disposição de não haverá perda de liberdade sem o devido processo legal e sem o julgamento penal. Dessa forma, a MP 427 promovia a implosão das garantias do cidadão brasileiro e afetava a credibilidade do próprio Estado de Direito no Brasil. Ives Gandra da Silva Martins. "De volta à ditadura Vargas”. Folha de São Paulo, 15/03/1994. O artigo também foi reproduzido no Diário da Câmara dos Deputados, 16/03/1994: 3653-3654.
} 
estabilidade do funcionalismo público; quebrar o monopólio de vários setores econômicos: mudar a organização sindical; ampliar o conceito de empresa de capital estrangeiro ${ }^{269}$.

Para os empresários, o principal problema da previdência era a aposentadoria por tempo de serviço, dado a alto valor despendido para a sua manutenção e ao desequilíbrio entre trabalhadores em atividade e na inatividade. Na opinião de alguns $^{270}$, a revisão deveria encontrar alternativas para evitar o colapso do sistema, entre as quais destacava-se a combinação entre o tempo de serviço e a idade, conhecida como “fórmula 95”271, segundo a qual o trabalhador poderia requerer sua aposentadoria ao somar 95 pontos: 35 anos de contribuição à previdência e 60 anos de idade.

A revisão foi tema debatido durante a realização do VII Congresso Nacional de Associações Comerciais, que resultou no documento "Carta de Blumenau” que identificou neste momento uma “ótima oportunidade para adaptar a Constituição ao contexto das transformações mundiais e inserir o país na senda da modernidade e da globalização das economias" ${ }^{272}$. Concordando com os industriais, defendiam a reforma do sistema eleitoral e político; a redefinição do papel do Estado na economia; a redução dos gastos públicos; a busca de fontes alternativas para o financiamento dos gastos sociais; a reforma tributária e o imposto único; a reforma fiscal; a reformulação do sistema financeiro e a abertura da economia. O documento propunha que no capítulo dos direitos sociais fossem mantidos apenas os princípios gerais, transpondo todo o resto para a legislação ordinária, com revisão, também dos direitos do trabalho.

No combate à sonegação e às fraudes, a Previdência endureceu a fiscalização quanto ao depósito das contribuições previdenciárias. Neste quesito, porém, ficou demonstrada a tênue fronteira entre as fiscalizações das relações de trabalho e da previdência social, uma vez que ambas se reportam à natureza do contrato de trabalho e do vínculo empregatício. Relações de emprego informais, terceirizações, contratos de trabalho temporários, prestação de serviços autônomos podem se configurar em formas de redução dos encargos sociais

\footnotetext{
269 “Fiesp identifica pontos de consenso para atuar na reforma da Carta de 88”. Gazeta Mercantil, 17/06/1993.

${ }^{270}$ Ver opinião de Antônio Ermírio de Moraes em carta inserida no discurso do deputado Nobel Moura (PP/RO). Diário da Câmara dos Deputados, 10/09/1993: 18884. A FIESP também preparou um documento com base em uma consulta-pesquisa com os 121 sindicatos patronais e identificou ser necessário alterar: aposentadoria por tempo de serviço para aposentadoria por idade aos 60 ou 65 anos; rever a estabilidade para o funcionalismo público; quebrar o monopólio de vários setores entre eles o petróleo e telecomunicações; mudar a atual organização sindical e alterar a definição da empresa de capital estrangeiro.

${ }^{271}$ A “fórmula 95” foi apresentada pelo ex-Ministro da Previdência Social, Antônio Britto.

272 Carta de Blumenau, 14/08/1992. Publicada no Diário da Câmara dos Deputados, 05/02/1993: 3056-3057.
} 
para as empresas, em sonegação de contribuições sociais para o governo e perda de direitos trabalhistas e previdenciários para os trabalhadores. As empresas prestadoras de serviços julgaram-se vítimas da fiscalização equivocada da Previdência Social, posto que seria atribuição do Ministério do Trabalho caracterizar a natureza dos contratos de trabalho ${ }^{273}$.

A Fundação Instituto de Pesquisas Econômicas (FIPE/USP) apresentou, nesse contexto, uma proposta de reforma fiscal, assinada junto com a FIESP, que conferia especial importância ao controle dos gastos públicos e ao equilíbrio entre receitas e gastos da União, através da redução do corpo do funcionalismo público, limitação da previdência pública aos realmente pobres, transferência de atribuições concernentes às cotas de repartição das receitas tributárias, extinção da maioria dos impostos vigentes e aumento do peso dos remanescentes, privatização e focalização da atenção pública nos serviços de saúde, educação, segurança e habitação. Em relação à crise da previdência, o documento destacava que, apesar do aumento da contribuição sobre a folha de pagamentos das empresas (6\% do PIB), o valor da aposentadoria vinha sendo comprimido e que o número de aposentados como proporção dos trabalhadores com carteira assinada também era crescente. $\mathrm{O}$ que o documento destacava eram dois dos principais argumentos para a reforma da previdência: o envelhecimento da população e a redução do estoque do trabalho formal.

O argumento de que o alto nível de impostos necessários para o financiamento do setor público é uma ameaça ao funcionamento perfeito do mercado, inibindo a competitividade das empresas é perfeitamente coerente com o que Olsson (1990: 246) denominou tax revolts e a reivindicação da redução da carga global de impostos.

A proposta da FIPE/FIESP foi concretizada através da Emenda Revisional do Deputado Nelson Proença, com base em cinco impostos: sobre a renda, sobre comércio exterior, seletivo, sobre consumo e sobre imóveis. Os impostos seletivos incidiriam sobre fumo, bebidas alcoólicas, armas, munições, receitas de concursos e prognósticos (loterias e afins). Esses impostos seriam responsáveis pela arrecadação de 2,7\% do PIB, ou seja, U\$ 10,8 bilhões.

\footnotetext{
${ }^{273}$ Ver a respeito discurso do Deputado Renato Johnsson (PP/PR). Diário da Câmara dos Deputados, 21/04/1994: 6319 .
} 
A descentralização de encargos e responsabilidades para Estados, Municípios e Distrito Federal também foi ponto importante de pauta para o aumento de disponibilidade de recursos para o Governo, pesando aí a crítica à Constituição na não equivalência entre as transferências de recursos e de encargos e atribuições. Duas questões entravam na agenda do governo: a estabilização monetária e a estabilização do déficit público. Em dezembro de 1993, o Presidente Itamar Franco iniciava discussões com os parlamentares e partidos políticos sobre o plano econômico formulado pela equipe econômica ${ }^{274}$, o qual propunha entre outras medidas, o corte de $15 \%$ no repasse das verbas do fundo de participação de Estados e Municípios. Os três objetivos do plano econômico eram: zerar o déficit público (estimado em 22 bilhões e 300 milhões de dólares para 1994); aumentar a arrecadação sem aumentar os impostos; aumentar as reservas cambiais do Brasil para combater a inflação ${ }^{275}$. A reforma monetária proposta se vinculava a esses objetivos e representaria uma carga tributária de 16 bilhões de dólares ${ }^{276}$. A eminência de sua aprovação levou os Ministros do Bem-Estar-Social, da Saúde e da Educação a defenderem ${ }^{277}$ a manutenção dos recursos destinados à área social, após os cortes orçamentários que já haviam sido instituídos.

\section{A revisão constitucional: o processo}

Oficialmente, a Comissão de Revisão Constitucional (CRC) foi instalada em 13 de outubro de 1993 e encerrada em 31 de maio de 1994. Ao longo de 80 sessões, votou apenas 19 mudanças, das quais, 6 foram aprovadas. A opção pela instalação de uma CRC única e a centralização da Emendas em único relator - deputado Nelson Jobim (PMDB/RS) contribuiu para o seu malogro. Pelo regimento, podiam apresentar Emendas apenas os

\footnotetext{
274 “(...) A reforma monetária proposta pelo Governo Itamar Franco é um passo importante na direção de um efetivo processo de combate à inflação. A era dos milagres chegou ao fim, restando ao administrador responsável a assunção do risco político de detalhar à sociedade brasileira as reais condições vigentes na economia e eliminando a ilusão de valores inerente ao processo inflacionário (...) A troca de moeda por si só não garante a estabilidade dos preços. É fundamental (...) o equilibrio das contas públicas e um estoque elevado de reservas internacionais (...)”. Deputado Jackson Pereira (PSDB-CE). Diário da Câmara dos Deputados, 18/03/1994: 3785-3786.

${ }^{275}$ Na justificativa do Deputado Jackson Pereira (PSDB-CE) o FSE e o compromisso com um orçamento austero eram reveladores da preocupação da equipe econômica em promover o ajuste fiscal em um ambiente de realismo, uma vez que a instabilidade econômica representava um risco para o país. Diário da Câmara dos Deputados, 18/03/1994: 3785-3786.

${ }^{276}$ Ver discurso do Deputado Cunha Bueno (PPR/SP), Diário da Câmara dos Deputados, 1\%03/1994: 2576.

277 Ver discurso do Deputado Roberto Franca (PSB/PE), Diário da Câmara dos Deputados, 23/02/1994: 2137-2138.
} 
congressistas, os Líderes dos partidos, as Assembléias Legislativas de pelo menos três Estados da federação com apoio da maioria de seus membros. Emendas populares poderiam ser oferecidas desde que representassem 15 mil eleitores organizados em no mínimo três entidades associativas. Os parlamentares não dispunham de direito a Emendas, cabendo-lhes apenas aprovar ou rejeitar as propostas em votação. O regimento vedava as iniciativas do Executivo na revisão constitucional, o que inibiu uma ação concertada e a apresentação de propostas de reforma.

Melo (1997b: 68-69) avalia que o processo de revisão foi vítima do regimento interno que fez concentrar o poder de agenda em um comando débil e com um poder desmesurado. A concentração do poder em Nelson Jobim se deu por default, após os principais articuladores políticos terem sido atingidos pela CPI do Orçamento.

O relatório final do Deputado Nelson Jobim (PMDB/RS), de 30/05/94, continha 17 mil Emendas, das quais, apenas seis, foram aprovadas. O relator geral contava com cinco relatores adjuntos e sete colaboradores, entre os quais se destacavam o Deputado Reinhold Stephanes (PFL/PR) ${ }^{278}$, e o Deputado Geraldo Alckimin (PSDB/SP). O substitutivo do relator incorporou todas as propostas (16) apresentadas por Stephanes, o que assegurou, na análise de Melo, a identidade entre a proposta desse Deputado e o substitutivo final ${ }^{279}$. No entanto, o relatório não foi apreciado, ele foi apresentado apenas como requisito formal na data-limite e não trouxe nenhuma mudança efetiva nos direitos originais instituídos em 1988.

A definição do conceito de seguridade social, o financiamento da previdência social, a especialização nas fontes de financiamento, mudanças nos planos de benefícios, unificação dos regimes de previdência dos servidores públicos e trabalhadores da iniciativa privada, regime de capitalização, teto de contribuições e benefícios previdenciários, critério de reajuste de benefícios e previdência complementar, foram temas centrais durante a revisão constitucional. Em larga medida, a pauta representava a desestruturação da agenda da ANC de 1988 (Melo, 1997b: 295), conforme apontado. Houve uma ampla convergência entre a pauta da reforma previdenciária e a pauta da reforma tributária, entre o

\footnotetext{
${ }^{278}$ Que fora Ministro da Previdência no final do Governo Collor.

${ }^{279} \mathrm{O}$ autor faz uma análise comparativa entre o processo de revisão constitucional de 1993 e a reforma constitucional de 1995, ocorrida sob o governo de Fernando Henrique Cardoso (MELO, 1997b: 320).
} 
financiamento da seguridade social e o déficit da previdência social, o gasto social e o déficit público. A agenda social e política eram confrontadas à agenda econômica.

Apesar do grande enfoque na privatização dado pelo Governo Collor, não vingou nenhuma proposta de privatização da previdência social naquele momento. Podemos afirmar que a contra-reforma da previdência em relação ao definido na Constituição de 1988 ainda não havia sido formulada como um projeto acabado. Em parte, a agenda da reforma da previdência social na revisão constitucional foi produzida CEESP e que, ao mobilizar um amplo espectro social, produziu uma especialização na área, da qual sobressaiu-se o nome do Deputado Antônio Britto, legitimando a própria idéia da reforma.

As propostas apresentadas no processo de revisão não se distanciavam muito daquelas apresentadas no relatório geral do Deputado Antônio Britto, da CEESP (1992). A influência do Deputado Antônio Britto lhe rendeu o cargo de Ministro do MPS, o que foi decisivo na construção da pauta da reforma.

Adquiriram centralidade nas discussões: 1) a inconsistência entre o conceito de seguridade social e o do seguro social; 2. a separação dos orçamentos da saúde, da previdência e da assistência social; 3. a introdução de um sistema previdenciário misto público e privado, básico e complementar, compulsório e opcional; 4. a unificação do regime do funcionalismo público; 5. o vínculo entre contribuição e benefício; 5. o regime misto entre regime de repartição e capitalização; 6. o aumento do tempo de contribuição combinado como atraso na idade para aposentadoria, para corrigir privilégios. Tiveram, sobretudo, propostas relativas à mudança nas regras de cálculo do valor dos benefícios e manutenção do seu valor real, com ampla defesa da “desconstitucionalização” da matéria.

O ambiente da revisão constitucional foi fortemente influenciado pelo comportamento defensivo do Tesouro diante da deterioração das contas públicas e da redução da liberdade fiscal do governo. O federalismo fiscal e a separação das fontes de financiamento da seguridade social promoveram uma drástica redução nos recursos disponíveis, principalmente, pela não correspondente transferência de encargos e responsabilidades. Ao mesmo tempo, a Lei de Custeio da Seguridade Social estabelecia um cronograma de desoneração da Previdência Social em relação aos encargos da União, que antes eram financiados com recursos do Finsocial, e era construído um consenso em torno da exclusão dos benefícios assistenciais não-contributivos da arrecadação previdenciária. 
A ameaça de perda de receita marcou o retorno da Frente Parlamentar Municipalista $^{280}$ que vinha defender os interesses dos Municípios na partilha das receitas nacionais expressa na recusa de qualquer decisão tomada na área tributária sem que os Municípios fossem ouvidos. Os líderes realizaram também reunião com o Ministro da Previdência, Sérgio Cutolo, para tratar da compensação financeira entre os dois regimes (RGPS e RPPS) nos casos de contagem recíproca do tempo de contribuição para efeito de aposentadoria $^{281}$.

O padrão de disputa que se sucedeu era de um conflito distributivo entre as áreas sociais e econômicas, com o determinante da não influência da área econômica do governo na determinação dos gastos sociais. Esse padrão de disputa evoluiu para a construção de um projeto de "receitas livres”, com a definição de um percentual que ficaria fora da rigidez orçamentária definida em 1988 e que permitiria também fugir ao conflito distributivo produzido pelo federalismo fiscal.

Para o Deputado Renato Johnsson, a revisão constitucional deveria se concentrar em quatro temas fundamentais: reforma tributária; redefinição do papel do Estado na economia, através do fim dos monopólios e privilégios; reforma do sistema previdenciário; reforma do sistema político ${ }^{282}$. O governo se engajou na instalação dos trabalhos de revisão, dada a natureza das mudanças necessárias nas áreas tributária e fiscal e o respeito ao princípio da anualidade para a criação de novos impostos e para o exercício de sua agressiva política de contenção do gasto público, o que justificou a FSE, que consolidou a idéia de "receitas livres".

Durante os trabalhos legislativos, O Líder do governo na Câmara, Deputado José Serra, passou a defender a revisão em duas fases: as matérias relativas a questões fiscais, tributárias e previdenciárias viriam em primeiro lugar e, depois, as demais matérias. A proposta de divisão das pautas com a retomada dos trabalhos em 1995, após as eleições, foi combatida pelo relator Nelson Jobim, que alegava ser o procedimento inconstitucional.

\footnotetext{
${ }^{280}$ A Frente Parlamentar Municipalista foi formada pela participação de ex-Prefeitos, ex-Vice-Prefeitos, exVereadores, municipalistas convictos, que defendem interesses dos Municípios e da população residente. O processo de revisão constitucional, e a possível perda de recursos, motivaram a reorganização da Frente, que aproveitou a ida a Brasília para distribuir fichas de adesão aos parlamentares. Diário da Câmara dos Deputados, 21/04/1994: 6318-6319.

${ }^{281}$ Compensação financeira entre a Previdência Social e Municípios nos casos em que houve transição de um sistema para outro.

${ }^{282}$ Deputado Renato Johnsson (PP/PR). Diário da Câmara dos Deputados, 26/11/1993:25588-25589.
} 
Na agenda do governo, as matérias econômicas e financeiras adquiriam prioridade em relação a questões políticas, civis e sociais. O governo manipulou a agenda da revisão constitucional e conseguiu que a primeira Emenda aprovada fosse justamente a instituição do FSE, que garantiria “receitas livres” num ambiente de rigidez orçamentária, permitindo a formação do superávit primário e o pagamento dos serviços da dívida externa. O FSE representava, assim, a reversão da vitória lograda pela seguridade social sobre a área econômica durante a Constituição de 1988.

O processo de revisão teve início em outubro de 1993 com os partidos de esquerda se alinhando pela obstrução do processo por alimentar discordâncias quanto a sua condução, quanto ao regimento interno e ao ritmo das votações ${ }^{283}$ ou porque não visualizavam, naquele contexto, motivação política para modernizar a Constituição sem ferir os direitos sociais nela inscritos ${ }^{284}$. A “inversão de pautas” seria a justificativa mais plausível para o nível de abstenção ${ }^{285}$, posto que, ao invés de realizar as grandes reformas econômicas e sociais, discutia-se projetos de pequeno porte, como redução do mandato, Câmara dos Vereadores, licença-maternidade etc. Assim, durante a revisão constitucional o Congresso foi dividido entre deputados pró-revisão e aqueles contrários e que seguiam a orientação partidária, como o PDT, PT, PC do B e PSB.

283 O Deputado Roberto Franca (PSB/PE) anunciava a decisão de seu partido em obstruir a revisão Constitucional tanto por questionar a sua legitimidade, quanto as medidas propostas.Para ele, como prática regimental, a obstrução seria uma forma de expressão dos partidos e do Congresso, à qual não caberiam críticas. O que tanto a obstrução, quanto o absenteísmo expressava era a falta de legitimidade da Revisão Constitucional. O parecer do Relator Nelson Jobim sobre a matéria constitucional era decisivo e seria apresentado em partes, cabendo prazo de 24 horas para votar pela aprovação ou rejeição, sem direito a emendas. Diário da Câmara dos Deputados, 05/02/1994.

${ }^{284}$ Ver discurso do deputado Amaury Muller (PDT/RS). Diário da Câmara dos Deputados, 11/02/1994: 1874-1875. “Temos uma Previdência problemática. Querem agora mexer não no custeio, mas nos benefícios, cancelando direitos que foram árdua e penosamente conquistados e representam apenas uma parcela pequena das verdadeiras prerrogativas que deveriam ser deferidas à classe trabalhadora". Na base da crítica estava justamente a alteração nas regras para concessão da aposentadoria, com o fim da aposentadoria por tempo de serviço, sob o argumento da alteração do perfil demográfico nacional. Também o Deputado Aécio Neves (PSDB/MG) alertava contra a gravidade do que estava sendo proposto, que o espírito da revisão estava sendo ditado unicamente pelo remanejamento das responsabilidades orçamentárias. Diário do Congresso Nacional, 11/02/1994, p. 1875. O Deputado Vivaldo Barbosa (PDT/RJ) também enfatizou que “(...) ao resistirmos à revisão constitucional, nada mais fizemos do que representar e expressar o maior e o melhor sentimento na nacionalidade brasileira e do interesse nacional. Nós defendemos o interesse nacional da resistência quando nos opusemos à revisão constitucional”. Diário da Câmara dos Deputados, 16/06/1994, p. 9649-9650.

285 “(...) Mas tenho de deixar o meu protesto - e deveria tê-lo feito antes - contra a inversão da pauta da revisão... Assim se explica o vazio nesta Casa. A continuar dessa forma (...) deixarei de comparecer, contribuindo para que esta Casa se esvazie cada vez mais (...)”. Deputado Francisco Evangelista (PPR-PB). Diário da Câmara dos Deputados, 08/03/1994: 3167. 
O Deputado Cunha Bueno expressava a sua indignação com o modo pelo qual o processo de revisão estava sendo conduzido: iniciado pelas ADTC e restritos às reformas econômicas. As declarações do Deputado José Serra de que a revisão constitucional deveria se esgotar nas reformas políticas fez com que percebesse a intenção na condução da agenda e a declarar que então "poderíamos encerrar a revisão constitucional neste momento. $O$ Fundo Social de Emergência não seria promulgado, ficaria para o ano que vem.... ${ }^{286}$.

O Deputado Gerson Peres também se preocupava com a sobreposição das agendas entre a votação do FSE e a votação da reforma tributária, posto que poderia a segunda atingir impostos que compõem a primeira e produzir a sua extinção ${ }^{287}$. A reforma tributária era ponto de discordância entre parlamentares. Os que defendiam sua realização durante a revisão apelavam para o fato de estarem legitimados para isso ${ }^{288}$; os que eram contrários defendiam que a matéria deveria ser amplamente debatida e não poderia ficar restrita ao parecer do relator Nelson Jobim.

286 Deputado Cunha Bueno (PPR/SP). Diário da Câmara dos Deputados, 0103/1994: 2576. O pronunciamento do Deputado Hélio Bicudo (PT/SP) seguia na mesma direção, ao denunciar que o Congresso Revisional insistia nas alterações na ordem econômica, tendo aprovado o Fundo Social de Emergência, um dispositivo transitório, sem que, ao menos o texto final tivesse sido sistematizado e sem a participação do povo. O prazo da revisão constitucional esgotava-se sem que houvesse a discussão das emendas apresentadas, e atropelado pelo fim do processo de cassação dos parlamentares com a CPI do Orçamento. Diário da Câmara dos Deputados, 16/03/1994: 3654-3655.

${ }^{287}$ O Deputado Gerson Peres (PPR/PA) se referia aos projetos de Emenda dos Deputados Luís Roberto Ponte e Flávio Rocha, que buscava simplificar o volume de impostos. Diário da Câmara dos Deputados, 23/02/1994: 2141. Também o Deputado Nelson Morro (Bloco Parlamentar-SC) defendia a urgência da reforma tributária como modo de corrigir as distorções e iniqüidades do sistema tributário e apelava para que fosse feita durante o processo de revisão constitucional, uma vez que havia investidura para isso: “(...) $a$ oportunidade de fazermos a reforma tributária é agora, pois estamos investidos de mandato para revisar a Constituição de 1988 (...)”. Os pontos centrais a serem atacados seriam a redução da tributação indireta, o alargamento da base e redução de alíquotas, simplificação operacional e aperfeiçoamento administrativo para minimizar a sonegação. Diário da Câmara dos Deputados, 26/04/1994: 6539-6542.

${ }^{288}$ O Deputado Nelson Morro (Bloco Parlamentar-SC) representa bem o primeiro grupo que defendia a urgência da reforma tributária como modo de corrigir as distorções e iniqüidades do sistema tributário e apelava para que fosse feita durante o processo de revisão constitucional, uma vez que havia investidura para isso: “(...) a oportunidade de fazermos a reforma tributária é agora, pois estamos investidos de mandato para revisar a Constituição de 1988 (...)”. Os pontos centrais a serem atacados seriam a redução da tributação indireta,o alargamento da base e redução de alíquotas, simplificação operacional e aperfeiçoamento administrativo para minimizar a sonegação. Diário da Câmara dos Deputados, 26/04/1994: 6539-6542. O deputado Giovanni Queiroz (PDT/PA) representa o segundo: “(...) 68, 65 e 57 são os números citados pela imprensa como o total de tributos, contribuições e encargos que a sociedade, através da pessoa física ou jurídica, deve pagar ao Estado (...) É uma irresponsabilidade do Congresso Revisor atrever-se a fazer isso dispondo apenas de 21 dias. Mesmo que tal prazo fosse destinado à discussão apenas dessa matéria, ainda seria insuficiente. E são doze pontos que devem ser discutidos e votados pelo Congresso Revisor (...)”. Diário da Câmara dos Deputados, 10/05/1994: 7229. 
$\mathrm{Na}$ revisão constitucional, os temas principais foram abandonados em nome do ajuste fiscal, fazendo com que a agenda econômica se sobrepusesse à agenda política ou social. O Deputado Aldo Rebelo afirmava em meados de abril: “a revisão da Constituição adentrou, mais uma vez no pântano da crise, e agora, ao que tudo indica, sem caminho de volta $^{289}$. Quase ao final do prazo constitucional, a revisão não foi garantida. O Regimento Interno fez com que a maioria do Congresso não fosse consultada sobre as prioridades, a qual passou a ver o processo revisor como ameaça contra princípios constitucionais do federalismo fiscal, e do mandato dos vereadores e parlamentares.

Os principais pontos que os parlamentares pró-revisão esperavam ver discutidos eram relativos ao Orçamento da União, como as transferências automáticas de recursos financeiros para Estados e Municípios e o financiamento dos direitos sociais, em especial, da Previdência. O Deputado Carlos Sant'anna, que participara da ANC de 1988, afirmava que a revisão era necessária porque “(...) introduzia responsabilidades para o Estado com as quais ele não tinha condições financeira de $\operatorname{arcar}(. .$.$) ” e “(...) não se tinha idéia exata$ de onde essa receita viria(...)" 290 .

Ao término da revisão constitucional apenas duas Emendas relevantes foram votadas: a redução do mandato do Presidente da República de cinco para quatro anos ${ }^{291}$ e a instituição do FSE para os exercícios financeiros de 1994 e $1995^{292}$. As demais Emendas aprovadas foram: convocação de titulares de órgãos submetidos ao Poder Executivo para prestar esclarecimentos ao Congresso ${ }^{293}$; definição da nacionalidade brasileira ${ }^{294}$; definição de casos de inelegibilidade ${ }^{295}$; renúncia de parlamentar submetido a processo ${ }^{296}$ de cassação política.

A revisão malogrou, como já era sentido ao longo do segundo semestre de 1993, principalmente em decorrência de falta de quorum motivada tanto pelo calendário eleitoral, quanto pela saturação da agenda com a CPI do Orçamento. As Emendas foram votadas entre março e maio de 1994 e o seu caráter restrito deixou em aberta muitas questões que

\footnotetext{
289 Deputado Aldo Rebelo (PC do B/SP). Diário da Câmara dos Deputados, 15/04/1994: 5767.

${ }^{290}$ Deputado Carlos Sant'anna (PP/BA). Diário da Câmara dos Deputados, 13/04/1994: 5428-5429.

${ }^{291}$ Emenda Constitucional de Revisão n. 5, de 07/06/1994.

${ }^{292}$ Emenda Constitucional de Revisão n. 1, de 1\%03/1994.

${ }^{293}$ Emenda Constitucional de Revisão n. 2, de 07/06/1994, que altera artigo 50 da Constituição Federal.

${ }^{294}$ Emenda Constitucional de Revisão n. 3, de 07/06/1994, que altera artigo 12 da Constituição Federal.

${ }^{295}$ Emenda Constitucional de Revisão n. 4, de 07/06/1994, que altera artigo 14 da Constituição Federal.

${ }^{296}$ Emenda Constitucional de Revisão n. 6, de 07/06/1994, que altera artigo 55 da Constituição Federal.
} 
seriam retomadas em uma nova revisão no ano de 1995, já sob o Governo de Fernando Henrique.

Dois destaques merecem ser realizados: nenhum item sobre a reforma da previdência social ou sobre a seguridade social foi aprovado; mesmo assim sua estrutura de financiamento foi afetada pela criação do FSE, que tinha por objetivo "o saneamento financeiro da Fazenda Pública Federal e a estabilização econômica, cujos recursos serão aplicados no custeio das ações dos sistemas de saúde e educação, benefícios previdenciários e auxílios assistenciais de prestação continuada, inclusive liquidação de passivo previdenciário, e outros programas de relevante interesse econômico e social” (art. $71)$.

Por efeito da $1^{\text {a }}$ Emenda de Revisão, passaram a integrar o FSE 5,6\% da arrecadação do imposto sobre renda e proventos de qualquer natureza; 86,2\% do IPTR; impostos sobre operações de crédito, câmbio e seguro; 35\% CSLL; 20\% do produto da arrecadação de todos os impostos e contribuições sociais da União, outras fontes de receitas. Na prática, $20 \%$ de todos os impostos, incluindo as contribuições sociais que sustentam a seguridade social foram destinadas ao pagamento dos serviços da dívida pública.

O calendário eleitoral interferiu decisivamente no processo de revisão constitucional e havia deputados que defendiam a interrupção dos trabalhos em maio e a sua retomada em outubro, após as eleições ${ }^{297}$. Os deputados já haviam alertado para a necessidade de se evitar que os calendários se misturassem, pois poderia impedir os trabalhos de revisão ${ }^{298}$. Temiam também o resultado da revisão sobre os resultados eleitorais.

A quinze dias do encerramento do prazo, o Deputado Pedro Irujo conclamava os deputados a colocarem-se acima das divergências partidárias e ideológicas para votar com seriedade a pauta de reformas: supressão da discriminação contra a empresa de capital estrangeiro, a reforma tributária e o sistema previdenciário, que seriam os principais pontos de estrangulamento da economia brasileira ${ }^{299}$.

\footnotetext{
${ }^{297}$ Deputado Osvaldo Bender (PPR/RS). Diário da Câmara dos Deputados, 20/04/1994: 6045.

${ }^{298}$ Deputado Ruberval Pilotto (PPR/SC). Diário da Câmara dos Deputados, 30/11/1993: 25802.

${ }^{299}$ Deputado Pedro Irujo (PMDB/BA). Diário da Câmara dos Deputados, 12/05/1994: 7502.
} 
O malogro da revisão constitucional foi visto como um "espetáculo triste $e$ melancólico”300 , “uma explosão nuclear infeliz e trágica”301. Não apenas porque se deixou de promover as reformas esperadas, mas pela sua própria condução. As práticas de obstrução e a falta de quorum foram os procedimentos que impediram a votação das emendas de revisão. No último dia, o painel registrava a presença de 284 parlamentares, embora a Casa estivesse cheia - "os fantasmas estavam aqui tentando, mais uma vez, perturbar a ordem e a condução dos trabalhos”, afirmaria o deputado Osório Adriano ${ }^{302}$.

O Deputado Jabes Ribeiro, no entanto ponderava que o resultado certamente foi negativo para a Casa, mas (quem sabe?) foi positivo para o país. O Deputado levava em consideração dois aspectos: a legitimidade da obstrução como um direito regimental dos parlamentares e a necessidade de discussões mais aprofundadas dos temas. Em sua avaliação, a revisão foi vítima da decisão de promovê-la no exato momento em que o Congresso enfrentava a CPI do Orçamento, que envolveu 19 deputados, e em ano eleitoral $^{303}$. Com o seu encerramento, a Fiesp anunciou que não contemplaria com contribuição financeira para a campanha eleitoral quem havia resistido, revelando o seu interesse nas reformas de caráter econômico, na previdência social e na reforma tributária.

Muito embora a revisão tenha sido concluída sem as reformas pretendidas, deixou muitas questões em aberto, o que fez do tema um compromisso de campanha eleitoral do candidato à presidência da República, Fernando Henrique Cardoso. O momento foi propício também ao lançamento da idéia de realização de uma nova ANC, temporária e exclusiva $^{304}$, composta por cidadãos e que se dissolveria após a promulgação da nova Constituição. A proposta era a de realização de uma ANC fora das regras democráticas de representação política, o que conduzia a um projeto corporativo de representação de interesses.

\footnotetext{
${ }^{300}$ Deputado Osório Adriano (Bloco Parlamentar-DF). Diário da Câmara dos Deputados, 02/06/1994: 87478748. Se alinharam ainda lamentando o malogro os deputados Roberto Campos, Delfim Netto, José Lourenço.

${ }^{301}$ Deputado Sérgio Arouca (PPS/RJ). Diário da Câmara dos Deputados, 02/06/1994: 8747.

302 Deputado Osório Adriano (Bloco Parlamentar-DF). Diário da Câmara dos Deputados, 02/06/1994: 87478748. À alcunha de “fantasmas”, o Deputado Agostinho Valente (PT/MG) respondeu que o problema era dele, “(...)se, de corpo presente, não conseguiu ter presença política na Revisão (...)”. Ademais, enfatizou que a revisão implicava em violação de preceitos constitucionais. Deputado Agostinho Valente (PT/MG). Diário da Câmara dos Deputados, 02/06/1994: 8748-8749.

${ }^{303}$ Deputado Jabes Ribeiro (PSDB/BA). Diário da Câmara dos Deputados, 02/06/1994: 8748.

${ }^{304}$ Pronunciaram-se contra a idéia de uma Constituinte exclusiva os deputados: Vivaldo Barbosa (PDT/RJ), Amaral Netto (PPR/RJ). Diário da Câmara dos Deputados, 16/06/1994: 9649-9650; 17/06/1994: 9785-9786.
} 
Na fase final de votação das Emendas de Revisão, o Deputado Wellington Fagundes (PL/MT) reclamava a atenção dos seus colegas para as propostas revisionais da previdência social e para a necessidade de promoção de mudanças radicais para garantir a sua sobrevivência $^{305}$. Os argumentos centrais seriam os mesmos que prevaleceriam durante todo o período: o crescimento do número de beneficiários sem a contrapartida das contribuições necessárias ao seu financiamento; a inatividade precoce permitida pela aposentadoria por tempo de serviço; aposentadorias especiais sem a comprovação das condições prejudiciais à saúde ou integridade física; unificação das previdências dos trabalhadores da iniciativa privada e do funcionalismo público, civil e militar.

Em sua avaliação, a Constituição de 1988 foi magnânima nos tópicos correspondentes aos benefícios previdenciários e assistenciais, num esforço de promoção de uma justiça social mais abrangente. No entanto, o pagamento de um salário mínimo em benefícios assistenciais (para idosos, deficientes e trabalhadores rurais) desequilibrou as contas públicas. A ausência do cumprimento da carência normal de contribuições e regras de aposentadoria mais generosas para os trabalhadores rurais, inscrevia suas aposentadorias como concessões assistenciais. Essas distorções deveriam ser corrigidas, mas, evitando-se a adoção de um modelo de previdência social mínima e mantendo o respeito aos direitos adquiridos.

Começava a ser construída a idéia de separação entre o que seriam benefícios assistenciais e benefícios previdenciários. À Previdência Social competia pagar somente os benefícios decorrentes de contribuições previdenciárias prévias. Os que não contribuíram (renda mensal vitalícia e aposentadoria dos trabalhadores rurais) deveriam ter seus benefícios custeados pela assistência social ou pelo Tesouro Nacional, assim como ocorria com os EPU ${ }^{306}$. O déficit financeiro da Previdência Social decorreria, assim, do pagamento de benefícios alheios à sua finalidade. Não se questionava a sua legitimidade enquanto direito, mas a sua definição enquanto política de assistência social.

O outro argumento prevalecente foi o crescimento desigual entre os contribuintes da previdência social e os beneficiários, com estimativa de uma taxa de crescimento de 8,9\%

\footnotetext{
${ }^{305}$ Deputado Wellington Fagundes (PL/MT). Diário da Câmara dos Deputados, 12/05/1994:7501-7502.

${ }^{306}$ Deputado Arnaldo Faria de Sá (PPR/SP). Diário da Câmara dos Deputados, 15/04/1994: 5787.
} 
para o primeiro grupo e de $187 \%$ para o segundo ${ }^{307}$ e que já havia sido apontado no documento produzido pelo consórcio FIPE/FIESP. As projeções, pessimistas, indicavam que em três décadas os benefícios deveriam corresponder a mais ou menos um terço do PIB brasileiro e que se tornaria impossível obter uma aposentadoria.

Paralelamente, o governo enviou ao Congresso Nacional, um projeto de orçamento para 1995, que foi considerado um dos mais austeros do país, em razão do esforço para a estabilização da economia ${ }^{308}$. O projeto impôs o corte em todos os programas governamentais.

A implementação do Plano Real e a conversão do salário mínimo em URV ${ }^{309}$ suscitaram uma nova disputa pelo pagamento dos benefícios da Previdência Social, assim como a crise na área da saúde. Os argumentos que enfatizavam a contenção do reajuste do salário mínimo concentravam-se no desequilíbrio que provocaria nas contas da Previdência Social. Nesse sentido, o Deputado Ivo Mainardi argumentava que a Previdência Social deveria concentrar seus esforços para elevar a receita no aumento da base de arrecadação e no combate à sonegação e não na negação dos direitos sociais ${ }^{310}$.

Os deputados demonstravam-se dispostos a destinar parte dos 5\% do Orçamento sobre o qual podiam arbitrar para resolver os problemas da previdência social (gastos decorrentes do aumento do salário mínimo) e da saúde ${ }^{311}$. Na saúde, seria necessário elevar o orçamento de 9 para 14 bilhões de dólares para resolver a crise de insuficiência de recursos.

No mesmo período, o governo havia desrespeitado a LOA e destinado sete trilhões de cruzeiros a mais para o pagamento de juros da dívida externa, perfazendo um total de 53 trilhões de cruzeiros. O colapso da saúde, com a paralisação dos hospitais conveniados ao SUS, inscrevia-se, dessa forma, no desvio de recursos da política social para o pagamento

\footnotetext{
${ }^{307}$ Projeção realizada pela ONU e apresentada pelo Deputado Clóvis Assis (PSDB/BA). Diário do Congresso Nacional, 22/06/1994: 10050-10051.

${ }^{308}$ Ver a respeito o discurso do deputado Prisco Viana . Diário da Câmara dos Deputados, 30/04/1994: 67846785.

${ }^{309}$ Com o programa de estabilização econômica do Governo Itamar Franco, os salários foram convertidos de cruzeiros reais em URV pela média dos quatro meses anteriores a março de 1994. Com a introdução do Real e da URV o salário mínimo e os proventos dos aposentados e pensionistas foram congelados até maio/95

${ }^{310}$ Deputado Ivo Mainardi (PMDB/RS). Diário da Câmara dos Deputados, 22/07/1994: 11258.

311 A crise da saúde conduzira a uma greve dos hospitais conveniados, que suspenderam o atendimento ao Sistema Único de Saúde em meados de abril de 1994. Apesar dos atrasos no repasse, o Secretário do Tesouro Nacional, Murilo Portugal alegava que os recursos para o pagamento do SUS não estavam atrasados. Diário da Câmara dos Deputados, 20/04/1994: 6045.
} 
de serviços da dívida externa ${ }^{312}$. Seriam necessários, em 1994, 20 bilhões de cruzeiros reais para liquidar os débitos atrasados desde o mês de fevereiro, num momento em que o governo havia negociado com credores internacionais um novo prazo para saldar parte da dívida externa.

Ao fazer o balanço do final de ano o Ministro da Previdência Social, Sérgio Cutolo afirmou, contrariando o discurso pessimista, que a "Previdência teve um bom ano"313, com as contas zeradas. O Ministro informou que a arrecadação havia sido de R \$ 23,5 bilhões e os gastos com benefícios haviam ficado no mesmo índice; que a Previdência havia arrecadado R\$ 300 milhões com o combate à fraude e à sonegação e que aguardava sentença judicial para o retorno de R 2 bilhões referentes a desvios de verbas. O Ministro informou ainda a suspensão de mais de 1 milhão de benefícios em decorrência de fraudes.

No balanço, o Ministro apresentava a intenção do Presidente recém-eleito, Fernando Henrique Cardoso, de acabar com a aposentadoria por tempo de serviço ou por idade, para criar um sistema de critérios combinados, 60 anos de idade mínima e 40 anos de contribuição $^{314}$, com exceção para os que ingressassem no mercado de trabalho aos 14 anos de idade, que poderiam se aposentar aos 54 anos. As medidas indicavam o fim da aposentadoria para setores privilegiados, como os servidores públicos da União, Estados e Municípios, do Legislativo e do Judiciário. O Presidente pretendia ainda acabar com as aposentadorias especiais concedidas a professores, ferroviários, aeroviários e jornalistas depois de 25 ou 30 anos de serviço e impor critérios de igualdade de aposentadoria para homens e mulheres.

As declarações do Ministro apresentavam o projeto do governo recém-eleito e lançava a discussão sobre o encaminhamento da reforma Previdenciária. Houve manifestação entre os deputados favoráveis às reformas e entre os contrários.

Os deputados da oposição começaram a se preparar para o que consideravam o "rolo compressor" do novo governo, que tornariam piores os direitos relativos à

\footnotetext{
312 O Deputado apresenta um quadro comparativo na dotação orçamentária de 1994, em bilhões de dólares: 9 bi para a saúde; 5,9 bi para a educação; 22 bi para a Previdência Social e 146 bi para encargos financeiros da União. Deputado João Paulo (PT/MG). Diário da Câmara dos Deputados, 19/04/1994: 5989-5991.

313 Ministro da Previdência, Sérgio Cutolo. "Previdência teve um bom ano", Brasília, Correio do Povo, dezembro/1994.

${ }^{314}$ Com esses novos critérios a chamada "fórmula 95” se tornaria “fórmula 100", como comentou o Deputado Arnaldo Faria de Sá (PPR/SP). Diário da Câmara dos Deputados, 07/12/1994: 14962.
} 
aposentadoria $^{315}$, além do receio de fortalecimento de propostas de previdência privada. O Deputado Arnaldo Faria de Sá declarava “(...) Acredito até que o novo Governo tenha grandes idéias, grandes propostas, grandes projetos. Vamos ajudá-lo (...) mas na área da Previdência, o novo Governo terá um crítico feroz. Vamos bater duro, exigir mais respeito para com os aposentados e pensionistas. Não me venha com números mentirosos (...) a Previdência está fechando o ano de 1994 com superávit, mesmo pagando cerca de seis milhões de benefícios de assistência social - o que representa seis milhões de salários mínimos todos os meses (...)”316.

Por outro lado, o malogro da revisão constitucional não desanimou aqueles que lutavam pela implementação das reformas administrativas, tributárias e da previdência social - "as três grandes questões que podem viabilizar o Estado brasileiro”, na fala do Deputado Germano Rigotto ${ }^{317}$. No entanto, suscitavam receio de que a exigência constitucional de votação nas duas Casas, em duas sessões, com três quintos dos votos favoráveis para que fossem aprovadas pudesse não ser cumprida. Assim, o Deputado José Abrão defendia que qualquer mudança no texto constitucional fosse conforme o seu artigo 60, ou seja, em respeito à própria Constituição ${ }^{318}$. Declarava, ainda, que o tema da previdência deveria ser debatido sem medo.

O ano legislativo se encerrou sob a disputa em torno do aumento do salário mínimo para R\$ 100,00, contribuindo para o acirramento do conflito a declaração do Ministro Sérgio Cutolo de que não havia déficit na Previdência e a destinação de U\$ 5 bilhões de reserva para a Previdência Social pela Comissão do Orçamento. Se havia recursos

\footnotetext{
315 Deputado Paulo Paim (PT/RS). Diário da Câmara dos Deputados, 06/12/1994: 14863-14864. Deputado Arnaldo Faria de Sá (PPR/SP). Diário da Câmara dos Deputados, 14/12/1994: 152756-152757.

316 Deputado Arnaldo Faria de Sá (PPR/SP), Diário da Câmara dos Deputados, 07/12/1994: 14962. O Deputado alertava ainda aos que já tinham direito adquirido à aposentadoria (integral ou proporcional) que a requeresse rapidamente, pois temia a edição de uma Medida Provisória que derrogasse os direitos. Associava a possibilidade à experiência com a extinção do abono de permanência em serviço e do pecúlio ocorrida em 1994, mas com data retroativa à primeira medida provisória, de dezembro de 1993. Diário da Câmara dos Deputados, 14/12/1994: 15276.

${ }^{317}$ O Deputado Germano Rigotto (PMDB/RS) reintroduzia, dessa forma, o tema das reformas que deixaram de ser implementadas no processo de revisão constitucional, mas apontava que seriam temas preponderantes na agenda do Presidente eleito, Fernando Henrique Cardoso, para a construção de um "Estado eficiente”. O Presidente deveria aproveitar o seu respaldo eleitoral para realizar mudanças profundas, especialmente na área tributária, cuja ineficiência tem provocado sonegação, informalização da economia, evasão fiscal e minado os recursos do Estado. Diário da Câmara dos Deputados, 02/12/1994: 14795.

${ }^{318}$ O Deputado temia principalmente as propostas de quorum reduzido e sessões unicamerais com votação única para as reformas da Previdência, Tributária e Administrativa. Diário da Câmara dos Deputados, 02/12/1994: 14793-14794.
} 
disponíveis, o aumento do salário mínimo não provocaria desequilíbrio nas contas previdenciárias. De outro modo, estava consolidada a disputa entre as fontes de pagamento para benefícios assistenciais e previdenciários. Deveriam ser excluídos das despesas da Previdência quase quinhentos milhões de dólares pagos (em 1994) a título de renda mensal vitalícia e aposentadoria rural, que se constituem em benefícios assistenciais. O benefício assistencial às pessoas portadoras de deficiência sem meios de subsistência também não deveria ser debitado das contas da Previdência Social.

As disputas que encerraram o ano de 1994 se manteriam ao longo da segunda metade da década de 1990 e expressam que, o que deveria ser a integração entre as áreas da previdência e assistência social resultaram numa disputa que visava estabelecer os limites entre elas. A questão central da disputa não está na legitimidade da concessão dos benefícios assistenciais e nem no mérito dos critérios da justiça social promovida, mas na disputa pelo seu financiamento e saber a quem compete assumir a responsabilidade pelos benefícios assistenciais. A definição conceitual e da base de financiamento eram implicadas no processo de racionalização da Previdência Social.

O amplo debate sobre o déficit previdenciário se traduz, assim, numa disputa em torno das “contas previdenciárias”, que englobariam não apenas a relação entre receitas e despesas, mas o estabelecimento do mérito daquilo que é debitado, para o que foi decisivo o controle público exercido pelo Legislativo, pelas entidades da sociedade civil e pelo Tribunal de Contas da União. O fortalecimento do vínculo entre contribuições pretéritas e benefícios previdenciários lançada como a base da reforma da previdência do governo Fernando Henrique Cardoso será decisiva para o estabelecimento dos limites entre assistência e previdência social, consagrando um projeto de independência da previdência enquanto política social, ponto alto no seu projeto de modernização institucional. 


\title{
CAPÍTULO VI
}

\author{
TEMPO DE REFORMAS:
}

AS REFORMAS PREVIDENCIÁRIAS DE

Fernando HeNRIQUe Cardoso e LuIz InÁcio LUla da Silva

\section{A reforma do governo Fernando Henrique Cardoso}

O governo de Fernando Henrique Cardoso e a sua agenda de reformas tiveram início com o veto presidencial ao PL que tratava do aumento do salário mínimo para R\$ 100,00, de autoria do deputado Paulo Paim e aprovado no Congresso no seu primeiro mês de mandato presidencial ${ }^{319}$. Sob o argumento de que o aumento acarretaria desequilíbrios insuperáveis na Previdência Social ${ }^{320}$, o Presidente enviou ao Congresso ${ }^{321}$ uma MP (MP 935) e um PL (PL 199/95) determinando mudanças na legislação ordinária para poder

\footnotetext{
${ }^{319}$ O discurso do deputado Philemon Rodrigues (PTB/MG) é elucidativo do clima de disputa no Congresso em torno da aprovação do salário mínimo e sua vinculação com o déficit da Previdência: "assistindo ontem à batalha para aprovação do salário mínimo, fiquei estarrecido com a preocupação de setores nesta Casa em apresentar dificuldades para aprovação do salário mínimo de 100 reais, argumentando que a Previdência Social não teria condições de pagar esse aumento aos aposentados (...) os aposentados têm sido colocados como coisa capaz de causar a insolvência de uma instituição (...)". Diário da Câmara dos Deputados, 20/01/1995: 1096-1097.

${ }^{320} \mathrm{O}$ argumento contrário mais forte no Congresso era o da necessidade de moralização e de reforma gerencial para dar conta de problemas como a má organização administrativa, deficiência na arrecadação da contribuição previdenciária, sonegação por parte das empresas, fraudes e desvios e a existência de milhares de aposentadorias "fantasmas", que desviavam bilhões de recursos da Previdência Social. Ver os discursos: Deputado Mário de Oliveira (PP/MG). Diário da Câmara dos Deputados, 21/04/1995: 7054-7055. “(...) Porque a Previdência Social pode ter seus problemas administrativos, gerenciais, mas não pode simplesmente descumprir o que estabelece o texto constitucional (...) Mas assalta-me uma dúvida: se a Previdência Social é uma coisa tão ruim, está tão difícil, está quebrada, como diz o Governo, por que não tem tanta gente interessada na previdência privada? (...)”. Deputado Arnaldo Faria de Sá. Diário da Câmara dos Deputados, 16/03/1995: 3472-3473. “(...) A otimização no gerenciamento da Previdência Social redundará em aumento de receitas, redução de despesas e melhora do atendimento à clientela (...)". Deputado Fernando Zuppo (PDT/SP). Diário da Câmara dos Deputados, 03/05/1995: 7842-7843. O argumento presidencial sobre o déficit nas contas da Previdência motivou a solicitação de instalação de uma auditoria nas contas do Instituto Nacional de Seguridade Social (INSS) para apurar a real situação contábil e financeira do órgão, pelo deputado Paulo Paim, na Comissão de Trabalho, Administração e Serviço Público. Ata da CTASP, 22/02/1995. Diário da Câmara dos Deputados, 03/03/1995: 2514-2515.

${ }^{321}$ Melo destaca que um Congresso e um Presidente recém-eleitos apresentavam forte legitimidade para dar início à reforma que já constava da agenda pública (MELo, 1997a).
} 
viabilizar o novo salário mínimo ${ }^{322}$. Mudanças na legislação ordinária, contudo, deveriam ser antecedidas por uma revisão constitucional, o que impeliu o governo a apresentar uma proposta de emenda constitucional, PEC 21/95 $5^{323}$, duas semanas mais tarde.

A MP 935 (08/03/95) autorizava o Tesouro a utilizar recursos da previdência para pagar os EPUs e retirava a garantia de apoio da União para cobrir eventuais insuficiências financeiras da Previdência Social e foi violentamente contestada. O Congresso se recusou a aceitá-la por ser improcedente, o ministro da Saúde recusou-se a assiná-la e o alto escalão do MPS realizou intenso lobby contra a sua aprovação.

Uma intensa mobilização contrária tomou conta do Congresso, envolvendo partidos como PMDB, PFL, PT e o próprio PSDB. O PT solicitou a formação de uma investigação formal pela Comissão de Fiscalização Financeira e Controle da Câmara, que resultou em mais um fórum ${ }^{324}$ de disputa simbólica em torno da crise financeira da previdência social. Na CCJR, o PPR votou contra a Emenda e foi simbolicamente punido com a retirada da vaga que ocupava por acordo com o PSDB na referida Comissão ${ }^{325}$.

Na sociedade civil, mais de 50 entidades associativas e sindicais representantes dos servidores públicos subscreveram documento enviado ao Congresso reivindicando o

\footnotetext{
${ }^{322}$ A partir da promulgação da Constituição Federal de 1988 os aumentos do salário mínimo passaram a estar vinculados à capacidade da previdência social em honrar seus compromissos com o pagamento de aposentadorias e pensões e esse ponto passou a se constituir em obstáculo ao aumento do salário mínimo e argumento central na necessidade da reforma previdenciária. O aumento do salário mínimo passou a vincularse à disponibilidade de recursos da Previdência Social e dos Estados e Municípios e cada vez menos às necessidades de sobrevivência dos trabalhadores. Como é o salário mínimo que determina o valor das pensões, aposentadorias e benefícios de prestação continuada, incluindo aqueles que nunca contribuíram para a Previdência, ele vai perdendo sua referência em relação ao mercado de trabalho, que também apresenta grande heterogeneidade. Em 1997, o Ministério do Trabalho apresentou uma proposta de dois salários mínimos diferentes: um para o setor privado e outro, para o setor público, empregadas domésticas e Previdência Social. Os objetivos dessa proposta eram separar o efeito fiscal da política do salário mínimo de sua função como balizador do mercado de trabalho e permitir uma determinação da estrutura do mercado de trabalho sobre os salários mínimos regionais. Essa proposta alterava a essência do que foi o salário mínimo: determinar um rendimento para o trabalhador que fosse o mínimo necessário para prover sua subsistência física. Essa idéia ganhou força por dois motivos: desvincular a política da previdência social da política salarial e incentivar a contribuição previdenciária em razão de salários maiores no mercado de trabalho. Se o benefício for determinado em função do nível salarial quando da ativa, os trabalhadores se sentirão mais motivados a contribuir, alterando a lógica de que independente de contribuir para ter direito a um salário mínimo na velhice. CAMARgo, José Márcio "Salário mínimo, um bom começo". O Estado de São Paulo, 07/02/1997. “Reajuste do mínimo depende da reforma, diz Stephanes”. O Estado de São Paulo, 19/02/1997.

323 A PEC 21 foi encaminhada através da Mensagem 306, de 17 de Março de 1995, do Poder Executivo.

324 Câmara dos Deputados. Relatório final da subcomissão especial para assuntos da previdência social. Comissão de Fiscalização Financeira e Controle, Brasília, setembro, 1995.

${ }^{325}$ Deputado Adylson Motta (PPR/RS). Diário da Câmara dos Deputados, 24/03/1995: 4243. O Deputado declarou que a votação seguiu a orientação de seu partido, que julgou a Emenda inconsistente, mal formulada e mal conduzida e denuncia a atitude do Líder do PSDB, deputado José Aníbal.
} 
reexame da matéria por ferir direitos adquiridos e a expectativa de direito ${ }^{326}$. A ampla contestação à MP explicitava que as “contas da Previdência” eram objeto de controle público, sujeitas a regras, à aprovação do Congresso Nacional e não poderiam ser manipuladas, nem pela instituição Previdência Social, nem pelo Executivo. Sujeitos a regras constitucionais, os repasses para cobertura de insuficiências financeira também não poderiam deixar de serem efetuados. O conflito que emerge é revelador das mudanças na interação entre Legislativo-Executivo em relação às questões previdenciárias.

As Comissões CSSF e a CTASP, em Audiência Pública conjunta ${ }^{327}$, ouviram os exMinistros da Previdência sobre a reforma previdenciária: Senador Jader Barbalho, Deputado Jair Soares, Dr. Jarbas Passarinho e Dr. Waldir Pires. Todos os convidados, exMinistros da Previdência, concordaram ser necessário realizar reformas, mas discordaram quanto ao seu teor. Jarbas Passarinho afirmou ser necessária a conjugação entre aposentadoria por tempo de serviço e idade; Waldir Pires foi favorável a uma previdência pública e obrigatória até dez salários mínimos que seguisse o modelo de repartição entre as gerações, e de uma previdência complementar acima desse limite, mas, no entanto, se posicionou contrário à idéia de desconstitucionalização do valor dos benefícios. O Senador Jader Barbalho manifestou-se a favor de reformas que restringissem privilégios e do fim da aposentadoria por tempo de serviço, mas contrário ao fim das aposentadorias especiais para algumas categorias profissionais. Todos concordavam que era preciso respeitar o direito adquirido, a expectativa de direito e definir as regras de transição. Por fim, o Deputado Jair Soares, presidente da CESP sobre a PEC 33/95, afirmou que a proposta do governo era precipitada e continha um conjunto de medidas restritivas e supressoras de direitos sociais. Sua visão era bastante negativa: o projeto não previa mecanismos de controle sobre fraudes e sonegações; não obrigava a União a saldar suas dívidas com o sistema previdenciário ${ }^{328}$ e, tampouco, enfrentava a questão do financiamento autônomo para a saúde.

\footnotetext{
326 “Previdência Social: uma análise compromissada com a verdade”, documento transcrito no Diário da Câmara dos Deputados, 16/03/1995: 3445-3446.

${ }^{327}$ Ata da Reunião conjunta (Audiência Pública) da Comissão de Seguridade Social e Família e a Comissão de Trabalho, de Administração e Serviço Público, sob a presidência dos Deputados Roberto Jefferson e Wigberto Tartuce, 06/04/1995. Diário do Congresso Nacional, 20/04/1995: 6937.

${ }^{328}$ Os Estados e Municípios também tinham uma dívida com o INSS (Instituto Nacional do Seguro Social) relativa à contribuição previdenciária não paga. Em abril de 1997, o INSS decidiu cobrar a dívida de R\$ 4,8 bilhões de 3,5 mil prefeituras referentes aos meses de janeiro e fevereiro daquele ano. A decisão do INSS foi bloquear o repasse do Fundo de Participação dos Municípios das prefeituras inadimplentes até o pagamento
} 
A reforma da previdência entrou na agenda pública no primeiro mês do Governo Fernando Henrique e permaneceu durante todo o seu primeiro mandato, com a aprovação ocorrendo apenas em dezembro de 1998. Foram quatro anos de intensos conflitos entre Legislativo e Executivo, burocracia previdenciária e burocracia econômica. Os conflitos se acirraram inclusive na formulação de dois projetos de reformas diametralmente opostos e conduzidos por grupos diferentes do governo. Na visão do Ministro da Previdência, Waldeck Ornélas, a reforma só foi efetivamente encerrada em dezembro de 1999, com a lei que definiu a introdução do fator previdenciário ${ }^{329}$ como redutor do valor da aposentadoria daqueles que se aposentam com idade inferior aos 65 anos de idade, se homem, e 60 anos, se mulher.

Na tramitação do PL, de 17/03/1995 o governo recorreu ao expediente da urgência urgentíssima $^{330}$ para enviá-lo diretamente ao plenário da Câmara, evitando o trâmite pelas CTASP e CSSF, o que o obrigou a muitas negociações. O Congresso apenas reagiu às iniciativas que partiram do Executivo sem conseguir implantar uma defesa articulada das iniciativas de reformas durante a revisão constitucional. As maiores dificuldades que o governo enfrentou estavam relacionadas aos procedimentos e ao comportamento dos

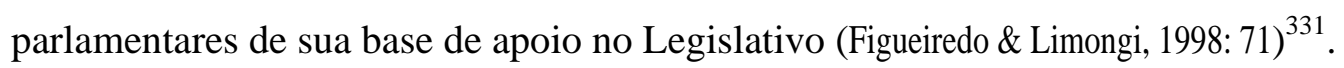

A PEC 21 apresentava a proposta de suprimir do texto constitucional, remetendo para a legislação complementar, todas as disposições relativas a critérios de concessão, cálculo e reajuste de benefícios previdenciários incluindo os dos servidores públicos, magistrados e membros do Ministério Público. Outras mudanças atingiriam as regras de elegibilidade e o reforço ao vínculo contributivo. O ponto mais expressivo era a

da dívida ou o seu re-parcelamento. "INSS vai cobrar débitos de 3,5 mil prefeituras”. O Estado de São Paulo, 15/04/1997.

${ }^{329}$ Lei 9.876/99. Ver Nota Técnica sobre fator previdenciário, Anexo 1, com fórmulas de cálculo do valor dos benefícios.

${ }^{330} \mathrm{O}$ expediente do pedido de urgência rompe com o percurso necessário ao debate e à tomada de decisão. É, nos termos de Ost, o exercício de uma tirania, que subverte a produção do direito por inteiro, marcando o triunfo do fato sobre o exame jurídico. No processo legislativo, o pedido de urgência acelera o curso das deliberações parlamentares, abreviam os prazos, contornam as normas e reduzem o poder da oposição. Assim, como o uso de Medidas Provisórias permite a aceleração da execução, com entrada imediata em vigor, o Executivo impõe a sua vontade sobre o Legislativo e define o ritmo da sua aprovação legal (OsT, 2005:340351)

${ }^{331}$ O governo tentou se beneficiar de sua ampla vitória eleitoral ao apresentar um novo "pacote” de reformas constitucionais. No entanto a estratégia revelou-se precipitada e em meio a disputas políticas por distribuição de cargos o governo não conseguiu formar a maioria de $3 / 5$ dos votos para aprovação das reformas constitucionais. A reforma da Previdência integrava um elenco de cinco reformas essenciais pretendidas pelo Governo: tributária, previdenciária, administrativa, política e do Judiciário (FIGUEIREDo \& LIMONGI, 1998). 
substituição da expressão “tempo de serviço" pela expressão “tempo de contribuição”, que modificava o critério de acesso, além de promover uma combinação entre idade mínima e tempo de contribuição. As aposentadorias especiais também deveriam ser revistas, exceto para professores (excluindo professores universitários) e para os trabalhadores em atividades de risco à saúde.

As medidas mais radicais referiam-se à unificação dos critérios de concessão de benefícios previdenciários a serem adotados nos regimes dos trabalhadores privados e dos servidores públicos (civis e militares) nos três níveis da federação. Apesar de modificar regras de elegibilidade e financiamento, o projeto preservava o regime de repartição de caráter público, o que decepcionou a equipe econômica, enquanto afirmava que, se não era a reforma necessária, era a possível. O ponto mais polêmico e que suscitou várias manifestações contrárias era aquele que conferia à União competência exclusiva para legislar sobre a previdência social, porque representava a sua remoção do controle público.

A exposição de motivos da PEC incorporava vários dos diagnósticos e recomendações formulados pelo IPEA e pelo MPS, ainda na década de 80, como a eliminação da aposentadoria por tempo de serviço; a separação do orçamento da seguridade social nas suas três áreas integrantes (previdência, assistência e saúde); reforço ao caráter contributivo da previdência; unificação dos regimes de previdência; criação de regimes privados complementares; controle dos fundos de pensão; fixação de teto de benefícios e fim dos privilégios ${ }^{332}$. A falta de sustentação financeira e atuarial era a motivação principal do projeto de reforma do Governo Fernando Henrique.

\footnotetext{
${ }^{332}$ Ao pôr em discussão pública a aposentadoria do servidor público como um privilégio que deveria ser removido, a proposta de emenda constitucional conduziu também à discussão sobre o fim da estabilidade do servidor público. O deputado Mauri Sérgio (PMDB/AC) afirmava a respeito que há um preconceito institucionalizado em nosso país contra o servidor público, que seria o responsável pela ineficiência e ineficácia dos serviços públicos. Desse modo, o fim da estabilidade, por si só, permitiria reduzir a burocracia, os encargos financeiros, equilibrar as contas públicas e garantir qualidade ao serviço público. Este tipo de argumento visa a confundir a opinião pública e fortalecer aqueles argumentos favoráveis ao fim dos privilégios. Diário da Câmara dos Deputados, 31/05/1995: 11681-11682. Um exemplo desse argumento é o discurso do deputado Adhemar de Barros Filho (PPR/SP): “(...) O que é o Estado brasileiro hoje? Pesado, lerdo, assente sobre os interesses corporativos de minorias bem situadas nos meandros do exercício do poder, e sempre interessadas na preservação do status quo, em geral; e, mais ainda, na permanência de regras consagradoras de suas vantagens pessoais e particulares (...)”. Diário da Câmara dos Deputados, 31/05/1995: 11698-11699.
} 
Na votação da admissibilidade, a CCJR da Câmara propôs o desmembramento da PEC em quatro Emendas ${ }^{333}$ porque ela tratava de artigos diferentes da Constituição: desconstitucionalizava as regras de acesso a benefícios como aposentadoria por tempo de serviço e idade e eliminação de outros direitos; conferia competência exclusiva ao presidente da República para fazer leis de custeio da seguridade social; permitia a quebra do sigilo bancário, fiscal e patrimonial dos devedores da Previdência Social e alterava a regra da universalização e gratuidade dos serviços de saúde como dever do Estado.

Para o Deputado Fernando Zuppo as propostas em pauta invertiam a ordem natural das coisas ao tentar suprimir direitos sociais a título de equilíbrio financeiro e esse é um dos pontos mais relevantes na mudança na forma de pensar a racionalidade do direito, com supremacia do econômico sobre o político ou o social. Para o Deputado, o desempenho financeiro da Previdência era afetado diretamente pela política econômica adotada, portanto, o seu resultado financeiro era conseqüência e não causa dos problemas econômicos. Desse modo, é reconhecível o fato já bastante apontado na literatura de que a receita tende a expandir-se em época de expansão da atividade econômica e retrair-se em época de recessão ${ }^{334}$, além de ser pressionada por uma maior demanda de benefícios. Seu argumento referia-se à dinâmica do mercado de trabalho, elemento ausente da justificativa pró-reforma.

A forma como a discussão se dava e as propostas de reforma promoviam uma inversão na pauta, com o direito submetido a critérios de racionalidade econômica, que enfatiza a relação entre custos e benefícios. A contabilidade da previdência adquire

\footnotetext{
${ }^{333}$ As quatro emendas são vão do número 30 a 33, sendo que a da Previdência recebeu a denominação de PEC 33, que modifica o sistema de previdência social e estabelece normas de transição. As demais trataram de temas correlatos, como a competência exclusiva do presidente em legislar sobre custeio de seguridade social; quebra do sigilo bancário e patrimonial de devedores da Previdência e alteração das regras de acesso ao sistema público de saúde - SUS.

${ }^{334}$ A retração da receita previdenciária é conseqüência da redução no nível de emprego, do nível salarial, do crescimento do mercado informal de trabalho e da alta carga fiscal imposta às empresas. O Deputado Fernando Zuppo (PDT/SP) enfatiza ainda que, além de problemas conjunturais, a previdência sofre com problemas gerenciais e estruturais, como a má administração, a evasão de contribuições, fraudes e sonegação. Do ponto de vista estrutural, é agravante o fato do seguro social operar apenas no regime de repartição simples, o que eleva a sobrecarga da previdência na cobertura dos riscos sociais, sem que haja a devida avaliação atuarial e financeira e correção do sistema. Por outro lado, mantém-se elevada a dívida histórica da União para com a Previdência Social em decorrência da não transferência de recursos legalmente devidos. Diário da Câmara dos Deputados, 03/05/1995: 7842-7843. O uso indevido de recursos previdenciários para saldar compromissos da União, estranhos à matéria previdenciária, também foi denunciada pelo Deputado Sílvio Abreu (PDT/MG). Diário da Câmara dos Deputados, 30/03/1995: 4813-4815.
} 
predominância nos debates em relação à realização da justiça social ou da redução das desigualdades sociais.

Durante a votação da reforma, o TCU divulgou os resultados de uma auditoria que teria encontrado R\$ 1,8 bilhões no caixa da Previdência ${ }^{335}$, o que sugeria que o quadro de falência no qual o governo se apoiava para justificar a reforma continha manipulações políticas. O próprio Ministério da Previdência Social mantinha divergência quanto ao seu conteúdo, apesar da divulgação intensa do Ministro Reinhold Stephanes na mídia.

Na opinião de Melo a atribulada tramitação da proposta na Comissão esteve fortemente associada ao padrão clientelista da Câmara, à fragmentação de interesses e falta de disciplina partidária e demandou intensa negociação pela sua aprovação (Melo, 1997b: 334). A primeira fase da reforma de FHC foi vivida como derrota e demandou ampla negociação política.

O Deputado Gerson Peres (PPR/PA), nomeado relator do projeto, declarou ser inconstitucional a Emenda que atribuía ao Presidente da República o poder exclusivo de propor leis sobre o financiamento da previdência e da saúde, rejeitando a retirada da Previdência Social do controle público. Após intensas negociações, a CCJR aprovou o relatório, em abril de 1995, com as seguintes modificações: rejeição da Emenda sobre a quebra do sigilo bancário e fiscal por parte da previdência de pessoas acusadas de sonegação; rejeição do fim da isenção das entidades filantrópicas e igrejas; rejeição da proibição dos aposentados recorrerem à justiça para garantir direitos adquiridos e aprovação da inclusão da expressão "na forma da lei" no capítulo que garante o direito universal à saúde. O projeto original não apenas tentava desconstitucionalizar regras previdenciárias, como agia contra o próprio Estado de Direito, revelando um perfil autoritário e centralizador do Executivo

O projeto teve que ser desmembrado, o que representou uma derrota para o Presidente da República, que anunciou a desaceleração das reformas, enquanto a sociedade e o Congresso se mobilizavam contra as medidas anunciadas. No entanto, o

\footnotetext{
335 Pelo resultado da auditoria do Tribunal de Contas da União, a Previdência Social encerrou o ano de 1994 com saldo positivo de R \$ 1,8 bilhão e com uma dívida ativa no valor de R \$ 34,0 bilhões, não sendo correta a afirmação do déficit previdenciário. A estimativa para o ano de 1995 era de superávit de R\$ 2,5 bilhões. A auditoria foi realizada a pedido de duas Comissões da Câmara dos Deputados e o relatório foi aprovado por unanimidade na plenária do TCU. Paulo Paim (PT/RS). Diário da Câmara dos Deputados, 09/05/1995: 92759276.
} 
desmembramento pode ser considerado uma solução intermediária, para que o projeto não fosse rejeitado globalmente sob a declaração de inconstitucionalidade e por tratar de matérias diferentes. Apenas a PEC 33/95 ${ }^{336}$, relativa à reforma da previdência, prosperou, a da saúde foi retirada e as demais não seguiram adiante, por serem inconstitucionais.

Diante da possibilidade de uma votação não favorável ao governo na CCJR, esse requereu e obteve o adiamento por cinco sessões. Para o Deputado Prisco Viana, com a PEC 33/95, o Poder Executivo colocou o Congresso diante de um assunto que demandava estudo aprofundado para se verificar a admissibilidade e a juridicidade, porque a proposta dispunha que fossem descontitucionalizadas normas substantivas da previdência social, remetendo-as a uma lei complementar que organizaria em novos moldes o sistema previdenciário. No entanto, desconstitucionalizar direitos significa usurpar prerrogativas exercidas pelo ANC em 1988 por delegação do povo ${ }^{337}$ e, portanto, deslegitimar a própria regra democrática do processo legislativo.

\footnotetext{
${ }^{336}$ A PEC 33/95 teve como núcleo central a modificação dos artigos 201 e 202 da Constituição Federal, que dispõem sobre a Previdência Social, para acentuar o seu caráter contributivo, obrigatório de preservação do equilíbrio financeiro e atuarial, ao especificar os segurados; estabelecer o vínculo contributivo como critério de elegibilidade para a aposentadoria; vedar o estabelecimento de critérios diferenciados para concessão de aposentadorias e pensões (aposentadoria especial); vedar o acúmulo de aposentadorias do RGPS; vedar o acúmulo de aposentadorias do RGPS e do regime próprio do serviço público; vedar o acúmulo de aposentadoria e remuneração de cargo, emprego e função pública; facultar a adesão a regime de previdência complementar; instituir a contribuição de servidores públicos ativos, inativos e dos pensionistas; unificar os regimes de previdência social; restringir a concessão do salário-família a trabalhadores de baixa renda; dispor sobre regras de transição para o RGPS; propor a extinção dos regimes de previdência relativos ao exercício de mandato eletivo. Pretendia, ainda, acabar com o décimo terceiro salário para aposentados e pensionistas e o direito dos idosos e deficientes físicos a um salário mínimo mensal. O núcleo essencial da PEC 33/95 foi aprovado ao final de 1998.

${ }^{337}$ Em discurso proferido em 18/04/1995 o deputado Prisco Viana fez uma análise pormenorizada do conteúdo da PEC 33/95 e apontou os defeitos da proposta governamental, que atingia outras normas constitucionais, apresentava defeitos de técnica legislativa, atingia direito adquirido e era discriminatória. Entendia que uma Emenda Constitucional não tem o poder de anular o patrimônio alicerçado na previdência social que a Constituição consagrou e que a revisão de seus fundamentos poderia ser proposta penas em caráter alternativo, opcional e para os ingressantes pela primeira vez no mercado de trabalho. Apesar do sentimento reformista ser predominante, o Deputado apontava a inabilidade do governo na sua condução, deixando de lado, por exemplo, o problema da administração, que envolvia sonegação de cerca de 40 bilhões de reais. Deputado Prisco Viana (PPR/BA). Diário da Câmara dos Deputados, 19/04/1995: 6682-6688. Para a Associação dos Magistrados Brasileiros (AMB), a causa fundamental da inviabilidade jurídica da PEC 33 residia na violação do princípio federativo, porque ao propor uma previdência social unificada, concentrava na União o poder exclusivo de instituir contribuições de custeio, escolher critérios de devolução para Estados e Municípios e controle de gerência. Feria, ainda, o direito individual adquirido e a isonomia. Paulo Benjamin Fragoso Gallotti, Presidente da Associação dos Magistrados Brasileiros, transcrita no Diário da Câmara dos Deputados, 28/04/1995, p. 7611-7612. Para Arnaldo Faria de Sá, “o texto originário do Governo contém aberrações inadmissíveis, denunciando que foi preparado por pessoas que ignoram os rudimentos mais elementares do Direito (...)”. Diário da Câmara dos Deputados, 28/09/1995: 23924. Ao longo do processo de reforma a AMB mobilizou-se contra os itens da reforma que feriam seus direitos corporativos
} 
Por se tratar de Emenda Constitucional, o regimento interno exigia a constituição de uma comissão temporária especial para sua apreciação, composta segundo critérios de proporcionalidade partidária ${ }^{338}$. A CESP teve como presidente o Deputado Jair Soares (PFL/RS) e como relator, o Deputado Euler Ribeiro (PMDB/AM), que possuía vínculos históricos com entidades do serviço público. A votação na comissão foi suspensa três vezes por obstrução de sindicalistas. Recebeu 83 emendas no prazo regimental de 10 dias e ouviu 34 pessoas em audiências públicas, incluindo especialistas em seguridade social, sindicalistas, entidades empresariais, burocracia da previdência social e do judiciário, ministros e militares.

Ao completar cem dias de governo, o Deputado José Genoíno (PT/SP) afirmava que “o governador precisa governar” e que até então, o presidente havia se envolvido apenas na administração de uma situação herdada (em referência ao programa de estabilização monetária) e em realizar reformas constitucionais, que dizem respeito à esfera das decisões parlamentares. Quanto às reformas da previdência, o deputado apontava o fracasso e a iminência em se retirar a proposta da pauta ${ }^{339}$, em decorrência de uma inabilidade política na condução das negociações no Congresso, que desorientaram a própria base de apoio ao presidente. Por outro lado, ressaltou, que a política de barganha que, ao mesmo tempo em que o enfraquecia, o amarrava a uma base infiel ${ }^{340}$.

como o fim da aposentadoria integral e vitaliciedade para juízes e o poder conferido aos governadores para fixar tetos salariais para a magistratura da Justiça Comum dos Estados. "Entidades de Juízes prepara protesto contra reformas”, O Estado de São Paulo, 13/02/1997.

${ }^{338}$ Silva apresenta a composição partidária da referida Comissão Especial (SILVA, 2007: 196-197).

339 “(...) Quanto à reforma da Previdência, ungida pelo Governo como a reforma das reformas, o fracasso é tão evidente que a emenda está na iminência de ser retirada. Em todo o processo das reformas, mas particularmente na da Previdência, o Governo cometeu o grave erro de negociar seu conteúdo apenas com a cúpula dos partidos governistas, abrindo espaço para que toda a discussão se partidarizasse. A não ser que seja por um ato de força ou pela via de um processo revolucionário, nenhum governo tem condições de imprimir mudanças substantivas em áreas sensíveis como a Previdência e o sistema tributário sem construir um consenso mínimo baseado num amplo processo de negociação entre governo, partidos e sociedade. Os erros de método na condução das reformas desorientaram a própria base governista, que já apresenta uma articulação precária”. Deputado José Genoíno. “O Governo Precisa Governar”. Diário da Câmara dos Deputados, 13/04/1995: 6362.

340 “(...) Fatias importantes do PMDB e do PFL movem-se exclusivamente pelo fisiologismo, pela política de barganha, trocando apoio por cargos ou por pedidos atendidos. As concessões que o Governo vem fazendo ao fisiologismo o enfraquecem politicamente, ao mesmo tempo em que o amarram a uma base infiel (...)”. Deputado José Genoíno. Diário da Câmara dos Deputados, 13/04/1995: 6362. O Deputado João Fassarella (PT/MG) enfatiza que “... formou-se um grande balcão de negócios, intermediado pelos líderes dos partidos que constituem a base de apoio do Governo e capitaneado por diferentes Ministros com o poder de decidir sobre reivindicações imediatas e localizadas (...)”. Diário da Câmara dos Deputados, 01/06/1995: 11844. 
Entre a aprovação da admissibilidade na CCJR e a instalação da Comissão Especial, o Congresso aprovou todas as reformas econômicas, que eram prioritárias ao governo ${ }^{341}$. A primeira fase da tramitação da PEC da previdência levou um ano e quatro meses. A Comissão Especial que deveria julgar o seu mérito demorou 135 dias para ser instalada pelo presidente da Câmara dos Deputados, Deputado Luís Eduardo Magalhães (PFL/BA) e, depois, levou 145 dias para chegar ao relatório final, que não foi votado em plenário, uma vez que o presidente da Câmara interrompeu o trabalho da comissão. A votação em plenário demorou mais 130 dias (Figueiredo \& Limongi, 1998: 71).

Durante a confusa tramitação dos projetos, o governo cogitou interromper o processo de reforma da previdência. A presidência da Câmara e o governo tentaram fazer uso de medidas regimentais, como o pedido de urgência, para conter as dificuldades políticas e as negociações, desviando a votação da comissão para o Plenário. O governo temia que, na Comissão, o projeto tivesse seu conteúdo alterado, em razão, principalmente, da experiência dos parlamentares no assunto. Um exemplo foi a tentativa da Comissão em assegurar o uso exclusivo dos recursos provenientes de contribuições sobre a folha de pagamento de salários para financiar despesas previdenciárias, o que tornaria esse recurso indisponível para medidas de política macroeconômica como o Fundo Social de Emergência.

Um dos aspectos relevantes da tramitação da PEC 33/95 foi a grande pressão exercida pelo governo para a aprovação do projeto original, o que revelava desrespeito à separação dos Poderes. ${ }^{342}$ Em 05/12/1995, o trabalho da CESP estava praticamente encerrado, após ter ouvido vários especialistas na área da Previdência. O parecer inicial do Deputado Euler Ribeiro foi contrário a alterar a Constituição, por entender que prejudicava

\footnotetext{
${ }^{341}$ Dentre as medidas econômicas aprovadas encontram-se a quebra do monopólio estatal do petróleo (EC 6), dos serviços de telecomunicações (EC 8), da navegação de cabotagem e transporte internacional (EC 7), do gás canalizado (EC 5) e a nova definição de empresa nacional (EC 5). Ainda estavam pendentes o encaminhamento das propostas da reforma tributária e fiscal, da reforma do Estado, da reforma do Poder Judiciário e o reinício das discussões da reforma da Previdência social, que teria sido adiada para "possibilitar maior nível de negociação entre as forças políticas e a sociedade”. Ver discurso do Deputado Fausto Martello (PPR/SP). Diário da Câmara dos Deputados, 03/08/1995: 15572-15573.

${ }^{342} \mathrm{O}$ deputado Confúcio Moura (PMDB/RO) declarou a respeito: “(...) acredito que o Governo, de um modo geral, está extrapolando os seus limites ao interferir acintosamente sobre condutas internas da Câmara dos Deputados, demonstrando não saber exercitar a democracia na sua plenitude (...)”. Diário da Câmara dos Deputados, 10/11/1995: 05050-05051. Nas palavras do Deputado Paulo Paim: “(...) o Governo manda nos três Poderes e tem um trabalho de mídia assustador. Da oposição tiraram até o discurso (...)” Diário da Câmara dos Deputados, 23/11/1995: 06332.
} 
direitos adquiridos pelos aposentados e subtraía expectativas de direito. Contudo, o mesmo recuou do parecer que daria em favor de um parecer de consenso ${ }^{343}$, que foi considerado melhor $^{344}$. O projeto substitutivo retomava a contribuição de inativos e pensionistas, que já havia sido considerada inconstitucional em maio de $1995^{345}$ pela CCJR e motivara o recurso impetrado pelos Deputados Alexandre Cardoso (Bloco/PSB/RJ), Nilson Gibson (PSB/PE) e Matheus Schmidt (PDT/RJ) e que foi acatado.

Fortalecia-se no Congresso a idéia de que era necessário iniciar uma reforma administrativa da Previdência antes de se mexer no conteúdo dos direitos, com melhoria da capacidade gerencial e fiscal e modernização do atendimento aos segurados. A reforma deveria realizar uma racionalização administrativa da Previdência Social, com adoção de técnicas de controle e fiscalização mais modernas, bem como melhorar o atendimento aos usuários e da qualidade das informações, de modo a facilitar o controle público da instituição. A racionalização permitiria melhorar tanto a arrecadação quanto a alocação de recursos, impedindo, assim, fraudes, desvios, sonegações, usos indevidos etc.

No entanto, nem o projeto original, nem o relatório Euler Ribeiro tocavam num outro ponto essencial à modernização da estrutura da Previdência, o princípio da administração colegiada ou dos Conselhos de participação de empresários, empregados e aposentados, como recomenda a OIT e como dispõe o texto constitucional. Na opinião do Deputado Franco Montoro Filho (PSDB/SP), os desvios de importâncias bilionárias e as irregularidades apuradas no INSS só ocorrem porque o governo administra sozinho,

\footnotetext{
343 Discurso do Deputado Álvaro Gaudêncio Neto (Bloco PFL/PB). Diário da Câmara dos Deputados, 21/11/1995: 05845-05846.

${ }^{344}$ Discurso do Deputado Paulo Paim (PT/RS). Diário da Câmara dos Deputados, 02/12/1995: 07550-07551.

345 A CCJR considerou a medida inconstitucional, o que confere parecer terminativo à proposta de contribuição de inativos e pensionistas. O seu retorno ao relatório não teria cabimento, por já ter a sua inconstitucionalidade declarada. No entanto, na tramitação regimental das propostas de emenda à Constituição, várias controvérsias foram formuladas, ensejando diversas questões de ordem, consultas e recursos no Plenário e nas Comissões envolvidas e motivou um parecer da Presidência da Câmara que reformou algumas decisões anteriores. Neste parecer, entendeu que, naquela Comissão, os vícios de inconstitucionalidade foram sanados através de uma nova Emenda, o que conduziu a dificuldades práticas, tais como as questões pendentes que ainda carecem de parecer de admissibilidade. O novo parecer determinou que compete à CCRJ pronunciar-se sobre a admissibilidade de PEC e que, uma vez inadmitida, deve deixar de tramitar e se tiver que ser submetida à apreciação, ela teria que ser feita antes do envio da proposição à Comissão Especial, muito embora a decisão de refazê-lo ou não seja uma questão da competência da Comissão Especial da Previdência. Também definiu que a admissibilidade parcial poderá ocorrer através de Emenda supressiva que sane o vício de inconstitucionalidade e que qualquer outro tipo de modificação é da competência da Comissão Especial. Ver a Comunicação da Presidência da Mesa (Deputado Luís Eduardo Magalhães) em questão de ordem relativas à tramitação das PEC 33 e 173, de 1995. Diário da Câmara dos Deputados, 19/01/1996: 01974-01976. Diário da Câmara dos Deputados, 19/01/1996: 01975-01976.
} 
recursos que pertencem à sociedade e também promove desvio de recursos da instituição para cobrir déficits do Tesouro Nacional. ${ }^{346}$ A denúncia explicitava que, a despeito da Previdência Social ter sido incluída como peça orçamentária, e, portanto, submetida ao controle público do Congresso, do TCU e dos Conselho de Participação popular, ${ }^{347}$ a administração dos recursos ainda era da competência do Executivo, sujeita a manipulações, uso indevido, falta de repasses etc. Deixar de ser estatal para se tornar pública é uma das grandes questões da Previdência, implícita em vários documentos que reivindicam, inclusive, a retirada do Estado de sua administração, entregando-a a empregados, empregadores e aposentados.

Um conflito entre o presidente da CESP, Jair Soares, e o líder de seu partido, Inocêncio Oliveira, que levou à renúncia do primeiro, foi a oportunidade que Luís Eduardo Magalhães (PFL/BA) encontrou para dissolver a CESP sob alegação de esgotamento de prazo. Houve temor na bancada governista de que a reforma pudesse emperrar. ${ }^{348} \mathrm{O}$ trabalho da CESP, do seu presidente e do relator foi valorizado pelos demais membros que ressaltaram o amplo processo democrático que envolveu, com várias audiências públicas, visitas a várias capitais, justificando o tempo necessário para realizar uma reforma justa. ${ }^{349}$

\footnotetext{
${ }^{346}$ Em discurso proferido no Congresso Nacional, o Deputado cita que em um levantamento oficial realizado em 1989, o governo devia 20 bilhões de dólares à Previdência e que em 1990, a dívida era de 1 trilhão de cruzeiros. O deputado apresentou o Projeto de Lei 502/95 que dispõe sobre a constituição do Conselho de Administração da Previdência Social (em nível nacional, estadual e municipal) e que visa assegurar o caráter democrático e da Previdência Social e uma forma de controle sobre o uso dos seus recursos. Discurso de Franco Montoro (PSDB/SP). Diário da Câmara dos Deputados, 26/01/1996: 02582-02585.

${ }^{347}$ O Conselho Nacional da Previdência Social foi criado em 1992 pela Lei $n^{\circ}$ 8213/91 e extinto pela MP 1799-5/1999. Sua principal atribuição era exercer o controle social sobre a gestão da instituição previdenciária, mas que apresentou ao longo de sua trajetória baixa funcionalidade (DELGADO; SCHWARZER; QUERINO \& LUCINI, 2002).

${ }^{348}$ O Deputado Osvaldo Biolchi (Bloco-PTB/RS), favorável à redefinição do modelo previdenciário do projeto do governo, afirmava que "é preciso superar imediatamente a disputa por espaço político que as discussões da reforma têm ensejado. Não há lugar para demagogia de vaidades diante de questão tão relevante (...) o Congresso Nacional tem em suas mãos uma oportunidade ímpar de corrigir distorções constitucionais de efeitos devastadores sobre as finanças públicas (...)”. Diário da Câmara dos Deputados, 14/02/1996: 04416.

349 “(...) No momento em que querem esquecer a figura do Presidente Jair Soares, no momento em que querem jogar pedras no Relator, Deputado Euler Ribeiro, venho à tribuna da Câmara dos Deputados para dizer que esses dois Parlamentares trabalharam com honestidade e lisura (...) passadas as quarenta sessões regimentais, foi avocada a proposta de emenda à Constituição ao Plenário desta Casa (...)”. Deputado Augusto Viveiros (Bloco/PFL-RN). Diário da Câmara dos Deputados, 16/02/1996: 04664.
} 
A PEC foi diretamente para discussão no plenário, antes que a CESP apresentasse o seu relatório final ${ }^{350}$. Em 13 de fevereiro de 1996, o Deputado Euler Ribeiro foi indicado para proferir parecer em plenário, que teve o seu substitutivo rejeitado em 06/03/1996 ${ }^{351}$. À derrota, o presidente da República reagiu violentamente identificando os parlamentares a lobistas de interesses contrários ao País. No entanto, o cerne do problema estava no já tenso relacionamento do Governo Fernando Henrique com o Congresso. O Presidente vinha usurpando a função legislativa e transformando a Câmara num fórum de discussões de suas propostas $^{352}$.

O procedimento adotado pelo Regimento Interno mandava que, uma vez rejeitado em plenário o substitutivo, deveria ser nomeada uma nova CESP para dar um novo parecer sobre a matéria. Para que o processo não fosse interrompido, iniciou-se uma discussão sobre a questão procedimental. A solução política encontrada foi a nomeação de um novo

${ }^{350}$ O Deputado Prisco Viana (PPR/BA) assim se pronunciou: “O ato da Presidência surpreendeu a Comissão quando ela já havia dado início ao processo de votação... Incabível fazer incidir sobre matéria sujeita a rito especial ( ...) a aplicação de preceito de rito ordinário ou comum para os projetos em geral”. Diário da Câmara dos Deputados, 14/02/1996: 4459-4560. A respeito o Deputado José Carlos Sabóia (Bloco-PSB/MA) declarou que "o governo já tinha desistido de fazer uma reforma de fato. Para evitar os caminhos normais da decisão legislativa (...) é bom deixar claro que os partidos de oposição nunca se opuseram a negociar uma reforma da Previdência. Ao contrário, quando deixou sua proposta de molho, no ano passado, o Governo já não estava disposto a negociar nada. E muito menos apresentar estudos técnicos e números confiáveis. Tratava-se e trata-se de tentar reeditar o rolo compressor acionado para a aprovação das mudanças constitucionais relativas à economia (...)”. Diário da Câmara dos Deputados, 14/02/1996: 04441-04442.

${ }^{351}$ O substitutivo de Euler Ribeiro foi derrotado no plenário por 294 votos a favor e 190 contra. A dissidência na base governista se concentrou no PMDB (38 votos contra), PSDB (nove), PPB (27) e PFL (sete) e produziu forte comoção no governo. Para garantir a aprovação, o tema foi tratado na convenção nacional do PFL, com punição para a indisciplina partidária e um processo de negociação que envolveu a concessão de um ministério ao PPB, a renegociação de dívidas de Estados e Municípios e concessões generosas a bancadas de vários estados. Ver: (Melo, 1997: 339-341). Nas palavras do deputado Paulo Paim, “(...) o relatório do Deputado Euler Ribeiro conseguiu descontentar a todos (...) Todos estão sendo prejudicados: os servidores públicos, os trabalhadores da área privada e os aposentados (...) O que contém o substitutivo do Deputado Euler Ribeiro? Ele acaba com a aposentadoria por tempo de serviço e institui a aposentadoria por tempo de contribuição (...) o substitutivo termina com a aposentadoria especial daqueles trabalhadores que a ela têm direito; não garante, como previsto no suposto acordo, a gestão quadripartite nem a exclusividade da administração dos recursos da seguridade para o Ministério da Previdência (...) de acordo com o projeto do Deputado Euler Ribeiro o trabalhador não poderá reunir a contagem do tempo de serviço do campo com o da cidade (...) Então, existe uma grande discriminação do trabalhador rural (...)”. Deputado Paulo Paim (PT/RS). Diário da Câmara dos Deputados, 28/02/1996: 04961-04962.

${ }^{352}$ A título comparativo, entre 1989 e 1994, foram enviadas nove PECs; apenas em 1995, o Governo Fernando Henrique Cardoso enviou 22 PEC e 66 Projetos de Lei Ordinária. O Governo Sarney editou 147 Medidas Provisórias; o Governo Collor, 159; Itamar Franco 416. Apenas no primeiro ano, o Governo Fernando Henrique Cardoso havia editado 450 Medidas Provisórias. A Constituição permite que o chefe do Executivo edite medidas provisórias com força de lei em casos de relevância e urgência e representa um resíduo autoritário nas novas democracias latino-americanas, que permite ao Executivo legislar sem o concurso do legislativo e atenta contra o princípio básico da separação dos poderes. Figueiredo e Limongi, ao analisarem a relação entre o Executivo e o Legislativo, se questionam se o abuso da edição de Medidas Provisórias indicaria “abdicação” ou “delegação” da tarefa de legislar (FIGUEIREDo \& LiMONGI, 1997). 
relator, o que não encontrava qualquer amparo legal. Em votação ao "efeito suspensivo" da decisão da Mesa, o plenário endossou a decisão do presidente da Câmara.

A PEC 33 continuou a tramitar e recebeu sete emendas aglutinativas, e a emenda seis foi apresentada pelos líderes governistas e tornou-se o novo texto da reforma, com relatório de Michel Temer (PMDB) e, as demais, pelos líderes da oposição. No dia 21/03/1996, a emenda de número seis foi aprovada, mas a tramitação foi interrompida, porque o Supremo Tribunal Federal acolheu mandado de segurança dos líderes do PDT e do PT na Câmara, Deputados Miro Teixeira e Sandra Starling. No entanto, conferiu parecer favorável ao governo. A aprovação da emenda Temer foi uma das mais expressivas vitórias do governo. Ao final da primeira fase da tramitação, ficou explícito o quanto as "regras do jogo” influem no processo decisório, tanto no tempo, quanto no ritmo de sua aprovação (Figueiredo \& Limongi: 1998; Melo: 1997a).

Entretanto, o projeto aprovado na Câmara foi substancialmente alterado pelo relator na PEC no Senado, Senador Beni Veras, para reintroduzir pontos que haviam sido rejeitados pela Câmara ${ }^{353}$, como introdução de idade mínima para aposentadoria ${ }^{354}$, novas regras para aposentadoria proporcional e o fim da contagem do tempo fictício para aposentadoria $^{355}$.

Esse novo parecer acrescentava pontos decisivos para sua aprovação, tais como o respeito ao direito adquirido, as regras de transição e a progressividade, que tornavam mais aceitáveis cortes a serem realizados ${ }^{356}$. A contribuição dos inativos foi um dos pontos de

\footnotetext{
${ }^{353}$ Fernando Henrique tanto elogiava o Congresso que votou as reformas econômicas, quanto criticava o Congresso que postergava a aprovação da reforma da Previdência. Para o governo, o Congresso vinha “cozinhando em água morna” reformas vitais, como a da Previdência e a Administrativa. Não havia necessariamente contradição, mas regras do jogo complicadas, que impunham a necessidade de se formar maioria parlamentar de três quintos, conferindo à minoria poder de veto. "As reformas e o desafio da globalização”. O Estado de São Paulo, 02/07/1997.

${ }^{354}$ A idade mínima para aposentadoria fixada no parecer do Senador Beni Veras era de 53 anos para homem e 48 para mulheres, durante a transição e, de 60 anos para homem e 55 para mulheres, para os novos ingressantes no sistema previdenciário.

${ }^{355}$ Tempo fictício é o tempo não trabalhado e que era contado para aposentadoria, como a contagem em dobro de férias e licenças-prêmios não gozadas, exclusivamente para funcionários públicos.

${ }^{356}$ Em pronunciamento nacional, O Presidente Fernando Henrique Cardoso discursou “(...) Se alguém lhe disser que a reforma da Previdência é para tirar direitos dos aposentados, não acredite. Dei instruções aos líderes do governo no Senado para apoiarem o relatório do senador Beni Veras. Na proposta do relator vai ficar claro que o valor real da aposentadoria será mantido, de modo que nunca mais ocorra o que houve na época da inflação, quando tudo subia, menos as pensões e as aposentadorias. Tanto com a reforma da Previdência quanto com a da administração o que eu quero é acabar com os abusos, com os privilégios” (...) Pedi que houvesse um teto salarial e um subteto (...) a minoria da Câmara derrubou o subteto. Mas no
} 
maior conflito entre as duas casas, assim como o regime de aposentadoria dos funcionários públicos. O Deputado Arnaldo Madeira, nomeado relator do projeto na Comissão Especial, concluiu rapidamente seu relatório, sem alterar o projeto aprovado no Senado. Mesmo assim, a votação foi demorada, cerca de seis meses entre primeiro e segundo turno ${ }^{357}$.

Dentre as medidas aprovadas na CESP estavam: o reforço do caráter contributivo da previdência; introdução de critérios que obrigam ao respeito à preservação do equilíbrio financeiro e atuarial da previdência; proibição de concessão de aposentadorias especiais; limitação na concessão do salário-família; diferenciação de alíquotas de contribuição das empresas em função da atividade econômica; idade mínima para aposentadoria de funcionários públicos. Dentre as medidas rejeitadas estavam a extinção do IPC e de fundos de pensão; definição de idade mínima para aposentadoria no RGPS; exigência da contribuição dos inativos; extinção de benefícios de acidente de trabalho; piso de um salário mínimo nos benefícios de prestação continuada e auxílio-reclusão. Várias medidas que afetavam interesses dos funcionários públicos foram aprovadas: proibição do acúmulo de aposentadorias e de aposentadoria com remuneração em cargos públicos; aposentadoria especial para professores universitários; idade mínima para aposentadoria combinada ao critério de tempo de contribuição; definição de tempo mínimo no serviço público (10 anos) e no cargo (5 anos) para aposentadoria.

Paralelamente, o governo iniciou negociação com as centrais sindicais dos trabalhadores em janeiro de 1996, que passou ao largo das deliberações em andamento na Comissão. Após a ocupação da plenária da CESP por duas vezes, por militantes da CUT e da Força Sindical e a suspensão da discussão da reforma, Fernando Henrique decidiu convocar as centrais sindicais para negociar os parâmetros da reforma (Silva, 2007). Durante

Senado nós vamos tentar corrigir isso (...)”. Fernando Henrique Cardoso. “O Brasil continua mudando para melhor”. O Estado de São Paulo. 1 . de Julho de 1997.

${ }^{357} \mathrm{O}$ atraso nas votações da reforma decorreu tanto dos obstáculos interpostos pela oposição quanto pela bancada governista, que não conseguia se entender. O parecer do deputado Moreira Franco, respeitando o pensamento do governo e as exigências do Tesouro, estabelecia que os funcionários aposentados não teriam direito aos aumentos concedidos aos funcionários em atividade. No entanto, o PMDB, em defesa dos direitos dos aposentados acertou com o deputado Moreira Franco que os vencimentos de aposentados e funcionários da ativa seriam sempre igual. Ao final, o parecer teve uma negociação ponto a ponto em cima de temas polêmicos, com os partidos da base governista. "Por que as reformas não são aprovadas". O Estado de São Paulo, 24/04/1997. “(...) a maioria desorganizada do presidente Fernando Henrique Cardoso só se organiza quando se trata de preparar as condições para reelegê-lo (...) o problema é que as lideranças do governo estão perdidas em meio às reivindicações e protestos das bancadas, já habituadas a condicionar seus votos a promessas de atendimento a pleitos variados (...)”. “A maioria desorganizada”. O Estado de São Paulo, 07/04/1997. 
as negociações, o presidente afirmou que quem fosse contra o acordo com as centrais sindicais era contra o país e vinculava o apoio de deputados e senadores às suas propostas ao sucesso eleitoral ${ }^{358}$. A negociação com as centrais deslocava o eixo da negociação do Congresso Nacional e promovia o seu enfraquecimento, usurpando o papel do Legislativo (Cohn, 1995: 59).

O Deputado José Genoíno foi um dos que se pronunciou contra a postura antidemocrática do Presidente e desrespeitosa para com o Legislativo $^{359}$. Declarava ainda que o Congresso representa a sociedade e não deveria ficar enredado numa disputa com as centrais sindicais, que representam apenas uma parte da sociedade. O governo deveria mergulhar no debate e na negociação dos grandes temas de uma reforma estrutural e profunda da previdência e que não foram contemplados no acordo entre as centrais sindicais e o governo: o sistema único e universal, com teto, piso e orçamento; a gestão colegiada; um critério justo para sair da polêmica entre tempo de serviço e tempo de contribuição $^{360}$.

A negociação não avançou e foi reconduzida para a $\operatorname{CESP}^{361}$. O ponto de discordância era a regra para aposentadoria dos servidores públicos. Em março de 1996, a CUT afirmou que não apoiaria o substitutivo do Deputado Euler Ribeiro. Em seguida, as Confederações Nacionais ligadas à CGT se reuniram em Brasília ${ }^{362}$ e tornaram público o documento "Em defesa do emprego, da Previdência Social, dos direitos trabalhistas e da estrutura sindical”, abrangendo toda a pauta relacionada à questão dos direitos trabalhistas e sindicais. Nesse documento, afirmavam que os trabalhadores não eram os responsáveis

358 “O Governo está indo ao encontro das centrais sindicais e negocia, neste momento em que se sedimenta uma vida nova na economia brasileira, a certeza de que não teremos greves nem prejuízos na atividade produtiva neste ano de 1996. Efetivamente, em princípio, pareceu-me que o Congresso Nacional tivesse sido diminuído em virtude desse ato do Executivo. Mas quero, depois de uma avaliação feita, dizer que agora, sim, vejo que a Previdência terá condições de ser equacionada como deve ser, com a participação efetiva dos trabalhadores brasileiros que comandam os homens da atividade produtiva”. Deputado Adroaldo Streck (PSDB/RS). Diário da Câmara dos Deputados, 19/01/1996: 01948

${ }^{359}$ Ver discurso do Deputado José Genoíno (PT/SP). Diário da Câmara dos Deputados, 19/01/1996: 01951.

${ }^{360}$ Deputado José Genoíno (PT/SP). Diário da Câmara dos Deputados, 19/01/1996: 01988.

${ }^{361}$ Para o deputado Ivan Valente (PT/SP) o acordo é a explicitação de que “(...) o Governo sabe que não tem base parlamentar para aprovar uma reforma que retira dos trabalhadores direitos importantes, mínimos $e$ básicos, enquanto beneficia os banqueiros e latifundiários (...)”. Diário da Câmara dos Deputados, 19/01/1996: 01988.

${ }^{362}$ A Plenária Nacional de Dirigentes Sindicais de todos os Estados Brasileiros se reuniu em 10/04/1996, em Brasília-DF, no Auditório Petrônio Portella e contou com a presença de 800 participantes, das Confederações Nacionais de Trabalhadores, a Confederação Geral dos Trabalhadores (CGT) e a União Sindical Independente (USI), que produziram o documento citado e que se encontra transcrito nos Anais da Câmara dos Deputados. Diário da Câmara dos Deputados, 11/04/1996: 09235-09236. 
pelo “custo Brasil”, mas heróis que contribuíam para elevar a economia brasileira ao posto de oitava do mundo. Afirmavam ainda ser necessária a realização de uma auditoria para apurar sonegação, fraudes e eliminar privilégios; estruturar um plano de custeio; centralizar os recursos no Ministério da Previdência; universalizar a previdência pública; adotar a gestão quadripartite (Governo, trabalhadores, empresários e aposentados). O documento identificava que a reforma pretendida pelo governo (com a adoção da aposentadoria por tempo de contribuição), num quadro de crescente informalidade nas relações de trabalho tenderia a inviabilizar o direito à previdência social para milhares de trabalhadores.

A Força Sindical defendia um sistema misto de previdência, baseado no modelo argentino (combinação entre repartição e capitalização) ${ }^{363}$. Sindicatos vinculados à CUT, como os bancários, começavam também a propor fundos de pensão, numa demonstração de que a reforma da Previdência Social acabaria aceita pelo Congresso Nacional. A proposta feita através de PL permitira a sindicatos, centrais, cooperativas e associações de profissionais criarem fundos de pensão para complementar a aposentadoria pública. Ao propor a criação de um fundo de pensão, a CUT aceitava o princípio de que a aposentadoria deveria guardar relação com as contribuições pagas ao longo da vida laboral. Essa medida pode ser lida como a admissão pública da reforma previdenciária ${ }^{364}$.

É forte o argumento de que as centrais sindicais não possuíam representantes no Congresso com poder institucional suficiente para bloquear o trâmite legislativo da reforma previdenciária e que Fernando Henrique teria tentado utilizar o acordo como uma forma de superar os obstáculos que sofria na sua base de sustentação na Comissão Especial (Silva: 194). No entanto, o acordo não agradou a ninguém: nem aos partidos da situação, nem os de oposição $^{365}$.

\footnotetext{
363 “Força Sindical vai propor sistema misto de Previdência”. O Estado de São Paulo, 07/03/1997.

364 "Sindicato propõe fundo de pensão". O Estado de São Paulo, 07/06/1997; “A Previdência da CUT”. O Estado de São Paulo, 11/06/1997, editorial.

${ }^{365}$ O deputado José Carlos Sabóia (PSB/MA) assim se pronunciou sobre as negociações com a Central única dos Trabalhadores (CUT): “(...) o que o Governo e a CUT fizeram só tem comparação com a prática de editar medidas provisórias: pretendem que os Parlamentares enfiem goela abaixo mudanças de cujas negociações não participaram (...) inclusive dos membros de uma comissão constituída para examinar o assunto, tudo indica que agora pretende estender seu arbítrio às matérias de conteúdo social(...)”.Diário da Câmara dos Deputados, 14/02/1996: 04441-04442. Para Waldomiro Fioravante (PT/RS) as negociações refletiram uma tentativa de “(...) desmobilizar a população, o governo anunciou que estava disposto a negociar (...) Mas, depois de adquirir a confiança de Vicentinho, aplicou-lhe um golpe, pois o próprio Presidente da CUT afirma que o que consta no substitutivo apresentado ontem por Euler Ribeiro não condiz com o que foi acordado(...)”. Diário da Câmara dos Deputados, 08/02/1996: 03963-03964.
} 
No decorrer do trâmite, o Presidente tentou valer-se de estratégias diferentes para tentar reduzir os custos políticos da reforma, e o acordo com as centrais sindicais seria apenas mais uma, que não deu certo. A aprovação da Emenda da reeleição no final de 1996 parece ter sido, para Silva (2007: 208-209), um ponto favorável para a aprovação da reforma da previdência. A mudança nas regras do jogo mudou o relacionamento do Executivo com a sua base de sustentação no Congresso. Sob esta nova conjuntura, foi possível renovar a base parlamentar na nova CESP, com novas indicações e redução da participação da bancada de oposição ${ }^{366}$.

Para Coelho (2001), as resistências em torno da PEC da Previdência demonstram como não é fácil o desmonte de políticas sociais ${ }^{367}$, o que acirrou a disputa entre as áreas previdenciária e econômica no governo FHC. A bandeira do Executivo deixava de ser a do “resgate da dívida social” e passava a ser a da estabilidade econômica e do controle do déficit público. Mudou o enfoque e o discurso na reforma da previdência, que passou de um conteúdo político (universalização de direitos de cidadania) para o domínio da racionalidade econômica.

Um novo lance que marcaria as disputas em torno da reforma da Previdência foi a tentativa de contornar o debate no Congresso em torno do acúmulo de pensões e aposentadorias por um(a) mesmo(a) beneficiário(a) através da edição de MP. O outro equívoco foi desrespeitar o direito adquirido pelos que já usufruíam dos benefícios. A MP teve que ser revogada pelo Presidente logo após a sua edição sob pressões políticas e diante do alto custo político que representava.

Para Ives Gandra Martins, o projeto de reforma constitucional de Fernando Henrique não avançou e teve seus textos originais descaracterizados. A propaganda oficial fazia com que se depositasse ampla esperança nas reformas tributárias e da previdência social, muito embora houvesse poucas chances de mudança real, exceto no aumento do poder impositivo do Estado em criar novos tributos. Não acreditava que as reformas

\footnotetext{
${ }^{366}$ A renovação da Comissão Especial da Previdência foi decisiva para que o governo conseguisse aprovar a sua reforma. O bloco de oposição perdeu duas vagas, do PDT e do PT, permanecendo com um total de 6, das quais apenas 1 não participara da primeira, o Deputado Matheus Schmidt (PDT/RJ). Na base governista, por outro lado, permaneceram apenas três deputados: Arnaldo Faria de Sá (PPB/SP), Jair Soares (PPB/RS) e Mário Cavallazi (PPB/SC). O presidente e o relator escolhidos eram parlamentares fiéis à nova orientação governista: José Lourenço (PFL/BA) e Arnaldo Madeira (PSDB/SP), respectivamente (SILVA, 2007).

367 "Às vezes parece que o Congresso não tem consciência da importância das decisões que está tomando ou não está tomando", declarou o presidente sobre a lentidão com que as reformas constitucionais tramitam no Congresso. "FH critica lentidão em aprovar reformas”. O Estado de São Paulo, 02/10/1997.
} 
propostas pudessem solucionar os problemas de falência progressiva da Previdência Social, da obsolescência do direito e do esgarçamento do Estado ${ }^{368}$. A sua visão era de descrédito tanto na realização das reformas quanto na sua eficácia para combater os problemas da crise fiscal do Estado.

Em setembro de 1997, o Presidente tentou iniciar uma nova reforma da Previdência, com a criação de uma comissão Executiva subordinada a seu gabinete e liderada por André Lara Resende. A “Reforma 2" era discutida por membros da equipe econômica: Lara Resende (BNDES), Francisco de Oliveira (IPEA), Kaizô Beltrão (IBGE). O teor dessa reforma seguia a proposta do modelo multi-pilar do Banco Mundial (World Bank, 1994), com a preservação do sistema de repartição com piso de até cinco salários mínimos; criação de um sistema de capitalização para as contribuições entre cinco e dez salários mínimos. Para o governo, era um projeto que não demandaria reforma constitucional e que não teria implicações sobre o processo atual de reforma. ${ }^{369}$

Oliveira e Beltrão (1997) argumentavam que o problema da reforma era um “conjunto de não(s)”, ou seja, está mais concentrado em definir como o sistema não deve ser, enquanto deveria começar a assumir um aspecto mais positivo ${ }^{370}$, ou seja, deveria deixar de ser reativa para se tornar propositiva. Para eles, a reforma de um sistema de previdência tem de ser apresentada por causa dos aspectos positivos, Ambos defendiam a adoção de um sistema misto com um regime de repartição simples para os benefícios básicos que deveria cobrir 90\% da população e um regime de capitalização acima de um determinado limite de renda. A capitalização deveria facilitar a formação da poupança interna que, por sua vez, geraria maior oferta de capitais e menor juros, mais investimentos, mais empregos e salários. Defendiam que o país precisava ousar, sair de uma postura tímida e defensiva e tornar-se capaz de romper com o "absurdo tupiniquim" da aposentadoria por tempo de serviço, da aposentadoria especial, acúmulo de aposentadorias, a compensação

\footnotetext{
${ }^{368}$ Martins, Ives GS. “Reforma constitucional e governabilidade”. O Estado de São Paulo, 10/03/1997: 3. 369 Ver entrevista coletiva concedida pelo Presidente Fernando Henrique Cardoso por ocasião do pronunciamento de 07/05/1998. "Não contem com quem votou contra vocês”. O Estado de São Paulo, 08/05/1998.

370 OliveirA, Francisco B. \& BELtrão, Kaizô. “Uma agenda positiva na reforma da Previdência”. O Estado de São Paulo, 06/06/1997: A-2.
} 
dos baixos salários com aposentadoria, privilégios e com a "vocação de tentar viver à custa do Estado" ${ }^{371}$.

Ao relacionarem os principais problemas da Previdência enumeraram do lado da receita, a redução da participação do salário do setor formal no PIB e do lado das despesas, a aposentadoria por tempo de serviço e os regimes especiais, a aposentadoria do trabalhador rural,os benefícios assistenciais e fatores gerenciais como o custo administrativo, a evasão de receita, fraudes, desvios, corrupção etc. (Oliveira; Beltrão; Ferreira, 1997). Para os autores, a reforma da Previdência deveria definir uma linha de corte além do qual o Estado não deveria intervir, deixar claro o limite da intervenção do Estado nas decisões se investimento e de poupança das famílias.

A PEC 33, que seguia em tramitação no congresso, foi aprovada em primeiro turno em 12/02/1998 372 . Em maio, começou a votação dos destaques da oposição, com derrota para o governo nos itens referentes à idade mínima para aposentadoria na iniciativa privada e do redutor de $30 \%$ do salário para manter aposentadoria integral no serviço público ${ }^{373}$. Em discurso proferido logo após a votação dos dois destaques da reforma da Previdência, o Presidente Fernando Henrique comentava a votação: "quem está votando contra as reformas, está na prática, votando contra o povo, votando contra o salário do trabalhador, está fazendo demagogia. As reformas são justas, elas acabam com o privilégio.”374 Os

\footnotetext{
${ }^{371}$ Idem.

${ }^{372} \mathrm{O}$ governo estimava que, se mantido o projeto aprovado em $1^{\circ}$ turno, seria possível uma economia aos cofres públicos de 17 bilhões de reais até 2006, o que daria um novo sentido à Previdência Social e que a adoção do conceito de proporcionalidade ao tempo de contribuição, forneceria a base para a implantação de uma Previdência justa e redistribuidora de renda. Diário da Câmara dos Deputados, 11/03/1998: 0574105742.

${ }^{373}$ Embora sem a aprovação em segundo turno e sem a votação dos destaques, o governo, através da MP 1.663 revogou o $\S 5^{\circ}$. do artigo 57, da Lei 8.213/1991, que permitia a contagem do exercício cumulativo de atividades insalubres, perigosas e penosas com a atividade comum. No texto da PEC em votação, falava-se em contagem "exclusiva de tempo" em atividades insalubres, no entanto, ainda não havia sido votada, não sendo cabível a medida provisória, da qual decorreu a Ordem de Serviço 600, de 02/06/1998, do INSS, ordenando o indeferimento de todos os pedidos de aposentadoria que contivessem a somatória de tempo de atividade insalubre, perigosa ou penosa com atividade comum. O atropelo legislativo foi combatido pelo Deputado Arnaldo Faria de Sá (PPB/SP). Diário da Câmara dos Deputados, 18/06/1998: 16541. O caso foi para julgamento no Supremo Tribunal Federal por representar um crime contra a Constituição. Deputado Paulo Paim (PT/RS). Diário da Câmara dos Deputados, 25/08/1998: 21825-2187. O STF pronunciou-se ainda a respeito da suspensão do direito a pensão e da proibição em somar os tempos de trabalho rural e urbano para fins de aposentadoria.

${ }^{374}$ Veja a íntegra do discurso do Presidente e a entrevista coletiva à imprensa: "Não contem com quem votou contra vocês”. O Estado de São Paulo, 08/05/1998. Um dos pontos a que se refere o Presidente é a aposentadoria do setor público e os privilégios envolvidos em forte lobby, onde se localiza o principal déficit, devido ao valor alto da aposentadoria e a sua precocidade. No seu discurso, distingue os já aposentados, os
} 
destaques não foram aprovados em razão das regras regimentais para alterar a Constituição que exige maioria de $3 / 5$ do Plenário ${ }^{375}$, enquanto o Presidente contava com a maioria simples.

O governo também não tinha obtido sucesso na votação do destaque relativo ao fim da estabilidade no serviço público, o que era visto como uma "meia reforma”376, que não aliviaria as contas públicas. Havia uma dupla expectativa, de tornar as regras para aposentadoria do servidor público mais rígidas na reforma da previdência e acabar com a estabilidade, na reforma administrativa. Juntas, as duas reformas ajudariam a recompor os gastos com pessoal no serviço público, principal item de despesas. Ambas as reformas eram consideradas essenciais na arrumação das contas públicas e o fim da estabilidade permitiria o uso da demissão para regular as contas do pessoal ativo, enquanto que a reforma da previdência regularia a dos inativos.

Sob a pressão do calendário eleitoral, os líderes do governo passaram a procurar os líderes da oposição para firmar acordos sobre a reforma da previdência. O Deputado Paulo Paim, embora sem pretender falar em nome da oposição, defendia que suspender a votação da reforma até os resultados eleitorais era a medida mais adequada e justa com os Parlamentares, tanto da base governista quanto da base de oposição. O acordo era “ninguém perde, ninguém ganha. Este é o acordo. Parem com a reforma”377. A votação de medida tão controversa a apenas dois meses da eleição poderia trazer grande prejuízo eleitoral, além do que a implementação das reformas dependia diretamente do resultado nas eleições para Presidência da República.

Em junho, atropelado pelo início da Copa do Mundo, o governo tentava concluir o segundo turno da reforma. Para assegurar votos da base aliada, até telegramas foram enviados aos deputados, assinados pelo presidente da Câmara Michel Temer (PMDB/SP),

que estão no mercado de trabalho e que devem seguir regras de transição e os que ainda ingressarão no mercado.

${ }^{375}$ O governo conseguiu 307 votos contra 148 da oposição.

376 “A meia reforma do Estado empregador”, O Estado de São Paulo, 29/03/98: 3.

${ }^{377} \mathrm{O}$ discurso do Deputado Paulo Paim é preciso em afirmar que o único acordo possível era suspender a votação e aguardar o resultado das eleições presidenciais. Havia expectativa de que caso vencesse a chapa Lula/Brizola, a reforma pudesse deixar de ser endossada. "Então, por que não deixar a votação da reforma para outubro, quando já teremos conhecimento do nome do novo Presidente, para ver se ele irá endossar ou não essa proposta de reforma?. Diário do Congresso Nacional, 20/06/1998: 17083-17084. 
pelo ministro da Previdência Social, e pelas lideranças do governo e dos partidos aliados ${ }^{378}$. Havia a expectativa de que a reforma, incluindo os seis destaques, poderia ser votada em um único dia. Os pontos mais delicados para o governo com a oposição de sua base aliada eram o redutorde $30 \%$ da aposentadoria com base na idade mínima exigida para os trabalhadores incluídos nas regras de transição; e aquele que pretendia derrubar a idade mínima para aposentadoria e acrescer 20\% no tempo de contribuição até alcançar os 35 anos. Por outro lado, o fim da aposentadoria especial dos magistrados era ponto em que teria que enfrentar forte lobby ${ }^{379}$. Em discurso o presidente afirma ser preciso fazer o Estado viver dentro de seus limites, de forma rápida, decisiva e definitiva.

Com essas derrotas e sem conseguir quorum para a votação, o governo decidiu adiar a votação para depois das eleições para presidente, governadores, deputados e senadores, em novembro. Em 15/12/1998, no encerramento do ano Legislativo, o projeto foi aprovado, restando 25 dispositivos sem regulamentação. Os técnicos da Previdência consideraram que a reforma permitiria acabar com o déficit explosivo, enquanto a equipe econômica considerava que ela não ajudaria a equilibrar as contas do INSS, apenas retardando o processo.

Apesar de ampla divulgação na imprensa, o Ministro Stephanes negava que estivesse sendo formulada uma segunda etapa de reforma. Em agosto de 1998, o Senador Antônio Carlos Magalhães, presidente do Congresso, e Jorge Bornhausen, presidente do PFL entregaram ao Presidente da República documento em que recomendam a privatização da Previdência Social, nos moldes do sistema chileno. A “reforma-2" pretendia criar um sistema privado de fundo de pensão, sob a forma de poupança individual capitalizada, por meio da qual cada "segurado” teria sua aposentadoria fixada com base no valor acumulado, após ter cumprido a carência de 35 anos ou mais de contribuição e descontada a taxa de administração do fundo ${ }^{380}$.

Em setembro de 1998, Waldeck Ornélas assumia o Ministério da Previdência e Assistência Social declarando que o presidente manifestava vontade de antecipar a

\footnotetext{
${ }^{378}$ O relator da emenda da Previdência, Deputado Arnaldo Madeira (PSDB/SP), afirmava que ele que era o relator, havia recebido quatro telegramas. "Governo espera concluir Previdência até sexta”. O Estado de São Paulo, 7/06/1998.

379 “ Entidades de juízes prepara projeto contra reforma”. O Estado de São Paulo, 13/2/1998.

380 “O pacote trabalhista, a proposta do PFL e as eleições”. Boletim Diap, julho/1998, n. 95, AnoVIII.
} 
“Reforma 2” para o ano de 1999, para conciliar as normas previdenciárias à análise econômica e financeira.

O novo ministro punha em foco a previdência dos trabalhadores do setor público, especialmente dos Estados e Municípios, que produziam enorme desequilíbrio nas contas públicas $^{381}$. Enfatizou que esse desequilíbrio não adquiria a mesma dimensão pública do déficit do INSS por estar escondido na conta de pessoal da União. No entanto, para o cumprimento da meta de estabilidade fiscal, era imprescindível o acerto nas contas públicas e para isso, foi criado o "Programa de Apoio à reforma dos Sistemas Estaduais de Previdência” (PARSEP), financiado pelo Banco Mundial e executado pelo MPAS em articulação com o Ministério da Fazenda. O principal objetivo do programa seria auxiliar os Estados no equacionamento de seus sistemas previdenciários.

No entanto, os custos de transição foram decisivos para o abandono do redesenho da Previdência Social. O governo flertou com dois projetos frágeis (Coelho, 2001: 141) e demonstrou sua inabilidade em garantir a participação na negociação dos vários grupos de interesse (Silva: 2007). A reforma de Fernando Henrique só foi possível com a aprovação da Emenda que permitiu a reeleição presidencial, que modificou as regras do jogo eleitoral ${ }^{382}$.

O projeto de reforma da Previdência, após quatro anos em trâmite, com várias estratégias políticas equivocadas e autoritárias, somente pode ser aprovado após a certeza da reeleição de Fernando Henrique Cardoso em primeiro turno, em outubro de 1998. Em seu discurso de posse, declarava que “(...) a reforma da Previdência, embora incompleta, abre perspectivas melhores para o equilíbrio das contas públicas. Vamos prosseguir com

\footnotetext{
${ }^{381}$ Waldeck Ornelas (artigo). "Previdência e Setor Público”. O Estado de São Paulo, 03/11/1998.

382 "Este é o momento ideal (...) a maioria do Congresso parece disposta a aprovar. Com a nova equação política solucionada, com a aprovação da reeleição para o Executivo e a eleição de novos presidentes do Senado e da Câmara, não se pode mais negligenciar prioridades (...)”. KAPAZ,, Emerson. “A hora é agora”, O Estado de São Paulo, 10/03/1997. O Deputado José Genoíno criticou a fórmula autoritária do Governo na condução da Emenda da reeleição, ao passar por cima da convenção do PMDB e do PPB para ser aprovada. Novamente a relação entre Executivo e Congresso ganhou destaque pela falta da institucionalização de regras democráticas. “(...) ele governa, compondo com interesses dispersos e difusos, com partidos fracos $e$ representações sociais fragmentadas. Os aliados mudam de importância dependendo dos interesses que estão em jogo. O poder torna-se o único ponto de aglutinação, não em torno de um projeto, mas em torno de interesses particularistas (...)”. GENoÍnO, José. “A favor das reformas democráticas”. O Estado de São Paulo, 22/02/1997. Dionísio Dias Carneiro.
} 
ela, eliminando privilégios e assegurando a continuidade dos benefícios em favor dos que realmente necessitam (...)”. 383

Os principais pontos da reforma previdenciária de Fernando Henrique Cardoso foram: a conversão da aposentadoria por tempo de serviço em aposentadoria por tempo de contribuição; a desconstitucionalização da regra do cálculo do valor dos benefícios; avinculação das contribuições previdenciárias ao pagamento dos benefícios previdenciários e a fixação do teto de benefícios em valor nominal de R\$ 1.200,00 e não mais expresso em salários mínimos. A desconstitucionalização da regra do cálculo do valor dos benefícios e o fim da paridade com o salário mínimo eliminaram duas das principais regras instituídas em 1988 e fizeram retornar à administração o poder de ajustar receitas e despesas ao longo do tempo.

A EC 20/98 consagrou o princípio do equilíbrio financeiro e atuarial e do caráter contributivo obrigatório à Previdência Social. Ao desconstitucionalizar a regra de cálculo do valor das aposentadorias, abriu espaço para que o tema fosse tratado em legislação ordinários. Em 1999, foi enviada ao Congresso Nacional uma série de PLs ordinárias e complementares, para regulamentar as alterações constitucionais, como os planos de custeio, benefícios e organização do regime geral. A reforma se fez observando os direitos adquiridos.

A Lei 9.876/99, que reorganizou o sistema previdenciário, foi considerada pelo Ministro da Previdência, Waldeck Ornélas, a última etapa do processo de reforma previdenciária no governo Fernando Henrique, cujo propósito era estreitar a relação entre contribuição e benefícios e criar atrativos para a incorporação dos trabalhadores autônomos e não assalariados, através das seguintes medidas ${ }^{384}$ :

1. ampliação do período de cálculo do salário de benefício;

2. introdução do fator previdenciário na fórmula do cálculo do benefício;

3. eliminação gradativa da escala de salários base dos contribuintes individuais;

4. homogeneização das categorias de segurados obrigatórios;

5. diferenciação entre contribuinte inadimplente e sonegador;

6. redução dos juros para indenização do tempo de serviço passado;

\footnotetext{
383 Íntegra do discurso de posse do Presidente Fernando Henrique Cardoso: "Por um Brasil solidário”. $O$ Estado de São Paulo, 02/01/1999.

384 (MPAS, 1999).
} 
7. vinculação do pagamento do salário-família à freqüência do filho na escola;

8. generalização da cobertura do salário-maternidade.

A ampliação do período de cálculo de aposentadoria parte da tese de que a maioria dos trabalhadores apresenta uma trajetória salarial linear, não havendo aumento da remuneração ao final de sua vida profissional. Desse modo, a ampliação do período de contribuição tende a cobrir gradativamente toda a trajetória profissional e conferir forte conteúdo de justiça social, corrigindo as vantagens auferidas pelos segmentos sociais mais favorecidos, ou seja, eliminando os privilégios. O que esta proposta revela é a ausência de uma carreira profissional, explicitada pela falta de progressão salarial. O que dela se espera é que possa estabilizar o déficit previdenciário atual ao estabelecer que todas as novas concessões deverão estar baseadas em critérios atuariais.

Para o governo, o fator previdenciário é uma proposta que visa a corrigir o desequilíbrio entre o tempo de contribuição e o tempo de usufruto dos benefícios. É uma resposta à pressão demográfica sobre o sistema e permite considerar o envelhecimento da população no cálculo do benefício, a partir da apuração do tempo de “sobrevida”. O fator previdenciário inclui critérios combinados entre idade no momento da aposentadoria, tempo de contribuição, esforço contributivo e expectativa de sobrevida, na definição do valor do benefício.

Além da introdução de um critério atuarial, o fator previdenciário premiará aqueles que postergarem sua aposentadoria com um benefício maior. A justificativa do governo é de que a introdução do fator previdenciário promoverá maior eqüidade social no sistema e permitirá ao governo se concentrar no subsídio e nas políticas sociais destinadas aos mais pobres, ou seja, atua como facilitador de medidas de focalização. Acredita-se que, com o ele, o sistema adquira flexibilidade e capacidade de adaptação às transformações sociais futuras. É uma forma de individualizar o cálculo do valor do benefício.

A escala de salários-base dos contribuintes individuais foi instituída para coibir a prática de contribuir com o percentual mínimo a maior parte da vida e às vésperas da aposentadoria passar a contribuir sobre o teto, com o objetivo de majorar a aposentadoria. Ela definiria um prazo mínimo em cada classe até que o contribuinte individual pudesse alcançar a última classe. Com a instituição do fator previdenciário, que deverá observar o 
esforço contributivo de todo o tempo, ela perde a razão de ser e deve ser gradualmente eliminada.

Se o fator previdenciário permitia adequar o sistema à evolução demográfica de forma a assegurar a solidariedade entre as gerações que caracteriza o regime de repartição simples, ele não permitia resolver o problema da baixa taxa de cobertura previdenciária, estimada em 43\% da PEA e de apenas 18,3\% entre as categorias de empregadores, domésticos e autônomos ou conta próprias (MPS, 1999).

A aprovação da reforma da Previdência se deu num momento de queda do PIB e aumento do desempergo, com estimativa que alcançasse $12 \%$ da PEA em 1999. O reconhecimento de aumento do desemprego foi acompanhado de alterações nas regras e valores para concessão de seguro-desemprego. ${ }^{385}$

A generalização do salário maternidade para todas as seguradas, incluindo a doméstica, a empresária, a autônoma, a especial e a avulsa visava a aumentar o contingente de mulheres contribuintes, o que está relacionado à expectativa de vida desse grupo. Esse segundo aspecto, praticamente ausente durante os debates que conduziram à reforma previdenciária, foi assumido como uma das maiores preocupações da Previdência pósreforma. O contingente de pessoas não cobertas deverá representar um enorme custo para a sociedade se permanecerem à margem do sistema previdenciário, porque deverão demandar benefícios assistenciais. O problema é tratar da captação desse contingente da assistência social para a previdência social, tornando-os contribuintes do sistema. Um projeto acabado de inclusão previdenciária será formulado, no entanto, apenas no governo Lula.

Em 2000, foi aprovada a Lei de crimes contra a Previdência Social, que alterou o Código Penal tipificando e definindo as penalidades contra os fraudadores, em atenção à cobrança política de imprimir maior racionalidade ao sistema. Em janeiro de 2002, foi sancionada a lei que permite o reconhecimento automático do direito, sem a necessidade de comprovação da qualidade de segurado ou do salário do benefício. Essa modificação permitiu ao INSS utilizar as informações sobre remunerações constantes do Cadastro Nacional de Informações Sociais (CNIS), conferindo maior segurança para beneficiários e para a instituição na concessão de benefícios.

385 “PIB cai 3\% e desemprego explode, diz economista”, O Estado de São Paulo, 03/11/1998. 
Os percalços enfrentados pelo Governo Fernando Henrique em seu primeiro mandato contribuíram para acender a tese do Congresso revisor a ser instalado em 1999, respaldado por consulta popular. O Deputado Miro Teixeira (PDT/RJ) propusera transformar o Congresso eleito em outubro de 1998 em Congresso revisor, com agenda e tempo definido. Essa proposta foi acolhida com simpatia, inclusive pelo Presidente da República e endossada pelo Deputados Inocêncio Oliveira (PFL/PE) e Aécio Neves (PSDB/MG). A agenda do Congresso revisor compreenderia os temas da estrutura políticopartidária, sistema tributário e o pacto federativo e teria como principal atributo a mudança nas regras do jogo: o quorum para aprovação seria o da maioria absoluta, em sessão conjunta da Câmara e do Senado, garantido apenas o rito de dois turnos. O Congresso revisor representava uma saída honrosa para o fracasso do governo nas reformas, porém inconstitucional e não vingou, por ser um golpe político ${ }^{386}$.

\section{A reforma de FHC e o fator previdenciário:}

O fator previdenciário representa “contribuições médias do trabalhador ao longo de sua vida laboral, acumuladas e corrigidas monetariamente, incidindo ainda, sobre estas, uma taxa de juros que varia de acordo com a escolha pessoal de cada segurado quanto a data da sua aposentadoria” (Ornelas; Vieira, 1999: 16-17) ${ }^{387}$. Para o governo, o fator previdenciário introduz no regime de repartição simples a equalização entre contribuição e benefícios, permitindo que ajustes demográficos sejam realizados de forma endógena ao sistema. O aumento da expectativa de sobrevida da população ou a mudança no perfil de entrada e saída do segurado no sistema estão inseridos no cálculo do salário de benefício.

A nova lei não produziu nenhum impacto sobre o estoque de benefícios, ou seja, entre os já aposentados. As novas regras passaram a ser aplicadas integralmente àqueles que ingressaram no mercado de trabalho após sua edição e, mediante uma regra de transição, para os que já participavam do mercado formal de trabalho. A expectativa é que seja retardado o ingresso de novas aposentarias, o que produziria impacto em longo prazo no volume dos gastos da Previdência, sem produzir impacto no estoque de aposentadorias.

\footnotetext{
386 “Tese do Congresso revisor provoca polêmica”. O Estado de São Paulo, 19/03/1998. “A Constituinte de 1999”. O Estado de São Paulo, 21/03/1998.

${ }^{387}$ Ver Nota Técnica sobre o fator previdenciário, Anexo I.
} 
Pinheiro e Vieira (1999), ao analisarem as mudanças nas regras do cálculo dos benefícios permitidas pelo fator previdenciário, apontam para dois resultados principais: o benefício passou a representar o esforço contributivo de toda a vida laboral e o ajuste entre o tempo de contribuição e o tempo de recebimento de benefício. Nesse segundo caso, contribuem também o aumento da idade para a aposentadoria e o tempo de carência para benefícios programáveis.

A introdução do fator previdenciário tende, desse modo, a estabelecer uma aproximação com o modelo de cálculo de benefício realizado no regime de capitalização. Foi, portanto, uma solução intermediária entre a privatização e a manutenção do regime de repartição simples ${ }^{388}$, no formato próximo de uma capitalização escritural ${ }^{389}$, no qual, apesar da manutenção do regime de repartição simples, dá-se a equivalência entre contribuições e benefícios, assim como mecanismos que garantem o ajuste do sistema às mudanças demográficas. No Brasil, a reforma não caminhou para a adoção de um modelo de capitalização escritural por ser impossível fixar uma taxa de juros de longo prazo. De outro modo, a operacionalização seria difícil, sobretudo, por falta de informações cadastrais de períodos extensos.

No MPS, a expectativa era de que a correlação entre contribuição e benefícios permitiria a estabilização do déficit do sistema a longo prazo. De qualquer forma, a regra foi desconstitucionalizada e voltou ao domínio técnico, dessa vez, amparado em critérios atuariais.

A aprovação da reforma deu início a uma série de medidas que visaram a racionalização do sistema previdenciário, com uma série de classificações das receitas e despesas previdenciárias que depuraram o sistema, isolando aquilo que era o cerne das despesas previdenciárias. Essas medidas passam pela rígida separação do que seja despesa previdenciária do regime geral, EPU e benefícios assistenciais e pelo reconhecimento de que renúncias previdenciárias devem ser cobertas com recursos do orçamento fiscal (entidades filantrópicas, clubes de futebol e sistema de tributação das pequenas empresas).

\footnotetext{
${ }^{388}$ No regime de repartição simples os trabalhadores ativos financiam os atuais inativos.

389 Tradução livre do inglês, national accounts; também tem sido denominada de capitalização virtual, modelo de contas nacionais, contas individuais ou contas imaginárias. Esse tipo de regime foi introduzido em países como a Suécia, Itália, Polônia e Lituânia. Funciona em regime de repartição simples, mas com contas imaginárias, onde são depositadas as contribuições de cada segurado, que são capitalizadas segundo uma determinada taxa de juros. O cálculo do benefício é feito com base na divisão do valor acumulado, pela expectativa de vida do segurado no momento da aposentadoria (PINHEIRO; VIEIRA, 1999).
} 
Muitas dessas já vinham sendo denunciadas pelo TCU que exigia maior transparência nas contas da Previdência.

Um efeito da reforma foi que a vinculação entre a contribuição realizada sobre a folha de pagamento de salários e pagamento de benefícios eliminou a possibilidade de desvio dos recursos da Previdência Social, permitindo que se penetrasse nos segredos e mistérios de sua “caixa preta” (Ornélas, 1999).

Um segundo efeito, foi produzido pela LRF, que instituiu o Fundo do RGPS e vinculou os recursos previdenciários a uma conta específica, que permite visualisar as receitas e despesas da Previdência, em separado, inclusive do custeio do INSS. Também por efeito da LRF o Orçamento Geral da União passou a trazer um balanço na conta previdenciária do regime próprio da previdência dos funcionários públicos. A mesma regra passou a valer para Estados e Municípios. A partir do ano de 2001, a LDO passou a explicitar as renúncias previdenciárias.

Em discurso proferido durante seminário, o Ministro afirmou que a reforma deu início a uma nova fase na história da Previdência, cujo efeito central deverá ser promover a cultura do seguro social, ou seja, a interiorização da idéia de é necessário contribuir no valor suficiente, para que no futuro possa receber benefícios previdenciários (Ornélas, 1999).

O novo foco do governo, a partir de então, seria aperfeiçoar os mecanismos gerenciais e administrativos e estimular a filiação dos trabalhadores (não formais) ao sistema previdenciário. As questões que a reforma deixou em aberto foram a fixação da idade mínima para aposentadoria no RGPS e a unificação dos regimes dos trabalhadores privados e servidores públicos em uma única instituição, com critérios uniformes.

A racionalização perpassa também a instituição com a adoção de procedimentos novos que também conferiram à instituição maior agilidade no atendimento às demandas dos usuários, com programas de terceirização no atendimento, criação de gerências executivas com mais autonomia, sistema informatizado e implantação de terminais de autoatendimento. “O objetivo de todas estas medidas é racionalizar os procedimentos e elevar a qualidade dos serviços. Busca-se, desta forma, introduzir uma grande melhoria no padrão administrativo e gerencial e, sobretudo, criar mecanismos sólidos e consistentes de combate à fraude, de combate à sonegação e à corrupção na administração previdenciária” (Ornélas, 1999: 24). 
Outras medidas adotadas que caminham no sentido da racionalização foram maior rigor na aplicação de multas para sonegadores; o PL de crimes contra a Previdência; gerenciamento por segmentos econômico com monitoramento mensal das 42.000 maiores empresas que respondem por $83 \%$ da arrecadação previdenciária; eficácia na ação fiscal e da ação executiva da Procuradoria etc. São medidas de racionalização que seguem os critérios da racionalidade econômica.

\section{Lei da Responsabilidade Fiscal, CPMF e DRU}

A CPMF foi instituída através da EC 12, de 15/08/1996 para financiar as ações e serviços de saúde. Considerada um bom instrumento arrecadatório, com baixa taxa de evasão, foi prorrogada continuamente até 2007, quando após um longo período de negociações cessou de existir. A partir de 1999, teve a sua alíquota majorada e passou a custear também as ações da previdência social nos exercícios de 1999, 2000 e 2001.

A EC 19, de 4/06/1998 estabeleceu o controle de despesas e finanças públicas e o custeio de atividades. A Lei de Responsabilidade Fiscal (LC 101, de 04/05/2000) visa ao cumprimento de metas de resultados entre receitas e despesas e a obediência a limites para a renúncia fiscal e geração de receitas para a seguridade social. Renúncia é igual a anistia, remissão, subsídio, crédito presumido, concessão de isenção, alteração de alíquota ou modificação de base de cálculo que implique em redução de tributo ou de contribuições.

A Lei de Diretrizes Orçamentárias deveria dispor sobre o equilíbrio entre receitas e despesas, as metas fiscais, o montante da dívida pública, a evolução do patrimônio líquido, a avaliação da situação financeira e atuarial dos regimes de geral de previdência social e o regime próprio dos servidores públicos e do FAT, bem como dos demais fundos públicos, a estimativa de renúncias fiscais e das despesas obrigatórias. Toda renúncia fiscal deverá ser acompanhada de estimativa de impacto orçamentário-financeiro. A LRF ${ }^{390}$ foi instituída com o objetivo de estabelecer normas de conduta ao administrador público com a finalidade de alcançar equilíbrio nas contas públicas e conferir moralidade à gestão pública. A LRF, quando adotada perante as contas da Previdência Social, é uma figura estranha, posto que os benefícios não podem deixar de ser pagos, ainda que em desrespeito à referida

${ }^{390}$ Lei Complementar 101, de 04/05/2000. 
lei. No entanto, deve servir como parâmetro de ajuste das contas previdenciárias da União, Estados e Municípios, conduzindo ao equilíbrio atuarial. Mas a LRF não impõe medidas restritivas quanto ao uso de recursos da seguridade social para outros fins.

A mesma lei criou o Fundo Previdenciário que permite a visualização da conta previdenciária isoladamente (contribuições de empregados e empregadores x pagamento de benefícios), tornando-a distinta dos EPU.

A EC 27, de 21 de março de 2000 instituiu a desvinculação de arrecadação de impostos e contribuições sociais da União no percentual de $20 \%$ da arrecadação de impostos e contribuições sociais da União, já instituídos ou que vierem a ser criados. O disposto não reduziria a base de cálculo das transferências a Estados, Distrito Federal e Municípios e excluía da desvinculação a arrecadação da contribuição social do salário educação. Primeiramente válido até 2003, foi reeditada.

A principal justificativa para implementação da $\mathrm{DRU}^{391}$ era a necessidade de criar receitas livres de vinculações. As vinculações das contribuições sociais à seguridade social, as vinculações da educação, o federalismo fiscal, somados a gastos fixos como o pagamento de pessoal e de benefícios previdenciários, levou o governo a enfrentar dificuldades para alocação de recursos de acordo com suas prioridade. Apesar da justificativa, a DRU vem sendo utilizada para a formação de superávit primário destinado ao pagamento dos serviços da dívida pública.

Em 2005, o Deputado Carlos Souza (PP/AM) apresentou o PL 5.584 que destinava integralmente os recursos livres da DRU para a Previdência Social. Do mesmo modo, o projeto destinava todo o montante arrecadado pela CPMF para complementar o OSS. As contribuições sobre o lucro e faturamento das empresas (Cofins e CSLL) deveriam ser destinadas à cobertura dos benefícios de trabalhadores rurais, idosos e portadores de deficiência. O projeto que buscava recompor o OSS e a integração entre as três áreas não foi aprovado. Ele já estava fora do tempo.

A EC 42, de 19/12/2003 (Lula) aprovou a integração entre as administrações tributárias nos níveis da federação e o compartilhamento de cadastros de informações fiscais. Pretendia instituir um regime único de arrecadação dos impostos e contribuições

\footnotetext{
${ }^{391}$ A DRU é na verdade uma reformulação do Fundo Social de Emergência, transformado primeiramente em Fundo de Estabilização Fiscal.
} 
sociais da União, dando formato primeiro a uma unificação de cadastros e, depois, à unificação da arrecadação.

\section{Governo Lula e a reforma da racionalidade}

Em janeiro de 1996, a Liderança do PT no Congresso apresentava uma nota sobre as negociações entre o Governo Fernando Henrique e as centrais sindicais, na qual afirmava o seu compromisso com um modelo de Seguridade Social universal e equânime e, para tal, objetivava uma reforma capaz de conferir-lhe estabilidade financeira e fixar parâmetros universais e justos para todos os brasileiros. O documento, em resposta à negociação direta entre as centrais e o governo, afirmava a legitimidade da negociação e enfatizava a divergência do partido em relação ao projeto original e ao substitutivo Euler Ribeiro. O documento apresentava ainda o que o PT entendia como pontos básicos para a reforma da Previdência $^{392}$ :

1. garantia da previdência pública com a centralização da arrecadação sob o controle da própria Seguridade Social e manutenção de orçamento próprio para evitar os desvios de recursos;

2. gestão pública e não meramente estatal, com administração compartilhada entre Estado, trabalhadores, empresários e aposentados;

3. regime básico com regras universais: piso de benefícios de um salário mínimo e teto de dez para todos os trabalhadores, sem qualquer exceção, com iguais direitos e deveres, claramente explicitados na Constituição;

4. previdência complementar para os benefícios acima de dez salários mínimos, sendo pública, privada ou na forma de fundos de pensão. Neste último caso, explicitandose a regra de financiamento 2/1 (patrões/empregados) no caso de estatais e serviços públicos;

5. transição gradual e negociada que não provoque corrida às aposentadorias, o que prejudicaria os serviços e orçamentos públicos, além de uma avalanche de recursos ao Poder Judiciário;

\footnotetext{
392 "Partido dos Trabalhadores: gabinete da Liderança”. Brasília, 17 de Janeiro de 1996. Diário da Câmara dos Deputados, 19/01/1996: 02012-02013.
} 
6. manutenção da aposentadoria por tempo de serviço: manutenção deste benefício, estudando-se fórmulas para aperfeiçoá-lo, de modo a não discriminar os trabalhadores de baixa renda e

7. financiamento da Previdência: sincronizar as discussões e votações das Reformas da Previdência e Tributária, de forma a equilibrar o orçamento Fiscal e o da Seguridade, estimular a atividade econômica e garantir o conjunto das políticas sociais.

Em 2002, Luiz Inácio Lula da Silva (PT/SP) foi eleito Presidente da República e deu início à sua própria reforma da Previdência. O ponto foi considerado prioridade pelo Presidente Lula, que buscou reforçar o sistema previdenciário público, básico e universal e fortalecer o regime de previdência complementar. Para alcançar o primeiro objetivo, a reforma buscou alterar os critérios de acesso, cálculo e benefícios dos servidores públicos. Para alcançar o segundo, a nova previdência passou a admitir um regime complementar também para servidores públicos, o que tornou possível a equivalência entre os tetos de aposentadoria nos dois regimes de previdência.

A proposta original seguia a instituição do modelo multi-pilar defendida pelo Banco Mundial e tinha como principais justificativas o fim dos privilégios dos servidores públicos regidos por critérios diferentes do RGPS, a contenção das despesas públicas com a folha de pagamentos $^{393}$ e o reforço ao vínculo entre contribuição e benefícios, dotando também o regime próprio de critérios atuariais. A justificativa para a reformulação do regime próprio dos servidores públicos foi: ausência de teto de benefícios, aposentadoria integral pela última remuneração ativa e a inexistência de limite de idade para concessão de aposentadoria.

Esse foi um dos pontos da reforma de Fernando Henrique que não satisfez empresários, economistas e dividiu a opinião pública. Ao final de sua reforma, o sistema previdenciário não havia sido modificado, apenas “ajustado”, o que fez muitos a denominarem de "meia reforma” ou "reforma meia-sola".

A PEC 40-A, de 2003, foi encaminhada ao Congresso Nacional acompanhada da Exposição de Motivos 29, subscrita pelo Ministro da Previdência Social e pelo Ministro

${ }^{393}$ As novas regras são válidas para a União, Estados e Municípios. 
Chefe da Casa Civil e, em obediência às normas regimentais, foi submetida à CCJR que proferiu pela sua admissibilidade, com duas emendas saneadoras. Em seguida, foi constituída a Comissão Especial destinada a proferir parecer à PEC 40-A, de 2003 (CESP).

O Presidente Lula, ao discursar para deputados estaduais e vereadores do PT reforçou o vínculo de solidariedade entre gerações existente no sistema de repartição simples: “(...) não estamos reduzindo salário de ninguém. Estamos pedindo: companheiro, deixa os $11 \%$ pra que amanha teu filho, teu neto possa se aposentar. Não estamos fazendo nenhuma maldade, não queremos privatizar a Previdência (...)”394. Esse vínculo, na verdade, inexistia para o funcionalismo público até 1998, visto que inexistia a contribuição para aposentadoria dos funcionários públicos e os gastos eram inseridos na folha de pagamentos do Estado. Os servidores públicos contribuíam apenas para o pagamento de pensões deixadas aos dependentes em caso de morte. O presidente nacional do PT, José Genoíno afirmou, no mesmo encontro, que a meta não era privatizar a previdência, mas melhorar o regime geral e que o foco seria a categoria dos servidores públicos, responsáveis pelo elevado déficit do sistema previdenciário, cujo montante chegava em 2003, a R\$ 56 bilhões.

Para o Presidente Lula, a reforma objetivava aumentar os direitos de quem não tem nenhum, melhorar as condições de vida da maioria da sociedade e permitir que os excluídos (do mundo do trabalho, da Previdência e da Saúde) "possam participar do processo distributivo do Estado brasileiro,395.

É interessante observar como, ao longo dos debates sobre a reforma da previdência, os beneficiários do sistema vão mudando de lugar, o que tem uma implicação sobre os objetivos da instituição. De expressão de um vínculo entre trabalho e mérito que a situava como produtora de status para os trabalhadores participantes do mercado formal de trabalho, teve o seu repertório expandido para abarcar um contingente mais amplo da população. A impossibilidade de financiamento conduziu à tentativa de um novo formato, no qual a previdência social partilharia com a assistência social e com a saúde o dever de proteção social. Novamente, a insuficiência financeira e a deterioração das contas públicas

\footnotetext{
${ }^{394}$ II Encontro Nacional de Deputados Estaduais e Vereadores do Partido dos Trabalhadores (PT), ocorrido em 27/06/2003 e que teve por objetivo discutir a situação da Previdência.

395 Discurso do Presidente Luiz Inácio Lula da Silva, durante o II Encontro Nacional de Deputados Estaduais e Vereadores do Partido dos Trabalhadores (PT), ocorrido em 27/06/2003.
} 
reconduziu os benefícios assistenciais para dentro da Previdência Social. Esse vai-vém expressa uma certa dificuldade em se estabilizar o lugar dos direitos sociais e, ao mesmo tempo, leva a um questionamento incessante sobre o que é a Previdência Social, qual o seu papel na sociedade. Deve a previdência social comportar-se como um seguro social para os contribuintes ou, ao contrário, deve destinar-se ao atendimento dos mais pobres, dos excluídos do mercado de trabalho? Muito próximo às questões da focalização, esse tipo de questionamento nega a experiência do trabalho como produtor da solidariedade social.

O foco da reforma nos benefícios previdenciários dos servidores públicos foi explicitado pelo Ministro da Previdência Social em Audiência Pública na CESP sobre a PEC 40/2003, em 25/06/2003 ${ }^{396}$. A justificativa foi centrada no desequilíbrio estrutural provocado pela adoção de critérios generosos de remuneração da aposentadoria, ausência de vínculo contributivo e permissão de averbação de tempo trabalhado na iniciativa privada para a contagem de tempo. Destacou, ainda, que a concepção da reforma foi balizada pelo respeito ao direito adquirido, por atribuir um conceito realmente previdenciário ao sistema e reverter o quadro de comprometimento de recursos do orçamento público com o pagamento de benefícios previdenciários.

A nova reforma foi aprovada em sistema bicameral, em votações de dois turnos em cada Casa, com maioria de 3/5 em apenas sete meses, representando uma vitória política para o Governo recém eleito ${ }^{397}$ : em agosto de 2003, na Câmara dos Deputados ${ }^{398}$ e, em dezembro de 2003, no Senado. A votação do segundo turno na Câmara dos Deputados envolveu acordo com os líderes de partidos de não apresentar destaques à matéria no segundo turno. Na mesma data, foi aprovada a reforma tributária (EC 42/2003).

Houve uma confluência dos Três Poderes para a aprovação da reforma da previdência, como voto favorável do Supremo em favor da instituição da cobrança de

\footnotetext{
${ }^{396}$ Ata da Audiência Pública da Comissão Especial que analisa a PEC 40/2003. Diário da Câmara dos Deputados, 26/06/2003: 1236.

${ }^{397}$ A vitória do governo na votação da PEC 40 foi objeto de elogio em editoriais de três importantes jornais: O Globo, o Estado de São Paulo e Folha de São Paulo, os quais citavam o tempo recorde, balanço positivo entre lucros e perdas, a não descaracterização do projeto original e a demonstração de confiabilidade. Ver edições do dia 07/08/2003.

${ }^{398}$ A PEC foi aprovada pela Câmara em 27/08/2003 e enviada ao Senado pelo Deputado José Sarney (PMDBAP) em 28/08/2003. Em 11/12/2003 foi aprovada no Senado. Na Câmara, a votação registrou 357 votos favoráveis, 123 contrários e 6 abstenções; no Senado, 51 votos a favor e 24 contrários. A votação em contrário ao determinado pela legenda do PT na Câmara resultou na expulsão de 4 deputados do PT. O episódio demonstra a disciplina exigida pelo governo na sua base aliada na votação de projetos de seu interesse, diferindo do padrão apresentado no Governo Fernando Henrique.
} 
contribuições previdenciárias. A Primeira Turma do $\mathrm{STF}^{399}$ reconheceu a validade das contribuições previdenciárias instituídas pelo Governo de Minas Gerais antes da aprovação da EC 20/98. Ao fazê-lo, sinalizou ao Governo Lula que a EC 20 foi o fator impeditivo para aprovação da cobrança de inativos através de Lei Ordinária em 1999, contrária, portanto, à Constituição e deixava claro que para instituí-la, bastaria aprová-la através de uma nova Emenda Constitucional.

A sinalização do STF foi decisiva para o Governo, que sabia de antemão que não sofreria ação de inconstitucionalidade caso instituísse a cobrança, sob alegação de que o novo tributo violaria um direito adquirido dos atuais servidores inativos. Para José Genoíno, a contribuição previdenciária dos inativos era "um imperativo de responsabilidade e de justiça social”, “uma contribuição solidária dos aposentados para com o sistema e a sociedade" e que deveria produzir "efeito distributivo" e "permitir que o Estado invista mais em outras áreas" ${ }^{\text {400. }}$.

A reforma da Previdência foi um grande teste para o Governo Lula e serviu para reafirmar a condução da política econômica, o seu compromisso com a estabilidade e conferir-lhe condições de governabilidade (Gramacho: 2003). A aprovação da reforma no primeiro ano permitiu que o Presidente aproveitasse o seu nível de popularidade, que formasse a maioria no Congresso ${ }^{401}$ e obtivesse espaço no Orçamento para uma gestão mais eficiente dos recursos tributários.

\footnotetext{
399 A decisão da Primeira Turma foi tomada por 3 dos 11 ministros do STF: Sepúlveda Pertence, Gilmar Mendes e Ellen Grace. No Governo Fernando Henrique a instituição da contribuição sobre aposentadorias e pensões pela Lei 9.783/99 foi derrubada por 11 votos a zero, em setembro de 1999, porque não era previsto no texto constitucional e porque não instituía nenhum beneficio em contrapartida. "STF sinaliza que não vai derrubar cobrança de inativos”. Folha de São Paulo, 22/06/2003. Dizia o Relatório do Ministro Celso de Mello: "Se é certo, portanto, que nenhum benefício ou serviço da seguridade social poderá ser criado, majorado ou estendido sem a correspondente fonte de custeio total (CF, art 195, \& $5^{\circ}$ ), não é menos exato que também não será lícito, sob uma perspectiva estritamente constitucional, instituir ou majorar contribuição para custear a seguridade social sem que assista àquele que é compelido a contribuir, o direito de acesso a novos benefícios ou a novos serviços”. Ação Declaratória de Inconstitucionalidade n. 2.010-2/DF, Medida Cautelar, Relator Ministro Celso de Mello, Pleno, DJ 12/04/2002 (apud RocHA, 2004: 156). No julgamento do Governo Lula participariam também os três ministros indicados pelo Presidente Luiz Inácio Lula da Silva: Carlos Ayres Britto, Joaquim Barbosa e Antonio César Peluso.

400 “O PT e a taxação dos inativos”. O Estado de São Paulo, 10/05/2003.

${ }^{401}$ A formação da maioria não era tarefa fácil para o Governo que tinha como aliados nas eleições o PT, PL, PCdoB, PCB e PMN. As negociações em torno da proposta de reforma da Previdência foram intensas e envolveram os três Poderes, diversas entidades de classe e tiveram ampla divulgação na imprensa. Entre a apresentação da proposta na mídia e a votação na Câmara o tema da reforma da Previdência teve ampla repercussão na mídia, a qual foi reduzindo enquanto se tinha a certeza de que não sofreria alterações significativas. Gramacho ao analisar a performance da reforma da Previdência na mídia, afirma que é possível estabelecer uma correlação entre a exposição e uma extensão na cobertura previdenciária. "A Previdência
} 
A PEC 40 buscava reformar as regras de concessão, cálculo e benefícios para os servidores públicos, como fim da aposentadoria proporcional na transição, redutor de $5 \%$ por ano antecipado na idade mínima para aposentadoria, estabelecer o mesmo teto para o regime próprio dos servidores públicos e afiliados ao RGPS e incentivar a permanência em serviço após cumprir regras de transição, através da concessão de um abono de permanência em serviço para servidores públicos. A grande questão era ampliar a base de financiamento do sistema previdenciário através da cobrança previdenciária de ativos e inativos e não seriam “discursos e petições corporativistas insustentáveis que bancarão as aposentadorias futuras, mas recursos concretos garantidos com propostas responsáveis e exeqüíveis" ${ }^{402}$.

O substitutivo do relator, deputado José Pimentel, retomou a situação vigente antes da EC 20/98 em relação ao atendimento da cobertura dos acidentes de trabalho, conferindo competência exclusiva à previdência social. A EC 20/98 havia estabelecido que o atendimento seria realizado concorrentemente pelo RGPS e pelo setor privado. Com o substitutivo, foram adotados critérios mais generosos que o proposto pelo governo na concessão das pensões e no teto para isenção de inativos do serviço público federal. Na votação na Câmara dos Deputados, os 128 destaques individuais apresentados ao relatório foram rejeitados em bloco pelos deputados. Também foram rejeitados os três destaques individuais apresentados pelo PFL e votados nominalmente: teto para pagamento integral das pensões, sem desconto; instituição de um regime especial de previdência, com benefícios limitados e contribuição reduzida para incluir 40,7 milhões de brasileiros que estão fora da previdência e a supressão da contribuição dos inativos.

As principais mudanças para os trabalhadores do RGPS foram: aumento do teto de contribuição e benefício; re-estatização do monopólio do seguro de acidente de trabalho e previsão de lei para facilitar a filiação de trabalhadores de baixa renda. As mudanças mais substanciais atingiram os servidores públicos com enrijecimento das regras de transição: a introdução de contribuição sobre aposentadorias e pensões com alíquota idêntica à dos servidores ativos (incidente sobre a parcela da pensão que superar o limite de isenção do

Social, como instituição pública de proteção de renda do trabalhador e de seus familiares, parece ter sido fortalecida ao longo do debate sobre a reforma da Previdência”. Gramacho, 2003: 14.

402 Declaração do presidente nacional do PT, José Genoíno. “O PT e a taxação dos inativos”, O Estado de São Paulo, 10/05/2003. 
imposto de renda); fixação de teto para remuneração (incluindo pensão e aposentadorias); introdução de critérios cruzados para aposentadoria; perda de direitos na aposentadoria proporcional (para os incluídos na regra de transição); introdução de fator redutor de proventos de $5 \%$ por ano de idade inferior àqueles estabelecidos ${ }^{403}$.

A fixação de critérios cruzados de idade, tempo de contribuição, tempo no serviço público, tempo no cargo, tinha por objetivo desincentivar a migração ao final de carreira do RGPS para o RPPS com objetivo de obter a vantagem da concessão de aposentadoria integral. Por outro lado, fortalece a vinculação dos funcionários públicos ativos com o Estado.

As regras para os futuros servidores públicos se tornaram ainda mais rígidas, o que deve desmotivar o ingresso na carreira pública: vínculo entre benefícios e contribuições, válido para trabalhadores ativos e inativos (incluindo pensões); perda da paridade entre ativos e inativos; submissão a tetos e subtetos remuneratórios (incluindo proventos, aposentadorias e pensões); introdução de novo cálculo para pensões (introdução de redutor de $30 \%$ sobre o que exceder o limite de $\mathrm{R} \$ 1.440,00)$.

O governo pretendia uma redução de $50 \%$ nas futuras pensões aplicáveis para valores que excedessem R $2.400,00$ e a Câmara aprovou um redutor de 30\% e, na cobrança de inativos, o teto sugerido pelo governo era de $\mathrm{R} \$ 1.200,00$ e foi aumentado para $\mathrm{R} \$ 1.440,00$ (em valores nominais).

Por força da Emenda Constitucional, os militares da Forças Armadas passaram a ter suas retribuições submetidas aos tetos e subtetos. Os demais militares (Polícias e Corpo de Bombeiros) ficaram sujeitos às mesmas regras dos demais funcionários públicos, com fixação de teto e subteto (proventos, aposentadorias e pensões) e fator redutor sobre as pensões. Os futuros militares não poderão utilizar tempo fictício para aposentadoria.

No Senado, o parecer do relator da reforma da previdência ${ }^{404}$, Senador Tião Viana (PT/AC) manteve o texto aprovado na Câmara dos Deputados, rejeitando as 321 emendas apresentadas, bem como os votos em separado, propostos por membros do colegiado; ficaram pendentes de apreciação os destaques à matéria. A votação ocorreu na madrugada

\footnotetext{
${ }^{403}$ Gilberto Guerzoni Filho. Consultoria Legislativa. Brasília, 18/07/2003. Estudo s/n. sobre a PEC 40/2003, Poder Executivo e o substitutivo do relator na Comissão Especial.

${ }^{404}$ No Senado a PEC tramitou com o no. 67/2003.
} 
do dia 25/09/2003 e registrou 14 votos favoráveis (PT, PMDB, PSB, PTB, PPS, PL) e sete contrários (PDT, PFL, PSDB) ${ }^{405}$.

O projeto original do governo previa uma economia de cerca de R 50 bilhões de reais em 20 anos; com as alterações realizadas pela Câmara, essencialmente com a regra das pensões e com a regra de transição, a economia cairia para R \$7,2 bilhões em 20 anos. $^{406}$ No entanto, para o Ministro da Previdência, Ricardo Berzoini, embora a economia seja importante, o mais importante é reverter a tendência ao crescimento do passivo previdenciário $^{407}$. Para a equipe econômica, os fundos de pensão são importante instrumento para incrementar a poupança interna do País, cujo montante chegava em 2002, a R 215 bilhões, com previsão de dobrar em dez anos.

Em relação ao déficit da Previdência, argumentava o Ministro que o problema era maior no serviço público, que somou R 39 bilhões em 2002, enquanto que no INSS foi de R\$ 17 bilhões, considerando as contribuições exclusivas para a Previdência Social. No entanto, o Ministro fazia questão de ressaltar que não se pode propriamente falar em déficit no INSS porque: 1 ) ele embute o sistema rural, justo e adequado, mas com alíquotas de contribuição diferenciadas em relação aos trabalhadores urbanos; 2) o INSS foi criado para ser subsidiado por contribuições sociais não diretamente vinculadas aos participantes, como a Cofins, a CSLL e a CPMF, pelo reconhecimento da insuficiência das contribuições sobre a folha de pagamentos para arcar com todos os compromissos assumidos. No entanto, considera que se deve sempre tomar cuidados para que o peso da Previdência não prejudique a partilha de recursos com a saúde e a assistência.

\footnotetext{
${ }^{405}$ Votaram contra o parecer do relator os senadores: Álvaro Dias (PDT/PR), Antônio Carlos Magalhães (PFL/BA), Arthur Virgílio (PSDB/AM), César Borges (PFL/BA), Demóstenes Torres (PFL/GO), José Jorge (PFL/PE) e Tasso Jereissati (PSDB/CE). Votaram a favor, os senadores: Aloísio Mercadante (PT/SP), Amir Lando (PMDB/RO), Ana Júlia Carepa (PT/PA), Antonio Carlos Valadares (PSB/SE), Fernando Bezerra (PTB/RN), Garibaldi Alves Filho (PMDB/RN), João Batista Mota (PPS/ES), José Maranhão (PMDB/PB), Magno Malta (PL/ES), Marcelo Crivella (PL/RJ), Pedro Simon (PMDB/RS), Renan Calheiros (PMDB/AL), Romero Jucá (PMDB/RR), Tião Viana (PT/AC). Boletim DIAP, 25/09/2003.

${ }^{406}$ A economia de R\$ 47 bilhões em 20 anos era estimada contando que todos os servidores com direitos adquiridos pelas atuais regras pediriam sua aposentadoria; poderia chegar a R \$ 49 bilhões se apenas metade solicitasse a aposentadoria. Nos Estados a economia poderia variar entre R\$ 10 e R \$ 15 bilhões em 20 anos, com um cálculo conservador. "Se o governo não tivesse tomado medidas fortes de responsabilidade fiscal, não estaríamos discutindo crescimento econômico para 2004 (...) a (reforma da) Previdência Social está inserida neste contexto, até pelos efeitos da redistribuição de renda”. Joaquim Levy, Secretário do Tesouro Nacional. Seminário "Reforma da Previdência - o Brasil e a Experiência Internacional”. Brasília: Palácio do Itamaraty, 01 e 02/10/2003. O seminário foi promovido pelos Ministérios da Previdência Social, das Relações Exteriores e pela Organização para Cooperação e Desenvolvimento Econômico (OCDE).

407 "Para ministro, é a reforma da racionalidade”. Gazeta Mercantil, 27/11/2003. Entrevista com o Ministro da Previdência, Ricardo Berzoini após a aprovação da PEC 40/2003.
} 
A entrevista do Ministro é um dos raros momentos em que se retorna ao tema da integração entre as três áreas da seguridade social, ainda que a referência seja apenas no aspecto financeiro, demonstrando o quanto o conceito já estava superado. Mas explicita também as duas principais questões no financiamento da previdência: reconhece a insuficiência da folha de pagamento como única fonte de financiamento; a presença de benefícios contributivos e não contributivos nas contas da Previdência. Ou seja, reconhece que há problema tanto na arrecadação, quanto nas despesas que influem negativamente sobre as contas previdenciárias.

Para o Ministro, o relatório de José Pimentel sobre a reforma "foi uma solução possível e viável e que tem o apoio do governo (...) é um texto que garante a justiça orçamentária e a sustentabilidade, e que está adequado à concepção de reforma da Previdência que vem sendo discutida desde janeiro (...)”408.

Para o Ministro, a nova lei provocava alterações profundas no sistema, como o fim das aposentadorias integrais e da paridade de vencimentos aos futuros funcionários públicos e da taxação dos inativos. O principal objetivo a ser alcançado era o incentivo à permanência no serviço público, adiando o impacto orçamentário das aposentadorias precoces. Nesse caso, o redutor do valor final do benefício é o que motivaria a permanência, por penalidade e não por incentivo, como afirmou o ministro.

A admissão de novas regras de inclusão de previdenciária para cerca de 40 milhões de trabalhadores informais foi uma inovação da reforma previdenciária, que já vinha sendo gestada no MPAS e que permitiria que pessoas menos favorecidas e inseridas no mercado informal de trabalho tivessem uma contribuição diferenciada (8\% sobre o salário mínimo), contra benefícios também diferenciados, tais como carência de 15 anos, benefício de valor único (um salário mínimo) e reconhecimento apenas da aposentadoria por idade. No entanto, o maior benefício a esse grupo populacional seria a garantia de renda em casos de doença, gravidez ou idade avançada.

O Ministro considerou que a regra de cálculo das pensões, alterada pela Câmara com o substitutivo do relator, foi o pior item da negociação pela aprovação do projeto, porque, com o original, a economia seria maior.

\footnotetext{
408 “Relatório foi solução possível e viável, diz ministro”. Agprev - Agência de Notícias da Previdência Social, 17/07/2003. http: $\$ www.previdenciasocial.gov.br/agprev/MostraNoticia.asp?, acesso em 20/06/2005.
} 
Quanto ao Sistema de Previdência Complementar, avaliava ser necessário criar medidas que assegurem que o governo não adotara posturas oportunistas de aplicações compulsórias ou de normatizações de encomenda, especialmente sobre os fundos de pensão.

Contudo, o que considerou mais importante foi imprimir racionalidade à previdência do servidor público, que era desprovida de critérios previdenciários e atuariais, ao reforçar o vínculo entre contribuição e retribuição. Acredita que a reforma é uma resposta do governo à pergunta “quem deve pagar a conta de um sistema desequilibrado?” Os que já se aposentaram, ou se deve jogar a conta para o futuro, para quem não vai mais se aposentar com regras benevolentes? Ao final, conclui que um sistema previdenciário não deve ser generoso às custas do emprego, do crescimento econômico e do orçamento social do país.

Todavia, a agenda de reformas no governo Lula não estava encerrada. As regras rígidas para a concessão de aposentadoria para o funcionalismo público foram o motivo da redação da PEC paralela da Previdência, que teve a atribuição sui generis de suavizar as regras de transição impostas pela PEC 40. A PEC paralela foi criada para tramitar simultaneamente à reforma da Previdência e incorporou as alterações apresentadas pelos senadores, de modo a não obstruir a votação e a aprovação do texto-base da proposta da PEC da Previdência. Foi uma proposta concebida pelo senador Paulo Paim (PT/RS), negociada pelo senador Tião Viana (PT/AC) ${ }^{409}$ e apresentada pelo então líder do PT no Senado, Ideli Salvatti (PT/SC). Os principais pontos da PEC paralela eram: integralidade da aposentadoria de funcionários públicos; paridade entre aposentadoria e vencimentos dos funcionários públicos; regras de transição; subteto de aposentadorias; contribuição de inativos; aposentadoria especial; contribuição da empresa para o INSS e inclusão previdenciária. O novo texto assegurou aposentadoria especial para portadores de deficiência, para servidores que exercem atividade de risco (policial) e para servidores cujas atividades sejam exercidas sob condições especiais que prejudiquem à saúde ou à integridade física.

Logo após a aprovação da EC 41 o governo iniciou negociações com os Estados para a sua regulamentação, uma vez que os Estados e Municípios deveriam se adequar à

${ }^{409}$ Tião Viana (PT/AC) foi o relator da reforma da Previdência no Senado, em 2003. 
legislação com a instituição de regime de previdência de caráter contributivo e solidário, mediante contribuição do poder público, dos servidores ativos, inativos e pensionistas. Mas, deveriam também enfrentar outros desafios como criar órgãos de administração unificados e implementar nova forma de cálculo dos benefícios. Devido à infra-estrutura, capacitação de técnicos e investimento de tecnologia requerido, os Estados deveriam ser integrados no PARSEP nessa segunda fase. O programa fora criado no governo Fernando Henrique Cardoso para permitir que Estados e Municípios se estruturassem para se adaptar à EC 20/98.

A estimativa do governo era de economia de 15\%, na média, dos custos previdenciários a partir da reforma. O Ministro se envolveu pessoalmente nos debates ocorridos a partir de então com todos os Estados. Aprovada em 18/06/2004, a Lei 10.887 fixou as novas regras para organização e funcionamento dos regimes próprios de previdência social dos servidores da União, Estado e Municípios. Dentre elas, destaca-se a definição de que a alíquota de contribuição mínima do servidor de Estados e Municípios fosse $11 \%$ (igual ou superior à da União). Estados e Municípios, na condição de empregadores deverão contribuir com alíquota não inferior a 11\% podendo chegar até o seu dobro. A referida lei estabeleceu também o controle do MPAS sobre os regimes previdenciários de Estados e Municípios, obrigando-os a alinharem-se à lei federal, sob pena de não obter o Certificado de Regularidade Previdenciária (CRP) ${ }^{410}$. O MPAS passou também a fiscalizar as finanças dos regimes próprios dos servidores públicos, através de prestações de contas bimestrais das contribuições dos servidores e das Prefeituras e Estados. A não obtenção do CRP gera prejuízos financeiros como o impedimento de realizar contratos, convênios, empréstimos e financiamentos federais. Através dessas medidas, o RPPS foi subordinado ao RGPS e ganhou rubrica própria nas contas da Previdência Social.

Um acordo partidário firmado em 30/05/2005 permitiu que o Plenário do Senado aprovasse, em dois turnos, a PEC paralela da previdência ${ }^{411}$, que restitui alguns benefícios dos aposentados do serviço público, retirados pela reforma, de dezembro de 2003, entre os quais destacam-se reajustes salariais idênticos aos concedidos aos funcionários da ativa

\footnotetext{
${ }^{410}$ O CRP foi criado por meio do Decreto 3.788, de 11/04/2001

${ }^{411}$ A PEC paralela da Previdência tramitou na Câmara com o nº 227/2004 e, no Senado, sob o nº 77/2003.
} 
(paridade salarial) ${ }^{412}$; garantiu aposentadoria integral para quem ingressou no serviço público até 31/12/2003; estabeleceu regra de transição que garante aposentadoria integral e paridade para quem ingressou no serviço público até a promulgação da EC de 1998; estabeleceu teto para proventos nos três níveis da federação; isenção de contribuição previdenciária para inativo portador de doença incapacitante; aposentadoria especial para portadores de deficiência, policiais e para quem exerce atividade em condições de risco à saúde.

Um item importante da PEC paralela e que redundará em outros conflitos refere-se à possibilidade de instituição de alíquotas de contribuição do empregador diferenciada em função da atividade econômica, da utilização intensiva de mão de obra, do porte da empresa ou da condição estrutural do mercado de trabalho. Na verdade, o item expressa a possibilidade de haver renúncia previdenciária de contribuições do empregador.

A PEC paralela foi promulgada em sessão conjunta do Congresso Nacional, em 05/07/2005. Para o Ministro Ricardo Berzoini a "aceitação das mudanças foi um meio de recompor o apoio da base aliada no Congresso" (e que) "não podemos trabalhar na tramitação da proposta com vencedores e derrotados (...) se não houver nenhuma negociação, o governo será chamado de intransigente. Se houver, é impossível trabalhar com a lógica de que alguém perdeu” ${ }^{413}$.

Não houve grandes alterações pelo Senado em relação ao texto original, mas a fixação de nova regra de transição, mais suave, voltada para os servidores que ingressaram muito cedo no serviço público, os quais poderão se aposentar com proventos integrais em idade mínima resultante da redução de um ano para cada ano que exceder os 35 anos de contribuição exigidos para homens e 30, para mulheres. Para ser incluído na nova regra de transição o funcionário deve ter ingressado no serviço público antes de dezembro de 1998, ter 25 anos de exercício no serviço público, 15 anos na carreira e cinco no cargo em que se der a aposentadoria. O texto final seguiu a tese da restrição de aposentadorias especiais concedidas apenas para os trabalhadores em atividades prejudiciais à saúde ou à integridade física, porém introduziu como novidade a possibilidade de uso de critérios diferenciados

\footnotetext{
412 O benefício retornou exclusivamente para o pagamento das aposentadorias; os pensionistas destes aposentados não terão direito à paridade.

413 “Diálogo é o melhor instrumento”. Agprev - Agência de Notícias da Previdência Social, 18/07/2003.

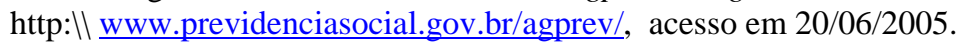


para deficientes, independentemente do tipo de trabalho que possuem, com remuneração também diferenciada (até o dobro do teto pago pelo INSS e isenção de contribuição previdenciária sobre suas aposentadorias).

O texto estabelece ainda que uma futura lei regulamentará o sistema especial de inclusão previdenciária, destinado a atender trabalhadores de baixa renda e aos que, sem renda própria, se dediquem exclusivamente ao trabalho doméstico, com benefícios de valor igual a um salário mínimo. Nas ações iniciadas pelo MPAS para ampliar a cobertura da previdência social foram contemplados trabalhadores rurais, os quebradores de pedra e aqueles que tendo sido segurados do INSS no passado, perderam a qualidade de segurado em decorrência de desemprego. A Lei 10.666/2003 tem por objetivo conceder aposentadoria no valor de um salário mínimo para todos os trabalhadores com mais de 65 anos (homens) e 60 anos (mulheres) que comprovem ter contribuído com o INSS por 11 anos em qualquer momento de sua vida.

O ponto de discordância em relação ao projeto formulado estava na criação de três subtetos para os servidores estaduais, um para cada poder: para o Executivo vale o salário do governador; no Judiciário, o de um desembargador; na Legislativo, o de um deputado estadual. Os deputados pretenderam transferir delegados, advogados e fiscais tributários estaduais do subteto do governador para o do Judiciário (que era maior), mas a medida foi rejeitada pelos senadores e deverá voltar à discussão.

Em fevereiro de 2007, instalou-se o Fórum Nacional da Previdência Social, que teria por objetivo formular propostas de mudanças consensuais que pudessem ser aprovadas no Congresso, válidas para os novos ingressantes. A expectativa do governo era que uma proposta formulada no Fórum fosse mais fácil de ser encaminhada ao Congresso. No entanto, desde o início, as centrais sindicais recusaram-se a negociar uma reforma que implicasse em "retirar direitos". Um dos pontos do debate foi a adoção de critérios combinados para aposentadoria: manutenção do fator previdenciário e elevação do tempo de contribuição ou eliminação do fator previdenciário, mas combinação entre elevação do tempo de contribuição e fixação de idade mínima.

O Fórum, no entanto, após nove meses de trabalho, chegou ao final sem consenso ${ }^{414}$ em torno de temas polêmicos, tais como aumento do tempo de contribuição dos

\footnotetext{
414 “Após nove meses, Fórum da Previdência acaba sem consenso”. Folha de São Paulo, 01/11/2007: B13.
} 
trabalhadores, mudanças na pensão por mortes e igualdade nos critérios de aposentadoria para homens e mulheres. O relatório elaborado por representantes do empresariado, dos trabalhadores e do governo se limita a fazer recomendações genéricas sobre alguns pontos em que as bancadas dos partidos chegaram a algum acordo.

Para o Ministro Luiz Marinho, a Previdência mantém suas contas desequilibradas e é necessário que haja mudanças para não penalizar as futuras gerações. O tempo de contribuições precisa ser elevado em cinco anos, senão pelo aumento da idade, deve ser pelo aumento do tempo de contribuição ${ }^{415}$. A partir do relatório final, o governo decidirá sobre o encaminhamento de uma nova proposta de reforma, ou não. A proposta de fixação de idade mínima - 60 anos para homem e 55 para mulheres - já havia sido levantada pelo ex-Ministro Nelson Machado ${ }^{416}$ como uma forma de substituir o fator previdenciário (que efetivamente produziu uma redução de $30 \%$ no valor dos benefícios), um dos temas debatidos durante o Fórum. Uma outra proposta, também em aberto, é a eliminação gradativa da diferença na idade de aposentadoria entre homens e mulheres, considerando questões demográficas e a inserção da mulher no mercado de trabalho.

Antes mesmo das conclusões do trabalho do Fórum o governo encaminhava ao Congresso uma nova proposta de reforma da previdência ${ }^{417}$, que, novamente, atingia o funcionalismo público. O governo pretendia estabelecer um teto para aposentadoria com base no texto fixado para os trabalhadores da iniciativa privada ${ }^{418}$ e criar um plano de previdência complementar para quem quisesse aumentar os rendimentos na aposentadoria. Em 2006, faltaram R\$ 35,1 bilhões no caixa do governo federal para cobrir as aposentadorias e pensões já concedidas, mesmo com as contribuições de ativos e inativos.

O mesmo PL criou a Fundação de Previdência Complementar do Servidor Público Federal (Funpresp), ao qual, Estados e Municípios poderão aderir, desde que se enquadrem no mesmo tipo de plano oferecido. Uma entidade jurídica de direito privado administrará as contribuições dos funcionários do Executivo, Legislativo e Judiciário, bem como as contrapartidas da União, que será a patrocinadora do fundo. O governo deverá fazer um aporte inicial de R\$ 50 milhões ao fundo e o plano será o mesmo para todos os

\footnotetext{
415 “Marinho defende maior tempo de contribuição”, Folha de São Paulo, 06/11/2007.

416 “Governo estuda aposentadoria com idade mínima”, Folha de São Paulo, 05/11/2006.

417 “Governo tenta nova reforma da Previdência”. Folha de São Paulo, 07/07/2007.

${ }^{418}$ Fixado em R\$ 2.890,00 em 2007.
} 
funcionários. Se aprovado o projeto, a contrapartida da União não poderá ultrapassar 7,5\% da diferença entre o salário individual e o teto do INSS. O dinheiro arrecadado será administrado por instituições financeiras escolhidas por licitação, e cada uma não poderá ultrapassar a administração de $40 \%$ dos depósitos.

As novas regras serão válidas para funcionários que ingressarem no serviço público após a criação da Funpresp, mas os que já são funcionários poderão aderir, fazendo jus a um benefício adicional. No entanto, dado ao difícil equilíbrio das contas na fase de transição, o governo não tem interesse na migração de um sistema ao outro, visto que provocará uma queda na arrecadação que a União hoje usa para pagar os que já se aposentaram e, ao mesmo tempo, aumentarão as despesas da União com a contribuição ao novo fundo.

A despeito da ampla mobilização pela defesa dos direitos em torno das reformas previdenciárias, desembargadores, ministros do Supremo, juízes e professores universitários seguem na direção contrária e têm ido à Justiça para garantir o direito de permanecer no cargo após os 70 anos, quando entrariam em aposentadoria compulsoriamente $^{419}$. O tema chegou a entrar na "PEC paralela" da previdência em 2003 para beneficiar apenas os professores do ensino superior, mas não prosperou. Um novo projeto, apresentado pelo Deputado Pedro Simon (PMDB/RS) com a justificativa centrada no aumento da expectativa de vida do brasileiro, foi aprovado no Senado e aguarda votação na Câmara, mas, se aprovada, deverá entrar em vigor imediatamente e valer para todos os servidores públicos.

O “decálogo previdenciário” de Fábio Giambiagi, IPEA ${ }^{420}$, publicado na imprensa, retomou o tema da reforma previdenciária em 2007, como uma agenda dos pontos que ainda precisariam ser revistos: idade mínima; redução da diferença entre homens e mulheres; aumento da idade para quem se aposenta por idade; extensão do período contributivo; transformação dos benefícios rurais em assistenciais; fim da pensão integral; extinção do regime especial aos professores; indexação de todas aposentadorias ao INPC e aumento da idade para elegibilidade do LOAS.

\footnotetext{
419 “Juízes rejeitam mudança em aposentadoria obrigatória”, Folha de São Paulo, 15/12/2007.

420 “Propostas para a Previdência (I): idade mínima”. Valor Econômico, 30/07/2007: A 15.
} 
As novas propostas (em aberto) do Ministro Luiz Marinho para a Previdência são: reduzir a $50 \%$ as pensões por morte para viúvas com um adicional de $10 \%$ por filho dependente e limitar o valor do auxílio-doença à média dos salários do segurado nos últimos 12 meses $^{421}$.

Ao final de quase 20 anos, a questão da previdência permanece aberta, porque, embora se tenha alcançado o equilíbrio nas contas, permanece a justificativa de que as mudanças são necessárias para preservar o futuro. Certamente, as novas gerações encontrarão critérios mais rígidos no acesso à aposentadoria, os quais se encontram fortemente vinculados aos novos requisitos da racionalidade econômica.

\section{Financiamento da Previdência Social}

Ao longo da discussão sobre a reforma previdenciária a CNI (2003) discutia internamente alternativas de financiamento da política de previdência social, trazendo o debate novamente para o campo da reforma tributária. Para os empresários, o foco de um novo modelo de financiamento não deve ser meramente arrecadatório, mas estar harmonizado com a necessidade de aumentar a eficiência do sistema tributário nacional aquele que não distorce a alocação de recursos na economia, não penaliza a competitividade da produção nacional e não desestimula investimentos.

No documento já estava consagrada a idéia de um sistema previdenciário sustentável no tempo e equilibrado financeira e atuarialmente. A principal razão apresentada para a reforma da previdência era de natureza econômica: a necessidade de recuperar o equilíbrio financeiro. O principal problema a ser atacado era o crescimento das despesas com o pagamento de aposentadorias dos servidores públicos e os critérios generosos de elegibilidade, que tornaram tênue a relação entre os benefícios recebidos e as contribuições pagas.

A redução da razão de dependência entre contribuintes e beneficiários do RGPS, que passou de 2,5 em 1990 para 1,2, em 2002 provocou grande desequilíbrio no sistema previdenciário, baseado no modelo de repartição entre as gerações, em que as contribuições

\footnotetext{
421 “Marinho quer novas regras na concessão de pensão por morte”, Valor Econômico, 25/04/2007.
} 
dos trabalhadores ativos, descontados os custos administrativos, são repartidos entre os inativos segundo critérios anteriormente estabelecidos.

O desequilíbrio do sistema previdenciário foi administrado ao longo do tempo com o aumento da alíquota de contribuição e a elevação do teto de contribuição do empregado, as quais, com o tempo revelaram-se contraproducentes e serviram de fator de desestímulo aos contratos de trabalho formais. No círculo vicioso que se formou, a queda do emprego formal promoveu a retração da base de arrecadação previdenciária (a folha de salários). Com isso, o governo recorreu ao aumento das contribuições sobre bases alternativas, como o lucro e o faturamento (Cofins, CSSLL, CPMF), que exerce efeitos perversos sobre o sistema econômico. No entanto, pouco desses recursos são destinados à Previdência Social, uma vez que visam financiar a seguridade social, que inclui a assistência social e a saúde.

Em 2002, apenas 25\% do arrecadado com a Cofins, CSSLL e a CPMF foi destinado à previdência social, apesar desta também arcar com a gestão dos benefícios assistenciais. Cerca de 75\% das receitas do INSS advêm das contribuições destinadas exclusivamente à previdência, que se mantém constantes devido à retenção das contribuições dos trabalhadores terceirizados pelas empresas contratantes de serviços, ao recolhimento das contribuições pela Justiça do Trabalho após sentenças ou homologação de acordos e à criação de certificados da dívida pública que permitem aos devedores quitarem suas dívidas com deságio.

No documento são enfatizadas as distorções que a base de financiamento da previdência provoca sobre a economia, como o estímulo à utilização de mais capital e menos mão de obra e aumento da informalização das relações de trabalho, como resposta às contribuições sobre a folha de pagamento de salários, a fuga de capitais e na escolha da alocação de recursos para a produção, alterando relação da demanda no mercado de bens e produtos. Defende, o documento, que a base ideal de arrecadação para o financiamento do RGPS deveria tender aos seguintes requisitos fundamentais ${ }^{422}$ :

1. gerar recursos em volume suficiente para o financiamento do sistema e seus programas, de modo a acompanhar o crescimento da economia;

${ }^{422}$ Ver (CNI, 2003: 10). 
2. ter estabilidade, não flutuar com o ciclo econômico, de modo a evitar desequilíbrio no fluxo de caixa e

3. não gerar distorções no sistema tributário e não ser prejudicial à alocação racional dos recursos e à geração de empregos.

É forte a interdependência entre as reformas da previdência social, do sistema tributário e das relações de trabalho, uma vez que o aumento da base de arrecadação previdenciária depende do aumento do emprego formal, que, por sua vez, depende da reforma tributária ${ }^{423}$. As duas metas implícitas seriam o crescimento econômico e o estímulo à adesão voluntária. No entanto, a preocupação empresarial concentra-se na contribuição sobre o faturamento bruto das empresas e sobre a movimentação financeira, que geram cumulatividade e ineficiência, de baixa transparência e prejudicial à competitividade dos produtos brasileiros.

O lucro não é uma base de financiamento estável, porque está sujeito às flutuações e ciclos econômicos, apesar de gerar montante suficiente para o financiamento da previdência. De outro modo, a tributação excessiva sobre a renda desestimula a formação de capital e pode ser repassada para o consumo. O faturamento como base de financiamento conflita com o desejo de um sistema tributário eficiente do ponto de vista alocativo, além de ser cumulativo e gerar distorções na alocação de recursos. A movimentação financeira é ampla o suficiente para gerar recursos para o sistema, mas não atende ao princípio da racionalidade e da eficiência, pois tem incidência cumulativa e gera distorções na alocação dos recursos. Sua grande vantagem é a facilidade de arrecadação e em formar uma base bastante ampla, incidindo inclusive sobre os segmentos da informalidade.

O valor adicionado seria a forma mais eficiente e neutra de arrecadar recursos compulsoriamente para as atividades do Estado: é ampla e estável, não cumulativa e não introduz distorções e ineficiências na alocação de recursos. A sua grande desvantagem é o desconhecimento da base de arrecadação, que torna difícil sua operacionalização. A transferência das contribuições incidentes sobre a folha salarial para a contribuição sobre o valor agregado traria vantagens, ao simplificar o sistema tributário e incentivar geração de

${ }^{423}$ (Idem: 13). 
empregos e redução do Custo Brasil. O maior problema está na sua compatibilização com uma reforma tributária mais ampla.

Com o documento, os empresários persistem na demonstração da confluência entre as duas agendas, a da reforma tributária e a da reforma previdenciária. A agenda de reformas dos empresários demonstra a intenção em modificar os critérios pelos quais a Previdência vem sendo financiada e, como item principal da proposta, está o seu deslocamento da esfera estatal e pública para a individual, com exclusividade. A Previdência Social deveria deixar de ser financiada como expressão de um seguro social para passar a servir como um mecanismo de poupança individual, ainda que compulsória.

\section{Crise gerencial e técnicas de gestão}

A racionalização e melhoria de técnicas de gestão têm sido abordadas na reforma previdenciária, como meio de aumentar a fiscalização, conter as fraudes e melhorar a eficiência institucional do sistema. Estes problemas demonstram como os temas são entrecruzados numa questão estrutural, que é a da modernização do Estado.

Duas medidas entrecruzadas com o problema da Previdência são a criação do SuperSimples ${ }^{424}$ e da Super-Receita. De um modo geral, as duas medidas, de caráter fiscal, atendem ao imperativo de melhorar a arrecadação, o controle e a fiscalização tributária, sob diretriz e comando do Ministério da Fazenda.

A criação da Receita Federal do Brasil, em abril de 2007, teve por objetivo agilizar a arrecadação e a fiscalização tributária, reduzir os custos de administração pública, aumentar a eficiência do fisco, reduzir a burocracia e unificar os servidores públicos. O seu objetivo maior é obter maior controle na arrecadação dos tributos sobre as empresas e

\footnotetext{
${ }^{424}$ Super-simples é o regime especial unificado de pagamento de impostos e contribuições federais, estaduais e municipais devidos pelas micro e empresas empresas. Foi instituído pela LC 123, de 14 de dezembro de 2006 e abrange os seguintes impostos e contribuições: IRPJ (Imposto de Renda da Pessoa Jurídica); IPI (Impostos sobre Produtos Industrializados); CSLL (Contribuição Social sobre o Lucro Líquido), PIS (Contribuição para o Programa de Integração Social); PASEP (Contribuição para a Formação do Patrimônio do Servidor Público); Cofins (Contribuição para o Financiamento da Seguridade Social) e Contribuição ao INSS (pessoa jurídica), ICMS (Imposto sobre a Circulação de Mercadorias e Serviços) e ISS (Imposto sobre Serviços). Os dois últimos são, respectivamente, de competência estadual e municipal, os demais, de competência federal. No Super-Simples, o empregador é isento dos $20 \%$ sobre a folha de pagamentos, correspondente à sua contribuição ao INSS, o que, somou em 2006 uma renúncia fiscal de R 5 bilhões de Reais, segundo dados do Ministério da Previdência Social/Secretaria de Previdência Social.
} 
combater a sonegação fiscal. É um processo de racionalização administrativa que visa a simplificar procedimentos administrativos, reduzir a burocracia e os tempos para a resolução de questões tributárias e tornar o Fisco forte. ${ }^{425}$

A Receita Federal do Brasil é resultado da fusão da Secretaria da Receita Federal e da Secretaria da Receita Previdenciária e sintetiza dois projetos de racionalização: administrativa e tributária. É a finalização de um longo processo que foi destituindo a Previdência Social de um de seus pilares de atuação (arrecadação e fiscalização) e conformando a sua subordinação à Receita Federal ${ }^{426}$. Com a criação da Receita Federal do Brasil, esta ficou responsável, também, pela arrecadação das contribuições sociais ${ }^{427}$, o que torna a Previdência totalmente dependente dos repasses por ela realizados. Um dos argumentos do governo na unificação é que a Receita Federal já era responsável pela arrecadação de cerca de 70\% dos tributos, especialmente após a adoção do Simples. Os auditores fiscais do INSS também foram incorporados à Secretaria da Receita Federal do Brasil, havendo racionalização e unificação dos recursos humanos ${ }^{428}$.

A fusão pode ser interpretada como uma das medidas que visam a imprimir maior racionalização na arrecadação de tributos e contribuições sociais, a partir da idéia de unificação também dos procedimentos de fiscalização e emissão de documentos públicos como a Certidão Negativa de Débito (CND). As mudanças objetivam aumentar a eficiência no recolhimento e reduzir a sonegação com a instituição do processo de fiscalização

\footnotetext{
${ }^{425}$ Governo Federal do Brasil. Informe Publicitário da Secretaria da Receita Federal do Brasil, Folha de São Paulo, 30/04/2007. A Super-Receita passa a ser responsável pela arrecadação do IRPF (Imposto de Renda da Pessoa Física); IRPJ (Imposto de Renda da Pessoa Jurídica), IPI (Imposto sobre Produtos Industrializados); ITR (imposto Territorial Urbano); IOF (Impostos sobre Operações Financeiras); CPMF (Contribuição Provisória sobre Movimentação Financeira); PIS (Contribuição para o Programa de Integração Social); PASEP (Contribuição para a Formação do Patrimônio do Servidor Público); Cofins (Contribuição para o Financiamento da Seguridade Social), CSLL (Contribuição Social sobre o Lucro Líquido); contribuição previdenciária das empresas incidentes sobre a remuneração paga ou creditada aos segurados a seu serviço, empregadores domésticos e demais trabalhadores; contribuição sobre concursos e prognósticos (loterias).

${ }^{426}$ Historicamente, as contribuições previdenciárias eram realizadas diretamente ao Instituto Nacional de Seguro Social através de depósitos bancários e o mesmo mantinha corpo técnico de auditores fiscais responsáveis pelas ações de arrecadação, controle, fiscalização e cobrança. A contabilidade em separado garantia autonomia ao INSS na gerência dos recursos previdenciários.

${ }^{427}$ Inclui as contribuições previdenciárias patronais, dos trabalhadores, de empregados domésticos, as que incidem sobre lucro e faturamento da empresa e sobre os concursos de prognósticos (loterias).

${ }^{428}$ Com a fusão, a Secretaria da Receita Federal deverá contar com um efetivo de 13.000 fiscais atuando em unidades descentralizadas. A estimativa realizada pelo Governo durante a tramitação do projeto de lei no Congresso Nacional era de que a Receita Federal do Brasil deverá contar com mais cinco delegacias, 60 turmas para julgamento em primeira instância de recursos de cobranças de impostos e contribuições sociais, 1.220 cargos de Procuradoria Geral da Fazenda Nacional (PGFN) e 120 unidades seccionais da PGFN.
} 
eletrônico. Do ponto de vista da administração de recursos humanos, permitirá maior especialização dos fiscais e unificação dos procedimentos fiscalizatórios ${ }^{429}$.

Durante o trâmite do PL no Congresso Nacional, grande foi o temor de que as contribuições previdenciárias de trabalhadores e empregadores pudessem ser utilizadas com finalidade diferente do pagamento de benefícios previdenciários. No texto final acabou por ser incluído um item que determinou que as contribuições sociais, incluindo créditos inscritos na dívida ativa da União, fossem depositadas diretamente no Fundo do RGPS, para evitar resistências. No entanto, restam dúvidas de que não haverá desvinculação institucional entre a captação da receita previdenciária e a realização das despesas pertinentes, em favor dos segurados do RGPS, com desvinculação das receitas para a composição do superávit primário, destinado a pagar os juros da dívida pública.

A dívida ativa do INSS passou também a ser incorporada à dívida ativa da União e cobrada pela PGFN, a qual já administra 800 mil processos de defesa da União e é responsável por dois milhões de execuções fiscais, num estoque total de R\$ 283,2 bilhões $^{430}$.

Uma das questões decisivas para a fusão foi simplificar o processo administrativo de cobrança de tributos federais, que, apenas no ano de 2004, somou R 423 bilhões de reais, o que também libera o MPS para cuidar de sua atividade-fim que é o pagamento de benefícios e prestação de serviços previdenciários, atendimento ao segurado e análise de processos administrativos que comprovem direito aos benefícios. Foi a primeira vez em que a Previdência Social entrou no debate sobre a melhoria da arrecadação.

A experiência de unificação da arrecadação tributária com a arrecadação das contribuições previdenciárias e/ou de seguridade social é o corolário do tratamento contíguo que ambas as questões vêm recebendo. Reforma previdenciária e reforma tributária passaram a fazer parte da mesma agenda política e são recorrentes na questão do aumento da carga tributária e no custo da mão de obra ou o peso dos encargos tributários sobre a folha de pagamento. A “desoneração da produção” é a formulação de uma proposta que junta as duas questões. A previdência social aparece, sobretudo, como um problema fiscal.

\footnotetext{
429 “A Super-Receita e os efeitos no INSS”. In: Valor Econômico, 29/05/2007, E7.

${ }^{430}$ Informação obtida na Agprev - Agência Câmara de Notícias, www.camara.gov.br/internet/agencia/materias.asp?pk=80163, acesso em 15/01/2997.
} 
Dentre os muitos aspectos levantados para a modernização do sistema previdenciário, foi forte aquele relacionado à sonegação fiscal, fraudes, desvios, pagamentos de benefícios ilícitos, má administração etc. Durante toda a década de 1990, houve denúncias de desvios bilionários de recursos da Previdência Social. Alguns especialistas enfatizaram que o principal problema da Previdência social era gerencial, principalmente no que se refere à arrecadação, cobrança de dívida ativa e fiscalização. Reinhold Stephanes (1993: p. 236) cita, por exemplo, inexistência de Cadastro da Previdência Social que permitisse conhecer as variáveis econômicas, demográficas e institucionais e as projeções de gasto anual com concessão de benefícios ${ }^{431}$.

A fusão torna-se um instrumento para o aumento da arrecadação fiscal do governo, com centralização dos dados dos contribuintes em um único cadastro de modo a permitir o cruzamento de dados e informações. A medida integra um conjunto de orientações do FMI para aumentar a captação da receita da União por meio de centralização da arrecadação e fiscalização.

Para se ter conhecer a magnitude dos recursos que a Secretaria da Receita Federal movimenta, dados recentemente divulgados demonstram que a carga tributária no Brasil no ano de 2006, foi de 34,23\% do PIB, a maior dos últimos cinco anos, num total de $\mathrm{R} \$$ 304,157 bilhões, incluindo impostos, contribuições sociais e taxas. A contribuição para o INSS foi a que apresentou maior elevação em 2006, atingindo R \$ 82.684 bilhões, 0,29\% a mais em relação ao arrecadado em 2005. Em 2007, nos sete primeiros meses, a Receita já havia arrecadado R\$ 335,606 bilhões, 10,34\% a mais em relação ao ano de $2006^{432}$. O aumento da arrecadação e o aquecimento da atividade econômica permitiram que houvesse

\footnotetext{
${ }^{431}$ O Cadastro Nacional de Informações Sociais (CNIS) passou a ser utilizado para fins de cálculo do saláriode-benefício apenas com a Lei 10.403, de 08/01/2002, que alterou a Lei do Plano de Benefícios (Lei 8.213/91). Até 2002, não havia em quê se basear para realizar as projeções atuariais da seguridade social definidas na LCSS e PBPS. A ausência de Cadastro impedia que se soubesse quantos segurados e dependentes existiam, o tempo de serviço, o salário de contribuição desses trabalhadores, qual o tempo para se completar os requisitos para percepção de benefícios, quantos novos benefícios deverão ser pagos a cada ano, qual a expectativa média da duração de cada benefício, etc., o que tornava impossível qualquer planificação econômica. O CNIS é composto por quatro bases de dados: a) Cadastro de Trabalhadores; b) Cadastro de Empregadores; c) Cadastro de Vínculos Empregatícios e Remunerações do Trabalhador Empregado e Recolhimentos do Contribuinte Individual; d) Agregados de Vínculos Empregatícios e Remunerações por Estabelecimento Empregador (MPS, 2006).

432 “Carga Tributária atinge 34,2\% do PIB em 2006”, Valor Econômico, 22/08/2007; “Carga de impostos é a maior da história”, Folha de São Paulo, 22/08/2007.
} 
aumento também no superávit primário do setor publico, que atingiu 4,37\% do PIB, o que lhe conferiu folga para cumprir a meta estabelecida para 2007, de 3,8\% do $\mathrm{PIB}^{433}$.

Os recursos da previdência continuam a ser utilizados para outro fim: financiar atividades econômicas do país. A dívida ativa de empresas e bancos que não pagaram o que é legalmente devido à Previdência somaram R\$ 78,7 bilhões, excluindo aquelas que estão questionando seus débitos na justiça e os devedores que parcelaram o débito. $\mathrm{O}$ artigo 88 da Lei 8.212 autorizava a divulgação da lista de devedores do INSS, exigência que só foi cumprida no ano de 2003 e deixou de ser exigida em 2007, com a criação da Secretaria da Receita Federal, por ferir princípios tributários.

433 “Superávit acima da meta abre espaço para PIB maior”. Valor Econômico, 30/08/2007. 


\title{
CAPÍtulo VII
}

\section{As REFormas da PREVIDÊNCIA}

\author{
"Quanto mais o ordenamento moderno \\ é dado por suposto, mais o "novo" será \\ associado ao "melhor". No caso de \\ instituições, "melhor" pode significar tanto \\ "mais eficiente" ou "mais justo"como ambos".
}

Agnes Heller e Ferenc Feher

Neste último capítulo não posso senão retornar à questão inicial do direito $\mathrm{em}$ movimento para reafirmar que, no Brasil, a Previdência Social permanece uma questão em aberto. A reforma permanece como um horizonte continuamente aberto no seu duplo sentido, enquanto um processo de reorganização e racionalização que não chegou ao fim e, enquanto um direito que deve permanecer em aberto (Ewald,1993).

Apesar de todas as críticas que lhe foram dirigidas, enquanto técnica, a previdência social permanece como um instrumento moderno na concretização da proteção social contra os riscos sociais e como um horizonte de expectativas (Koselleck, 2006) para o conjunto da população. Se, ela é incapaz de realizar a igualdade distributiva prometida, ainda é a segurança esperada na velhice ou na doença, uma segurança sócio-econômica (Flora \& Heidenheimer, 1987): ter um emprego formal e ter acesso aos direitos trabalhistas e previdenciários que lhe acompanham, permanece como objetivo compartilhado pela maioria.

Apesar de longo, o processo de reforma não provocou mudanças estruturais ${ }^{434}$ no sistema previdenciário, ou seja, o seguro social obrigatório sob administração pública foi

\footnotetext{
${ }^{434}$ Reformas estruturais implicam na introdução de um componente privado compulsório no sistema previdenciário. Mesa-Lago identifica três modelos distintos de reforma previdenciária estrutural: o substitutivo, o misto e o paralelo. No primeiro caso, há a substituição do pilar público pelo pilar privado e não são permitidas novas filiações; adoção do regime financeiro de capitalização e administração privada. No modelo misto, há a combinação entre a oferta de um benefício básico pelo pilar público e sua complementação pelo pilar privado; adota-se o regime financeiro de repartição no pilar público e no segundo pilar, a administração pode ser pública, privada ou mista. No modelo paralelo, há concorrência entre o regime público e privado. Outra diferença importante no segundo pilar (para qualquer dos três modelos) reside no plano de benefícios e contribuições, que podem ser definidos ou indefinidos: quando o benefício é definido
} 
preservado (Coelho: 2001). A concepção de seguridade social foi definitivamente abandonada, com as áreas integrantes disputando recursos para realizar, cada qual, a sua finalidade.

Ao olharmos para toda história da Previdência Social não podemos deixar de ser capturados pela metáfora de Heller e Feher (1995), do pêndulo que se move incessantemente de um extremo ao outro e que contradiz as oposições binárias, tanto quanto a imaginação que aponta sempre à frente em busca do progresso, do melhor, do mais eficiente. A Previdência Social é aquela instituição que, possuindo a tarefa de ordenar a sociedade, inclui os dois aspectos normativos e decisivos: renovação e estabilidade. A dinâmica da modernidade faz com que o pêndulo oscile sem parar entre extremos (individualismo e comunitarismo, Estado e mercado). O que empurra o pêndulo e o faz mover-se incessantemente são os conflitos sociais e a capacidade de imaginar, de instituir, no sentido que lhe atribui Castoriadis (1992).

Situado entre dois extremos - privatização e estatização - o pêndulo das reformas simplesmente os ultrapassou, promovendo ao mesmo tempo renovação e continuidade. Preservou-se a instituição pública e o direito contributivo e obrigatório e renovou-se o próprio direito. Ultrapassou-se a idéia de dever do Estado e renovou-se a idéia do direito do cidadão. Mais do que a idéia de direito, o que perpassou o conjunto das reformas foi uma idéia de dever, do que se deve dar à sociedade como contrapartida para obtenção de direitos sociais. Essa mudança de perspectiva alterou o próprio sentido da solidariedade social para reforçar não o vínculo distributivo, mas, o contributivo, como um dever de contribuição.

As reformas, realizadas em tempos diferentes, conduziram apenas a mudanças paramétricas (Melo: 2002; Silva: 2007) ou, de caráter incremental (Coelho, 1997; Melo, 1997b: 343), que implicaram na mudança de parâmetros, que pode indicar o enxugamento de benefícios, elevação da idade de aposentadoria e aplicação de penalidades para a aposentadoria antecipada, maior rigor nos critérios de qualificação para benefícios de aposentadoria por invalidez, mudança no método de indexação de preços, e visam, em termos de economia política da previdência, a tornar a dívida em circulação menor.

(BD), o seu valor é previamente contratado com base nos rendimentos salariais do trabalhador; quando o benefício é indefinido, ele dependerá do total acumulado durante a vida profissional e da rentabilidade dos fundos de pensão. Um quarto modelo de reforma foi o adotado pelo Brasil, paramétrico, que preserva o caráter predominantemente público (MESA-LAGo, 2003). 
Muito embora toda a crítica à reforma tenha sido formulada com base na retirada de direitos constitucionais, o que pode ser observado é a introdução de medidas de racionalização e de técnicas de controle ao acesso a recursos públicos. E essas medidas não podem ser analisadas tão somente na perspectiva dos direitos atribuídos diretamente aos cidadãos, elas também seguem na direção oposta, com retração na política de subsídios, combate a fraudes e sonegação, cobrança da dívida previdenciária de Municípios, Estados e da União, da obrigação do Estado empregador, fim de renúncias previdenciárias, mudança nos depósitos bancários, agilidade no trato processual, dentre outras.

A retração nas receitas previdenciárias (provocada pela alteração na relação de proporção entre contribuintes e beneficiários) ${ }^{435}$ obrigou a uma recomposição da relação entre receitas e despesas. A revisão dos critérios para acesso aos direitos se enquadra perfeitamente na alteração do lado das despesas, enquanto todas as medidas que envolvam a arrecadação, controle e gerenciamento dos recursos da Previdência Social se enquadram numa alteração do lado das receitas, que não vêm sendo devidamente valorizados.

Apesar das suas deficiências, a previdência social ainda se constitui na mais significativa técnica de proteção social no Brasil, de caráter duradouro e que proporciona segurança econômica a um amplo contingente populacional pertencente ao mercado de trabalho formal. Enquanto instituição, também é aquela que na trajetória das políticas sociais é dotada de maior estabilidade, e, portanto, portadora da promessa de alguma segurança sócio-econômica.

As reformas visaram mais a adaptação dos mecanismos de proteção social à nova dinâmica econômica e social que o aperfeiçoamento da proteção social. As reformas não buscaram melhorar o nível do atendimento às demandas sociais, mas compatibilizar o atendimento já garantido às restrições financeiras do Estado. A racionalidade econômica determinou as diretivas da reforma, numa inversão de pautas. O critério para a reformulação dos benefícios e dos direitos em vigor foi a relação entre receitas e despesas da Previdência Social. A escassez de recursos determinou a necessidade de melhorar a sua gestão e as técnicas de distribuição e fortaleceu-se a idéia de uma cisão entre direitos previdenciários e assistenciais, o que determinou também uma sistematização na

\footnotetext{
${ }^{435}$ As duas razões explicativas (para a alteração na relação entre contribuintes e beneficiários) foram: a mudança no perfil demográfico e alterações no mercado de trabalho (informalização do emprego, desemprego e rebaixamento do nível salarial).
} 
apresentação das contas da Previdência Social, permitindo que a questão do financiamento fosse inteiramente explicitada.

Na busca da eficiência, as reformas se irradiaram não apenas para a abrangência do direito, mas sobre a sua concepção, administração, gerência e gestão. Ao final tivemos uma reforma que redefiniu quem são os sujeitos do direito, de quê direito e de quê forma eles devem ser acessados, para fazer valer o vínculo contributivo. Elas se reportam não apenas ao conteúdo do direito, mas às regras de acesso, fiscalização e gerência administrativa. A Previdência Social foi capturada por um duplo movimento de racionalização e de adequação a critérios da racionalidade econômica, ou seja, a racionalização foi realizada a partir de uma ação racionalmente orientada e embasada em cálculos e na escassez de recursos.

As reformas não tiveram um sentido unívoco e é possível identificar em cada governo um acento diferente, com uma prevalência da idéia de privatização até meados da década de 1990; a idéia de composição de pilares mistos até o final da década de 1990 e, a partir daí, uma preocupação com a inclusão previdenciária e a melhoria das técnicas de gestão. Os servidores públicos tiveram, ao longo de todo o período, os critérios de suas aposentadorias criticados e identificados a privilégios e foram os mais atingidos durante as reformas.

Ironicamente, os servidores públicos também tiveram precedência nas reformas que visaram retrair direitos funcionais, visto que historicamente sempre se mantiveram na vanguarda no momento de sua conquista (Esping-Andersen, 1998; Flora \& Heidenheimer, 1987; Teixeira \& Oliveira, 1986).

Observamos, do mesmo modo, que a resistência em torno da realização de reforma foi mais intensa até meados da década de 1990, amparada, sobretudo, pela expectativa de constituição de uma seguridade social e de consolidação dos direitos constitucionais. Até a revisão constitucional de 1993, houve, não apenas uma intensa disputa pela regulamentação dos direitos, mas também uma defesa da idéia de seguridade social, com a expectativa de que se pudesse constituir um Ministério da Seguridade Social que efetivamente garantisse a integração entre saúde, previdência e assistência social e fosse um contra-poder capaz de inibir as investidas dos Ministérios econômicos sobre seus recursos. 
Foram amplas as disputas pela alocação de recursos tais como definidos pelos diplomas legais, enquanto os orçamentos eram manipulados, os repasses não realizados nos valores definidos e no tempo certo. As disputas em torno das "contas da Previdência" demonstravam que este seria o ponto central de uma pauta de reformas que certamente se realizaria sob o governo de Fernando Henrique Cardoso. A partir de então, a disputa foi pelo estabelecimento do limite, o ponto de corte além do qual a reforma não poderia ultrapassar.

Sob o governo de Luiz Inácio Lula da Silva, a hipótese da reforma já estava devidamente assimilada, passando a ser capitaneada pelos seus antigos opositores. A reforma desta vez incidiria mais pesadamente sobre o corpo do funcionalismo público, restringindo aquilo que constituía o diferencial denunciado em relação ao regime privado de trabalho: regras menos rígidas para acesso a aposentadoria e ausência de teto do benefício.

\section{Reformas na América Latina}

A privatização e a combinação entre um regime público e privado de previdência, fizeram parte da agenda da América Latina, influenciadas pelo modelo de privatização ocorrido no Chile, na Argentina e no Uruguai e pelo documento do Banco Mundial (World Bank, 1994), que preconizava a adoção de pilares múltiplos para o regime de pensões e aposentadorias. Na segunda metade da década de 1990 observou-se uma aceleração do movimento em direção aos sistemas de multi-pilar, mesmo entre os países membros da OCDE (James, 2001: 42).

No documento de 1994, o Banco Mundial propunha um modelo previdenciário no qual deveriam ser combinados diferentes regimes em um sistema misto - público e privado - para alcançar duplo objetivo: proteção social e desenvolvimento econômico. O modelo ideal preconizado deveria combinar um pilar público, obrigatório e básico; um pilar privado e compulsório; e um pilar voluntário do sistema. A diferença entre eles estava no acento 
posto na capacidade contributiva dos trabalhadores e na possibilidade de aumentar a poupança individual interna. O Banco Mundial defendia que a adoção de um modelo misto era mais eficaz em realizar a redistribuição de renda para a camada mais pobre da população, enquanto a poupança deveria ser o mecanismo adotado para a população com melhor nível de renda. Por outro lado, a responsabilidade da administração deveria ser partilhada entre o poder público (regimes de repartição) e a iniciativa privada (regimes de capitalização).

No modelo misto, o pilar público poderia ser financiado mediante impostos ou contribuições deduzidas da folha de pagamento e cobriria os trabalhadores de baixa renda e os riscos associados à perda da capacidade de trabalho (doença, acidente, velhice). O pilar privado compulsório seria financiado por contribuições individuais dos trabalhadores, supervisionado pelo Estado e administrado pela iniciativa privada, com o objetivo de fomentar a poupança individual, prover um seguro individual e reduzir as obrigações do pilar público. Ao buscar o auto-interesse os indivíduos estariam contribuindo para o bem estar geral ao contribuir para elevar o nível da poupança do Estado, necessária ao desenvolvimento econômico. O pilar voluntário do sistema ofereceria uma renda complementar para os trabalhadores que desejassem melhorar o aporte do seu beneficio previdenciário, contribuindo para aumentar a poupança interna individual. Para a camada mais pobre, o sistema público manteria um mecanismo de redistribuição de renda.

O modelo misto do Banco Mundial propunha não apenas uma combinação entre público e privado, compulsório e voluntário, básico e complementar, mas também entre o sistema de repartição simples e o sistema de capitalização. Seria desejável ter um sistema que permitisse a individualização da conta previdenciária e que estabelecesse uma correlação entre a contribuição efetivamente dada ao sistema e o benefício recebido.

No entanto, reformas estruturais com conversão do regime de repartição para o regime de capitalização geram custos de transição a serem suportados pelo Estado no curto prazo, devido à absorção da dívida herdada do sistema anterior. Esses custos representam o conjunto de obrigações acumuladas até a data presente e o valor das contribuições futuras dos atuais segurados, ou seja, os compromissos de longo prazo com aposentados, pensionistas e com os trabalhadores ativos que já contribuíram e adquiriam direitos como futuros beneficiários. Na transição, ocorre uma defasagem de financiamento entre as 
receitas do sistema de repartições simples remanescentes e os gastos necessários para cobrir as despesas e é preciso encontrar outra fonte de receita capaz de supri-la (James: 2001: 21).

Na transição para o regime de capitalização, os governos devem continuar a cumprir suas obrigações atuais, e só pode fazê-lo através do aumento das contribuições ou dos impostos, ou ainda, através da emissão de títulos da dívida pública. Entretanto, o aumento de impostos é impopular e tem elevado custo político, enquanto que o aumento da dívida, além de elevar os custos dos juros do governo, pode modificar a situação creditícia perante os órgãos externos ou mesmo provocar transtorno nos mercados financeiros. Por fim, o financiamento da dívida previdenciária indica que a reforma não gera o impacto positivo esperado sobre a poupança nacional ${ }^{437}$ e, num primeiro momento, a dívida pública pode inclusive aumentar. Portanto, são claros os limites econômicos e políticos à realização de reformas estruturais.

Nos países em que a obrigação previdenciária é grande (dívida previdenciária implícita) a agenda de reforma é mais facilmente colocada em pauta, no entanto, ela restringe o grau de capitalização e de privatização que pode ser alcançado (James \& Brooks, 2001). Paradoxalmente, os países com economia mais vulnerável são aqueles que têm maior dificuldade para financiar os custos de transição, o que contribui para a manutenção das políticas sociais. Um reflexo desta situação pode ser a conturbada pauta de reformas no período Fernando Henrique, com sua dupla agenda de reformas e a opção final pelo abandono da reforma estrutural, dada a ameaça de especulação que seguiria a emissão de nova dívida explícita. No Brasil havia ainda o agravo da contestação pública do sistema tributário, com a grande incidência de contribuições sociais, tributos em cascata e o peso dos encargos sociais sobre as empresas que impediriam a criação de novos (ou majoração de antigos) impostos e contribuições.

A magnitude do déficit previdenciário e a capacidade de financiar os custos de transição influenciaram de forma decisiva o curso das reformas na Argentina, no Uruguai e no Brasil (Coelho: 102), muito embora não seja condição suficiente para explicar o seu resultado. No Brasil, as restrições impostas pelos órgãos internacionais para a contração de

\footnotetext{
${ }^{437}$ Os benefícios macroeconômicos esperados da reforma estrutural são relativos ao aumento do nível da poupança interna e sua estabilidade no longo prazo, o que reduziria a dependência do capital estrangeiro. No entanto, o impacto sobre a poupança interna é dependente de duas condições: aumento da poupança voluntária e financiamento da transição através de corte nos gastos públicos e de aumento de impostos (James \& Brooks, 2001).
} 
novos empréstimos foram decisivas para barrar a reforma estrutural, num primeiro momento.

Tanto na Argentina, quanto no Chile, o custo da transição de um regime a outro foram suportados por recursos do BID e do Banco Mundial. No Uruguai, os custos iniciais de transição foram sustentados por financiamentos do BID, de US\$ 150 milhões e do Banco Mundial, de US\$ 100 milhões $^{438}$. No Brasil, enquanto se discutia a Reforma da Previdência no governo Fernando Henrique Cardoso, os custos da transição foram estimados em cerca de 200\% do PIB pela CEPAL, 218\% pelo IBGE/IPEA e 250\% pela FGV/RJ (Coelho: 2001; Pinheiro \& Vieira: 1999). Tais estimativas, a falta de financiamento e a ameaça de crise econômica levaram o governo a desistir da implantação do regime de capitalização, que vinha sendo tratada no projeto que ficou conhecido como "Reforma 2".

Ao final dos processos reformistas ocorridos na década de 1990, os resultados demonstram que não prevaleceu um único modelo de previdência social na América Latina. Houve substituição de modelo previdenciário no Chile (1981), Bolívia (1997), México (1997), El Salvador (1998), Nicarágua (1980) e República Dominicana (2001). A adoção do modelo misto com predomínio do pilar privado se deu na Argentina (1994), Uruguai (1996) e Costa Rica (2001). O modelo de concorrência entre regime público e privado foi adotado no Peru (1993) e na Colômbia (1994). Na maioria desses países houve migração intensa para o novo sistema, motivadas seja pela impossibilidade de aderir ao modelo antigo, por transferências compulsórias ou por políticas de incentivo (positivo ou negativo). Por exemplo, no Chile a antiga contribuição patronal foi incorporada ao salário dos trabalhadores que optaram pelo novo sistema, enquanto no Peru houve aumento de alíquota de contribuição para os que permaneceram no velho regime (Mesa-Lago: 2003).

Em comparação com outros países que realizaram reformas em seus sistemas previdenciários na América Latina, o Brasil realizou uma reforma tímida e fortaleceu o caráter público, compulsório e contributivo do sistema previdenciário. Embora sem unificar o RGPS e o RPPS, as diretrizes foram as mesmas para ambos. Na verdade, o Ministério da Previdência Social assumiu a gerência do RPPS, cujo controle perpassa também as

\footnotetext{
${ }^{438}$ Reformas estruturais geram no curto prazo um expressivo déficit fiscal associado aos custos de transição que são absorvidos pelo Estado, além dos custos com o financiamento para a sua implantação e faz com que a transição possa se prolongar por mais cinqüenta anos (COELHO, 2001: 97).
} 
transferências do FPE e FPM. Todas os níveis da federação foram implicados no controle das contas previdenciárias dos entes públicos.

Em termos de mudanças nos critérios de elegibilidade para acesso aos benefícios, as mudanças mais sensíveis ocorreram no RPPS, modificando substancialmente os parâmetros, com reflexo em outras áreas do governo. Uma das mudanças mais significativas foi a adoção de um "regime previdenciário único” para servidores públicos, a exemplo do que já ocorrera com o Regime Jurídico Único ${ }^{439}$, que unificou as condições de ingresso e carreira para funcionários civis, magistrados e membros do Ministério Público e do Tribunal de Contas da União ${ }^{440}$. A extinção do IPC e a criação de um plano previdenciário facultativo ${ }^{441}$ alteraram as condições para o benefício de aposentadorias para Senadores, Deputados Federais e Suplentes. Como o plano é facultativo, os parlamentares que não aderirem se tornarão segurados obrigatórios do RGPS.

A única carreira de Estado a receber tratamento diferenciado foi a dos militares, que foram preservados sob o argumento de que se distinguiam das demais carreiras públicas ao exercer atividades peculiares. Os militares conseguiram consagrar a tese de que seus benefícios não possuem caráter de um autêntico vínculo previdenciário e, portanto, contributivo, cabendo ao Estado garantir-lhes os meios de subsistência digna ao passarem para a inatividade ${ }^{442}$. O regime previdenciário próprio para os militares manteve o benefício, contestado, da pensão concedida a filhas de militares que nunca contraem matrimônio de maneira oficial ${ }^{443}$.

\section{Reformas Paramétricas no Brasil:}

\footnotetext{
${ }^{439}$ Instituído pela Lei 8.112/90.

${ }^{440}$ EC 41, de 19 de Dezembro de 2003.

${ }^{441}$ O Plano de Seguridade Social dos Congressistas foi instituído pela Lei 9.506, de 30 de Outubro de 1997 com critérios idênticos aos adotados para o cálculo dos benefícios dos servidores públicos civis federais de mesma remuneração.

${ }^{442}$ Enquanto se discutia a PEC 40, os militares conseguiram a aprovação de uma Emenda em separado, tratando especificamente dos militares, que ganharam uma sessão (III, do Capítulo VII, Título III) própria na Constituição Federal, através da EC 18, de 05/02/1998. A justificativa faz parte do Relatório do Deputado José Pimentel, Relator da PEC 40, na Câmara dos Deputados.

${ }^{443}$ A contrapartida é o pagamento de uma alíquota de 1,5\% sobre as parcelas dos proventos. Ver MP 2.131, dezembro de 2000, que foi reeditada como MP 2.215-10, de 31 de Agosto de 2001.
} 
Os princípios constitucionais diretivos do sistema previdenciário contemplam uma concepção solidária de justiça distributiva, que envolve deveres, sacrifícios, vantagens e proteção e contribuem na construção de um modelo destinado a subsidiar a concretização dos direitos previdenciários, ao possibilitar o equilíbrio entre as metas sociais relevantes e os imperativos macro-econômicos que têm condicionado os direitos sociais e as reformas. (Rocha, 2007: 127).

“A Previdência Social é o seguro social para a pessoa que contribui. É uma instituição que tem como objetivo reconhecer e conceder direitos aos seus segurados... é utilizada para substituir a renda do trabalhador contribuinte quando perde a capacidade de trabalho, seja pela doença, invalidez, idade avançada, morte e desemprego involuntário" ${ }^{444}$. No seguro social, as relações de custeio e de benefício são independentes no seu funcionamento, mas profundamente relacionadas na sua finalidade de proteção social, o que justifica, por exemplo, o amparo aos que pouco contribuíram com o sistema, enquanto outros deverão contribuir sem ter direito a novos benefícios. Exemplos dessas situações são, respectivamente, casos de aposentadoria por invalidez e aposentados que retornam ao exercício de atividade remunerada, sem direito a uma nova aposentadoria.

No Brasil, o instrumento básico de realização da solidariedade social é o seguro social, cuja viga mestra é a previdência social. A solidariedade é o princípio estruturante de todos os direitos sociais, portador das diretrizes essenciais da seguridade e apto a catalisar a articulação entre Estado e sociedade. A solidariedade foi densificada pelos princípios da seguridade social (Rocha: 128), enquanto que as reformas produziram um novo significado para o conceito de seguridade social, a capacidade contributiva.

A pauta da agenda de reformas foi objeto de controvérsias em torno de sua constitucionalidade por ferirem os princípios diretivos ${ }^{445}$, as quais definem um processo de judicialização do debate ${ }^{446}$ (Rocha, 2004; Gonçalves, 1996).

\footnotetext{
${ }^{444}$ Definição dada pelo Ministério da Previdência Social no seu sítio: www.previdenciasocial.gov.br, acesso em 22/02/2007.

${ }^{445}$ Rocha apresenta os objetos de controvérsia em torno das diretivas constitucionais nas reformas da Previdência, através documentos produzidos pelo STF (Relatórios de Ministros em Ação Direta de Inconstitucionalidade, Acórdãos, Súmulas). A participação do Judiciário no processo de reforma previdenciária é uma questão pouco abordada pela literatura. Este tipo de abordagem ajuda na compreensão do papel ativo que o Judiciário vem exercendo no processo de reforma, muitas vezes ajudando na definição do seu contorno (RocHA, 2007).

${ }^{446}$ Gonçalves analisou a jurisprudência em torno das questões previdenciárias e concluiu que o Poder Judiciário vem se destacando com uma preocupação efetiva em torno da justiça material e se manifestado em
} 
Dentro do escopo das reformas da previdência, diferenciam-se aquelas de âmbito constitucional e aquelas que dependeram de legislação ordinária ou de normas regulamentadoras. Como os direitos da seguridade social foram minuciosamente disciplinados na Constituição Federal de 1988, qualquer alteração enseja um debate com características de reforma constitucional, até mesmo para tornar possível a adoção de leis ordinárias.

Em termos constitucionais, ocorreram duas reformas com conteúdo bem definido, uma em 1998, no Governo Fernando Henrique Cardoso, e outra, em 2003, no Governo Luiz Inácio Lula da Silva. Seus produtos foram respectivamente a EC 20, de 15 de dezembro de 1998 e a EC 41, de 19 de dezembro de 2003, as quais introduziram mudanças importantes nos dois regimes de previdência.

Analisadas em conjunto, as mudanças processadas fortaleceram aquelas diretivas constitucionais, inclusive o caráter público e obrigatório do sistema previdenciário, muito embora, do ponto de vista individual dos beneficiários, possa ter havido retração de direitos, com regras mais severas de acesso e elegibilidade. No entanto, o controle público saiu enfraquecido nas reformas, com o cálculo do valor dos benefícios retornando à condição de matéria técnica da previdência, dessa vez, com adoção de critérios atuariais.

Nas reformas, o acento foi posto nas questões mais diretamente relacionadas com 0 financiamento da previdência: o caráter contributivo, o equilíbrio financeiro e atuarial, a irredutibilidade do valor real dos benefícios, a universalidade e a proteção contra os riscos sociais. Não houve alteração na disposição geral de que " $a$ ordem social tem como base o primado do trabalho, e como objetivo o bem-estar e a justiça sociais" estejamos sendo obrigados a repensar os critérios pelos quais se pautam. Nesse sentido, houve coerência entre as razões apontadas para a reforma - o déficit e o envelhecimento da população - e o seu resultado.

Um primeiro aspecto a ser abordado foi o reforço ao caráter contributivo e obrigatório da Previdência Social, imediatamente associado à proteção contra os riscos sociais, de onde decorre a ênfase no caráter de seguro social, que traça uma linha demarcatória entre direitos contributivos e não-contributivos. A palavra risco foi extraída

favor da busca do bem estar social, que pode ser identificada não apenas nas decisões de caráter individual, mas também nas opções em favor da integridade da seguridade social (GONÇALVES, 1996).

${ }^{447}$ Art. 193. Constituição da República Federativa do Brasil, 2007. 
do direito dos seguros privados e a qualificação "social” indica que a proteção passa a ser atribuída à sociedade (Farias: 1998; Ewald: 1996). O conjunto de riscos cobertos oscila de acordo com o sistema previdenciário adotado em cada país, mas em geral, abrange eventos incidentes sobre a renda do trabalhador, quando da impossibilidade de auferi-la através do trabalho.

A Constituição Federal de 1988 estabeleceu um valor mínimo ${ }^{448}$ para o benefício, como requisito à preservação de um nível de vida comparável ao desfrutado pelo segurado anteriormente à consolidação do risco. Criou também a fórmula da “irredutibilidade do valor do benefício" 449 visando garantir que não houvesse rebaixamento nas condições de vida dos inativos com o passar do tempo. Ao criar regras para o cálculo do valor e correção das aposentadorias, a Constituição Federal tornou essa uma decisão política e pública, fora da esfera de decisão do Poder Executivo. Essas três medidas, em conjunto, formaram o núcleo central das disputas em torno das contas da Previdência e pautaram o debate público na regulamentação da seguridade social e da previdência social e na reforma do Governo Fernando Henrique.

O direito à prestação previdenciária aparece, assim, como uma combinação entre o resultado econômico da atividade produtiva e o exercício da solidariedade social, que é convertida em proteção social, individual e previsível, da qual o poder público não pode desincumbir-se sob alegação de dificuldades financeiras. O vínculo contributivo produz uma relação jurídica própria entre indivíduo e Estado e torna o direito previdenciário passível de ser exigido na Justiça, o que não ocorre com a Assistência Social ou com a Saúde. Por este motivo, diferentemente do que ocorreu com estas duas áreas, o Tesouro não deixou de repassar para a previdência social os valores apurados como a diferença entre o arrecadado e o dispêndido a título de benefícios previdenciários.

A polêmica em torno das “contas da Previdência” é exemplo da dificuldade que a política de assistência social de caráter universal enfrenta para se impor, uma vez que o ponto central dessa disputa é a origem dos recursos que devem financia-la. Se os recursos provêm da contribuição dos trabalhadores e empregadores sobre a folha de salário, então,

\footnotetext{
448 “Art. 201, § 5 . Nenhum benefício que substitua o salário de contribuição ou o rendimento do trabalho do segurado terá valor mensal inferior ao salário mínimo”. Constituição da República Federativa do Brasil, 2007.

${ }^{449}$ Art. 194, item IV, Constituição da República Federativa do Brasil, 2007.
} 
ela se afirma como uma modalidade da previdência social. No entanto, a política de previdência social se afirma cada vez mais como um seguro social vinculado à cobertura de riscos sociais previstos, dos quais a pobreza não faz parte. A própria definição da previdência social como seguro social de natureza contributiva e de filiação obrigatória promove a expulsão dos benefícios da assistência social de seu escopo de cobertura. O que é reforçado pelo contingenciamento do respeito ao equilíbrio financeiro e atuarial, que indica que as “contas” não podem ultrapassar o limite de gasto disponível em caixa, oriundos principalmente das contribuições sobre a folha de pagamento de salários.

É por negação que se tem construído a política de assistência social que se ergue em torno dos benefícios de prestação continuada, pagos pela Previdência Social, enquanto estrutura administrativa, mas financiados por toda a sociedade com base nas contribuições sociais definidas no texto constitucional. Também é por negação que se pretende que a Previdência Social seja auto-suficiente, não dependente do financiamento de toda a sociedade, como comprova o não repasse de recursos do Orçamento da Seguridade Social para seu financiamento.

A Constituição Federal de 1988 conferiu densidade à proteção contra os riscos sociais ao promover uma relação de hierarquização e seleção de situações de necessidade social a serem atendidas pelo regime geral, que resultou numa obrigação jurídica do Estado proteger os cidadãos contra a ocorrência dos riscos sociais eleitos ${ }^{450}$. Com a não implantação do sistema de seguridade social, a Previdência Social viu suas competências em pagamento de benefícios serem aumentadas sem o aporte de mais recursos financeiros. Durante os debates, a posição defensiva que assumiu tratou de promover a distinção entre previdência, assistência e saúde. Talvez o ataque mais direto tenha sido contra a saúde, cujos gastos foram historicamente relacionados ao aumento do déficit previdenciário. Ao final do processo das reformas ficou muito claro o peso dos benefícios assistenciais e das aposentadorias dos trabalhadores rurais (não contributivos) nas despesas previdenciárias. $\mathrm{O}$

\footnotetext{
450 “Art. 201. Os planos de Previdência Social, mediante contribuição atenderão, nos termos da lei, à: I cobertura dos eventos de doença, invalidez, morte, incluídos os resultantes de acidentes do trabalho, velhice e reclusão; II- ajuda à manutenção dos dependentes dos segurados de baixa renda; III - proteção à maternidade, especialmente à gestante; IV- proteção ao trabalhador em situação de desemprego involuntário; V-pensão por morte do segurado, homem ou mulher, ao cônjuge ou companheiro, observado o disposto no § $5^{\circ}$. e no art 202”. Redação original da Constituição da República Federativa do Brasil, 1988.
} 
resultado mais importante, e não esperado, dos debates sobre a reforma, talvez tenha sido o da promoção de uma concepção clara do que é um seguro social e suas finalidades.

Nessa nova perspectiva, concebe-se que o seguro social perante os riscos deva exercer ações preventivas e reparatórias com a recomposição do equilíbrio econômico dos segurados afetados por necessidades sociais deles decorrentes, mediante o pagamento de prestações substitutivas (Rocha: 147). Não há solidariedade social sem contribuição social. O que deve ser redistribuído é a contribuição que a sociedade realiza para si própria. Os benefícios previdenciários materializam a proteção social com base na renda que o segurado recebia, ou seja, com base no salário de contribuição.

A nova interpretação da força vinculativa à Previdência pelo caráter contributivo e obrigatório abriu caminho para os projetos de inclusão previdenciária, cujos objetivos são: aumentar a arrecadação previdenciária e aumentar o número de afiliados ao sistema, para reduzir, no futuro, a concessão de benefícios de caráter não-contributivo, como aqueles próprios da assistência social e da previdência social rural.

Identificada como a segunda reforma previdenciária no Governo Lula, a agenda de inclusão previdenciária institui um sistema especial para atender a trabalhadores de baixarenda e àqueles, sem renda própria, que se dediquem exclusivamente ao trabalho doméstico no âmbito de sua residência, desde que pertencentes a famílias de baixa renda ${ }^{451}$. Aos incluídos no sistema especial, será garantido benefício no valor igual a um salário-mínimo e alíquotas de contribuição e carência inferiores às vigentes para os demais segurados do regime geral. O objetivo da inclusão previdenciária é aumentar a arrecadação e ampliar a base de cobertura do sistema previdenciário.

A edição da Emenda Constitucional da inclusão previdenciária suscitou novos PLs no Congresso Nacional $^{452}$, versando sobre aposentadoria para as donas-de-casa ${ }^{453}$,

\footnotetext{
${ }^{451}$ Art. 201, § 12 da EC 47, 05 de Julho de 2005. Constituição da República Federativa do Brasil, 2007.

${ }^{452}$ PL 5.773/05, PL 5.866/05, PL 5.933/05, PL 6.169/05, PL 6.295/05, PL 6.366/05 e o PLS 318/05. O PLS 318/05, aprovado no Senado, pretendia fixar a alíquota de contribuição em $11 \%$ sobre o limite mínimo mensal do salário de contribuição, desde que esses segurados renunciassem ao direito ao benefício de aposentadoria por tempo de contribuição. Nesse Projeto de Lei, considerou-se trabalhador de baixa-renda o contribuinte individual com renda mensal de até dois salários mínimos e que trabalhe por conta própria, sem relação de emprego, e do segurado facultativo sem renda própria que se dedique exclusivamente ao trabalho doméstico no âmbito de sua residência e pertença a família de baixa renda.

${ }^{453}$ O dirigente do Sindicato Nacional dos Aposentados da CUT - Epitácio Luiz Epaminondas estimou que existam cerca de 1,8 milhões de donas-de-casa sem renda ou que recebem menos de um salário mínimo mensal, durante Audiência Pública para discutir a inclusão previdenciária na Comissão de Seguridade Social e Família. Ata da Reunião da CSSF do dia 23/05/2006. Diário da Câmara dos Deputados, 23/05/2006.
} 
estagiários, trabalhadores sem vínculo empregatício (trabalhadores autônomos, avulsos, diaristas, trabalho temporários, trabalho em tempo parcial, trabalho em regime de empreitada, trabalho de assessoramento ou consultoria e trabalho do profissional liberal). A maior parte desses trabalhadores teria como condicionante o exercício de um número restrito de horas de trabalho e a não configuração de relação de emprego.

A CSSF rejeitou, por sua vez, o projeto que pretendia instituir o trabalho sem vínculo empregatício, por representar um entrave ao desenvolvimento nacional e por institucionalizar o trabalho precário e à margem dos direitos trabalhistas. Este parecer indica que o projeto de inclusão previdenciária não pode concorrer com as relações de emprego formais que garantem tanto o direito trabalhista quanto o previdenciário ${ }^{454}$. Apesar de ser visto como um projeto que garantirá o futuro do sistema previdenciário, a inclusão previdenciária não isenta o governo de criar mecanismos para formalizar as relações de emprego.

Para assegurar a contribuição previdenciária entre os autônomos e na contratação de cooperativas de trabalho, a alíquota de contribuição foi reduzida e a pessoa jurídica contratante passou a ser responsável pelo recolhimento da parte que cabe tanto ao empregador quanto ao trabalhador. A Previdência Social, desse modo, vai se adequando às modificações introduzidas nos contratos de trabalho, se posicionando de forma neutra, mas fortalecendo o princípio da obrigatoriedade da contribuição.

A obrigatoriedade do recolhimento das contribuições impõe restrições ao acesso à cobertura do seguro social, pois deixam de estar cobertos todos os que não possuem capacidade contributiva ou que exercem atividade no mercado informal de trabalho. Esses, quando em condição de incapacidade permanente para o trabalho, serão amparados pela política de assistência social, que também contempla prestações em espécie, no valor de um salário mínimo. O vínculo contributivo é o ponto de cisão entre os benefícios assistenciais e os previdenciários, assim como define o tipo de relação do Estado para cada grupo específico de atendidos. O debate sobre a inclusão previdenciária dos últimos anos visa exatamente a promoção de um grupo ao outro, ou seja, fazer passar os futuros dependentes da assistência à condição de beneficiário da previdência, através da sua promoção à

\footnotetext{
${ }^{454}$ Ver a respeito o parecer do relator do deputado Darcício Perondi (PMDB/RS) sobre o PL 428/03, do senador Paes Landim (PFL/PI). Ata da Comissão de Seguridade Social e Família, Diário da Câmara dos Deputados, 24/2/2006.
} 
condição de contribuinte. É o reconhecimento do peso dos benefícios assistenciais nas contas (presentes e futuras) da Previdência. O ponto central é como criar estímulos que façam com que cidadãos não contribuintes passem a desejar contribuir através da promoção de critérios diferenciais. A questão é a remoção da irracionalidade da Previdência Social.

A inclusão previdenciária é um projeto que segue na contramão da direção adotada pelas demais reformas previdenciárias, uma vez que não parte da retração dos direitos, mas do aumento da arrecadação, através da inclusão daqueles que hoje estão fora da previdência social, seja devido à precária inserção no mercado de trabalho, seja devido à deterioração do mercado de trabalho formal. O envelhecimento da população e a baixa cobertura do sistema fazem com que a relação entre contribuintes e beneficiários vá diminuindo cada vez mais, contribuindo para o desequilíbrio da contabilidade da Previdência. Os projetos de inclusão previdenciária mantêm, no entanto, o caráter facultativo da contribuição.

É preciso considerar que os trabalhadores de baixa-renda que hoje não estão inscritos no sistema previdenciário deverão ser inseridos nos programas assistenciais de renda continuada ao entrarem em idade avançada ${ }^{455}$, com recebimento de um salário mínimo mensal. De outro modo, o projeto de inclusão pretende atrair aqueles trabalhadores de renda mais elevada e que não estão inscritos na Previdência, como autônomos, profissionais liberais e empresários. Para incentivar a redução da informalidade no mercado de trabalho, por sua vez, é necessário que ocorra: desenvolvimento econômico, reforma trabalhista e reforma tributária. A previdência social, para o governo, é sensível a esses três temas.

Como compromisso público entre gerações, o direito decorrente do já contribuído não pode simplesmente ser derrogado sem provocar uma desordem pública que afete a própria estabilidade do governo. A saída é buscar uma fórmula que permita o ajuste, seja modificando as regras de modo a retardar o acesso a benefícios programáveis (aposentadorias), seja modificando as regras de cálculo. Nas reformas, as duas saídas foram tentadas. Na reforma no Governo Fernando Henrique, um dos principais pontos foi retirar do texto constitucional as regras de cálculo dos benefícios previdenciários, trazendo-a de volta ao âmbito das decisões técnicas. Ao “desconstitucionalizá-la”, despolitizou-a.

\footnotetext{
${ }^{455}$ Com a clivagem de gênero que estabelece um diferencial de 5 anos para homens e mulheres, portanto, ao completarem, respectivamente, 65 e 60 anos de idade.
} 
Doravante não apenas os índices de reajuste passam a ser de natureza técnica, mas o próprio resultado tornou-se dependente da combinação entre idade e tempo de contribuição. O fator previdenciário não apenas implantou uma nova regra para o cálculo do benefício, mas introduziu um elemento atuarial nas contas da Previdência e permitiu a individualização no cálculo do valor da aposentadoria.

Na primeira reforma ${ }^{456}$, a conversão da “aposentadoria por tempo de serviço” para “aposentadoria por tempo de contribuição” fortaleceu o caráter contributivo e obrigatório do sistema previdenciário, nos regimes dos trabalhadores da iniciativa privada e dos servidores públicos. A inversão provocada não é apenas a substituição dos termos, mas uma mudança na força vinculativa da proteção social derivada do trabalho ou da filiação e manutenção do vínculo com a Previdência Social. Na versão anterior, era o fato de ter exercido atividade remunerada (trabalho) que conferia o direito à aposentadoria por contagem de tempo e, na nova versão, o direito deriva diretamente do vínculo contributivo individual de cada beneficiário. Pelo sistema antigo, o trabalhador deveria comprovar que trabalhou e não necessariamente que contribuiu com o sistema para garantir o acesso aos benefícios ${ }^{457}$. O fator previdenciário pretende ser como "uma linha de corte em relação ao sistema que houve até agora" (Ornélas, 2000: 15) na busca de adequação entre contribuição e rendimentos.

A conversão para "aposentadoria por tempo de contribuição” foi, sem dúvida, uma fórmula política intermediária entre a manutenção e a extinção da "aposentadoria por tempo de serviço”, que vem sendo defendida por técnicos, políticos e pelo Governo. Entre as principais críticas ao modelo está o seu caráter estranho na cobertura dos riscos sociais. A “aposentadoria por tempo de trabalho” vem sendo desconstruída como direito, por não corresponder à idéia de risco social, o que a torna um privilégio dos trabalhadores mais bem situados no mercado de trabalho, com postos mais estáveis, qualificados e com remuneração mais elevada. São trabalhadores que se aposentam cedo, em plena capacidade produtiva, contribuindo para elevar o déficit da Previdência Social. No discurso oficial as

\footnotetext{
456 “Art. 201, \& $7^{\circ}$. "É assegurada aposentadoria no regime geral de previdência social, nos termos da lei, obedecidas as seguintes condições: I. 35 anos de contribuição, se homem e 30 anos de contribuição, se mulher". Redação dada pela EC 20, de 1998. Constituição da República Federativa do Brasil, 2007

457 Para facilitar a transição da aposentadoria por tempo de serviço para a aposentadoria por tempo de contribuição, a EC 20/98, em seu artigo $4^{\circ}$ permitiu que todo o tempo de serviço fosse considerado como tempo de contribuição. Regras mais rígidas foram adotadas, no entanto, na admissão como segurado facultativo, com impedimento, por exemplo, de crianças contribuintes.
} 
aposentadorias por tempo de serviço correspondem a uma grande parte dos gastos com benefícios.

O argumento central para a revisão do tempo de contribuição é a sua interpretação como um mecanismo perverso de transferência de renda, dos mais pobres para os mais ricos, posto que seus valores são, em média, 144\% maiores do que a média de todos os benefícios da Previdência e que os seus beneficiários são os trabalhadores com maior renda e com maior estabilidade no emprego. As aposentadorias por tempo de serviço correspondem a 16,7\% do total das aposentadorias e 37,2\% das despesas previdenciárias, enquanto que 59,6\% das aposentadorias por idade, correspondem a 38,5\% das despesas (Ornélas, 2000: 18; Brasil, 2002)). No entanto, pesquisas têm demonstrado que se deve ter cuidado com essas afirmações, posto que, do ponto de vista atuarial, a aposentadoria por tempo de serviço é a que menos onera a Previdência, pois suas taxas de retorno são as menores, sendo que os seus beneficiários são os que mais contribuíram quando ativos (Calsavara:2001:52).

Tabela 20: Brasil: Taxas anuais de retorno por tipo de programa de benefício

\section{PROGRAMA}

TAXA ANUAL DE RETORNO (\%)

Ap. idade (5 anos de contribuição)

$43,93 \%$

Ap. idade (12 anos de contribuição)

$15,06 \%$

Ap. idade (15 anos de contribuição)

$11,25 \%$

Ap. idade (40/45 anos de contribuição)

$2,86 \%$

Ap. tempo de serviço (25/30 anos contribuição)

$7,60 \%$

Ap. tempo de serviço (30/35 anos contribuição)

$7,02 \%$

Ap. tempo de serviço (35/40 anos contribuição)

$5,46 \%$

Fonte: Banco Mundial, 1995. In: Calsavara (2001: 42)

Os dados do Banco Mundial demonstram que nas duas modalidades de aposentadorias - tempo de contribuição e idade - os beneficiários recebem mais do que contribuíram para o sistema, sendo que quanto menor o tempo de contribuição maior será a taxa de retorno. Os dados demonstram que não há redistribuição de renda dos mais pobres em favor dos mais ricos. Embora as aposentadorias por tempo de contribuição sejam aquelas com valor mais elevado, são os seus beneficiários os maiores e mais regulares 
contribuintes do sistema. Como os benefícios são calculados de acordo com a contribuição, os resultados indicam que as suas contribuições também foram as mais altas.

Historicamente, a aposentadoria por tempo de serviço foi conhecida como aposentadoria ordinária, o que a distinguia das demais fórmulas, amparadas no conceito de risco social (velhice e invalidez). Não é a primeira vez que é combatida como um direito estranho ao sistema previdenciário e de trabalho, ou como anomalia perante demais sistemas previdenciários existentes em outros países. No Governo de Getúlio Vargas ela chegou a ser suspensa em dezembro de 1930, em decorrência do crescimento das despesas das CAPs. Enquanto perdurou a suspensão, o governo manteve apenas o pagamento da aposentadoria por invalidez e pensões de sobreviventes ${ }^{458}$.

A combinação dos critérios tempo e idade para aposentadoria preconizada durante as reformas e objetivada para os servidores públicos também não é uma inovação deste momento. O duplo critério foi introduzido em 1923, abolido em 1925 e reeditado em 1931, definindo como idade mínima para aposentadoria 50 anos de idade e 30 anos de serviço ${ }^{459}$. A criação do IAPI em $1936^{460}$ simplesmente não previu a concessão da aposentadoria ordinária, que já era reconhecida como o benefício mais importante e dispendioso sustentado pelo sistema.

Oliveira \& Teixeira (1986: 131-138) apontam que a adoção de medidas “contencionistas”, naquele momento, estava relacionada à crise econômica do final dos anos 1920, que provocou queda na arrecadação e aumento nas despesas públicas, levando o Estado a intensificar uma política de socialização de perdas. As restrições impostas à previdência, assistência e saúde foram dirigidas a conter as despesas públicas, de modo que o governo pudesse continuar a injetar os recursos disponíveis nos setores produtivos da economia.

\footnotetext{
${ }^{458}$ A suspensão, como medida de emergência e temporária, foi adotada pelos Decretos 19.554, de 31 de Dezembro de 1930 e pelo Decreto 20.048, de 28 de Maio de 1931 e embora não se tenha registro do período de vigência, foram adotados como parte das medidas contencionistas do Governo Vargas. (OLIVEIRA \& TEIXEIRA, 1986: 77-78).

${ }^{459}$ O Decreto 20.465, de 01/10/1931 que promoveu uma reforma das CAPs (Caixas de Aposentadorias e Pensões) trazia várias medidas contencionistas, entre as quais o estabelecimento do duplo critério para aposentadoria ordinária e a possibilidade de que benefícios tivessem valor rebaixado, em razões de ordem atuarial, econômica ou política; o calculo do benefício seria proporcional e igual para todas as faixas. O Decreto 21.081, de 24/12/1932 reduziu o valor do benefício e restringiu a assistência médica. Para Oliveira, a medida abria a possibilidade da Previdência não honrar seus compromissos com os segurados. Idem: 78.

${ }^{460}$ Lei 367, de 31/12/1936 e Decreto 1.918, de 27/08/1937. Ibidem: 82.
} 
Em 1998, a instituição da “aposentadoria por tempo de contribuição” pode ser considerada equivalente à eliminação da aposentadoria especial ${ }^{461}$ para algumas categorias profissionais, por eliminar condições díspares de acesso aos benefícios, vincular a percepção de benefício ao tempo de contribuição e, principalmente, retardar a aposentadoria. Aos trabalhadores sujeitos a trabalho em condições especiais, que prejudiquem a saúde ou a integridade física, foi mantido o direito à aposentadoria especial em observância à garantia dos direitos relativos à saúde do trabalhador. Para Reinhold Stephanes a mudança nos critérios para concessão de aposentadoria especial introduziu um novo conceito que realmente vincula o direito às condições especiais de trabalho e não a toma como prêmio para determinadas categorias profissionais ou como compensação pela baixa proteção à saúde do trabalhador. Nesse ponto, a mudança fez-se acompanhar da mudança nas prestações do seguro de acidentes de trabalho (SAT) a cargo do empregador, que modificou as alíquotas de contribuição para complementar as prestações por acidente de trabalho ${ }^{462}$.

Nos RPPS, a alteração foi ainda mais significativa, posto que inexistia o vínculo contributivo do servidor até a edição da EC 03/93 ${ }^{463}$. A EC 20/98, não apenas reforçou o vínculo contributivo, mas conferiu-lhe ainda "caráter solidário e em respeito ao princípio do equilíbrio financeiro e atuarial "464. Essa Emenda abriu espaço para que o vínculo contributivo avançasse também em direção aos rendimentos dos inativos do serviço

\footnotetext{
${ }^{461}$ Perderam o direito a aposentadoria especial os professores universitários, jornalistas e aeronautas. O direito foi mantido apenas para professores do ensino infantil, fundamental e médio.

462 A Lei 9.732, 11/12/1998 estabeleceu que a contribuição da empresa para complementação das prestações previdenciárias serão acrescidas de $6 \%$, $9 \%$ ou $12 \%$ conforme a atividade especial exercida pelo segurado, que pode se aposentar com 15, 20 ou 25 anos de trabalho. O seu objetivo é induzir à prevenção de acidentes com manutenção dos agentes nocivos à saúde dentro dos limites de tolerância determinados pela Organização Mundial da Saúde. Como assinala Reinhold Stephanes, "é inadmissível o dano causado à saúde do trabalhador pelo exercício do trabalho", ou seja, não há compensação, benefício que o justifique. STEPHANES, Reinhold. "Um novo conceito de aposentadoria especial”, O Estado de São Paulo, 23/12/1998. 463 “Art. 40, \& $6^{\circ}$. As aposentadorias e pensões dos servidores públicos federais serão custeadas com recursos provenientes da União e das contribuições dos servidores na forma da lei”. EC 03, de 17 de Março de 1993. Parágrafo alterado em função de nova redação conferida pela EC 20/98. Constituição da República Federativa do Brasil, 2007.

464 “Art. 40 - Aos servidores titulares de cargos efetivos da União, dos Estados, do Distrito Federal e dos Municípios, incluídas suas autarquias e fundações é assegurado regime de previdência de caráter contributivo, observados critérios que preservem o equilíbrio financeiro e atuarial e o disposto neste artigo. EC 20, de 15/12/98. Constituição da República Federativa do Brasil, 2007.
} 
público, com a EC 41/03 465 . Ademais, ficou estabelecido que a contribuição da União para o RPPS não poderia exceder o dobro da contribuição do servidor estatutário.

A contribuição dos inativos com base no princípio da solidariedade acendeu uma ampla discussão jurídica sobre a contribuição previdenciária e sua destinação específica, posto que a mesma medida havia sido julgada inconstitucional para os segurados do RGPS em 1998, que passou a ser protegido contra a incidência de contribuição sobre aposentadorias e pensões. ${ }^{466} \mathrm{O}$ argumento central era o de que a tributação sobre os rendimentos provenientes de benefícios previdenciários atentava contra a natureza do seguro social, posto que a obrigação contributiva cessaria com a passagem à inatividade ${ }^{467}$. Todavia, o mesmo argumento não foi considerado válido para os servidores públicos, visto que a cobrança de inativos foi considerada constitucional e segue em vigor.

Os servidores públicos foram os vilões de toda a década de 1990, acusados de serem detentores de privilégios que deveriam ser corrigidos, seja pela sua integração ao RGPS, seja pela redefinição dos critérios para concessão dos benefícios que os aproximassem dos vigentes para os trabalhadores da iniciativa privada. De fato, as medidas de maior impacto repercutiram sobre o servidor público federal, que, manteve, ao final da década, praticamente apenas o benefício da estabilidade (Rocha: 180), com a introdução de critérios similares aos vigentes na Previdência Social: unificação do teto de benefícios nos dois regimes ${ }^{468}$; vedação de acúmulo de aposentadorias e vencimentos na administração pública $^{469}$; a introdução de um componente atuarial no cálculo da aposentadoria, que põe

\footnotetext{
465 O art. 40 recebeu nova redação com a edição da EC 41/2003, para constar que "é assegurado regime de previdência de caráter contributivo e solidário, mediante contribuição do respectivo ente público, dos servidores ativos e inativos e dos pensionistas, observados critérios que preservem o equilíbrio financeiro e atuarial e o disposto neste artigo”. EC 41, 19 de Dezembro de 2003. Constituição da República Federativa do Brasil, 2007.

466 “Art. 195, II. Do trabalhador e dos demais segurados da previdência social, não incidindo contribuição sobre aposentadorias e pensão concedidas pelo regime geral de previdência social de que trata o art. 201”. Redação dada pela EC. 20, de 15/12/1998. Constituição da República Federativa do Brasil, 2007.

${ }^{467}$ A respeito do debate sobre a inconstitucionalidade e os relatórios dos Ministros do Supremo Tribunal Federal, ver (RocHA, 2004: 210-215).

${ }^{468}$ Estipulado em 2003 no valor de R\$ 2.400,00 (Dois Mil e Quatrocentos Reais), a ser reajustado de forma a preservar o seu valor real, atualizado pelos mesmos índices aplicados aos benefícios do regime geral de previdência social (art. 5, EC 41/2003). Constituição da República Federativa do Brasil, 2007.

${ }^{469}$ A Constituição, já com novas redações conferidas pelas EC19, de 04/06/1998 e a EC 34, de13/12/2001, apenas admitem a percepção simultânea de proventos e remuneração para cargos acumuláveis, cargos eletivos; cargos em comissão e servidores aposentados que reingressaram por novo concurso público até a data da publicação da EC20/1998. A EC 34 trata exclusivamente de acúmulo de atividades privativas da área da saúde. Constituição da República Federativa do Brasil, 2007.
} 
fim ao princípio da integralidade da aposentadoria e institui o salário de contribuição ${ }^{470}$; fim da regra de paridade que estabelecia revisão de pensões e aposentadorias na mesma proporção de data dos vencimentos dos servidores ${ }^{471}$; proibição da contagem de "tempos fictícios de trabalho" para fins de aposentadoria ${ }^{472}$.

Quanto a critérios específicos dos servidores estatutários, as principais alterações foram a instituição de teto para remuneração em cargos, funções e empregos públicos ${ }^{473}$ e o fim da isonomia de vencimentos ${ }^{474}$. Foram criados ainda regimes complementares de previdência para servidores estatutários, mediante aprovação do Poder Executivo, e proibida a existência de mais de um regime próprio de previdência social para os servidores titulares de cargos efetivos, assim como a existência de mais de uma unidade gestora em cada ente estatal ${ }^{475}$.

Uma demarcação rígida passou a separar os regimes previdenciários destinados aos servidores ocupantes de cargos efetivos e os ocupantes de cargo em comissão (de livre provimento) ou temporário. Enquanto os primeiros são afiliados dos regimes próprios de previdência social, os segundos serão necessariamente afiliados do regime geral. A Lei do Emprego Público (Lei 9.962, de 22/02/2000) permitiu a contratação de agentes públicos através de contrato regido pela CLT e a Lei 8.647 proibiu a inclusão de servidores contratados de ingressarem no regime previdenciário público. As restrições tendem à

\footnotetext{
${ }^{470}$ A MP 167, de 19 de fevereiro de 2004, determinou no seu artigo $1^{\circ}$ que se considere a média atualizada das remunerações utilizadas como base para as contribuições aos regimes de previdência a que esteve vinculado, para o cálculo dos proventos de aposentadoria dos servidores ocupantes de cargo efetivo. $\mathrm{O}$ valor dos proventos deve corresponder a $80 \%$ de todo o período contributivo. Como nem todos os regimes existentes exigiam recolhimento de contribuições, o parágrafo $2^{\circ}$ deste artigo prevê que seja considerado como base de cálculo dos proventos a remuneração do servidor no cargo efetivo no mesmo período.

${ }^{471}$ Com a EC 41/2003, a base para o reajuste de aposentadorias e pensões passa a ser o critério da preservação do valor do real, definido em lei, com mecânica similar à do RGPS. § $8^{\circ}$, art. 40, EC 41/2003. Constituição da República Federativa do Brasil, 2007.

${ }^{472}$ Art 40, § 10, EC 20/98. O artigo põe fim à contagem em dobro de férias e licenças-prêmios não usufruídas como tempo de trabalho na contagem para a aposentadoria por tempo de contribuição (voluntária). Constituição da República Federativa do Brasil, 2007.

${ }^{473}$ O Art. 37, EC 41/03 estipula que a maior remuneração e/ou subsídio dos ocupantes de cargos, funções e empregos públicos da administração direta, autarquia ou fundação, dos membros de quaisquer Poderes da União, dos Estados, do Distrito Federal ou dos Municípios será a dos Ministros do Supremo Tribunal Federal ou dos Desembargadores do Tribunal da Justiça, no Poder Legislativo, incluindo o Ministério Público, Procuradores e Defensores Públicos. A EC 41/2003 apenas reforçou o que já estava estipulado no Inciso XI, do art. 37, da EC 19, 04/06/1998. Constituição da República Federativa do Brasil, 2007.

${ }^{474}$ Inciso XIII, Art. 37 da Constituição Federal de 1988, com nova redação dada pela EC 19/98, que veda a vinculação ou equiparação de quaisquer espécies remuneratórias no serviço público. Constituição da República Federativa do Brasil, 2007.

${ }^{475}$ Art. 40, § 20, EC 20/ 1998. Constituição da República Federativa do Brasil, 2007.
} 
redução do tamanho do Estado, com tendência à queda na contratação de servidores públicos mediante concurso e aumento na contratação por livre provimento de cargos, como ocorreu com a criação de 1.332 cargos em $2004^{476}$.

A extinção de alguns benefícios como abono, pecúlio, auxílio natalidade e auxílio funeral antecederam as reformas constitucionais e tiveram como objetivo enxugar o número de benefícios e reduzir as despesas. Outros benefícios, inscritos na Constituição, ficaram restritos aos trabalhadores de baixa-renda, em reforço ao princípio da seletividade da seguridade social, como é o caso do salário-família ${ }^{477}$ e do auxílio-reclusão ${ }^{478}$.

A tentativa de repassar os encargos com o salário-maternidade para os empregadores foi frustrada pelo STF que entendeu que poderia haver discriminação na contratação de mulheres no mercado de trabalho, além de retrocesso histórico, deixando a maternidade de ser considerada situação de risco social. A investida foi determinada pelo diferencial do cálculo desse valor de benefício em relação ao teto de benefícios da previdência social, uma vez que a Constituição determinava licença de cento e vinte dias com salário integral da segurada. Pleiteava-se, dessa forma, a revogação do inciso XVIII do artigo $7^{0}$ da Constituição e o repasse de seus encargos para o empregador, quando ultrapassasse o teto dos benefícios previdenciários. Ao longo das reformas, esse benefício acabou estendido às trabalhadoras que antes não tinham direito, tais como autônomas e empresárias, numa política de criar atrativos para a filiação à Previdência Social.

As mudanças mais significativas no setor privado foram, entretanto, aquelas que resultaram na alteração das regras para o cálculo do valor da aposentadoria. A desconstitucionalização da regra de cálculo permitiu ao legislador introduzir um componente atuarial no mecanismo de cálculo (expectativa de sobrevida, idade e tempo de contribuição) e ampliação do período básico de cálculo (Lei 9876, de 29/11/1999).

O MPS considerou que no primeiro ano pós-reforma a instituição fechou o caixa com uma redução no déficit de $\mathrm{R} \$ 10,07$ bi (0,9\% do PIB), mas que voltou a subir em 2001, atingindo R\$ 12,8 bi. A Lei 9876, de 26/11//99 regulamenta as disposições constitucionais e promove verdadeiramente a reforma aprovada pela EC 20: ampliação do

\footnotetext{
${ }^{476}$ MP 163, de 23/01/2004.

${ }^{477}$ Inciso XII, art. $7^{\circ}$, com redação conferida pela EC 20/98. Constituição da República Federativa do Brasil, 2007. v

478 “Art. 201, IV - salário-família e auxílio-reclusão para os dependentes dos segurados de baixa renda”. EC. 20/1998. Constituição da República Federativa do Brasil, 2007.
} 
período de cálculo do beneficio; consideração da idade e da expectativa de vida na fórmula de cálculo do benefício; eliminação gradativa da escala de salários base dos contribuintes individuais; homogeneização do valor das contribuições da empresa; diferenciação entre inadimplente e sonegador; redução de juros para indenização de tempo de serviço passado; generalização do pagamento do salário-maternidade pelo INPS $^{479}$. A lei instituiu o fator previdenciário, que é um mecanismo de redução do valor da aposentadoria em função da idade e da expectativa de vida e que pretende funcionar como incentivo à permanência do trabalhador no mercado de trabalho após completar o tempo mínimo para requerimento da aposentadoria.

No setor público, as reformas foram mais amplas e modificaram não apenas as regras de acesso e critérios de elegibilidade, mas produziu a concepção de previdência social para servidores públicos. Nesse sentido, cabe destacar que as reformas criaram uma conta para aposentadoria distinta da folha de pagamentos dos servidores ativos, alimentada por contribuições de servidores (ativos e inativos) e do Estado empregador, que até então não existia. As reformas restringiram também o acesso ao acúmulo de aposentadorias que era mais freqüente entre servidores públicos e objetivaram garantir maior tempo de permanência no serviço público, através da introdução do critério cruzado entre tempo de contribuição e idade mínima para aposentadoria. Retardar aposentadorias é uma medida que ajuda a equilibrar as contas públicas, posto que diferentemente da iniciativa privada, o crescimento do ativo dos servidores público é controlado pelo próprio Estado empregador. Permanece em aberto a questão da adoção do mesmo teto de benefícios adotado no RGPS e a remoção do critério diferencial de idade entre homens e mulheres na concessão da aposentadoria.

Os dois pontos em aberto e que não considerados centrais no avanço do processo de racionalização da Previdência Social são: extinção da diferença de critérios de acesso à aposentadoria entre homens e mulheres, dada a sobrevida maior entre mulheres, que afeta o tempo de permanência no sistema e despesas com pensão por morte; inclusão do critério idade no cálculo do benefício (quanto mais jovem se aposentar, menor será seu beneficio) que reduz as chances de alguém se aposentar cedo. A expectativa é de que a idade média de aposentadoria se eleve para 60 anos de idade. Ainda é cedo para avaliar os resultados. O

\footnotetext{
${ }^{479}$ Ver Nota Técnica sobre o fator previdenciário, Anexo 1.
} 
número de aposentadorias já vinha caindo anteriormente à reforma como resultado da repressão ou antecipação da demanda. Com a retração do emprego formal, também deve cair o número de beneficiários e dependentes do sistema previdenciário, enquanto poderão aumentar o número daqueles dependentes de benefícios assistenciais, sem vínculo contributivo, o que pode alterar toda a dinâmica do principal pólo de política social no Brasil e de maior estabilidade. Essa é a questão em aberto com implicações presentes e futuras sobre o grau de segurança sócio-econômica.

\section{Nota sobre a previdência complementar}

Embora a previdência pública tenha prevalecido após as reformas, não houve constrangimento para o crescimento do seguro privado, a título de previdência complementar, que, ao contrário, foi incentivada publicamente.

No cenário de discussão pós-privatização, que abriu espaço para a previdência privada aberta ${ }^{480}$, o movimento tem demonstrado o crescimento na oferta e na demanda; o crescimento de opções por aplicações de curto prazo e planos para crianças com resgate aos 18 anos de idade. A adesão a planos para menores de 18 anos cresceu 76\% em 2007,

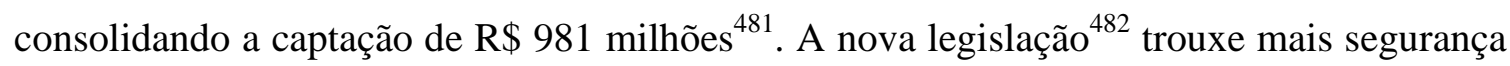
para os planos e criou novas regras, estipulando que, quanto mais tempo o dinheiro ficar aplicado no plano, menor será o desconto do Imposto de Renda. Uma hipótese para o crescimento é a preocupação dos pais com o futuro dos filhos, relacionados tanto à educação quanto com a ausência de trabalho.

Após analisar esses dados, chegamos à conclusão de que a opção pela previdência complementar não tem visado necessariamente garantir a aposentadoria no futuro, mas, tem funcionado como uma poupança individual com resgate pré-fixado e a curto prazo. Se, por um lado, o incremento da previdência complementar revela uma maior preocupação em garantir uma poupança de longo prazo ${ }^{483}$, por outro, revela mais a busca por uma

\footnotetext{
${ }^{480}$ Que não inclui os fundos de pensão fechados.

481 "Planos para jovens ajudam a formar cultura da poupança”, Valor Econômico, 29/11/2007. "Evolução da Previdência”, Valor Econômico, 13/12/2007.

${ }^{482}$ Lei 11.196, de novembro/2005.

483 Afirma-se que, no Brasil, é baixa a cultura de poupar para o futuro. No entanto, o fenômeno pode ser explicado pelo baixo rendimento dos salários que faz com que seja necessário o uso freqüente de crédito, tais
} 
oportunidade de investimento rentável, do que a busca de uma aposentadoria complementar. Em depósitos de maior aporte de recursos, revela-se um expediente sui generis de evitar brigas na partilha de herança, funcionando como uma redistribuição da herança realizada em vida.

A questão com a qual as seguradoras vêm se preocupando é como tornar o participante conservador, como convencê-lo a permanecer mais tempo no plano, de modo que o plano de aposentadoria complementar acompanhe o seu “ciclo de vida” por inteiro. Uma propaganda de um banco privado veiculada na imprensa dizia: “você tem uma dívida com o seu futuro, pague com o $13^{\circ}$. (salário)”. Campanhas desse tipo visam criar a própria idéia de previdência privada e complementar em relação à previdência pública que ainda permanece no imaginário como a fonte de segurança sócio-econômica em situações de risco social.

No primeiro semestre de 2007, a captação foi de $\mathrm{R} \$ 12,4$ bilhões, com crescimento de 26\% em relação ao mesmo período de 2006, segundo dados da Fenaprevi (Federação Nacional de Previdência Privada e Vida) ${ }^{484}$, superando as expectativas iniciais. O vicepresidente da entidade, Marco Antônio Rossi, aponta três fatores determinantes: o aumento da expectativa de vida do brasileiro que o leva a investir mais na programação de sua velhice; a possibilidade de reduzir os gastos no Imposto de Renda, tanto da pessoa física quanto da jurídica; e a oferta de planos de previdência privada das empresas aos seus empregados como um diferencial na contratação.

O volume de reservas técnicas do setor foi crescente, com apontam os dados:

como financiamentos, empréstimos e cartão de crédito. Se, por um lado, é baixa a capacidade de poupança, por outro, a instabilidade econômica, a inflação e até mesmo a insegurança ajudam a explicar o baixo investimento. Cabe lembrar os confiscos nos depósitos bancários realizados pelo Governo Collor e as falências bancárias.

${ }^{484}$ Os dois planos novos que têm maior aderência são o VGBL (Vida Gerador de Benefício Livre) e o PGBL (Plano Gerador de Benefício Livre). O primeiro é indicado para quem faz declaração de Imposto de Renda no modelo simplificado e a tributação do imposto incide apenas sobre o rendimento. No segundo, as aplicações podem ser deduzidas na declaração do IR até o limite de $12 \%$ da renda bruta anual e a tributação incide sobre o valor total resgatado; é indicado para quem faz a declaração do IR no modelo completo. Os planos tradicionais eram constituídos basicamente por grupos de funcionários de empresas e, embora ainda aceitem depósitos, não são mais oferecidos por nenhuma seguradora. A migração é uma alternativa, mas, deve-se avaliar os riscos envolvidos, principalmente em relação ao tempo previsto até a aposentadoria. A diferença entre os planos tradicionais e os novos é a rentabilidade. "Previdência privada tem aumento de $26 \%$ na captação”. Folha de São Paulo, 16/08/2007; “Setor cresce 26\% no primeiro semestre”, Valor Econômico, 16/08/2007: D1. “Velha aposentadoria”, Valor Econômico, 30/10/2006: D1. 
Tabela 21: Volume de reservas técnicas do setor (R\$ bilhões)

\begin{tabular}{ll}
\hline Ano & Valores \\
\hline 2001 & 24,2 \\
2002 & 32,0 \\
2003 & 48,5 \\
2004 & 66,0 \\
2005 & 81,5 \\
2006 & 93,2 \\
2007 & 110,4 \\
\hline
\end{tabular}

Fonte: Fenaprevi, dados de 30/11/2007

A questão que fica em aberto é como criar uma cultura de poupança e de previdência ao mesmo tempo. O curto prazo nos investimentos sustenta, de um lado, o descrédito na previdência privada tanto quanto um descrédito na segurança financeira, enquanto reforça o mérito da instituição pública de previdência social.

\section{Nota sobre racionalização na Previdência Social}

Em paralelo às reformas que afetaram os direitos previdenciários propriamente ditos, ocorreram várias medidas de racionalização na administração e gestão dos benefícios que modificaram não apenas a instituição, mas também o seu relacionamento com o sistema bancário, com a justiça, com Estados e Municípios e redefiniu o jeito de administrar. Nesse ponto, combinam-se reformas no direito e reformas administrativas que impactaram diretamente nas contas da Previdência. Se as restrições impostas aos direitos objetivaram racionalizar custos e assegurar o gozo de apenas um benefício, as restrições impostas a outras instituições também visaram a racionalizar o uso dos recursos públicos.

O controle do uso dos recursos públicos (arrecadação e despesas) tornou-se parte do movimento de racionalização da Previdência Social. Do lado da arrecadação, algumas medidas que podem ser citadas são: maior rigor na fiscalização do pagamento de 
contribuições previdenciárias sobre a participação nos lucros e resultados das empresas ${ }^{485}$; reembolso à Previdência de renúncias previdenciárias praticadas pela equipe econômica ${ }^{486}$ e controle sobre trabalhadores contratados por prestadoras de serviços ${ }^{487}$.

Em 2006, os Ministérios da Fazenda, do Planejamento e do Desenvolvimento apresentaram ao Presidente Lula um pacote de desoneração sobre a folha de pagamentos de salários da empresa que mudaria a contribuição patronal à Previdência Social como forma de estimular a contratação formal de trabalhadores ${ }^{488}$. O principal ponto da medida dizia que $5 \%$ da contribuição patronal seria calculado com base no faturamento e os demais $15 \%$ sobre a folha de pagamento de salários. A mudança progressiva seria uma forma de evitar a perda de arrecadação. As contribuições dos trabalhadores permaneceriam inalteradas.

A desoneração da folha de pagamentos, principal reivindicação empresarial para a redução dos encargos sociais, está em debate no governo desde 2003, sem que tivesse sido possível formular uma proposta concreta capaz de superar as dificuldades técnicas e políticas envolvidas. A versão apresentada em maio de $2007^{489}$ apresentava duas alternativas: fixar a alíquota de contribuição das empresas intensivas em mão de obra em 20\% sobre o teto do benefício previdenciário $(\mathrm{R} \$ 2.894,28)$ independente do salário de cada trabalhador e criar uma faixa de isenção da contribuição previdenciária (válida para empregados e empregadores). Como alternativa à perda de recursos, o governo propôs a compensação com aumento da alíquota do Cofins (faturamento da empresa).

O Ministro da Previdência, Luiz Marinho assumiu o cargo em meados de 2007 com forte disposição de brigar com a Fazenda pelos recursos da Previdência e imprimiu uma separação rígida entre a contabilidade da Previdência e a renúncia previdenciária (em favor da micro e pequena empresa, das exportações, das entidades filantrópicas, dos clubes de futebol etc). Para o ministro "a Previdência não tomou essas decisões, foi o governo, o

\footnotetext{
485 “Programas de PLR causam autuações”, Valor Econômico, 22/11/2006: D1.

486 À proposta do Ministro da Fazenda, Guido Mantega, de desonerar alguns setores econômicos da contribuição patronal, o Ministro da Previdência reagiu exigindo o reembolso à Previdência. "Marinho cobra de Mantega compensação", Valor Econômico, 18-20/05/2007: D1.

${ }^{487}$ A medida visa a coibir fraudes nas operações, através de controle de operações, rastreamento de ações, etc. Um dos objetivos da Previdência era proteger os empréstimos consignados a aposentados através da folha de pagamentos. O INSS detectou sinais de fraude nas operações e solicitou investigação da Polícia Federal. Nos contratos de prestação de serviços existem cláusulas de confidencialidade e restrições de uso das informações, sanções penais e administrativas. "INSS pede ajuda da PF para apurar fraudes com crédito consignado", Folha de São Paulo, 16/08/2007.

488 “Contribuição patronal ao INSS pode mudar”, Folha de São Paulo, 10/11/2006.

489 “Governo estuda reduzir INSS para empregador”, Folha de São Paulo, 16/05/2007.
} 
Estado Brasileiro, que paga por elas" ${ }^{\text {490 }}$. O problema da Previdência é reduzir o déficit de R \$ 42,06 bilhões em 2006 para algo próximo a R\$ 4 bilhões, com a separação da contabilidade exclusiva da Previdência, sem benefícios assistenciais, sem benefícios da área rural e sem renúncia previdenciária.

Em 2004, através do Acórdão 35, o TCU já havia determinado que fossem devolvidos aos cofres da Previdência Social os valores correspondentes à renúncia previdenciária dos segurados especiais, do empregador rural (pessoa física ou jurídica), dos empregadores domésticos e dos clubes de futebol, cujos montantes encontram-se descritos na tabela abaixo:

Tabela 22: Estimativa das Renúncias Previdenciárias - 2006

\begin{tabular}{|c|c|}
\hline Segmento & Valor (R\$ milhões) \\
\hline 1. SIMPLES & $5.109,8$ \\
\hline 2. Entidades Filantrópicas & $4.314,3$ \\
\hline 3. Exportação da Produção Rural & $1.788,9$ \\
\hline 4. CPMF & 285,9 \\
\hline Subtotal A & $11.498,9$ \\
\hline 5. Segurado Especial & $4.505,0$ \\
\hline 6. Empregador Rural & $1.388,4$ \\
\hline 7. Empregador Doméstico & 511,9 \\
\hline 8. Clube de futebol profissional & 57,3 \\
\hline Subtotal B & $6.562,7$ \\
\hline Total das Renúncias & $18.061,6$ \\
\hline
\end{tabular}

Somando todos os valores, a estimativa para 2006 era de que a renúncia chegaria a R\$ 18 milhões, o que somado ao pagamento de benefícios estranhos à previdência contribui para explicar o déficit previdenciário.

Uma outra disputa travada pelo Ministro deu-se com o Governo do Estado de São Paulo para exigir desse a realização dos depósitos previdenciários dos funcionários públicos contratados temporariamente pelo governo. Como a reforma previdenciária de

\footnotetext{
490 Declaração do Ministro Luiz Marinho ao jornal Valor Econômico, 18-20/05/2007: B5; "Governo vai desonerar folha para aliviar efeito do câmbio”, Valor Econômico, 18-20/05/2007: A1. O objetivo do governo era a desoneração da folha de pagamento com a passagem da contribuição previdenciária para o faturamento, através do aumento do COFINS. "Governo vai desonerar folha de pagamentos de quem emprega mais", Valor Econômico, 18-20/05/2007: A12.
} 
1988 determinou que os trabalhadores temporários devem necessariamente estar vinculados ao RGPS, o governo do Estado deveria repassar R 15 bilhões aos cofres da Previdência a título de contribuição previdenciária de 205 mil trabalhadores ${ }^{491}$. Para driblar o problema, o governo propôs um PL que tornava os servidores temporários, efetivos. A negociação entre os dois órgãos governamentais permitiu uma saída para o Governo de São Paulo, mas não eliminou a possibilidade de questionamento futuro na Justiça.

A folha de pagamento do INSS também sofreu uma modificação fundamental. A maior parte das contribuições previdenciárias é feita através de arrecadação bancária. O INSS pagava, em valores de 2007, R\$ 250 milhões por ano para os bancos realizarem o pagamento a aposentados e pensionistas ${ }^{492}$. Com o avanço do crédito consignado em folha de pagamentos o governo descobriu que a folha de pagamentos é um ativo valioso e, em vez de pagar, pretende receber pela “carteira de clientes”. Em 2006, o então secretário do Tesouro Nacional, Joaquim Levy, começou uma discussão sobre a venda da folha de pagamentos em lotes, a serem adquiridos em leilões. Temendo tumultos no pagamento dos aposentados, o Ministério da Previdência assumiu as negociações pedindo para que estabelecessem seus preços para a compra do direito de pagar os benefícios. O Ministério deixou de realizar o pagamento aos bancos desde setembro de 2006, quando acabou o contrato, e apenas aguarda o momento de formalizar a questão, seja através de negociação direta, seja através de leilão.

Em questões que envolvem disputa jurídica, no entanto, a Previdência Social não obteve apenas vitória. O Supremo Tribunal de Justiça definiu, por unanimidade, a aplicação do prazo de cinco anos para a cobrança de contribuições previdenciárias, valendo o prazo

\footnotetext{
491 O INSS acionou o Estado de São Paulo na Justiça a respeito da pendência. Em 1999, o Supremo Tribunal Federal havia tomado uma decisão favorável ao governo, mas o Estado de São Paulo não se enquadrou, graças a liminares. Para o governo, o Estado deveria se enquadrar para obter o certificado de regularidade previdenciária que lhe daria o direito a repasses voluntários da União e empréstimos. "Para conter R \$ 15 bi, Serra investe em disputa com o INSS”, Folha de São Paulo, 28/04/2007; 'Serra e Marinho fecham um acordo sobre servidores de SP”, Folha de São Paulo, 15/05/2007; "Marinho cede a Serra em projeto da Previdência paulista”, Folha de São Paulo, 15/05/2007.

492 "Governo quer oferta por folha de aposentado", Folha de São Paulo, 26/11/2007; "Governo pressiona bancos a pagar pela folha do INSS”, Valor Econômico, 26/11/2007; "Folha do INSS em discussão", Valor Econômico, 11/12/2007.
} 
estabelecido pelo Código Tributário Nacional ${ }^{493}$. A redução do prazo para cobrança de contribuições reduziu o estoque da dívida ativa da Previdência Social.

A fixação de uma regra mais duradoura para o salário mínimo, a adoção de uma política de reajuste para o salário do funcionalismo, a regulamentação da Emenda dos gastos da saúde e o controle do déficit da Previdência foram itens que constaram da agenda fiscal do governo em 2006. Tratados em conjunto, as medidas visavam a fixar uma meta de gastos para os próximos anos, freando os gastos públicos. A equipe econômica demonstrava-se, mais uma vez, preocupada com o impacto do salário mínimo sobre as contas da Previdência. A estimativa era que cada R\$ 1 de aumento no salário mínimo, elevava o déficit em R 190 milhões ao ano. Durante o período, cogitou-se a ampliação gradual da Desvinculação das Receitas da União até que atingisse 30\% das receitas.

A SRF decidiu acabar com a divulgação da lista dos devedores da Previdência Social como determinava a Lei 8.212/91. Na última lista divulgada a dívida alcançava R\$ 129,894 bilhões ${ }^{494}$. Com a fusão dos órgãos de arrecadação (Receita Previdenciária e Receita Federal), houve uma sobreposição legislativa, uma vez que o Código Tributário Nacional proíbe a divulgação de informações sobre devedores. Sob este argumento, o montante da dívida da Previdência Social perdeu transparência, tornando-se assunto técnico a ser tratado privadamente.

\footnotetext{
493 A Lei 8.212, de 1991 estabeleceu prazo de 10 anos para a decadência do tributo. A definição do novo de cinco anos afeta a maior parte da dívida exigida. "STJ delimita prazo de cinco anos para INSS cobrar contribuições”, Valor Econômico, 20/08/2007.

${ }^{494}$ A última versão da lista foi publicada em 31/03/2007. "Receita suspende a divulgação de lista de devedores do INSS”, Folha de São Paulo, 16/06/2007.
} 


\section{CONSIDERAÇÕES FINAIS}

Procuramos demonstrar como a Previdência Social vem passando por um amplo processo de racionalização, que atingiu não apenas os critérios de elegibilidade para acesso aos benefícios programáveis, como é o caso de aposentadorias e pensões, mas também determinou a própria reorganização institucional e a adoção de tecnologias e metodologias mais modernas de gestão, assim como a sua configuração estrita como um seguro social.

Embora o aspecto mais relevante do conflito em torno da Previdência tenha sido as propostas de reforma e o longo tempo demandado para que pudessem ser efetivamente adotadas, a forma como o debate foi conduzido produziu efeitos que não tem sido devidamente valorizados pelos pesquisadores.

$\mathrm{O}$ enfoque dado às contas públicas e ao déficit da Previdência pelo Governo produziu uma inversão no modo como o debate fora conduzido no período pré-constituinte e fez com que a análise do custo do direito se sobrepusesse à análise dos gastos sociais.

Se, até meados da década de 1980, prevaleceu a crítica quanto ao nível de gastos sociais e a necessidade de fortalecimento de políticas sociais voltadas à garantia de renda para as populações mais pobres, ao longo das décadas de 1990 e 2000, a crítica voltou-se contra o nível de direitos assegurados pela Constituição Federal de 1988 e a explosão dos gastos sociais.

A inversão na pauta provocou um conflito que teve nas "contas da Previdência” o seu ponto central, com a construção de um referencial que permitiu a constatação de déficit como o produto da diferença entre as receitas e as despesas previdenciárias. Mas essa versão foi fortemente contestada por pesquisadores que denunciavam uma metodologia que sonegava receita e incluía despesas não cabíveis nas contas da Previdência.

A tensão que esse tipo de disputa contém é reveladora de dois modos de entender o papel dos gastos sociais e de resolver o conflito distributivo. Nesse trabalho identificamos esses dois modos como embasados em duas racionalidades distintas: a racionalidade política e a racionalidade econômica. Como tipos ideais, a racionalidade política zela pela 
realização do princípio da cidadania, da universalização e da seguridade social, enquanto que a racionalidade econômica zela pelas contas públicas e pela contenção do déficit público.

Uma vez que as condições de austeridade fiscal e de crise nas finanças públicas já estavam dadas durante a década de 1980, a definição de novos direitos constitucionais, a elevação do valor dos benefícios e a instituição do salário mínimo como uma garantia de renda mínima, só podem ser vistas como uma irracionalidade. E é exatamente como irracionalidade que o crescimento do número de benefícios e o aumento do seu valor serão apresentados ao longo do debate sobre a reforma da Previdência.

Os projetos de reforma tributária, por outro lado, buscaram demonstrar a necessidade de reduzir os encargos sociais, com redução do número de impostos e contribuições, fim da sua incidência em cascata e a necessidade de repensar o esquema de financiamento da Previdência Social, o que demonstrou a confluência entre as duas agendas públicas.

O longo processo de reforma foi aqui decomposto em "tempos", o que permitiu identificar como os argumentos foram sendo montados e como foram ganhando consistência, alimentados por questões como a reforma tributária, a reforma fiscal e a reforma do Estado.

O "tempo da regulamentação" é o que melhor apresenta a tensão entre os dois modos de compreender o direito à seguridade social inscrita na Constituição. É o momento em que a seguridade social é confrontada com a situação econômica prevalecente nos anos 1980 e com a dos anos 1990, que demonstram a sua irracionalidade diante das contas públicas.

A tensão que então se observa é pela efetivação dos direitos instituídos através da regulamentação, que será a principal reivindicação política até meados da década de 1990. De outro lado, a eleição de Collor radicalizava com uma proposta que era diametralmente oposta, com ênfase na privatização.

O “tempo da revisão constitucional” também abriu um campo fértil para a retomada dos debates constituintes em torno do modelo de seguridade social, dos conceitos, base de financiamento e definição de direitos. A revisão constitucional malogrou e junto com ela as expectativas de constituição de um sistema de proteção social mais abrangente. 
O “tempo das reformas” finalmente é aquele em que a reforma da Previdência é negociada e aceita, quando o debate mais fortemente se vê conduzido pelo discurso da racionalidade econômica. Esse é um tempo em aberto, que aponta para um processo que parece não ter se esgotado.

Ao longo da década de 1990, o discurso amparado na racionalidade econômica vai adquirindo centralidade e se sobrepondo sobre as medidas que exigiam a instituição da Seguridade Social. É nesse momento que a previdência social adquire centralidade no debate, sobrepondo-se às demais áreas integrantes do conceito de seguridade social. Essa centralidade pode ser observada não apenas a partir do debate sobre o défict previdenciário.

De um certo modo, a Previdência Social retomou o nível do debate da década de 1980 que já apontava para a existência de déficit e denunciava que o financiamento de políticas estranhas ao conceito de previdência era o responsável pelo déficit financeiro, especialmente, a saúde, que se universalizava, sem a contrapartida de recursos fiscais. Vieram a discussão pública várias questões históricas com as quais a Previdência se confrontava, entre elas o fato de exercer o suporte das principais políticas de proteção social sem o aporte de recursos fiscais. O conflito que passa a travar com a área da saúde é de caráter distributivo e vai contribuir para reafirmar o seu caráter específico de seguro social. É um conflito tanto distributivo quanto conceitual que busca estabelecer a exata distinção entre o que é previdência e o que é assistência.

De todas as inovações introduzidas pela Constituição Federal de 1988, certamente, o fato de ter submetido a Previdência Social ao controle público, com a sua inclusão no Orçamento da Seguridade Social, foi o que permitiu que o debate fosse alimentado pela exigência de maior transparência nas suas contas. É exatamente nesse ponto que o processo de sistematização e de racionalização se tornaram mais evidentes. Contribuíram para com esse processo não apenas o Legislativo, mas também o Judiciário e o Tribunal de Contas da União, no exercício do papel de controle externo ao Executivo.

Aos argumentos de déficit previdenciário, a oposição argumentou a favor do combate aos desperdícios, fraudes, sonegações, desvios e renúncias previdenciárias. Aos argumentos de privilégios dos trabalhadores do mercado formal (sobretudo pelo instituto da aposentadoria por tempo de serviço), a oposição sustentou a existência de duas naturezas distintas de benefícios - previdenciários e assistenciais. Nesse processo foram denunciadas 
todas as manipulações que contribuem para reduzir os recursos da Previdência Social. Do lado da arrecadação, destacam-se: a denúncia contra a renúncia fiscal, sonegações, apropriações indébitas, subsídios, isenções, critérios diferenciados de contribuição, etc, que deveriam ser financiadas com recursos fiscais. Do lado das despesas, tratou-se de promover uma distinção entre benefícios assistenciais e previdenciários; benefícios de trabalhadores rurais e urbanos; do RGPS e do RPPS. Esses dois movimentos foram acompanhados da exigência da contrapartida de recursos fiscais para o seu financiamento, de forma que o peso deixasse de recair sobre a arrecadação previdenciária. Em relação ao RPPS os termos do debate conduziram à exigência de que o Estado cumprisse com o seu papel de empregador e passasse a contribuir, efetivamente, para o custeio de aposentadorias dos funcionários públicos. Os Estados e Municípios também se viram compelidos a caminhar no mesmo sentido, sob pena de ter recursos orçamentários cortados.

As reformas realizadas contribuíram para reforçar o vínculo contributivo dos benefícios previdenciários e para promover uma inversão na forma como a solidariedade social vinha sendo pensada no contexto brasileiro. A capacidade contributiva se torna o princípio através do qual a solidariedade social pode ser exercida, acentuando mais a dimensão do dever de contribuir do que o direito que se retira da sociedade.

Ao final do primeiro ciclo de reformas (1999) foram revistos os critérios de elegibilidade e acesso aos benefícios previdenciários, sobretudo, as aposentadoria por tempo de serviço, que foram convertidas em aposentadorias por tempo de contribuição. A introdução do fator previdenciário proporcionou a adoção de uma forma de cálculo que permite individualizar o tempo de contribuição necessário à aposentadoria e o valor do benefício. A privatização da Previdência Social foi afastada como projeto diante dos altos custos de transição que provocariam e, ao final, foi reafirmada como pública, de vínculo obrigatório e de caráter contributivo. A previdência privada, embora venha conquistando mercado, ainda não tem se revelado como alternativa à previdência pública na concessão de aposentadorias e pensões.

O segundo ciclo de reformas afetou mais diretamente o conjunto do funcionalismo público, que além de ter revisto os critérios de elegibilidade e acesso aos benefícios, passaram a contribuir para o sistema. Os inativos do serviço público também foram 
atingidos pela reforma, contrariamente aos da iniciativa privada, que foram poupados da contribuição.

A partir de 1999 vários procedimentos administrativos, judiciais e tecnológicos contribuem para a continuidade do processo de racionalização. A criação da Secretaria da Receita Federal que promoveu a unificação da arrecadação previdenciária e fiscal certamente deverá re-configurar o debate em torno das contas da Previdência Social.

Em síntese, a afirmação da escassez de recursos públicos, da penúria fiscal, do déficit público serviu para criar um outro referencial ao debate sobre os direitos previdenciários, diferentes daquele que preconizavam a introdução do critério de cidadania de acesso aos direitos predominante na década de 1980. Esse discurso fez retroceder a perspectiva de adoção de um modelo de seguridade social tal como inscrito na Constituição. No entanto, fez com que as propostas determinassem mudanças profundas no modo como a política de previdência social era entendida. Se as reformas que produziram mudanças nos critérios de elegibilidade e acesso aos benefícios foram um resultado importante, o debate público em torno das contas da Previdência foi significativo para o início de um processo de racionalização que tem alcançado dimensões antes impensáveis. Talvez esse seja o seu resultado não previsto e também o mais importante. O controle público que a Constituição tornou possível sobre as contas da Previdência foi a chave de acesso para uma discussão pública sobre a aplicação dos recursos previdenciários. 


\section{Bibliografia}

ABRANCHES, Sérgio (1992). "Questão social, previdência e cidadania no Brasil”. In: GoMES, Ângela M. de Castro (org.). Trabalho e previdência: sessenta anos de debate. Rio de Janeiro: FGV/CEPDOC.

Abrúcio, Fernando L. \& Loureiro, M.R. (2002) (org.). O Estado numa era de reformas: os anos FHC. Parte II. Brasília: Ministério do Planejamento e Gestão/ SEGES.

AFonso, Carlos A. \& SouzA, Herbert (1977). O Estado e o desenvolvimento capitalista no Brasil: a crise fiscal. Rio de Janeiro: Paz e Terra.

AlBER, Jens (1987). "Government Responses to the Challenge of Unemployment: the Development of Unemployment Insurance in Western Europe”. FLORA, Peter \& HEIDENHEIMER, Arnold J. (org.). The Development of WelfareSstate in Europe and America. New Brunswick (USA); London (UK): Transactions Books: 151-183.

ALBERTI, Verena (2001) (coord.). Entre a solidariedade e o risco: a história do seguro privado no Brasil. Rio de Janeiro: FGV; Funenseg.

AlmeIDA, Maria Hermínia T. \& MoyA, Maurício (1997). “A reforma negociada: o Congresso e a política de privatização”. Revista Brasileira de Ciências Sociais vol. 12, nº 34, jun.: 119-132.

(2001). "Federalismo, democracia e governo no Brasil: idéias, hipóteses e evidências”. Boletim Informativo e Bibliográfico de Ciências Sociais, $n^{\circ}$ 51: 13-34.

ALVES, Mário (1994). “Os financiamentos e os benefícios previdenciários”. In: MPS/CEPAL. A Previdência Social e a revisão constitucional. Debates. Vol. II. Brasília: 201-211.

ANDRADE, Eli G. (2003). “Estado e previdência no Brasil: uma breve história”. In: MARQUES, Rosa M et al. A Previdência Social no Brasil. São Paulo: Ed. Fundação Perseu Abramo: 69-84.

ANDRAdE, Eli G. (1999). (Des) equilíbrio da previdência social brasileira - 1945-1997 (componentes, econômico, demográfico e institucional). Tese de Doutorado. Minas Gerais: CEDEPLAR/UFMG.

ANDREWS, Christina \& Kouzmin, Alexander (1998). "A discurso da nova administração pública”. In: Lua Nova, 45: 97-122.

ARENDT, Hannah (1981). A condição humana. Rio de Janeiro: Forense-Universitária; Rio de Janeiro: Salamandra; São Paulo: Edusp.

ARRETCHE, Marta \& RoDriguez, Vicente (1998). "Descentralizar e universalizar a atenção à saúde”. In: ARRETChe, Marta \& Rodriguez. Vicente (org.). Descentralização das políticas sociais no Brasil. São Paulo: Fapesp/IPEA/Fundap. 
Azeredo, B; Vianna, M.L.W.; Gorgulho, L. \& Goldenstein, S (1993). O sistema previdenciário brasileiro na revisão constitucional: análise das propostas de reforma. Rio de Janeiro: CEPP/IUPERJ, $\mathrm{n}^{\circ}$ 14, texto para discussão.

AZEvedo, Sérgio \& MELo, Marcus André (1997). A política da reforma tributária: federalismo e mudança constitucional. Revista Brasileira de Ciências Sociais, vol. 12, nº 35, fev: 3-27.

Aureliano, Liana; DraiBe, Sônia M. (1989). “A especificidade do 'welfare state’ brasileiro. In: MPAS/CEPAL (1989). Política social em tempo de crise: articulação institucional $e$ descentralização. Brasília: MPAS/CEPAL, vol. I - Reflexões sobre a natureza do bem estar, Economia e Desenvolvimento, $n^{\circ} .3$.

BACHA, Edmar \& KLEIN, Herbert S. (1986) (org.). A transição incompleta: Brasil desde 1945. Rio de Janeiro: Paz e Terra.

BACHELARD, Gaston (1978). O novo espírito científico. In: Os Pensadores. São Paulo: Abril Cultural: 89-179.

BALDWIN, James (1990). The Politics of Social Solidarity: Class Bases of the European Welfare State 1875-1975. Cambridge: Cambridge University Press.

BALERA, Wagner (1993). "O custeio da previdência social”. In: MPS/CEPAL. A previdência social e a revisão constitucional. Debates, vol. I. Brasília: 73-90.

Baptista, D.B.A., (2003). Idosos no Município de São Paulo: expectativa de vida ativa e perfis multidimensionais de incapacidade a partir da SABE. Dissertação de Mestrado. Minas Gerais: Cedeplar/UFMG.

BARBosa, Eni M. M. (1991). "O processo de regulamentação da assistência social: avanços e retrocessos”. Rio de Janeiro: IPEA, TD n 222.

BATIK, Mariana (2004). "Previdência do trabalhador: uma trajetória inesperada”. In: São Paulo em Perspectiva, 18(3): 33-40.

BELTRÃo, Kaizô I. (2000). MAPS: uma versão amigável do modelo demográfico-atuarial de projeções e simulações de reforma previdenciária do IPEA/IBGE. Rio de Janeiro: IPEA, TD774.

(1995). “A dinâmica populacional brasileira e a Previdência Social”. São Paulo em Perspectiva, Vol. 9, n . 4, out.-dez.: 60-65.

(1993). “A Previdência social e a revisão constitucional”. In: MPAS/CEPAL (1993/1994). A Previdência Social e a revisão constitucional. Debates, Vol. II.

\& MANIERo, Leandro V.F. (1993). “Aposentadoria por tempo de serviço: diagnóstico e alternativas”. In: MPS/CEPAL. A Previdência Social e a revisão constitucional. Pesquisas. Vol. I. Brasília. 
; SUgahARA, Sonoe; PEYneAU, Fernanda P.L. \& MENDONÇA, João L. (2003). Mercado de trabalho urbano: clivagens raciais na década de 1990. Rio de Janeiro: IPEA, TD 987.

\& PINHEIRO, Sonoe S. (2002a). Estimativa de mortalidade para a população coberta pelos seguros privados. Rio de Janeiro: IPEA, TD 868. (2002b). Uma avaliação dos dados do PNAD com respeito à Previdência Social: população ativa e inativa. Rio de Janeiro: IPEA, TD 871.

BENOIT, Lelita Oliveira (1999). Sociologia comteana: gênese e devir. São Paulo: Discurso Editorial.

BEVERIDGE, W.H. (s/d). "Seguro Social e Serviços Aliados" (Plano Beveridge). In: GuEdeS, Marques. O Plano Beveridge. Lisboa: Editorial-Século: 241-339.

BobBio, Norberto (1992). A era dos direitos. Rio de Janeiro: Campus.

BoschETTI, Ivanete (2003). "Implicações da reforma da previdência na seguridade social brasileira”. Psicologia \& Sociedade, $\mathrm{n}^{\circ}$. 15(1), jan/jun: 57-96.

BouRgEOIS, Louis (1902). La solidarité. Paris: Librairie Armand Colin.

BrAgA, Jose Carlos S. (1986). Saúde e previdência. São Paulo: Hucitec.

BREAK, G (1977) - "Social Security as a Tax". In: BoskIN, M (1977). The Crisis in Social Security. San Francisco; Califórnia: Institute for Comtemporary Studies.

BRIGgS, Asa (1961). "The Welfare State in Historical Perspective". European Journal of Sociology, 2: 221-258.

CALSAVARo, Rogério P. (2001). “A previdência muito além da questão social”. In: Conjuntura Social, jan-mar: 37-68.

CAMPILONGo, Celso F. (1994). “Crise do Estado, mudança social e transformação do direito no Brasil”. São Paulo em Perspectiva, $n^{\circ} 8$ (2):15-20.

CARVALHO, Ruy Q. \& BERNARDES, Roberto (1996). "Reestruturação industrial, produtividade e desemprego". São Paulo em Perspectiva, V. 10, nº 1, jan. - mar.: 53062.

CASTEL, Robert (1998). As metamorfoses da questão social: uma crônica do salário. Petrópolis: Vozes.

CASTORIADIS, Cornelius (1992). A instituição imaginária da sociedade. São Paulo: Paz e Terra.

Castro, Maria H; Machado, Érica M \& Rocha, Paulo ENM (1997). “O jogo orçamentário da União: relações Executivo-Legislativo na terra do pork-barrel”. In: DINIZ, Eli; AzEVEDo, Sérgio de (org.). Reforma do Estado e democracia no Brasil, Brasília: UNB/ENAP.

CECHIN, José (2001). “A previdência social nos lares brasileiros”. Conjuntura Social, jan-mar:1336. 
CoElHo, Vera Schattan P. (2003) (org.). A reforma da previdência social na América Latina, São Paulo: Editora FGV.

(2001). "Poder Executivo e reforma da Previdência na América Latina”. Novos Estudos Cebrap, nº.61, novembro: 93-108.

(1999). “A reforma da Previdência e o jogo político no interior do Executivo”. Novos Estudos Cebrap, nº 55: 121-142.

CoHN, Amélia (1995). “A Reforma da previdência social: virando a página da história?” São Paulo em Perspectiva, $n^{\circ}$ 4. São Paulo: 54-59.

(1989). “Caminhos da reforma sanitária”. Lua Nova, n 19, nov: 123-140.

(1980). Previdência Social e processo político no Brasil. São Paulo: Moderna.

COHN, Gabriel (1995). “Como um hobby ajuda a entender um grande tema” (prefácio). In: WEBER, Max. Os Fundamentos racionais e sociológicos da música. São Paulo: Edusp: 9-19.

CомTE, Auguste (1978). “Catecismo positivista”. In: COMTE (1978). Os Pensadores. São Paulo, Abril Cultural.

Costa, Vanda R. (1994). A revisão constitucional: reforma ou contra-reforma. Comunicação apresentada no XVIII Encontro Nacional da ANPOCs. Caxambu, nov.

Coutinho, Mauricio C. \& SALM, Cláudio (1986). Previdência Social. In: BACHA, Edmar \& KLEIN, Herbert S. (org.). A transição incompleta: Brasil desde 1945. Rio de Janeiro: Paz e Terra.

Cuthright, P. (1965). "Political, Economic Development and National Social Security Programs.” American Journal of Sociology, n 70: 537-550.

DAIN, Sulamis (2003). “Condições Econômicas e Sociais”. In: MARQUES, Rosa Maria et al (2003). A Previdência Social no Brasil. São Paulo: Ed. Fundação Perseu Abramo.

(1993). “Financiamento da seguridade social”. In: MPS/CEPAL. A previdência social e a revisão constitucional”. Debates, Vol. II. Brasília: 101-113.

(1989a). “A crise da política social: uma perspectiva comparada”. In: MPAS/CEPAL. A política social em tempo de crise: articulação institucional e descentralização. Brasília: vol. I - Reflexões sobre a natureza do bem estar. Brasília: MPAS/CEPAL:

(1989b). "O financiamento das políticas sociais no Brasil: características estruturais e desempenho no período recente”. In: MPAS/CEPAL. A política social em tempo de crise: articulação institucional e descentralização. Brasília: vol. II - Financiamento das políticas sociais no Brasil. Brasília: MPAS/CEPAL: 41-158.

; SoARES, Laura T. \& CASTILHO, Marta R. (1994). “O financiamento da previdência social no contexto de uma nova reforma tributária”. In: MPAS/CEPAL. A política social em 
tempo de crise: articulação institucional e descentralização. Brasília: vol. II - Financiamento das políticas sociais no Brasil. Brasília: MPAS/CEPAL.

DAHRENDORF, Ralf (1992). O conflito social moderno: um ensaio sobre a política da liberdade. Rio de Janeiro: Jorge Zahar; São Paulo: Edusp.

DELGADO, Guilherme C. (2002) “ O orçamento da seguridade social precisa ser recuperado”. Acompanhamento e Análise, n5, ago. Brasília: IPEA.

; Schwarzer, Helmut; QUERINo, Ana C; LuCINI, Juana Andrade (2002). A participação social na gestão pública: avaliação da experiência do Conselho Nacional de Previdência Social (1991/2000). Brasília: IPEA, TD 909.

DESROSIÈRE, Alain (1993). La politique des grands nombres. Histoire de la raison statistique. Paris: La Découverte.

DinIZ, Eli (1997b). Crise, reforma do Estado e governabilidade. Rio de Janeiro: Fundação GetúlioVargas.

(1986). “A transição política no Brasil: perspectivas para a democracia”. Sociedade e Estado. Brasília: UNB, vol. I, n 2, jul.-dez: 65088.

\& Azevedo, Sérgio de (1997) (org.). Reforma do Estado e democracia no Brasil. Brasília: UNB/ENAP.

\& BoschI, Renato R. (1987). "Empresários e Constituinte: continuidades e rupturas no modelo de desenvolvimento capitalista no Brasil”. Cadernos de Conjuntura, n. 11, out., Rio de Janeiro: IUPERJ: 1-32.

DraiBe, Sônia M. (2003). “A política social no período FHC e o sistema de proteção social”. Tempo Social, vol. 15, n² 2, nov.: 63-101.

(1997). “A política social na América Latina: o que ensinam as experiências recentes de reformas?” In: Diniz, Eli; Azevedo, Sérgio (org.). Reforma do Estado e democracia no Brasil. Brasília: ENAP/ UNB: 213-258.

(1993a). “As políticas sociais e o neoliberalismo”. Revista USP, Dossiê Liberalismo/Neoliberalismo, $\mathrm{n}^{\circ}$. 17, Mar-Mai: 86-101.

(1994). "Previdência e assistência dentro do sistema de proteção social”. In: MPS/CEPAL: A previdência social e a revisão constitucional. Debates, vol. II. Brasília:145153.

\& HENRIQUE, Wilnês (1988). "Welfare State, crise e gestão da crise: um balanço da literatura internacional”. Revista Brasileira de Ciências Sociais, vol 3, nº6, fev: 53-78.

DonZelot, Jacques (1984). L'invention du social. Essai sur le déclin des passions politiques. Paris: Fayard. 
Duguit. Leon (1908). Le droit social, le droit individuel et la transformation de l'État. Paris. Félix Alocan Editeur.

DuMONT, J.P. (1988) Les systèmes étrangers de sécurité sociale. Paris: Economica.

DURKHEIM, Émile (1995). Da divisão do trabalho social. São Paulo: Martins Fontes.

EISEN, Arnold (1978). "The meanings and confusions of Weberian 'rationality”. British Journal of Sociology, vol. 20, $\mathrm{n}^{\circ}$ 1: 57-70, March.

ELIAS, Norbert (1998). Sobre o Tempo. Rio de Janeiro: Zahar.

ELLENY JR., Roberto de G. (1998). Modelo de gerações superpostas com muitas gerações: algorítmo de solução. Rio de Janeiro: IPEA, TD 593.

ESPING-ANDERSEN, Gosta (1998). The Three Worlds of Welfare Capitalism. New Jersey: Princeton University Press.

EWALD, François (1993). Foucault: a norma e o direito. Lisboa: Vega.

EWALD, François (1986). L'Etat providence. Paris: Bernard Grasset.

FAGNANI, Eduardo (1997). "Política social e pactos conservadores no Brasil". Economia $e$ Sociedade. Campinas, $n^{\circ}$. 8, jun.

FALEIRos, Vicente de Paula (1980). A política social do Estado capitalista: as funções da previdência e da assistência sociais. São Paulo: Cortez.

FARIA, Carlos A. Pimenta de (1998). "Uma genealogia das teorias e modelos do Estado de BemEstar Social”. Boletim Informativo e Bibliográfico de Ciências Sociais, n’. 46: 39-71.

FARIAS, José F. de C. (1999). A teoria do Estado no fim do século XIX e no início do século XX: os enunciados de Leon Duguit e Maurice Hauriou. Rio de Janeiro: Lumens Júris. (1998). A origem do direito de solidariedade. Rio de Janeiro: Renovar.

FARO, Clóvis de (1993) (org.). Previdência social no Brasil: diagnósticos e sugestões de reforma. Rio de Janeiro: FGV.

FERNANDES, Anníbal (1993). “Acidente de trabalho e a previdência social”. In: MPS/CEPAL. A previdência social e a revisão constitucional. Debates, Vol. I. (Palestra proferida em 23/03/93): 107-125.

Figueiredo, Argelina F; LiMOngi, Fernando (1998). "Reforma da Previdência e Instituições Políticas”. Novos Estudos Cebrap, nº 51, jul: 63-90 (1997). “O Congresso e as Medidas Provisórias: abdicação ou delegação?”. Novos Estudos Cebrap, n 47, mar.: 127-154.

(1995). "Mudança constitucional, desempenho do legislativo e consolidação institucional”. Revista Brasileira de Ciências Sociais, n² 29, out.: 175-200. 
FIORI, José L. (1992) “Poder e credibilidade: o paradoxo político da reforma liberal”, Lua Nova, nº 25: 185-196.

FLICKINGER, Hans-Georg (2000) (org.). Entre caridade, solidariedade e cidadania.Porto Alegre: EDIPUCRS.

(2000b). “A trajetória das políticas sociais na Alemanha”. In: FLICKINGER, HansGeorg (org.). Entre caridade, solidariedade e cidadania.Porto Alegre: EDIPUCRS: 45-79.

FlorA, Peter; Heidenheimer, Arnold J. (org) (1987a). "The Historical Core and Changing Boundaries of the Welfare State”. In: Flora, Peter; Heidenheimer, Arnold J. (org.). The Development of Welfare State in Europe and America. New Brunswick (USA); London (UK): Transactions Books: 17-34.

(1987b). The Development of Welfare State in Europe and America. New Brunswick (USA); London (UK): Transactions Books.

FlORA, Peter; Alber, Jens (1987). "Modernization, democratization and the development of Welfare State in Western Europe”. In: Flora, Peter \& Heidenheimer, Arnold J. (org). The development of Welfare State in Europe and America. New Brunswick (USA); London (UK): Transactions Books: 37-80.

FREUND, Julien (1987). Sociologia de Max Weber. Rio de Janeiro: Forense-Universitária.

FouCAUlt, Michel (1995). As palavras e as coisas. São Paulo: Martins Fontes.

GENTIL, Denise Lobato (2007). "A política fiscal e a falsa crise do sistema de seguridade social no Brasil: análise financeira do período recente”. In: Sicsú, João (org.). Arrecadação e gastos públicos: de onde vê, para onde vão? São Paulo: Boitempo: 29-35.

GERSCHMAN, Sílvia \& ViannA, Maria L.T.W.(org.). A miragem da pós-modernidade: democracia e política social no contexto da globalização. Rio de Janeiro: Ed. da Fiocruz.

Giacomoni, James (2005). Orçamento público. São Paulo: Atlas.

Giambiagi, Fábio \& ALÉM, Ana Cláudia (2000). Finanças Públicas. Rio de Janeiro: Campus. ; ReIS, José G. \& URANI, André (2004) (org.). Reformas no Brasil: balanço e agenda. Rio de Janeiro: Nova Fronteira.

GODELIER, Maurice (s/d). Racionalidade e irracionalidade na economia. Rio de Janeiro: Tempo Brasileiro.

GoMEs, Ângela de C. (1992). Trabalho e previdência: sessenta anos em debate. Rio de Janeiro: FGV/CPDOC.

(1979). Burguesia e Trabalho: política e legislação social no Brasil (1917-1937). Rio de Janeiro: Campus. 
GONÇALVES, Marcus O.C. (1996). A jurisprudência e a promoção do bem-estar social emmatéria de previdência. Tese de Doutorado. FD/USP.

GougH, Ian (1975). "State Expenditure in Advanced Capitalism”, New Left Review, n’. 92, jul-ago:

GrAMACHO, Wladimir (2003). "Imprensa e inclusão social na Previdência”. In: Conjuntura Social, Brasília: MPS, maio-ago: 7-14.

GRECO, Marco A. (2005a). "Solidariedade social e tributação”. In: GRECO, Marco A. \& GodoI, Marciano Seabra (org.). Solidariedade social e tributação. São Paulo: Dialética: 168-189.

\& GoDOI, Marciano Seabra (2005b) (org.). Solidariedade social e tributação. São Paulo: Dialética.

GuEDES, Marques. O Plano Beveridge. Lisboa: Editorial-Século.

GURVITCH, George (1931). L'idée du droit social. Notion et systéme du droit social. Paris: Librairie du Recueil Sirey.

HABERMAS, Jürgen (1997). Direito e Democracia entre facticidade e validade. Rio de Janeiro: Tempo Brasileiro, 2 vol. (1995). “Três modelos normativos de democracia”. Lua Nova, nº 36: 39-53.

HAgGARD, Stephan \& KAUfMAN, Robert (1993). “O Estado no início e na consolidação da reforma orientada para o mercado”. In: SoLA, Lourdes (org.). Estado, mercado e democracia: política e economia comparada. São Paulo: Paz e Terra: 391-421.

HARRIS, Richard A. \& Milkis, Sidney M (1996). The Politics of Regulatory Change. New York; Oxford: Oxford University Press.

HARVEY, David (2003). Condição pós-moderna. São Paulo: Ed. Loyola.

HEIMANN, E. (1929). Sociale theorie der kapitalismus. Frankfurt:Suhrkamp.

Heller, Agnes \& FeHÉr, Ferenc (1994). "O pêndulo da modernidade”. Tempo Social, Ver. Sociologia USP, vol. 6, n 1-2 (editado em jun 1995): 47-82.

Henriques, Maria H. F.T. \& Beltrão, Kaizô, I.(1986). As Migrações Internas e a Previdência Social. Brasília: IPEA: TD 100.

Hochman, Gilberto (1992). "Lógica da ação burocrática e políticas públicas - o caso dos cardeais da Previdência Social”. Ciências Sociais Hoje, Rio de Janeiro: Rio Fundo/Anpocs: 102-138.

Holmes, Stephen \& Sunstein, Cass R. (1999). The Cost of Rights: Why LibertyDepends on Taxes. New York/London: W.W. Norton \& Cia.

HORKHEIMER, Max (1976). Eclipse da razão. Rio de Janeiro: Editorial Labor do Brasil.

Hume, David (1963). Ensaios Políticos. São Paulo: IBRASA.

IssuANI, Ernesto A. (1984). "Previdência e assistência social na América Latina: limites estruturais e mudanças necessárias”. Dados, 27 (3), Rio de Janeiro: 307-320. 
Ivo, Anete B. L. (2004). “A reconversão do social: dilemas da redistribuição no tratamento focalizado”. São Paulo em Perspectiva, vol. 18, nº. 2, abr/jun: 57-67.

JAMES, Estelle (2001). "Novos sistemas previdenciários: experiências, evidências e questões pendentes”. A economia política da reforma da Previdência. Coleção Previdência Social, vol. 9, Brasília: MPS: 9-47.

\& BROoKs, S. (2001). “A economia política da reforma estrutural do sistema previdenciário”. A economia política da reforma da Previdência. Coleção Previdência Social, vol 9, Brasília: MPS: 49-91.

JORGE, Eduardo (2005). “Setenta centavos: a réplica”. In: Saúde e Sociedade, 14(1), jan-abr: 23-26.

KopITZ, P (1993). "Reforming Social Security Systems". In: Finance \& Development. Washington, jun.

KoRNHAUSER, Lewis A. (2002). "El nuevo análisis economico del derecho: las normas jurídicas como incentivos”. In: ROEMER, Andrés (compilador). Derecho y economia: una revisión de la literatura. México: Fondo de Cultura Económica: 102-122.

KosellecK, Reinhart (2006). Futuro Passado: contribuição à semântica dos tempos históricos. Rio de Janeiro: Contraponto (Ed. PUC/RJ).

KING, Desmond (1988). "O Estado e as estruturas sociais de bem-estar em democracias industriais avançadas”. Novos Estudos, São Paulo, nº. 22, out: 53-76.

LACERDA, Maurício de (1980). A evolução legislativa do direito social brasileiro. Rio de Janeiro: Nova Fronteira.

LEITE, Celso Barroso (1993). “A previdência social e a revisão constitucional”. In: MPS/CEPAL. A previdência social e a revisão constitucional. Debates, vol.I. Brasília: 14-40 (palestra proferida em 10/03/1993).

LEFORT, Claude (1991). “Os direitos do homem e o Estado-providência”. In: LEFORT, Claude (1991). Pensando o político. Rio de Janeiro: Paz e Terra: 37-62.

LEFORT, Claude. Pensando o político: ensaios sobre democracia, revolução e liberdade. Rio de Janeiro: Paz e Terra.

LOPES, José Reinaldo L. (2006). "Decidindo sobre recursos escassos: raciocínio jurídico e economia”. In: LOPES, José Reinaldo L (2006). Direitos Sociais: teoria e prática. São Paulo: Método: 265-303.

LOPES, José Reinaldo L (2006). Direitos Sociais: teoria e prática. São Paulo: Método.

LOURAUX, Nicole (1992) "Elogio do Anacronismo". In: NovaEs, Adauto (1992). Tempo e História. São Paulo: Companhia das Letras: 57-70.

LUCA, Tânia R. de (1980). O sonho do futuro assegurado. São Paulo: Ed. Contexto. 
Malloy, James M. (1986). Política de previdência social no Brasil. Rio de Janeiro: Graal. (1976a). “A política da previdência social no Brasil: participação e paternalismo”. Dados, $\mathrm{n}^{\circ}$. 13, Rio de Janeiro: 93-115.

(1976b). "Previdência social e classe operária no Brasil (uma nota de pesquisa)”.Estudos Cebrap, n. 115-131.

MARQues, Rosa Maria et al (2003). A Previdência Social no Brasil. São Paulo: Ed. Fundação Perseu Abramo.

(1995) "Mudanças no mundo do trabalho e proteção social”. São Paulo em Perspectiva, Vol. 9, n ${ }^{\circ}$ 4, out-dez: 46-53.

MENDES, Áquila (2004). “O governo Lula e a contra-reforma previdenciária. São Paulo em Perspectiva, São Paulo, v. 18, nº 3, set: 3-15.

; BATich, Mariana \& MENDES, Áquilas (2003). "Previdência social brasileira: um balanço da reforma”. In: São Paulo em Perspectiva, 17 91): 111-121.

MARShall, Thomas H. (1967a). Política social. Rio de Janeiro: Zahar. (1967b). Cidadania, classe social e status. Rio de Janeiro: Zahar.

MARTINEZ, Wladimir N. (1993). “O financiamento da seguridade social”. In: MPS/CEPAL. A previdência social e a revisão constitucional. Debates, vol. I. Brasília: 41-72 (palestra proferida em 11/03/1993).

Martins, Sérgio Pinto (1999). Direito da seguridade social. São Paulo, Atlas.

MATtos, Paulo T.L. et al. (2004) (coord.). Regulação Econômica e Democracia: o debate norteamericano. São Paulo: Editora 34.

McGreevey, William P.; Piola, Sérgio \& VianNA, Solon M. (1986). "Saúde e assistência médica no Brasil a partir dos anos 80". In: BACHA, Edmar; KLEIN, Herbert, S. (1986). A transição incompleta: Brasil desde 1945. Rio de Janeiro: Paz e Terra.

MEEK, Ronald L (9171).Economia e ideologia: o desenvolvimento do pensamento econômico. Rio de Janeiro:Zahar.

Melo, Marcus André. (2002) “A transição incompleta: a reforma da previdência social no governo FHC”. In: ABRÚCIO, Fernando L \& LOUREIRo, M.R. (org.). O Estado numa era de reformas: os anos FHC. Parte 2. Brasília: Ministério do Planejamento e Gestão/ SEGES.

(1997a). “O jogo das regras. A política da reforma constitucional de 1993/1996. Revista Brasileira de Ciências Sociais, $\mathrm{n}^{\circ}$. 33, ano 12, fev.: 63-84.

(1997b) “As reformas constitucionais e a Previdência Social”. In: DINIZ, Eli \& Azevedo, Sérgio R. (org.). Reforma do Estado e democracia no Brasil: dilemas e perspectivas. Brasília: UNB/ENAP, 1997: 295-348. 
(1995a). “Crise do mundo do trabalho e seguridade social”. São Paulo em Perspectiva, $n^{\circ} 4: 40-45$.

(1995b). “Ingovernabilidade: desagregando o argumento”. In: VALLADARES, L. (org). Governabilidade e pobreza. Rio de Janeiro: Civilização brasileira: 23-48.

Mesa-LAgo, Carmelo (2003). “A reforma estrutural dos benefícios de seguridade social na América Latina: modelos, características, resultados e lições”. In: CoELHO, Vera S.P. (org.), A reforma da previdência social na América Latina. São Paulo: Editora FGV.

Montagner, Paula; Brandão, Sandra M. C. (1996). "Desemprego: novos aspectos de um velho problema”. In: São Paulo em Perspectiva, São Paulo, v. 10, no.1, jan./mar: 36-45.

МотA, Ana Elizabete (1995). Cultura da crise e seguridade social. Um estudo sobre as tendências da previdência e assistência social brasileira nos anos 80 e 90. São Paulo: Cortez.

MouRA, Alexandrina S. (1989) (org.). O Estado e a s políticas públicas na transição democrática. São Paulo: Vértice.

MPS (2001). A economia política da reforma da previdência. Coleção Previdência Social, vol 9. Brasília: MPAS

MPAS/CEPAL (1989). A política social em tempo de crise: articulação institucional e descentralização. Brasília: vol. I e Vol. II.

MPAS (1986). Rumos da Nova Previdência. Brasília - Anais do grupo de trabalho para reestruturação da Previdência Social, Tomo 1 e 2.

MPAS/CEPAL (1993). A Previdência Social e a revisão constitucional. Debates e Pesquisas, 6 volumes. Brasília: MPAS/CEPAL.

Munhoz, Dércio \& WerLang, Sérgio (1994). “A previdência social e a reforma fiscal”. In: MPAS/CEPAL (1994). A Previdência Social e a revisão constitucional. Debates, Vol. II. Brasília: 63-87.

NABAIS, José Casalta (2005). "Solidariedade social, cidadania e direito fiscal”. In: GRECo, Marco A. \& GoDoI, Marciano Seabra (org.). Solidariedade social e tributação. São Paulo: Dialética: 110-140.

NOBRE, Renarde Freire (2000). "Racionalidade e tragédia cultural no pensamento de Max Weber”. Tempo Social: Revista de Sociologia da USP, 12 (2): 85-108, novembro.

NogueIRA, Rios (1985). A crise moral e financeira da Previdência Social. São Paulo: Difel.

NoRonhA, Eduardo G. (1998). O modelo legislado de relações de trabalho e seus espaços normativos. Tese de Doutorado. FFLCH/USP.

NovaEs, Adauto (1992). Tempo e História. São Paulo: Companhia das Letras.

O’Connor, James (1973). The Fiscal Crisis of the State. New York: St Martins’s Press. 
OFFE, Claus (1984). Contradictions of the Welfare State. London: Hutchinson Education.

OIT (1983). Sècurité Sociale: Quelle méthode de Financement? Une Analyse Internationale. Genève.

OLIVEIRA, Francisco Eduardo Barreto de. (1994) "Seguridade social; igualdade, eqüidade ou solidariedade?” In: Conjuntura Social, n. 8, Brasília, MPS, agosto.

(1992a) Proposta de um referencial básico para a discussão da Seguridade Social. Rio de Janeiro: IPEA, TD 251.

\& Beltrão, Kaizô I.\& FerReirA, Mônica G. (1997). Reforma da Previdência, Rio de Janeiro: IPEA, TD 508.

; BELTRÃo, Kaizô I.\& Maniero, Leandro V.F. (1993). “Aposentadoria por tempo de serviço: diagnóstico e alternativas”. In: MPS/CEPAL (1993). A previdência Social e a Revisão Constitucional. Brasília.

OlIVEIRA, Francisco de (1998a). Os direitos do antivalor: a economia política da hegemonia imperfeita. Petrópolis: Vozes.

(1998b). “A economia política da social-democracia”. In: OLIVEIRA, Francisco de (1998). Os direitos do antivalor: a economia política da hegemonia imperfeita. Petrópolis: Vozes.

(1992b). Collor, a falsificação da ira. Rio de Janeiro: Imago.

Oliveira, Francisco de; Paoli, Maria C.P.M. (1999) (org.). Os Sentidos da Democracia. Petrópolis: Vozes; Brasília: Nedic: 307-334.

OliveirA, Jaime A.A. \& TEIXEIRA, Sônia M. Fleury (1986). (Im) Previdência Social: 60 anos de História da Previdência no Brasil. Petrópolis: Vozes.

OLsson, Sven E. (1990). Social Policy and Welfare State in Sweden. Lund: Arkiv.

ORNÉLAS, Waldeck; Vieira, Solange P. (1999) "Novo rumo para a previdência brasileira”. Conjuntura Social, out./dez: 7-25.

ORNÉLAS, Waldeck (2000). “A Previdência social sem “caixa-preta”. Conjuntura Social: reforma da previdência - mudanças e perspectivas. Brasília: MPAS, v. 11, nº.1: 7-10, jan-mar.

Ost, François (2005). O tempo do direito. Bauru: Edusc.

OUTHWAITE, William \& BotTomore, Tom (1996) (ed.). Dicionário do pensamento social do século XX. Rio de Janeiro: Jorge Zahar ed. [Editoria brasileira: Lessa, Renato \& Santos, Wanderley Guilherme. Tradução: Eduardo Francisco Alves, Álvaro Cabral].

PAOLI, Maria Célia P. M. (2002). "Empresas e responsabilidade social: os enredamentos da cidadania no Brasil”. In: SANTOS, Boaventura Souza. Democratizar a democracia. Os caminhos da democracia participativa. Rio de Janeiro: Civilização Brasileira: 373-418. 
(1993). “Constituinte e direito: um modelo avançado de legítima organização da liberdade”. In: SousA JR., José Geraldo (org.). Introdução Crítica ao Direito do Trabalho, Série o Direito achado na rua, v. 1. Brasília: UNB.

PereirA, Carlos \& Mueller, Bernardo (2000). "Uma teoria da preponderância do Poder Executivo: o sistema de comissões no Legislativo brasileiro”. Revista Brasileira de Ciências Sociais, vol. 15, no 43: 45-67.

PIERson, Christopher (1991). Beyond the Welfare State? Pennsylvania: The Pennsylvania State University Press.

PIERUCCI, Antônio Flávio (2003). O desencantamento do mundo: todos os passos do conceito em Max Weber. São Paulo: Editora 34.

PINHEIRo, Sonoe S. \& SUgahara, Tomie (2001). Perfil dos funcionários públicos ativos nas áreas federal, estadual e municipal? Comparação de bases disponíveis: RAIS, PNAD e SIAPE. Rio de Janeiro: IPEA, TD 837.

PinheIro, Vinícius C. \& VIEIRA, Solange P. (1999). "A reforma da previdência no Brasil: a nova regra de cálculo dos benefícios”. Conjuntura Social, MPAS, vol. 10, nº . 4, out-dez: 51-67.

PIRES, Júlio Manoel. A Política Social no período populista. São Paulo. IPE/USP, 1995.

PosNer, Richard A.(2002a). "El movimiento del análisis económico del derecho”. In: RoEMER, Andrés (compilador) (2002). Derecho y economia: una revisión de la literatura. México: Fondo de Cultura Económica: 221- 241.

POSNER, Richard A. (2002b). "La decadencia del derecho como disciplina autónoma: 1962 -1987”. In: ROEMER, Andrés (compilador). Derecho y economia: una revisión de la literatura. México: Fondo de Cultura Económica: 102-122.

Possas, Cristina (1981). Saúde e trabalho: a crise da previdência social. Rio de Janeiro: Graal.

RANCIÈRE, Jacques (1996). O desentendimento. São Paulo: ed. 34.

REIS, Fábio Wanderley (2000). Política e racionalidad: problemas de teoria de método de uma sociologia crítica da política. Belo Horizonte: UFMG.

REZENDE, Fernando (1987). A Política Social e a crise econômica. Rio de Janeiro: IPEA, TD 111. (1984). Imprevidência da Previdência. Revista de Economia Política, v. 4, n. 2, ab/jun, 1984.

\& AFOnso, José R. (1987). A reforma fiscal no processo de elaboração da nova Constituição. Rio de Janeiro: IPEA, TD 121.

\& MAHAR, Denis (1974). Saúde e Previdência Social: uma análise econômica. Rio de Janeiro: IPEA/INPES, Relatório de Pesquisa, n. 21.

\& SILVA, Beatriz A. (1987). Contribuições Sociais, IPEA/INPES, TD 107. 
(1985). Fundos Sociais. IPEA/INPES, TD 85.

REZENDE, Flávio da Cunha (2002). “Gastos públicos e mudanças recentes no papel do Estado nacional”. Novos Estudos Cebrap, nº. 62, março 2002: 123-138.

RIBEIRo, Renato Janine (2000). A sociedade contra o social. São Paulo: Companhia das Letras.

RIMLIMgER, G. (1971).Welfare policy and insdustrialization in Europe, América and Rússia. New York: John Weley and Sons.

Rios-Neto, Eduardo L.G. (2005). “Questões emergentes na análise demográfica: o caso brasileiro”. Revista Brasileira de Estudos Populacionais, São Paulo, v. 22, nº.2: 371-408, jul./dez.

(1994). “A previdência social e as implicações demográficas”. In: MPS/CEPAL. A previdência social e a revisão constitucional. Debates. Vol. II. Brasília: 165-176.

RochA, Daniel M. (2004). O Direito Fundamental à Previdência Social. Porto Alegre: Livraria do Advogado.

ROEMER, Andrés (2002) (compilador). Derecho y economia: una revisión de la literatura. México: Fondo de Cultura Económica.

Rosanvallon, Pierre (1997). A crise do Estado Providência. Goiânia: Ed. EFG; Brasília: UNB.

RosanVAllon, Pierre (1999). La nouvelle question sociale: repenser l'État Providence. Paris: Seuil.

Rose-ACKeRMAN, Susan (2004). “Análise econômica progressista do direito - e o novo Direito Administrativo”. In: MATTos, Paulo T.L.et al. (coord.). Regulação Econômica e Democracia: o debate norte-americano. São Paulo: Editora 34.

ROTHSCHILD, Emma (2003). Sentimentos Econômicos. Rio de Janeiro; São Paulo: Record.

SACHETTO, Cláudio (2005). "O dever de solidariedade no direito tributário: o ordenamento italiano”. In: Greco, Marco A.\& Godoi, Marciano S. (2005) (org.). Solidariedade social e tributação. São Paulo: Dialética: 9-52.

SADER, Eder (1988). Quando novos personagens entraram em cena: experiências, falas e lutas dos trabalhadores da Grande São Paulo (1970-1980). Rio de Janeiro: Paz e Terra. 
SANTOS, Boaventura Souza (2002). Democratizar a democracia. Os caminhos da democracia participativa. Rio de Janeiro: Civilização Brasileira

SANTOS, Boaventura Souza (1989). "O Estado, a sociedade e as políticas sociais em Portugal: o caso das políticas de saúde”. In: Moura, Alexandrina S. (1989). O Estado e as políticas públicas na transição democrática. São Paulo: Vértice/Ed. Revista dos Tribunais; Recife: Fund. Joaquim Nabuco: 326-389.

SANTOS, Maria Helena et al (1997). “O jogo orçamentário na União: relações ExecutivoLegislativo na terra do pork-barrel”. In: DINIZ, Eli; AZEVEDo, Sérgio de (org) (1997). Reforma do Estado e democracia no Brasil, Brasília: UNB/ENAP.

SANTOS, Rita de Cássia Bessa (2001). Empresários e a modernização das relações de trabalho. Dissertação de Mestrado, FFLCH/USP.

SANTOS, Wanderley Guilherme dos (1987). Cidadania e Justiça: a política social na ordem brasileira. Rio de Janeiro: Campus.

ScotT, Colin (2006). "Responsabilização no Estado regulador”. In: MATTOs, Paulo T. L. (coord). Regulação Econômica e democracia: o debate europeu. São Paulo: Singular: 87-117.

SEN, Amartya (1992). “Comportamento econômico e sentimentos morais”. Lua Nova, nº. 25: 105125.

SENNET, Richard (1999). A corrosão do caráter: conseqüências pessoais do trabalho no novo capitalismo. Rio de Janeiro: São Paulo: Record.

SHAFRITZ, Jay M.; HYDE, Albert C. (1999). Clásicos de la Administración pública. México: Fondo de Cultura Económica.

SICSÚ, João (2007) (org.). Arrecadação e gastos públicos: de onde vem? Para onde vão?São Paulo: Boitempo.

SILVA, Ademir A. (2004). "A reforma da Previdência Social brasileira: entre o direito social e o mercado”. São Paulo em Perspectiva, v. 18, nº. 3, jul-set:16-32.

SiLVA, Sidney Jard (2007). Reforma da Previdência em Perspectiva Comparada. São Paulo: Humanitas.

SILVA, Pedro L. Barros da (1997). “A natureza do conflito federativo no Brasil”. DiNIZ, Eli \& AzEvedo, Sérgio de (1997) (org.). Reforma do Estado e democracia no Brasil. Brasília: UNB/ENAP: 251-363.

(1992). Limites e obstáculos à reforma do Estado no Brasil: a experiência da Previdência Social na Nova República. Tese de Doutorado em Ciência Política, FFLCH/USP.

SoARES, Laura T.R. (2001). Ajuste neoliberal e desajuste social na América Latina, Petrópolis: Vozes. 
SolA, Lourdes (org.). Estado, mercado e democracia: política e economia comparada. São Paulo: Paz e Terra: 391-421.

souza Fo , Carlos F.M.S. (1999). “Os direitos invisíveis”. In: Oliveira, Francisco de; PaOli, Maria C.P.M. (org.). Os Sentidos da Democracia. Petrópolis: Vozes; Brasília: Nedic: 307-334.

SposAtr, Aldaíza et al (1989). Os direitos (dos desassistidos) sociais. São Paulo: Cortez: 33-104.

SWEDBERG, Richard (2005). Max Weber e a idéia de sociologia econômica. Rio de Janeiro: Ed. da UFRJ; São Paulo: Beca Produções Culturais.

TAPIA, Jorge Ruben B.; HENRIQUE, Wilnês (1995). “Crise, reforma e políticas sociais na América Latina”. São Paulo em Perspectiva, vol. 9, nº. 4, out-dez: 66-72.

TAVARES, Olga (1998). Fernando Collor: o discurso messiânico: o clamor ao sagrado. São Paulo: Annablume.

TEIXEIRA, Aloísio . “O conceito de seguridade social na Constituição de 1988”. In: MPS/CEPAL. A previdência social e a revisão constitucional. Debates. Vol. II. Brasília, 1994: 33-45.

TEIXEIRA, Sônia M. Fleury (1984). "Previdência x Assistência na política social brasileira”. Dados, v. 27 (3), Rio de Janeiro: 321-345.

(1989). "Assistência na Previdência Social: uma política marginal”. In: Sposati, Aldaíza \& FalCão, Maria do C. \& TeiXeira, Sônia M. Fleury (1989). Os direitos (dos desassistidos) sociais. São Paulo: Cortez: 33-104.

Telles, Vera da S. (1999).Direitos Sociais: afinal do que se trata? Belo Horizonte: Ed. UFMG.

THERBorN, G. (1987). "Welfare State and Capitalist Markets”. Acta Sociológica, 30, (3/4): 237254.

TITMUSS, R (1958). Essays on the Welfare State. Londres: George Allem \& Unwin.

UGÁ, Maria Alícia D. (2003). “Ajuste estrutural, governabilidade e democracia”. In: GERSCHMAN, Sílvia \& VianNA, Maria L.T.W. (org). A miragem da pós-modernidade: democracia e política social no contexto da globalização. Rio de Janeiro: Ed. da Fiocruz.

VARSANO, Ricardo (1998). Uma análise da carga tributária no Brasil. Rio de Janeiro:IPEA, TD583.

VELloso, João P. R. (1993). “Rigidez orçamentária da União” In: VELloso, João P. R. Brasil: a superação da crise. São Paulo: Nobel.

VIANA, Ana L. d’Ávila; EliAs, Paulo E. \& Ibañez, Nelson (2005) (org.). Proteção social: dilemas e desafios. São Paulo: Hucitec.

ViAnNA, Maria Lucia T.W. (2005). "seguridade social e combate à pobreza no Brasil: o papel dos benefícios não contributivos”. In: vianA, Ana L. d’Ávila; Elıas, Paulo E. \& Ibañez, Nelson (org.). Proteção social: dilemas e desafios. São Paulo: Hucitec: 89-122. 
VianNA, Maria Lucia T.W. (2000). A americanização (perversa) da seguridade social no Brasil: estratégias de bem-estar e políticas públicas. Rio de Janeiro: Revan: UCAM/IUPERJ. (1997). "Benefícios privados, vícios públicos”. In: Diniz, Eli \& Azevedo, Sérgio de (org.). Reforma do Estado e democracia no Brasil, Brasília: UNB/ENAP.

VianNA, Maria Lúcia T. Werneck; SiLVA, Beatriz Azeredo (1989). Interpretação e avaliação da política social no Brasil: uma bibliografia comentada. In: MPAS (1989). Política Social em Tempo de Crise. MPS/CEPAL, Brasília.

ViANNA, Solon Magalhães (2005). “A Seguridade Social e o SUS: re-visitando o tema”. In: Saúde e Sociedade, n. 14/1, Jan-Abr.: 7-22.

VITA, Álvaro de (2000). A Justiça igualitária e seus críticos. São Paulo: Unesp.

ZANIRATo, Silvia Helena (2003). O Descanso do Guerreiro: um estudo sobre a instituição da Previdência Social no Brasil. Maringá: Ed. EDUEM.

WEBER, Max (2004). Economia e Sociedade. Brasília: UNB; São Paulo: Imprensa Oficial, Vol. 1. (1995). Os fundamentos racionais e sociológicos da música. São Paulo: Edusp. (1979a). "Os três tipos puros de dominação legítima”. In: Weber, Coleção Grandes Pensadores Sociais. São Paulo: Ática: 128-141. (1979b). "Religião e racionalidade econômica”. In: Weber, Coleção Grandes Pensadores Sociais. São Paulo: Ática: 142-160.

(1979c). “A ‘objetividade’ do conhecimento nas Ciências Sociais”. In: Weber, Coleção Grandes Pensadores Sociais. São Paulo: Ática: 79-127.

(1974). "Rejeições religiosas do mundo e suas direções”. In: Ensaios de Sociologia. Rio de Janeiro: Zahar: 371-410.

WILENSKy, Harold L. (1975). The welfare state and equality. Structural and Ideological roots of Public Expenditures. Berkeley. University of California Press.

WORLD BANK (1994). Averting the old age crisis: policies to protect the old and promote growth. New York: Oxford University Press. 


\section{Fontes:}

ANFIP (2006). Associação Nacional dos Auditores Fiscais da Previdência Social. Análise da seguridade social em 2005. Brasília: ANFIP

ANFIP (2002). Associação Nacional dos Auditores Fiscais da Previdência Social. Análise da seguridade social em 2001. Brasília: ANFIP

BRASIL. Diário da Câmara dos Deputados (1990-2002)

BrasıL (s/d). Comissão Mista de Planos, Orçamentos Públicos e Fiscalização. Congresso Nacional. “Cartilha do Orçamento da Câmara dos Deputados”. Sítios: www.senado.gov.br/siga e www.camara.gov.br/orçamento acesso em 25/03/2006.

BRASIL (2006). Ministério da Previdência Social/Instituto Nacional do Seguro Social/ Empresa de Tecnologia e Informações da Previdência Social. Anuário Estatístico da Previdência Social Suplemento Histórico (1980-2005). Vol. 3. Brasília: MPS/DATAPREV, 2006.

BRASIL (2003). Trabalhos Relevantes sobre a Previdência Social: uma contribuição do TCU ao debate da reforma da Previdência Social. TCU: Brasília. Disponível em: www.tcu.gov.br , acesso em 23/08/2005.

BRASIL (2003b). Secretaria de Orçamento Federal/Ministério do Planejamento, Orçamento e Gestão. Vinculações de Receitas dos Orçamentos Fiscal e da Seguridade Social e o Poder Discricionário de Alocação dos Recursos do Governo Federal - vol. 1, nº. 1. Brasília: SOF.

Brasil (2002). Ministério da Previdência e Assistência Social (MPAS). Livro Branco da Previdência Social. Brasília: MPAS/GM, 2002 - P. II.

BrASIL (1998). Ministério da Previdência e Assistência Social (MPAS). Livro Branco da Reforma da Previdência Social. Brasília: MPAS/GM.

BRASIL (1995). Câmara dos Deputados. Relatório final da subcomissão especial para assuntos da previdência social. Comissão de Fiscalização Financeira e Controle, Brasília, setembro.

BRITTO, Antônio (1992). "Relatório Final da Comissão Especial para Estudo do Sistema Previdenciário”. In: Previdência em Dados, v. 7, $\mathrm{n}^{0}$ 2, abr.-jun. [Diário da Câmara dos Deputados, 28/3/1992: 5343].

CNI (2003). Alternativas de financiamento da Previdência Social. Brasília: CNI, março.

CNI (1994). Rumo ao crescimento da indústria. Brasília: CNI.

CóDIGO TRIBUTÁRIO NACIONAL (2007). São Paulo: Saraiva.

CONSTITUIÇÃo DA REPÚBLICA FEDERATIVA DO BRASIL (2007). São Paulo: Saraiva.

CONSTITUIÇÃo DA REPÚBLICA FEDERATIVA DO BRASIL (2002). São Paulo: Saraiva. 
CONSTITUIÇÃo DA REPÚBLICA FEDERATIVA DO BRASIL (1988). São Paulo: Saraiva.

CTASP. Comissão de Trabalho, Administração e Serviço Público (1990-2005).

FERREIRA, Carlos E.M. (1997). “O Brasil e os Desafios da Globalização”. In: Série Papers, São Paulo: Fundação Konrad-Adenauer-Stiftung, pp.15-25..

FIESP (1993). Uma proposta de reforma tributária e de seguridade social. In: Conjuntura Social, Brasília, 4 (1), jan.: 5-20.

LOA. Lei Orçamentária Anual (1995-2005).

Mello, Fernando Collor de (1991). Projeto de Reconstrução Nacional: opção democrática pelo desenvolvimento. Brasília: Presidência da República, março.

MPAS (1986). Rumos da nova Previdência. Anais do GT para reestruturação da Previdência Social. Brasília: MPAS, Tomo I e II.

MPS (1999). “Síntese da Exposição de Motivos da Lei 9876/99”. In: Conjuntura Social, out/dez: 27-50.

ORNÉLAS, Waldeck (2000). Discurso. In: Conjuntura Social, jan-mar: 11-25.

\section{PERIÓDICOS:}

FolHa de São PaUlo (1995-2007)

ESTADO DE SÃo PAULO (1995-2007)

VALOR ECONÔMICO (2005-2007)

BOLETIM DIAP (2002-2007)

AGÊNCIA CÂMARA DE NoTíCIAS (2005-2007). www.camara.gov.br/internet/agencia/matérias/asp
Agência
de
Notícias
da
previdência Social
(2005-2007)

WWW.PREVIDENCIASOCIAL.GOV.BR/AGPREV 
Anexo 1

Nota Técnica sobre o fator previdenciário

O fator previdenciário representa “contribuições médias do trabalhador ao longo de sua vida laboral, acumuladas e corrigidas monetariamente, incidindo ainda, sobre estas, uma taxa de juros que varia de acordo com a escolha pessoal de cada segurado quanto a data da sua aposentadoria” (ORNELAS; VIEIRA, 1999: 16-17).

O fator previdenciário introduz no regime de repartição simples a equalização entre contribuição e benefícios, permitindo que ajustes demográficos sejam realizados de forma endógena ao sistema. O aumento da expectativa de sobrevida da população ou a mudança no perfil de entrada e saída do segurado no sistema estão colocados no próprio cálculo do salário de benefício.

\section{Cálculo do valor do benefício com o fator previdenciário:}

\section{$\mathbf{S b}=\mathbf{M} \times \mathbf{f}$}

onde: $\mathrm{Sb}=$ salário de benefício;

M= Média dos $80 \%$ dos maiores salários de contribuição do segurado durante todo o seu tempo de contribuição, corrigida monetariamente; $\mathrm{f}=$ fator previdenciário

\section{Cálculo do fator previdenciário:}

$$
f=\underline{\operatorname{Tc} \times \mathbf{a}} \times(1+\underline{\operatorname{Id}+\operatorname{Tc} \times a})
$$

Es 100

Onde: $\mathrm{f}=$ fator previdenciário

Tc= tempo de contribuição de cada segurado

$\mathrm{a}=$ alíquota de contribuição do segurado;

Es= expectativa de sobrevida do segurado na data da aposentadoria

$\mathrm{Id}=$ idade do segurado na data da aposentadoria

Primeiro, o tempo de contribuição é multiplicado pela alíquota e dividido pelo período médio em que o segurado irá receber seu benefício (busca-se a equalização entre o período de contribuição de cada segurado individual com o tempo médio de recebimento do benefício, isto é, expectativa de sobrevida). 
Segundo, paga-se um prêmio para os segurados que permanecerem em atividade (associado a uma taxa de juros em regime de capitalização dos recursos acumulados ao longo do período de contribuição). Com a medida busca-se maior justiça e equilíbrio no fluxo de caixa da Previdência.

\section{Fator de transição:}

$$
f n=(f \times \underline{n})+\frac{(60-n)}{60}
$$

Onde: $f n=$ fator de transição

$\mathrm{N}$ = número de meses decorridos entre a data de promulgação da lei e a data da aposentadoria do segurado

$\mathrm{F}=$ fator previdenciário

Foi utilizada a alíquota de 31\% para o cálculo do fator previdenciário (20\% da contribuição da empresa e $11 \%$ da contribuição dos segurados empregados). Para os contribuintes individuais que pagam alíquotas de 8\% e 9\% haverá um subsídio maior. Nos dois casos, há subsídios, que deverão ser compensados pela alíquota de $20 \%$ de contribuição das empresas sobre a folha de pagamentos como um todo, sem respeitar o teto de contribuição. A alíquota de 31\% é um subsídio às classes menos organizadas e que recebem salários menores (Ornelas; Vieira, 1999). Em 1999, somente aqueles que excederam o teto, representaram $17 \%$ da contribuição total de empresas e empregados.

Foi concedido abono de 5 anos de tempo de contribuição às mulheres; de 10 às professoras do ensino infantil, fundamental e médio; de 5 anos para professores do ensino infantil, fundamental e médio, correspondente ao tempo diferencial de aposentadorias desses. No cálculo do fator previdenciário, o abono de cinco anos das mulheres deve ser somado ao tempo de contribuição. Por exemplo, uma mulher que se aposentar com 30 anos de contribuição e 55 anos de idade, terá o seu fator previdenciário relativo a 35 anos de trabalho e 55 anos de idade. 


\section{Anexo 2}

Propostas de reforma da seguridade social divulgadas (1991, 1992, 1993), segundo a origem:

\section{De origem parlamentar}

- Dep. Lysâneas Maciel (PDT/RJ) - apresentada na Comissão Britto

- Dep. Aloísio Vasconcelos (PMDB/MG)- apresentada na Comissão de Revisão

- Dep. Vasco Furlan (PRN/SC) - apresentada na Comissão de Revisão

- Dep. Celso Bernardi (PDS/RS) - apresentada na Comissão de Revisão

- Dep. Renato Johnson (s/ partido) - apresentada na Comissão de Revisão

- Estudo das Subcomissões: Financiamento e Servidores Públicos

- Estudo da Assessoria Legislativa: Servidor Público, Financiamento e benefícios

- Relatório Antônio Britto

\section{Do Executivo}

- PEC n. 51 (Emendão) - Collor

- Estudo do MTPS (gestão Antônio Magri)

- Estudo do MTPS (gestão Reinhold Stephanes)

- Estudo do MEFP (PEC/92)

- Relatório da Comissão Executiva da Reforma Fiscal (MEFP)

- Delineamento Básico da Reforma Fiscal (MEFP -16/06/92)

- Proposta para Seguridade (Comissão de Reforma Fiscal - MEFP)

- “Uma Visão Teóirca sobre a Previdência”, de L. Schymura (FGV)

- Estudo para a Reforma Fiscal (MEFP -28/7/92)

- “Uma Proposta Alternativa para a Seguridade Social Brasileira”(F. Oliveira; A. Médici e K. Beltrão)

- Emenda Constitucional - Governo Itamar Franco (5/11/92)

\section{De Entidades Empresariais}

- $\quad$ FIERGS - apresentada na Comissão Britto

- Federação Associações Comerciais do RS - apresentada na Comissão Britto

- "Previdência Social no Brasil: uma Proposta de Reforma”, publicada pelo Instituto Liberal, 1991

- Plano K: (Mendonça de Barros e Associados), em Este País Tem Jeito?, Ed. Rio Fundo, 1992.

- “Uma Proposta de Reforma Tributária e da Seguridade Social”(FIESP, Revista da Indústria, 1992)

\section{De Entidades do Mercado de Seguridade}

- ABRAPP - apresentada na Comissão Britto

- “Cenários da Previdência Social 1”, Uriel Magalhães, ABRAPP?FGV. 
- “Cenários da Previdência Social”, documentos 2, 3 e 4 (F. Oliveira; A Médici e K. Beltrão) ABRAPP/EPGE/FGV

\section{Entidades de Trabalhadores e Profissionais}

- Associação Nacional de Fiscais da Previdência, apresentada na Comissão Britto

- Fórum das Entidades dos Servidores Públicos Federais - Comissão Britto

- " “Um Modelo de Previdência Social”, WN Martinez, ANFIP, 1992

- “Um Projeto para o Brasil”, Força Sindical, 1993

- “13 Pontos em Defesa da Previdência Social”, CUT, 1993.

\section{De especialistas}

- Aloísio Teixeira (UFRJ) - apresentada na Comissão Britto

- Mário Henrique Simonsen, "Bases para a Reforma Tributária e Reestruturação da Previdência”, Fórum Nacional, 1992.

\section{Quadro 2}

Modelos de Seguridade sugeridos pelas propostas

\begin{tabular}{lllll}
\hline Modelo/ origem & Chileno & Universalista & Sistema misto & NA \\
\hline Legislativo & 2 & 2 & 1 & 3 \\
Empresários & 5 & - & 1 & - \\
Mercado seguros & 1 & - & 2 & - \\
Trabalhadores e funcionários & - & - & 1 & 2 \\
Especialista & 1 & 1 & - & - \\
Executivo & 1 & 1 & 9 & - \\
ANFIP & - & 1 & 1 & - \\
Totais & 10 & 5 & 15 & 5 \\
& $(28,6 \%)$ & $(14,3 \%)$ & $(42,8 \%)$ & $(14,3 \%)$ \\
\hline
\end{tabular}

Fonte: Azeredo; Werneck Vianna; Gorgulho \& Goldenstein (1993) 
Quadro 3: Integrantes da Comissão Especial da Previdência para a PEC 33/95

\begin{tabular}{|c|c|c|c|}
\hline \multirow{2}{*}{$\begin{array}{l}\text { Integrantes } \mathbf{1}^{\mathrm{a}} \text {. Comissão } \\
\text { Deputado }\end{array}$} & \multicolumn{3}{|c|}{ Integrantes $2^{\mathrm{a}}$. Comissão } \\
\hline & Partido & Deputado & Partido \\
\hline Jair Soares (Presidente) & PPB & José Lourenço (Presidente) & PFL \\
\hline Euler Ribeiro (Relator) & PFL & Arnaldo Madeira (Relator) & PSDB \\
\hline Augusto Viveiros & PFL & Aldir Cabral & PFL \\
\hline César Bandeira & PFL & Magno Bacelar & PFL \\
\hline Jair Siqueira & PFL & Messias Gois & PFL \\
\hline Lídia Quinan & PMDB & Osório Adriano & PFL \\
\hline José Aldemir & PMDB & José Carlos Vieira & PFL \\
\hline Rita Camata & PMDB & Armando Abílio & PMDB \\
\hline Fátima Pelaes & PSDB & Darcísio Perondi & PMDB \\
\hline Renato Johnsson & PSDB & Djalma de A. César & PMDB \\
\hline Antônio Kandir & PSDB & Etvalda G de Menezes & PMDB \\
\hline Marcia Marinho & PSDB & Ronaldo Perim & PMDB \\
\hline Marisa Serrano & PSDB & Sandro Mabel & PMDB \\
\hline Remi Trinta & PSDB & Antônio C. Pannunzio & PSDB \\
\hline Eduardo Mascarenhas & PSDB & Edson Silva & PSDB \\
\hline Mario Cavallazi & PPB & Marconi Perillo & PSDB \\
\hline Laprovita Vieira & PPB & Nelson Otoch & PSDB \\
\hline Arnaldo Faria de Sá & PPB & Zulaiê Cobra & PSDB \\
\hline Prisco Viana & PPB & Gerson Peres & PPB \\
\hline Rodrigues Palma & PTB & Mário Cavallazi & PPB \\
\hline Vicente Cascione & РTB & Roberto Campos & PPB \\
\hline Luiz Buaiz & PL & Arnaldo Faria de Sá & PPB \\
\hline Pimentel Gomes & PPS & Jair Soares & PPB \\
\hline José Augusto & PPS & Roberto Jefferson & PTB \\
\hline Cidinha Campos & PDT & Luiz Buaiz & PL \\
\hline Eurípides Miranda & PDT & Matheus Schmidt & PDT \\
\hline Jair Meneguelli & $\mathrm{PT}$ & Jair Meneguelli & $\mathrm{PT}$ \\
\hline Eduardo Jorge & PT & Eduardo Jorge & PT \\
\hline Alexandre Cardoso & PSB & Alexandre Cardoso & PSB \\
\hline Jandira Feghali & PC do B & Jandira Feghali & PC do B \\
\hline
\end{tabular}

Fonte: Diap, 1998 